UNIVERSIDADE DE SÃO PAULO

ESCOLA DE COMUNICAÇÕES E ARTES

LUCAS BASTOS GUIMARÃES BAPTISTA

Espaço e tempo como parâmetros de composição fílmica: um estudo comparativo

SÃO PAULO 



\section{Espaço e tempo como parâmetros de composição fílmica: um estudo comparativo}

Tese apresentada à Escola de Comunicações e Artes da Universidade de São Paulo, para obtenção do título de Doutor em Meios e Processos Audiovisuais.

Área de Concentração: Meios e Processos Audiovisuais.

Orientador: Prof. Dr. Cristian da Silva Borges.

Versão Corrigida (versão original disponível na Biblioteca da ECA/USP)

\section{SÃO PAULO}



Autorizo a reprodução e divulgação total ou parcial deste trabalho, por qualquer meio convencional ou eletrônico, para fins de estudo e pesquisa, desde que citada a fonte. 

Baptista, Lucas Bastos Guimarães

Espaço e tempo como parâmetros de composição fílmica: um estudo comparativo / Lucas Bastos Guimarães Baptista - São Paulo: L. Baptista, 2019. 375 p.: il.

Tese (Doutorado) - Programa de Pós-Graduação em Meios e Processos Audiovisuais - Escola de Comunicações e Artes / Universidade de São Paulo.

Orientador: Prof. Dr. Cristian da Silva Borges.

Bibliografia

1. Estética cinematográfica 2. Teoria de cinema 3. Análise fílmica 4. Espaço e tempo I. Borges, Cristian da Silva II. Título. 



\section{FOLHA DE APROVAÇÃO}

Lucas Bastos Guimarães Baptista

Espaço e tempo como parâmetros de composição fílmica: um estudo comparativo

Tese apresentada ao Programa de Pós-Graduação em Meios e Processos Audiovisuais, para obtenção do Título de Doutor.

Área de Concentração: Meios e Processos Audiovisuais.

Linha de Pesquisa: História, Teoria e Crítica.

Orientador: Prof. Dr. Cristian da Silva Borges.

Aprovado em:

\section{Banca examinadora}

Prof. Dr.

Instituição: Assinatura:

Prof. Dr.

Instituição: Assinatura:

Prof. Dr.

Instituição: Assinatura:

Prof. Dr.

Instituição: Assinatura:

Prof. Dr.

Instituição: Assinatura: 



\section{AGRADECIMENTOS}

Ao Prof. Dr. Cristian da Silva Borges, pela confiança e pelo incentivo, pela orientação tranquila, e pelas observações que ajudaram a desenvolver o projeto e o próprio texto.

Ao Prof. Dr. Luiz Carlos Oliveira Jr. e ao Prof. Dr. Mateus Araújo Silva, pelos comentários na qualificação, e à Profa. Dra. Flávia Cesarino Costa, ao Prof. Dr. Carlos Adriano Jerônimo de Rosa, à Profa. Dra. Patrícia Mourão de Andrade, e ao Prof. Dr. Mateus Araújo Silva, pelos comentários na banca de defesa, fundamentais para que a tese encontrasse sua forma definitiva.

Ao Conselho Nacional de Desenvolvimento Científico e Tecnológico (CNPq), pela bolsa concedida, sem a qual a pesquisa não teria sido possível.

Aos amigos e colegas com quem discussões e conversas frequentemente ajudaram a refletir sobre os temas aqui tratados: Alexandre Wahraftig, Bernardo Versiani, Bruno Andrade, Calac Nogueira, Cristiane Senn, Daniel de Oliveira, Edson Costa, Fábio Visnadi, Filipe Chamy, Guilherme Savioli, Ivan Amaral, João Vitor Leal, Kevin Albuquerque, Lívia Lima, Luan Gonsales, Maria Chiaretti, Matheus Cartaxo, Natália Belasalma, Nikola Matevski, Pedro Faissol, Rafael Dornellas, Rodrigo Faustini, Sabrina Greve, Vinícius Nogueira, e a Bruno Cursini, pela generosidade em copiar e escanear textos importantes para a pesquisa.

Aos meus pais, pelo apoio constante. 



\title{
RESUMO
}

O objetivo desta tese é propor uma comparação das formas como o espaço e o tempo são elaborados em filmes das mais diversas inclinações, a fim de estabelecer alguns parâmetros do que seria a composição fílmica de maneira geral. A hipótese central é que uma análise comparada dessas formas possibilita organizar uma visão de conjunto do cinema: uma visão descritiva, não prescritiva; uma visão baseada nas próprias estratégias composicionais utilizadas pelos cineastas, mais do que em teorias externas. Para realizar essa investigação, será proposto um esquema em três partes que permite um diálogo com a bibliografia tradicional e que serve como referência para a análise dos filmes.

Palavras-chave: Estética cinematográfica; Teoria de cinema; Análise fílmica; Espaço e tempo.

\begin{abstract}
This thesis proposes a comparative study of the modes by which space and time are constituted in films of various dispositions, in order to establish the parameters of what would be film composition in a more general sense. The central hypothesis is that a comparative analysis of those forms enables us to organize a more unified point of view towards the films: a point of view which is descriptive, not prescritipve, and which is based on the strategies utilised by the filmmakers themselves, more than on preconceived theories. In order to advance this, we propose a three-part structure which serves as a reference to compare both theoretical writings and the films to be analyzed.
\end{abstract}

Keywords: Film aesthetics; Film theory; Film analysis; Space and time. 

1. FOTOGRAMA - MODOS DE ARTICULAÇÃO

1.1. O grau zero da composição 23

1.2. A linearidade da projeção 30

1.3. Ciclos e reiterações 36

1.4. O princípio de variação 47

1.5. Anatomia cromática 54

1.6. Filme, Fluxus, Flicker 59

1.6.1. Polarização do fotograma 63

1.6.2. Montagem métrica 66

2. MOVIMENTO - PLASTICIDADE COMBINATÓRIA

2.1. As coordenadas da tela 67

2.2. Ponto e linha sobre plano 76

2.3. A tendência orgânica 86

2.4. Permutações figurativas 95

2.5. Revisão das coordenadas 107

$\begin{array}{lll}\text { 2.6. Influências e desdobramentos } & 117\end{array}$

$\begin{array}{ll}\text { 2.6.1. A pintura e a superfície da tela } & 118\end{array}$

2.6.2. A música e a estrutura temporal 123

2.6.3. O paradigma da animação 127

2.6.4. A montagem rítmica e o conceito de intervalo 128 
3. PLANO - PROPRIEDADES E LIMITES

3.1. A hipótese do contínuo 135

3.2. A paralaxe do movimento e o fora-de-campo 143

3.3. Causalidade e reversibilidade 149

3.4. Sob o microscópio 156

3.5. Estados da matéria 164

3.5.1. Questionamento e afirmação das bordas 166

$\begin{array}{ll}\text { 3.5.2. Pontos de congelamento e ebulição } & 171\end{array}$

3.5.3. Repetição e diferença 177

$\begin{array}{ll}\text { 3.5.4. Imagem sobre imagem } & 179\end{array}$

$\begin{array}{ll}\text { 3.5.5. A elasticidade do plano } & 181\end{array}$

4. CENA - A CAIXA DE ATRAÇÕES

4.1. Entre o palco e a fantasmagoria 187

4.2. A física da caixa 203

4.3. Coreografia, ou o valor do movimento 215

$\begin{array}{ll}\text { 4.4. Possibilidades de uma caixa } & 227\end{array}$

4.4.1. O problema da integração 236

PARTE III - VIRTUALIDADE

5. SEQUÊNCIA - ENCADEAMENTO E FIGURAÇÃO

5.1. A linearização da montagem 243

5.2. Paralelismo e convergência 253

5.3. O ponto de vista e as coordenadas do suspense 269

5.4. Da figuração à montagem intelectual 293

5.5. O contexto de implicação 305

5.5.1. Variantes da figuração 310

5.5.2. O gesto e a ligação vertical 316

5.5.3. Permutações virtuais 322 
Bibliografia

Filmografia 357 



\section{INTRODUÇÃO}

O objetivo desta tese é propor uma comparação das formas como o espaço e o tempo são elaborados em filmes das mais diversas inclinações, a fim de estabelecer alguns parâmetros do que seria a composição fílmica de maneira geral. Os termos desse projeto serão aqui definidos mais claramente e servirão de base para a hipótese central, a ser abordada mais adiante. As definições comentadas, por sua vez, devem permitir a compreensão dos problemas envolvidos e, a partir deles, dos critérios que devem ser exigidos nesta proposta.

Em que consiste a ideia de "composição" fílmica? De que modo esse termo, que faz parte do vocabulário corrente de artes como a música e a pintura, se apresenta no discurso sobre o cinema? Não nos cabe aqui esgotar a questão e sim traçar suas principais linhas de força, evidenciando o potencial contido no próprio questionamento.

Quando Jacques Aumont e Michel Marie se propõem a definir o termo, eles incluem uma concisa retrospectiva, observando as contribuições feitas por autores de diferentes procedências. Eles indicam que a composição foi descrita como possuindo ao menos duas acepções. A primeira delas é análoga ao uso do termo na pintura e equivale aos aspectos visuais do cinema. O sentido da "organização da superfície da imagem" foi retomado, sobretudo durante o período do cinema silencioso, por nomes como Béla Balázs, Sergei Eisenstein, Élie Faure e Fernand Léger. Quando se referem à composição fílmica, estes autores têm em mente a "disposição geral das linhas, movimentos de conjunto, arranjo das luzes e sombras, harmonia das cores, colocação das personagens e dos objetos, 'atmosfera afetiva' da ação apresentada". A segunda acepção do termo está ligada à música e envolve a utilização dos elementos sonoros (falas, ruídos, silêncios e músicas) nos eixos da sucessividade e da simultaneidade. Por essa via, alguns autores se referem a formas de encadeamento contínuo, rupturas, fusões, mas também a "relações 
entre os elementos co-presentes em um dado momento do filme (contrastes, encobrimentos parciais ou completos, contrapontos)".

$\mathrm{Na}$ tentativa de generalizar essas vertentes e de incluir som e imagem sob um mesmo conceito, é proposta então a seguinte definição para a composição: "a ação de formar o todo e o resultado dessa ação". A ação de formar o todo, isto é, o ato de compor, ou ainda o conjunto de técnicas envolvidas na criação e organização do objeto final. Aqui a composição é algo que sugere uma disciplina, no sentido usual encontrado no campo das possibilidades artísticas. Quando se diz que um músico "estuda composição", por exemplo, o que ele estuda é precisamente este conjunto de técnicas. Mas também $o$ resultado dessa ação, ou seja, a unidade particular e perceptível, o que Aumont e Marie descrevem como "a ordem, as proporções e as correlações das diferentes partes de uma obra de arte",2. Algo passível de análise e reflexão, portanto, como quando um crítico "estuda a composição" de uma obra. Partindo dessa definição, podemos dizer que a realização e a análise de um filme, como vetores inversos, encontram-se no ponto representado pelo objeto, onde cristalizam e reencontram suas diretrizes. A composição parece incluir um conhecimento particular sobre os elementos presentes na arte, os modos pelos quais pode-se articular tais elementos, e as formas alcançadas por tais articulações. A composição envolveria, de uma só vez, a constituição final da obra e seu processo constituinte.

No contexto de um dicionário, Aumont e Marie definiram a composição com um estudo teórico comparativo. Em uma conferência dedicada ao tema, o cineasta norteamericano Hollis Frampton colocou suas preocupações no plano prático, buscando definir a composição "a partir da própria maneira como os filmes são feitos". A caracterização de Frampton como um artista ligado às vanguardas modernistas o torna um caso representativo deste tipo de reflexão. Ele aponta duas atividades básicas em qualquer obra cinematográfica: filmagem e montagem.

Primeiro, o material fílmico é gerado. O material é nada mais do que a fita com as imagens; gerá-la é filmar um pretexto, isto é, imprimir imagens sobre a emulsão fotográfica. Então, o material é estruturado. Estruturar o material cinematográfico é determinar, por quaisquer meios, que fitas de filme devem entrar na composição e quais

\footnotetext{
Jacques Aumont, Michel Marie, Dicionário teórico e crítico de cinema, trad. Eloisa Araújo Ribeiro (Campinas: Papirus, 2001), pp. 57-58.

2 Ibid.
} 
não devem; se devem entrar na composição integralmente ou em parte; e em que ordem as fitas de filme serão integradas. ${ }^{3}$

Assim como Aumont e Marie identificam diferentes acepções do termo "composição", Frampton reconhece diferentes abordagens possíveis nas duas atividades. Alguns cineastas, ele diz, viram a montagem como "nada mais que o fechamento de um esquema que preestabeleceu todas as qualidades do material cinematográfico e todos os aspectos de seu acúmulo". Neste caso, a criação do material torna-se algo como a concretização de um planejamento, a ser apenas reduzida e ordenada na etapa seguinte. ${ }^{4}$ Para outros, a montagem seria sinônimo de decodificar "as implicações do material cinematográfico acumulado em um vácuo intencional". Aqui, o material é criado, não tendo em vista um programa estabelecido anteriormente, mas como num estado de sintonia, de afinação com certas referências que permitem alguma amplitude de ação. Estruturar o material seria, portanto, sinônimo de filtrar o conjunto, efetuando as ligações subjacentes às suas qualidades. Entre as duas posições haveria não uma separação estrita, mas uma linha modulada continuamente.

A filmagem e a montagem são, assim, as duas etapas fundamentais com as quais o cineasta se confronta. Elas constituem os dois momentos inevitáveis em sua prática, como numa generalização dos aspectos visuais e sonoros mencionados por Aumont e Marie. Uma segunda polaridade é ainda identificada por Frampton, em relação à dependência ou independência da composição fílmica de códigos derivados externamente, como a linguagem. Se filmagem e montagem são "o ato de compor o todo", esta segunda polaridade diz respeito a uma concepção de como será "o resultado deste todo".

Onde o filme foi visto como subordinado à linguagem, a composição fílmica tornou-se nada mais que a realização de um roteiro minuciosamente especificado. Onde o ato de fazer um filme alcançou completa independência da linguagem, uma decupagem, ou lista métrica de planos, sintetizada empiricamente após a obra ser completada, desloca o roteiro em um gesto de inversão temporal. Frequentemente o roteiro se torna rarefeito, tomando a forma de breves direções verbais, rascunhos gráficos ou mesmo notações

Hollis Frampton, "Notes on Composing in Film" (1976), in On the Camera Arts and Consecutive Matters: The Writings of Hollis Frampton, ed. Bruce Jenkins (Cambridge/Londres: The MIT Press, 2009), p. 155. Todas as traduções são nossas, exceto quando indicado.

4 É importante no pensamento de Frampton a noção de que a "filmagem" inclui não apenas o registro contínuo com uma câmera, mas a "criação do material" de maneira geral. Em outros textos, Frampton defende a apropriação de material alheio e a interferência neste material como estratégias criativas válidas. Para seus fins, "não há evidência na lógica estrutural da fita de filme que diferencie 'material bruto' de obra 'terminada'. Sendo assim, qualquer pedaço de filme pode ser visto como 'material bruto', para ser utilizado de qualquer maneira imaginável na construção ou reconstrução de uma nova obra". Ver Hollis Frampton, "For a Metahistory of Film: Commonplace Notes and Hypotheses" (1971), op cit., p. 136. Veremos nos três primeiros capítulos da tese alguns desdobramentos desse raciocínio. 
numéricas; em seu nível mais remoto, o "roteiro" se reduz à pré-visualização mais ou menos completa no olho da mente. ${ }^{5}$

Da mesma forma, não uma marcação discreta, mas uma modulação contínua separa os dois extremos.

As preferências de cada autor (teórico ou cineasta) se manifestam naturalmente em uma dessas direções, e não são raras no discurso sobre o cinema as defesas e os ataques a um método particular. Mas o que interessa a Frampton é a descrição do "campo de possibilidades" e daquilo que está envolvido na composição de maneira geral. O estudo da composição aqui é como um estudo das "regras do jogo", das categorias que permitem não um tipo específico de cinema, mas o cinema como um todo. Quando Jean Mitry afirma que a consecução temporal da composição fílmica exige um pensamento dramático, por exemplo, ou quando Peter Kubelka afirma que a natureza da fita de filme exige um pensamento ao nível do fotograma, em ambos os casos há uma mobilização de certas áreas do cinema em detrimento de outras; há o reforço de algumas técnicas e a redução do escopo de resultados desejados. No campo imaginado por Frampton, deve ser possível estabelecer a localização dessas posturas sob as mesmas coordenadas.

Neste ponto, devemos traçar uma ligação da ideia de composição com as discussões acerca das teorias de cinema. A visão sugerida por Frampton, de um campo onde diferentes formas cinematográficas poderiam ser dispostas e vistas umas em relação às outras, é consonante com o tratamento dado à reflexão cinematográfica por alguns teóricos.

Quando se propõe a exposição das "principais teorias de cinema", Dudley Andrew procura destacar uma série de autores e colocá-los frente a questões comuns. Ele diz ter escolhido "os pensadores que articulam melhor uma posição, que têm atrás de si ou um raciocínio extensivo ou uma tradição importante". Com isso, ele divide os autores em dois grupos: aqueles que se destacam por uma tendência formativa e os que constituem uma tendência realista. Para os realistas (André Bazin, Siegfried Kracauer), o registro fotográfico é enfatizado positivamente como o traçado da luz sobre o material fílmico, a marca do mundo a ser representado em sua continuidade e unidade fundamentais - o que exige uma continuidade equivalente nos planos, e a diminuição das interferências plásticas e rítmicas da montagem. Os autores formativos, por sua vez (Rudolf Arnheim, Béla Balázs), defenderiam um cinema que manipula e reconstitui o mundo, exaltando os 
aspectos considerados expressivos na tecnologia fílmica - do que decorre uma defesa da sobreposição, decomposição, distorção ou alteração das aparências, através da montagem e de intervenções visuais. As diferenças internas em cada grupo são elaboradas cuidadosamente, mas os fatores que permitem a separação dos autores em dois lados são cruciais na estrutura da análise.

Essa caracterização resulta da sistemática comparação que é efetuada a partir dos quatro grandes tópicos colocados por Andrew, que os encara como categorias derivadas das causas aristotélicas:

1. A "matéria-prima" inclui perguntas sobre o veículo, tais como as que procuram sua relação com a realidade, fotografia e ilusão, ou as que dizem respeito a seu uso do tempo e do espaço, ou mesmo as que se referem a processos como cor, som e a decoração da sala de exibição. Tudo o que existe como um estado de coisas com o qual começa o processo cinematográfico pertence à categoria da "matéria-prima".

2. Os "métodos e técnicas" de cinema compreendem todas as perguntas sobre o processo criativo que dá forma ou trata a matéria-prima, indo das discussões sobre os desenvolvimentos tecnológicos (como a tomada em zoom) à psicologia do cineasta ou mesmo à economia da produção cinematográfica.

3. "Formas e modelos" do cinema é a categoria que contém perguntas sobre os tipos de filmes que foram ou poderiam ser feitos. Perguntas sobre a capacidade do cinema de adaptar outros trabalhos de arte pertencem a esta categoria, assim como perguntas sobre gênero e expectativa da plateia ou sobre a repercussão. Aqui analisamos os filmes partindo da premissa de que são um processo completo no qual a matéria-prima já se tornou forma através de vários métodos criativos. O que determina essas formas e como elas são reconhecidas por uma plateia?

4. "Objetivo e valor" do cinema é a categoria que se relaciona aos aspectos mais amplos da vida, pois aqui residem todas as perguntas que investigam o objeto do cinema no universo do homem. Uma vez que a matéria-prima foi moldada por um processo, obtendo determinada forma significativa, que significa isso para a humanidade? ${ }^{6}$

O esquema de Andrew nos permite observar a disposição de certos problemas relativos à composição fílmica por autores com formações e objetivos contrastantes. É uma premissa de sua análise que o diálogo existe apenas com a base comum estabelecida pelas perguntas: se encaramos isoladamente as proposições de cada autor, multiplicam-se não apenas as divergências entre as ideias, mas também entre os próprios métodos críticos. Algumas das posições foram derivadas de questões práticas; outras, de uma investigação puramente teórica; o que permanece constante é a adesão de cada uma delas

\footnotetext{
Dudley Andrew, As principais teorias de cinema, trad. Teresa Ottoni (Rio de Janeiro: Zahar, 2002), p. 16 (foi preferido retraduzir o termo "cinematic" como "cinematográfico" em vez de "cinemático", para manter o vocabulário de Andrew mais próximo do conjunto bibliográfico tratado no decorrer da tese). As quatro causas descritas por Aristóteles são: a causa material, a causa formal, a causa eficiente e a causa final. Ver Física, liv. II, cap. 3, e Metafísica, liv. V, cap. 2.
} 
a uma espécie de programa, a um conjunto de noções subjacentes que delimita o discurso ao mesmo tempo em que define seu objeto. ${ }^{7}$

Se o interesse é um desenvolvimento propriamente teórico, não basta que se reforce os princípios: na análise de cada autor, é preciso que as respostas sejam aplicáveis a mais casos do que aqueles que geraram as perguntas. As proposições devem ser incorporadas na unidade da disciplina teórica. Isto ocorre porque a teoria do cinema "não está preocupada basicamente com filmes ou técnicas individuais, mas com o que pode ser chamado de a própria capacidade cinematográfica". ${ }^{8}$ Há aqui uma ligação estreita com as abordagens de Aumont/Marie e Frampton, no sentido de que as potencialidades criativas do cinema - a "capacidade cinematográfica", em toda a sua extensão e variedade podem vir a delimitar uma área de estudos. É fundamental que as perguntas digam respeito à realização dos filmes, desde o tratamento da matéria até seu objetivo, passando pelos métodos e modelos formais; é este ponto que coloca a composição no plano da atividade teórica, dando referências sólidas e comuns para comparar as mais diferentes tendências. De maneira geral, estuda-se o que pode ser feito com a "capacidade cinematográfica", e uma das coisas que se aprende no decorrer desse estudo é a “composição fílmica”.

A aproximação do estudo da composição a uma concepção de teoria fílmica torna necessários alguns esclarecimentos. Não é parte do escopo desta introdução uma revisão sistemática do papel da teoria no cinema. É de nosso interesse, antes, apontar certas relações entre o que caracteriza o estudo teórico e a ideia de composição. Podemos resumir as observações feitas até aqui em três tópicos: (1) o estudo da composição fílmica envolve o conjunto de práticas que formam uma obra e os resultados possíveis da utilização dessas práticas; (2) as etapas constituintes da composição podem ser representadas por uma espécie de "campo", onde as diferentes tendências são dispostas

A postura de Andrew guarda semelhanças com a noção de "paradigma" difundida por Thomas Kuhn. Um paradigma é um conjunto de princípios, generalizações teóricas e métodos de trabalho que coordenam as práticas de um grupo de cientistas. Não se pretende aqui uma adaptação da tese de Kuhn para o domínio da estética, mas é importante para o argumento de Andrew a delimitação da área a ser tratada, e do trabalho do crítico/teórico como contido dentro dessa área. Uma citação de Kuhn é representativa desse argumento: "o homem que luta para resolver um problema definido pelo conhecimento e pela técnica existentes não se limita simplesmente a olhar à sua volta. Sabe o que quer alcançar; concebe seus instrumentos e dirige seus pensamentos de acordo com seus objetivos". Ver Thomas Kuhn, A estrutura das revoluções científicas, trad. Beatriz Vianna Boeira e Nelson Boeira (São Paulo: Perspectiva, 2010), p. 130.

8 Andrew, As principais teorias de cinema, op. cit., p. 13. A proposta de Andrew remete ao formalismo russo, de cujos textos ele parece derivar o vocabulário. Ver, por exemplo, Boris Eikhenbaum, "A teoria do "método formal", in Teoria da literatura: formalistas russos, ed. Dionísio de Oliveira Toledo (Porto Alegre: Globo, 1973), pp. 8-9, onde é comentado o preceito de Jakobson de que a "ciência literária" deve estudar a "literaridade" - seu termo para a "capacidade literária". 
sob princípios comuns; (3) a definição dos princípios que organizam o campo deve prezar pela amplitude e coerência interna, de modo a incluir uma variedade de posturas sem necessariamente traçar entre elas uma hierarquia.

Em 1976, Dudley Andrew propôs o esquema das quatro categorias de perguntas e dividiu os autores analisados em duas vertentes, os formativos e os realistas; no ano seguinte, Ismail Xavier estabeleceu um quadro organizado ao redor de um eixo semelhante, que denominou a opacidade e a transparência. Ambos viram-se perante uma multiplicidade de posturas e sentiram a necessidade de agrupá-las em tendências, como numa identificação dos principais direcionamentos tomados pelo acúmulo da reflexão fílmica. ${ }^{9}$ Nos dois casos, não é mencionada a "composição" durante a descrição do método de análise, mas é explícita a recorrência dos três tópicos citados anteriormente. Num caminho análogo ao de Andrew, Xavier afirma que o propósito de sua investigação é “organizar a concepção assumida por diferentes autores e escolas quanto ao estatuto da imagem/som do cinema frente à realidade (dentro das concepções conflitantes que se tem desta)." ${ }^{10}$ Em seguida, ele define com clareza a já mencionada relação entre o caráter particular de cada concepção e a posição que ela vem a ter no quadro teórico geral:

Para evitar confusões raramente faço uso do termo "teoria", uma vez que, esquematicamente, as perspectivas são compostas em dois momentos básicos: há, em cada proposta, uma ideologia de base que pretende explicar, ou simplesmente postular, a existência de certas propriedades, na imagem/som do cinema. Dentro do espaço criado por tal ideologia é feita uma determinada proposição referida à prática cinematográfica, basicamente no que diz respeito ao modo de organizar a imagem $/ \mathrm{som}$, tendo em vista a realização de certo objetivo sociocultural tomado como tarefa legítima do cinema. Em geral, a conexão entre teoria "geral" e norma "particular" ganha nitidez na medida em que a norma, referida ao que o cinema "deve ser", procura apoio numa teoria que, em primeiro lugar, garanta que o cinema "pode ser" o que se lhe pede e, em segundo lugar, afirme que "é mais próprio à sua natureza" ser o que se lhe pede. Por estes motivos, prefiro usar o termo "estéticas cinematográficas", aplicado a proposições dispostas a orientar uma determinada prática e uma determinada crítica cinematográfica. ${ }^{11}$

A cautela quanto ao uso do termo "teoria" é sintomática. Na estrutura argumentativa do texto, seus objetos não são teorias "propriamente ditas" justamente por aderirem a uma "ideologia" específica; a teoria "de fato" envolveria, de alguma maneira, a recusa a tal

\footnotetext{
9 Na década seguinte, Noel Carroll apresentou um quadro praticamente idêntico ao de Andrew numa breve exposição de escolas teóricas. Em lugar do termo "formativo", Carroll se referiu à mesma tradição como "criacionista". Ver Noel Carroll, Mystifying Movies (Nova York: Columbia University Press, 1988), pp. 106-111.

10 Ismail Xavier, O discurso cinematográfico: a opacidade e a transparência (Rio de Janeiro: Paz e Terra, 1977), p. 13.

11 Ibid., pp. 13-14.
} 
adesão. Nas palavras de Andrew, teorizar sobre o cinema é "formular uma noção esquemática da capacidade dessa arte". ${ }^{12}$ Estão pressupostas aqui tanto a generalização como a coordenação das diferenças num mesmo quadro. É crucial, ainda, a relação entre o caráter propositivo das "estéticas" e a relação deste com a composição fílmica, já que cada uma das perspectivas refere-se a "modos de organizar a imagem/som" e argumenta sobre as propriedades mais importantes ou sobre os efeitos mais desejáveis.

Podemos traçar uma relação da teoria com a composição retomando, assim, a compreensão teórica tanto de Aumont como de Frampton. Quando Aumont define a função da teoria fílmica, ele recorre a alguns aspectos já colocados em sua descrição da composição. Ele parece supor "a ação de formar o todo e o resultado dessa ação", bem como o sentido de estudo comparativo mencionado anteriormente:

Uma teoria é a atitude que compreende a elaboração de conceitos capazes de analisar um objeto. Contudo, o termo tem ressonâncias normativas que convém dissipar. Uma teoria do cinema, no sentido que é dado aqui, não se refere a um conjunto de regras segundo as quais conviria realizar filmes. Ao contrário, essa teoria é descritiva, esforça-se por explicar fenômenos observáveis nos filmes, assim como pode considerar hipóteses ainda não atualizadas nas obras concretas, criando modelos formais. ${ }^{13}$

Parece ser um consenso que o objetivo do esforço teórico é a descrição, e que essa atitude, análoga à das ciências naturais, pressupõe um desinteresse fundamental, um desligamento do autor em relação às preferências e aos direcionamentos possíveis do campo artístico, de modo que ele seja capaz de observar as relações dos fatos com as possibilidades fora de uma escala de valores. Alguns dos gestos críticos não tiveram a metodologia científica como norte; em muitos casos, predomina o impulso ensaístico ou mesmo jornalístico; o objetivo da teoria seria, então, receber tais contribuições $e$ distinguir as condições em que se deram as descobertas, separando o que é inevitável e fixo do que é possivel e contingente. O resultado desse esforço seria um campo que envolve tanto os "fenômenos observáveis nos filmes" quanto hipotéticos "modelos formais"; tanto a dedução a partir de princípios quanto a indução a partir de observação empírica.

Outro problema deve ser considerado sobre a menção a uma teoria fílmica. Este problema diz respeito à unidade ou multiplicidade da teoria, ou ainda, aos direcionamentos da investigação teórica. Os esquemas propostos até aqui partiram de uma

12 Andrew, As principais teorias de cinema, op. cit., p. 15

13 Jacques Aumont, A estética do filme, trad. Marina Appenzeller (São Paulo: Papirus, 2006), p. 15 (grifo nosso). 
análise comparativa de textos sobre filmes, bem como da generalização da prática dos cineastas. Entretanto, em sua revisão, na qual se baseia para definir a teoria fílmica, Aumont nos lembra que a teoria procede "internamente", retirando dos filmes sua terminologia e seus conceitos, mas também "externamente", retirando de disciplinas outras que não o cinema, categorias e métodos que serão então aplicados ou adaptados aos objetos fílmicos. A tendência de operar "internamente" seria exemplificada pelo trabalho de André Bazin, que resultaria "da teorização acumulativa das observações mais pertinentes da crítica de filme quando esta é praticada com certa sutileza". Um autor como Jean Mitry, por sua vez, recorrendo a múltiplas referências estabelecidas fora do cinema, seria uma prova de que o pensamento fílmico "não poderia se constituir sem as contribuições da lógica, da psicologia da percepção, da teoria das artes etc."14

A mesma dualidade é expressa por Frampton quando este se refere aos objetivos desejáveis para o estudo da composição fílmica. Ele defende que se traga para o estudo "uma compreensão ampla dos axiomas de cada disciplina da qual o filme, conscientemente ou não, se apropriou"; ao mesmo tempo, ele descreve uma visão que não depende completamente dessas disciplinas:

Até aqui, o estudo do filme tem sido compartimentalizado horizontalmente, em busca de evoluções diacrônicas paralelas, e verticalmente, por uma tipologia crassa que distingue espécimes cinematográficas umas das outras de acordo com seu uso social. Tal morfologia supõe que filmes individuais, e mesmo conjuntos de obras, são objetos isolados; considera que entender um filme envolve nada mais do que determinar sua localização precisa em uma grade pré-determinada. Nós propomos outra morfologia, radicalmente diferente... uma que veja o filme não por fora, como um produto a ser consumido, mas por dentro, como um código orgânico em evolução, diretamente responsável e responsivo, como qualquer outro código, à mediadora suprema: a consciência. ${ }^{15}$

O que temos aqui é uma imagem da teoria como podendo ser direcionada "para dentro", voltando as atenções para o objeto fílmico e seus processos constituintes, no sentido de uma área autônoma; mas também "para fora", abrindo o objeto fílmico a uma série de contextos externos a ele, marcando seus pontos de contato com outras áreas. A "teorização indígena", neste caso, seria derivada de um olhar direto para as obras, conduzindo a uma visão do cinema como o "código orgânico" mencionado por Frampton. A outra teorização seria o resultado de contribuições metodológicas que não dizem

\footnotetext{
14 Aumont, A estética do filme, op. cit., pp. 14-15.

15 Frampton, "Notes on Composing in Film", op. cit., p. 155.
} 
respeito necessariamente ao trabalho direto com a matéria fílmica, mas que o atravessam continuamente, em seus efeitos ou em seu arcabouço conceitual.

Os recortes efetuados por Andrew e Xavier incluem, em seus comentários finais, uma menção aos desenvolvimentos teóricos que, a partir dos anos 1970, aproximaram disciplinas como a semiologia e a psicanálise lacaniana do pensamento cinematográfico, e as exigências que tais escritos pareciam trazer, buscando relacionar o cinema com uma área mais ampla do campo das humanidades. A predominância desses tópicos pareceu representar, então, uma guinada centrífuga nos estudos teóricos. Nas décadas seguintes, ataques foram desferidos a esta predominância, e ao que alguns autores viram como sendo um excesso de abertura a disciplinas que se propunham, mais do que descrever, “explicar e valorizar" os processos fílmicos. Um dos exemplos mais característicos desses ataques é a compilação organizada por Noel Carroll e David Bordwell em 1996, onde a ideia da "grande teoria" é atacada em favor de um trabalho "intermediário", sem adesão a sistemas filosóficos ou a disciplinas estabelecidas à parte do cinema. ${ }^{16}$ Enquanto as "grandes teorias" tomariam como base questões mais amplas, muitas vezes relativas às funções sociais e psíquicas do cinema, o trabalho intermediário se preocuparia com questões de ordem prática, ligadas diretamente à realização e à descrição. O principal erro das "concepções monolíticas da teoria fílmica", para Carroll, é "supor um corpo unificado de ideias com certas proposições de base, das quais conclusões sobre casos concretos se seguem em vários caminhos, uma vez que certas possibilidades empíricas são consideradas". ${ }^{17}$ Dessa forma, a teorização se tornaria a aplicação de uma unidade de pensamento maior às questões cinematográficas - nos termos de Frampton, a compreensão do filme seria baseada em "sua localização em uma grade pré-determinada".

Um ponto semelhante é levantado num debate publicado na revista October, em 2014, onde Malcolm Turvey argumenta que as "grandes teorias" tenderam a supor uma visão filosófica que se aproximava de uma doutrina, com uma terminologia e mesmo uma historiografia próprias. Um dos problemas dessa postura é que, se os axiomas sobre os quais a teoria é construída são derrubados em seu terreno original (filosofia, semiologia,

16 Carroll e Bordwell consideram sobretudo a influência desses autores no ambiente acadêmico. A mesma trajetória é descrita no domínio mais específico dos debates sobre cinema experimental, por P. Adams Sitney, no posfácio da $3^{\text {a }}$ edição de Visionary Film (Nova York: Oxford University Press, 2002), pp. 409-410.

17 Ver Noel Carroll, "Prospects for Film Theory: A Personal Assessment", in Post-Theory: Reconstructing Film Studies, eds. David Bordwell e Noel Carroll (Madison: University of Wisconsin Press, 1996), pp. 38-41. O texto de Carroll retoma alguns dos argumentos desenvolvidos na primeira parte de seu livro Mystifying Movies, onde são analisadas as teorias dos "semióticos psicomarxistas". 
psicanálise, etc.), também seus desdobramentos no cinema seriam postos em dúvida, pois o pensamento cinematográfico estaria acoplado a outro pensamento, "nãocinematográfico". Turvey diferencia essas abordagens daquelas sugeridas pelos teóricos das primeiras décadas do cinema, que tendiam a ser mais pontuais, mais pragmáticas, parecendo supor uma epistemologia heterogênea e especulativa. Havia também o contato com outras disciplinas, mas o trabalho se realizava progressivamente, mais de acordo com os problemas práticos do que com postulados filosóficos anteriores. ${ }^{18}$ Em contraste ao conjunto de "proposições esotéricas", o que essas objeções apontam é o desejo de um avanço gradativo, esperando que o sucesso parcial das análises propicie condições para novos avanços.

Uma argumentação sistemática contra os impulsos centrífugos da teoria foi apresentada pelo crítico literário Northrop Frye. A bibliografia de Frye é caracterizada por uma série de obras voltadas à metodologia crítica, e parte delas possui uma visão que utiliza o pensamento sobre a literatura para se referir ao pensamento estético como um todo. ${ }^{19}$ A matriz argumentativa nesses livros é semelhante aos procedimentos teóricos citados aqui em relação ao cinema, e Frye defende abertamente uma guinada centrípeta uma concentração na autonomia do campo da arte, a descrição de suas práticas concretas e de seus modelos formais. Ao criticar a definição da composição literária, de sua compreensão e de seus valores por uma disciplina externa, Frye menciona constantemente o que chama de "falácia do determinismo",

que se dá quando um acadêmico com um interesse especial em geografia ou economia expressa tal interesse pelo dispositivo retórico de colocar seu estudo favorito em uma relação causal com tudo o que lhe interessar menos. Tal método proporciona a ilusão de se compreender um assunto conforme se avança em seu estudo, não havendo perda de tempo. Seria fácil compilar uma longa lista de determinismos na crítica, todos eles, sejam marxistas, tomistas, liberal-humanistas, neoclássicos, freudianos, junguianos ou existencialistas, substituindo uma atitude crítica por crítica, propondo todos, em vez de encontrar uma estrutura para a crítica dentro da literatura, ligar a crítica a uma dentre a miscelânea de estruturas fora dela. Os axiomas e postulados da crítica, entretanto, devem brotar da arte da qual a crítica se ocupa. A primeira coisa que o crítico literário deve fazer

18 Ver "Roundtable on the Return to Classical Film Theory", October 148 (primavera de 2014), pp. 22-23. Assim como Carroll e Bordwell, Turvey se refere sobretudo aos teóricos que surgiram na França a partir dos anos 1960 e 1970, como Christian Metz e Gilles Deleuze. Dudley Andrew também participa do debate, e inclui o nome de Jacques Rancière entre os autores que representariam um interesse na abertura do cinema a outras disciplinas.

19 Alguns dos principais livros com as reflexões de Frye sobre o tema são The Educated Imagination (Toronto: CBC Enterprises, 1963), The Well-Tempered Critic (Bloomington: Indiana University Press, 1963) e The Stubborn Structure (Ithaca: Cornell University Press, 1970). 
é ler literatura, realizar uma pesquisa indutiva de sua própria área e deixar seus princípios críticos modelarem-se unicamente a partir de seu conhecimento dessa área. ${ }^{20}$

Numa transposição desses comentários para o terreno de Carroll ou Turvey, poderíamos dizer que a "teoria centrípeta" seria "um exame do cinema com base em uma estrutura conceitual concebida a partir de uma pesquisa indutiva do campo cinematográfico".

Se tomamos como base essas críticas ao impulso centrífugo da teoria, somos levados a dizer que a abertura da composição a critérios externos pode eventualmente distorcer a unidade derivada da própria arte em prol de uma unidade determinada fora dela. Mais do que uma rejeição de aspectos interdisciplinares, o que tais críticas apontam é o quanto as disciplinas operam com a definição de seus objetos. "A física é um campo organizado de conhecimento sobre a natureza", argumenta Frye, mas "um estudante dessa disciplina afirma que está estudando física, não natureza". ${ }^{21}$ Nesse sentido, o estudo da composição fílmica parece ter ao menos uma parte inextricavelmente ligada ao impulso centrípeto, pois se a composição diz respeito às técnicas e às formas presentes no campo criativo da arte - se a composição é "um campo organizado de conhecimento sobre o cinema", incluindo tanto o conhecimento prático quanto o teórico -, é de uma análise do próprio campo que seriam necessariamente derivados os princípios que regulam as variadas disposições.

\section{II}

A definição da composição, a concepção de uma teoria descritiva e a importância do impulso centrípeto do pensamento serão os pilares sobre os quais serão construídas as investigações desta tese. Não se trata de uma negação do impulso centrífugo; trata-se, antes, de uma tentativa de desenvolver certo potencial que envolve as ideias de composição e teoria aqui expostas. Se há alguma necessidade de coexistência entre os

20 Northrop Frye, Anatomia da crítica, trad. Marcus de Martini (São Paulo: É Realizações, 2014), pp. 115 116 (grifo nosso). Na página 10 da introdução a esta edição, João Cezar de Castro Rocha comenta o projeto de Frye de um modo que permite ligações diretas com as relações aqui descritas entre a teoria e a composição: "é como se o fazer literário articulasse sua própria teoria, ou, para dizê-lo de outro modo, é como se a identificação de padrões recorrentes de organização da imaginação literária equivalesse ao exercício crítico e teórico mais valioso". Para questões relativas às escolas críticas com as quais Frye dialogou (entre elas a nova crítica e o estruturalismo), e que servem como desdobramentos das questões aqui tratadas, ver também a introdução à edição canadense, por Robert D. Denham.

21 Frye, Anatomia da crítica, op. cit., p. 121. Também aqui há um raciocínio próximo de Thomas Kuhn, como citado em relação a Dudley Andrew. 
dois direcionamentos na teoria, deve ser possível e mesmo desejável uma investigação nesta direção.

Para isso, iremos recorrer a um quadro formado por dois parâmetros composicionais: o espaço e o tempo. Se o estudo da composição envolve o conjunto de práticas que formam as obras e os resultados possíveis da utilização dessas práticas; se as etapas constituintes da composição podem ser representadas numa espécie de campo, onde diferentes tendências são dispostas sob princípios comuns; e se a definição dos princípios que organizam o campo deve prezar pela amplitude e coerência interna, de modo a incluir a variedade de posturas sem estabelecer entre elas uma hierarquia - por essas exigências, as categorias do espaço e do tempo, como os eixos elementares da composição, podem servir como referências privilegiadas num estudo centrípeto do cinema.

Quando Éric Rohmer aborda o tema, ele afirma que o cinema é "uma arte do espaço". Em primeiro lugar, por ser uma arte visual, sendo percebida mesmo através da representação espacial. Em segundo lugar, por ser "uma arte do movimento", devendo organizar os movimentos através de uma hierarquia, excluindo a "mera agitação". A montagem, em vez de uma quebra do espaço ou do movimento, contribui para essa organização ao sugerir contiguidade e continuidade para além do campo de visão da tela. Não se trata de uma negação do fator temporal, mas de um vocabulário crítico que privilegia certos filmes e, através deles, certos princípios teóricos. Mais especificamente, Rohmer argumenta de uma posição tipicamente baziniana, em que o cinema deve ser erigido sobre a "ontologia fotográfica". ${ }^{22}$ Foi Bazin, afinal, quem declarou que pode-se "tirar qualquer realidade da imagem cinematográfica, exceto uma: a do espaço."23

É dando continuidade a este argumento que Rohmer propõe uma definição dos principais tipos de espaço no cinema:

1) O espaço pictórico. A imagem cinematográfica, projetada sobre o retângulo da tela fugidia e móvel como ela seja -, é percebida e apreciada como a representação mais ou menos fiel, mais ou menos bela de uma parte do mundo exterior.

2) $\mathrm{O}$ espaço arquitetônico. Partes do mundo, naturais ou fabricadas, tais que a projeção sobre a tela nos representa, com mais ou menos fidelidade, recebendo uma existência objetiva, e podendo, como tal, ser objeto de um julgamento estético. É com essa realidade que o cineasta se mede no momento da filmagem, que a restitui ou trai.

22 Ver Éric Rohmer, "Cinema, the Art of Space" (1948), in The Taste for Beauty (Nova York: Cambridge University Press, 1989), p. 19.

23 Ver André Bazin, "Teatro e cinema" (1951), in O que é o cinema? (São Paulo: Cosac Naify, 2014), p. 185. 
3) O espaço fílmico. Com efeito, não é do espaço filmado que o espectador tem a ilusão, mas de um espaço virtual reconstituído no seu espírito com o auxílio dos elementos fragmentários que o filme lhe fornece.

Esses três espaços correspondem a três modos de percepção pelo espectador da matéria fílmica. Eles resultam também de três abordagens, geralmente distintas, do pensamento do cineasta e de três etapas do seu trabalho, onde ele utiliza, a cada vez, técnicas diferentes. A da fotografia no primeiro caso, a da cenografia no segundo, da mise en scène propriamente dita e da montagem no terceiro. ${ }^{24}$

A classificação de Rohmer serve como base para uma análise de Fausto (F.W. Murnau, 1926), um filme adequado em vários sentidos ao cinema de sua preferência. Mas o que nos importa no texto é o reconhecimento de que existem diferentes modos de pensar a matéria fílmica, diferentes abordagens técnicas de um mesmo campo de possibilidades. $\mathrm{O}$ aspecto teórico aqui se encontra no fato de que os tipos de espaço são classificados e descritos esquematicamente. Há uma atenção, ainda que parcial, ao domínio dos fatos, ao que independe do caráter prescritivo.

De maneira semelhante, quando Peter Gidal aborda o tema, partindo de uma visão radicalmente oposta à de Rohmer, numa dedicação ao cinema experimental, e principalmente a um cinema que privilegia a materialidade da duração, ele propõe uma definição dos principais tipos de tempo no cinema:

(1) O 'tempo real', isto é, o tempo presente como o foi para o cineasta, denotado e não conotado, no momento da filmagem, edição, impressão, projeção, e inter-relações entre essas etapas. Frequentemente, o 'tempo real' é apresentado em planos isolados ou em segmentos fílmicos utilizados por sua duração de fato [...]. (2) Há o tempo ilusionista, o tempo feito para parecer o que não é, como na montagem convencional e (deve ser dito) em grande parte da montagem eisensteiniana. Por exemplo, corte de 10h15, de um interior em Londres - amantes se beijam - meia-noite à beira do lago, um marido e uma esposa matam um ao outro (plano geral), cada um implicando uma cadeia linear de eventos com o tempo comprimido, ou uma simultaneidade com o tempo comprimido. (3) O terceiro 'exemplo' é o do tempo pós-newtoniano, einsteiniano. Aqui não há valor absoluto que não o da interação entre o momento fílmico e o espectador. Esse tempo relativista pode mas não necessariamente - se conectar ao 'tempo real'. A noção de 'tempo real' em si é incapaz de considerar precisamente a natureza relativa do tempo, a ausência de um relógio universal, ainda que, na falta de uma definição mais precisa, 'tempo real' sirva para meus propósitos $\left[\ldots . .{ }^{25}\right.$

Assim como Rohmer, Gidal direciona a formulação aos filmes que constituem sua área de interesse e que dialogam com a tradição modernista do cinema. $\mathrm{O}$ aspecto teórico, novamente, se encontra no fato de que diferentes tipos de tempo são descritos

24 Éric Rohmer, L'organisation de l'espace dans le Faust de Murnau (Paris: Cahiers du cinéma, 2000), pp. 6-7.

25 Peter Gidal, "Theory and Definition of Structural/Materialist Film", in Structural Film Anthology (Londres: British Film Institute, 1978), pp. 9-10. 
separadamente, de maneira esquemática. Também aqui há o reconhecimento de que as coordenadas devem ser indicadas com alguma neutralidade.

Se o objetivo da teoria, como consideramos anteriormente, é "receber as contribuições e distinguir as condições em que se deram as descobertas, separando o que é inevitável e fixo do que é possível e contingente", podemos então observar as duas classificações e através delas identificar o que parece útil à reflexão sobre filmes que se encontram em outras regiões do campo de possibilidades que não aquelas preferidas por Rohmer e Gidal. Aqui se encontra uma das propostas da tese: o cruzamento e a organização das formas fílmicas serão feitos através de um princípio comum, identificado na própria estrutura comentada por esses autores. Partiremos dos esquemas colocados por Rohmer e Gidal, considerando que eles tocam em grande parte das reflexões sobre essas categorias composicionais em suas respectivas tradições. Tanto na descrição do espaço por Rohmer como na descrição do tempo por Gidal há um mesmo princípio, que podemos chamar de "princípio das dimensões". Nos dois casos, cada tipo é tratado como um nível, uma dimensão que depende da anterior para se constituir, e que deve, de alguma maneira, integrar a dimensão anterior sob um novo sentido.

O espaço pictórico diz respeito à "disposição geral das linhas" e aos "arranjos de luzes e sombras". Este é o espaço que o cinema compartilha com a pintura, isto é, a tela determinada por suas coordenadas bidimensionais. O espaço arquitetônico envolve a "colocação de personagens e objetos" e possui uma relação de analogia com o espaço real, "o mesmo com o qual o cineasta se confronta durante a filmagem". O espaço arquitetônico, portanto, deve pressupor o espaço pictórico: deve integrar o referencial bidimensional, ainda que não se torne idêntico a ele. O que ocorre é uma absorção do espaço pictórico pelo espaço arquitetônico, elaborando uma nova unidade que inclui a profundidade tridimensional sobre as coordenadas bidimensionais. O espaço fílmico, por sua vez, estabelece ligações entre as partes apresentadas e, através delas, compõe uma nova unidade, um espaço "virtual”. Nesse sentido, o espaço fílmico não existe concretamente sobre a tela, já que é caracterizado pelas relações das propriedades de um espaço com as propriedades de outro espaço, existindo apenas como o resultado desse conjunto na mente do espectador.

O mesmo princípio se encontra na classificação de Gidal. O tempo real, "denotado e não conotado", é o tempo cronométrico, o tempo absoluto, sendo por isso inevitável em qualquer modalidade da composição fílmica. Por essa razão, o segundo tipo, o tempo ilusionista, deve necessariamente se constituir sobre esta dimensão: deve absorver o 
tempo cronométrico ainda que dê a ele outro sentido, o sentido "interno" de sua representação particular. O tempo ilusionista, quando identificado com o registro contínuo, é análogo ao espaço arquitetônico, o tempo “com o qual o cineasta se confrontou no momento da filmagem". A dimensão seguinte diz respeito ao que Gidal chamou de tempo pós-newtoniano, que se constitui sobre a referência absoluta do tempo cronométrico e sobre as possíveis ilusões de continuidade e compressão do registro - o que resulta disso é um novo patamar, o deslocamento do sentido temporal para a relação entre "o momento fílmico e o espectador".

Podemos então resumir as duas classificações da seguinte maneira:

1. Espaço pictórico - o espaço bidimensional da tela

2. Espaço arquitetônico - o espaço tridimensional da cena

3. Espaço fílmico - o espaço virtual da mise en scène + montagem

1. Tempo real - o tempo cronométrico da projeção

2. Tempo ilusionista - o tempo interno da representação

3. Tempo pós-newtoniano - o tempo relativo da interação espectador/filme

Os números atribuídos aos tipos correspondem ao que chamaremos aqui de as "dimensões da composição fílmica".

A primeira dimensão, que chamaremos de superfície da composição fílmica, é o nível básico, o mínimo denominador comum. Independente do valor atribuído, essa dimensão é absolutamente inevitável na articulação composicional, ainda que o desejo seja diminuir ou sublimar suas propriedades. No caso do espaço pictórico, ela se define pelas características bidimensionais e superficiais da imagem. Pode-se trabalhar a superfície da imagem e os limites do enquadramento, mas não se pode ignorá-los. O mesmo é válido para o tempo real, um tempo incontornável devido à própria lógica da projeção e da ordenação constante dos fotogramas segundo a velocidade convencional do projetor.

A segunda dimensão trata de uma absorção e superação da primeira, e será aqui definida como a profundidade da composição. Para utilizar a metáfora visual, é como um olhar através da superfície: a manutenção dela com o acréscimo de um terceiro eixo. Dessa maneira, o espaço arquitetônico aceita como dado o espaço pictórico, mas inclui certas características que não estavam presentes nele, como a impressão de 
tridimensionalidade e a unidade cênica. Num processo semelhante, o tempo ilusionista supõe o tempo cronométrico, mas dá a ele outro sentido: a cada plano, a duração absoluta deve ser redefinida pelos critérios estabelecidos na segunda dimensão, um nível superior de organização.

O princípio se repete com a terceira dimensão, que compreende uma nova etapa da "relativização" das anteriores. Ela será chamada aqui de virtualidade da composição. O espaço fílmico, como definido por Rohmer, é o espaço que conjuga diferentes recortes cênicos, o que significa que absorve o espaço arquitetônico (que por sua vez absorve o pictórico), mas acrescenta a ele um novo critério, que é o da unidade "virtual", uma unidade que abarca a mise en scène e a montagem, relacionando diferentes planos, fazendo com que o espectador seja capaz de inferir a partir deles um mesmo espaço ou um complexo particular de relações espaciais. O tempo pós-newtoniano opera na mesma lógica, como uma integração do tempo cronométrico e das possíveis ilusões de continuidade, no que poderíamos chamar de "virtualização" da temporalidade.

As três dimensões se caracterizam então por uma correlação dos tipos de espaço e tempo, como níveis comuns entre eles. Elas podem ser resumidas da seguinte maneira:

\section{DIMENSÕES}

1. SUPERFÍCIE

2. PROFUNDIDADE

3. VIRTUALIDADE

\section{ESPAÇO}

PICTÓRICO

ARQUITETÔNICO

FÍLMICO

\section{TEMPO}

REAL

ILUSIONISTA PÓS-NEWTONIANO

Esse quadro será a grade que sustenta os capítulos a seguir. É através dessas três dimensões, e dos problemas relativos a elas, que a tese será desenvolvida. É importante, entretanto, mencionar dois pontos.

O primeiro é que, no cruzamento entre as duas tipologias, devemos fazer algumas alterações para manter a consistência das três dimensões. Em sua formulação inicial, Rohmer não parece considerar as intervenções diretas sobre a película que caracterizam o cinema de alguém como Stan Brakhage; mas como estas ocorrem na superfície da imagem, serão aqui tomadas como parte desta primeira dimensão. Da mesma forma, Gidal parece considerar a montagem em continuidade uma instância do tempo ilusionista, tendo o mesmo estatuto que um plano isolado; mas consideraremos aqui o tempo ilusionista como essencialmente o tempo do plano, isto é, do registro contínuo; a montagem será vista mais em relação à dimensão seguinte. 
O segundo ponto é que, apesar de partirmos dos termos sugeridos por Rohmer e Gidal, eles não serão retomados e discutidos na tese. Constam como referências iniciais, mas tendo estabelecido esta grade, nosso interesse é justamente explorar as observações pontuais que permitiram sua generalização. As questões relativas ao espaço e ao tempo surgirão no decorrer das análises, e junto com elas surgirão termos e conceitos que nos levarão a dialogar com outros autores. A grade das dimensões serve aqui como hipótese de trabalho, mais do que um sistema a ser provado.

\section{III}

A hipótese central da tese é que uma análise comparada das formas de espaço e tempo é uma maneira de organizar uma visão de conjunto do cinema: uma visão descritiva, não prescritiva; uma visão baseada nas próprias estratégias composicionais utilizadas pelos cineastas, mais do que em teorias externas. O esquema das três dimensões permite essa análise comparada porque nos dá referências que dialogam com parte considerável da bibliografia, isto é, não nega a fortuna crítica e teórica, ainda que a coloque em perspectiva; e porque, contra essas referências, as práticas e os resultados composicionais dos filmes podem ser medidos.

A tese é organizada, portanto, em três partes. Cada uma delas corresponde a uma das dimensões, e cada uma delas lida com uma série de problemas relativos à composição. Dentro de cada parte, os capítulos se voltam a elementos particulares, como uma maneira de filtrar as possibilidades e delimitar um conjunto de objetos. Em cada capítulo, um conjunto de filmes é analisado, tendo sua composição descrita e os aspectos temporais e espaciais identificados, comentados e contextualizados no esquema geral.

Os capítulos da primeira parte tratam de filmes que exploram a superfície da composição, ou seja, que tratam mais diretamente da tela como um elemento bidimensional e achatado, e do tempo cronométrico, absoluto, da projeção. O capítulo 1 analisa filmes em que a imagem é reduzida à própria homogeneidade da tela e nos quais a articulação temporal é igualada à articulação de padrões de fotogramas. $\mathrm{O}$ capítulo 2 analisa filmes que incluem na tela formas abstratas - desenhos, pinturas ou colagens - de modo a lidar com o movimento. Os contextos em que surgiram os filmes destacados serão comentados, assim como os princípios gerais que podemos inferir a partir deles.

$\mathrm{Na}$ segunda parte, os capítulos se voltam à profundidade da composição. O capítulo 3 serve como introdução, tratando das propriedades do plano, um elemento 
privilegiado nesta dimensão. O capítulo 4, por sua vez, serve como um estudo de caso, voltando a atenção para um tipo específico de articulação cênica, que tratamos aqui em diálogo com as “atrações”. Novamente, as características específicas das obras serão postas lado a lado com os princípios derivados e generalizados - e, neste caso, também postas em relação com algumas das conclusões do primeiro capítulo.

$\mathrm{Na}$ terceira parte, o quinto e último capítulo trata da virtualidade da composição através do problema do encadeamento dos planos. Com a análise de alguns casos específicos, as questões relativas à virtualidade serão consideradas em diferentes etapas históricas e com filmes de inclinações estilísticas diversas. Mantendo o caráter construtivo da argumentação, observações e conclusões feitas nos capítulos anteriores servirão como referências constantes.

Na medida em que buscamos uma visão de conjunto do cinema e das coordenadas da composição, a possibilidade de comparações internas neste campo é necessariamente um dado positivo. No que se segue, as comparações ocorrem em pelo menos três níveis. Como os capítulos incluem análises de filmes que lidam com as mesmas questões formais, há uma comparação entre as seções de cada capítulo, uma comparação que tende a ser cumulativa, levando à seção final que serve como uma conclusão parcial - todos os capítulos são encerrados desta forma. Além disso, há comparações entre os capítulos que lidam com a mesma dimensão: comparações menos sistemáticas, mas que ocorrem também de maneira cumulativa, com as conclusões de um capítulo servindo de base para descrições no capítulo seguinte. Por fim, há comparações que ocorrem entre diferentes partes da tese, que dizem respeito a princípios gerais, normalmente ligados por analogia ou por um aspecto semelhante ao das próprias dimensões. Esse último tipo naturalmente tende a ser mais disperso, pois essas comparações não ocorrem no sentido de um argumento linear, mas como observações que surgem periodicamente para marcar os pontos de ligação com os resultados anteriores. Nas considerações finais será feita uma tentativa de coordenar de maneira mais concisa estas comparações.

Uma suposição da tese é que, investigando as formas espaciais e temporais do material fílmico, pode-se chegar a algo como um conjunto de princípios básicos. Sobre estes princípios, outras formas, mais complexas, poderiam ser derivadas, por combinação ou distorção. Por essa ótica, a enumeração dos elementos e de seus modos de articulação nos permite considerar as transformações possíveis, e considerando sistematicamente essas transformações, pode-se descrever ou pelo menos imaginar algo como as coordenadas composicionais de maneira mais ampla. É nessa perspectiva que a tese 
procede, sendo recorrente em cada capítulo a tentativa de descrever as polaridades e escalas que possibilitam a organização dos procedimentos formais.

Nesse sentido, a escolha dos objetos a serem analisados serve como um exemplo do que possibilita o esquema das dimensões, uma exposição particular da utilidade desse esquema - mas deve ser possível considerar exemplos alternativos ou intermediários a partir dos princípios descritos. Na impossibilidade de uma investigação exaustiva, devemos necessariamente propor um recorte, e nisso tomamos o mesmo critério mencionado por Andrew quanto às teorias: buscar exemplos representativos, que articulam de maneira mais econômica ou mais intensa certas propriedades. Mesmo que não existam filmes que concretizem algumas dessas possibilidades, elas ainda assim podem ser descritas fazendo referência ao esquema - é o caso dos contrafactuais, como veremos já no primeiro capítulo.

Por fim, a tese considera - porque seus objetos assim o fizeram - que o cinema é determinado por seus materiais, o que significa que lidamos necessariamente com a composição filmica. Algumas observações realizadas aqui podem ser válidas para outras formas de registro e reprodução audiovisual, e um diálogo entre diferentes suportes é certamente produtivo na reflexão sobre a composição cinematográfica. Porém, a fim de delimitar o campo de atuação da pesquisa e se ater mais rigorosamente aos preceitos dos filmes e autores considerados, foi preferida a concentração no suporte fílmico. 
PARTE I

SUPERFÍCIE 


\section{FOTOGRAMA \\ MODOS DE ARTICULAÇÃO}

\subsection{O grau zero da composição}

Em 1968, um cineasta norteamericano apresentou, durante uma palestra, um tema que ocupou parte considerável de sua carreira: as condições básicas do cinema enquanto dispositivo material. Através de uma análise das possibilidades e dos critérios envolvidos na composição de obras fílmicas, Hollis Frampton se propôs a enumerar os mínimos denominadores comuns, o que ele chamou de "os axiomas irredutíveis" de sua arte. Como ponto de partida, tomou o próprio contexto em que as obras são apresentadas, a sala escura onde nos sentamos voltados para uma tela branca retangular na qual uma luz é projetada. Neste cenário, caso nada seja feito, vemos o retângulo branco iluminado pelo projetor. Não se pode nunca ver mais que isso - este é um dos limites da arte do cinema. Mas pode-se modular a luz do projetor, isto é, pode-se ver menos. Pode-se colocar na frente da luz um filtro, algo que bloqueia todas as frequências exceto, por exemplo, o vermelho, de modo que se veja, distribuída de maneira homogênea, uma tonalidade vermelha enfatizando o formato retangular. Ou então, pode-se colocar na frente do projetor, em vez de um filtro, algo cujo formato bloqueia parcialmente a luz, tornando visível a silhueta do objeto, uma figura disposta no interior da tela. Para facilitar este processo, para maior precisão e variedade das modulações, pode-se utilizar o filme, "uma fita transparente de qualquer comprimento desejável, perfurada uniformemente com pequenos buracos em suas extremidades laterais, de modo que possa ser transportada por rodas dentadas". 26

Sendo um material fotossensível, o filme pode conter um registro fiel de onde a luz esteve e onde não esteve no momento de sua exposição, bem como as incontáveis

26 Hollis Frampton, “A Lecture” (1968), Op. cit., p. 127. 
subtrações do espectro luminoso que determinam as cores. A câmera é então definida como "uma máquina para gerar material fílmico". Através da câmera, pode-se expor o filme a diferentes frequências, sendo mais usual a de 24 quadros por segundo, a mesma frequência do projetor. A exposição pode ser feita com a câmera estática, ou a câmera pode ser movimentada com as mãos, ou sobre um tripé, ou sobre trilhos e gruas. Mas a câmera não é uma necessidade, e sim uma ferramenta com diversas possibilidades operacionais. Sem ela, pode-se manipular diretamente a fita de filme: pode-se recortar e combinar fitas diferentes, que podem ou não ter sido geradas pelo próprio cineasta; podese alterar o conteúdo das fitas com tintas, riscos, colagens, ou durante o processo de revelação do material.

O projetor é um intérprete mecânico, de precisão extrema. Nos termos de Frampton, o projetor "lê o filme", que é de uma só vez "a partitura e a substância da obra". Uma decorrência é que compor um filme, em última análise, consiste em estabelecer o que será colocado no projetor. Pela natureza mesma da fita de filme, sua projeção deve ocorrer em determinada ordem; ela deve possuir um ponto inicial e um ponto final, entre os quais se define a duração da obra. O que apresentar e quando apresentar na projeção são as reduções básicas das tarefas do cineasta. Toda e qualquer obra fílmica, independente de sua procedência, de sua escala e de seu lugar no campo das formas possíveis, deve necessariamente ocorrer em tais condições.

Qual seria, então, o mínimo que um cineasta pode fazer? Mais especificamente, qual o mínimo a ser feito em termos de modulação da projeção sem que com isso se deixe de fazer um filme? Sem o filme para modular a luz, o resultado é o ataque direto e contínuo da luz do projetor sobre a tela branca. O mínimo seria, então, a fita de filme que mais se aproximasse deste resultado. Este seria, por assim dizer, o grau zero da composição fílmica.

Em 1964, Nam June Paik criou uma obra satisfazendo precisamente estas condições. Zen for Film se volta ao que pode ser considerado o "vazio" do cinema: uma película transparente, permitindo que a luz do projetor atravesse o material e atinja a tela sem qualquer outro tipo de filtro. Este princípio de composição sugere a mais absoluta regularidade. Toda a película é transparente; não há qualquer variação ou progressão aparente que resultem das escolhas feitas pelo cineasta. Sobre a tela, a obra de Paik é um bloco de luz branca e silenciosa com duração de 20 minutos na qual o formato é o mesmo em toda a sua extensão. Ela parece "amorfa", sem qualquer divisão interna que sugira um 
modo de organização. Sua construção é idêntica ao gesto composicional que delimita um início e um final para a projeção.

Considerando esses aspectos, nos aproximamos da "completude" do que Paul Sharits chamou de "obras homogêneas", estruturadas como "uma constante e simultânea gestalt":

nestas obras, que parecem ter o tipo de coesão na qual formato e limite são indistinguíveis, não se pode falar de "início" e "fim", porque isso implica uma fragmentação do formato do filme, e um formato temporal que possui realmente uma única parte não pode ser apreendido como tal se lhe atribuímos três partes discretas ("início", "final", "meio"). ${ }^{27}$

A imersão causada pela repetição incessante é a estratégia de Paik. Uma das consequências é a diminuição das articulações de um momento a outro, como se as diferenças entre eles devessem ser igualadas ou sublimadas numa estase fílmica. Nesta obra, “a forma é dissolvida na repetição. Ela perde gradualmente seus contornos à medida que prossegue". ${ }^{28}$

Há outro dado a ser considerado, entretanto, que aproxima o filme das preocupações de um movimento do qual Paik foi um integrante. O Fluxus constituiu-se nos anos 1960 como um grupo de artistas das mais variadas nacionalidades e com trabalhos em diferentes meios, sob interesses comuns que incluíram a rejeição das fronteiras entre as práticas artísticas, bem como entre "arte" e "vida". ${ }^{29}$ Revisões das categorias básicas de cada atividade estiveram no cerne das propostas. Duas das mais importantes influências neste contexto foram os ready-mades de Marcel Duchamp e as reflexões musicais de John Cage.

Em 1952, Cage, sob influência do zen budismo, criou uma de suas peças mais célebres. Entre os preceitos derivados de suas aulas com Daisetz Suzuki, ele dedicou atenção particular a um sensorialismo radical, à exigência de "abrir os olhos e ouvidos todos os dias", percebendo os detalhes da vida cotidiana em sua dimensão mais imediata. A peça em questão fez as vezes de um manifesto: uma partitura composta inteiramente de

27 Paul Sharits, "Words Per Page", Film Culture 65/66 (1978), p. 38.

28 Ina Blom, "Boredom and Oblivion", in The Fluxus Reader, ed. Ken Friedman (Nova York: Academy Editions, 1998), p. 83.

29 Ver David D. Toris, "Zen Vaudeville", in The Fluxus Reader, p. 107. "A anti-arte", escreveu George Maciunas, "é a natureza, é a verdadeira realidade - é uma coisa só. A chuva é anti-arte, o burburinho de uma multidão é anti-arte, o voo de uma borboleta ou o movimento dos micróbios são anti-arte. São tão belos e tão significativos para se apreciar quanto a arte em si. Se o homem pudesse experimentar o mundo, o mundo concreto que o cerca (das ideias matemáticas à matéria física), da mesma forma que experimenta a arte, não haveria necessidade de arte, artistas e outros elementos 'não-produtivos'." 
pausas, ela teria como resultado apenas o silêncio. Seu título, 4'33', representaria a duração da performance. Reações polêmicas se seguiram, e as respostas de Cage no decorrer dos anos mantiveram-se constantes. Em 1957, ele sintetizou sua posição:

Não há algo como um espaço vazio ou um tempo vazio. Sempre há algo para ser visto, algo para ser ouvido. Na verdade, ainda que tentemos criar o silêncio, não podemos fazêlo. Para certos objetivos técnicos, é desejável ter uma situação tão silenciosa quanto possível. Esta sala é chamada de câmara anecoica, e suas seis paredes são feitas de um material especial, formando uma sala sem ecos. Eu entrei numa dessas salas anos atrás, na Universidade de Harvard, e ouvi dois sons, um agudo e um grave. Quando os descrevi para o engenheiro responsável, fui informado de que o som agudo resultava do meu sistema nervoso, e que o grave era a circulação do meu sangue. Até a minha morte haverá sons. E eles continuarão após a minha morte. Não precisamos mais temer pelo futuro da música. ${ }^{30}$

A simplicidade aparente do comentário encobre duas premissas fundamentais no projeto de Cage e na influência por ele exercida sobre o Fluxus. Essas premissas guardam uma estreita relação com as definições sugeridas por Frampton para o dispositivo fílmico. A primeira é que a experiência musical é igualada à percepção de sons, independente de suas fontes: instrumentos construídos e afinados especificamente para a performance musical tornam-se casos especiais, mas não necessários; fitas magnéticas e ruídos em geral se tornam igualmente aceitáveis. A segunda é que a composição musical é igualada à organização dos sons, independente dos princípios envolvidos: a determinação consciente de notas e sua condução nos eixos harmônico e melódico se tornam casos especiais, mas não necessários; colagens e processos estocásticos (com origem em eventos aleatórios e envolvendo indeterminação) tornam-se igualmente possíveis.

No caso de 4'33”, não há sons gerados pelo intérprete em seu instrumento, logo não há um princípio de organização interna a ser deduzido. $\mathrm{O}$ único evento aparente, que sugere uma relação de equivalência com o gesto composicional, é o procedimento que identifica a existência de uma performance, a delimitação e a concentração nos sons que deverão, afinal, constituir a música. Mas se o silêncio de fato não existe, e se as atenções estão à espera de sons, então os ouvintes deverão perceber os sons do próprio contexto em que estão inseridos. É neste ponto que surge a articulação buscada por Cage; é na própria marcação de um início e de um final, isto é, na proposta de uma moldura temporal, que a peça torna-se paradigmática. Ao determinar que de um momento até outro "haverá

30 John Cage, Silence (Hanover: University Press of New England, 1973), p. 8. Para mais sobre a relação de Cage com o zen budismo, ver Hannah Higgins, Fluxus Experience (Berkeley: University of California Press, 2002), pp. 83-88. 
música", o intérprete opera uma dinamização de seu entorno, fazendo com que ruídos normalmente ignorados, considerados indesejáveis, negligenciáveis ou imperceptíveis, dispersos no espectro da atenção, tornem-se a atmosfera, tornem-se mesmo parte estruturante da peça, na medida em que lhe conferem referências de substância, duração e sentido. Os ruídos locais podem incluir andamentos, timbres e cruzamentos inesperados; podem ser distribuídos pelo tempo das mais variadas formas; as combinações são tantas, e tão dependentes das condições de cada apresentação, que torna-se impossível repetir uma performance. O gesto mínimo do compositor, a escolha de um ponto inicial e de um ponto final, no contexto de uma apresentação pública ou de uma gravação, ao estabelecer uma moldura, destaca uma parte da realidade sonora. Sendo destacada, esta parte se torna significativa.

A única definição possível de silêncio na música seria então algo como "a base de ruídos sobre a qual se assenta a articulação do compositor”. A peça de Cage revela, dessa forma, uma condição básica das próprias convenções da performance musical. Ela se direciona à "superfície" da percepção musical, ao seu aspecto mais elementar, onde limites são evidenciados, postos no centro da atenção. Não significa com isso que toda peça deva expor os mesmos princípios; significa apenas que é em relação a esta dimensão que todo gesto composicional na música deve ser necessariamente medido.

De maneira análoga, o filme de Paik, criando uma moldura espaço-temporal, termina por destacar aspectos relativos ao contexto da projeção cinematográfica, e que podemos chamar de "ruídos fílmicos":

Sobre a tela, de início, não vemos nada. Na verdade, o próprio brilho da reflexividade desmedida da tela pode nos fazer desviar o olhar. Mas conforme nossos olhos se ajustam e nos tornamos mais atentos à superfície mínima, começamos a perceber pequenos eventos que fomos treinados para ignorar. As pequenas marcas de poeira na lente ou na película, os pequenos riscos ou cortes, tudo é amplificado na tela como um quadro abstrato, iluminado, progredindo infinitamente em sutis variações. ${ }^{31}$

A fita de filme de Paik é transparente, o que significa que é o mínimo filtro possível para a luz projetada. O mínimo filtro possível, contudo, não é uma ausência de filtro: a lâmpada do projetor e o material fílmico são eles mesmos visíveis através de pequenas irregularidades em suas superfícies. Por menores que pareçam tais intervenções, ao serem projetadas na tela - e principalmente, ao serem projetadas numa base regular, sobre o

31 Andrew V. Uroskie, Between the Black Box and the White Cube (Chicago: University of Chicago Press, 2014), p. 30. 
máximo de transparência de que o projetor é capaz -, toda e qualquer interferência tornase perceptível, e torna-se, como os ruídos na peça de Cage, parte integrante da experiência, parte da substância e da estrutura da obra. ${ }^{32}$ A tela iluminada, como um microscópio, amplifica e dá significado a estes fatores.

Desprovido de ruídos, Zen for Film seria um bloco idealizado, um modelo da obra homogênea mencionada por Sharits. No eixo do espaço, seria a perfeita uniformidade superficial da tela branca, enquanto na dimensão temporal a experiência seria idêntica à cronometria da projeção dentro do intervalo proposto. Mas ao absorver as interferências e dar a elas destaque, o filme permite que sua moldura espaço-temporal receba fatores externos e que seja por eles influenciada de maneira imprevisível. Os ruídos transformam a tela e a duração como rugosidades afetam um tecido. Os grãos e riscos podem surgir em diferentes posições na tela, em diferentes padrões rítmicos na projeção. A composição, idealmente "lisa", ganha assim pontos de referência, ainda que sua disposição seja caótica. Um comentário de Karlheinz Stockhausen sobre a música estocástica serve como analogia: "É uma distribuição aleatória de elementos dentro de certos limites. Pode-se medir apenas estatisticamente." Um ruído, lembra Stockhausen, "nada mais é do que uma distribuição estatística de ondas que, em determinados limites, é não-periódica". ${ }^{33}$ Por este raciocínio, no momento em que os ruídos visuais exibissem periodicidade, constância ou padrão, a atenção seria capturada e direcionada; um risco que surgisse e desaparecesse a intervalos regulares seria percebido como uma espécie de motivo rítmico, assim como partículas acumuladas numa região da tela sugeririam uma concentração visual que marcaria o espaço. $O$ aspecto caótico faz com que mesmo a periodicidade seja imprevisível, ou ainda, que possa ser medida apenas estatisticamente.

Imaginar "contrafactuais" de Zen for Film é um modo de generalizar sua composição, observando por ângulos diversos a "forma homogênea". Ao especular sobre possíveis transformações, podemos tentar compreender o papel das decisões particulares que definem a obra. Um filme transparente com metade da duração, ou um filme com a mesma duração, mas coberto por um filtro vermelho, levariam a experiências distintas; o comprimento e a tonalidade da fita de filme são afinal parâmetros incontornáveis e

32 Para mais sobre a relação entre Cage e Paik, ver Craig Dworkin, No Medium (Cambridge, Mass.: The MIT Press, 2013), pp. 127-138. O próprio Cage viu no filme de Paik um complemento de 4'33”. É preciso lembrar também que, além da exibição em cinemas, Zen for Film foi projetado como loop em galerias, deslocando a moldura temporal para um ciclo indefinido e reforçando a projeção como um fator de desgaste no material fílmico.

33 Karlheinz Stockhausen, em Jonathan Cott, Stockhausen: Conversations with the Composer (Londres: Picador, 1974), p. 69. 
determinantes na qualidade de uma obra. Mas realizando as mudanças na totalidade da obra, estes casos compartilhariam a homogeneidade composicional, e o fato de servirem como base constante para a absorção dos ruídos. A estratégia de Paik radicaliza e expõe a característica comum a esses exemplos - a escolha de uma película transparente, intensificando as condições subjacentes; a duração de 20 minutos, tempo suficiente para que ocorra uma absorção pela repetição. ${ }^{34}$

Há um aspecto passível de generalização nesta propriedade: quanto mais próxima da "homogeneidade transparente", mais a obra permite a absorção dos ruídos fílmicos. Por envolver condições básicas da composição e da projeção, este fator existe, ainda que em diferentes graus, em todo e qualquer filme, independente de seu estilo e de sua procedência. Mesmo filmes que incluam conscientemente grãos e partículas de sujeira em sua composição também podem exibir riscos e grãos suplementares; é algo que varia de cópia a cópia, sendo uma característica contingente do filme como objeto material, e não uma concepção formal. Uma tentativa de memorizar os ruídos em determinada cópia levaria invariavelmente ao fracasso na medida em que seriam diferentes de todas as outras cópias do filme, podendo ser diferentes inclusive de projeções sucessivas da mesma cópia. ${ }^{35}$

Zen for Film, como um experimento, revela que todos os filmes, mesmo aqueles que buscam reduzir as escolhas e intervenções, e com isso diminuir tanto quanto possível a articulação do espaço e do tempo, mesmo estes devem absorver elementos que sugerem algum tipo de articulação, ainda que o façam de maneira inconsciente, dispersa, aleatória. Nesse sentido, como um grau zero da composição fílmica, Zen for Film nos serve de

34 Os contrafactuais serão mencionados no decorrer do texto como um meio de observar a composição dos filmes por diferentes ângulos; não como um método de demonstração, mas uma ferramenta heurística. $\mathrm{O}$ contrafactual é geralmente apresentado na forma condicional: se $x$, então $y$. A distinção feita aqui entre $o$ "factual" e o "contrafactual" é que o primeiro se refere a um resultado já obtido, enquanto o segundo refere-se a outro resultado, que poderia ter sido obtido mas não o foi. É, portanto, uma forma de investigar as condições envolvidas num processo - quais fatores levariam a tal resultado, ou como seria o resultado caso tais fatores tivessem sido modificados. Para os fundamentos lógicos da questão, ver David Lewis, Counterfactuals (Oxford: Blackwell, 1973).

35 Para mais sobre este tópico, ver Nelson Goodman, Languages of Art (Indianapolis: Hackett, 1976), pp. 113-115. Goodman propõe que as artes sejam classificadas como autográficas ou alográficas. Artes autográficas seriam aquelas nas quais a distinção entre "obra" e "cópia" é relevante: um exemplo seria a pintura, onde o próprio objeto da tela é considerado a obra de arte, enquanto uma reprodução da mesma imagem é considerada uma cópia da obra original. Artes alográficas seriam aquelas nas quais a distinção não é tão relevante: numa arte como a música, por exemplo, a partitura serve como uma espécie de projeto ou mapa para obras musicais, e não é em si uma obra original que serve de medida para outras; cada performance "realiza" a mesma partitura, de modo que há certa originalidade em cada realização. No caso do cinema, pode-se dizer que há um aspecto alográfico na composição - há algo que o cineasta determina e que é reproduzido em cada uma das cópias -, mas uma obra como Zen for Film enfatiza justamente o aspecto autográfico envolvido neste processo. Na terminologia de Goodman, consideraremos aqui o aspecto alográfico da composição fílmica. 
referência para análises posteriores. Como na peça musical de Cage, não significa que todos os filmes devem expor essas características; significa que todos devem necessariamente ser construídos sobre esta dimensão básica. É precisamente por este fator que a "entropia" revelada no filme de Paik - a tendência incontornável do material fílmico de absorver irregularidades externas a ele -, apesar de subjacente a todas as análises seguintes, não será posta no centro de nossa atenção. Se no cinema, como na música, a ausência de ruídos não existe, e se o silêncio fílmico é algo como "a base de ruídos sobre a qual se assenta a articulação do cineasta", o inevitável permanecerá informativo, mas fora de nosso alcance, para que outros níveis condicionais, e para que as escolhas composicionais possam tomar a frente.

\subsection{A linearidade da projeção}

Em 1965, George Brecht, também integrante do Fluxus, realizou um filme intitulado Entrance to Exit. O filme abre com a imagem de uma placa de entrada (entrance), ao que se segue um curto fade para a tela branca. Durante aproximadamente três minutos, a tela se mantém branca, sendo complementada por um ruído que se torna cada vez mais grave. De repente, a tela começa a escurecer lentamente, enquanto o ruído segue no mesmo processo, independente da imagem. Após seis minutos, já com a tela preta, surge a imagem de uma placa de saída (exit), ao que se segue um novo fade para a tela branca.

Consideremos a seção central de Entrance to Exit, que toma a maior parte de sua duração. Se o filme de Paik exibe uma tela homogênea, igualando a absorção em sua claridade contínua à moldura (espacial) da tela e (temporal) dos 20 minutos, o filme de Brecht estabelece a partir de sua metade uma gradação desta tela. Conforme a luminosidade é diminuída, os critérios que permitem a apreensão dos ruídos visuais são invertidos, de modo que ainda podem ser percebidos, mas cada vez mais contra um fundo preto, ou seja, tornando os ruídos claros mais visíveis que os escuros. A tela é um dos elementos articulados: a tela, em toda a sua extensão, como um objeto uniforme e achatado, é transformada num longo fade. Entre as imagens figurativas das placas, outro elemento é articulado: o ruído, que tem suas qualidades alteradas também em conjunto, num único parâmetro - a altura do som. Mesmo os planos das placas, ainda que durante poucos segundos, começam escuros e tornam-se progressivamente mais claros, ecoando este movimento. 
George Maciunas, mentor do Fluxus, apontou o quanto este filme se aproxima da arte conceitual, na sua ênfase de uma ideia. Paik iguala o gesto composicional à moldura espaço-temporal, condição inevitável para a existência de uma obra fílmica; mas Brecht parece igualar a uma etapa seguinte, pressupondo esta moldura e sobrepondo a ela uma ideia extremamente simples. Maciunas usou o termo "estrutura monomórfica" para se referir a esta ideia. Um filme de estrutura monomórfica seria aquele que exibe um único padrão formal; Entrance to Exit seria então um filme de estrutura "progressiva", envolvendo uma "transição". ${ }^{36} \mathrm{O}$ filme é constituído de mudanças, travessias de $a$ até $b$, como se descrevesse transformações: a tela branca se torna preta, o ruído agudo se torna grave. Se considerarmos que a base desta composição, como de todas as outras que utilizam o material fílmico, é a dimensão exposta pelo filme de Paik, podemos dizer que Brecht sobrepõe à regularidade transparente uma referência direta à "passagem" da fita de filme, instituindo na própria obra um direcionamento análogo ao direcionamento do material pelo projetor. A analogia é estendida ao espectador na sala de cinema, posicionando o evento entre as placas de entrada e saída.

Paul Sharits refere-se a este aspecto como "processual". A qualidade processual reforça o caráter "linear" da projeção fílmica, e o fato de que através dela o tempo é experimentado como uma "seta", isto é, com uma direção vetorial específica. Sharits cita pelo menos dois desdobramentos cruciais para este argumento. O primeiro é que a ideia de narrativa, com todas as suas possibilidades de articulação, depende desta suposição: depende que os eventos sejam apresentados com algum grau de equivalência com o movimento da projeção, através da mesma seta temporal. O segundo é que mesmo a sugestão de uma "temporalidade negativa", de um "movimento invertido", deve ser necessariamente sobreposta à linearidade da projeção. Em outras palavras, "conceitos vetoriais retrogradativos" só podem existir no cinema relacionados à direcionalidade única da projeção. Sharits reforça que esta direcionalidade é a base da cognição filmica, por ser como a linha reta de "nosso próprio campo temporal isotrópico". 37 É esta percepção de linearidade, de uma transformação gradativa, análoga à projeção do material fílmico, que caracteriza o principal gesto de Entrance to Exit. O espectador do filme de Brecht absorve a tela como uma constante, uma moldura que determina os limites

36 George Maciunas, "On 'Structural Film"” (1969), in Film Culture Reader, ed. P. Adams Sitney (Nova York: Cooper Square, 2000), p. 349. Os comentários de Maciunas são uma resposta ao artigo de Sitney. Veremos mais adiante como os filmes estruturais relacionam-se com as mesmas categorias.

37 Ibid., pp. 39-40. Para uma fundamentação científica deste argumento, ver o segundo capítulo de Hans Reichenbach, The Direction of Time, ed. Maria Reichenbach (Berkeley: University of California Press, 1971). 
espaciais da obra, dentro da qual uma característica é alterada: a luz do projetor é progressivamente bloqueada pela materialidade da película.

Os efeitos cognitivos subjacentes a essa transformação foram definidos a partir de experimentos sobre a percepção visual; eles se encontram no cerne do funcionamento do dispositivo fílmico, na projeção de uma fita em determinada frequência. Jacques Aumont descreve, por exemplo, os experimentos em que dois pontos luminosos, afastados no espaço, são mostrados a um sujeito, variando a distância temporal entre eles:

Enquanto o intervalo entre os dois flashes for muito pequeno, eles serão percebidos como simultâneos. Se, ao contrário, for muito elevado, os dois flashes serão percebidos como dois acontecimentos distintos e sucessivos. É na zona intermediária - de 30 a 200 milisegundos entre cada flash - que surge o movimento aparente. Foram-lhe relacionadas diversas formas, rotuladas com letras do alfabeto grego: o movimento alfa é um movimento de expansão ou de contração (com dois flashes situados no mesmo lugar, mas com tamanhos diferentes), o movimento beta corresponde à experiência descrita acima (movimento de um ponto a outro), etc.; o conjunto desses fenômenos, muito diferentes uns dos outros, mas aparentados, costuma ser chamado hoje "efeito phi". ${ }^{38}$

No caso de fotogramas completamente semelhantes ou completamente diferentes entre si, o efeito não seria possível. É a proximidade luminosa entre os estímulos - a semelhança parcial entre fotogramas sucessivos - que sugere uma transformação contínua. Num comentário sobre a percepção do ritmo, Paul Fraisse comenta o princípio de "agrupamento" desses estímulos, sejam eles luminosos ou sonoros:

De maneira geral, toda modificação periódica qualitativa ou quantitativa de um elemento determina o agrupamento. Uma diferença na altura de um som, por exemplo, terá um efeito semelhante a uma acentuação; o prolongamento de um som, um efeito diferente, caso este prolongamento seja relativamente fraco ou forte. ${ }^{39}$

A percepção do agrupamento só é possível quando os estímulos se seguem numa velocidade tal que pareçam distintos um do outro (o que Fraisse chama de "limite inferior"), e se não estão separados a ponto de parecerem eventos independentes ("limite superior”). É a dissolução destes limites - a regularidade do fade aliada à suavização dos contrastes - que torna Entrance to Exit um caso exemplar da estrutura monomórfica comentada por Maciunas, e que sugere um movimento único, sem acentuações ou

38 Jacques Aumont, A imagem, trad. Estela dos Santos Abreu e Cláudio Cesar Santoro (Campinas: Papirus, 1990), pp. 46-47. Para uma das primeiras integrações destes experimentos a uma concepção estética do cinema, ver Hugo Munsterberg, The Photoplay: A Psychological Study (Nova York: D. Appleton and Company, 1916), que dedica o terceiro capítulo ao movimento.

39 Paul Fraisse, Les structures rythmiques (Paris: Éditions Érasme, 1956), pp. 11-12 (grifo nosso). 
variações de frequência. A "impressão de movimento" é geralmente definida como o deslocamento aparente de objetos dentro de um mesmo campo visível; o fade não possui um movimento nesse sentido (não é uma alteração de posicionamento, e sim de luminosidade, ou seja, da "qualidade" do campo visível de um momento a outro; é "um movimento sem direção", na descrição de Sharits ${ }^{40}$ ), mas é ainda assim enquadrado nas observações de Max Wertheimer, responsável pelos experimentos originais:

Dois objetos são apresentados como estímulos sucessivos. Eles são percebidos como sensações; $a$ é visto no início, $b$ no final. Entre eles "o movimento de $a$ até $b$ é visto" sem uma exposição factual de um movimento correspondente, ou de estímulos espaçotemporais contínuos entre $a$ e $b$. As circunstâncias psicológicas podem - sem qualquer viés - ser designadas $a \phi b$, onde $\phi$ representa o que ocorre além das percepções de $a$ e $b$, o que ocorre no espaço entre $a$ e $b$, o que se acrescenta a $a$ e $b$. [...] Independente de como se considere a percepção do movimento [...], ao menos um dos dois pontos seguintes é exigido pelos fatos, ainda que tomem formas e direções diferentes: I. $\phi$ é algo pertinente de maneira uniforme a $a$ e $b$, algo construído sobre eles, que os instiga e os conecta. II. O conteúdo fenomênico de $\phi$ é dado por, ou se baseia em posições subjetivas em relação ao contínuo espaço-temporal intermediário, que não são apresentadas objetivamente. Devese então dizer: $\phi$ é uma entidade que claramente diz respeito a $a$ e $b$. É o que os conecta. Portanto, $a$ e $b$ devem ser considerados como o arcabouço necessário, mesmo fundamental, para $\phi$. Por fim, $\phi$ existe por um complemento subjetivo das posições intermediárias entre $a \mathrm{e} b .^{41}$

Numa comparação entre os minutos centrais do filme de Brecht e um recorte da mesma duração no filme de Paik, teríamos algo como a seguinte figura, uma representação "não-estrita" 42 onde a fita superior representa Zen for Film, e a fita inferior,

Entrance to Exit:

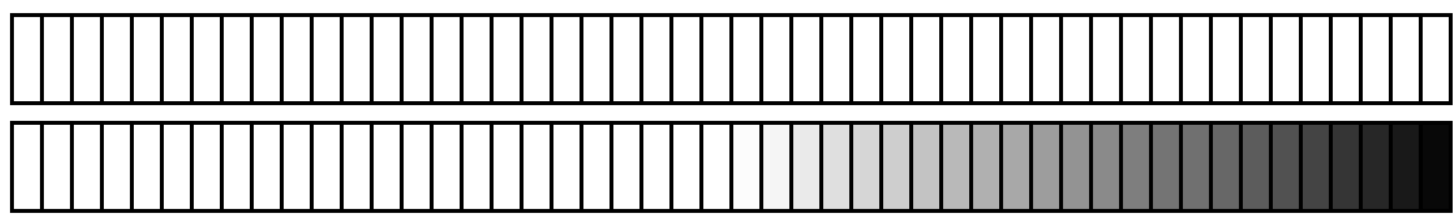

40 Ibid., p. 40. Ver também Yvonne Spielmann, "Paul Sharits: From Cinematic Movement to NonDirectional Motion", in Avant-Garde Film, eds. Alexander Graf e Dietrich Scheunemann (Nova York: Rodopi, 2007), pp. 197-215.

41 Max Wertheimer, On Perceived Motion and Figural Organization, ed. Lothar Spillmann (Cambridge, Mass.: The MIT Press, 2012), p. 23. Ver também Joseph Anderson e Barbara Anderson, "Motion Perception in the Motion Pictures", in The Cinematic Apparatus, eds. Teresa de Lauretis e Stephen Heath (Londres: Macmillan, 1988), pp. 76-95.

42 Consideraremos uma representação "não-estrita" uma disposição gráfica para se referir aos filmes mas que não estabelece relação de correspondência exata entre os "quadros" das figuras e os fotogramas, isto é, em que os quadros representam "etapas gerais da obra". Representações "estritas" serão aquelas em que há esta correspondência: em que cada quadro representa exatamente um fotograma. 
Diferente de Zen for Film, que iguala seu formato global à moldura submetida ao processo da projeção, Entrance to Exit tem seu formato definido por ao menos uma marcação em seu centro, a prova de uma intervenção suplementar neste processo. A homogeneidade dos primeiros minutos é semelhante nos dois casos. Mas conforme a luminosidade da tela é diminuída por Brecht, o tempo da projeção é modulado, e sobre ele é composta uma espécie de curva, algo que redireciona a atenção sob outra frequência que não a da pura cronometria - a frequência do fade. Como a modulação é suave em suas gradações, não há ênfase nas diferenças, e sim na transição, na transformação de um fotograma em outro, isto é, no caráter contínuo da fita de filme.

Considerando o tempo da projeção como uma linha reta, o filme de Paik também pode ser representado não-estritamente como uma linha sobreposta à cronometria da projeção, enquanto o filme de Brecht se caracteriza por um desvio, um redirecionamento das propriedades visuais em determinada frequência:

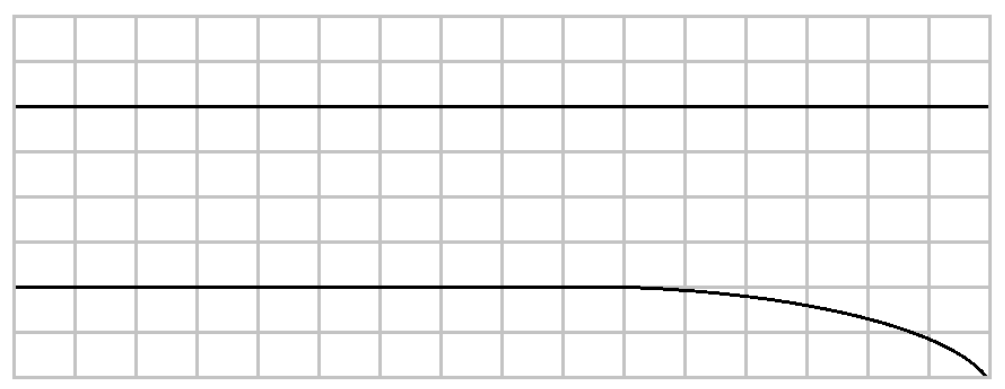

Conforme avança o fade, estas mudanças informam nossas expectativas. Se nos primeiros minutos não há nada que possa sugerir um direcionamento específico, a partir do momento em que a tela inicia seu escurecimento cada fração de segundo é a concretização de um processo, a confirmação de que há um padrão em curso. Se em Paik a homogeneidade criava uma base fixa, receptiva à aleatoriedade dos ruídos, em Brecht a linearidade conduz estes mesmos fatores, esculpindo a temporalidade. Isso é enfatizado pelas estratégias de som, paralelas nos dois casos: a presença do som em Entrance to Exit reflete a transformação progressiva da imagem, ao passo que em Zen for Film o silêncio reflete a ausência de articulações visuais.

O vocabulário utilizado nessas descrições não é arbitrário: a terminologia da psicologia da percepção diz respeito a fenômenos básicos da cognição, e muitas vezes ao que parece independente da interpretação do espectador ou de sua formação cultural, sendo uma espécie de reflexo do organismo. Há uma sugestão, nestes filmes e nos 
comentários sobre eles, de que certa dimensão da composição envolve a "superfície da percepção". Assim como o espaço da tela e o tempo da projeção são elementos inevitáveis na composição de uma obra fílmica, esta dimensão seria subjacente às outras, por ser enraizada nas próprias condições materiais do dispositivo. Por essa perspectiva, articular a dimensão mais superficial do material fílmico é análogo a articular a dimensão mais superficial da cognição: o cineasta, ao compor um filme, compõe uma ordenação cognitiva. Nos casos em que o espaço da tela é considerado "em bloco", e nos quais a superfície da imagem, em conjunto, é o único elemento visual, a articulação temporal ganha a frente. O trabalho da composição torna-se o trabalho com as durações absolutas das fitas de filme. Um comentário de Frampton é útil para compreender essa relação entre a materialidade do filme e a percepção do tempo:

O tempo no cinema é precisamente tão plástico, maleável e tátil quanto a substância física do próprio filme. É plástico a ponto de atingir um limite quando se é colocado contra o fotograma uma vez a cada vinte e quatro fotogramas. Quando se chega nisto, [o tempo] se torna rígido, ainda que possa ser comprimido, atenuado. Há também algo que é plástico, maleável, e, por assim dizer, tátil. As divisões vão muito além de 1/24 de segundo, e isso, claro, é o vasto organismo que nos atravessa e pelo qual atravessamos, e que chamamos de consciência. A consciência da passagem do tempo, a densidade, a noção de que algo acontece, de que nada vai acontecer. [...] Tempo é o nome para algo que é uma consciência, que é uma espécie de condição irredutível da aproximação, de se estar consciente de outras coisas com uma duração plástica [...]. ${ }^{43}$

Assim como no caso de Paik, pode-se imaginar contrafactuais para o filme de Brecht, como um modo de testar as propriedades identificadas e localizar com mais precisão as escolhas do cineasta. Se Entrance to Exit tem a duração total de seis minutos, e se propõe um fade do branco ao preto iniciado após três minutos, pode-se imaginar variantes desta estratégia. Um fade com o dobro da duração, ou então um fade da mesma duração, mas do preto ao branco, levariam a experiências distintas; o ponto de início do fade, bem como sua frequência e duração, são parâmetros cruciais na apreensão da obra. O fade poderia alterar seu andamento também de maneira progressiva; poderia se iniciar em outro ponto da mesma moldura temporal. Estes casos compartilhariam, todos eles, a linearidade composicional, e o fato de que a percepção é submetida a uma frequência estabelecida pelo cineasta, ainda que sobreposta à cronometria da projeção. Alinhada às preferências do Fluxus, a escolha de Brecht é pelo caminho mais simples, pela exibição

43 Hollis Frampton, citado em Rachel Moore, Hollis Frampton: (nostalgia) (Londres: Afterall Books, 2006), p. 5. 
do maior contraste possível, e pela transição da maior transparência para a maior opacidade no material.

Excetuados os ruídos na tela e os planos figurativos que lhe servem de moldura, Entrance to Exit não apresenta qualquer outro tipo de imagem que não a tela durante seu fade central. Mas um dado é importante, considerando as definiç̧ões aqui expostas: mantendo o fade, alguma linearidade estaria presente igualmente em filmes que incluíssem outros conteúdos visuais. Como o fade articula a luminosidade da imagem como um todo, o conteúdo "interno" da tela, independente de suas qualidades, deve necessariamente ser absorvido por este processo, e quaisquer outros problemas de articulação visual devem necessariamente ocorrer através dele. Sendo o fade uma técnica amplamente utilizada, isso significa que a linearidade é sobreposta a uma série considerável de imagens fílmicas, e que não há qualquer relação de dependência necessária entre as duas camadas. A linearidade do fade ocorre independente de articulações visuais suplementares. A modulação da luminosidade da tela sob determinada frequência é, nesse sentido, uma das formas básicas da linearidade fílmica, uma transformação contínua da superfície espacial através do tempo da projeção.

\subsection{Ciclos e reiterações}

Em 1965, Tony Conrad marcou uma posição entre os interesses do Fluxus e a então nascente tendência dos "filmes estruturais". Matemático de formação, Conrad manteve certa proximidade com o Fluxus através de suas colaborações musicais com La Monte Young e o grupo Theatre of Eternal Music. Seu primeiro filme, The Flicker, foi descrito por P. Adams Sitney como um dos casos paradigmáticos de "um cinema de estrutura, em que o formato do filme inteiro é predeterminado e simplificado". Nos filmes considerados por Sitney, este formato "seria a impressão primária da obra", algo "determinado para explorar aspectos do material [fílmico]", e que teria como táticas formais "recorrências, antíteses e um ritmo generalizado". O filme estrutural seria aquele que insiste em seu desenho global, de modo que o "conteúdo" interno é minimizado, tornado secundário. ${ }^{44}$

44 P. Adams Sitney, "Structural Film" (1969), in Film Culture Reader, op. cit., p. 327. No "Postscriptum" do artigo (pp. 345-346), Sitney aborda as críticas de Maciunas, que são apresentadas em seguida (p. 349). Para mais sobre a relação dos filmes estruturais com o Fluxus, ver Birgit Hein, "Structural Film", in Film as Film: Formal Experiment in Film, 1910-1975, ed. Phillip Drummond (Londres: Arts Council of Great Britain, 1979), pp. 93-96. 
The Flicker deriva seu nome de um efeito do dispositivo cinematográfico, fonte de uma das técnicas mais presentes na vertente estrutural. A projeção da fita de filme é dividida em etapas; cada seção do material (ou "fotograma") corresponde a uma imagem apresentada sobre a tela; uma vez projetada esta seção, a fita é movida por rodas dentadas, fazendo com que outra seção (outro fotograma) seja colocada perante a luz do projetor, e assim por diante. A alta velocidade da projeção faz com que as menores diferenças entre os fotogramas ganhem destaque, e a intermitência do dispositivo se reflete na experiência do espectador, criando o efeito estroboscópico chamado de "cintilação" (flicker). Para suavizar o efeito, os projetores são equipados com um obturador giratório que bloqueia a fita nos intervalos entre as imagens. ${ }^{45}$

O filme de Conrad parte de uma redução ao contraste básico entre fotogramas pretos e fotogramas brancos. Se Zen for Film servia como base regular e homogênea para a absorção luminosa da tela, e se Entrance to Exit apresentava uma transformação gradual, variando lentamente os parâmetros visuais e sonoros, criando a sugestão de um processo análogo à projeção, The Flicker propõe uma gradação distinta. A estratégia do filme é a brusca alternância entre luz e escuridão. O choque mais radical entre as imagens, a mais completa inversão dos parâmetros visuais - a mudança do preto ao branco, ou do branco ao preto - é o gesto recorrente da composição. Em vez de manter estável a taxa de alternância, Conrad inicia numa frequência e atravessa todo o campo das possibilidades. Como no filme de Brecht, o resultado é também uma "passagem”, uma mudança de $a$ até $b$. Mas enquanto Paik e Brecht ignoravam ou aceitavam a suavização da cintilação, Conrad perturba justamente este fator:

O dispositivo clássico da projeção obedece a uma regra implícita: a da utilização de um número de imagens (isto é, da quantidade de película) necessário e suficiente para produzir uma impressão de movimento contínuo. O limiar a partir do qual essa impressão pode nascer situa-se em torno de 24 imagens por segundo. Se levarmos em conta o tempo de fechamento do obturador, veremos que cada imagem ocupa a tela durante aproximadamente 1/50 de segundo. Aquém desse limiar, o olho começa a perceber uma cintilação que corresponde ao momento da obturação, e o espectador se conscientiza da descontinuidade do desenrolar do filme. Ora, o flicker film, como filme convencional, é projetado a 24 imagens por segundo. Portanto, é agindo num outro nível do dispositivo fílmico que ele subverte as convenções ilusionistas do espetáculo cinematográfico, a saber, dissociando a velocidade da gravação da velocidade de projeção - o que o cinema ilusionista só autoriza, por convenção, nos efeitos de câmera lenta ou acelerada. No flicker, filmado imagem por imagem, a projeção não é mais a reconstituição da gravação:

45 Ver Aumont, A imagem, op. cit., p. 31. 
a percepção do défilement [desvelamento] real, descontínuo, pode então substituir a ilusão do movimento contínuo. ${ }^{46}$

The Flicker é uma jornada pelas frequências de alternância entre os fotogramas pretos e brancos. A etapa que inicia o filme consiste em longos períodos de fotogramas brancos sendo brevemente interrompidos por um único fotograma preto. Conforme se avança, aumenta nos períodos o número de fotogramas pretos. Próximo ao centro do filme, a alternância torna-se cada vez mais acelerada, atingindo o ápice quando um fotograma branco é alternado com um preto. Do centro em diante, o princípio é invertido: são os fotogramas pretos que se tornam predominantes de maneira gradual, atingindo o extremo oposto quando longos períodos de fotogramas pretos são brevemente interrompidos por brancos. A duração total é de 30 minutos. Como nos exemplos anteriores, o filme sustenta uma faixa sonora paralela e análoga à sua experimentação visual: um ruído intermitente é acelerado de modo a corresponder à frequência da projeção.

Cada uma das etapas, isto é, cada período de fotogramas, é repetido algumas vezes, cada um deles gerando um determinado efeito rítmico. Para visualizar alguns períodos, podemos considerar estritamente cada fita como um "módulo" a ser repetido:

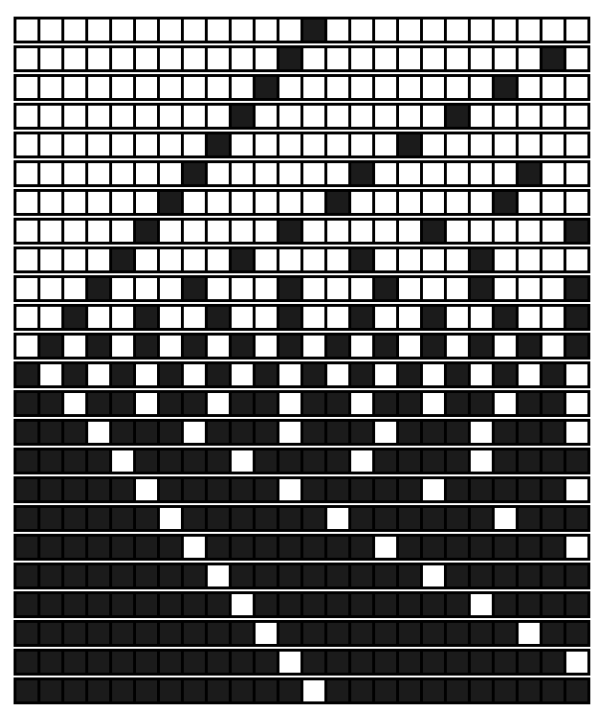

46 Philippe-Alain Michaud, Filme: por uma teoria expandida do cinema, trad. Vera Ribeiro (São Paulo: Contraponto, 2014), p. 139. Para mais sobre a neutralização do flicker no dispositivo cinematográfico e sua retomada pelas vanguardas, ver Noel Burch, "Primitivism and the Avant-Gardes: A Dialectical Approach" (1987), in In and Out of Synch: The Awakening of a Cine-Dreamer (Aldershot: Scolar Press, 1991), pp. 157-186. 
Entre os módulos regulares há uma série de módulos com alternância irregular. Além da variedade na percepção rítmica, esta multiplicidade faz com que o filme inclua uma série de efeitos causados pela cintilação: sugestões de cores, variações de luminosidade, formas geométricas. Ao comentar estes efeitos, Conrad demonstra tanto um conhecimento dos experimentos científicos como uma afinidade com a "ordenação cognitiva" sugerida por Frampton:

Tecnicamente, o alcance da percepção do flicker ou da luz estroboscópica é inferior a uma frequência de aproximadamente 40 flashes por segundo (40 fps), acima da qual a luz parece contínua. A projeção sonora padrão é feita a 24 fps. Abaixo de 4 fps, o único efeito real é a luz sendo ligada e desligada. Mas na faixa de 6 a $18 \mathrm{fps}$, mais ou menos, coisas estranhas acontecem. The Flicker vai gradualmente de $24 \mathrm{fps}$ a $4 \mathrm{fps}$ e então retorna à faixa do flicker novamente. O primeiro efeito perceptível é geralmente uma matriz giratória e fragmentada de padrões cromáticos, provavelmente um efeito do tipo afterimage. A visão se estende às áreas periféricas e imagens de fato podem ser "alucinadas". Então um estado hipnótico se inicia, e as imagens se tornam mais intensas. Fixar os olhos num único ponto é útil ou necessário para provocar os efeitos máximos. O próprio cérebro está diretamente envolvido em tudo isto; não é coincidência que uma das principais frequências de ondas cerebrais, o chamado ritmo alfa, esteja entre os 8 e 16 ciclos por segundo. Assim, o sistema nervoso central deve ele mesmo ser considerado como um tipo de mecanismo sensório... ${ }^{47}$

Num experimento realizado no departamento de Psicologia da New York University no final dos anos 1960, sujeitos foram submetidos a projeções privadas do filme, após as quais preencheram questionários, descrevendo o que visualizaram. Além de cores, como verde ou azul, e formas geométricas, como círculos e espirais, foram recorrentes imagens descritas como "rostos" e "insetos". O importante é notar que as imagens não estão "no filme" (que exibe apenas fotogramas pretos e brancos), mas que também não estão simplesmente "na mente do espectador". Elas ocorrem na fronteira entre as duas esferas: é na modulação "do corpo pela técnica do cinema que esta percepção emerge". ${ }^{48}$ Em vez

47 Tony Conrad, "On The Flicker", Film Culture 41 (verão de 1966), p. 2. Alguns ciclos induzem em células cerebrais uma espécie de sincronia com a frequência dos filmes, o que pode às vezes causar ataques epilépticos. Entre os flickers aqui mencionados, o filme de Conrad é o único que inicia com uma cartela advertendo sobre tais efeitos, o que talvez seja um reflexo de sua vontade de apresentar todo um conjunto de reações, como num experimento científico. Ver também Stephen Salniker, "Visual Responses in Perceptual Cinema", Journal of the University of Film Association, vol. 32, n. 1/2 (inverno/primavera de 1980), p. 34.

48 Scott C. Richmond, Cinema's Bodily Illusions (University of Minnesota Press, 2016), p. 148. Seria preciso um experimento controlado para determinar em que medida certos efeitos decorrem de certas frequências: para saber se todo e qualquer espectador vê a mesma cor/imagem no mesmo período; se tal efeito varia, e se varia, em qual margem; e se depende do nível de atenção do espectador, ou de outras condições. Um aprofundamento destas noções levaria também a um estudo cimático das frequências utilizadas no filme. A Cimática é a disciplina que estuda padrões de vibração, e a representação visual destes padrões ocorre geralmente na disposição de um material (areia, por exemplo) sobre um disco que recebe vibrações; conforme o material se organiza geometricamente na superfície do disco, são traçadas 
de estimular um funcionamento "psico-interpretativo", The Flicker exige respostas do sistema nervoso autônomo - um estágio pré-consciente, "psicofísico". 49

$\mathrm{Na}$ medida em que os módulos sucedem uns aos outros, o espectador percebe as variações rítmicas que os diferenciam. Iniciado com a mesma tela branca de Paik e Brecht, The Flicker expõe imediatamente seu princípio rítmico subjacente na faixa sonora: mesmo a película transparente, apresentada por alguns segundos, é colocada em perspectiva com o ruído acelerado da projeção, isto é, com a divisão do contínuo temporal em um determinado número de etapas. Imerso nos padrões de cintilação, o espectador é carregado por essas etapas. A proximidade entre os fotogramas brancos e pretos aumenta, levando finalmente ao ápice - o limite absoluto da alternância rítmica da projeção -, invertendo em seguida o processo, numa estrutura semelhante à curva gaussiana ou "curva em forma de sino":

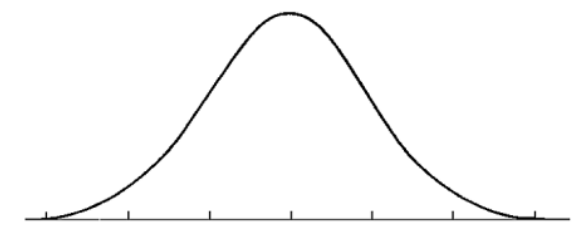

Consequentemente, o filme de Conrad não possui uma forma homogênea ou simplesmente linear. Há a sugestão de uma progressão através da mudança gradual nas frequências de flicker; a partir do centro do filme, no entanto, a progressão é invertida, tanto no ritmo como na luminosidade. Se de início o filme sugere uma curva em ascensão, esta mesma curva é logo tornada descendente. Nos termos de Sharits, a partir do meio do filme ocorre uma "transformação retrogradativa". Este fator é devido ao interesse de Conrad por atravessar a totalidade do campo das frequências. Mais do que uma "transformação contínua", o filme parece descrever uma escala ou um espectro uma "transformação discreta" de $a$ em $b$, evidenciando a divisão do contínuo em várias partes.

Conforme a descrição do espectro se aproxima do fim, as mesmas frequências são retomadas em ordem inversa, sugerindo uma estrutura simétrica. Com isso, The Flicker

as correlações entre as frequências rítmicas e as formas geométricas. Para mais sobre as definições cimáticas e as descrições dos experimentos, ver Hans Jenny, Cymatics (Macromedia, 2001), sobretudo os dois primeiros capítulos.

49 Ver Malcolm Le Grice, Abstract Film and Beyond (Cambridge, Mass. e Londres: The MIT Press, 1977), pp. 105-108. 
parece coordenar o interesse pela regularidade de Paik com o interesse pela linearidade de Brecht, sobre uma forma baseada em reiterações. Os módulos de fotogramas são repetidos, e por determinados períodos são repetidos de maneira idêntica, o que gera um resultado diverso da homogeneidade e da linearidade. É apenas depois de um certo número de repetições que os módulos são transformados. Isso cria um efeito que, como o próprio Conrad reconhece, é uma amplificação da regularidade cíclica dos fotogramas na projeção - a manutenção de um mesmo número de fotogramas por segundo, equivalente à manutenção de uma mesma ordem de fotogramas no módulo. Se o fade no filme de Brecht parece construir um movimento análogo à linearidade da projeção, o movimento de Conrad tem como referência a intermitência da projeção. Assim como é a semelhança parcial entre os fotogramas de Entrance to Exit que permite a linearidade do fade, é a semelhança parcial entre os módulos que permite a gradação em The Flicker. ${ }^{50}$

Uma diferença em relação aos filmes do Fluxus é que, apesar de se voltar à dimensão mais superficial do dispositivo fílmico, a estrutura de The Flicker não apresenta a mesma simplicidade "monomórfica". Há ainda a escolha de um único gesto, a eleição de uma única técnica que cria a obra como um algoritmo composicional; mas ainda que as regras sejam simples, a estrutura torna-se mais complexa pela reiteração. $O$ aspecto ambivalente se reflete nas discordâncias entre Sitney e Maciunas sobre o que caracteriza a principal contribuição do filme.

Por um lado, Sitney reconhece que é uma estrutura altamente determinada, com proporções rítmicas dispostas rigorosamente, fazendo com que os efeitos sejam distribuídos por toda a duração, com cada uma das metades do filme exibindo as mesmas frequências, invertendo apenas sua ordem e luminosidade. Isso faz com que o filme seja uma "grade", no sentido apontado por Rosalind Krauss como uma característica usual da arte minimalista. ${ }^{51}$ Assim como em certas telas de op art (de Victor Vasarely ou Bridget Riley, por exemplo) a superfície bidimensional da obra é preenchida com padrões monocromáticos, repetitivos e reduzidos a formas geométricas básicas, criando efeitos de

\footnotetext{
50 "Reiteração" não será considerada aqui como sinônimo de "repetição", mas como "repetição aproximada", ou ainda, "a retomada de um elemento ou conjunto de elementos, modificando um de seus parâmetros". Um termo com significado aproximado seria "retroalimentação".

51 Ver Rosalind Krauss, "Grids", October 9 (verão de 1979), pp. 51-64. Krauss identifica a grade como uma forma emblemática das ambições modernistas nas artes visuais. Tornada explícita no cubismo, a grade na pintura seria uma tendência a mapear não um espaço tridimensional, como ocorria na perspectiva renascentista, mas o próprio espaço superficial da tela. Ver também Amy Goldin, "Patterns, Grid, and Painting", Artforum, vol. 14, n. 1 (setembro de 1975), pp. 50-54.
} 
volume e profundidade, também o filme de Conrad parte de reduções extremas das superfícies visual e rítmica, explorando com isso os aspectos cognitivos do seu material.

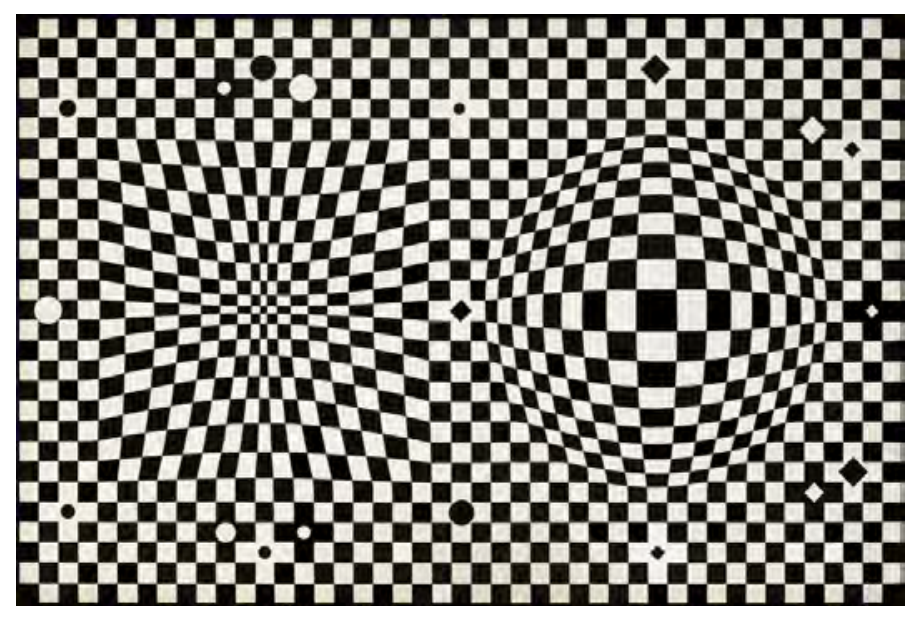

Victor Vasarely, Vega III (1957-59)

Por outro lado, Maciunas destaca o fator progressivo envolvido nesta apresentação. Ele reconhece que a redução das frequências sucedida por sua elevação corresponde à descrição de uma curva; nos termos da pura impressão visual, é um aumento e uma diminuição de tensão. Ao enfatizar este ponto, Maciunas classifica The Flicker como mais uma instância das formas progressivas, ainda que a progressão seja atravessada por repetições e invertida a partir do meio.

As declarações de Conrad reforçam esta dualidade. Ele se diz interessado ao mesmo tempo em "uma unidade geral de estrutura" e na ideia de que, partindo de uma quase ausência de impressões, é capaz de "chegar a um completo ataque aos sentidos". Em outras palavras, Conrad se interessa tanto pelo aspecto "estático" como pelo aspecto "dinâmico" de sua composição, e como ambos são integrados por um princípio de repetição e reiteração:

Uma forma ser estática não significa que ela possui essa qualidade de maneira absoluta. Por exemplo, quando eu digo que me interesso por estase versus movimento, não me refiro a um estado absolutamente estático, mas antes a algo com relativamente pouco movimento, ou mesmo sem qualquer movimento aparente. A estase pode ser vista, particularmente no meu trabalho, como repetição ou como várias repetições. ${ }^{52}$

O número elevado de repetições, as diferenças mínimas entre as reiterações e a longa duração do filme afirmam o aspecto meditativo presente em outros filmes do Fluxus, que

52 Tony Conrad, em Tony Mussman, “An Interview with Tony Conrad", Film Culture 41 (verão de 1966), pp. 3-4. 
tendem a reforçar a imersão na experiência imediata. Mas neste ponto Conrad se aproxima também de outras características recorrentes nas obras estruturais, como a tentativa de suspender a cronologia numa espécie de diagramação do fluxo temporal.

Podemos nos perguntar: qual a flexibilidade desta forma proposta por Conrad? Seu filme atravessa toda uma escala de frequências; mas o faz para demonstrar a simetria dessa mesma escala. Nesse sentido, a segunda metade do filme é ela mesma uma versão contrafactual da primeira. Inverter as cores e as frequências de toda a obra levaria a uma variante "em reflexo" do filme: o formato geral permaneceria o mesmo. Por outro lado, isolar os módulos e reordená-los descaracterizaria o fator que sustenta a gradação das mudanças. Assim como uma intermitência no fade deslocaria a linearidade de Entrance to Exit, uma reordenação das frequências alteraria o espectro de The Flicker. É neste ponto que a escolha de Conrad se demonstra clara em suas intenções. O filme abre com a tela branca justamente para que possa atingir ao final a tela preta, e para garantir que toda a travessia será possível. Em decorrência disso, a alternância mais radical deve necessariamente se posicionar no centro da obra. No caso de um filme iniciado com essa mesma alternância, a travessia deveria optar pela predominância dos fotogramas pretos $o u$ dos fotogramas brancos, o que negaria o caráter simétrico e o desejo de abarcar a totalidade de uma escala.

Um segundo exemplo serve para complementar estas ideias e observar por outro ângulo o mesmo princípio formal. Assim como Tony Conrad, Takahiko Iimura esteve próximo tanto do Fluxus como da vanguarda americana centrada na Film-Makers' Cooperative. Ele colaborou em mais de uma ocasião com Yoko Ono, e entre 1966 e 1969 produziu retratos filmados de Stan Brakhage, Stan Vanderbeek, Jack Smith e Jonas Mekas. Dez anos após The Flicker, Iimura compôs também uma obra baseada em reiterações, e no "preenchimento gradual de períodos". Assim como Conrad, ele buscou atravessar as possibilidades de sua estrutura, em termos de frequências cromáticas e rítmicas.

Em 24 Frames per Second (1975), módulos de um segundo são apresentados, todos constituídos por fotogramas pretos e/ou brancos. Seu princípio básico é a "mobilidade" de fotogramas contrastantes dentro de um mesmo período. Os módulos são precedidos por cartelas com frações, onde o denominador é sempre 24, o total de fotogramas num segundo de filme, e o numerador indica sempre a quantidade de fotogramas "móveis" neste intervalo. Nos primeiros módulos, sob a cartela $1 / 24$, um único fotograma branco é apresentado, cercado por 23 fotogramas pretos. O ciclo é 
retomado 24 vezes, e a cada vez o fotograma branco tem sua posição alterada na série: da posição 1 , passa à posição 2 , desta à 3 e assim por diante, até a posição 24 , de modo que todas as possibilidades são visualizadas. Uma representação estrita dos primeiros segundos seria a seguinte figura:

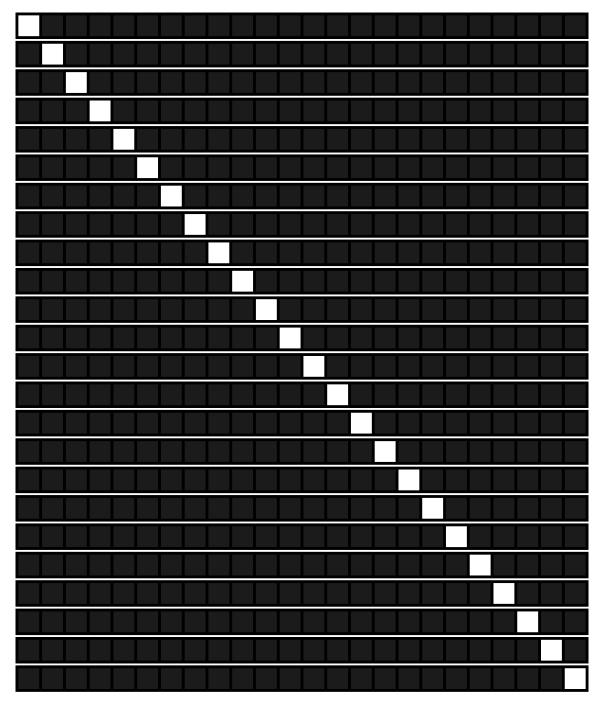

Há uma discrepância entre o pulso de um segundo e o período marcado pelos fotogramas destacados. Ainda que as distâncias entre os fotogramas brancos sejam idênticas, a reiteração os desloca gradualmente, de modo que tornam-se cada vez mais afastados de uma medida regular a partir do primeiro fotograma. Podemos designar estritamente os pontos como as marcações dos ciclos de um segundo, e observar como os fotogramas brancos surgem cada vez mais afastados dessa referência:

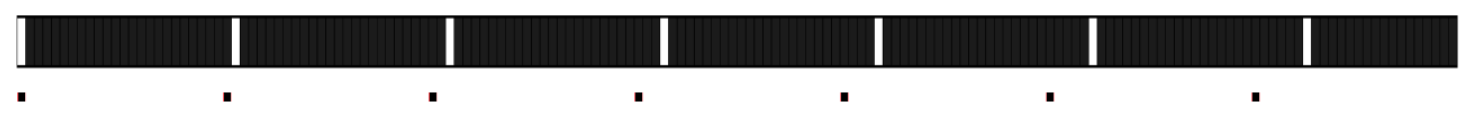

Em seguida, o mesmo ciclo é retomado, mas invertendo as cores: um único fotograma preto é apresentado entre fotogramas brancos. A mudança de posição do fotograma preto também ocorre a cada reiteração, e há também o esgotamento de todas as possibilidades. O mesmo deslocamento entre os ciclos é notado, mas com os parâmetros luminosos invertidos, fornecendo referências precisas para a experiência temporal com a luz e a escuridão crescentes.

Na segunda etapa, sob a cartela $2 / 24$, o processo é repetido, mas agora com dois fotogramas contíguos - primeiro, brancos entre pretos; depois, pretos entre brancos; 
sempre esgotando todas as possibilidades. O mesmo ocorre nas etapas seguintes: 3/24, $4 / 24$, etc. Todas as etapas mantêm rigorosamente as mesmas regras. Na última etapa, 24/24, um segundo de fotogramas brancos é alternado com um segundo de fotogramas pretos. O filme é uma exploração gradual de todas as possibilidades deste sistema, com duração de aproximadamente dez minutos. ${ }^{53}$

Duas características podem ser apontadas, permitindo uma comparação com os exemplos já mencionados.

1. O filme de Iimura apresenta sucessivamente os diferentes posicionamentos dos fotogramas numa série. As possibilidades são apresentadas como descrições dessa mesma série, e cada retomada do ciclo é a variação de um parâmetro específico. Como em The Flicker, o caráter descritivo envolve uma espécie de linearidade. Os fotogramas poderiam iniciar na posição 24 e terminar na posição 1, mas iniciam sempre na posição 1 e terminam sempre na posição 24; poderiam ser dispersos na série, mas são sempre contíguos. A experiência temporal, portanto, a gradual modulação rítmica e luminosa construída pelo filme, tem um direcionamento reforçado.

2. O filme apresenta após cada etapa o seu inverso monocromático. Ao fím de cada módulo é apresentado seu "contra-módulo", isto é, o mesmo processo, mas com os fotogramas pretos e brancos invertidos. Este fator, junto com a separação das etapas por cartelas, parece diminuir o aspecto linear da projeção - separando os padrões como diferentes experimentos isolados uns dos outros. Se as posições fossem apresentadas unicamente com fotogramas brancos móveis e sem as cartelas, a impressão de um preenchimento gradativo da escuridão ganharia a frente. Isso é impedido pela constante interrupção e pela inversão dos parâmetros luminosos. Mas o fato de apenas a cor ser invertida, nunca a ordem das posições, reforça a direção intencionada: como todas as posições avançam no ciclo, a sugestão de progressão no filme, quando ocorre, é sempre "para frente".

O que The Flicker e 24 Frames per Second têm em comum é portanto algo diferente da repetição idêntica: é o que chamaremos aqui de reiteração, ou a repetição que varia um único parâmetro, criando um direcionamento intermitente. Esse direcionamento, nos dois filmes, sugere a descrição de um espectro, de uma escala formada pelos elementos selecionados - em ambos os casos, fotogramas pretos e brancos.

\footnotetext{
53 A partitura do filme é reproduzida em Scott MacDonald, “An Interview with Taka Iimura”, Journal of the University of Film Association, vol. 33, n. 4 (outono de 1981), p. 42.
} 
Outra característica que permite uma comparação entre os dois filmes é o que Iimura descreve como uma dialética dos elementos:

\begin{abstract}
Assim como o tempo não pode ser desligado do espaço, a escuridão é uma parte fundamental da luz. O símbolo chinês yin/yang foi um conceito filosófico importante em minhas obras deste período. Sua estrutura dupla, com o positivo no negativo e o negativo no positivo, quer dizer que as polaridades são estruturas intercambiáveis. Seria mais correto dizer que é um tipo de dialética, ainda que não seja exatamente a dialética como é normalmente entendida na cultura ocidental. Como o símbolo chinês ilustra, pode haver o branco no preto e vice-versa; são estruturas interrelacionadas. Num filme, esse tipo de movimento ou troca de fotogramas positivos e negativos é apresentado no tempo, e o positivo e o negativo se tornam, em alguma medida, permutáveis. ${ }^{54}$
\end{abstract}

Este argumento revela as propriedades "comutativas" e "não-comutativas" envolvidas na composição de uma obra. Pode-se dizer que um aspecto é comutativo se permanece inalterado com a inversão das propriedades dos elementos. Nos dois filmes, o ritmo visual é comutativo no sentido de que a inversão do preto ao branco não descaracteriza as proporções temporais, marcadas pelas frequências de alternância entre as duas cores. Isso não significa que a experiência das durações seja idêntica no caso dessas inversões, mas sim que o jogo binário entre os fatores representa a propriedade comutativa em seu estado mais simples. Já o aspecto linear é comutativo apenas em The Flicker, mas nãocomutativo em 24 Frames per Second. O filme de Conrad descreve um espectro simétrico; suas proporções formam uma curva gaussiana, de modo que a impressão de movimentação através dessa escala é sugerida justamente pelo aumento e diminuição dos intervalos; uma inversão das proporções faria apenas com que a curva fosse vista com intervalos opostos, levando também à simetria. Mas o filme de Iimura descreve um espectro assimétrico; a descrição de sua escala depende que ela seja apreendida numa determinada direção, pois as possibilidades não são dispostas como uma curva gaussiana, e sim como duas curvas ascendentes, sendo construídas alternadamente - vemos uma etapa da curva de fotogramas brancos preenchendo os períodos de fotogramas pretos, em seguida uma etapa da curva de fotogramas pretos preenchendo os períodos de fotogramas brancos.

É crucial nesta distinção o fato de que 24 Frames per Second não se constitui de módulos repetidos de maneira acelerada, e de que não cria os mesmos efeitos fisiológicos. Sua organização é balanceada, havendo um quase didatismo na apresentação de seu

54 Esperanza Collado, "Takahiko Iimura in Interview", Experimental Conversations 5 (inverno de 2009/2010). Em: <www.experimentalconversations.com/articles/484/takahiko-iimura-in-interview>. Acesso em março de 2018. 
espectro. Em vez da cartela inicial advertendo sobre o radicalismo da experiência do flicker, há nele uma série de cartelas identificando cada um dos módulos, permitindo ao espectador algo como um exercício aritmético, um acompanhamento do preenchimento dos módulos com referências quanto à duração e extensão do processo.

\subsection{O princípio de variação}

A partir dos filmes comentados até aqui, e das formas descritas a partir deles, podemos derivar três princípios gerais, que dizem respeito às suas estratégias de composição.

1. Um princípio de homogeneidade, caracterizado pela manutenção dos elementos no decorrer da projeção, como se o filme tivesse no horizonte a imagem de um bloco estável. Zen for Film seria um caso-limite deste princípio, um filme em que a repetição é levada à menor escala possível, o fotograma, diminuindo ao máximo a ideia de progressão e reforçando a constância da tela.

2. Um princípio de linearidade, caracterizado pela mudança gradual dos elementos no decorrer da obra, como se o filme buscasse emular em seu próprio interior o desvelamento contínuo da fita ocorrido na projeção. Entrance to Exit seria um caso exemplar deste princípio: após uma etapa homogênea, a transição progressiva, já existente na faixa sonora, é levada também ao nível do fotograma.

3. Um princípio de reiteração, caracterizado pela transformação cíclica de elementos, como se o filme buscasse emular o processo intermitente dos fotogramas projetados. The Flicker seria aqui um exemplo: um filme no qual alguma linearidade é percebida, mas sem atingir o nível do fotograma; em vez disso, a linearidade existe nas etapas mais amplas, interrompidas por uma retomada periódica que enfatiza o caráter cíclico atuante na transformação do material.

Nestes filmes, a relação entre a imagem e o som tende ao paralelismo ou à analogia. Em Zen for Film, a tela branca constante sugere a completa ausência de articulação visual, sendo acompanhada por uma ausência de sons. Em Entrance to Exit, a gradação do fade é acompanhada por uma gradação sonora, do agudo ao grave. Em The Flicker, a intermitência dos fotogramas pretos e brancos é acompanhada por um ruído intermitente, ecoando a rápida alternância visual.

Em 1960, Peter Kubelka compôs uma obra importante neste quadro, incluindo o paralelismo como apenas uma possibilidade entre outras. Nascido em Viena, Kubelka 
permaneceu distante do contexto das vanguardas americanas até meados dos anos 1960, quando foi reconhecido como um dos precursores dos filmes estruturais. Seu Arnulf Rainer é amplamente considerado o pioneiro dos flicker films, e ainda que guarde semelhanças com os outros filmes comentados, é também uma ilustração do que diferencia Kubelka destes movimentos. Mais do que as vanguardas que lhe foram contemporâneas, suas preocupações o levaram a mencionar frequentemente a arquitetura renascentista e a música clássica europeia, onde ele buscou referências de ritmo e harmonia - o ritmo como o controle preciso das medidas temporais e a harmonia como o manuseio dos elementos sonoros e visuais sob regras recorrentes. Em termos gerais, Kubelka se concentra na necessidade de "dar forma ao tempo":

Eu sentia falta de uma forma satisfatória. [...] Eu vi quão bela era a arquitetura clássica; eu vi templos gregos e a arquitetura renascentista. Eu havia estudado música e conhecia as estruturas rítmicas na música e o fantástico deleite temporal com o qual a música pode lhe capturar. Mas no cinema não havia nada! Quando se considera o tempo em que o filme ocorre (um filme normal, narrativo, bom ou ruim), é um tempo que não possui forma; é muito amorfo. Então eu quis criar algo que pudesse estabelecer para meus olhos um tempo harmônico, como a música estabelece um tempo harmônico, rítmico, medido para o ouvido. ${ }^{55}$

Em Arnulf Rainer, ritmo e harmonia são reduzidos à mais pura materialidade. Kubelka parte de quatro elementos - fotograma branco, fotograma preto, ruído e silêncio - e efetua diferentes combinações entre eles. Não mais tendo em vista a repetição homogênea, a progressão contínua ou a gradação intermitente, mas uma exploração das diferentes possibilidades deste sistema. O processo de criação envolveu o que ele chamou de "a descoberta das leis naturais" do material fílmico, testes em looping de certos padrões de modo a conhecer cada um deles, identificando suas particularidades. Um dos padrões seria a alternância entre um fotograma preto e um fotograma branco - este seria o caso "mais forte", de maior contraste e tensão. Outro seria a repetição de fotogramas pretos ou de fotogramas brancos no mesmo período. Também seriam possíveis combinações de dois fotogramas pretos e dois brancos, três pretos e dois brancos, etc. As mesmas possibilidades existem na relação entre som e imagem: pode-se repetir os fotogramas pretos enquanto o silêncio e o ruído são alternados, pode-se alternar rapidamente os fotogramas pretos e brancos enquanto o silêncio é mantido constante, etc.

55 Peter Kubelka, "The Theory of Metrical Film", in The Avant-Garde Film: A Reader of Theory and Criticism, ed. P. Adams Sitney (Nova York: Anthology Film Archives, 1987), pp. 144-145. A declaração refere-se a Adebar (1958), mas é representativa do pensamento de Kubelka em seus filmes posteriores. 
Dentro deste universo, existem dois limites de intensidade, um máximo (a alternância constante de preto e branco, ruído e silêncio) e um mínimo (uma série contínua de fotogramas pretos e silêncio, a ausência de impulsos luminosos e sonoros). Partindo da definição de Kubelka, Arnulf Rainer toca nos limites materiais do cinema. O filme contém os pontos mais extremos da escala de luminosidade e ruído, bem como os pontos mais extremos das relações entre imagem e som. Entre todas as combinações, sob as coordenadas de luz e sombra, som e silêncio, há um quadro com vários filmes possíveis.

Através de uma notação binária, Kubelka pôde organizar sua estrutura numa verdadeira codificação do material fílmico. Considerando a imagem como " $\mathrm{X}$ " e o som como "-", atribuindo a cor vermelha ao "preenchimento" (branco/luz) e a cor preta ao "vazio" (preto/silêncio), ele representou diferentes padrões, ilustrando as relações temporais entre seus elementos básicos. ${ }^{56}$ Uma possibilidade seria a homogeneidade escolhida por Paik:

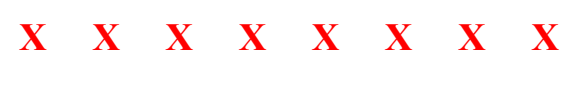

Outra seria a manutenção do silêncio com a cintilação mais extrema do filme de Conrad:

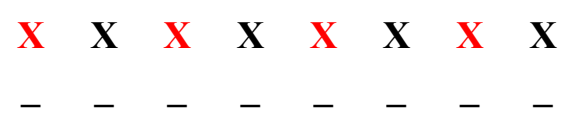

Outra ainda seria uma espécie de contraponto audiovisual, em que um padrão é repetido na imagem e no som, e em seguida mantido na imagem e invertido no som:

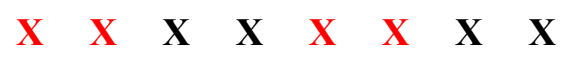

Philippe-Alain Michaud descreve a complexa estrutura criada no filme, com ênfase no caráter aritmético, baseado em certas proporções:

Os módulos fundamentais que o compõem são microestruturas de 1, 2, 4, 8, 12 ou 24 imagens. O conjunto apoia-se em grandes unidades de 576 fotogramas (ou seja, 24x24,

56 Para a partitura de Arnulf Rainer, ver Carlos Adriano e Bernardo Vorobow, Peter Kubelka: A essência do cinema (São Paulo: Babushka, 2002), p. 20. 
isto é, $1^{2}$ segundo). Cada unidade comporta um conjunto de temas de comprimento variável: $288,192,144,96,72,48,36,24,18,16,12,9,8,6,4$ ou 2 imagens, ou seja, 16 temas. Uma unidade jamais contém a totalidade dos temas. Em cada uma delas, estes se sucedem do mais longo para o mais curto, obedecendo a um princípio de intensificação. Consideremos a segunda unidade, cujo tema, o mais longo, comporta 144 quadros. Estes consistem em um módulo de 24 quadros, repetidos seis vezes, que se decompõe assim: 3 pretos, 4 brancos, 2 pretos, 6 brancos, 1 preto, 8 brancos. É sucedido por uma sequência de 96 quadros, cujo módulo básico, quatro vezes repetido, compõe-se de 24 quadros: 4 pretos, 4 brancos, 2 pretos, 2 brancos, 2 pretos, 2 brancos, 2 pretos, 1 branco, 1 preto, 1 branco, 2 pretos, 1 branco. O ritmo é mais discordante que no primeiro tema: o terceiro e o quarto temas estendem-se por 18 quadros cada um. Compõem-se de luz branca contínua, enquanto o sistema de oposição dos tons tem continuidade. Embora a alternância de imagens pretas e imagens brancas possa produzir efeitos ópticos singulares, Arnulf Rainer é construído de tal maneira que o efeito estroboscópico não se prolonga o suficiente para induzir efeitos sensoriais indeterminados. ${ }^{57}$

Podemos representar estritamente os módulos descritos como fitas de um segundo, dispostas separadamente para visualizar mais claramente os padrões e para que as proporções temporais sejam identificadas:

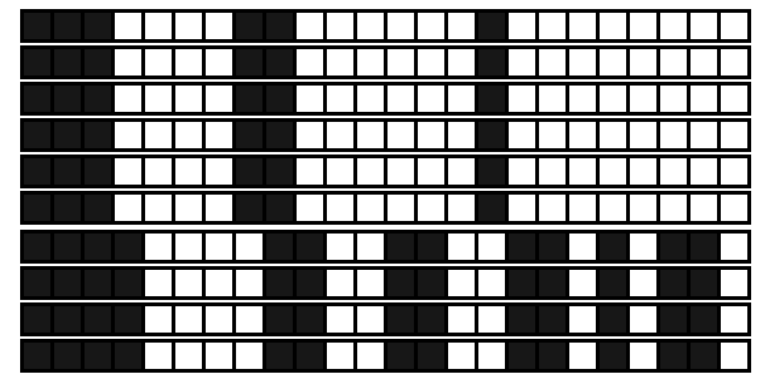

Elas podem também ser dispostas continuamente, numa tentativa de se aproximar da experiência sucessiva da projeção:

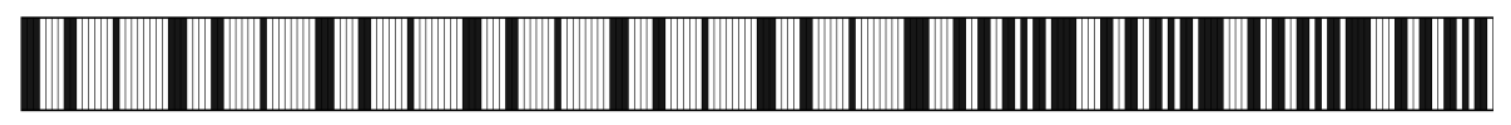

No filme de Kubelka, a homogeneidade da tela branca em silêncio dura apenas alguns segundos - e não se repete em outros momentos. A transição progressiva não é encontrada, pois os elementos são reduzidos ao branco e preto completos, eliminando as gradações. A reiteração também é rejeitada como princípio global, sendo admitida unicamente dentro de módulos isolados. O importante com isso é notar que Kubelka não se interessa pela concentração num único padrão. As possibilidades exploradas pelos

57 Michaud, Filme, op. cit., p. 144. 
filmes do Fluxus constituem casos paradigmáticos, e são por ele devidamente apreendidas; mas dentro de sua estrutura, nenhuma das possibilidades ganha a frente e domina toda a obra. É a mudança constante de um padrão a outro que caracteriza Arnulf Rainer. Quando um padrão ocorre no filme, ele só é retomado com alguma mudança, ou mesmo em sua completa inversão, geralmente com algum distanciamento temporal. Nesse sentido, a influência mais alinhada ao projeto de Kubelka não é Cage, mas um conterrâneo vienense: Anton Webern. ${ }^{58}$

O objetivo declarado de Webern foi a máxima integração dos elementos musicais, a maior unidade possível em cada composição. A forma mais natural para isso, em seu argumento, seria a "variação", ou a "repetição alterada" de uma ideia. Uma repetição exata reforça a ideia, enfatiza mesmo que se trata de algo reconhecível; mas repetir a ideia modificando a cada vez um parâmetro diferente faz com que se tenha tanto a impressão de recorrência como a impressão de variedade - sugere, em outras palavras, a multiplicidade na unidade.

O sistema da música tonal organiza a escala de doze notas de maneira hierárquica, estabelecendo um centro de gravidade (a "tônica") ao redor do qual as outras notas se dispõem em determinados níveis de consonância. O desenvolvimento temático da música tonal é portanto regido hierarquicamente: as variações tonais refletem os diferentes graus de importância atribuídos às notas. É neste ponto que Webern faz a defesa do método serial, pelo qual se abandona a lógica da tonalidade. Em vez de uma hierarquia de notas refletindo a importância de cada uma delas na estrutura geral da composição, o serialismo propõe um sistema não-hierárquico, permitindo que todas as notas sejam igualmente consideradas no decorrer da obra. Isso possibilita a exploração das várias ordenações do mesmo conjunto. Webern enfatiza o aspecto combinatório deste método:

a forma básica, a série de doze tons, pode gerar variantes - também usamos as doze notas de trás pra frente... e então invertidas [verticalmente na partitura] - como se fossem vistas num espelho - e então a inversão retrogradativa. Isso nos dá quatro formas. Mas e então, o que fazemos com elas? Podemos basear essas formas em cada grau da escala. 12 x 4 nos leva a 48 formas. ${ }^{59}$

58 A comparação entre os dois artistas não é incomum. Ver, por exemplo, P. Adams Sitney, "Kubelka Concrete", Film Culture 34 (1964), pp. 48-51; Peter Gidal, Materialist Film (Londres: Routledge, 1989), pp. 171-173. Para mais sobre o contexto vienense e a influência de Webern na vertente do "cinema formal austríaco", ver Peter Weibel, Beyond Art: A Third Culture (Nova York: Springer Wien, 1997), pp. 141-153.

59 Anton Webern, The Path to the New Music, ed. Willi Reich (Bryn Mawr: Theodore Presser, 1963), p. 41. Ver também Kathryn Bailey, The Twelve-Tone Music of Anton Webern (Nova York: Cambridge 
Um exemplo seria seu Concerto para nove instrumentos, Op. 24 (1934), em que a série de doze notas é reordenada e seccionada em quatro grupos de três notas, sendo cada grupo uma variação dos outros. ${ }^{60}$ As mesmas variações encontradas na estrutura da série ocorrem nos motivos e na composição como um todo. As simetrias são então multiplicadas, e um mesmo princípio estrutural organiza os diferentes níveis da obra, o que levaria a uma maior unidade.

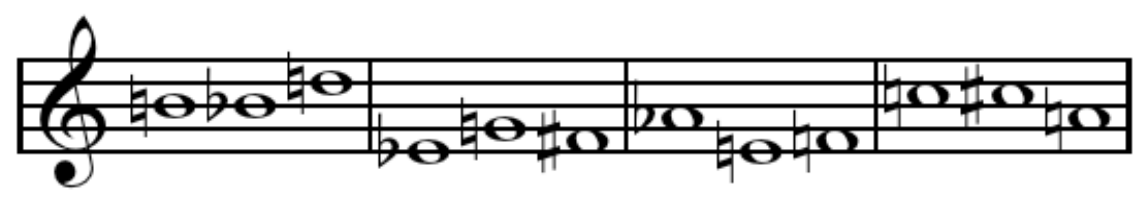

A série do Concerto para nove instrumentos, Op. 24 (1934), de Anton Webern.

Assim como Webern propõe o abandono da tonalidade como modo de unificação dos elementos musicais, defendendo em vez disso o uso de séries que criariam as combinações internas dos motivos, Kubelka realiza uma abstração combinatória de seus componentes, tornando seu filme o equivalente a uma apresentação de permutações em determinada ordem e em determinada duração (aproximadamente seis minutos).

A recusa da homogeneidade, da linearidade e da reiteração como princípios totalizantes parece fazer com que Arnulf Rainer tenha um maior grau de arbitrariedade que os outros filmes mencionados. A ideia de um "gesto composicional", bastante cara ao Fluxus e absorvida parcialmente por Conrad e Iimura, não possui o mesmo sentido na obra de Kubelka. A ausência de um formato global reconhecível - o fato de o filme não sugerir a imagem de um "bloco", uma "linha" ou um "espectro" - deve-se à insistência nas variações. Não há a exploração de toda uma trajetória: há uma seleção extremamente pontual dos resultados possíveis. Uma vez percebida a lógica de Entrance to Exit ou The Flicker, alguma margem de previsão é dada ao espectador; uma vez tomadas as decisões iniciais, os sistemas parecem avançar quase automaticamente. A exploração de Kubelka, ao contrário, poderia continuar indefinidamente, de maneira imprevisível. É praticamente impossível "esgotar" suas premissas. Por essa mesma razão, imaginar um contrafactual de Arnulf Rainer é uma tarefa consideravelmente diversa dos outros casos, visto que os

University Press, 1991), onde a autora apresenta matrizes das composições de Webern (no Apêndice II) e analisa algumas de suas escolhas de séries e combinações (Apêndice III).

60 Ver Kathryn Bailey, "Symmetry as Nemesis: Webern and the First Movement of the Concerto, Opus 24", Journal of Music Theory, vol. 40, n. 2 (outono de 1996), pp. 246-247. 
critérios que informam as escolhas de Kubelka são menos definidos - e o próprio filme já comporta, por assim dizer, seus vários contrafactuais. O filme é caracterizado menos por uma única ideia, e mais por um conjunto de ideias: a seleção e ordenação das variações preferidas pelo cineasta, dentro da moldura temporal também por ele definida.

O próprio Kubelka criou, décadas depois, uma variação de seu filme. É sintomático que em Antiphon (2012) a mesma estrutura de Arnulf Rainer seja mantida, mas invertendo todos os elementos: onde num filme havia o branco, no outro há o preto; onde num havia o preto, no outro há o branco; onde num havia ruído, no outro há silêncio; e onde num havia silêncio, no outro há ruído. Kubelka frequentemente apresenta os dois filmes num mesmo programa. Primeiro, Arnulf Rainer é projetado; em seguida, Antiphon; finalmente, ambos são projetados simultaneamente, sobre a mesma tela, numa performance que ele denominou Monument Film. Dessa forma, a arbitrariedade de Arnulf Rainer não apenas não é negada como é afirmada por sua própria inversão, que mantém exatamente as mesmas proporções.

Essa mesma arbitrariedade caracteriza a dispersão dos aspectos comutativos e nãocomutativos no decorrer dos filmes. Era a regularidade e a previsibilidade dos filmes do Fluxus que permitiam uma percepção global da obra; é a recusa a esses termos que impossibilita aos flickers de Kubelka uma classificação igualmente precisa. Alguns de seus módulos sugerem a comutatividade rítmica, pela regularidade dos intervalos; outros, pela irregularidade ou homogeneidade, sugerem a não-comutatividade. Alguns períodos reforçam o caráter intercambiável de fotogramas pretos e brancos, de som e silêncio, como quando sua alternância é acelerada; outros reforçam como a escuridão silenciosa e o ruído luminoso são as mais completas inversões possíveis no material fílmico. Mais uma vez, é a escolha pelas variações que caracteriza estes filmes.

O método de Kubelka - desde sua familiaridade com os elementos básicos até sua disposição dos padrões de modo a não reforçar nenhuma possibilidade mais que as outras - sugere um acesso ao material fílmico e uma concepção de suas articulações como um instrumento ou uma ferramenta a ser aplicada de diferentes maneiras. Como um compositor musical, Kubelka recorre a seus elementos como notas a serem combinadas em motivos e melodias, o que, no seu caso, se traduz necessariamente em padrões rítmicos, em sobreposições e subtrações consecutivas de luz e sombra, som e silêncio. Em vez do isolamento e da alteração de um único parâmetro, há a alteração de praticamente todos os parâmetros. O resultado é uma estrutura única, que não possui precedentes ou previsibilidade em seus modos de organização. O alto grau de arbitrariedade, e o fato de 
haver uma infinidade de outras combinações possíveis, destaca ainda mais a unicidade desta estrutura. É também por este fator que Kubelka parece indicar o mesmo processo a outros cineastas, em especial jovens e iniciantes: como num exercício, ele sugere a composição de uma obra análoga para "desenvolver uma noção de ritmo e uma sensibilidade para o silêncio e o som". ${ }^{61}$

\subsection{Anatomia cromática}

Todos os filmes mencionados até aqui fizeram uso de fotogramas pretos e/ou brancos. Zen for Film elege o branco como sua totalidade e Entrance to Exit realiza uma travessia entre o branco e o preto, ao passo que The Flicker e Arnulf Rainer desenvolvem estruturas complexas baseadas em padrões de alternância, isto é, na inversão de uma cor ao seu extremo oposto. Porém, todos permanecem no eixo monocromático.

Em 1966, Paul Sharits compôs um filme que estabelece um importante diálogo com essas obras. Assim como Tony Conrad, Sharits manteve ligações com o Fluxus (suas primeiras obras constam na antologia Fluxfilm) e com o cinema estrutural (do qual foi considerado um dos principais nomes). Seu Ray Gun Virus é um flicker que recorre não apenas a duas cores, mas que busca abarcar todo o espectro cromático. $\mathrm{O}$ filme exige que primeiro sejam descritas suas estratégias locais, e apenas em seguida sua estrutura mais ampla.

Há uma série de "frases" no filme de Sharits, construídas como padrões que evidenciam o potencial de seus elementos. Entre essas frases, quatro tipos podem ser destacados: (1) períodos em que uma única cor é mantida na tela durante alguns segundos; (2) transições de uma cor ao preto ou ao branco, em diferentes velocidades; (3) alternâncias de cores, em diferentes frequências, onde uma cor predomina; (4) alternâncias, também em diferentes frequências, de uma mesma cor em diferentes matizes, criando efeitos de "esfericidade" no quadro, como se a tela fosse contraída e expandida - o efeito gama, a "expansão e contração do estímulo conforme se aumenta ou se diminui a luminosidade". ${ }^{62}$ Há ainda combinações entre as frases mencionadas. Como um refrão, o flicker às vezes estaciona brevemente numa cor, ao que se segue um fade, e

61 Ver P. Adams Sitney, “Kubelka Concrete”, Film Culture 34 (1964), pp. 49-50.

62 Ver Bill Nichols e Susan J. Lederman, "Flicker and Motion in Film", in The Cinematic Apparatus, p. 101. 
depois a retomada do flicker. Isso ocorre mais de uma vez, em diferentes momentos no decorrer do filme, e com diferentes cores. Durante os 14 minutos da obra, há um único padrão sonoro, um ruído intermitente, semelhante ao de The Flicker, evocando o ritmo acelerado da projeção.

$\mathrm{Na}$ descrição dessas estratégias, pode-se identificar uma absorção das mesmas técnicas que determinaram a totalidade dos outros filmes. O que caracterizava Zen for Film - a permanência de uma única cor, repetida ao nível do fotograma, reforçando o princípio de homogeneidade - está presente momentaneamente em Ray Gun Virus. Da mesma forma, o que se destacava como o gesto linear de Entrance to Exit - a transição gradual de uma cor a outra - é retomado periodicamente por Sharits. A variação que rege os flickers de Kubelka é tornada então um fator central.

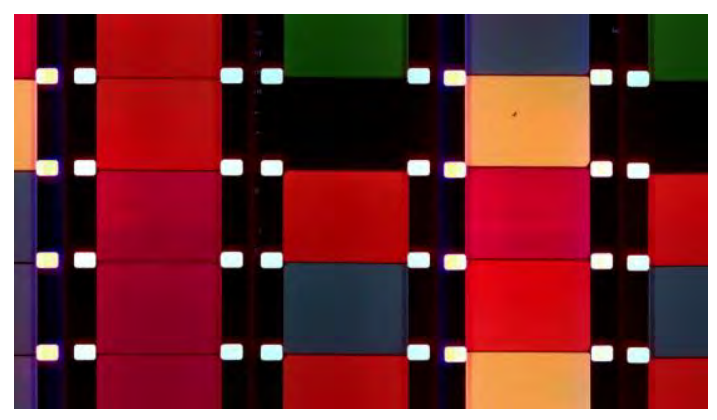

Fitas de Ray Gun Virus (Paul Sharits, 1966), exibidas no documentário Paul Sharits (François Miron, 2012).

Amplamente considerado como o primeiro flicker colorido, Sharits foi na verdade precedido pela obra de outro americano, Dwinell Grant, que em 1943 realizou Color Sequence. ${ }^{63} \mathrm{O}$ filme de Grant parece um breve experimento se comparado a outros filmes

63 Entre os autores considerados nesta pesquisa e que tratam dos cineastas relacionados aos flickers, apenas dois citam o filme de Grant: Philippe-Alain Michaud e William Moritz. Outros (Sitney, James, Le Grice, Gidal, Dwoskin, Beauvais, Noguez) não o mencionam, e afirmam o pioneirismo de Kubelka, Conrad e Sharits. Uma hipótese, citada por Moritz, é a de que o filme praticamente não foi exibido até meados dos anos 1970, em razão do desconforto de Grant com a obra. Ver William Moritz, "NonObjective Film: The Second Generation", in Film as Film, op. cit., p. 68. Sitney provavelmente conhecia o filme, pois consta no ciclo "The Essencial Cinema", programado por ele e por outros membros-fundadores do Anthology Film Archives entre 1970 e 1975. Outra hipótese, então, seria a de que havia o conhecimento por parte de alguns desses autores, mas que a distância histórica e as diferenças composicionais fizeram com que não considerassem o filme de Grant tão importante quanto os flickers dos anos 1960, ao menos não o suficiente para traçar uma mesma linhagem. Em todo caso, os cineastas aqui mencionados declararam desconhecer os flickers uns dos outros enquanto terminavam os seus próprios. A questão parece envolver, nesse sentido, menos a influência direta e mais a historiografia geral. A hipótese de Moritz é reforçada pelos documentos da sociedade Art in Cinema, nos quais o nome de Grant é citado apenas duas vezes: cartas de Herman Weinberg (1946) e Hans Richter (1947) demonstram interesse pela exibição de seus filmes; mas nos dois casos, não há menção a 
deste capítulo; além da menor duração (aproximadamente dois minutos), não há nele uma radicalização dos elementos ou da estrutura, mas sim a exploração pontual de algumas possibilidades. Uma técnica utilizada por ambos é o que Philippe-Alain Michaud descreveu como um "deslizar imperceptível e contínuo do contraste para a fusão". Alternando as cores em ritmos decrescentes, o filme de Grant cria uma espécie de dissolução progressiva das marcações temporais num "efeito de vibração regularmente intensificado". ${ }^{64}$ Para exemplificar este procedimento, podemos representar estritamente um trecho em que três cores são alternadas, em padrões de 6/5/4/3/2/1 fotogramas:

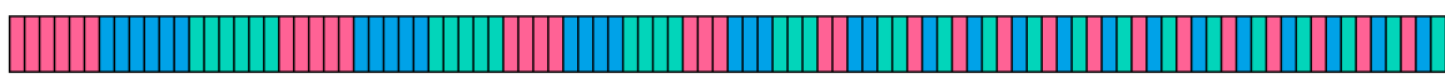

Nos últimos segundos, isso é combinado com uma breve homogeneidade e dois fades em sequência. Podemos representar estritamente o trecho, comparando as diferentes proporções e o uso das tonalidades em fitas de um segundo:

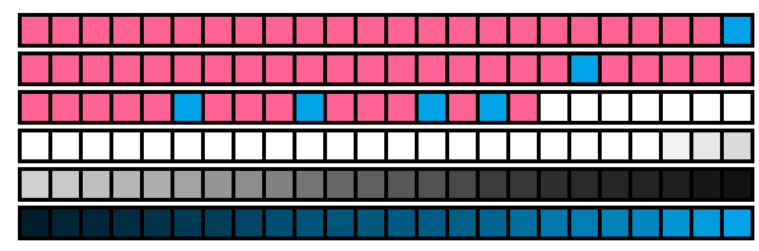

Podemos ainda dispor as mesmas fitas em sequência, numa tentativa de se aproximar da experiência da projeção:

Assim como Sharits, Grant coordena as diferentes possibilidades através de sua preferência pela variação. Não há um padrão eleito como central. Mas, apesar deste interesse comum, o filme de Sharits tem um reforço na direção oposta. Diferente de Kubelka, que buscava dispersar seu formato global pela recusa de um esquema reconhecível, Sharits termina por recorrer a um esquema, e nesta escolha, se aproxima do

Color Sequence. Ver Scott MacDonald, ed., Art in Cinema: Documents Towards a History of the Film Society (Filadélfia: Temple University Press, 2006), p. 55, 168.

64 Michaud, Filme, op. cit., p. 141. As representações estritas do filme de Grant se baseiam na análise de Michaud. 
"espectro" de Conrad. A descrição da estrutura de Ray Gun Virus por Regina Cornwell menciona esse aspecto, e o quanto a organização do filme se dá por regiões tonais, marcadas por variações internas:

A estrutura cromática do filme parte de um dominante amarelo, passa por um centro vermelho até que atinge o azul. Brevemente, formações de preto e branco cintilantes seguem o título, sucedidas por cores fracas - fracas a ponto de quase não serem distinguíveis do branco, como se estivessem lutando para existir - e então uma seção dominada por amarelo, cintilando com outras cores. O centro vermelho cintilante é sucedido por fades de amarelo para o preto e então fades de vários tons para o preto. Uma seção aleatória se segue, sem repetições de padrões cromáticos, em fades para o branco. Estes fades, que são inicialmente longos e suaves, tornam-se mais abruptos e instáveis, finalmente terminando em flashes. O filme termina num azul fraco e pouco cintilante. ${ }^{65}$

Há, portanto, uma predominância de cores em algumas etapas do filme. Além das “dominantes" mencionadas por Cornwell, há também a predominância, em momentos específicos, de branco ou preto como "pontos de fuga" nos fades.

A comparação feita por Michaud entre Color Sequence e algumas telas de Ellsworth Kelly é útil para compreender a disposição dos padrões cromáticos de Sharits contra as referências do preto e do branco. ${ }^{66}$ Em diferentes obras, Kelly dispõe quadrados de várias cores e com as mesmas proporções sobre um fundo preto ou branco, de modo que as distâncias e os contrastes devem necessariamente ser vistos em relação a este fundo, na forma como se distribuem pela superfície:
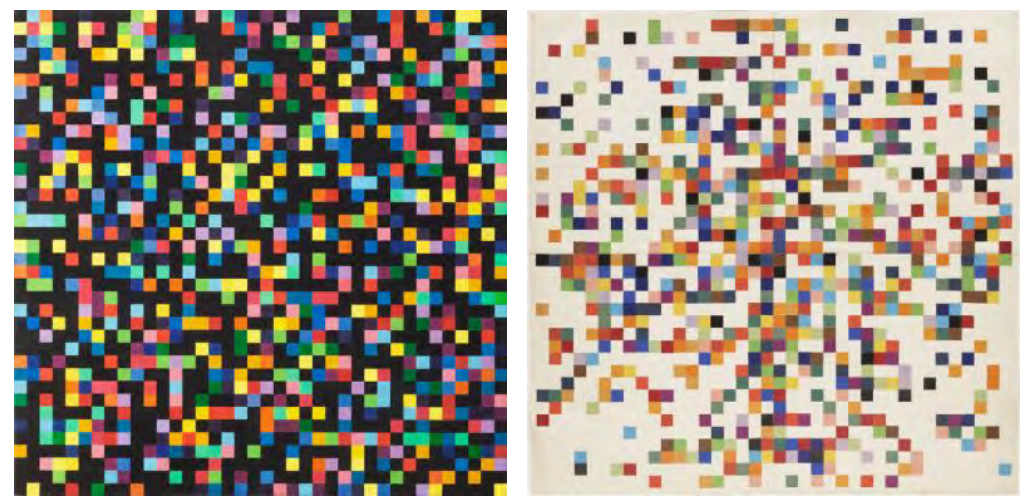

Ellsworth Kelly, Spectrum Colors Arranged by Chance (1951-53)

Numa estratégia semelhante, Sharits interrompe seu flicker periodicamente com movimentos em direção à luminosidade ou à escuridão, criando diferentes contextos para

65 Regina Cornwell, "Paul Sharits: Illusion and Object", Artforum, vol. 10, n. 1 (setembro de 1971), p. 57.

66 Sitney também comenta brevemente a relação entre Kelly e o cinema experimental americano, destacando Sharits como um caso especial no tratamento das "vibrações cromáticas". Ver P. Adams Sitney, "The Idea of Abstraction”, Film Culture 63/64 (1977), pp. 13-14. 
as alternâncias coloridas, realizando temporalmente o que Kelly propõe no espaço. Os mesmos padrões, cercados por fades ao preto e ao branco, criam efeitos distintos. Os mesmos padrões, dispostos em comprimentos diferentes da fita de filme, e ocorrendo com diferentes cores, terminam criando uma arquitetura interna na obra. Como na jornada de Conrad pelas frequências de alternância entre preto e branco, há uma jornada na escala de cores sendo delineada.

O ritmo em The Flicker ou Arnulf Rainer era necessariamente um ritmo binário. É por essa razão que se pode falar de um aspecto comutativo nestes filmes: inverter a luminosidade dos fotogramas alteraria qualitativavemente a experiência, mas não deslocaria o padrão de alternâncias que caracteriza o ritmo. Nestes casos, todos os efeitos devem ser criados por combinações de blocos monocromáticos. É a partir das mesmas duas linhas simples que deve-se chegar aos efeitos complexos, sejam variedades de contraponto audiovisual ou sugestões ópticas por determinadas frequências. Inserir as cores neste processo, e sobretudo incluir as cores em seus diferentes matizes, faz com que essas propriedades sejam rapidamente modificadas. Não há mais um ritmo binário pois o jogo das alternâncias, quando ocorre, não possui mais uma referência polarizada. Pode-se criar a polaridade rítmica em certo período, mas absorver a variedade cromática significa que o filme não irá postular um contraste absoluto, e que a sucessão das cores e sua recorrência irão sugerir mais variáveis que a mera inversão luminosa.

Não sendo mais o resultado da pura inversão, o ritmo não é mais comutativo por toda a obra. Em vez de apenas duas possibilidades para as mesmas medidas, há uma série inesgotável de combinações cromáticas a serem consideradas. Como ilustração, pode-se imaginar um padrão de alternância em que dois fotogramas de cores diferentes são alternados repetidas vezes, levando a efeitos completamente diferentes: pode-se alternar um fotograma preto e um branco; um fotograma preto e um verde; um fotograma verde e um vermelho; um fotograma verde e outro verde, mas com uma leve diferença de matiz; etc. Há toda uma escala de contrastes a ser experimentada nestas combinações.

Se tentarmos imaginar a forma total de Ray Gun Virus a partir das cores dominantes a fim de tentar compreender a razão das escolhas composicionais, perceberemos que existem inúmeros contrafactuais para o filme mesmo se nos focarmos em um único parâmetro. Sharits poderia manter exatamente os mesmos padrões rítmicos, mas alterando a posição das cores, o que já levaria a um número incrivelmente elevado de possibilidades; poderia variar alguns dos padrões, mantendo as mesmas grandes regiões cromáticas, o que sugeriria uma liberdade de articulação equivalente à de Kubelka; 
poderia, finalmente, reordenar tanto as cores como os padrões rítmicos. Duas decisões de Sharits apontam para a função de sua estrutura: (1) ele poderia eleger uma cor e organizar todo o filme ao redor dela (como uma tônica cromática), mas prefere a passagem entre grandes blocos de cores dominantes, entre os quais praticamente todas as outras cores são exploradas; (2) ele poderia distribuir os fades ao preto e ao branco de maneira aleatória, ou segundo padrões de alternância que os aproximassem, mas prefere dispô-los em etapas específicas do filme.

Não é o espectro de Conrad, e não é a variação de Kubelka que parecem reger Ray Gun Virus, portanto, mas uma espécie de cruzamento dos dois princípios. Há o interesse pela organização de uma escala: Sharits refere-se frequentemente à mandala como sua imagem de referência, uma organização diagramática de cores. Ao mesmo tempo, há também uma recusa da reiteração em prol da variedade, um interesse pela exploração combinatória, mas sem deixar de incluir gradações e recorrências, isto é, sem deixar de sugerir que há um contorno geral sendo traçado. Sharits parece, afinal, descrever uma vasta escala de elementos ao mesmo tempo em que investiga as combinações internas desta escala. ${ }^{67} \mathrm{O}$ resultado é uma forma que, de uma só vez, busca representar uma totalidade e dinamizá-la no processo de sua representação - uma “diagramação livre”, ou que podemos chamar de uma "forma anatômica".

\subsection{Filme, Fluxus, Flicker}

Todos os filmes mencionados neste capítulo articulam apenas uma dimensão do espaço: a superfície da própria tela. A tela é tomada por eles como um quadro uniforme e achatado, equivalente à seção correspondente da fita de filme, o fotograma, e apenas sua luminosidade e sua tonalidade são manipuladas. Como isso ocorre na projeção do filme, a composição se torna sinônimo de padrões impostos às manipulações no decorrer do tempo cronométrico, pois são eles que determinam o formato das obras. Conforme os padrões são criados e distribuídos pela duração, surgem determinados efeitos, e o acúmulo deles cria determinadas formas e estruturas.

67 Assim como Paik, Sharits também exibiu seu filme em galerias. Mas diferente de Paik, ele não recorreu ao loop, e sim à disposição das fitas nas paredes, colunas dispostas lateralmente, como uma "espacialização" das proporções que, durante a projeção, são experimentadas temporalmente. Kubelka fez o mesmo com Arnulf Rainer. 
Nesta dimensão, uma dimensão incontornável dadas as condições materiais do cinema, pode-se dizer que são filmes que articulam o nível mais elementar do espaço fílmico: a tela bidimensional. Por sua vez, considerando as extensões da fita de filme, e por serem casos em que o filme é preenchido por blocos de cores, portanto sem qualquer outro tipo de conteúdo visível (ou audível, já que os ruídos ecoam as escolhas visuais, sendo todos, sem exceção, ruídos "genéricos"), a única referência temporal é a relação entre a duração dessas cores e a duração da projeção, o que significa que é também este nível de tempo elementar, inevitável, que recebe uma articulação direta: a cronometria da projeção. Além das molduras de início e final que marcam os limites da duração, são as medidas internas da obra que revelam as formas temporais na composição.

Consideremos o fato de que estes filmes pressupõem a tela, ou o fotograma, como seu elemento básico. Com duas exceções (Iimura e Grant), todos surgiram nos anos 1960; com uma exceção (Grant), todos estiveram de algum modo ligados a duas tendências da vanguarda americana: o Fluxus e o cinema estrutural. Podemos então nos perguntar quais as razões para enfatizar o fotograma, e como isso se percebe nas formas desenvolvidas por essa escolha.

Um comentário de Regina Cornwell sobre Sharits é exemplar nesse sentido, revelando o quanto as preocupações do Fluxus em relação ao imediatismo da experiência atravessam sua composição:

[Ray Gun Virus] reduz o meio aos seus componentes mais simples ao passo que revela as complexidades desses componentes. Sharits lida conscientemente com a fita de filme como uma fita de fotogramas individuais, cada um deles exposto a vários graus de cor e luz, cada um possuindo sua própria imagem de cor e luz. Ao abandonar a capacidade tradicional do filme de registrar uma ilusão tridimensional, Ray Gun Virus projeta seus fotogramas cromáticos e acromáticos sobre uma tela achatada, criando suas próprias ilusões, e ilusões de ilusões. A imagem da tela é em si uma ilusão: removida a um grau da fita de filme no projetor, e a dois graus do rolo original, é uma ilusão como todo filme é uma ilusão nesse sentido. Mas ao confrontar o preto, o branco e as cores, o espectador se torna mais consciente do fato de que está perante uma ilusão, e, paradoxalmente, esta ilusão possui um imediatismo temporal. É algo experimentado no tempo presente, e que não se refere - como uma ilusão representativa - a um tempo e espaço anteriores. Malevich, em Essays on Art, II, fala de um novo realismo, alcançado através do Suprematismo e de outras artes radicais de seu tempo, e da relação do espectador com essas obras: “...as novas obras de arte insistem na expressão do conteúdo real de cada sensação, uma realidade que sempre permanece real para o espectador." E, mais adiante, numa cristalização: "Uma imagem real é também um novo fator que não nos leva para outro lugar, mas nos força a perceber e experimentar a obra em seu próprio lugar." Este é o caso de Ray Gun Virus. ${ }^{68}$

68 Idem. 
O argumento de Cornwell é que, afastando-se da "capacidade tradicional do filme de registrar uma ilusão tridimensional", e sobretudo pelo modo como Sharits o faz, numa rápida sucessão de fotogramas coloridos, o resultado seria uma ênfase na superfície visual. Não mais um espaço através do qual se veem determinadas imagens, a tela se torna o próprio espaço a ser visto.

As vanguardas europeias dos anos 1920 também buscaram se afastar da capacidade "realista" do cinema. Mas nos "filmes absolutos" de Hans Richter, Viking Eggeling e Oskar Fischinger encontramos formas pictóricas semelhantes às da pintura modernista - figuras geométricas e manchas coloridas são deslocadas, transformadas e multiplicadas. A tela não é considerada, portanto, o único elemento visual a ser articulado. Neste ponto, é Iimura quem aponta essa diferença como fundamental para compreender as preocupações de seu filme, e que ressoam nos outros casos mencionados:

A tradição do filme de vanguarda é dominada pela exploração visual do material fílmico. O cinema de vanguarda começou nos anos 1920 com artistas cujos interesses principais eram visuais e espaciais. Entretanto, ainda que esta tradição seja bastante forte, os aspectos visuais que preenchem o espaço fílmico são apenas um fator. Outro fator é a temporalidade. Este aspecto tem sido negligenciado. É sempre tratado como uma espécie de fator de suporte ao fator visual. Ainda que todos os filmes devam ter uma certa sequência temporal, a temporalidade em si nunca foi tratada como um tema em si [...]. ${ }^{69}$

O argumento de limura é que os interesses das vanguardas dos anos 1920 envolviam uma certa plasticidade fílmica, mas que esta plasticidade dependia de formas no interior da tela, e mesmo de formas em movimento. Livrar-se desses interesses, ou seja, livrar-se dos conteúdos visíveis no interior da tela, seria equivalente a abrir caminho para a exploração direta das formas temporais. A tela se tornaria, assim, o meio privilegiado de exploração das durações fílmicas.

Livrar-se do potencial mimético do cinema foi portanto um desejo constantemente perseguido pelas vanguardas, mas nem sempre com o mesmo radicalismo. Em 1966, Theodor Adorno declarou sua insatisfação com esta insuficiência:

O processo fotográfico do cinema, primordialmente representacional, coloca um significado intrinsicamente superior no objeto, como deslocado da subjetividade, mais que em técnicas esteticamente autônomas; este é o aspecto retardatário do cinema no processo histórico da arte. Mesmo quando o cinema dissolve e modifica seu objeto tanto quanto pode, a desintegração nunca é completa. Consequentemente, não permite a

69 Scott MacDonald, “An Interview with Taka Iimura”, Journal of the University of Film Association, vol. 33, n. 4 (outono de 1981), p. 33. 
construção absoluta: seus elementos, independente de quão abstratos sejam, sempre mantêm alguma representatividade; eles nunca possuem valor puramente estético. ${ }^{70}$

Adorno se restringe às vanguardas que mantiveram o caráter fotográfico e figurativo como um de seus pilares criativos. Ele afirma que manter o caráter representacional apenas para distorcê-lo não é um caminho válido ou interessante; mas quando trata de alternativas à representação, menciona unicamente técnicas como desfoque, sobreposição e flashback. Na própria crítica de Adorno há a suposição da figuração como um dos fundamentos da composição fílmica. O cinema sugerido por ele, um cinema da "desintegração completa do objeto" ou de uma "construção absoluta", parece situar-se justamente à frente destas considerações - parece necessitar do passo seguinte a este raciocínio.

Annette Michelson contrapõe então ao comentário de Adorno o cinema experimental americano dos anos 1960 e 1970, com ênfase nos filmes estruturais, mas descrevendo características que poderiam igualmente se aplicar ao Fluxus:

A empreitada da vanguarda americana é mais claramente compreendida como direcionada à destruição destas suposições canonicamente recebidas e estabelecidas. A produção dos anos 1960 e 70 [...] contraria essas suposições em sua exposição das propriedades e dos processos fílmicos (de grão, luz, emulsão, revelação, registro), em sua insistente interceptação e em seu bloqueio da continuidade diegética [...].

Branca ou preta ou preenchida por cores, subliminar ou assertiva, fraca ou saturada, granulada ou densa, a tela se encontra livre de imagens, mais que vazia; ela sinaliza mais imediatamente um reconhecimento do formato e da superfície, das fronteiras e da luminescência da própria tela, a impossibilidade do vazio. Este reconhecimento atravessa o desenvolvimento da cinematografia avançada nesta época, como se uma implosão acelerada tivesse condensado a sucessão de imagens gerada pela montagem hiperbólica das práticas da vanguarda num integral e radiante retângulo cintilante. ${ }^{71}$

Aqui, de fato, estão filmes compostos como se para realizar a cinefilia iconoclasta de Adorno, purgada de qualquer traço mimético. Aqui está um projeto análogo em sua iconoclastia ao Suprematismo como propagandeado por Malevich, tendo início em 1915. "Até agora, tivemos o realismo dos objetos, mas não de unidades de cores pintadas", declarou Malevich. ${ }^{72}$

70 Theodor Adorno, citado em Annette Michelson, "Frampton's Sieve" (1985), in On the Eve of the Future: Selected Writings on Film (Cambridge Mass.: The MIT Press, 2017), p. 231. Para uma contextualização dos comentários de Adorno sobre o cinema, ver Mateus Araújo Silva, "Adorno e o cinema: um início de conversa", Novos Estudos CEBRAP 54 (julho de 1999), pp. 114-126, onde se propõe que as formulações de Adorno, mesmo quando se referem à natureza do cinema em geral, dizem respeito mais à sua reação enérgica contra o cinema hollywoodiano.

71 Michelson, "Frampton's Sieve", op. cit., p. 158, 159.

72 Annette Michelson, "Gnosis and Iconoclasm: A Case Study of Cinephilia" (1998), op. cit., p. 61. 
Evidentes nas declarações de Michelson estão as dimensões de celebração e sublimação do aparato fílmico - de modo correlato, o uso da "tela vazia" como o apogeu da atitude vanguardista. É esta ênfase na materialidade do meio, no imediatismo da experiência, que encontramos nos filmes aqui tratados. Mas há outra característica, complementar e melhor representada por um autor citado por Cornwell e Michelson - Kazimir Malevich.

\subsubsection{Polarização do fotograma}

No século XVII, o cientista britânico Robert Fludd incluiu, num tratado cosmológico de extração hermética, uma imagem do espaço antes da criação divina: um quadrado negro em cujas bordas havia a inscrição Et sic in infinitum ("e assim até o infinito"), indicando que o vazio, representado pela escuridão da imagem, continuava para além dos limites da moldura. Três séculos mais tarde, Malevich, em sua "tentativa de livrar a arte do lastro da objetividade", chegou à mesma imagem, um quadrado preto, que ele dispôs numa moldura branca. As diretrizes do Suprematismo, defendidas pelo pintor russo, sugeriam uma purificação de sua arte; sugeriam uma pintura sem outro objeto que não a si mesma, uma pintura reduzida à própria superfície. ${ }^{73}$ Não mais a verdade de um objeto visível através de sua representação iconográfica, o que Malevich dizia representar, na redução dos seus materiais ao próprio formato da tela, na superfície enfatizada e depurada, livre das referências de perspectiva e orientação gravitacional, era um outro universo, essencialmente espiritual. Numa adaptação provavelmente inconsciente da inscrição de Fludd, ele afirmou: "Vou exibir o que eu vejo no espaço infinito do crânio do homem."74

73 Kazimir Malevich, citado em Gerry Souter, Malevich: Journey to Infinity (Nova York: Parkstone Press, 2008), pp. 110-114. Para as declarações de Malevich sobre o cinema, especialmente a relação entre as vanguardas soviéticas e a abstração, ver Kazimir Malevich, "Pictorial Laws in Cinematic Problems" (1929), in The White Rectangle: Writings on Film, ed. Oksana Bulgakowa (Berlim e São Francisco: Potemkin Press, 2002), pp. 77-84.

74 Kazimir Malevich, citado em Evgueny Kovtun, Russian Avant-Garde (Nova York: Parkstone, 2007), p. 40. 


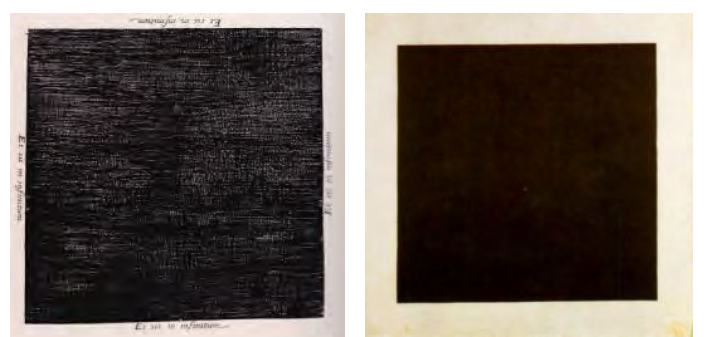

Robert Fludd, Utriusque cosmi... (1617) e Kazimir Malevich, Quadrado negro (1915) ${ }^{75}$

Entre o Fluxus e os filmes estruturais há um trânsito constante entre a afirmação do filme como "objeto" e do filme como uma espécie de "máquina da consciência". Basta apenas recordar os efeitos induzidos pelas frequências aceleradas, pelas combinações de cores, e a insistência de Frampton ou Conrad em manipular os fotogramas tendo em vista a manipulação da cognição do espectador. Há toda uma vertente que dá prioridade a este fator, representada aqui por um comentário de William Wees:

Estritamente falando, os efeitos de flicker não estão de maneira alguma no filme; são apenas estimulados por ele. Fotogramas pretos e brancos alternados, por exemplo, evocam percepções de um cinza efêmero e levemente cintilante. Alternar fotogramas vermelhos e azuis produz um violeta comparavelmente vívido, ainda que pouco substancial. A cor percebida e as rápidas pulsações são criadas pelo sistema visual do espectador, em resposta à ordem e à frequência, assim como ao brilho e ao matiz dos fotogramas alternados. Quando a luz continua a cintilar, toda a imagem parece se expandir e se contrair ou mesmo se elevar da superfície da tela, flutuando de maneira desconcertante em algum plano ambíguo, impossível de se fixar no espaço. Na verdade, não está "no espaço" de forma alguma. Está "no" disparo temporalmente organizado das células cerebrais. É, literalmente, uma "forma temporal interna", como Sharits a denomina, criada pelo "funcionamento elétrico-químico do próprio sistema nervoso [do espectador]". O mesmo pode ser dito da visão como um todo, mas geralmente há uma semelhança considerável, ou uma relação icônica, entre o estímulo externo e a representação interna desse estímulo. O espectador de um filme de flicker, no entanto, vê coisas que são muito diferentes daquilo que está no filme em si. Por essa razão, pode-se dizer que o flicker é o meio mais efetivo para o cineasta gerar imagens diretamente na mente do espectador $\left[\ldots . .{ }^{76}\right.$

Malevich se refere ao "espaço infinito do crânio do homem", mas também ao "realismo das cores pintadas", e esta dualidade aparece igualmente nos filmes de flicker. O argumento de Rosalind Krauss para a grade como forma emblemática do modernismo pictórico envolve a mesma ambivalência. “A força mítica da grade”, segundo Krauss, é

75 O título completo da obra de Fludd é Utriusque cosmi maioris scilicet et minoris metaphysica, physica atqve technica historia (Oppenheim, 1617-21). A imagem citada encontra-se no quinto capítulo do primeiro livro, De tenebris et privatione.

76 William Wees, Light Moving in Time: Studies in the Visual Aesthetics of Avant-Garde Film (Berkeley: University of California Press, 1992), p. 148. 
nos permitir "pensar que estamos lidando com o materialismo (ou às vezes a ciência, ou a lógica), quando ao mesmo tempo nos liberta em direção à crença (ou ilusão, ou ficção)". ${ }^{77}$

É significativo também que o branco e o preto se alternem como referências de "espaço vazio". Objetivamente, o branco representa o vazio "material", no sentido descrito por Frampton e considerado pelo Fluxus, isto é, a ausência de pigmentos ou marcas visuais na película, de modo que se torna um equivalente para a apreensão direta da luz do projetor, como se não houvesse a película como mediação. O preto, por sua vez, parece representar algo como um vazio "psicológico", a ausência de estímulos luminosos, considerando menos a superfície da película e mais o espaço da tela como constante visual, equivalente a uma tela mental do espectador sobre a qual prováveis figuras seriam dispostas. Em todo caso, as coordenadas onde existem tais obras parecem traçadas pelos dois aspectos. $^{78}$

Há outra dualidade presente, entre "formatos previsíveis" e "formatos imprevisíveis". Por um lado, há um desejo de dar à obra um tipo de traçado reconhecível, algo que possa delinear o material fílmico na experiência temporal da mesma maneira que um objeto tem seu perfil delineado no espaço. Por outro lado, há um desejo de resistir a este traçado; de dispersar, geralmente por multiplicação e inversão, as características que permitiriam tal percepção. De modo geral, o primeiro tipo abarcaria Entrance to Exit e talvez as formas lineares como um todo, assim como, em menor medida, The Flicker, cujas "recorrências" e "ritmo generalizado" de cada etapa praticamente conduzem o espectador por seu sistema. O segundo tipo seria representado por Arnulf Rainer, uma negação radical das estruturas monomórficas e um mergulho na arbitrariedade das variações, mas também por certos períodos de Ray Gun Virus cujas combinações cromáticas são igualmente arbitrárias.

77 Krauss, "Grids", op. cit., p. 54. Alguns dos artistas citados por Krauss e Michelson (Yves Klein, Ad Reinhardt, Robert Ryman) são vistos por elas como herdeiros de Malevich. São também, em sua maioria, contemporâneos das vanguardas cinematográficas americanas, uma relação explorada em outros textos pelas duas autoras. Ver, por exemplo, Annette Michelson, "Reading Eisenstein Reading Capital", October 3 (primavera de 1977), pp. 82-83.

78 É importante mencionar que tanto os cineastas deste capítulo como seus exegetas referem-se às cores como absolutamente "simples". Sejam os flickers monocromáticos ou coloridos, supõe-se que as imagens são sempre as mesmas, como versões idealizadas de uma mesma cor. Exceto quando mencionado, considera-se que um "fotograma preto", por exemplo, representa sempre "o mesmo preto". Essa postura obviamente desconsidera variações luminosas que podem ocorrer desde a composição dos fotogramas até a projeção dos filmes. Como essas variações não são perceptíveis em detalhe durante a projeção, e como toda uma tradição crítica as toma como negligenciáveis, elas não serão consideradas aqui. 


\subsubsection{Montagem métrica}

Em comum, todas essas obras devem recorrer a uma mesma técnica, talvez a única técnica passível de alguma exploração nesse contexto. Ela foi definida, em outro momento, por Sergei Eisenstein, que a denominou "montagem métrica":

O critério fundamental desta construção são os comprimentos absolutos dos fragmentos. Os fragmentos são únicos de acordo com seus comprimentos, numa fórmula esquemática correspondente à do compasso musical. A realização está na repetição desses "compassos". A tensão é obtida pelo efeito da aceleração mecânica, ao se encurtarem os fragmentos, ao mesmo tempo preservando as proporções originais da fórmula. ${ }^{79}$

O caráter propositivo dos escritos de Eisenstein faz com que as descrições sejam tingidas por suas preferências estéticas, como quando ele declara que "a complexidade excessiva do ritmo métrico produz um caos de impressões, em vez de uma clara tensão emocional". A constatação procede, como nos confirmam os filmes de Kubelka e Sharits em certos momentos; mas nessas obras sua função é prevista e deslocada por critérios distintos da busca de Eisenstein por unidade e equilíbrio dramáticos ou temáticos. A completa abolição figurativa dos flickers não parece ser levada em conta por Eisenstein em sua definição.

O termo "montagem métrica" foi mais tarde retomado por Kubelka, e é nos filmes aqui tratados que ele parece alcançar sua plenitude de sentido. Se a montagem métrica consiste na utilização de fragmentos desconsiderando os conteúdos internos das imagens, uma de suas máximas concentrações deve ocorrer nos filmes em que simplesmente não há “conteúdo interno", exceto a uniformidade luminosa do quadro. É importante por isso mencionar algo que já é reconhecido por Eisenstein: o fato de que o "caráter métrico", ainda que não seja o princípio consciente na criação de um filme ou de uma sequência, está presente de qualquer forma em sua composição. Em outras palavras, a articulação da fita de filme deve necessariamente supor a articulação dos comprimentos de suas partes. A montagem métrica, nesse sentido, representa a dimensão mais superficial da montagem, por lidar com características "absolutas" do material.

79 Sergei Eisenstein, "Métodos de montagem" (1929), in A forma do filme, trad. Teresa Ottoni (Rio de Janeiro: Jorge Zahar, 2002), p. 79. Ver também Sergei Eisenstein, "Rhythm", in Sergei Eisenstein: Selected Works, vol. II: Towards a Theory of Montage, ed. Michael Glenny e Richard Taylor (Londres: I.B. Tauris, 2010), p. 236. 


\section{MOVIMENTO}

\section{PLASTICIDADE COMBINATÓRIA}

\subsection{As coordenadas da tela}

Em 1914, um pintor finlandês radicado na França concebeu o plano de uma obra que deveria se posicionar na interseção entre duas artes. Partindo do caráter visual da pintura, ele buscava se aproximar da temporalidade da música. O projeto de Léopold Survage foi denominado "O ritmo colorido" (Le Rythme coloré), e algumas de suas anotações foram publicadas à época. De maneira significativa, a defesa de uma "arte autônoma de formas em movimento" o levou a se afastar dos meios tradicionais da pintura e da música. "É o modo de sucessão no tempo", ele argumentou, "que estabelece a analogia entre o ritmo sonoro na música e o ritmo cromático - a realização da qual eu defendo por meios cinematográficos". ${ }^{80}$

Survage propôs que formas abstratas fossem pintadas e fotografadas sequencialmente, e que suas mudanças constituíssem o desenvolvimento de uma obra fílmica. Contemporâneo de Kandinsky, ele imaginou, como o pintor russo, as analogias possíveis entre as artes da visão e da audição, e o complemento de formas espaciais por formas temporais. É sintomático que, preparando sua obra, Survage tenha realizado uma série de desenhos que representavam apenas as etapas dos movimentos. Ele planejava contratar artistas que fariam os desenhos intermediários, isto é, que fariam algo como a dedução entre as etapas, na tentativa de completar a passagem entre elas. As configurações visuais estáticas não bastavam; deveriam ser postas em movimento, sofrer mudanças, entrar em relação umas com as outras. "No mundo plástico", ele afirmou, "a forma visual de qualquer corpo nos é válida apenas como ponto de partida". As formas

Léopold Survage, "Colored Rhythm" (1914), in French Film Theory and Criticism: A History/Anthology, 1907-1939, vol I: 1907-1929, ed. Richard Abel (Princeton: Princeton University Press, 1988), p. 90. 
visuais seriam, então, os elementos básicos; mas os elementos deveriam ser "coreografados" para que a obra ganhasse vida. Na sua coreografia, os seguintes aspectos seriam considerados: a transfiguração plástica de uma forma em outra; a integração e a desintegração de formas; o movimento das formas, inclusive pela mudança das cores; o movimento das formas para dentro e para fora do campo de visão; a atividade cinética no campo de visão; o movimento em direção à tela e afastando-se dela. ${ }^{81}$

Apesar de nunca realizado, o projeto de Survage representa uma aspiração de cineastas no início do século XX, aspiração que seria concretizada na década de 1920 . Entre os pioneiros, Hans Richter e Viking Eggeling ocupam um papel central. Assim como Survage, ambos foram ligados à pintura. No final dos anos 1910, uma colaboração havia se solidificado com base em ideais comuns; Richter e Eggeling, influenciados pelas diversas escolas do modernismo, desenvolveram um formato peculiar, uma espécie de rolo ou pergaminho em que formas abstratas eram pintadas lado a lado, representando diferentes proporções e transformações. Ao vocabulário do Futurismo e do Neoplasticismo, eles acrescentaram uma lógica sequencial. Como no caso de Survage, a maior referência temporal foi a música. O comentário de Richter sintetiza sua postura:

Para nós, a música tornou-se o modelo. No contraponto musical, encontramos um princípio que se encaixou em nossa filosofia: cada ação produz uma reação correspondente. Isso ocorre na fuga contrapontística, onde encontramos o sistema apropriado, uma dinâmica e um arranjo polar de energias opostas, e neste modelo vimos a imagem da própria vida: uma coisa crescendo, outra decaindo, num casamento criativo de contraste e analogia. $^{82}$

O desejo de formular uma nova sintaxe artística, na qual o olho se movia por um caminho já estabelecido, e na qual as imagens criavam uma arte do desvelamento, em constante referência à passagem do tempo, levou-os, naturalmente, ao cinema. ${ }^{83}$

O primeiro filme de Richter corresponde quase inteiramente à sua descrição. Em Rhythmus 21 (1921), toda a composição é baseada em formas monocromáticas, recortes de papel fotografados em sucessão. Linhas e barras, pretas e brancas, são movidas sobre a

81 Ver Standish Lawder, The Cubist Cinema (Nova York: Anthology Film Archives, 1975), pp. 25-26.

82 Hans Richter, citado em Lawder, The Cubist Cinema, op. cit., p. 43.

83 Oferecendo uma série de formas que se desvelavam espacialmente, o rolo convertia a simultaneidade dessas imagens em um processo unidirecional. Em vez de etapas discretas, o próprio espaço contínuo do desvelamento era dado ao espectador. A diferença fundamental em relação ao cinema - no qual as imagens substituem umas às outras discretamente sobre uma mesma tela, permitindo a impressão de movimento sem enfatizar o movimento do suporte - constituiu o fator de maior interesse para Richter e Eggeling. Ver R. Bruce Elder, Harmony and Dissent: Film and Avant-Garde Art Movements in the Early Twentieth Century (Ontario: Wilfrid Laurier University Press, 2008), pp. 43-44. 
tela em ângulos retos. $\mathrm{Na}$ superfície planar, essas formas são dispostas durante aproximadamente três minutos, e suas transformações constituem a totalidade da obra.

$\mathrm{Na}$ primeira seção, uma tela preta é invadida por duas barras verticais que surgem nas bordas laterais. Como duas cortinas brancas, elas se movem num ritmo regular até o centro da tela, preenchendo-a integralmente. Mas tão logo a tela se torna branca, uma barra preta vertical surge em seu centro, sendo ampliada em direção às bordas horizontais no mesmo ritmo, até cobrir toda a superfície da imagem. Nos termos de Richter, uma ação produz uma reação correspondente:
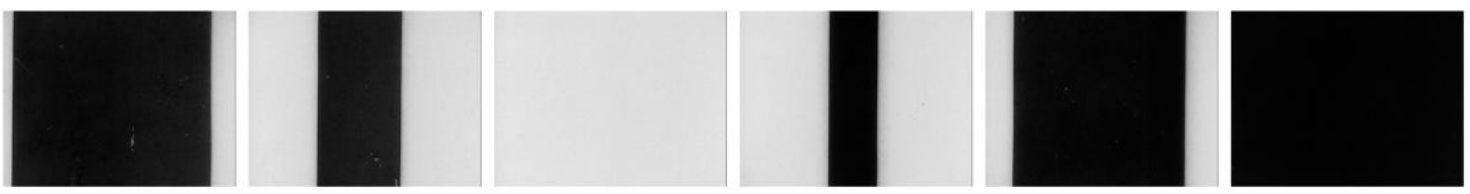

Em outra seção do filme, o mesmo processo ocorre com barras horizontais:
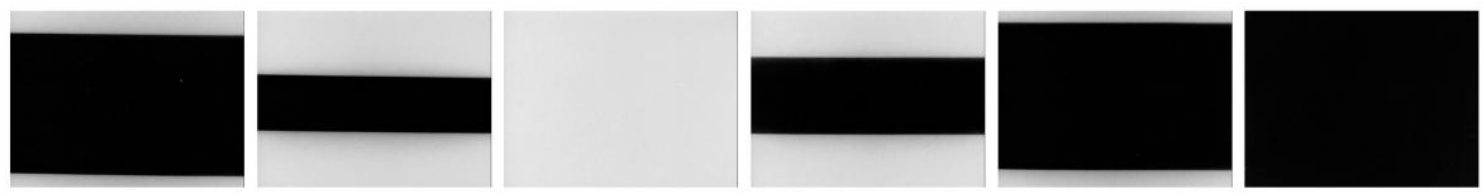

Mais adiante, se repete com um movimento horizontal, de um lado a outro. A tela preta é invadida por uma barra vertical branca que surge na parte direita; a barra se move, ou tem seu volume ampliado lateralmente, até que toda a tela se torna branca, ao que se segue um processo complementar em que uma barra vertical preta invade a tela pelo mesmo lado e a preenche gradualmente:
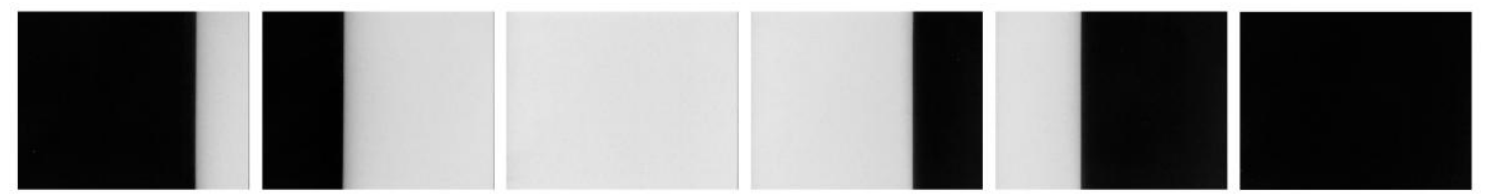

Entre alguns dos "contrapontos", há também movimentos que não são respondidos por seu inverso. Há, por exemplo, o quadrado branco que preenche a tela e é progressivamente reduzido, revelando um fundo preto que é finalmente igualado à tela inteira quando o quadrado desaparece: 

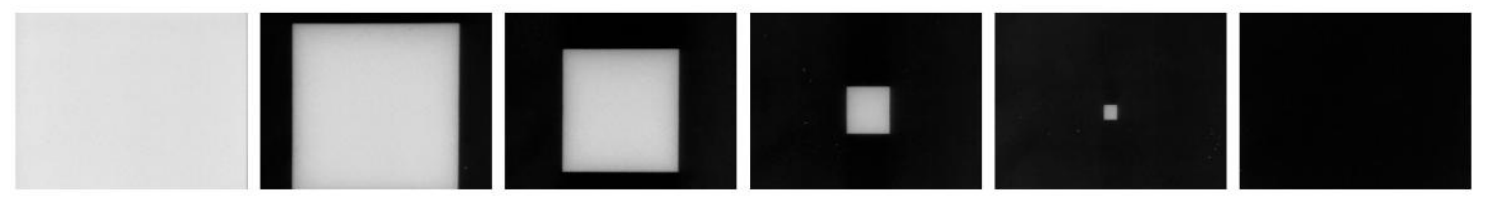

A predominância desses fatores atesta a importância dada à própria tela como um elemento manipulável. Nas palavras de Richter:

[Eu] utilizava simplesmente a tela de projeção, a tela de cinema, que eu comprimia, tornava a esticar, na horizontal e na vertical, na diagonal, e assim sucessivamente. Tirava partes dela e fazia essas partes moverem umas às outras, concentrando-me unicamente nos diferentes tipos de movimento, na tentativa de articulá-los. ${ }^{84}$

A ausência de formas no interior da tela faz com que um flicker, como Arnulf Rainer ou Ray Gun Virus, torne-se a articulação direta do aspecto cronométrico da fita de filme. Estas obras distribuem a luminosidade de maneira uniforme em cada fotograma; reduzindo ao máximo a articulação espacial, as estruturas resultantes, baseadas nas possibilidades de combinar fotogramas como blocos de cores, refletem muitas vezes algum caráter da projeção, seja sua linearidade ou sua intermitência. De maneira semelhante, Richter busca ecoar características absolutas da tela, suas coordenadas espaciais básicas. Esse aspecto é resumido num comentário de Philippe-Alain Michaud:

[Rhythmus 21], como [Richter] sugeriu, proveio inteiramente de uma concepção dedutiva do enquadramento, segundo a qual nada aparece na tela que não seja deduzido da própria forma da tela. As superfícies retangulares são superfícies paralelas ao plano de inscrição, as linhas verticais ou horizontais são superfícies perpendiculares a ele (ou paralelas ao eixo de projeção). Abolida toda diferença de natureza entre a tela e o que aparece na tela, emerge um parâmetro indicial na representação. ${ }^{85}$

Se a repetição de fotogramas de uma mesma cor reforça o caráter global da tela, sua presença como a totalidade do espaço composicional, a inclusão de figuras altera radicalmente este fator. O novo problema pode ser descrito como o da relação entre uma imagem e o plano no qual ela se inscreve. Essa relação foi estudada por autores como Rudolf Arnheim, que encara a tela como uma espécie de "campo", com forças dinamizadas por quaisquer mudanças em seu interior. Neste campo, o centro é tido como uma região privilegiada. As análises de Arnheim voltam-se à pintura, mas na medida em

84 Hans Richter, citado em Michaud, Filme, op. cit., p. 91.

85 Michaud, Filme, op. cit., p. 91 (grifo nosso). 
que envolvem imagens em superfícies delimitadas e achatadas, os mesmos parâmetros encontram-se na imagem cinematográfica. Ele resume a questão da seguinte maneira:

O centro é parte de uma complexa estrutura secreta que pode ser explorada por meio de um disco, de certa forma como limalhas de ferro revelam as linhas de força num campo magnético. Se um disco é colocado em diversos lugares no interior do quadrado, pode-se descobrir que em alguns lugares parece solidamente estático; em outros, exibe uma atração em determinada direção; ou sua condição torna-se instável e vacilante. ${ }^{86}$

A tela cinematográfica é tradicionalmente retangular, o que significa que há simetria reflexiva em seus eixos horizontal e vertical. O centro geométrico encontra-se num ponto a igual distância das bordas superior e inferior, bem como entre as bordas esquerda e direita. O ponto central é portanto o único incapaz de ser transposto a outro ponto correspondente, horizontal ou verticalmente simétrico. É a este ponto, como a um núcleo, que os elementos dispostos na tela parecem se reportar, e é em relação a ele que estabelecem uma tensão espacial. Quanto mais próximo do centro, mais se tende a algo como a resolução ou eliminação desta tensão: uma certa estabilidade visual.

A ausência de figuras na tela, o preenchimento de todo o espaço visível por uma única cor e textura - ainda que possa levar a intensas articulações, como nas aceleradas mudanças de cor dos flickers -, tende a reduzir essa tensão. Retomando a analogia de Arnheim, podemos dizer que a tela, quando desprovida de imagens, é um campo magnético sem as limalhas de ferro que revelariam suas linhas de força. ${ }^{87}$ Se a tela vazia é o mínimo em termos de dinâmica visual, o que Richter parece propor é um gesto que mantém a textura uniforme e o formato retangular, mas que efetua divisões e subdivisões neste espaço. Enfatizando as coordenadas espaciais em sua superficialidade

86 Rudolf Arnheim, Art and Visual Perception (Londres: Faber and Faber, 1972), p. 3. Para uma abordagem que contextualiza o pensamento de Arnheim com outras pesquisas sobre a imagem cinematográfica, ver Jacques Aumont, A imagem, onde o autor alemão é frequentemente citado. Algumas observações de Arnheim foram testadas e reforçadas em Gerald F. Herbener, G. Norman Van Tubergen, Scott Whitlon, "Dynamics of the Frame in Visual Composition", Educational Communication and Technology, vol. 27, n. 2 (verão de 1979), pp. 83-88. Os experimentos do artigo buscam determinar com alguma precisão os valores (quantitativos, em termos de atenção dos sujeitos) das posições dentro do quadro, independente do significado do objeto posicionado. Que as regiões do quadro tenham algum "sentido" ou "valor semântico", é algo tacitamente aceito; mas as relações entre as posições e os sentidos não são definidas precisamente. É importante mencionar que os estímulos considerados no artigo são monocromáticos e estáticos. Cor e movimento, como Arnheim e outros autores reconhecem, também influenciam a percepção desses valores.

87 Pode-se argumentar que uma exceção seria o efeito gama, quando as frequências de flicker sugerem a expansão e contração da tela. Mas esta é uma decorrência da velocidade dos estímulos, e apenas indiretamente dos conteúdos visuais dos fotogramas, já que o efeito não depende de cores específicas e sim dos níveis de contraste entre elas. As observações de Arnheim, baseadas em imagens estáticas, dizem respeito à articulação dos conteúdos dentro do espaço da tela. 
bidimensional, Rhythmus 21 nos permite assim observar as mudanças na tela como marcações num diagrama de forças.

Num texto sobre Piet Mondrian que serve como aplicação de sua teoria, Arnheim diferencia o "centro absoluto" da imagem (isto é, o centro geométrico da tela, independente das formas em seu interior) dos "centros perceptivos" (criados justamente pela organização plástica do pintor). A dinâmica da obra, argumenta Arnheim, é como a resultante das tensões entre os diferentes centros. A distância entre os centros, a disposição de alguns deles no mesmo eixo e os pequenos deslocamentos causados pelos formatos retangulares constituem a arquitetura interna do quadro de Mondrian. Como uma obra baseada também em divisões do espaço pictórico em ângulos retos e preenchimentos cromáticos, o resultado é semelhante aos procedimentos de Rhythmus 21 . Diferente de figuras em que o centro perceptivo coincide com o centro absoluto, Richter propõe mudanças nessa relação, fazendo a coincidência ocorrer apenas pontualmente.
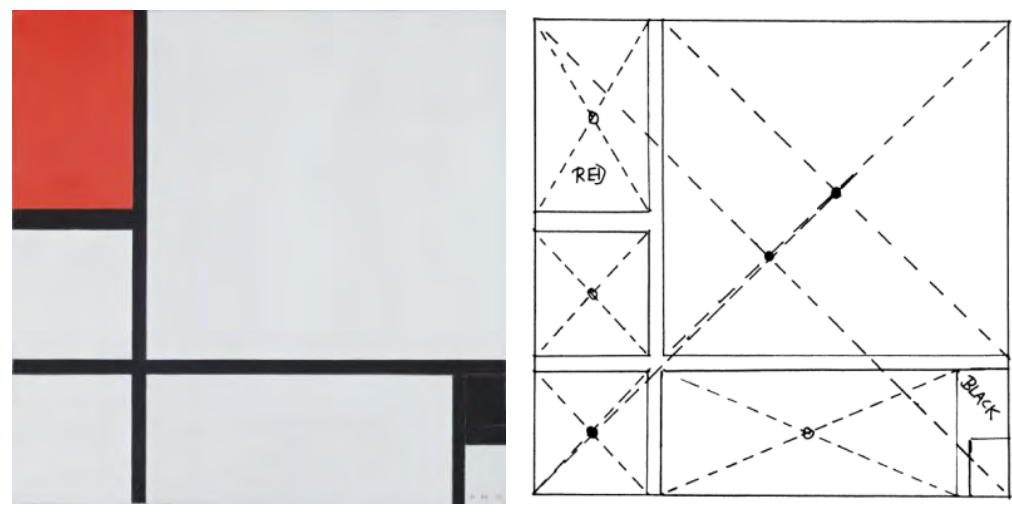

Piet Mondrian, Composição (1929), e o diagrama de Arnheim. ${ }^{88}$ Cada um dos quadrados e retângulos possui um "centro perceptivo", e a dinâmica total da imagem resulta da interação entre esses centros e o "centro geométrico" da tela.

Vale destacar o forte princípio comutativo estabelecido pelo filme. Se The Flicker, inteiramente baseado no contraste de fotogramas pretos e brancos, alterna suas frequências rítmicas e constrói com isso uma curva simétrica, Richter nos apresenta inversões direcionais e cromáticas de suas formas e de seus movimentos. Em lugar da comutatividade temporal de Conrad, voltada à estrutura geral da obra, prefere-se uma

88 Arnheim generaliza essa concepção, incluindo tanto o espaço bidimensional da tela como o espaço tridimensional da escultura ou da arquitetura: "Podemos apenas especular vagamente sobre os fatos neurológicos que criam centros perceptivos de maneira universal, mas sua existência é tão evidente quanto a dos centros gravitacionais na física." Ver Rudolf Arnheim, "The Center Surviving Mondrian”, The Journal of Aesthetics and Art Criticism, vol. 44, n. 3 (primavera de 1986), pp. 292-293. A associação Richter-Mondrian é frequente; autores como Sitney e Lawder a mencionam em suas descrições de Rhythmus 21, e o próprio Richter se disse influenciado pelo Neoplasticismo. 
comutatividade espacial em certas regiões da obra, com atenção particular à simetria horizontal e vertical da tela, mas também ao direcionamento dos movimentos. A lógica de ação/reação faz com que Richter mantenha uma constante mobilidade, e a semelhança das durações contribui para a impressão de complementos visuais. Quando não são as inversões do mesmo movimento, são contrastes em outros parâmetros que criam as novas relações: uma linha horizontal sucedida por uma vertical, uma linha mais densa sucedida por uma mais fraca, uma figura isolada sucedida por um grupo de figuras. A diferença fundamental em relação ao filme de Conrad é que Richter não procura estruturar seus movimentos de forma a sugerir um esquema geral. Nesse sentido, ele se aproxima do princípio de variação.

Dois outros aspectos devem ser aqui considerados. O primeiro diz respeito ao fato de que a comutatividade nas cores e nas direções atinge também a distinção entre "figura" e "fundo". As condições para essa distinção foram estabelecidas por Edgar Rubin: (1) superfícies fechadas tendem a ser percebidas como figuras e o espaço ao seu redor, como fundo; (2) áreas menores tendem a ser percebidas como figura e áreas maiores, como fundo; (3) figuras tendem a se mover e fundos tendem a ser estáticos; (4) formas sólidas, com maior densidade de textura, assim como formas mais luminosas, tendem a ser percebidas como figuras. ${ }^{89}$ As formas de Richter são todas fechadas, e possuem todas a mesma textura, uma solidez genérica e achatada. O que é incessantemente modificado em seu filme é o tamanho, bem como a posição dessas formas. A redução de todo o processo a combinações monocromáticas torna proeminentes essas características básicas. É constante então a troca da função dada ao branco e ao preto: na maioria das seções, a percepção de que o preto é o fundo estático a ser preenchido por linhas brancas em movimento é imediatamente sucedida pela inversão dessa configuração, e vice-versa. Isso reforça o interesse de Richter pela tela como o campo absolutamente superficial no qual as proporções devem ser modificadas e onde as regiões espaciais independem de quais elementos as preenchem ou atravessam. Em outras palavras, é o aspecto puramente relacional da tela que é posto em evidência. O caráter binário e intercambiável da alternância rítmica de fotogramas pretos e brancos ganha aqui sua contraparte espacial.

89 Ver Kurt Koffka, Principles of Gestalt Psychology (Londres: Kegan Paul, Trench, Trubner \& Co., 1936), pp. 177-210. Para uma exposição histórica do problema em seu tratamento pela psicologia da percepção, bem como a descrição dos principais experimentos, ver Ernest Glen Wever, "Figure and Ground in the Visual Perception of Form", The American Journal of Psychology, vol. 38, n. 2 (abril de 1927), pp. 194-226. 
Um segundo ponto diz respeito à presença de movimentos e sua articulação dos contrastes visuais. É a construção do movimento que interessa a Richter. Em vez de uma filmagem que permite reproduzir o movimento de objetos tridimensionais, o filme utiliza recortes de papel, fotografados em ordem e posição variáveis; submetidos à projeção na velocidade padronizada, seus movimentos não sugerem a reconstrução de um tempo natural, mas a construção de um tempo artificial. Mais especificamente, é o caráter mecânico do movimento que rege a maior parte de Rhythmus 21. As barras deslizam sobre a tela como se transformassem o espaço numa progressão ritmicamente regular. Se a linearidade do fade sugere um "movimento sem direção", o movimento aqui é precisamente direcionado. Movimentos retilíneos uniformes atravessam um espaço que nos serve de referência constante, pois a duração e a distância são marcadas simultaneamente pelas coordenadas da tela. Essa continuidade é muitas vezes estendida à transição de um movimento a outro: como apenas duas cores são envolvidas no processo, uma etapa pode iniciar logo após a outra desde que o final de uma e o início da outra sejam telas vazias, brancas ou pretas. Um exemplo disso é a tela preta sendo invadida por uma barra branca, até que o branco toma completamente o espaço e a barra preta é que passa a invadir a tela. O resultado é uma continuidade geral do filme, e uma redução do contraste entre as diferentes imagens.

No entanto, há momentos em que as formas são brevemente alternadas por outro princípio. Algumas dessas operações são descritas por Malcolm Turvey:

Figuras brancas sobre um fundo preto tornam-se figuras pretas sobre um fundo branco, criando uma impressão extremamente instável de profundidade; o cinza é introduzido em algumas figuras, tornando ainda mais instável a noção de profundidade (estariam os quadrados e retângulos brancos atrás dos cinzas, ou vice-versa?) [...]. Mas há muitas outras variações imprevisíveis: movimentos são repentinamente acelerados e repentinamente desacelerados; stop motion substitui o movimento contínuo da parte inicial do filme, criando jump cuts erráticos entre figuras grandes e pequenas; movimentos de afastamento tornam-se movimentos laterais, e vice-versa; figuras múltiplas aparecem ao mesmo tempo, algumas se afastando, outras se aproximando, algumas movendo-se lateralmente, algumas permanecendo estáticas. Ainda assim, apesar de todas essas mudanças ou "variações" surpresas, um padrão básico, ou "tema", permanece no decorrer do filme: quadrados e retângulos brancos movem-se lateralmente, afastando-se ou aproximando-se num fundo preto. Em outras palavras, uma impressão de ordem é mantida apesar da desordem momentânea. ${ }^{90}$

90 Malcolm Turvey, "Dada Between Heaven and Hell: Abstraction and Universal Language in the Rhythm Films of Hans Richter”, October 105 (verão de 2003), p. 30. 
Richter mantém, portanto, a fluidez e a continuidade como apenas um dos polos de sua obra. Também as relações entre o móvel e o estático, entre a passagem gradual de uma posição a outra e o salto entre as posições são postas em seu mecanismo de polaridades. As inversões ocorrem no mesmo eixo (esquerda e direita, cima e baixo), mas também na troca de um eixo pelo outro (horizontal e vertical).
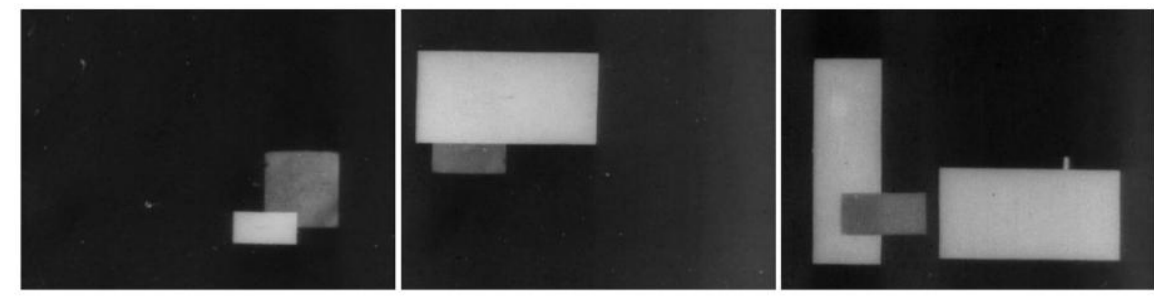

Três imagens sucessivas em Rhythmus 21 (Hans Richter, 1921). Cada uma delas permanece estática na tela por alguns segundos, e não há transição progressiva de uma a outra; elas são substituídas por cortes secos.

Assim como Kubelka, Richter se propôs encontrar os elementos básicos do dispositivo fílmico, chegando à mais completa redução material do cinema como a distribuição de luz e sombra. Ambos aproximam-se ainda na rejeição de uma única operação dominante na composição de um filme. Tanto Arnulf Rainer como Rhythmus 21, tendo definido seus elementos, recorrem a variações e evitam a sugestão de um esquema geral. Porém, enquanto Kubelka determinou seu vocabulário a partir de fotogramas inteiramente preenchidos por luz ou sombra, Richter se concentrou na distribuição de luz e sombra no espaço interno dos fotogramas. A arte fílmica se torna, assim, não a coordenação de fitas de filme pretas e brancas, na tentativa de criar padrões temporais, mas a coordenação de fitas de filme em que os padrões são criados pela distribuição de preto e branco no espaço constante da tela. Os padrões rítmicos permanecem, como revela o título do filme de Richter; mas não é a pura duração que se torna a fonte do interesse, e sim a duração concretizada nas formas visuais em movimento.

A proposta comum é que uma obra crie e resolva tensões, e que essas tensões sejam derivadas de características do próprio material. A crença é que, na ausência de imagens representacionais, na preferência por operações rítmicas e geométricas, algo como uma linguagem universal será tornada possível, de modo que o artista, ao compor um filme, poderá prever e coordenar também a experiência do espectador. A "ordenação cognitiva" mencionada no caso dos flickers ganharia portanto um equivalente nas 
imagens geométricas. Em sua simplicidade de forma e textura, em sua recusa de sugestões volumétricas e em suas trajetórias reduzidas aos eixos horizontal, vertical e diagonal, essas imagens sugerem uma analogia com os fotogramas cromáticos do capítulo anterior. "Como os elementos desta linguagem não possuíam significado intrínseco", argumenta Bruce Elder, "nenhuma concepção prévia era invocada". O ritmo faria com que os elementos fossem integrados: "o princípio de polaridade inerente ao ritmo elevaria as contradições entre os elementos, tornando-os compreensíveis". ${ }^{91}$ A síntese dos fatores relacionais do meio e a atenção para a universalidade da experiência evocam ainda Malevich, de cujo projeto Richter tinha conhecimento, encontrando em seu Quadrado negro algo como um antecessor estático de Rhythmus $21 .{ }^{92}$

Se generalizado para um modelo de experimentos, o filme de Richter serve como uma verdadeira matriz para se explorar as coordenadas da superfície fílmica. Nesta matriz, rapidamente se multiplicam os contrafactuais. $\mathrm{O}$ que experimentamos quando a tela escura é gradualmente coberta por uma barra luminosa? Qual é a experiência dessa gradação quando ocorre num determinado ritmo e em determinada direção? Qual é a experiência quando isso ocorre no mesmo ritmo, mas na direção inversa? O que resulta de uma tela que é sucessivamente dividida em partes retangulares? No movimento de suas coordenadas básicas, como a atenção pode ser concentrada em diferentes regiões desse espaço? Como se pode construir ritmicamente a passagem entre esses movimentos? Como pode se dar a relação entre movimentos contínuos e saltos entre configurações estáticas? Nesta arte combinatória, uma infinidade de operações se coloca ao cineasta. Como Kubelka, Richter nos propõe sua versão particular: uma versão que privilegia certos ritmos e padrões, não encobrindo sua filiação às correntes pictóricas da época e revelando alguns dos parâmetros fundamentais da articulação de formas visuais.

\subsection{Ponto e linha sobre plano}

Imaginemos uma tela preta. Dentro deste espaço uniforme, imaginemos uma marcação luminosa: um ponto. O ponto se move, e sua trajetória marca a superfície da tela, criando

91 Elder, Harmony and Dissent, op. cit., pp. 138-139, 140, 148.

92 Richter e Malevich se conheceram em 1927 e discutiram a possibilidade de um projeto em conjunto: um filme baseado nas diretrizes do Suprematismo. Apesar de o projeto nunca ter sido finalizado, as notas de Malevich e os desenhos de Richter sugerem algo semelhante à obra fílmica de Richter, com figuras geométricas, movimentos simples e inversões de cor. Ver Timothy O. Benson e Aleksandra Shatskikh, "Malevich and Richter: An Indeterminate Encounter", October 143 (inverno de 2013), pp. 52-68. 
uma linha. Algumas perguntas se colocam em relação a esta operação, básica para a compreensão de qualquer movimento representado num filme. Quais as posições inicial e final do ponto, e quais as posições intermediárias? Qual o seu formato e o seu tamanho? Qual a sua cor e a sua textura? Estas perguntas dizem respeito às propriedades espaciais; considerando as propriedades temporais, podemos ainda nos perguntar qual é a duração do traçado, ou em que frequência se apresenta na projeção.

Em 1924, Viking Eggeling apresentou o resultado de suas pesquisas numa obra que tangencia algumas dessas perguntas. Symphonie Diagonale abre com uma tela preta. Uma figura branca, formada por uma série de linhas diagonais, surge na região central. A figura é diminuída lateralmente, da direita para a esquerda, e o caminho traçado por essa diminuição revela uma figura idêntica, na mesma exata posição da primeira. A segunda figura desaparece e dá lugar a outra, semelhante em tamanho mas constituída por mais linhas, e voltada para o outro lado da tela. O mesmo processo se repete, com a figura agora sendo diminuída lateralmente, da esquerda para a direita, revelando outra versão da mesma forma. Uma comparação dos movimentos em suas etapas revela a estrutura comum e as direções invertidas:
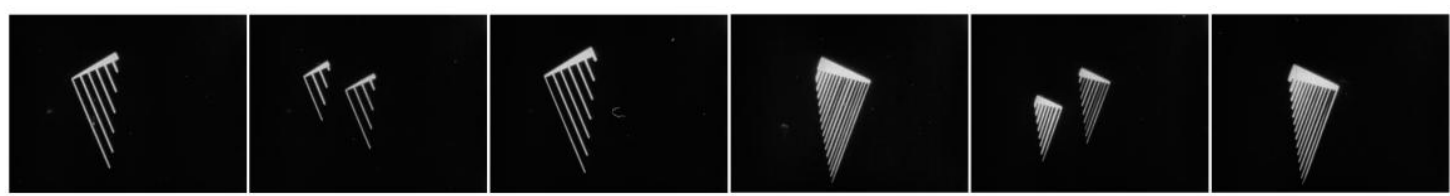

Em seguida, outro movimento é apresentado. Uma figura surge no centro da tela, mas desta vez o movimento ocorre de baixo para cima, e a figura revelada difere da anterior. O processo se repete, com a figura inclinada para o lado oposto. Novamente, há uma estrutura comum, em três etapas, invertendo as direções:
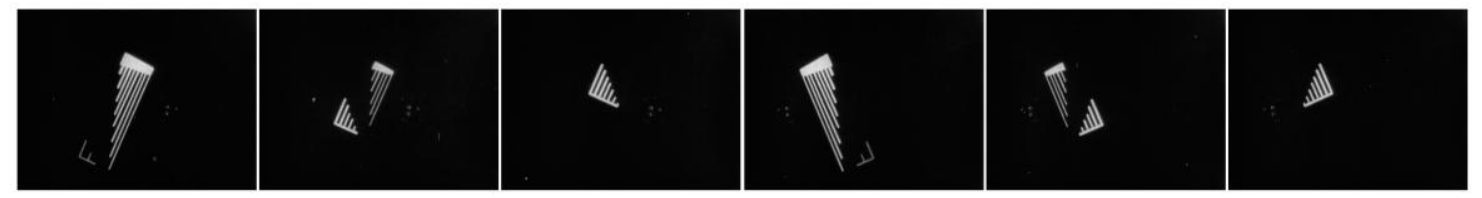

Na seção seguinte, é introduzida uma nova operação. Num ritmo regular, uma série de linhas surge na parte superior da tela, sendo ligeiramente variadas em suas posições, sugerindo quadrados inclinados num ângulo de 45 graus. No total, as linhas 
passam por 19 variações, todas elas mantendo a mesma concentração na região superior e ocorrendo em ângulos retos umas em relação às outras. Podemos visualizar quatro dessas variações, tendo em mente que não se dão sempre de maneira contínua, mas às vezes em pequenos saltos, com as linhas aparecendo e desaparecendo periodicamente:

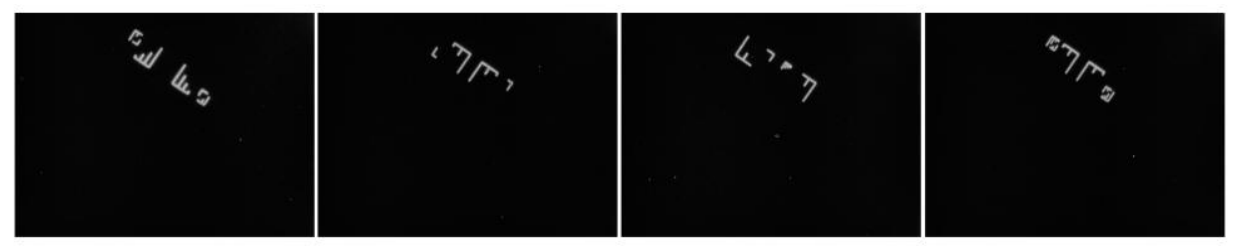

Em seguida, uma figura composta surge no centro da tela, atravessando o espaço da parte superior direita à parte inferior esquerda, inclinada num ângulo de aproximadamente 45 graus. A natureza composta da figura é revelada pela variação periódica de suas partes, que são acrescentadas e subtraídas, assim como têm seus contornos desenhados ou apagados. O ritmo das modificações é semelhante ao da seção anterior, e da mesma forma, há mudanças progressivas e saltos repentinos. Assim como na seção inicial, as figuras são retomadas em diferentes configurações, sempre reforçando as diagonais. Podemos visualizar o conjunto inicial e algumas de suas etapas posteriores:

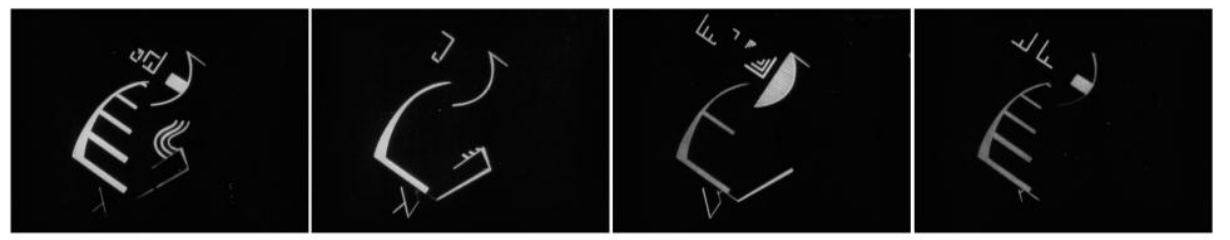

O processo de figuras que têm partes reveladas pelo traçado luminoso e apagadas pela escuridão é retomado numa seção central. Eggeling parece supor uma figura traçada continuamente, como se esta figura estivesse numa posição fixa sobre a tela. Ele revela então uma de suas partes na mesma frequência em que subtrai outra, de modo que o conjunto parece ser apagado num extremo e construído no outro:
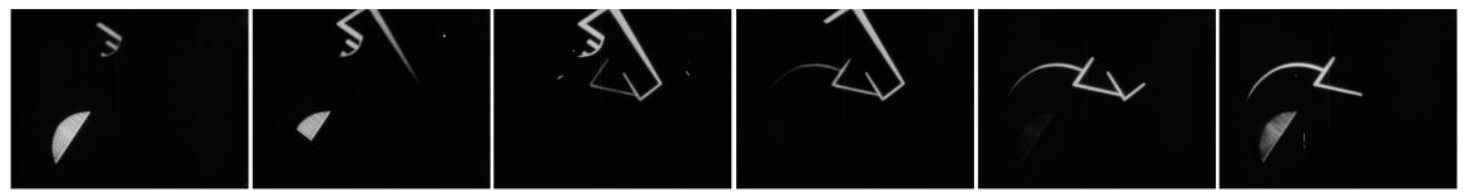
Apesar das pesquisas comuns, já no início da obra são expostas as diferenças em relação a Rhythmus 21. Eggeling não parte da tela como um modelo do qual irá deduzir seus elementos, como não busca repetir o mesmo formato retangular em suas figuras. Pelo contrário, há no seu filme a manutenção de uma tela preta na qual ocorre uma disposição de formas curvas e diagonais. Mantida constante entre as figuras, a tela preta torna-se o único fundo: o breve surgimento das figuras apenas confirma sua permanência como base da composição, a estabilidade que permite medir todas as mudanças. A concepção que parece reger o filme de Eggeling não é a da tela como um elemento maleável, mas a da tela como um espaço a ser preenchido por eventos.

O centro da tela, como nos lembra Arnheim, é um ponto de equilíbrio, assim como as bordas marcam os limites deste espaço. Uma sucessão de imagens que traçam linhas do centro às bordas equivale, portanto, a uma dinamização do ponto de equilíbrio em relação às fronteiras visuais que o cercam. No filme de Richter, isso é realizado às vezes de maneira simétrica (um quadrado perfeitamente centralizado) ou então de maneira assimétrica (quadrados dispostos em outras regiões da tela), mas quase sempre com regularidade nos ângulos e movimentos. As figuras de Richter apresentam um centro perceptivo bem definido; assim como na tela de Mondrian, são as aproximações e os distanciamentos entre o centro absoluto e os centros perceptivos que constituem a obra. Em Symphonie Diagonale, os mesmos fatores são deslocados. Duas imagens de Kandinsky servem como ilustração do princípio envolvido:
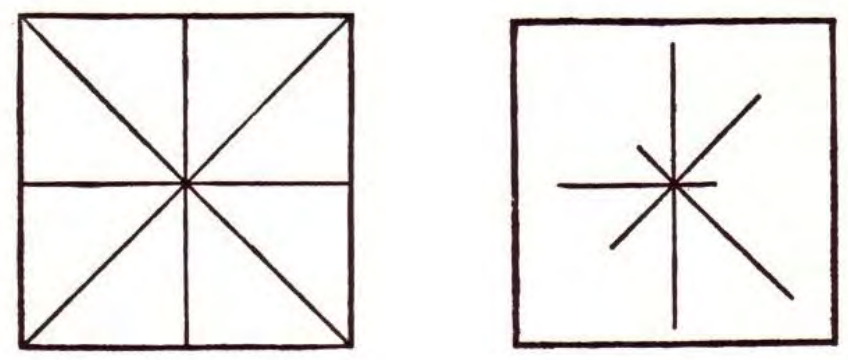

$\mathrm{Na}$ primeira imagem, um quadro tem suas linhas de força traçadas de maneira perfeitamente equilibrada, na mais completa simetria horizontal, vertical e diagonal. $\mathrm{Na}$ segunda imagem, as linhas são traçadas de modo equilibrado no eixo vertical, mas desequilibrado no eixo horizontal e nas diagonais. O segundo caso, o de uma disposição desigual de forças e movimentos, ocorre nos dois filmes; o primeiro ocorre brevemente no filme de Richter, mas nunca no filme de Eggeling. Aqui a metáfora do campo de 
forças é significativa, pois é na vetorização dos elementos visuais que podemos descrever como algumas linhas parecem compensar outras por equivalência simétrica, e como algumas parecem evidenciar, por desequilíbrio (ausência de compensação), uma certa porção do quadro. ${ }^{93}$

As escolhas de Richter tendem a se voltar para um ou dois eixos do espaço: as figuras são retangulares, e os movimentos tendem a ser horizontais ou verticais, apenas ocasionalmente sendo combinados e sugerindo um movimento diagonal. Eggeling, inscrevendo em seu título a preferência por um dos eixos, apresenta já em suas figuras uma radical alteridade em relação à tela. Elas não são deduzidas do formato inevitável do espaço no qual a imagem é inscrita; são traçadas sobre este espaço, marcações dinâmicas mesmo quando estáticas. Os movimentos, por sua vez, ocorrem tanto nos eixos horizontal e vertical como em padrões semicirculares, enfatizando a liberdade do traçado.

Se o que caracteriza a homogeneidade é a repetição de um mesmo fotograma, mantendo sob margens praticamente idênticas as referências espaciais e temporais, e se o máximo da homogeneidade é atingido na completa ausência de imagens no espaço da tela, pode-se dizer que Symphonie Diagonale sustenta a homogeneidade em seus períodos de tela preta silenciosa. É um papel de base da composição, de fundo vazio, desprovido de estímulos luminosos e sonoros, que o filme confere à forma homogênea. Independente de suas propriedades visuais, o papel dos "eventos" aqui torna-se a quebra da homogeneidade. $\mathrm{O}$ aspecto visual dessa homogeneidade, porém, não é inteiramente abolido: as figuras são sobrepostas a ela, de modo que permanece algo da continuidade subjacente, da equivalência cronométrica dos fotogramas pretos e a projeção. As quebras da homogeneidade, por sua vez, alternam-se de modo ainda mais sistemático que no filme de Richter. Em Rhythmus 21, um dos princípios recorrentes é a comutatividade que seu autor chamou de "ação e reação", quando um movimento é seguido pela inversão de seu direcionamento. Eggeling não apenas recorre a este princípio como o torna praticamente uma lei estrutural. Assim como Richter, ele nos apresenta um movimento e seu inverso; mas a inversão ocorre muitas vezes em mais de um eixo, de modo que vemos a mesma figura se movendo em direções diferentes, e também a inversão desta figura movendo-se nas mesmas direções. As compensações, as ações e reações são assim multiplicadas. Mais

93 Ver Wassily Kandinsky, Point and Line to Plane (Nova York: Dover, 1979), p. 138. Para uma descrição mais elaborada das compensações, ver Hermann Weyl, Symmetry (Nova Jersey: Princeton University Press, 1952), um estudo dos variados tipos de simetria na arte e na ciência. 
do que Rhythmus 21, Symphonie Diagonale parece buscar a enumeração de todas as combinações de seu sistema:

A dinâmica de contraponto de Eggeling, o que ele chamou de "baixo contínuo da pintura" [Generalbass der Malerei], abarca generosamente e sem discriminação todas as relações possíveis entre as formas, incluindo as relações horizontais e verticais. Sua abordagem, metódica a ponto de ser científica, o levou ao estudo analítico do comportamento dos elementos formais sob diferentes circunstâncias. Ele tentou descobrir quais "expressões" uma forma poderia tomar sob a influência de vários opostos: pequeno contra grande, luz contra sombra, um contra muitos, a parte de cima contra a de baixo, e assim por diante. ${ }^{94}$

A organização dessas relações por Eggeling se dá especialmente nos eixos diagonais, muitas vezes tornados espaços vazios, ao redor dos quais as figuras são posicionadas e movimentadas.

Arnheim, como Paul Fraisse, nos lembra que a percepção de um padrão rítmico ou de uma combinação de elementos visuais depende das regras de agrupamento formuladas por Wertheimer. Estas regras

se referem a fatores que fazem com que algumas partes pareçam mais próximas que outras. Estas regras podem ser tratadas como aplicações de um mesmo princípio básico o princípio da semelhança. O princípio afirma que $o$ grau em que partes de um padrão se assemelham entre si ajuda a determinar o grau em que são vistas como um conjunto. ${ }^{95}$

A cada agrupamento, as propriedades dos eventos são confrontadas em termos de semelhança ou contraste. O fade, por exemplo, é apreendido como um único processo justamente pela semelhança entre os fotogramas contíguos. É a gradação da luminosidade a cada etapa da projeção que torna o fade um conjunto unificado de fotogramas; aumentado o contraste, isto é, tornando os fotogramas visualmente distintos ou temporalmente isolados, menos essa unidade é percebida, até que se alcança a intermitência do flicker. O princípio de ação/reação em Symphonie Diagonale, como em Rhythmus 21, é uma elaboração desta lei. Conforme as figuras mantêm a regularidade de seus movimentos, bem como seu direcionamento e sua textura constantes, elas são agrupadas como um único evento. Na medida em que diminuem a continuidade desses fatores - aumentando os intervalos entre as etapas, ou travando os movimentos com pequenos saltos -, os eventos podem ser fragmentados em séries de eventos menores. Mas a estratégia central nos dois filmes é a completa inversão de um ou mais parâmetros

\footnotetext{
94 Lawder, The Cubist Cinema, op. cit., p. 42.

95 Arnheim, Art and Visual Perception, op. cit., p. 67 (grifo nosso).
} 
envolvidos na caracterização dos eventos, em geral o direcionamento ou a orientação dos movimentos, de modo que um novo evento é apresentado como uma variação do anterior. Eggeling acrescenta a isso uma exploração da unidade visual das figuras, decompondo algumas delas sobre o espaço constante da tela.

Em Symphonie Diagonale, como em Rhythmus 21, a construção da linearidade se dá por meio de uma mesma técnica: recortes ou desenhos estáticos, fotografados isoladamente em determinadas frequências para que a projeção dê às suas configurações plásticas a impressão de um único processo de metamorfose. Ambos os filmes demonstram com isso a possibilidade de compor com o movimento, e também, de maneira geral, a flexibilidade do evento visual no cinema. Mantidas na tela por uma certa duração, as figuras tornam-se estáveis, passam a ter algo como uma identidade; suas partes então podem ser retiradas ou movimentadas, de modo que percebemos a mesma figura sendo alterada; não a tela, mas um objeto dentro da tela. Demonstra-se, assim, que as configurações visuais numa série de fotogramas podem ser agrupadas para sugerir uma unidade. Um fotograma torna-se, assim, mais do que um evento - torna-se parte de um evento de nível superior, representado pela série de fotogramas.

Nos dois filmes, há pouca variação na velocidade dos movimentos. As figuras se movem quase sempre de maneira uniforme, seguindo a velocidade estabelecida no início da obra. A linearidade, em vez de ser articulada em suas possibilidades temporais (tendo sua velocidade aumentada ou diminuída), é simplesmente mantida ou abandonada. Isso nos leva a outro ponto de ligação de Eggeling com a concepção de Richter. Apesar de suas formas parecerem mais livres em relação à tela, há também em seu desenvolvimento, e no próprio ritmo geral dos movimentos, a mesma tendência mecânica: as velocidades dos eventos ou dos grupos de eventos são regulares, e os saltos têm intervalos temporais semelhantes, como uma engrenagem que opera sempre na mesma frequência, ecoando a absoluta regularidade do projetor.

A tendência mecânica coexiste com algo que podemos chamar de uma "musicalização do espaço". Em seu estudo sobre o ponto e a linha dispostos no plano pictórico, Kandinsky recorreu à analogia musical para designar o efeito das formas visuais. Formas posicionadas em determinada região da tela, com determinada cor e textura, para Kandinsky, teriam certos "sons", como instrumentos com timbres reconhecíveis; como se cada configuração vibrasse de maneira particular dentro do mesmo campo. A relação com a música é defendida por ele como essencial para a concepção de uma pintura autônoma: 
Um pintor que não se satisfaz com a mera representação de fenômenos naturais, independente de quão artísticos estes sejam, e que busca criar a vida interior, observa com inveja a simplicidade e facilidade com as quais este objetivo já é alcançado numa arte não-material como a música. É facilmente compreensível que ele se concentre nesta arte e que tente torná-la recíproca ao seu próprio meio. É disso que deriva algo da busca moderna, na pintura, por ritmo, por construção abstrata e matemática, repetição cromática, e por maneiras de dar movimento às cores. ${ }^{96}$

A associação com a música se torna uma fonte de analogias para conceber a manifestação dinâmica nas imagens estáticas. Se os pontos representam marcações no espaço do quadro, as linhas seriam como gestos ou melodias entre um ponto e outro, uma temporalização das medidas espaciais. Dessa forma, Kandinsky buscou transpor gestos humanos a verdadeiros esquemas gráficos. A intensidade de um movimento poderia ser representada pela espessura de uma linha; um pulso dissonante, pela distribuição irregular de ângulos no plano; uma dissolução, pelo afastamento gradual de pontos.
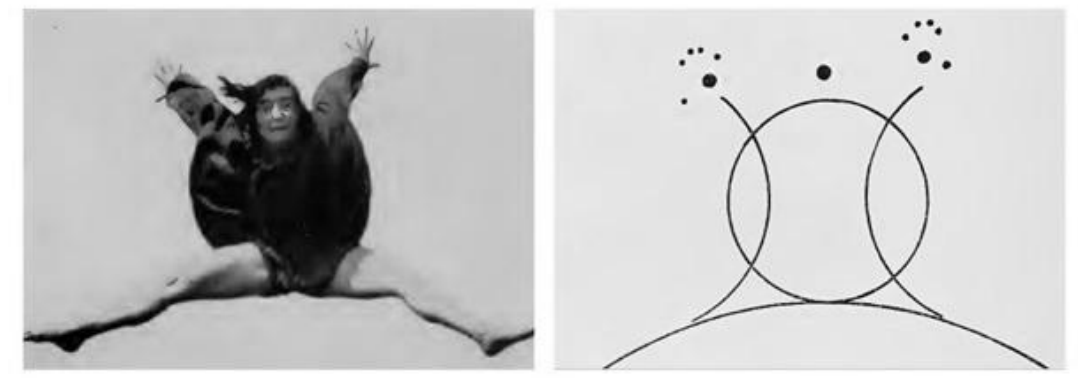

Um salto da dançarina Gret Palucca e o gráfico da fotografia realizado por Kandinsky. ${ }^{97}$

Num argumento semelhante ao de Arnheim, Kandinsky afirma que o traçado de uma linha reta, ao ser redirecionado bruscamente, formando um ângulo, revela as forças envolvidas no espaço da tela. Uma linha que no decorrer de seu traçado é deslocada 45 graus para baixo, por exemplo, revelaria com isso a influência de forças invisíveis no plano de inscrição, como se a pressão em certa direção deformasse a figura original. $O$ princípio é que a linha reta representa a forma mais concisa do traçado espacial, a mínima aplicação de uma força direcional, e que um ângulo, ou mesmo uma linha curva, exibem

96 Wassily Kandinsky, citado em Lawder, The Cubist Cinema, op. cit., p. 30.

97 Kandinsky, Point and Line to Plane, op. cit., pp. 42-43. Arnheim comenta o desenho de Kandinsky e argumenta que, se por um lado a abstração da figura humana evidencia as "linhas de força" da pose, e se chega mesmo a intensificar algumas de suas propriedades, por outro lado talvez diminua efeitos que resultam justamente do reconhecimento de que é uma figura humana - por exemplo, o fato de que braços e pernas não são apenas linhas, mas órgãos que podem ser estendidos até um certo limite, isto é, que articulam a resistência e a flexibilidade do corpo como um todo. Ver Arnheim, Art and Visual Perception, op. cit., pp. 390-391. 
influências suplementares. Disso decorre que, quanto mais complexa a disposição da linha, seja pelo número de forças influentes ou pela intensidade das forças - quanto mais ela se afasta da simplicidade da linha reta -, mais dinâmica é a figura.

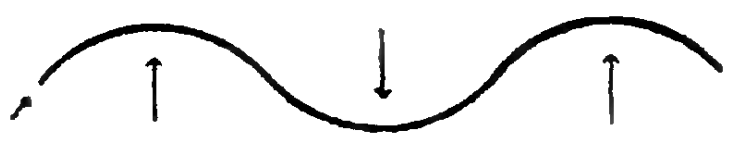

Uma representação feita por Kandinsky de uma linha sendo deformada por pressões exercidas em suas diferentes partes. ${ }^{98}$

A influência de Kandinsky sobre Eggeling é tradicionalmente reconhecida. O "vocabulário" de Symphonie Diagonale, formado por linhas curvas e diagonais, semicírculos e padrões angulares, é típico da fase mais célebre do pintor russo, e representativo da variedade de deformações possíveis sobre a linha reta:

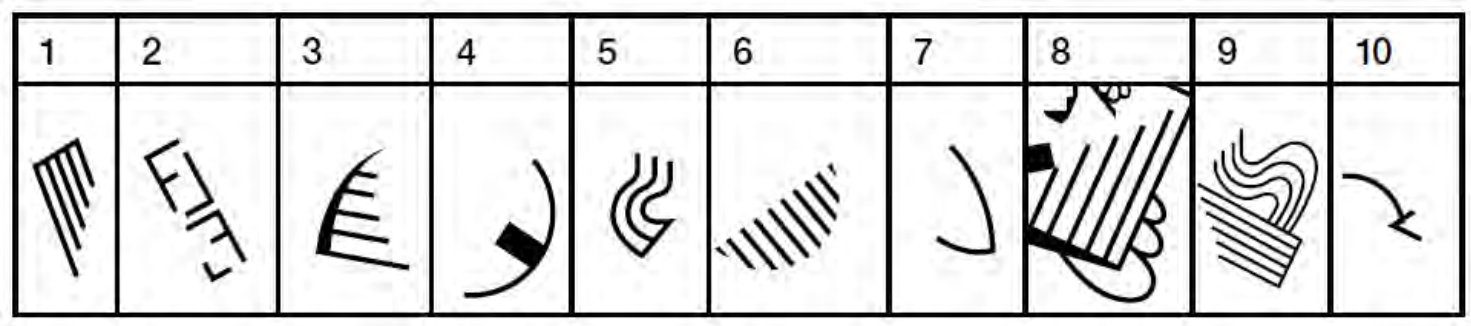

Mas é a concepção estrutural de Kandinsky, e sua relação formulada entre a pintura e a música, que parece ter exercido maior atração sobre Eggeling, assim como sobre Richter. ${ }^{99}$ Eggeling faleceu no ano seguinte ao lançamento de seu filme, de modo que suas reflexões não foram desenvolvidas. Elas foram, entretanto, comentadas por Richter, que demonstra uma consciência da terminologia utilizada à época por outros pintores modernos, na mesma concepção analógica entre as artes:

Durante meses, estudamos e comparamos nossos desenhos analíticos feitos em centenas de papéis, até que os observamos como seres vivos que cresciam, se decompunham, mudavam, desapareciam - e então renasciam. Finalmente poderíamos operá-los como instrumentos (e foi exatamente assim que os chamamos). Uma linha vertical foi tornada significativa pela horizontal, uma linha forte tornada ainda mais forte por uma linha fraca,

98 Kandinsky, Point and Line to Plane, op. cit., p. 85. O argumento é uma adaptação da primeira lei de Newton: um corpo permanece em repouso ou em movimento retilíneo uniforme a menos que alguma força sobre ele seja exercida.

99 Para a referência do "vocabulário" de Eggeling, ver Elder, Harmony and Dissent, op. cit., p. 450. 
uma unidade simples importante contra várias, uma forma definida tornada clara contra uma indefinida, e assim por diante. ${ }^{100}$

Polaridade como um princípio geral da vida $=$ um método composicional para qualquer expressão formal. Proporção, ritmo, número, intensidade, posição, som, tempo, e assim por diante. Empiricamente, polaridade parece uma relação de contraste em oposições grandes ou pequenas; espiritualmente, como uma relação análoga entre objetos, que se diferenciam uns dos outros uma vez mais, em outra esfera. [...] Os princípios estéticos deste alfabeto conduzem à obra de arte total. Isso ocorre porque esses princípios, aplicados sem dogma e sinteticamente, são relevantes não apenas à pintura mas também à música, linguagem, dança, arquitetura e drama. ${ }^{101}$

A aspiração de Richter e Eggeling a uma "obra de arte total", dependente da abstração de seus elementos e da redução da arbitrariedade de seus desenvolvimentos - a recorrência de transformações geométricas -, caracteriza-se de forma distinta nos dois filmes. Como a tela é a matriz dos eventos em Rhythmus 21, sua flexibilidade é limitada ao tamanho das figuras e à direção dos movimentos, sendo estes parâmetros combinados nos trechos mais complexos. A tela vazia dá a Eggeling uma liberdade maior na escolha de suas figuras. Mas essa liberdade é contraposta a um rigor estrutural ainda maior: as transformações executadas em Symphonie Diagonale são mais exaustivas, e são inclusive dispostas na totalidade da obra de maneira simétrica, com as últimas seções repetindo as primeiras. $^{102}$

A concepção de uma obra "autônoma", de uma estrutura que se desenvolve de acordo com leis únicas ao cinema, é o princípio compartilhado pelos dois artistas. $\mathrm{Na}$ bifurcação deste caminho, Richter conduz uma exploração da tela em suas divisões internas, em suas relações de continuidade e descontinuidade, nas progressões e nos saltos criados inteiramente por valores de luz e sombra, as polaridades básicas da matéria fílmica. Eggeling, por sua vez, investiga a criação de formas no interior de uma tela neutralizada, uma tela esvaziada de qualquer conteúdo ou sugestão de movimento, concentrando nas figuras luminosas e em suas variações toda a atenção, criando assim uma espécie de vocabulário com o qual o cineasta expõe, em sua livre manipulação, as coordenadas de uma geometria temporal. ${ }^{103}$

${ }^{100}$ Richter, citado em Turvey, "Dada Between Heaven and Hell", op. cit., pp. 31-32.

${ }^{101}$ Hans Richter, "Basic Principles of the Art of Movement" (1921), in The Promise of Cinema: German Film Theory, 1903-1933, eds. Anton Kaes, Nicolas Baer, Michael Cowan (Oakland: University of California Press, 2016), p. 456.

102 Ver Elder, Harmony and Dissent, op. cit., p. 122.

${ }^{103}$ Ver Hans Richter, "Demonstration of the "Universal Language", in Hans Richter: Activism, Modernism, and the Avant-Garde, ed. Stephen C. Foster (Cambridge, Mass.: The MIT Press, 1998), pp. 184-239. Para uma investigação das fontes e influências comuns à pintura moderna e ao projeto de 


\subsection{A tendência orgânica}

Como filmes silenciosos, Rhythmus 21 e Symphonie Diagonale devem necessariamente transpor a música à dimensão gráfica. Há neles um vocabulário plástico, derivado da influência de nomes como Mondrian e Kandinsky, que privilegia os eixos básicos da imagem bidimensional. Sobre um conjunto de figuras é aplicado então um conjunto de transformações. Nos dois casos, os movimentos e os intervalos tendem a ser mecanizados: a travessia de uma figura sobre a tela ou a revelação de um traçado são regulares, como o são os cortes secos que interrompem a continuidade e enfatizam a distância entre as configurações visuais. Estas operações parecem independentes das figuras que deslocam ou do momento em que ocorrem na obra, impessoais como o próprio dispositivo que projeta a fita de filme. Nesse sentido, a influência musical é mantida sobretudo pela abstração visual, pelo redução do contraponto à lógica de ação/reação, e pela busca por formas consideradas "puras" ou "universais".

No mesmo período, outro cineasta alemão procurou criar obras também inspiradas na analogia musical, mas que fossem voltadas à dinâmica temporal e à maleabilidade das formas visuais. O Studie nr. 6 (1930) de Oskar Fischinger é representativo de sua produção da época, quando pinturas em movimento eram acompanhadas por peças musicais que lhe serviam de referência estrutural - neste caso, Los Verderones (1929), de Jacinto Guerrero. A abordagem visual de Fischinger é semelhante à de Eggeling em pelo menos um aspecto: ambos partem de uma tela preta constante, sobre a qual dispõem figuras luminosas. Já de início, entretanto, percebe-se uma diferença crucial. Se as formas de Eggeling sugerem o traçado angular e claramente delineado de Kandinsky, outras formas são utilizadas por Fischinger; formas que exibem as marcas de sua fatura, a textura da tinta, a irregularidade da pincelada. Além disso, são outros os tipos de movimento. Em vez do isolamento dos eixos horizontal, vertical e diagonal, são curvas e combinações entre os eixos, combinações irregulares e inesperadas, que constituem a obra de Fischinger.

Num trecho ilustrativo da seção inicial, formas brancas semicirculares aparecem na região central da tela, movendo-se para a região superior. Conforme se movem, não

Richter e Eggeling, com ênfase na relação entre misticismo e abstração, ver o segundo capítulo de Elder, Harmony and Dissent. 
permanecem idênticas: são como que afetadas pela velocidade e têm seu formato levemente alterado, sobretudo num aumento de sua largura. As primeiras figuras seguem o movimento até desaparecer na borda superior, como se continuassem indefinidamente num espaço além da tela; mas as figuras seguintes, à medida que se aproximam da borda, são gradualmente comprimidas até que desaparecem. Podemos visualizar algumas etapas deste movimento:
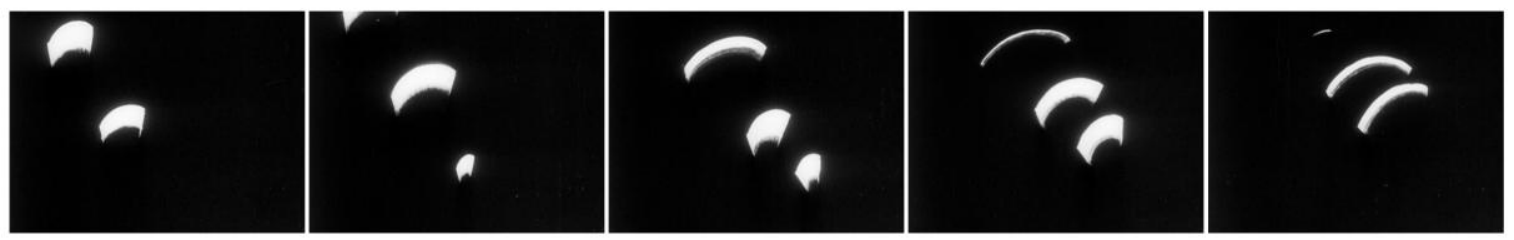

A travessia de formas que sofrem mudanças de formato e tamanho, bem como mudanças de orientação e direção, é a estratégia central do filme - travessias de uma borda a outra, de um lado a outro, trajetos em linha reta ou em curvas. Em algumas ocasiões, as formas são multiplicadas durante o movimento, como células num processo de mitose:
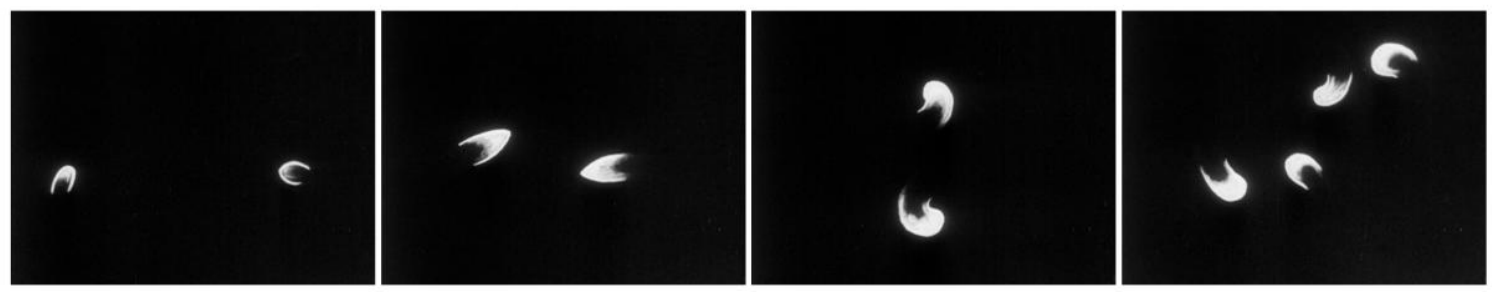

A analogia orgânica parece aqui a mais adequada por marcar a diferença em relação às preferências mecânicas de Richter e Eggeling. Assim como as figuras e as direções, as frequências dos movimentos também são variadas constantemente. Um movimento pode começar rápido e diminuir sua velocidade gradualmente, ou pode fazer o caminho oposto. Figuras movendo-se em determinada direção e velocidade podem ser contrapostas a outras figuras, sob outro tipo de movimento. A conjunção entre as várias características das figuras e a influência que parecem exercer umas sobre as outras, como a proximidade das bordas que altera o formato de uma figura, a velocidade de uma figura que atrai as outras, ou diferentes figuras que são aproximadas, cruzadas e combinadas em movimentos complementares - a conjunção desses fatores sugere a interdependência dos 
elementos, como se convivessem num mesmo ambiente e pudessem com ele interagir. É neste ponto que a proximidade de Fischinger com a música se revela distinta. É menos a noção de regras combinatórias e mais a noção da música como uma "evolução de formas" que lhe serve de influência.

William Moritz, ao descrever o método de trabalho de Fischinger, comenta essa interação com a música:

Ele rabiscava e rascunhava constantemente. Quando encontrava imagens e movimentos de que gostava, ou um procedimento técnico em particular que o intrigava, selecionava uma música de fundo com atmosfera e consistência suficientes para sustentar essas noções e formas. Ele então analisava a música, ouvindo a gravação repetidamente enquanto a minutava, marcando a partitura e finalmente transpondo a música a um sistema numérico no qual suas dinâmicas eram colocadas em termos de números de fotogramas. Trabalhando então com este gráfico numérico, ele poderia compor suas imagens, num processo análogo ao da coreografia. Se as formas e os movimentos não fossem auto-suficientes e interessantes como pura experiência visual, ele os redesenhava até que o fossem, às vezes descartando sequências filmadas que não pareciam funcionar. E, talvez mais importante, ele alterava a música sem piedade, para que se encaixasse em seus planos ópticos - rearranjando frases, deixando de fora seções inteiras, acelerando, etc. $^{104}$

Moritz rebate assim uma das principais críticas direcionadas a Fischinger, de que seus filmes seriam meras ilustrações de peças musicais. ${ }^{105}$ Em seu comentário, o próprio Fischinger enfatiza o fator interativo de suas construções visuais com as estruturas musicais, comparando a banda sonora a um rio que flui paralelo às imagens:

A parte óptica não é perfeitamente sincronizada a cada onda do rio - é uma caminhada bastante livre, nada é forçado, nada é sincronizado exceto em seções mais amplas. $\mathrm{O}$ filme é em alguns trechos perfeitamente sincronizado, mas em outros corre livremente sem preocupar-se muito com a música -, como uma caminhada prazerosa à margem de um rio. ${ }^{106}$

A ausência da sincronia como uma regra geral atesta o princípio mencionado, um princípio de complementaridade, mais do que de correspondência. Há uma semelhança com as ideias de Kandinsky, para quem a lógica musical poderia ser transposta ao

\footnotetext{
104 William Moritz, “The Films of Oskar Fischinger”, Film Culture 58/59/60 (1974), p. 80.

105 Ver, por exemplo, Alfred Frankenstein, "Art and Music" (1946), in Art in Cinema, op. cit., p. 43. Fischinger é acusado de "ligar rigorosamente, ponto a ponto, batida a batida", seus filmes às peças musicais; o resultado, ainda que "singelo", é apontado como "infantil". Frankenstein estende a crítica para os filmes dos irmãos John e James Whitney, onde ruídos são sintetizados por computador a partir das formas gráficas, e que seriam por isso meras inversões da "falácia de Fischinger".

106 Oskar Fischinger, citado na introdução de The Music and Sound of Experimental Film, eds. Holly Rogers e Jeremy Barham (Nova York: Oxford University Press, 2017), p. 5.
} 
universo visual. A presença da banda sonora parece servir a este fim: a música não como um roteiro a ser adaptado, não uma limitação à criatividade visual, mas como o ambiente no qual se movem as figuras, às vezes enfatizando seus relevos particulares, às vezes dele se desprendendo para alçar voos próprios. ${ }^{107}$ Como na variação de Kubelka, o paralelismo é apenas uma das possibilidades.

Há um procedimento a ser destacado, e que ilustra uma das contribuições de Fischinger ao desenvolvimento das formas plásticas em movimento. Em determinado trecho do filme, quatro figuras semicirculares são conduzidas por diferentes trajetórias até o centro da tela, ao que repentinamente se elevam, em sincronia rítmica; à elevação, segue-se um movimento, também sincrônico, em que as figuras são conduzidas à parte de baixo da tela; conforme se aproximam da borda inferior, o movimento é subitamente interrompido. Podemos visualizar algumas das etapas:

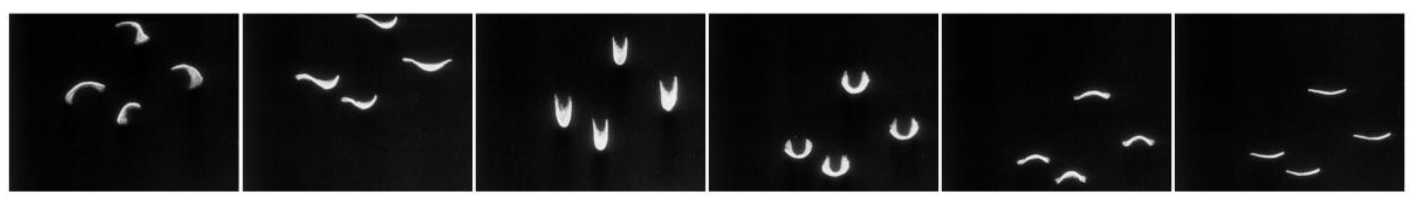

Durante todo o trecho, o formato das figuras é maleável, de modo que o próprio contorno delas reage à velocidade e à direção dos movimentos. Além disso, é importante a relação dos movimentos com as regiões da tela. O movimento para cima é seguido de um movimento para baixo, mas as deformações são diferentes em cada direção. Enquanto sobem no espaço da tela, as figuras parecem flutuar, como se elevadas por um impulso próprio; mas enquanto descem nesse espaço, parecem atraídas por uma força localizada na parte de baixo, até que finalmente cessam o movimento ao atingir uma região-limite. A analogia é clara: numa operação abstrata, Fischinger reconstrói as condições de percepção gravitacional.

\footnotetext{
${ }^{107}$ Para uma ressalva importante, ver Moritz, "The Films of Oskar Fischinger", op. cit., p. 80: "A única limitação que a música impôs a Fischinger se encontra na circunscrição dos potenciais [visuais] a alguns estilos e movimentos. Os sons claramente delimitados, as harmonias bem espaçadas, a recorrência de frases melódicas e os ritmos de dança simples, camponesas, de grande parte da música clássica europeia do século XIX, pareciam exigir um certo tipo de figuras geométricas e movimentos coreográficos." Richter e Eggeling também pareciam interessados especialmente na música deste período, mais do que em contemporâneos como Schoenberg e Stravinsky.
} 
Outro filme de Fischinger, Studie nr. 7 (1931) retoma os mesmos princípios, desta vez acompanhado de um movimento da Rapsódia húngara n. 2 (1847), de Franz Liszt. ${ }^{108}$ Sobre o mesmo fundo preto, formas luminosas movem-se desta vez em padrões circulares, como se flutuando ao redor de centros imaginários:

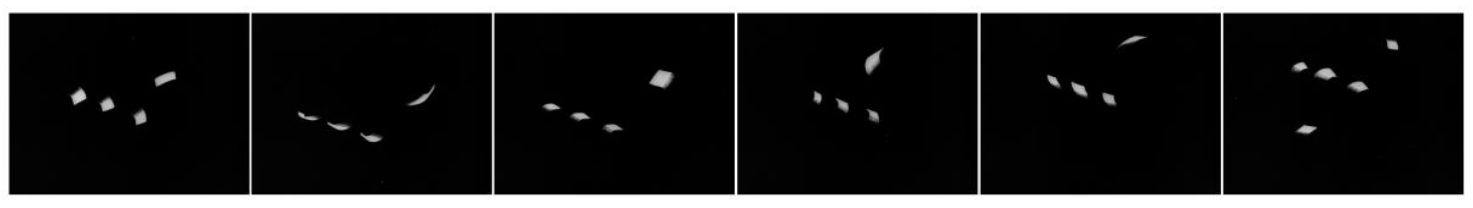

A partir da metade do filme surgem outras formas, que retomam a ideia de uma construção orgânica. No canto superior esquerdo, um losango é ampliado e a densidade de seu contorno é progressivamente diminuída até que as linhas se curvam como se atraídas por seu centro. Enquanto isso, linhas iniciadas no lado esquerdo atravessam horizontalmente o losango e se contorcem em espirais próximas ao lado direito. Na parte inferior da tela, linhas menores e ainda mais curvadas têm sua densidade e sua largura reduzidas conforme se aproximam da parte superior da tela. Podemos visualizar algumas destas etapas:

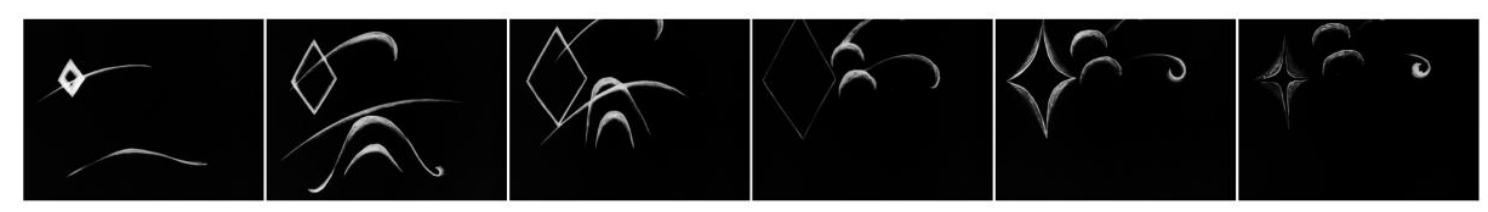

Os processos coexistem; as diferentes formas e regiões da tela são mobilizadas num período comum, e mesmo a estrutura geral dos eventos é semelhante, descrevendo travessias e reduções de alguma propriedade (tamanho ou densidade). Mas é a independência das figuras no que diz respeito à sua frequência, e sobretudo à ausência de qualquer esquematismo gráfico, de uma redução das coordenadas a um eixo ou a um padrão rítmico, que garantem a organicidade do conjunto.

Numa seção posterior, linhas e um losango surgem em diferentes regiões da tela, e conforme se movem em direção à borda superior, têm seu formato e sua densidade

\footnotetext{
108 Ver Moritz, "The Films of Oskar Fischinger", op. cit, pp. 136-137. Moritz cita Studie nr. 7 como o primeiro uso da tela preta como fundo constante por Fischinger, ainda que sua própria descrição de Studie $n r .6$ mencione a mesma abordagem. Ele se refere provavelmente ao fato de que tanto o $n r .6$ como o $n r .7$ foram iniciados em 1930, e que talvez o primeiro a ser finalizado e numerado não tenha sido o primeiro a ser concebido.
} 
modulados a frequências variadas. Como em Studie $n r$. 6, a tendência à emulação figurativa (padrões semicirculares, como asas de pássaros) coexiste com a pura abstração gráfica (linhas que se contorcem e são comprimidas em espirais):

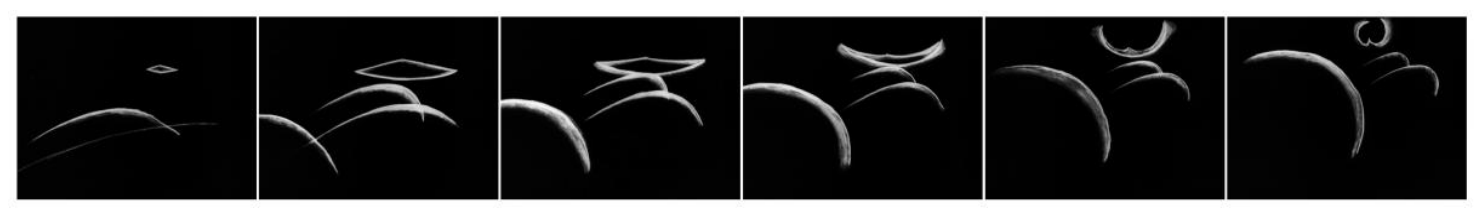

Que estes movimentos ocorram em seções lentas da composição de Liszt, e que não busquem reproduzir cada uma das notas ou cada um dos instrumentos envolvidos na banda sonora - em outras palavras, que se voltem à concepção geral da peça, ao seu caráter lânguido resumido em um conjunto de gestos abstratos -, essa característica reforça o argumento de que Fischinger não realizava uma tradução estrita, mas sim um complemento das formas visuais às formas sonoras.

Durante os anos 1930, como tantos outros artistas europeus, Fischinger imigrou para os Estados Unidos, onde logo se tornou a principal influência para animadores locais. ${ }^{109}$ No mesmo período, Mary Ellen Bute iniciou suas próprias obras fílmicas, também abstrações desenvolvidas com acompanhamento musical. Em 1939, com Spook Sport, Bute empregou um jovem escocês recém-saído da unidade de produção fílmica do General Post Office (GPO) britânico, e as técnicas desenvolvidas por ele revelam a permanência da influência de Fischinger, sobretudo em sua tendência orgânica. Este jovem, Norman McLaren, ao se estabelecer na National Film Board do Canadá, faria nos anos seguintes um conjunto de obras que levariam adiante os princípios evidenciados por Fischinger. ${ }^{110}$

\footnotetext{
109 Durante o mesmo período, a crescente influência de Fischinger lhe rendeu um convite para trabalhar em Fantasia (1940), produzido por Walt Disney. O resultado foi sintomático: as contribuições de Fischinger, dando preferência a formas completamente abstratas, logo foram reformuladas por outros animadores do estúdio, que acrescentaram referências figurativas aos seus desenhos. Somando isso à sincronia entre a imagem e o som, ganhava a dianteira justamente a ideia de "música ilustrada" da qual o cineasta alemão cuidadosamente desviou em sua própria filmografia. Fischinger abandonou a produção antes de seu término, mas suas contribuições podem ser identificadas no segmento inicial do filme, com a Tocata e fuga em ré menor, BWV 565 (c. 1704), de Johann Sebastian Bach. Ver Moritz, "The Films of Oskar Fischinger", op. cit., p. 63.

${ }^{110}$ Para mais sobre os animadores do "período de transição", durante a Segunda Guerra, ver David Curtis, Experimental Film (Londres: Studio Vista, 1971), pp. 33-37.
} 


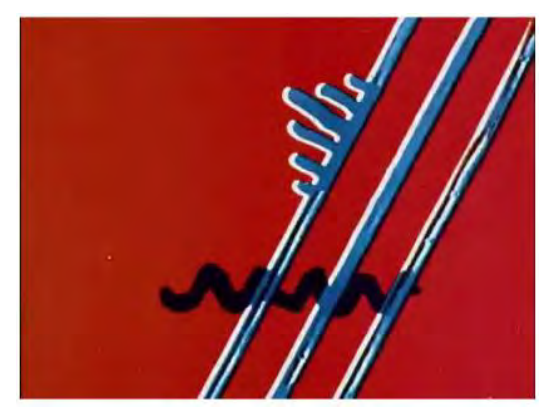

Boogie-Doogle (1940), um exemplo das animações abstratas criadas por Norman McLaren. Sobre fundos coloridos, formas maleáveis são por ele coreografadas e transformadas, em processos semelhantes aos de Fischinger.

Em 1977 e 1978, com a colaboração de Grant Munro, McLaren desenvolveu uma série de filmes que apresentam didaticamente os princípios envolvidos na criação de suas obras, os princípios do "movimento animado". A ideia básica é de que o movimento pode ser decomposto em etapas, e que cada etapa marca uma posição específica do objeto sobre a tela, o movimento sendo portanto caracterizado pelos padrões impostos aos posicionamentos. Como exemplo, McLaren isola um único eixo do espaço, o eixo horizontal, para representar o movimento de uma esfera branca pela tela preta. Utilizando marcações, como numa régua, é o caráter métrico do espaço que é por ele posto em evidência. A escala apresentada se inicia com uma disposição absolutamente regular e segue com acréscimos progressivos. Se o movimento regular leva aos resultados mecânicos de Richter e Eggeling, os movimentos com diferentes graus de aceleração fazem com que os objetos pareçam ganhar vida no decorrer de sua progressão, e que pareçam impulsionados ou atraídos em determinada direção. A conclusão é que a transposição de medidas espaciais à construção do movimento afeta diretamente o caráter temporal:

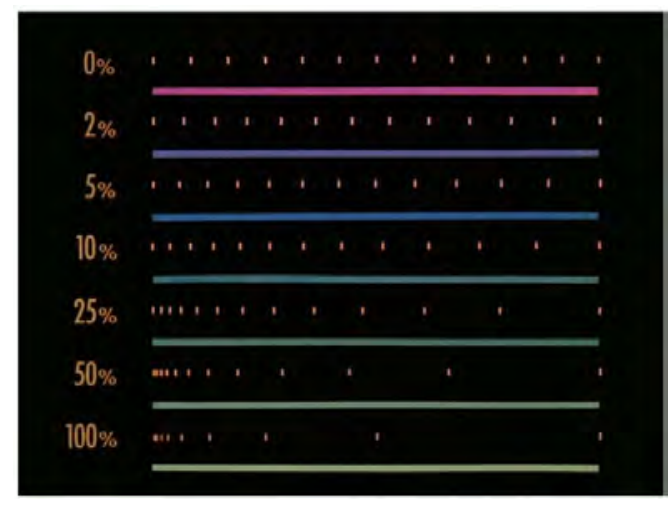


O princípio gravitacional é ilustrado por McLaren através da mesma escala. Considerando um movimento no eixo vertical, como um objeto em queda, os mesmos padrões são aplicáveis, cada um deles representando um tipo de movimento. No caso inicial, da absoluta regularidade das medidas, a orientação gravitacional é inexistente; o movimento parece emular não a dinâmica real de um objeto atraído pelo solo, mas o traçado na própria superfície da tela, onde a dinâmica ocorre na relação entre o centro e as bordas. Conforme aumentam as distâncias entre as etapas, a atração gravitacional torna-se cada vez mais presente. O mesmo ocorre após o impacto do objeto com o solo. Invertendo a direção das escalas, pode-se representar o objeto batendo no solo e movendo-se na direção oposta, sugerindo com isso o caráter de todo o evento - a consistência e maleabilidade do objeto e do próprio solo, e a presença ou ausência de outras forças além da gravidade.

McLaren nos mostra ainda uma escala nos contornos do solo, como se buscasse representar a passagem de um objeto sobre um terreno em corte seccional. O mesmo princípio escalar é aplicado: as proporções indicam a maior ou menor presença da orientação gravitacional, de modo que outras forças podem ou não interferir no processo. Pode-se, por exemplo, representar os diferentes níveis de atrito entre o objeto e o solo, contraindo os intervalos para indicar maior aspereza e expandindo para indicar maior deslizamento.
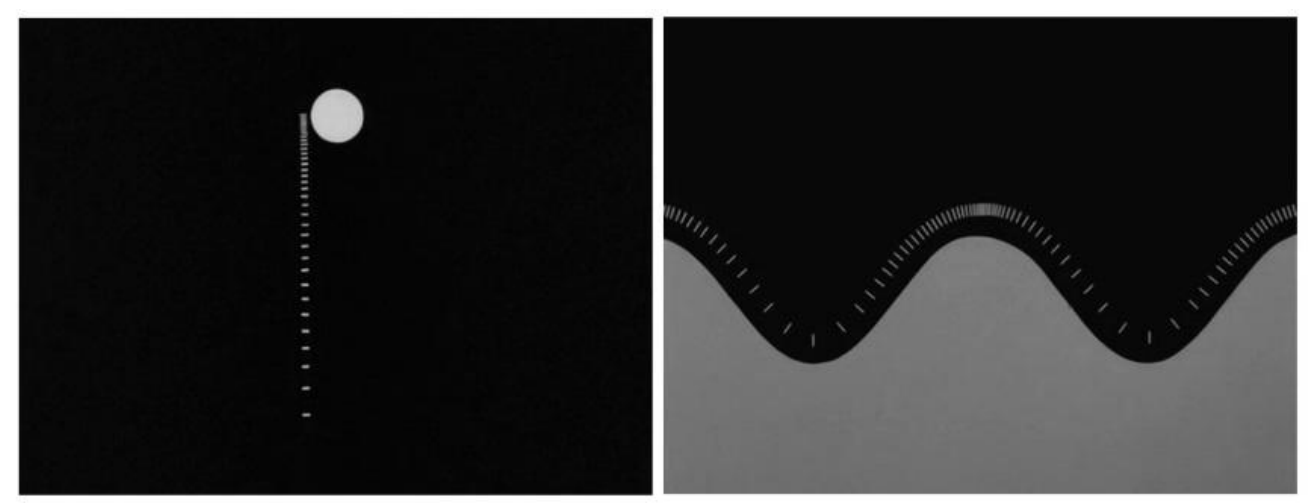

As representações de trajetórias sob a orientação gravitacional: em queda livre, e deslizando sobre um terreno.

Os princípios evidenciados por McLaren são responsáveis pelos efeitos de construção e abolição da gravidade em animações como as de Fischinger, em que formas abstratas, no decorrer de trajetórias puramente gráficas e que poderiam descrever apenas a geometria superficial da tela, passam a sugerir um campo de forças direcionadas, 
condições que influenciam os movimentos e que os atraem para certas regiões mais do que a outras. Esta dualidade fundamental entre a tela como superfície simétrica e relacional (onde as posições e direções parecem intercambiáveis, reguladas apenas pelo centro geométrico) e a tela como um campo influenciado pela orientação gravitacional, assimétrico (onde regiões inferiores e superiores têm diferentes valores e propriedades), é o que que diferencia o projeto de Fischinger do projeto de Richter e Eggeling, e que nos permite expandir a concepção das animações e colagens abstratas.

Uma decorrência frequente desta tendência é a maleabilidade das formas visuais, algo desenvolvido por Fischinger já em seus primeiros filmes. McLaren ilustra isso com barras luminosas sobre um fundo preto, formas radicalmente abstratas, mas que pelas frequências aplicadas a seus movimentos tornam-se quase humanizadas, uma vez que é imposta a suas posições uma combinação entre as gradações dos posicionamentos e a dinâmica que parece ter gerado os movimentos. Em lugar de um processo mecânico, imposto sobre as figuras, é uma força orgânica que parece estimular os resultados, como se as próprias figuras realizassem os movimentos. ${ }^{111}$ Como na transcrição gráfica dos movimentos por Kandinsky, é uma transposição da dinâmica temporal à configuração espacial que é proposta:

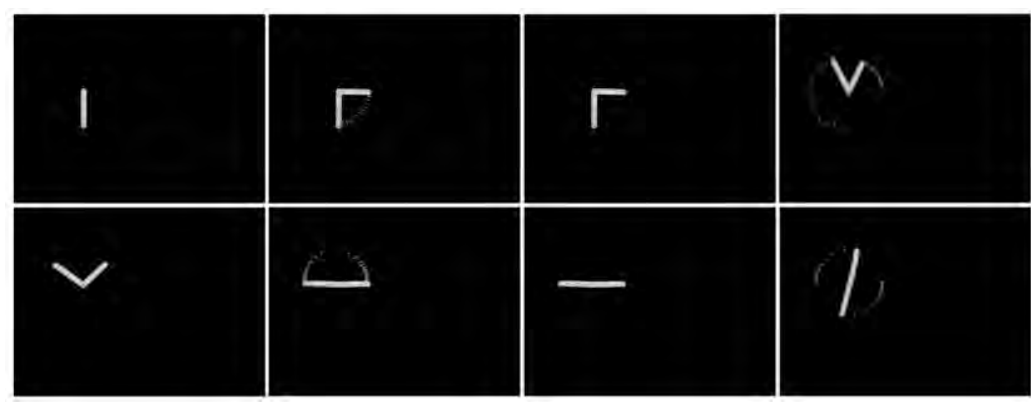

A propriedade orgânica surge portanto como uma oposição à tendência mecânica, podendo se manifestar em dois níveis: na maleabilidade das formas visuais e na movimentação dessas formas. O extremo do mecanismo, representado por um filme como Rhythmus 21, apresenta formas rigidamente delineadas, constantes em seus contornos e

111 Uma distinção pode ser feita entre "movimento" e "deslocamento", sendo o primeiro um "evento ativo" e o segundo um "evento passivo". Um objeto, por essa definição, se move quando é ele mesmo a causa da mudança de posição, e é deslocado quando forças externas causam a mudança de posição. As condições que levam à percepção de um movimento como tendo uma causa interna ou externa foram estudadas por Albert Michotte; os experimentos descritos por ele complementam as observações feitas por McLaren sobre os modos de atribuir "vida" a figuras inanimadas. Ver Albert Michotte, The Perception of Causality (Londres: Methuen, 1963), pp. 183 ss. 
em suas texturas, alteradas em direções e frequências retilíneas e uniformes. Neste caso, a artificialidade dos movimentos é posta em primeiro plano e sua imposição arbitrária às formas visuais parece conduzir a obra. Um acréscimo do fator orgânico faria com que as figuras se tornassem menos rígidas, que seus contornos e suas texturas fossem modificadas conforme se movessem; ou então, os próprios movimentos se tornariam gradativos, ou em diferentes gradações. No extremo da tendência orgânica teríamos um filme como Studie $n r$. 6, em que as figuras resistem à delineação rígida, sendo maleáveis a tal ponto que o menor deslocamento basta para alterar seu formato. Neste caso, os movimentos ocasionalmente representam a atração de uma das partes da tela, na maioria das vezes a parte inferior, sugerindo a orientação gravitacional e criando um ambiente no qual as figuras interagem "fisicamente" com a tela.

\subsection{Permutações figurativas}

Como um dos principais nomes influenciados por Fischinger após sua mudança para os Estados Unidos, Harry Smith desenvolveu uma abordagem que toca nas mesmas questões por outro ângulo. Nos anos 1950, Smith inaugurou uma fase crucial em sua filmografia: em lugar das animações com formas geométricas que havia herdado das vanguardas europeias, ele passou a explorar o uso de figuras recortadas de livros e catálogos, nas quais aplicava princípios de deslocamento e transformação. ${ }^{112}$

Em Mirror Animations (1956) encontramos um caso emblemático dessa postura. O filme abre com uma tela preta em silêncio. A tela é logo atravessada por recortes de flocos de neve que se movem da parte superior até a parte inferior, numa velocidade regular. O último dos flocos é atraído pelo centro, onde permanece estático, enquanto os outros descem até desaparecer na parte de baixo. O floco remanescente é então atingido por raios dos dois lados da tela alternadamente, e transforma-se numa figura humana com vestes sacerdotais. Neste momento tem início a música, uma versão de Misterioso, de Thelonious Monk. Podemos visualizar as principais etapas deste trecho:

\footnotetext{
${ }^{112}$ Para um relato mais pormenorizado das influências de Smith e o contexto das vanguardas pictóricas nos EUA, ver Judith A. Switzer, "The Animated Abstractions of Harry Smith", Millennium Film Journal 6 (primavera de 1980), pp. 73-75.
} 

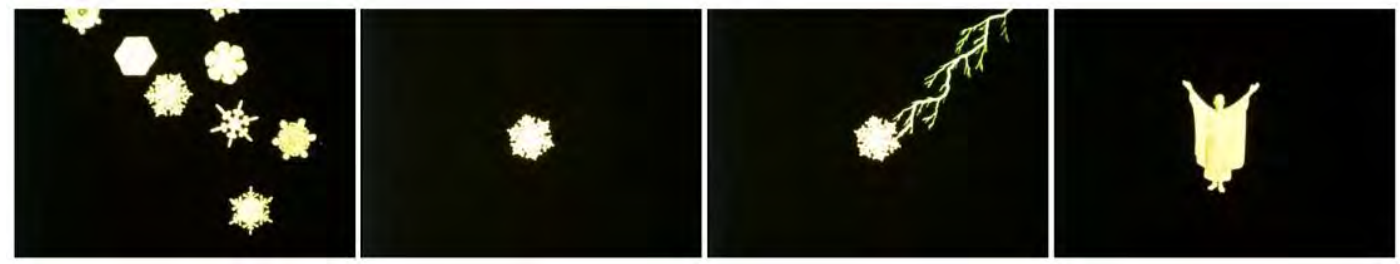

Uma esfera desce da parte superior da tela até as mãos do sacerdote. No momento em que este joga a esfera para o alto, têm início outra seção da música, e uma série de figuras coloridas atravessam o espaço em movimentos retilíneos. Conforme o sacerdote direciona os braços a uma parte da tela, as figuras atravessam aquela mesma região, de um lado a outro. Quando os braços são apontados para baixo, por exemplo, linhas coloridas atravessam o eixo vertical como se irradiassem do topo à parte de baixo, e surge no canto inferior direito um peixe, movendo-se horizontalmente em direção ao canto inferior esquerdo. Os gestos do sacerdote "ativam" um a um todos os lados da tela:
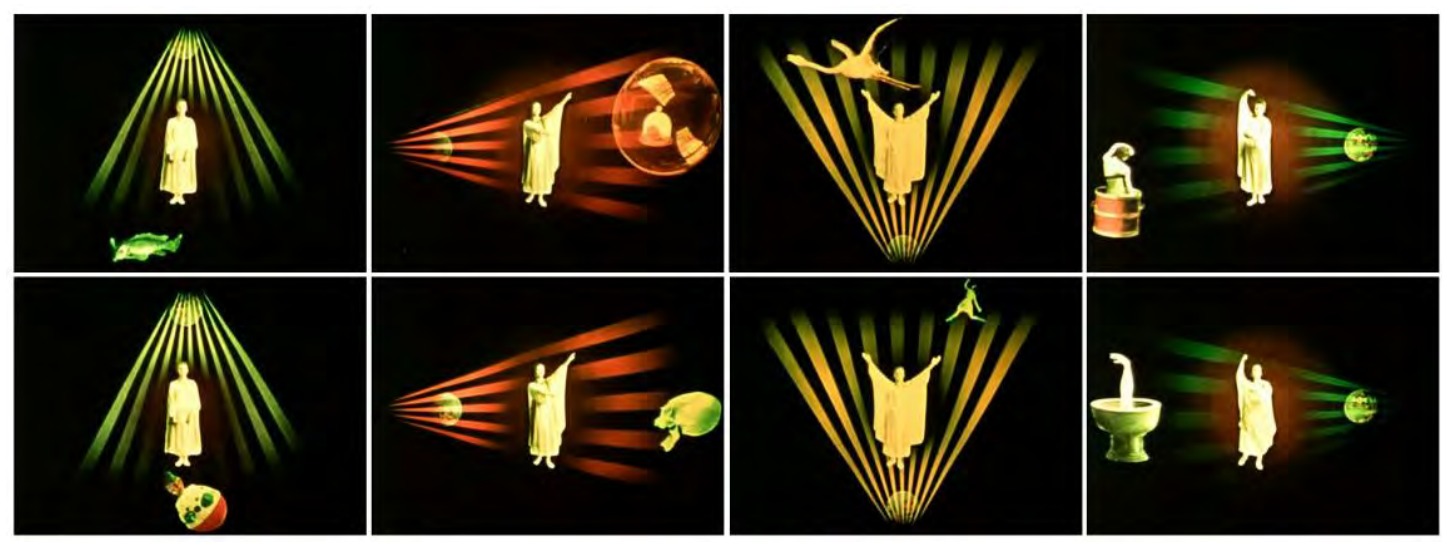

Podemos visualizar ainda as direções em que ocorrem os movimentos, tendo em mente que ocorrem em sincronia com as frases musicais (todas de duração semelhante, aproximadamente quatro segundos), e percebendo como as regiões da tela são mobilizadas duas vezes cada, sempre na mesma ordem, mas a cada vez com um direcionamento distinto:

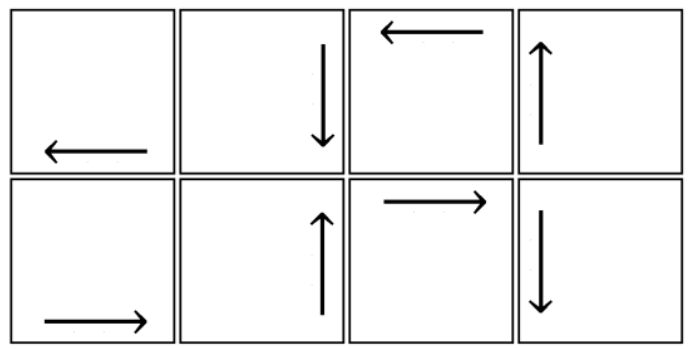


O filme prossegue multiplicando as variações ao redor da figura do sacerdote. Ele é transformado numa fonte, mantida no centro do quadro, enquanto outras figuras atravessam a tela nas mesmas regiões da seção inicial. Linhas coloridas são recorrentes, brilhando e tingindo as regiões escuras da tela com suas cores, numa alternância de verde e vermelho. Em seguida, o sacerdote retorna, apenas para ser cercado por duas outras figuras - uma dançarina e um sapo - que o transformam num tapete persa, em meio a círculos coloridos. As variações então passam a ocorrer sobre o tapete, como a sombra da dançarina projetada sobre ele, ou objetos que saem de trás dele e são colocados em cima do sapo. Podemos visualizar algumas dessas etapas:
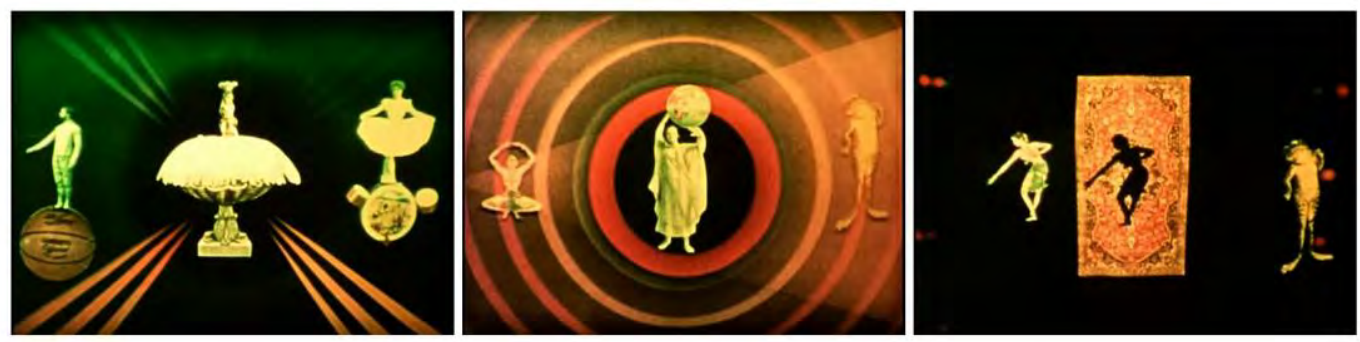

Quando o sapo "entra" no tapete, ocorre uma completa reorganização do espaço. Sendo retirado o tapete numa explosão luminosa, é revelada uma nova figura - um carteiro sobre um espaço vagamente cúbico, como um palco teatral. Permanece o fundo escuro, mas há agora linhas que sugerem chão e paredes. Neste espaço, o carteiro movimenta a dançarina como se fosse um objeto, jogando-a de um lado a outro conforme as paredes são multiplicadas e subtraídas. A orientação gravitacional é parcialmente presente nestes momentos. As duas figuras entram numa pequena caixa que, ao ser aberta, realiza uma nova transformação no espaço: objetos e ídolos saem da caixa e o palco dá lugar a um ambiente sem chão ou paredes, onde as figuras parecem flutuar. Podemos visualizar algumas dessas etapas e identificar como o espaço cúbico é primeiro sugerido, depois construído efetivamente, servindo de palco às transformações, e finalmente abolido:
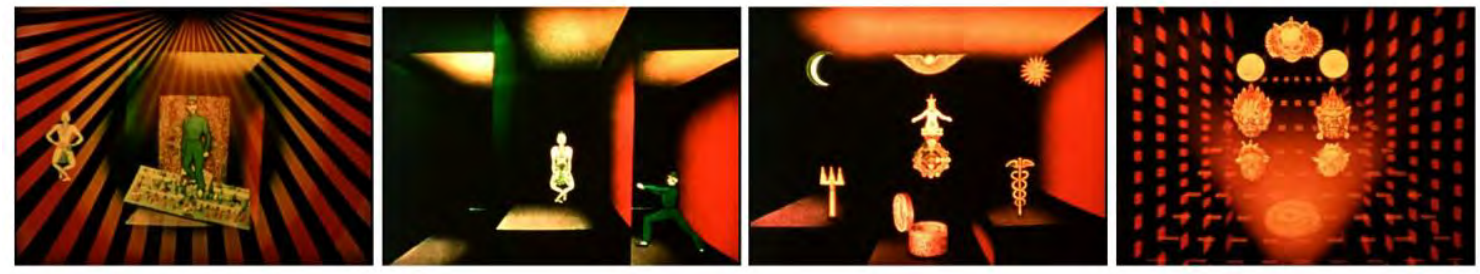
Essa alternância entre o espaço de uma "caixa fechada" e o espaço "aberto" tornase frequente na segunda metade do filme. A caixa surge novamente, ainda que por um período mais curto; outras figuras surgem e são transformadas, retomando os padrões geométricos e os movimentos anteriores - disposições simétricas ou circulares, trajetórias próximas às bordas, sempre acompanhadas de linhas e círculos brilhantes e coloridos. No final, retorna o sacerdote, e seu gesto parece trazer de volta, agora simultaneamente, as figuras da seção inicial, junto com uma movimentação circular ao redor do personagem centralizado.
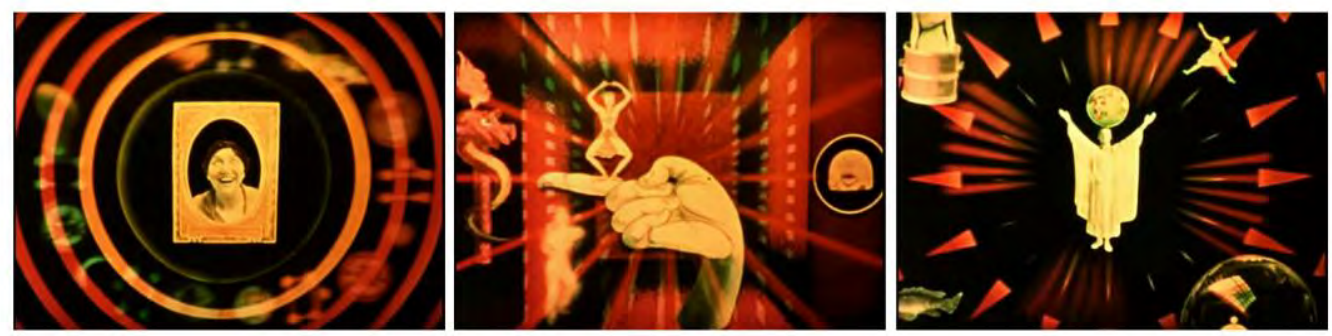

Imagens da seção final de Mirror Animations (Harry Smith, 1956): (1) a movimentação de formas em padrões circulares, ao redor de uma figura central; (2) a sugestão de um espaço cúbico, onde as figuras são orientadas pela gravidade; (3) a retomada do espaço "aberto", onde as figuras flutuam livremente.

Uma primeira e óbvia diferença em relação aos filmes anteriores é que a maior parte das figuras do filme de Smith não são apenas formas geométricas e traçados coloridos: são também pessoas, animais, objetos reconhecíveis. A decorrência imediata é que as operações de transformação, movimentação e combinação das figuras podem sugerir algo como uma narrativa. Consideremos, por exemplo, os segundos iniciais do filme, quando flocos de neve atravessam a tela da região superior à região inferior, até que um deles é fixado no centro da imagem, sendo atingido por dois raios e transformado numa figura humana. O movimento dos flocos de neve é regular, sem a gradação espacial ou temporal que possibilitaria a construção da referência gravitacional; mas o simples fato de serem flocos de neve movimentados da parte de cima à parte de baixo da tela sugere um "sentido": sugere a queda destes elementos. Da mesma forma, os raios atingindo o floco de neve sugerem a causa da transformação deste no sacerdote. A ideia subjacente é que raios atingem um objeto causando um impacto considerável no objeto e envolvendo uma concentração da energia. A mera sucessão raio-transformação é suficiente para indicar um evento mágico. Se na natureza a sucessão não implica a causalidade, aqui é 
precisamente a causalidade que parece representada pela transformação que sucede os raios. $^{113}$

Richter e Eggeling falam em termos de "perguntas e respostas" ao comparar seus movimentos a construções musicais. As inversões em Rhythmus 21 e Symphonie Diagonale se caracterizam pelos diversos tipo de simetria e pelo fato de que as mesmas figuras, ou as mesmas transformações, podem ocorrer em múltiplas orientações. O caráter relacional do espaço predomina nestes casos, onde a tela é vista como uma superficíe achatada na qual formas luminosas se movimentam em padrões arbitrários. A referência gravitacional nas animações de Fischinger e McLaren introduz uma assimetria nesta concepção espacial: as regiões superiores e inferiores da tela passam a ter valores diferentes. Isso é estendido à maleabilidade de suas figuras na medida em que elas são transformadas justamente pela interação com o espaço. Uma massa cromática pode então parecer "cair" no quadro e, ao tocar no limite inferior da imagem, ter seu formato alterado, como um objeto sendo afetado pelo contato. No filme de Smith, o uso da figuração coexiste com a redução dessas referências ao mínimo possível. Seus recortes não se movem com a fluidez e a constante gradação das imagens de Fischinger; além disso, não são maleáveis, mas perfeitamente fixos em suas poses. Eles tendem a exibir movimentos regulares, mas sem a mecanização contínua de Richter e Eggeling. São movimentos que parecem avançar em saltos, uma consequência direta do fato de Smith utilizar recortes, devendo restringir as configurações visuais dos objetos às configurações já existentes no material original.

Outro aspecto diz respeito aos diferentes tipos de espaço sugeridos no decorrer do filme. Há pelo menos dois tipos: o espaço da tela como um todo, achatado e sem qualquer tipo de orientação gravitacional exceto a atração do centro geométrico, e o espaço de um "teatro mágico" onde as figuras interagem como se estivessem numa caixa. Judith

113 Alguns dos efeitos na percepção da causalidade identificados por Michotte são o "efeito de ampliação" (quando um objeto parece estender seu movimento a outro objeto) e o "efeito de lançamento" (quando um objeto parece ser deslocado a partir do impacto com outro). No decorrer de seus filmes, Smith utiliza uma versão desses efeitos, algo que parece retomar a crença mítica segundo a qual a sucessão de fatores basta para estabelecer uma relação de causalidade. Nesse sentido, se o raio toca o floco de neve e em seguida o floco se transforma num sacerdote, o raio deve ser a causa da transformação. Para um comentário mais detido das relações entre a causalidade como vista pela ciência e pelo pensamento mítico, ver Ernst Cassirer, A filosofia das formas simbólicas, vol. II: O pensamento mítico (São Paulo: Martins Fontes, 2004), pp. 90 ss. Roland Barthes identifica a confusão proposital entre consecutividade e consequência como o próprio fundamento da narrativa, associando-a à falácia post hoc, ergo propter hoc. Ver Roland Barthes, "Introduction à l'analyse structurale des récits", Communications 8 (1966), p. 10 . 
Switzer enfatiza o quanto essas características decorrem da própria interação entre as figuras e suas transformações:

As dinâmicas espaciais da colagem resultam do jogo contínuo entre os níveis de escuridão e clareza nas relações de figura e fundo. Quando figuras são organizadas em colagens, as regiões do espaço desenvolvem-se umas em relação às outras, em vez de em relação a uma estrutura espacial pré-concebida. Contextos espaciais são construídos e destruídos pelas relações internas entre os objetos à medida em que eles são justapostos e combinados. Primeiro plano e plano de fundo tornam-se intercambiáveis, e o olho trata a totalidade da superfície como um campo de interesse. Conforme as figuras arcanas de Smith são combinadas e transformadas, experimentamos este campo de atenção indiferenciado como um espaço sem um interior. ${ }^{114}$

Numa chave semelhante, Sitney refere-se às transições

entre um plano achatado de ação e uma profundidade ilusória, entre animação feita por colagens e as convulsões abstratas da imagem como um todo, entre a gravidade e a tela como um campo aberto de movimentos, entre a sequência de transformações e as mudanças abruptas. ${ }^{115}$

Uma ligação entre o filme de Smith e as animações de Fischinger é que ambos trabalham com a transição de um domínio a outro. O fato de que uma determinada configuração, um determinado modelo de condução das formas é possível, não significa que será fixo no decorrer da obra; pelo contrário, significa que será constantemente transformado, será construído e abolido com frequência. É nessa transformação permanente que as formas visuais são desenvolvidas.

O filme mais complexo de Smith, e também sua obra mais longa, é Heaven and Earth Magic (1962), que serve como ilustração dessas mesmas tendências quando levadas aos seus níveis mais extremos. Em vez dos três minutos de Mirror Animations, Heaven and Earth Magic dura 66 minutos. Em vez do acompanhamento musical, há uma base silenciosa, quebrada apenas ocasionalmente por ruídos isolados, quase sempre em sincronia com os objetos. Em vez do vermelho e do verde brilhantes que contaminam as regiões mais escuras da tela, há um fundo negro constante, e as figuras possuem todas, sem exceção, a mesma textura monocromática. A longa duração faria também com que a recorrência das figuras e o encadeamento de suas transformações pudessem delinear com mais detalhes algo como uma narrativa. Ainda assim, a "trama" é frequentemente descrita apenas em termos gerais, evidenciando seu caráter arbitrário, beirando o surrealismo: a

\footnotetext{
114 Ibid., pp. 80-81 (grifo nosso).

115 Sitney, Visionary Film, op. cit., p. 246.
} 
perda de uma melancia causa uma dor-de-dente na personagem e sua ida ao dentista torna-se uma viagem ao paraíso, seguida de um retorno à Terra.

Mais importante que o enredo é o modo como Smith parece ter alcançado a estrutura do filme. Ele descreve sua busca pelas figuras a serem recortadas e combinadas da seguinte maneira:

Primeiro, eu coletei partes de velhos catálogos, livros, etc. Depois eu criei fichas para todas as combinações possíveis entre as partes; então, passei alguns meses testando as fichas em busca de uma ordem lógica. Um roteiro foi escrito. [...] Todas as permutações possíveis foram construídas: digamos que há um martelo, um recipiente, uma mulher e um cachorro. Várias coisas podem então ser feitas - martelo bate no cachorro; mulher bate no cachorro; cachorro pula no recipiente e assim por diante. Era possível construir um número imenso de referências cruzadas. ${ }^{116}$

A procura em catálogos e livros foi feita, de acordo com Smith, sem intenções particulares pois não havia, segundo ele, o plano de uma narrativa. A partir desta coleta, inconsciente ou aleatória, foram as combinações internas que o interessaram. A listagem das "referências cruzadas" tornou-se, assim, o método para a criação do conjunto de transformações possíveis.

Já nas primeiras imagens é possível identificar o caráter permutativo do filme. Uma figura masculina surge na tela escura como num palco, caminhando em pequenos saltos enquanto soa o uivo de um lobo. A sugestão de elementos externos ao espaço visível continua na faixa sonora quando ouve-se o miar de um gato. Espacialmente, o mesmo princípio se manifesta quando o pequeno homem sai de cena e retorna com um imenso sarcófago, que ele posiciona no lado direito da tela. A operação se repete, e outro sarcófago é colocado no lado esquerdo. Esta abertura resume algumas das técnicas recorrentes em Heaven and Earth Magic. Em grande parte do filme, a figura do "homúnculo" serve como um análogo do sacerdote em Mirror Animations, aquele que parece conduzir ou presenciar o espetáculo das transformações. Da mesma forma que no filme anterior, essas transformações envolvem o posicionamento e a substituição dos objetos no espaço da tela; mais especificamente, a criação de padrões geométricos, quase sempre simétricos e circulares. No trecho inicial, um objeto é posicionado à direita e depois um objeto semelhante é posicionado à esquerda, ilustrando o princípio comutativo que será atuante no resto da obra, de que tudo o que ocorre de um lado da imagem deve ter sua correspondência no outro lado. Orientado pela gravidade e com referências

${ }^{116}$ Harry Smith, citado em Sitney, Visionary Film, op. cit., pp. 249, 255. 
figurativas, o trecho realiza assim uma adaptação da "ação e reação" mencionada por Richter:
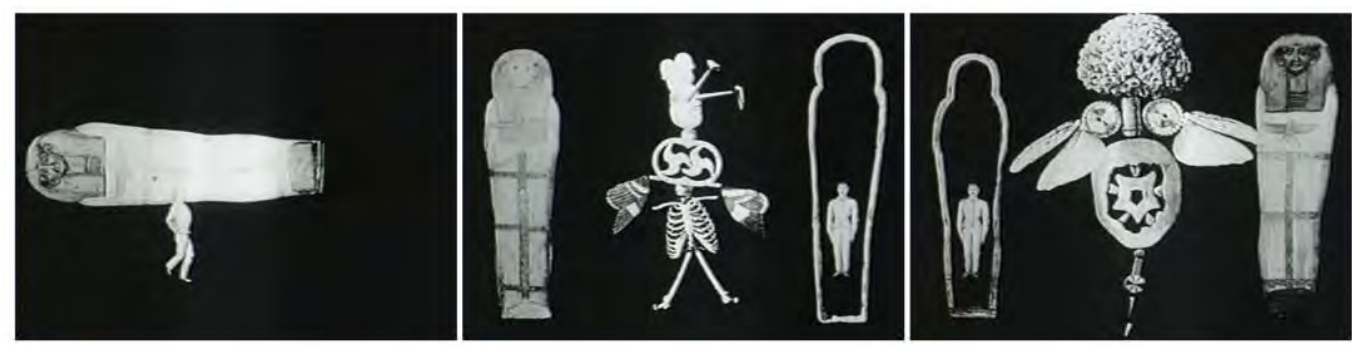

Numa das seções seguintes, a orientação gravitacional é abolida justamente quando é traçado sobre a tela o "esqueleto" de uma caixa, semelhante ao "teatro mágico" de Mirror Animations - uma espécie de estrutura arquetípica do espaço em profundidade, um modelo da sala em perspectiva. ${ }^{117}$ Nesta sala, as linhas traçam ainda o contorno de uma cabeça humana em perfil. A figura centralizada do homúnculo, como a do sacerdote no filme anterior, torna-se o núcleo ao redor do qual se movem objetos em padrões semicirculares. Os objetos às vezes parecem flutuar livremente e às vezes parecem seguir o comando ou o interesse do homúnculo:
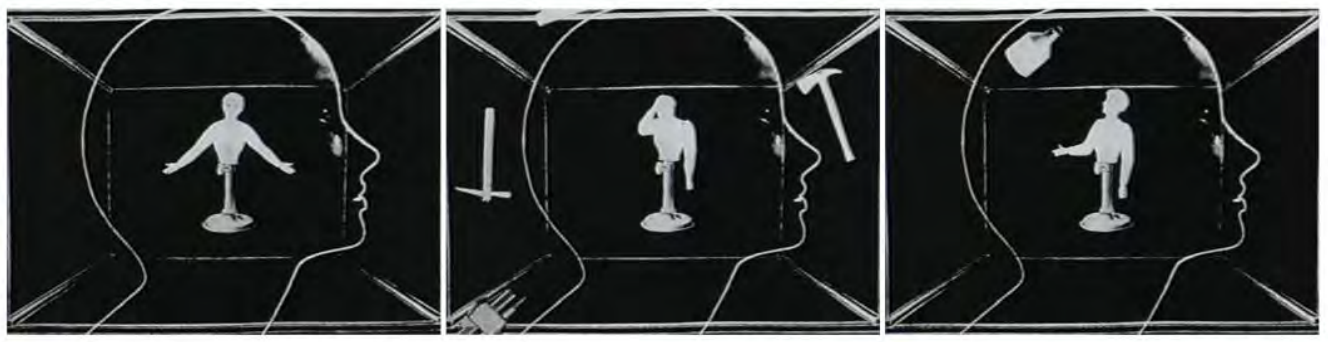

$\mathrm{Na}$ mesma sequência, mais adiante, a orientação gravitacional torna-se presente. $\mathrm{O}$ homúnculo toca o solo e passa a coordenar a transformação de objetos nos dois lados da tela. São recorrentes aqui imagens de molduras e cabeças. Além da cabeça inscrita no

117 É interessante neste ponto considerar o argumento de David Bordwell a favor da teoria "construtivista" do espaço. Ver David Bordwell, Narration in the Fiction Film (Madison: University of Wisconsin Press, 1985), p. 107: "Nenhum sistema pictórico pode copiar inteiramente o espaço empírico. Uma teoria construtivista enfatiza que todo sistema espacial pictórico enfatiza algumas funções. [...] Mas se quisermos imagens que nos forneçam informações sobre as posições, os tamanhos e as dimensões relativas dos objetos num espaço passível de medição e visto por um único ponto de vista, então a perspectiva científica não é tão 'arbitrária' quanto outros sistemas. Para este propósito, a perspectiva científica fornece mais informações, e as informações mais precisas, sobre o que pode ser visto [...]." Bordwell considera aqui o trabalho de autores como E.H. Gombrich, R.L. Gregory e Julian Hochberg. 
espaço cúbico e que emoldura parte da ação, há recortes de cabeças que surgem dentro de molduras menores, posicionados nos lados direito e esquerdo:
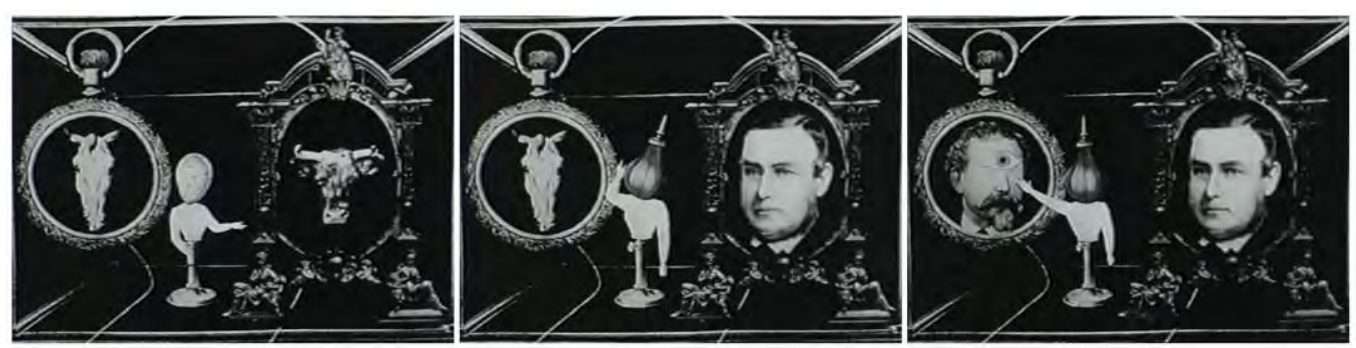

A manipulação espacial, e mais especificamente a definição do espaço como sendo ou não orientado pela gravidade, é uma das características marcantes do filme. Ainda mais do que em Mirror Animations, ela explicita a oscilação entre um espaço fechado, determinado por coordenadas gráficas (como as linhas que descrevem um cubo), onde as figuras parecem inseridas, e um espaço aberto, igualado à escuridão da tela, no qual as figuras parecem transitar com mais liberdade, podendo inclusive dele sair. Judith Switzer comenta a presença dessa oscilação como uma ausência de tensão entre certas qualidades espaciais e refere-se ao homúnculo como o "mago" de Smith, uma espécie de avatar do próprio cineasta na obra:

Uma das tensões tradicionais que foi destruída é a tensão entre o centro e a borda do plano pictórico. Uma figura que se aproxima do limite do plano normalmente aumenta sua tensão até o momento de contato com a fronteira, quando atinge seu limite máximo. Um dos primeiros movimentos do mago na abertura do filme destrói a tela-como-moldura quando o mago sai por um lado da tela apenas para reaparecer do outro lado, sem nunca ter cruzado a tela. A sensação de um espaço fora-da-tela é ainda reforçada quando as múmias são trazidas dos dois lados do quadro. Mais adiante, um cachorro corre por toda a extensão do quadro com uma melancia, saindo por um lado e entrando pelo outro várias vezes. Ainda mais adiante, há um segmento curto em que uma roda gigante parece girar o plano da tela verticalmente, movendo os objetos. Temos a clara impressão de que há um "mago cineasta" por trás do plano da tela, dirigindo a operação. O espectador logo percebe que as bordas da tela não apresentam obstáculos e que há algo como um espaço fora-da-tela cercando o plano da tela, como se ela estivesse no centro de uma esfera. ${ }^{18}$

Switzer aponta também como as possibilidades de movimentos são determinadas aos poucos, em contextos particulares, relacionando-se com situações anteriores, mais do que com um sistema fixo de expectativas:

\footnotetext{
118 Judith A. Switzer, "The Spatial Strategies of Harry Smith's Heaven and Earth Magic", Film Reader, vol. 3 (1978), p. 209.
} 
Não apenas as fronteiras da tela não oferecem qualquer fonte de tensão, mas a falta da usual orientação gravitacional de cima a baixo também destrói a competição entre as partes superior e inferior do plano. Nos minutos iniciais o cachorro define algumas possibilidades incomuns de movimento, andando de um lado a outro da tela, de cima para baixo e dali para os lados. Enquanto isso, objetos flutuam para o topo da tela e dali para cima. Entramos num mundo algo como aquele revelado pelas pinturas de Klee, um "universo subaquático povoado por forças fantasmas onde as coisas caem para cima". Os movimentos distensionados das figuras flutuam num espaço ambíguo e num igualmente ambíguo universo sonoro. ${ }^{119}$

A comparação entre Smith e Paul Klee é significativa. Switzer menciona as telas de Klee nas quais há uma referência direta ao fundo do mar, o que o pintor suíço representa como um espaço escuro e sem orientação de escala ou profundidade. Numa escuridão indistinta, formas geométricas coexistem com figuras diversas, de peixes a flores e objetos vagamente definidos. A ambiguidade desses espaços nos filmes de Smith faz com que os objetos surjam e se movam não como o fariam em seus contextos usuais, mas como "símbolos num código". ${ }^{120}$ Mesmo a causalidade é tornada apenas uma possibilidade: Smith alterna o encadeamento causal com uma espécie de parataxe, a simples enumeração sucessiva ou simultânea, temporal ou espacial.

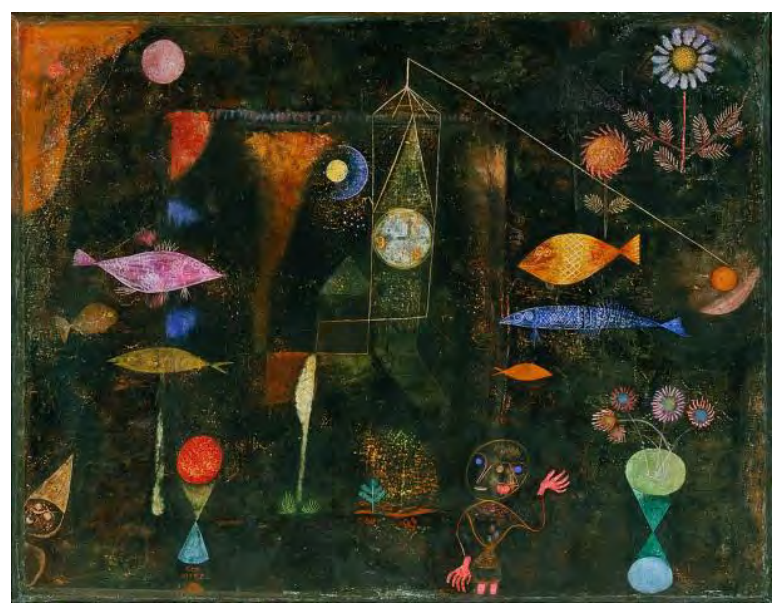

Paul Klee, Fish Magic (1925)

Apesar da presença de imagens figurativas e de uma narrativa rudimentar, a construção espacial e a tendência combinatória das figuras nos levam a um aspecto distinto no filme de Smith. O fato de que o encadeamento narrativo é muitas vezes posto em segundo plano, parecendo mesmo servir como pretexto para a multiplicação de

\footnotetext{
119 Idem.

${ }^{120}$ Ibid., p. 219.
} 
imagens de maneira autônoma, sugeriu a diferentes autores a mesma impressão: o filme como representação da mente.

O argumento é formulado mais claramente por Noel Carroll. Ele aponta que há, na construção geral, uma série de "metáforas cotidianas sobre estados de consciência como fontes imagísticas". A concepção do devaneio como uma espécie de flutuação na consciência seria um exemplo; outro seria a imagem de um oceano profundo no qual objetos estão imersos. Nos dois casos, o "espaço da consciência” é análogo a um ambiente no qual o movimento é parcialmente livrado da força gravitacional e no qual a velocidade e a orientação direcional são tornadas imprevisíveis. O fundo preto é desprovido de luminosidade, uma anulação da materialidade fílmica e da superfície da tela onde a imagem é projetada; como a perfeita ausência de estímulos, uma base homogênea equacionada à escuridão genérica da sala, o fundo preto serve então como metáfora para esta concepção do espaço mental. Outro aspecto citado por Carroll é a antropomorfização de faculdades mentais. No centro do filme está a figura do acrobata em miniatura que parece testemunhar, e às vezes conduzir, grande parte das ações. $\mathrm{O}$ homúnculo de Smith teria no filme o papel de uma faculdade mental personificada, o agente centralizador da consciência. ${ }^{121}$

Carroll avança o argumento para tocar em algumas das imagens recorrentes:

O filme apresenta a si mesmo como imagem, ou ainda, como um conjunto de imagens da consciência, da própria mente. Isso é tornado explícito na iconografia do filme durante a ascensão da heroína ao paraíso. A cadeira de dentista se transforma nos contornos de uma cabeça. A cabeça, por sua vez, é inscrita numa caixa, o mesmo tipo de imagem que John Locke evocou quando propôs a analogia da mente com um gabinete, um armário, uma sala escura. Duas imagens convencionais da mente, a cabeça e a caixa, contêm a ação, funcionando como molduras no quadro cinematográfico, sugerindo assim que o terceiro quadro nesta rima, a tela cinematográfica, deve ser compreendido em relação à cabeça e à caixa como outra figura para a mente. Aqui, o quadro é comprovadamente proposto como um correlato da consciência. ${ }^{122}$

${ }^{121}$ Ver Noel Carroll, "Mind, Medium and Metaphor in Harry Smith's Heaven and Earth Magic" (1977/1978), in Interpreting the Moving Image (Nova York: Cambridge University Press, 1998), p. 179. Em Visionary Film, Sitney refere-se à composição de Smith como uma "mímese da mente humana", algo que está no cerne de sua morfologia da vanguarda americana. Annette Michelson apresenta discordâncias significativas em relação às interpretações de Sitney e Carroll, e propõe uma visão psicanalítica do filme. É no texto de Michelson que encontramos uma análise mais detida dos processos de transformação das imagens, especialmente de seus significados para a narrativa do filme. Ver Annette Michelson, "The Mummy's Return: A Kleinian Film Scenario" (1995), in On the Eve of the Future, op. cit., pp. 245-272.

${ }^{122}$ Ibid., p. 180. 
É importante notar que a "representação da mente" não envolveria aqui um modelo mental fixo ou mesmo modelos logicamente consistentes. A tela é às vezes uma "paisagem mental", às vezes "a mente como sala escura" ou "a mente como máquina". O ponto crucial no argumento de Carroll diz respeito menos ao fato de que o filme é consistente nessas representações, e mais ao que recorre a várias delas, ainda que não sejam conciliáveis. $^{123}$

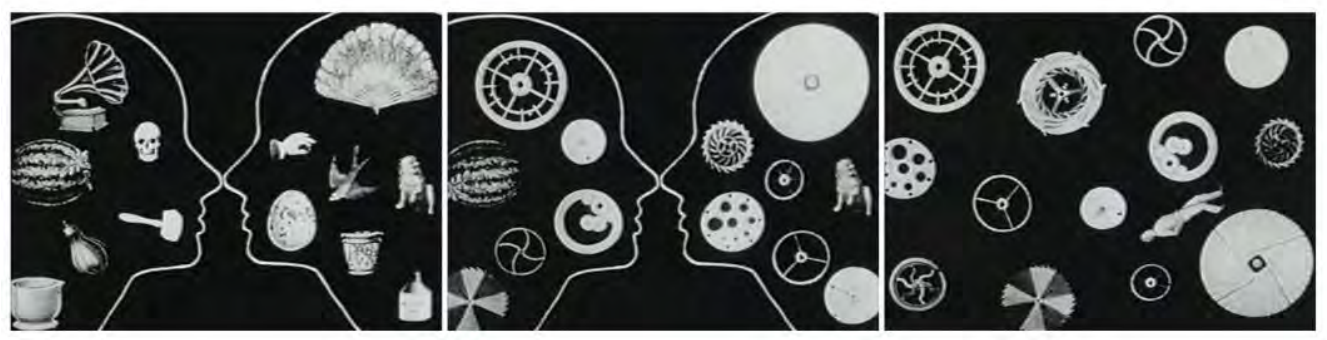

Representações da mente em Heaven and Earth Magic: a cabeça, como recipiente a ser preenchido por objetos; os objetos constituindo as engrenagens da maquinação mental; e a fragmentação dos contornos da cabeça, mantendo o funcionamento das engrenagens na totalidade do espaço da tela.

A abordagem explorada por Smith envolve a coexistência de dois impulsos. Por um lado, a influência das vanguardas europeias, que se manifesta no caráter geométrico de seus movimentos e nas estruturas combinatórias de suas transformações. Por outro lado, o interesse no caráter figurativo dos recortes, e na sugestão de metáforas ou breves aglomerados narrativos. É talvez no terreno intermediário entre os domínios que devam ser posicionados os filmes de Smith: a plasticidade por ele composta trata a maleabilidade

${ }^{123}$ A maior influência nos modelos mentais de Smith parece ser o empirismo britânico, algo já apontado por Carroll. Além de John Locke, ver David Hume, A Treatise of Human Nature (Oxford: Oxford University Press, 1992), p. 253: “A mente é uma espécie de teatro, onde várias percepções aparecem sucessivamente; passam, repassam, deslizam e se misturam numa variedade infinita de posturas e situações. [...] São as percepções sucessivas, apenas, que constituem a mente; não temos a menor distinção do lugar onde tais cenas são representadas, ou de quais materiais são compostas." $\mathrm{Na}$ literatura, um caso comparável seria o de Jonathan Swift, contemporâneo de Hume. Para uma leitura que tangencia alguns desses pontos, ver Walter J. Ong, "Swift on the Mind", in Rhetoric, Romance, and Technology: Studies in the Interaction of Expression and Culture (Ithaca: Cornell University Press, 1971), pp. 204-209. O argumento de Ong envolve a recorrência da terminologia mecânica e geométrica na obra de Swift. Em Gulliver's Travels (1726), por exemplo, Swift está frequentemente preocupado com a ampliação e a diminuição dos objetos, com as relações entre ilhas como caixas isoladas, sistemas fechados com regras próprias e com os costumes satirizados por seu automatismo. Nos termos de Ong, o autor irlandês "favorece a redução imediata de problemas complexos em termos de posição ou movimentação". Vale lembrar que Swift é um dos expoentes do que Northrop Frye chamou de "sátira menipeia". Sitney, que em sua morfologia da vanguarda americana retoma alguns termos de Frye, inclui Heaven and Earth Magic entre as obras mitopeicas, mas sua própria descrição da sátira menipeia no cinema é apropriada ao filme de Smith: "um diálogo de formas e vozes, aberto a elaborações narrativas mas não as exigindo, no qual personagens encarnam ideias mais do que manifestam psicologias complexas". Ver Sitney, Visionary Film, op. cit., p. 410. 
das figuras como análoga à maleabilidade dos sentidos por elas sugeridos, e às próprias concepções espaciais que decorrem de suas organizações. A referência da imaginação, central ao discurso crítico sobre suas obras, parece apropriada inclusive pelo fato de que Smith recorre na maioria das vezes a figuras criadas para outros fins. É na apropriação de um imaginário já definido e na recontextualização desse imaginário que seu processo criativo é revelado. Assim, o potencial gráfico das imagens é posto lado a lado com seu potencial semântico; a gravidade e a narrativa surgem como possibilidades, como fases neste processo de constante metamorfose. A narrativa serve como uma moldura rudimentar dentro da qual ocorrem as variações, numa lógica semelhante à da "anatomia" proposta por Sharits em Ray Gun Virus.

\subsection{Revisão das coordenadas}

Tanto Hans Richter como Harry Smith organizaram suas obras a partir de recortes, fotografados de modo a criar o movimento. Sejam as imagens retângulos ou figuras humanas, monocromáticas ou coloridas, sejam os movimentos retilíneos ou circulares, contínuos ou abruptos, o princípio é basicamente o mesmo: algo foi posicionado frente à câmera, que registrou na frequência desejada as impressões luminosas sobre a fita de filme, que foi então submetida à frequência da projeção. Em 1963, Stan Brakhage realizou um filme que complementa de maneira significativa essa abordagem.

Mothlight abre com uma tela clara, aparentemente o resultado de uma película transparente, mas vagamente amarelada. De repente, objetos passam rapidamente sobre a imagem: asas de mariposas em alta velocidade atravessam verticalmente o espaço, da região inferior à região superior. Na medida em que prossegue o movimento, as asas de mariposas dão lugar a outros objetos: folhas secas e o que parecem ser pedaços de galhos, caules ou partículas de sujeira. Durante aproximadamente quatro minutos, nos quais não há qualquer som, a obra prossegue no desenvolvimento dessa abordagem, variando os tons, as texturas, a proporção que os objetos ocupam no espaço da tela, assim como suas durações.

Brakhage dispôs entre fitas adesivas transparentes os objetos, e em seguida transpôs o conjunto para uma fita de filme. O resultado é uma obra composta inteiramente sem a câmera, tendo como única referência o dispositivo que projeta as imagens sobre a tela. Essa escolha gera uma série de consequências, das quais a mais imediata é a 
continuidade peculiar de alguns movimentos. A câmera, ao registrar um fotograma por vez, terminaria por marcar regularmente as seções da fita de filme, evidenciando como a experiência visual é dividida em quadros; na ausência da câmera, a fita de filme aparenta ser contínua, sem as marcações, sugerindo um fluxo incessante. A fita deve ainda ser submetida à projeção, isto é, deve ser apresentada em seções numa frequência regular; mas todo o esforço de Brakhage consiste em reconstruir essa continuidade original. Paul Sharits refere-se ao modo como o filme "permite que o comprimento natural de seus elementos determinem sua duração na tela", exemplificando com o momento em que uma longa folha passa sobre a tela, em vez de sugerir uma passagem da câmera sobre ela, ou dela em frente à câmera - teríamos assim, "fixado na fita de filme, o processo que está ocorrendo de fato" (a fita de filme passando no projetor). ${ }^{124}$ Neste processo, não parece haver um único momento em que não há algo pulsando sobre a imagem. Riscos e partículas de sujeira se multiplicam e se aglomeram ao redor dos objetos, numa retomada daquele mesmo fator que Zen for Film tornava explícito: a inevitabilidade dos ruídos, a "entropia fílmica". 125
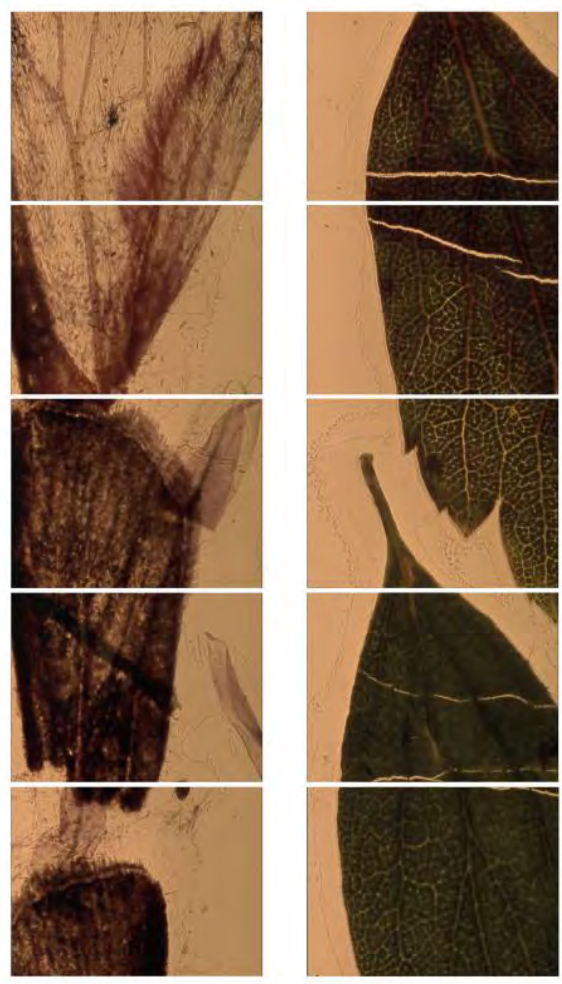

${ }^{124}$ Paul Sharits, "Words Per Page", op. cit., p. 36. Para mais sobre o "desvelamento" como a passagem da fita de filme tornada invisível pelos movimentos do plano, ver Thierry Kuntzel, "The Défilement: A View in Close-Up", Camera Obscura 2 (outono de 1977), p. 56.

125 Apesar de suas reservas quanto ao Fluxus, Brakhage teve em John Cage uma influência fundamental no início de sua carreira, a ponto de utilizar uma de suas composições em In Between (1955). 
Dois trechos de Mothlight (Stan Brakhage, 1963), dispostos verticalmente para se aproximar do movimento percebido sobre a tela. A continuidade é sugerida apesar do isolamento de suas seções em fotogramas. A verticalidade do movimento e a inscrição de todos os elementos visuais no mesmo plano pictórico sugerem ainda a reconstrução da passagem da fita pelo projetor.

A relação da continuidade da fita de filme com a necessária divisão desta continuidade em fotogramas é o que gera os principais efeitos em Mothlight. Em certos momentos, Brakhage seleciona um conjunto de objetos semelhantes e os dispõe de tal maneira que suas posições na tela sejam praticamente as mesmas. Vemos então algo como a tentativa de manter os objetos fixos no espaço, uma tentativa obliterada pela velocidade da projeção, que evidencia as mínimas diferenças entre os objetos, revelando, com as partículas no fundo da imagem, o movimento constante da película. $O$ filme absorve então este fator, e em alguns casos, conjuntos de objetos parecem descrever processos, como quando galhos são posicionados no centro da tela e progressivamente fragmentados; quando flores são posicionadas no canto esquerdo, atravessadas por caules e ramos; ou quando folhas são posicionadas no canto direito, num progressivo aumento de seus tamanhos:

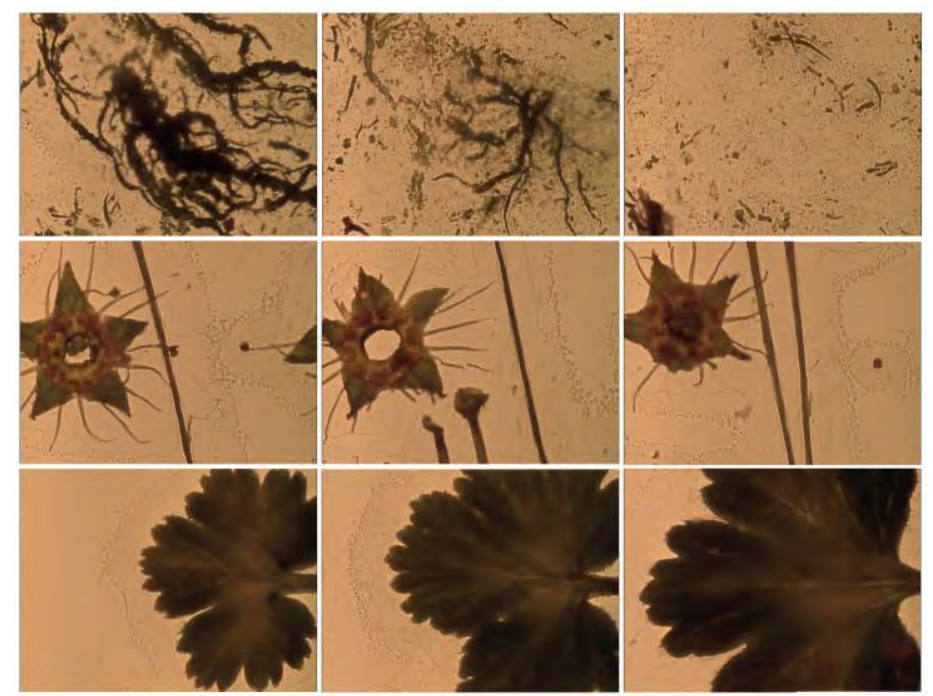

Comentando o desenvolvimento temporal do filme, Sitney o descreve da seguinte maneira:

Três vezes os materiais das mariposas e plantas são introduzidos à tela, ganhando velocidade como se em pleno voo, para um movimento de calma e separação; então, no coda, uma série de irrupções de asas de mariposas ocorre com força decrescente, entrecortadas com passagens de branco (todo o filme se fixou numa matriz branca, e as 
asas e flores raramente preenchem toda a tela). A penúltima irrupção retoma a grandeza da primeira, mas é um último suspiro, e uma única asa, depois da mais longa passagem de branco, encerra o filme. ${ }^{126}$

Em sua defesa do caráter musical da obra, semelhante à terminologia de Kandinsky, Brakhage insiste que "as formas das asas e o vôo recriado da mariposa por entre as flores possuem cores recorrentes que são melódicas" e que "as próprias formas, com suas ações recorrentes, têm o mesmo sentido de integridade de uma fuga". ${ }^{127}$ Brakhage retoma o argumento de que a tentativa de construir um filme como ilustração de uma peça musical leva a obras inferiores. Como Fischinger, ele afirma que a música serve de inspiração, mas que a construção fílmica deve manter sua autonomia, uma das razões pelas quais abandonou o som em grande parte de sua filmografia. Em Mothlight essa autonomia seria uma decorrência da movimentação organizada dos elementos sobre a película: as texturas que marcam os objetos e os distribuem em partes da obra, em padrões de alternância; as "melodias" representadas pelas trajetórias dos objetos no espaço da tela, em suas maiores ou menores extensões, maiores ou menores complexidades; e a integração de todos esses fatores por um movimento generalizado.

Malcolm Le Grice comenta a montagem do filme, identificando nesses procedimentos algumas das influências no cinema de Brakhage:

Como montador, num nível abstrato, Brakhage continua o desenvolvimento histórico de relações de montagem baseadas em semelhanças de forma, movimento e cor, e contraponto. Ele também continua o desenvolvimento do pulso da montagem, imagens intercaladas umas com as outras ou com guias vazias ou coloridas. No nível das associações de imagens, ele desenvolve uma forma de fluxo de consciência joyceano, usando cortes rápidos para estabelecer uma forma aglomerada de psicomontagem, uma extensão da forma surrealista. [...] Este processo é bastante semelhante ao Expressionismo Abstrato, e, como tal, preocupa-se com a materialização de relações psicoassociativas, fortemente baseadas em analogias corporais, mais do que literárias. A estrutura ou a forma neste tipo de processo não é a priori, mas sim o resultado de uma busca por uma "lógica" durante o processo de seleção e construção. ${ }^{128}$

A menção do "fluxo de consciência" e a comparação com o Expressionismo Abstrato, sobretudo Jackson Pollock, são ambas constantes na fortuna crítica de Brakhage. No

\footnotetext{
126 Sitney, Visionary Film, op. cit., p. 174.

127 Stan Brakhage, em Stan Brakhage: Interviews, ed. Suranjan Ganguly (Jackson: University Press of Mississipi, 2017), p. 92. Brakhage comenta que é precisamente por se interessar pela música e por ela constituir uma de suas maiores fontes de inspiração que ele prefere manter o som como algo à parte e pensar a criação visual de maneira análoga. Para mais sobre a importância da música na composição de seus filmes, ver Marie Nesthus, "The Influence of Olivier Messiaen on the Visual Art of Stan Brakhage in Scenes from Under Childhood, Part One", Film Culture 63/64 (1976), pp. 39-50.

128 Malcolm Le Grice, Abstract Film and Beyond, op. cit., p. 90 (grifo nosso).
} 
trecho destacado, Le Grice reconhece a importância dos filmes de Richter, Eggeling e Fischinger na formação do cineasta americano; mas acrescenta a essas uma outra influência: Le retour à la raison, filme realizado em 1923 por Man Ray. Em breves momentos deste filme (que tem duração total de três minutos), Man Ray utiliza uma técnica que ele chamou de rayograph - a disposição de objetos sobre papel fotográfico que é então exposto à luz, inscrevendo o formato e a textura dos objetos diretamente na imagem, sem a necessidade de uma câmera. Em Le retour à la raison, os planos filmados com a câmera são interrompidos pelos rayographs - em algumas seções, por silhuetas de pregos, e em outras por aglomerados de pedras e partículas de sujeira. As imagens surgem brancas sobre um fundo preto ou pretas sobre um fundo branco, e seus movimentos são distintos daqueles compostos por Brakhage em Mothlight. Em lugar da reconstrução da passagem da película pelo projetor, o filme de Man Ray dá preferência às diferentes organizações dos elementos visuais sobre a tela, os pequenos e grandes contrastes que essas organizações podem criar e a velocidade com a qual podem ser apresentados. ${ }^{129}$
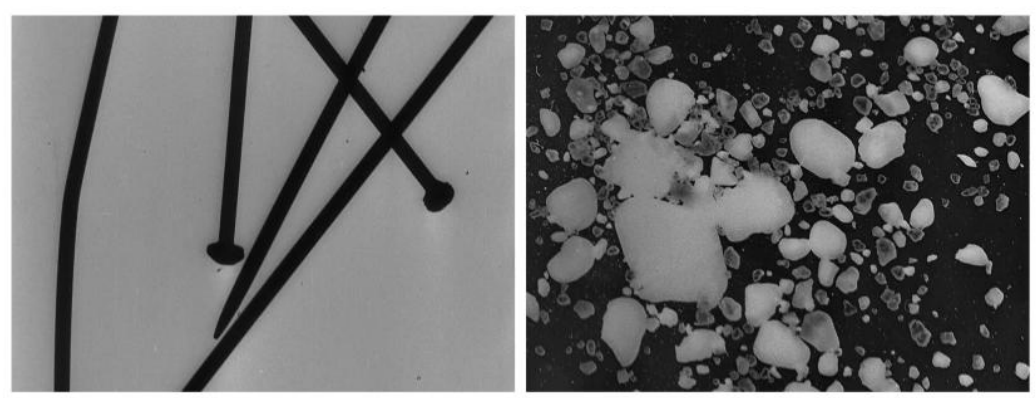

Imagens de Le retour à la raison (Man Ray, 1923) criadas com a técnica do rayograph, o que Le Grice identifica como sendo um dos antecessores de Mothlight em sua ênfase da materialidade fílmica.

Apesar de uma descrição adequada da composição do filme de Brakhage, a insistência de Le Grice no aspecto "materialista" da obra entra em conflito com alguns dos ideais expostos pelo cineasta americano. No mesmo período em que realizou Mothlight, Brakhage publicou seu texto mais famoso, uma espécie de manifesto em que já no parágrafo inicial é exposto seu horizonte criativo:

Imagine um olho não governado pelas leis fabricadas da perspectiva, um olho livre dos preconceitos da lógica da composição, um olho que não responda aos nomes que a tudo se dá, mas que deve conhecer cada objeto encontrado na vida através da aventura da percepção. Quantas cores há num gramado para o bebê que engatinha, ainda não

129 Para mais sobre a influência da técnica de Man Ray sobre as outras vanguardas dos anos 1920, ver David Curtis, Experimental Film, op. cit., pp. 17-20. 
consciente do "verde"? Quantos arco-íris pode a luz criar para um olho desprovido de tutela? Que consciência das variações no espectro de ondas pode ter tal olho? Imagine um mundo animado por objetos incompreensíveis e brilhando com uma variedade infinita de movimentos e gradações de cor. Imagine um mundo antes de "no princípio era o verbo". ${ }^{130}$

O vocabulário e a retórica sugerem uma sensibilidade distinta daquela defendida por Le Grice. No decorrer do texto, em vez de uma ênfase na materialidade do dispositivo fílmico, o que Brakhage desenvolve é uma série de especulações sobre como esse dispositivo poderia ser superado, ou ainda, como suas convenções poderiam ser destruídas em nome de uma liberdade imaginativa. A filmografia de Brakhage a partir deste momento, bem como suas intervenções críticas, são constituídas cada vez mais por uma elaboração destas ideias. Além de Mothlight, Brakhage fez poucos filmes baseados em colagens nos anos seguintes, entre os quais pode-se destacar The Garden of Earthly Delights (1981). A técnica à qual dedicou mais frequentemente seus esforços, sobretudo a partir dos anos 1980, foi a pintura diretamente na película, e é nos filmes compostos de tal maneira que encontramos uma representação mais direta de suas preocupações.

Uma característica de sua passagem da colagem à pintura é que a intermitência que Mothlight tinha como modo recorrente é aos poucos abandonada. Se o filme de 1963 oscilava entre a representação da fita de filme correndo verticalmente pela projeção a determinada frequência e a constância da tela como espaço que magnetiza a atenção, os filmes pintados irão se entregar cada vez mais à segunda experiência. A transparência da base material, aliada ao tamanho reduzido e à natureza discreta dos elementos utilizados em Mothlight terminavam por ecoar o ritmo acelerado da projeção e com isso permitiam a identificação dos movimentos que fugiam a essa tendência - as travessias de objetos maiores pela tela. Mas numa obra como The Dante Quartet (1987) não há mais a sugestão dessa intermitência na projeção, e menos ainda de movimentos verticais, equacionando a tela à seção da fita projetada. Tudo o que nos é dado a ver é um espaço repleto de cores, sem divisões claras nas proporções da imagem, apenas uma profusão de tonalidades que se misturam incessantemente. As cores sugerem às vezes pinceladas, às vezes borrões, sendo modificadas por algo que se parece menos com a trajetória e mais com a metamorfose de um objeto. Não há objeto, entretanto, ao menos não no sentido usual do termo: a ausência de divisões internas faz com que o resultado visual seja um deslocamento constante de massas cromáticas e luminosas. Não há distinção entre figura

${ }^{130}$ Stan Brakhage, "Metáforas da visão" (1963), in A experiência do cinema, ed. Ismail Xavier, trad. Ismail Xavier e João Luiz Vieira (São Paulo: Graal, 2003), p. 341. 
ou fundo. A tela, em sua totalidade, é o objeto sendo transformado, mas num sentido distinto daquele proposto por Richter. As cores na maioria das vezes parecem surgir e desaparecer na escuridão ou na claridade da película, como as duas polaridades fundamentais da obra. Não mais o "pulso da montagem” identificado por Le Grice, aqui o uso das guias pretas e brancas torna-se sinônimo de um fundo homogêneo que define o ambiente onde existem as cores, mas não a estrutura rítmica em que se apresentam.

Para definir mais claramente sua postura, Brakhage diferencia dois modos de pensamento visual, que ele denomina "geométrico" e "carne-inefável". O primeiro seria aquele dependente da percepção de energias como "formas", absorvendo a multiplicidade sensorial através de categorias e aproximações de ideais geométricos. Nos termos já mencionados, seria uma tendência mecânica - a presença de figuras simples, de contornos bem definidos, e movimentos com direcionamentos e ritmos previsíveis. O segundo modo seria uma espécie de antídoto à rigidez, uma inclinação às formas variáveis que resistem tanto à nomenclatura como à geometrização, numa busca por maior organicidade. ${ }^{131}$ Brakhage defende que, no cinema, pela constituição dos instrumentos utilizados, há uma tendência natural à geometrização. Mas haveria uma saída: ainda que a câmera e as lentes aproximem-se da perspectiva renascentista, um fato é que todo filme se resolve, fundamentalmente, num jogo de luzes e sombras. A ilusão de movimento, como a ilusão de profundidade, ocorre necessariamente sobre a pulsação interna da tela. O caminho sugerido para quebrar o domínio geométrico seria então a revisão de todo o aparato técnico e de seus critérios usuais: cuspir nas lentes, destruir o mecanismo de foco, alterar a velocidade de registro da câmera, subexpor e superexpor os filmes, usar filtros naturais e artificias, ignorar as especificidades dos negativos ou da fotometria. Seu uso da colagem e da pintura no filme segue este direcionamento. ${ }^{132}$

${ }^{131}$ Stan Brakhage, "Geometric Versus Meat-Ineffable" (1994), in Correspondences, ed. Erik Steinhoff (Chicago: Chicago Review, 2001), pp. 47-48.

132 Para um comentário voltado às condições técnicas da pintura diretamente na película, ainda que considerando resultados diferentes daqueles preferidos por Brakhage, ver Norman McLaren, Cameraless Animation (Montreal: National Film Board of Canada, 1958). 

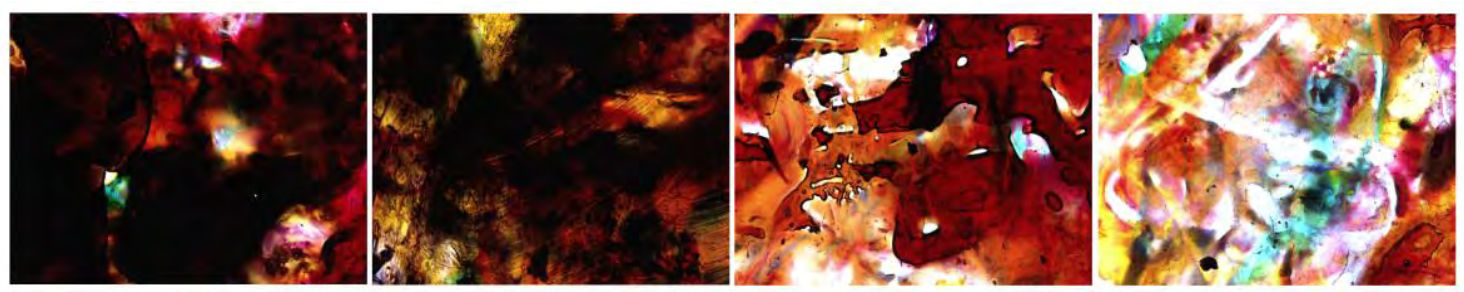

Fotogramas sucessivos de The Dante Quartet (Stan Brakhage, 1987)

No esforço de Brakhage para rever o uso da tecnologia fílmica, e sobretudo em sua rejeição aos parâmetros "geométricos", há uma diminuição das referências temporais no interior da obra. Michelson cita a radicalização da temporalidade fílmica presente

no postulado de um presente contínuo, de um tempo fílmico que devora a memória e a expectativa na apresentação da presentidade. Para fazê-lo, deve-se, é claro, destruir as coordenadas espaço-temporais nos termos das quais eventos passados e presentes definem-se como tendo seu lugar no tempo. [...] E é neste ponto, é claro, que Brakhage se coloca no território do expressionismo, elevando o processo de abstração e contraindo a profundidade do espaço visual a ponto de dissolver a espacialidade da narrativa. ${ }^{133}$

A dissolução da "espacialidade da narrativa" ocorreria, segundo Michelson, na rejeição do espaço em perspectiva e de toda uma gramática baseada no plano e na montagem pautada na causalidade. Mas deve-se acrescentar que a própria linearidade contínua dos objetos sobre a superfície da tela em Mothlight é uma dessas referências. Ainda que só possa ser descrita como "narrativa" de maneira geral, é necessariamente uma referência de passagem unidirecional, um eco à linearidade da projeção. São precisamente estes os fatores negados nos filmes pintados.

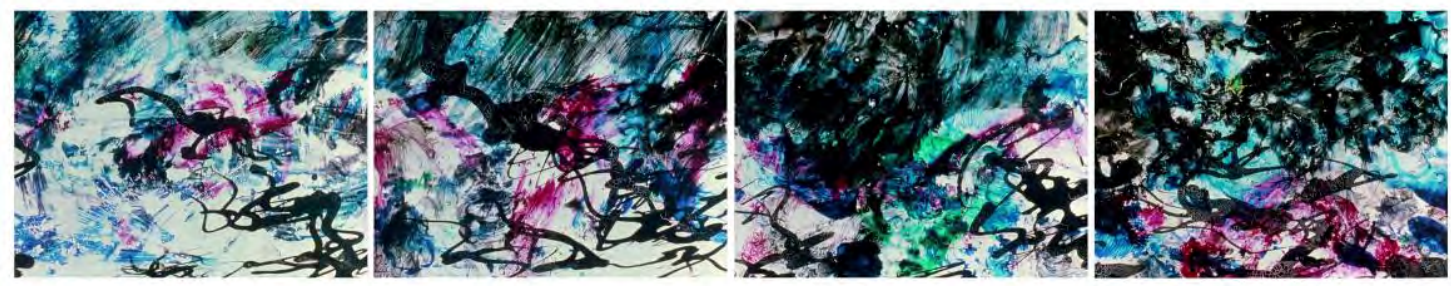

Fotogramas sucessivos de Persian Series \#1 (Stan Brakhage, 1999), outro exemplo de filme inteiramente pintado sobre a película, evitando o uso de formas claramente definidas ou movimentos "geometrizados".

Um comentário de Brakhage é significativo e parece afastar possíveis suspeitas de que seu projeto incluiria a completa aleatoriedade, a ausência de qualquer planejamento

133 Annette Michelson, “Camera Lucida/Camera Obscura” (1973), in Stan Brakhage: Filmmaker, ed. David James (Filadélfia: Temple University Press, 2005), p. 53. 
ou tentativa de dar aos filmes algum tipo de unidade. Brakhage afirma que uma obra deve "definir um paradigma do caos experimentado na vida cotidiana sendo em si mesma uma construção um tanto diferente dele". O filme, para ele, deve se referir a algum evento buscando ser fiel ao espírito do evento e não às suas aparências. Como exemplo deste processo, ele cita uma composição feita com tintas aplicadas à película e que teria como base a visualização de um objeto concreto - uma alface sobre a mesa. A argumentação é reveladora de suas relações com as animações dos anos 1920, especialmente a abordagem de Fischinger. As pontas e os ângulos do vegetal, ele diz, podem ser "traduzidos" em termos musicais, em uma instrumentação específica, como golpes de pizzicato; as curvas e os cachos, como arpejos de oboé. Características visuais, estáticas, poderiam então ser adaptadas a uma dimensão temporal. Pintar essas qualidades sobre o filme seria uma absorção do que pode ser visto do objeto, ao mesmo tempo em que consideraria o movimento da própria absorção do objeto pela consciência, as alterações que constituem a contemplação, a passagem da dimensão visual à dimensão musical e desta novamente à visual, estruturada na fita de filme. As tintas, as cores dispostas sobre o filme, seguiriam então a própria subjetividade do cineasta, em sua interação com o objeto. Resta ao final pouco do objeto como percebido inicialmente, mas uma maior proximidade do pensamento visual suscitado por ele. ${ }^{134}$ A composição, nesse sentido, torna-se algo como uma fórmula química, designando uma determinada substância sem conter o que a observação direta nos mostra dela; não reflete a percepção sensível fixada no objeto, mas a linha diretriz do movimento dessa percepção.

Podemos nos perguntar como estes filmes de Brakhage se relacionam com os outros exemplos citados. Parece haver uma relação complexa entre uma obra como Mothlight e os princípios de homogeneidade, linearidade e reiteração. Symphonie Diagonale, como os estudos de Fischinger e as colagens de Smith, mantém um fundo preto constante sobre o qual ocorrem todas as movimentações e transformações. A escuridão neutra é então igualada à base constante da tela. Mothlight possui uma base constante, mas ela é repleta de partículas e traços que se movem na frequência da projeção, criando um efeito inteiramente diverso da base homogênea - é algo como a “intermitência sobreposta à homogeneidade". Da mesma forma, por breves momentos Mothlight reforça a tela como a moldura para todas as imagens, conferindo a elas, portanto, um estatuto semelhante - quando os materiais são dispostos na mesma região do

134 Ver Stan Brakhage, "Painting Film" (1996), in Correspondences, op. cit., pp. 61-63. 
quadro. Mas isso dá lugar à tela como uma seção da fita de filme, submetendo os materiais de cada fotograma à passagem contínua.

A rejeição de movimentos geometricamente simples - algo presente em Richter, Eggeling e Smith - parece fazer com que os filmes de Brakhage sejam próximos da organicidade dos estudos de Fischinger. Mas não há o mesmo sentido de organicidade na condução das formas visuais que foram apontadas em Fischinger. Em primeiro lugar, as colagens e os filmes pintados de Brakhage não possuem qualquer orientação gravitacional. No caso de Mothlight, a única orientação espacial é a verticalidade da projeção: o eixo vertical da imagem, em vez de tornado assimétrico pela interação das figuras, é tornado um índice da cronometria da própria fita de filme, independente das figuras que nela são dispostas. Em segundo lugar, não há em Brakhage o mesmo interesse em complementar uma peça musical apresentada ao espectador. As referências de andamento e tensão de Fischinger variam, mas dentro de uma lógica de repetições e inversões, ecoando a linguagem musical, fazendo com que seus filmes tenham semelhanças estruturais com os de Richter e Eggeling.

A tradição europeia dos anos 1920, enraizada nas pesquisas dos pintores modernistas, buscou fixar as leis materiais do cinema, os limites expressivos que permitiriam a criação dos filmes. Esses filmes elegem suas coordenadas e buscam energizar o quadro de forma mais ou menos organizada, elegendo tipos de figuras e de movimentos como um vocabulário plástico ou uma instrumentação particular - tudo isso parecendo servir para garantir a unidade da obra. O projeto de Brakhage, especialmente em sua passagem das colagens aos filmes pintados, torna-se uma revisão dessa tradição, a busca pelas regiões da composição em que essas mesmas coordenadas, os mesmos movimentos claramente delineados e as mesmas noções de estrutura seriam dissolvidos. Se o princípio de ação e reação servia, para Richter e Eggeling, como um meio de explorar as combinações de movimentos em diferentes partes da tela; e se o princípio de orientação gravitacional servia, para Fischinger e Smith, como um meio de caracterizar a evolução de suas figuras num espaço constante - ambos são abolidos por Brakhage, que dá preferência a movimentos multiplicados e sobrepostos, a uma concepção da tela como um espaço a ser permanentemente energizado em todas as suas regiões e do desenvolvimento temporal como um fluxo permanente, paralelo à projeção. 


\subsection{Influências e desdobramentos}

Assim como os filmes do capítulo anterior, os exemplos aqui citados articulam apenas uma dimensão do espaço: a superfície da tela. Mas, diferente daqueles, estes não vêem a tela apenas como "um quadro uniforme e achatado, equivalente ao fotograma" - em outras palavras, não dão preferência à tela desprovida de quaisquer outras imagens que não a de si mesma. O que realizam é uma investigação da plasticidade da tela, através de todo um conjunto de formas visuais que são mobilizadas por diferentes técnicas e tornadas elementos em padrões de ritmo e movimento. A superfície da tela é articulada; mas torna-se um plano onde são inscritas outras imagens, e a combinação destas imagens, por sua vez, revela propriedades do plano de inscrição. No domínio temporal, a referência cronométrica predomina através da técnica de animação ou a articulação de fotogramas em pequenos incrementos, seja pela fotografia de recortes e desenhos, seja pela colagem e pintura diretamente sobre a película. Estes filmes lidam com a divisão do contínuo temporal e seu correlato, o movimento, nas menores unidades possíveis. O surgimento de imagens no espaço da tela, prescindindo do registro "natural' feito pela câmera, e portanto da referência de uma unidade espaço análoga à do tempo "real", faz com que a plasticidade em questão incorpore padrões rítmicos criados, assim como os padrões nos filmes de flicker, com referência direta à métrica da projeção.

Observando quando e onde surgiram estes filmes, percebemos que alguns momentos se destacam: a Alemanha dos anos 1920 e 1930 (Richter, Eggeling, Fischinger), e os Estados Unidos dos anos 1950 e 1960 (Smith, Brakhage). Diferente da contemporaneidade que parecia indicar semelhanças de contexto no caso do Fluxus e dos filmes estruturais, aqui há uma transição em curso, um deslocamento histórico e continental que transforma e ramifica algumas influências. Consideremos, portanto, algumas das questões presentes nessa transição, e que parecem guiar a composição dessas obras, bem como as reflexões que suscitaram. Essas questões podem ser divididas em dois grupos: (1) a influência da pintura na concepção da tela como uma superfície espacial, e (2) a influência da música na concepção de uma estrutura desenvolvida temporalmente. 


\subsubsection{A pintura e a superfície da tela}

A recorrência de nomes da pintura modernista no discurso dos cineastas nos anos 1920 atesta a importância que os desenvolvimentos nas artes visuais tiveram na elaboração das obras cinematográficas. Em sua quase totalidade, os cineastas dedicados às vertentes aqui consideradas foram influenciados por pintores contemporâneos ou de um período imediatamente anterior, sendo eles próprios pintores de formação. Nas primeiras décadas do século XX, ao menos um aspecto parece relacionar essas diferentes escolas, sobretudo no que diz respeito à influência que tiveram sobre o cinema. Trata-se de uma noção associada a críticos como Clement Greenberg, para quem as tentativas de "autodefinição" das artes levaram à ênfase de suas condições materiais. A tendência à autodefinição, à determinação das especificidades, é um preceito tipicamente modernista que Greenberg identificou como sendo "a intensificação da tendência autocrítica iniciada pela filosofia kantiana”. O cerne do modernismo estaria no uso de métodos característicos para que uma disciplina critique a si mesma, para afirmá-la mais firmemente em sua área de competência. As vanguardas modernistas, para Greenberg, enfatizaram o "instinto de autopreservação das artes", buscando o que parecia irredutível a cada uma delas, seu terreno particular, exclusivo. A tarefa da crítica modernista numa arte seria a eliminação dos efeitos compartilhados com outras artes. Surge dessa forma a noção de que a garantia de eficiência de uma arte, a razão de sua pureza, coincide com a definição de seu próprio meio. ${ }^{135}$ A história das vanguardas pictóricas é descrita como a história da rendição progressiva ao meio, cuja resistência consiste principalmente na negação da tela plana, nos esforços para "ver através" dela, construindo o espaço da perspectiva. Com essa rendição, a pintura não apenas se livraria da imitação e da literatura, mas também da confusão com a escultura, que por sua vez enfatizaria a resistência de seus materiais à forma. $\mathrm{O}$ crescente achatamento da tela leva então ao uso de imagens não-figurativas, mas também a colagens e à ênfase da tinta como tinta, de modo que os materiais não parecem fazer referência a nada exceto a si próprios. ${ }^{136}$

\footnotetext{
${ }^{135}$ Ver Clement Greenberg, "Modernist Painting" (1961), in Clement Greenberg: The Collected Essays and Criticism, vol. 4: Modernism with a Vengeance, 1957-1969, ed. John O'Brien (Chicago: University of Chicago Press, 1988), pp. 85-92. Para uma exploração desse argumento na relação do cinema com outras artes, ver Noel Carroll, "Medium Specificity Arguments and the Self-Consiously Invented Arts: Film, Video, and Photography" e "The Specificity of Media in the Arts", in Theorizing the Moving Image (Nova York: Cambridge University Press, 1996).

136 Ver Clement Greenberg, "Towards a Newer Laocoon" (1940), in Clement Greenberg: The Collected Essays and Criticism, vol. I: Perceptions and Judgements, 1939-1944, ed. John O’Brien (Chicago: University of Chicago Press, 1988), pp. 24-34.
} 
Os cineastas dos anos 1920 que mencionamos aqui realizaram uma das tentativas mais diretas de dar ao cinema um lugar no movimento descrito por Greenberg. Recebendo a tecnologia cinematográfica pela associação com o registro "transparente" da câmera, com sua base no realismo codificado da perspectiva renascentista, eles propuseram um desvio que tocaria nos desenvolvimentos contemporâneos da pintura envolvendo justamente a rejeição da mímese e do espaço em profundidade. Se a pintura, compondo um "espaço pictórico" sem referências diretas ao mundo exterior, foi capaz de estabelecer diversas escolas no mesmo período, também o cinema seria capaz de absorver essas descobertas e contribuir adicionando o movimento como um parâmetro fundamental.

De maneira condizente, o vocabulário destes filmes é muitas vezes derivado da obra de pintores que tiveram preocupações semelhantes, como num reconhecimento de que a investigação da superfície pictórica já havia sido iniciada numa arte de imagens estáticas. Estabelecido o conjunto de formas, são estabelecidas em seguida as operações que as colocarão em movimento, como serão dispostas e deslocadas no espaço da tela, sobrepostas, fragmentadas, recompostas. Os filmes tornam-se, desse modo, a sucessão de operações aplicadas às formas visuais. Uma estratégia para isso é a geometrização das figuras: a escolha de formas simples, imediatamente reconhecíveis, desprovidas de associações temáticas específicas, algo como arquétipos visuais. Uma estratégia complementar é a geometrização dos movimentos: a escolha de trajetórias igualmente simples e regulares, apreensíveis como padrões estáveis e sem grandes variações rítmicas. É nos filmes de Richter e Eggeling - assim como na série Lichtspiel (1921-25), de Walter Ruttmann - que tais estratégias são apresentadas de maneira mais clara, ecoando as linhas retas da tela e/ou a regularidade da projeção. Nos estudos de Fischinger, como nas animações de McLaren e de Len Lye, essa geometria tende a se dissolver em figuras maleáveis e os movimentos tendem a combinar retas e curvas com maior frequência, incluindo tanto a regularidade como a irregularidade nos ritmos. ${ }^{137}$ Smith e Brakhage trabalham com outros elementos; tanto os recortes de Smith como os objetos de Brakhage em Mothlight evocam uma realidade exterior à tela, deslocando a ideia de um vocabulário simplificado da mesma maneira. Em vez de dissolver a geometria em abstrações "orgânicas", ambos parecem buscar a complexidade nas relações entre os elementos e as transformações aplicadas a eles. Smith, como outros de seus contemporâneos que

${ }^{137}$ Ver Roger Horrocks, Art That Moves: The Work of Len Lye (Auckland: Auckland University Press, 2009), pp. 139-176. 
preferiram a colagem figurativa (Stan Vanderbeek, Lawrence Jordan), mantém algo da geometrização dos movimentos, mas os padrões criados por esses movimentos transformam os significados usuais das figuras. Brakhage, por sua vez, não dá a mesma importância ao caráter figurativo da colagem, e multiplica de tal maneira os movimentos que qualquer noção de um padrão geométrico tende a se dispersar no conjunto da tela. Nesse sentido, além de radicalizar a materialidade da superfície, inscrevendo suas imagens diretamente sobre a fita de filme, Brakhage parece alinhado às tentativas mencionadas no capítulo anterior de resistir à formatação geral das obras exemplificadas em Kubelka e Sharits pelo uso da variação. Temos com isso uma escala que inclui, de um lado, a geometrização completa da obra, e de outro a tentativa de resistir à geometrização, com alguns casos situados no terreno intermediário, ou mesmo jogando com a mobilidade neste campo.

Entre as ramificações apontadas nesses filmes, uma que merece um comentário mais detido é a diferença entre o que chamamos de uma tendência "mecânica" e uma tendência "orgânica". Isso nos leva às diferentes propriedades espaciais e temporais reveladas pelos filmes. No território da mecanização, os movimentos, descrevendo a regularidade com a qual as figuras são dispostas no tempo, ecoam a regularidade da projeção, em sua impassibilidade e independência dos conteúdos visuais. Essa relação entre o fator mecânico e uma concepção de materialismo, cujo elogio foi feito por nomes como Le Grice e Gidal, é talvez a mais próxima das ideias de Greenberg. Nesta linhagem, algumas ideias do capítulo anterior parecem retomadas em outra chave: a noção de movimentos ou formatos previsíveis, e de uma organização determinada por "ritmos generalizados", características associadas aos filmes estruturais. Mesmo a dedução dos elementos a partir das "coordenadas absolutas" do material fílmico é algo em sintonia com os preceitos de Conrad ou Kubelka.

No território da organicidade, outras questões se colocam. Partindo da mesma superfície plástica, os filmes sugerem por vezes uma adaptação desse mesmo espaço; o que antes parecia dominado pela simetria ganha um sentido particular que transforma a tela num ambiente onde diferentes regiões possuem diferentes valores, influenciando a constituição das formas visuais e de seus movimentos. O deslocamento afeta a simetria entre as coordenadas da tela, levando finalmente à construção das condições que permitem ao espectador identificar uma orientação gravitacional. Nos filmes de inclinação mecanicista, a tela sugere a arbitrariedade dessa simetria; os movimentos ocorrem em todas as direções e orientações possíveis justamente por não haver diferença 
entre as regiões do espaço - trata-se de um espaço completamente relacional, orientado pelas tensões entre o centro geométrico e os centros perceptivos. Nos filmes de inclinação organicista, a tela se torna às vezes um campo assimétrico no qual os conteúdos visuais parecem ter sua arbitrariedade reduzida, visto que agora devem responder a uma regra geral imposta sobre o plano onde se inscrevem. O princípio se estende à arbitrariedade dos movimentos, diminuída sempre que a regularidade dá lugar às variações mais flexíveis, incluindo movimentos progressivos, bem como trajetórias irregulares e circulares. Os objetos visuais, antes submetidos a uma maquinação impessoal, tornam-se como que seres vivos em transformação, muitas vezes ativos e interagindo uns com os outros. Essas mudanças constituem assim uma espécie de retorno indireto à figuração: mesmo recorrendo a imagens abstratas, os filmes são capazes de sugerir configurações visuais análogas a configurações figurativas, num verdadeiro animismo cinematográfico. $^{138}$

O que deve ser notado é que, mesmo com essa bifurcação, as condições perceptivas orientam todas as imagens em seu nível mais imediato. ${ }^{139}$ Além da orientação gravitacional, um de seus efeitos complementares - a percepção de um horizonte, ou seja, de uma linha que serve de "base" para o espaço pictórico - revela-se uma propriedade constante tanto em obras figurativas como em obras abstratas - desde filmes como Le merle (Norman McLaren, 1958) até as colagens de Harry Smith. Inspirado nas pesquisas de Max Wertheimer sobre este tópico, Jean Mitry reconstruiu um dos experimentos com alunos do Institut des Hautes Études Cinématographiques (IDHEC). O experimento constituiu na apresentação da imagem de um horizonte; primeiro com a linha paralela às bordas horizontais da tela, depois com a câmera inclinada num ângulo de vinte graus. Durante a projeção, o projetor e a tela foram inclinados também num ângulo de vinte

${ }^{138}$ Há certamente toda uma gama de convenções envolvidas na percepção das estratégias da "tendência orgânica": convenções de formato, tamanho, movimento, etc. Em seu livro sobre a psicologia da representação pictórica, Gombrich menciona frequentemente a importância dessas convenções. Ele menciona, por exemplo, que certos aspectos de uma imagem nos parecem análogos à realidade ainda que outros sejam claramente irreais; como se houvessem qualidades mínimas necessárias (ainda que não suficientes) à compreensão dessas analogias. Este fato é crucial na elaboração e recepção de obras abstratas, especialmente as da vertente organicista, baseadas no conhecimento prévio de convenções figurativas. As convenções teriam assim uma função reguladora, coordenando as expectativas sobre como os aspectos reais e irreais se apresentam numa imagem. Ver E.H. Gombrich, Art and Illusion: A Study in the Psychology of Pictorial Representation (Oxford: Phaidon, 1990), pp. 53 ss. Para mais sobre a relação entre as convenções e a analogia nas imagens, ver Jacques Aumont e Michel Marie, Dicionário teórico e crítico de cinema, op. cit., pp. 16-17.

139 Para a base perceptiva da orientação gravitacional em imagens abstratas, ver Arnheim, Art and Visual Perception, op. cit., p. 20. 
graus. As duas imagens a seguir representam um esquema do que foi projetado aos alunos:
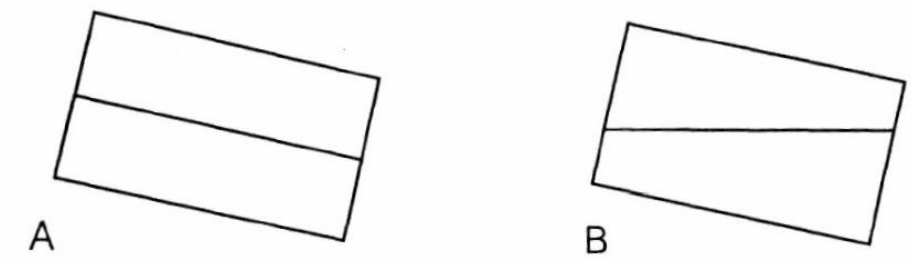

No primeiro caso, o horizonte (correto na câmera) e as linhas horizontais do quadro mostraram um ângulo de vinte graus em relação ao chão. Mas após três ou quatro minutos (de acordo com os alunos), a linha do horizonte havia se normalizado. A imagem, vista inicialmente como torta, era agora vista como normal. No segundo caso, o horizonte (paralelo ao chão durante a projeção) parecia estar perfeitamente horizontal num quadro inclinado. Mas, após um período ainda mais curto (aproximadamente três minutos), a imagem era percebida como normal mais uma vez: um horizonte inclinado numa tela vertical. $^{140}$

Mitry argumenta que o experimento "revela o efeito regulador do quadro", e o modo como a imagem, como estrutura formal, depende do quadro para ser compreendida. Se o horizonte da imagem, por si só, não confirma a inclinação do quadro, uma vez que o quadro é corrigido o horizonte da imagem é visto como inclinado. Apesar de ser uma propriedade estável, o que alguns filmes revelam é que a orientação pelo horizonte e pela gravidade não é um dado, mas sim algo a ser construído. Sobretudo nas obras de Fischinger e Smith, torna-se evidente que não há uma noção estrutural pré-concebida à qual as figuras são submetidas; pelo contrário, é a própria interação das figuras que constrói essas propriedades. ${ }^{141}$ Ainda que o quadro possua um "efeito regulador" (como as "linhas de força" mencionadas por Arnheim), o efeito é tornado visível ou não pela articulação das formas visuais. É o que permite a Fischinger e Smith incluir tais percepções como apenas uma das possibilidades em seus filmes. ${ }^{142}$

140 Jean Mitry, Esthétique et psychologie du cinéma, vol. II: Les formes (Paris: Editions Universitaires, 1965), pp. 82-85. “Ainda que projetemos uma certa 'intencionalidade' sobre esse espetáculo", continua Mitry, "não somos capazes de nos identificar completamente com ele, e de transferir a ele nosso centro de gravidade, já que não nos é dada [...] a imagem de nossos corpos e de nossos arredores imediatos."

141 Isso não significa que a orientação gravitacional do próprio espectador não influencie na percepção das imagens. Arnheim comenta essa influência em algumas ocasiões: ver Art and Visual Perception, op. cit., pp. 23-24, 30-32, 101-103, 184-187, e o segundo capítulo, "Vertical and Horizontal", de The Dynamics of Architectural Form (Los Angeles: University of California Press, 1977). Consideramos aqui unicamente a orientação gravitacional sugerida na própria composição dos filmes.

142 Ainda que não sejam analisadas aqui, deve-se mencionar que grande parte das animações tradicionais, mais especificamente os cartoons, trabalham com a manutenção desses efeitos. Em outras palavras, 


\subsubsection{A música e a estrutura temporal}

A segunda questão frequente nesses filmes é a influência da música. Richter e Eggeling já a mencionavam nos anos 1920, e Brakhage retoma o discurso nos anos 1960 com algumas alterações. O que encontramos em projetos tão distintos é uma visão que remonta a um comentário de Walter Pater em 1877:

Todas as artes aspiram constantemente à condição da música. Pois enquanto em todas as outras formas artísticas é possível diferenciar a matéria da forma, e a compreensão pode sempre fazer essa distinção, ainda assim é constante o esforço da arte para destruí-la. Que a simples matéria de um poema, por exemplo, a saber, seu tema, seus incidentes ou situações - que a simples matéria de uma tela, as circunstâncias de um evento, a topografia de uma paisagem -, que não signifiquem nada sem a forma, o espírito, a articulação desta forma, este modo de articulação, que isso torne-se um fim em si mesmo, que deva penetrar cada parte da matéria: isso é o que todas as artes aspiram, e alcançam em diferentes graus. ${ }^{143}$

Surgido em outro contexto que não o das escolas do modernismo, o argumento de Pater possui uma relação ambivalente com a tese de Greenberg sobre o desenvolvimento histórico das artes. Por um lado, Greenberg reconhece que a música funciona como referência para outras artes no sentido de que seria "puramente formal". Em seu afastamento da noção de "imitação", e de referências claras a significados externos, a música teria se aproximado do ideal de uma arte que descreve apenas a si mesma. Mesmo as diferentes acepções da "matéria" na pintura (Pater não considera a tinta, mas o "tema" como a matéria pictórica) não impedem Greenberg de aceitar a tese geral. Por outro lado, o reconhecimento de que uma arte tradicional como a música serve de referência às outras contraria a defesa da especificidade do meio, tornada o próprio critério de autonomia

trabalham com a analogia estável da realidade pictórica com a realidade exterior à imagem. Além dos efeitos comentados neste capítulo, parte das estratégias comuns na criação da unidade espaço-temporal nos cartoons é semelhante às estratégias para criar unidades espaço-temporais em obras de realismo fotográfico, como veremos nos capítulos seguintes.

143 Walter Pater, "The School of Giorgione" (1877), in The Renaissance: Studies in Art and Poetry, ed. Donald L. Hill (Berkeley: University of California Press, 1980), p. 106. Essa aspiração remonta pelo menos até Gustave Flaubert, que defendia uma postura semelhante em suas cartas a Louise Colet. Argumentando que "não existem na literatura quaisquer temas artísticos belos", Flaubert afirmava já em 1852 que a obra literária não deriva sua força do mundo exterior ou de categorias conceituais a priori, mas que tem sua própria lógica e validade internas. A redução da importância do "tema" é acompanhada por um reforço da "textura e estrutura" da construção verbal, seu ritmo e sua sonoridade, o que poderíamos chamar de sua superfície. Uma das aspirações de Flaubert é criar uma obra "sobre nada", "suspensa no ar", sustentada apenas "pela força de seu estilo". Ver Gustave Flaubert, Correspondance, III (Paris: Louis Conard, 1927), p. 346. 
estética. Se a pureza da música depende de ela "não produzir um objeto", como seria possível à pintura alcançar pureza semelhante, sendo a condição própria da pintura a de produzir objetos? O fato de que ambos os argumentos funcionam essencialmente por analogias talvez nos sirva para compreender o papel que tiveram no pensamento dos cineastas.

David Bordwell propõe uma síntese das razões pelas quais a música serviu como analogia de maneira tão constante às vanguardas dos anos 1920:

A música tornou-se o modelo de como a unidade formal pode colocar em cheque, controlar e se sobrepor à representação. Isso depende, por outro lado, de uma concepção da música como a arte do puro padrão e do puro processo. Não é apenas o fato de a música ser não-referencial, como supõe a vanguarda purista. A música é útil como modelo por suas propriedades arquitetônicas. Uma peça musical exibe forma em diferentes níveis, de figuras rítmicas ou construções motívicas e melódicas através de formas mais amplas (rondó, sonata), até a estrutura global de uma sinfonia ou de uma ópera. O que fez a analogia atraente foi o modo como uma peça musical poderia ser analisada como um sistema de sistemas: texto e música, melodia e ritmo, voz principal e acompanhamento. Por essa analogia, o filme torna-se uma forma em larga escala, constituída por sistemas menores. ${ }^{144}$

Se a pintura fornece o vocabulário plástico a ser utilizado pelos cineastas, e pelos quais seriam capazes de investigar a superfície da tela, a música parece fornecer os modos de condução deste vocabulário no decorrer da projeção. A analogia musical funciona, portanto, como um complemento temporal à analogia pictórica, espacial. A música tornase, deste modo, o paradigma de "estrutura temporal".

Assim como os critérios da pintura influenciam a escolha por formas geométricas, por combinações de cores, texturas e mesmo as técnicas de intervenção na película, os critérios da música influenciam a escolha por ritmos e combinações de movimentos. John Whitney, um dos cineastas americanos influenciados pelas vanguardas dos anos 1920, resume esse posicionamento ao definir a música como "o exemplo supremo do

\footnotetext{
${ }^{144}$ David Bordwell, "The Musical Analogy", Yale French Studies 60 (1980), p. 142. Alguns textos da época que exemplificam a presença da analogia musical são Léon Moussinac, "L’harmonieux enchaînement des images" (1925), e Abel Gance, "La musique de la lumière" (1927), in L'Art du cinéma, ed. Pierre Lherminier (Paris: Editions Seghers, 1960). Apesar de não defenderem necessariamente os filmes aqui citados, ambos reforçam o potencial abstrato e a centralidade do ritmo na condução das imagens. "Será necessário", diz Moussinac, "que o ritmo cinematográfico seja tão poderoso que torne-se suficiente em si mesmo, e que nossos olhos se adaptem, se aperfeiçoem à percepção das infinitas oscilações deste ritmo". Para mais sobre o contexto histórico no qual se desenvolve a analogia no discurso sobre o cinema, ver Dominique Château, "Le rôle de la musique dans la définition du cinéma comme art", Cinémas: Revue d'études cinématographiques, vol. 3, n. 1 (1992), pp. 79-94; e a seção "Le origini dell'analogia musicale", em Alberto Boschi, "Le origini della teoria del cinema", in Storia del cinema mondiale, vol. V: Teorie, strumenti, memorie, ed. Gian Piero Brunetta (Torino: Giuliu Einaudi, 2001), pp. 370-373.
} 
movimento transformado em padrão". Não apenas a disposição de formas espaciais, para Whitney o filme deve dispô-las segundo regras propriamente temporais, inclusive segundo uma "ordem métrica":

A ordem métrica é uma parte importante da estrutura da poesia, tanto quanto é importante na estrutura harmônica da música. O padrão das notas e o padrão rítmico são interrelacionados e entrelaçados na música assim como padrões silábicos, rítmicos e de sentido são entrelaçados na poesia. ${ }^{145}$

Whitney defende - e nisso parece em consonância com Richter, Eggeling, Fischinger e mesmo Smith - que a determinação desses elementos como uma escala interna da obra é o que permitiria ao espectador não só acompanhar os eventos e compreendê-los como relacionados uns aos outros, mas perceber os modos como eles dão sentido ao tempo, inscrevendo nele suas proporções, definindo, instigando, deslocando e frustrando as expectativas. ${ }^{146}$ É à recusa sistemática de uma escala, e de uma "organização de sentido" no filme, que Michelson se refere quando menciona a preferência de Brakhage por um "eterno presente".

O diferente tratamento dado a essas influências pelos cineastas tem, por complemento, uma diferença na recepção de suas obras pela crítica. Ainda que sejam vistos como partes de uma mesma tradição, os filmes suscitam considerações e ressalvas que nos permitem observar as ressonâncias que suas escolhas tiveram no discurso crítico. Uma diferença é representada pelas discordâncias entre William Moritz e Malcolm Le Grice. Em sua revisão do legado das animações dos anos 1920, Moritz exibe uma clara preferência pela tendência organicista dos filmes:

Em termos de estilo, Fischinger claramente pertence ao grupo das imagens exuberantes, dinâmicas, multidimensionais e palpáveis, como os filmes de Ruttmann em sua complexa multiplicidade de técnicas, em vez do sereno, delicado, intelectual e classicamente simples Symphonie Diagonale de Eggeling, ou os igualmente simples, brutos e mecânicos

\footnotetext{
145 John Whitney, Digital Harmony (Peterborough: McGraw-Hill, 1980), p. 39.

146 Ver, por exemplo, Ludwig Wittgenstein, Observações filosóficas, trad. Adail Sobral e Maria Stela Gonçalves (São Paulo: Edições Loyola, 2005), p. 55: “A expectativa, por assim dizer, prepara um padrão para medir o evento quando ele acontece e, mais do que isso, ela o faz de modo tal que vai ser necessariamente possível medir um com relação ao outro, quer o evento coincida com a graduação esperada, quer não." Pode-se argumentar que há todo um conjunto de expectativas derivadas do contexto em que a obra se encontra - o fato de ser uma obra de determinado cineasta, gênero, país, período, etc. Ainda que essas expectativas sejam determinantes, nos concentramos nas expectativas ligadas à organização interna da composição, com a qual as outras devem necessariamente interagir. Para uma investigação do papel da expectativa na música, partindo de uma definição semelhante e numa abordagem que dialoga com a psicologia da percepção, ver Leonard B. Meyer, Emotion and Meaning in Music (Chicago e Londres: University of Chicago Press, 1956), pp. 43-82.
} 
recortes de papel dos filmes de Richter. Por outro lado, pode-se ver na limitação consciente das imagens e nas sutis variações rítmicas produzidas nos filmes de Fischinger alguma ligação com a obra de Eggeling. O ponto importante, então, parece ser que cada um desses artistas se destacava num modo diferente e pessoal, assim como, digamos, Kandinsky, Kupka, Klee, O'Keefe, Moholy-Nagy e Malevich também o fizeram. Fischinger geralmente manipulava um espaço livre e sugerido, especializando-se na apresentação de imagens místicas e orientadas como voos de átomos, cometas e planetas. Ruttmann manejava principalmente, de maneira rica e complexa, os potenciais da tela como um espaço contido e literal, como a tela de um artista, especializando-se em imagens sensuais cuja beleza luminosa é derretida por um perfeito controle de matizes de cinza (que eram às vezes tingidos), ou em dinâmicas ópticas fortes, de contornos bem definidos. Eggeling explorou os aspectos pictóricos de uma única forma, delicada e refinada, conscientemente limitada e suspensa no nada, de modo que poderia ser revelada novamente em todas as suas facetas, todos os seus componentes, todas as suas variações. E Richter [...] lida, de acordo com Malcolm Le Grice e David Curtis, com a experiência mínima ou estrutural dos ritmos puramente luminosos, sem qualquer imagem para os obscurecer; eu pessoalmente considero sua noção rítmica um tanto inadequada, e me parece que os efeitos mais interessantes, assim como os problemas estéticos, surgem acidentalmente em seus filmes, já que não são explorados consistentemente ou completamente. ${ }^{147}$

Le Grice, por sua vez, encara os mesmos filmes em relação à produção dos anos 1960 (incluindo a sua própria obra, de caráter marcadamente "estrutural"). Uma genealogia pictórica é também sugerida por ele, culminando na divisão em dois campos, um representado por Mondrian e o outro por Kandinsky. Seu elogio é direcionado à abstração "arquitetônica" (Mondrian), em contraposição à abstração "cinética" (Kandinsky) - os termos que ele utiliza para se referir às tendências que aqui chamamos de "mecânica" e “orgânica”. É assim que Le Grice destaca positivamente Richter e Eggeling, argumentando que "a concentração em formas mais retilíneas e diagonais simples mostra um desejo de relacionar mais diretamente a geometria predominante da tela às analogias mecânicas do dispositivo fílmico". É de seu interesse o aspecto esquemático dessas obras e o fato de que as formas são "definidas linearmente, combinadas com estruturas aditivas e subtrativas com transformações básicas de reflexão e rotação". ${ }^{148}$

Uma observação complementar é feita por Jean Mitry. Crítico da analogia musical, Mitry faz a defesa das obras que trazem a música concretamente, isto é, que possuem o acompanhamento musical de fato (Fischinger, Lye, McLaren). Suas objeções quanto à vertente silenciosa (Richter, Eggeling, Ruttmann) envolvem o argumento de que os fatores puramente fílmicos não seriam capazes de dar o mesmo sentido ao tempo:

\footnotetext{
${ }^{147}$ Moritz, "The Films of Oskar Fischinger", op. cit., p. 167.

148 Malcolm Le Grice, "German Abstract Film in the Twenties", in Film as Film, op. cit., pp. 31-34. Para uma crítica de Moritz à visão histórica de Le Grice, ver William Moritz, "Beyond 'Abstract' Criticism", Film Quarterly, vol. 31, n. 3 (primavera de 1978), pp. 29-37.
} 
Enquanto notas e acordes, por si mesmos, não significam nada, palavras ou imagens têm significados bem definidos. E tais significados, variando de acordo com seu lugar na oração, podem ser intensificados por uma qualidade emocional produzida por várias relações métricas. Entretanto, o ritmo existe apenas quando essas relações fornecem às palavras e imagens um novo sentido relativo aos seus sentidos originais. Mas ao passo que uma sequência musical cria seu próprio significado conforme se desenvolve, como formas visuais não têm nenhum sentido em si mesmas, não se pode esperar que tenham parte em nenhuma sequência. Não podem, assim, ser empregadas da mesma forma que os sons. Tentar criar um ritmo cinematográfico semelhante ao ritmo musical é lutar contra uma óbvia impossibilidade. Nos filmes experimentais de Ruttmann, as formas geométricas em movimento não determinam qualquer sentimento ou emoção particulares. Apenas contribuem à percepção de uma cadência sem fundações reais. ${ }^{149}$

A arbitrariedade que Mitry destaca como negativa é precisamente aquela elogiada por Le Grice, da mesma forma que as qualidades puramente visuais aprovadas por Moritz são insuficientes a Mitry como fatores organizadores da composição. Considerando essas posições, temos algo como um quadro comparativo onde as mesmas características dos filmes são reconhecidas e avaliadas, mas cada vez por um ângulo particular.

\subsubsection{O paradigma da animação}

Outra divisão útil para se compreender as relações entre esses filmes e a maneira como descrevem toda uma região da composição fílmica envolve o papel da animação nesse contexto. Mais especificamente, é uma definição dupla, feita por Tom Gunning, que nos permite observar essas relações com mais clareza:

Pode ser útil dividir nosso termo animação em dois sentidos relacionados, mas separados. $\mathrm{O}$ primeiro, que eu chamo de animação ${ }_{1}$, refere-se à produção técnica de movimento pela rápida sucessão de fotogramas descontínuos, compartilhada por todas as imagens cinematográficas em movimento. Eu defino animação ${ }_{2}$ mais estritamente, em referência ao gênero de animação como é normalmente entendido: imagens em movimento que recebem movimento artificialmente, em vez de um movimento automaticamente capturado através da fotografia em movimento contínuo. [...] Eu descreveria animação ${ }_{2}$ como não apenas exibindo mas também jogando com a produção de movimento da animação ${ }_{1}$. Com isso eu pretendo invocar a atitude lúdica quase sempre preferida pela animação. [...] Pode-

\footnotetext{
149 Mitry, Esthétique et psychologie du cinéma, vol. II, op. cit., p. 141. Mesmo Arnheim teve uma atitude negativa em relação a alguns destes filmes. Apesar de reconhecer "o grande potencial estético de formas coloridas em movimento", os filmes de Richter, Eggeling e Fischinger foram por ele chamados de "curiosidades de museu". Assim como Adorno, ele fez a defesa de um certo realismo fotográfico como base fundamental para as vanguardas no cinema. Ver Rudolf Arnheim, "Art Today and the Film" (1965), in The New American Cinema: A Critical Anthology, ed. Gregory Battcock (Nova York: E.P. Dutton, 1967), pp. 57-63.
} 
se dizer, tautologicamente, que todas as imagens em movimento se movem, mas que a animação ${ }_{2}$ também brinca com o movimento; direciona nossa atenção ao efeito do movimento e explora seus limites; seu "espaço de ação", a liberdade de seus movimentos. A animação ${ }_{2}$ brinca com o movimento e com a impressão de maravilhamento, chamando atenção a seus próprios processos. A animação ${ }_{2}$ suscita alguma curiosidade sobre como foi feita, ainda que isso não exija uma compreensão técnica. A animação ${ }_{2}$ restitui à imagem em movimento a impressão de maravilhamento que as primeiras projeções de imagens em movimento causaram. ${ }^{150}$

Priorizando o argumento de Gunning, mais do que sua terminologia, podemos reformular a questão dando destaque ao seu caráter construtivo. (1) A sucessão de fotogramas descontínuos é um princípio básico do cinema, uma de suas características elementares é algo inevitável, presente em todo e qualquer filme, de modo que podemos dizer que há sempre um "princípio de animação". (2) A sugestão do movimento contínuo deve necessariamente supor a sucessão de fotogramas descontínuos, mas deve também compor essa sucessão de uma forma específica - é algo possivel, e mesmo algo provável, considerando a história do cinema. (3) Algumas obras desenvolvem o princípio, supondo que a projeção de fotogramas descontínuos para sugerir a continuidade pode levar à criação de fotogramas descontínuos para sugerir a continuidade do movimento - é o que chamamos, não de um gênero, mas de uma "técnica de animação". (4) Um subconjunto dessas obras hipostasia o princípio; supõe que, sendo o movimento uma propriedade construída, esta propriedade pode ela mesma ser elevada ao posto de "tema", expondo e explorando as condições de sua construção, para efeitos variados, como suspense e comédia - é a tendência da animação que encontramos num cineasta como Norman McLaren e no gênero que normalmente chamamos de cartoon. Como uma pirâmide, o princípio de animação funciona assim como uma base, sobre a qual são dispostos outros níveis, que concentram as propriedades do nível anterior, levando a obras cada vez mais específicas.

\subsubsection{A montagem rítmica e o conceito de intervalo}

No capítulo anterior, foi apontado que os filmes recorriam à técnica que Eisenstein denominou "montagem métrica", isto é, a montagem que considera apenas os

\footnotetext{
${ }^{150}$ Tom Gunning, "Animating the Instant: The Secret Symmetry Between Animation and Photography”, in Animating Film Theory, ed. Karen Beckman (Durham e Londres: Duke University Press, 2014), p. 40 (grifo nosso).
} 
comprimentos absolutos dos materiais. Os filmes deste capítulo devem necessariamente considerar as mesmas características, visto que são todos, sem exceção, compostos através da animação. Mas a presença de imagens dentro da tela exige que suas propriedades sejam coordenadas; e a presença do movimento, ou da combinação de movimentos, exige que outro fator temporal seja considerado. Ao nível de construção que se baseia neste outro fator, Eisenstein deu o nome de montagem rítmica:

Aqui, ao determinar o comprimento dos fragmentos, o conteúdo dentro do quadro é um fator que deve ser igualmente levado em consideração.

A determinação abstrata dos comprimentos dos fragmentos dá lugar a uma relação elástica dos comprimentos reais.

Aqui, o comprimento real não coincide com o comprimento matematicamente determinado do fragmento de acordo com uma fórmula métrica. Aqui, seu comprimento prático deriva da especificidade do fragmento, e de seu comprimento planejado de acordo com a estrutura da sequência.

É bastante possível aqui encontrar casos de total identidade métrica dos fragmentos com suas medidas rítmicas, obtidas através de uma combinação dos fragmentos de acordo com seu conteúdo. ${ }^{151}$

Eisenstein refere-se ao plano como a menor unidade passível de articulação, mas consideremos aqui não o registro feito pela câmera, e sim o conjunto de fotogramas dispostos em sucessão, e que, por suas propriedades visuais, são agrupados num mesmo conjunto, seja numa configuração estática, seja numa configuração em movimento. Conforme as figuras são dispostas e deslocadas no espaço da tela, diferentes proporções estão implicadas no resultado. As proporções temporais representam o fator rítmico propriamente dito: descrevem "um gráfico das fases em mutação, das contradições dentro de uma unidade". ${ }^{152}$ Um conjunto ritmado é, nesse sentido, como uma linha musical ou uma frase. A manipulação dessas proporções leva, então, a diferentes tipos de ritmo: manter estáveis as distâncias entre as partes leva a um ritmo regular; variar gradualmente, aumentando ou diminuindo aos poucos as distâncias, leva a um ritmo progressivo; modificar as distâncias sem qualquer regra aparente leva a um ritmo irregular. Recorrendo a diferentes maneiras de dar forma e sentido aos segmentos métricos, os filmes aqui tratados exemplificam algumas categorias do aspecto rítmico da composição. Considerando um segmento de dez segundos, suas proporções internas podem ser divididas igualmente, num movimento regular; podem descrever um movimento progressivo, aumentando ou diminuindo gradualmente a distância entre os estímulos;

\footnotetext{
151 Sergei Eisenstein, "Métodos de montagem" (1929), in A forma do filme, op. cit., p. 81.

152 Sergei Eisenstein, “Laocoon”, in Selected Works, vol. II: Towards a Theory of Montage, op. cit., p. 130.
} 
podem ser irregulares, evitando a sugestão dos tipos anteriores. Cada uma dessas possibilidades gera um efeito distinto, e suas combinações, alternâncias, passagens de uma a outra sugerem um repertório de operações rítmicas disponíveis.

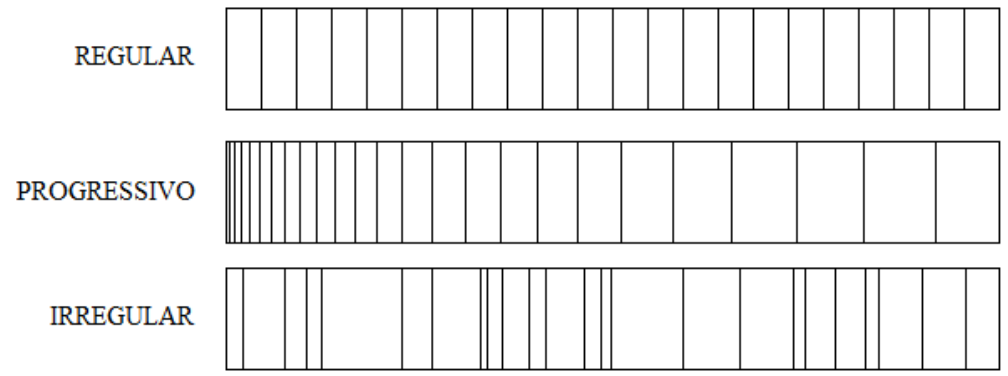

Três tipos de ritmo, considerando as distâncias métricas entre as etapas de um movimento, ou as diferentes configurações visuais apresentadas em sucessão.

Como o caráter métrico da montagem decorre do caráter métrico da própria projeção, ele permanece subjacente em obras cuja organização é feita através de uma montagem rítmica. A montagem rítmica, nos termos de Eisenstein, é uma variante de montagem métrica: supõe o caráter métrico, acrescentando a ele um novo critério, o "conteúdo interno" das imagens. As relações possíveis entre essas duas dimensões da montagem são inúmeras, já que uma mesma extensão métrica pode comportar diferentes articulações rítmicas no mesmo período.

Isso nos leva a um conceito complementar, também mencionado por Eisenstein, e voltado às proporções espaciais: o conceito de intervalo. Tanto Eisenstein como Dziga Vertov apresentaram, em diferentes ocasiões, descrições do que seria um "intervalo" no cinema. ${ }^{153}$ A primeira menção, por Vertov, é feita num texto de 1922:

Intervalos (a tradução de um movimento a outro) são o material, os elementos da arte do movimento, e de maneira alguma os movimentos em si. São eles (os intervalos) que levam os movimentos a uma resolução cinética. [...] A organização do movimento é a organização de seus elementos, ou de seus intervalos, em frases. Em cada frase há uma ascensão, um ponto alto, e uma queda (expressados em vários graus) de movimento. Uma composição é feita de frases, assim como uma frase é feita pelos intervalos do movimento. ${ }^{154}$

A primeira menção por Eisenstein data de 1929:

${ }^{153}$ Para mais sobre o contexto histórico em que surgiram os debates sobre a noção de intervalo, ver Annette Michelson, "The Wings of Hypothesis: On Montage and the Theory of Interval", in Montage and Modern Life, 1919-1942, ed. Matthew Teitelbaum (Cambridge, Mass: MIT Press, 1992), pp. 60-81.

154 Dziga Vertov, "We: Variant of a Manifesto" (1922), in Kino-Eye: The Writings of Dziga Vertov, ed. Annette Michelson (Berkeley: University of California Press, 1984), pp. 8-9. 
A quantidade de intervalo determina a pressão da tensão. (Ver na música, por exemplo, o conceito de intervalos. Pode haver casos em que a distância da separação é tão grande que leva a uma pausa - a um colapso do conceito homogêneo de arte. Por exemplo, a "inaudibilidade" de determinados intervalos.) A forma espacial deste dinamismo é a expressão. As fases de tensão: o ritmo. ${ }^{155}$

As duas definições, surgidas no mesmo período que os "filmes absolutos" alemães, possuem em comum com estes a analogia musical e o fato de que buscam implicar as proporções do interior da imagem na progressão do filme, e mais especificamente, as “tensões" entre essas etapas. Para exemplificar o uso dessas tensões, Eisenstein propõe a representação gráfica de dois planos em sucessão, com o efeito da passagem entre eles. Como o ângulo resultante do cruzamento de duas linhas, a distância entre as configurações visuais, ao efetuar uma transição, cria algo como uma terceira imagem, que não é idêntica às duas anteriores mas que delas é dependente. Esta terceira imagem não está presente na tela durante a presença da imagem A ou durante a imagem B, mas sim no intervalo mental entre as duas:

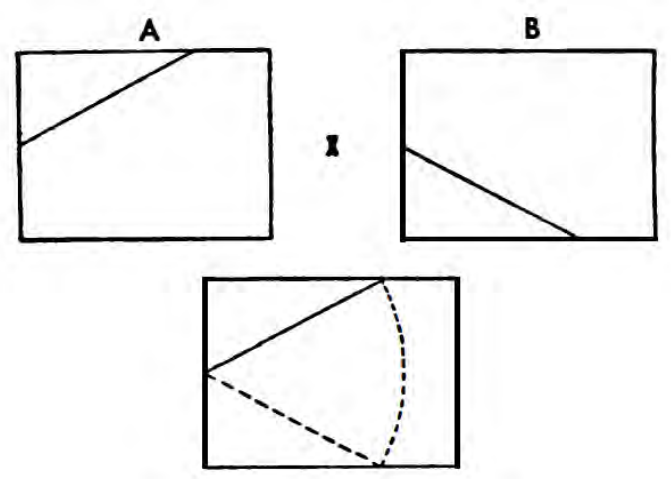

Eisenstein menciona ainda a possibilidade de haver "uma escala de intervalos". Em outras palavras, que possam haver intervalos com uma tensão - uma distância entre configurações visuais - tão extrema que levaria a uma "quebra". A contraparte seria um intervalo com tensão tão amena - uma distância tão pequena - que a sugestão de uma terceira configuração seria praticamente inexistente. Entre os dois polos, haveria uma série de possibilidades intermediárias.

A noção de intervalo remete aos experimentos de Wertheimer em que estímulos sucessivos criam a impressão de passagem entre eles, ainda que não haja a "exposição factual" do movimento. Recordemos a formulação de Paul Fraisse das leis de

${ }^{155}$ Sergei Eisenstein, "Dramaturgia da forma do filme" (1929), in A forma do filme, op. cit., p. 51. 
agrupamento: toda modificação periódica, qualitativa ou quantitativa, determina o agrupamento. As modificações periódicas, no caso destes filmes, são as propriedades que determinam o tipo de movimento ou progressão. Elas são quantitativas em termos métricos ou rítmicos, isto é, de acordo com as durações absolutas ou as distâncias entre as etapas. Elas são qualitativas em termos visuais, isto é, de acordo com a textura, o formato e a posição das formas sobre a tela. Quanto maiores essas modificações, mais elas funcionam como acentuações no mesmo processo; quanto menores elas forem, mais funcionam como um reforço da continuidade ou uniformidade deste processo. Há um limite inferior, quando as modificações são tão amenas que tornam-se praticamente imperceptíveis como modificações na unidade, até que se igualam à real ausência de modificações: é o caso da repetição exata das configurações visuais ou a homogeneidade. Há um limite superior, quando as modificações são tão extremas que tornam praticamente imperceptível a unidade, restando apenas o contraste entre elementos dispersos: é o caso da inversão completa das configurações visuais. Entre os dois limites há uma escala na qual se posicionam as mais diversas operações formais, de modo que o conceito de intervalo pode servir como a generalização de um princípio elementar de composição. É a formulação de um critério que permanece mesmo quando não articulado diretamente: toda obra fílmica que articula imagens no espaço da tela, mesmo aquelas que não partam de premissas semelhantes às de Vertov e Eisenstein, todas articulam em alguma medida a distribuição plástica dos materiais na imagem. ${ }^{156}$

156 Jacques Aumont propõe que o intervalo seja considerado como "a distância visual mantida entre dois planos". Ele enfatiza que o intervalo é visual, não intelectual, isto é, que depende das qualidades plásticas da imagem, mais do que de seu campo semântico. Ainda que possa ter reverberações no significado do filme, o intervalo é primeiramente "o que permite fazer do tempo um material formal". Ver Jacques Aumont, $O$ olho interminável, trad. Eloísa Araújo Ribeiro (São Paulo: Cosac Naify, 2004), pp. 104-106. 
PARTE II

\section{PROFUNDIDADE}




\section{PLANO \\ PROPRIEDADES E LIMITES}

\subsection{A hipótese do contínuo}

Em 2001, Jacques Aumont e Michel Marie se propuseram o trabalho de definir um dos conceitos fundamentais do cinema. No contexto de um dicionário teórico e crítico, repleto de termos cuja aplicação é restrita a discussões específicas, a noção de plano permeia a maior parte dos comentários. Igualado frequentemente à "unidade mínima" do cinema, o plano, quando abordado com o rigor necessário, revela-se um conceito de difícil tratamento. ${ }^{157}$ De maneira característica, as tentativas de definição oscilam entre a insuficiência e a tautologia. "O plano", nos dizem os autores, "é o que resta, no filme terminado, de uma tomada efetuada no momento da filmagem". Há uma correspondência parcial entre o plano e a tomada - um registro fílmico em continuidade feito com a câmera. O plano é o que sobra desse registro no filme terminado, ou seja, é aquilo que o cineasta decide incluir do registro em sua obra, podendo retirar trechos e manter a continuidade do segmento restante. $\mathrm{Na}$ experiência com o filme, nos deparamos com planos dispostos em sucessão, de modo que o plano pode ser definido também como "qualquer segmento de filme compreendido entre duas mudanças de plano". Não há menção direta no texto, mas uma decorrência é que um filme pode se constituir de um único plano, inclusive de um plano cuja equivalência com a tomada é completa, sem que haja subtração para inclusão na obra final. ${ }^{158}$

O plano é então perceptível como algo contínuo, um registro que se desenvolve no tempo, sendo passível de mudanças. Mas ainda que comporte tais mudanças, o plano é apreendido como um só elemento, isto é, possui uma unidade. É como unidade que o

\footnotetext{
${ }^{157}$ Ver, por exemplo os artigos de Pascal Bonitzer, "Voici (La notion de plan et le sujet du cinéma)", Cahiers du cinéma 273 (janeiro-fevereiro de 1977), e "Qu'est-ce qu'un plan?", in Le champ aveugle: essais sur le réalisme au cinéma (Paris: Cahiers du cinéma, 1999).

158 Ver Jacques Aumont e Michel Marie, Dicionário teórico e crítico de cinema, op. cit., p. 230.
} 
plano é classificado, através de suas propriedades internas: o modo como apresenta e desenvolve sua continuidade particular, como dá preferência a certas escalas e movimentos. Investigar os modos pelos quais essa unidade é classificada e as categorias que eles implicam nos levaria talvez a uma visão mais ampla do conceito. Aqui, o estudo das origens históricas do plano serve como um ponto de entrada plausível. Nos últimos anos do século XIX, a criação do cinematógrafo por Auguste e Louis Lumière representou não apenas a gênese de uma arte, mas também a primeira exploração sistemática do plano. Por serem tentativas de investigar as possibilidades do dispositivo em seu período inicial, as obras dos Lumière são exemplos importantes: filmes que se apresentam em planos únicos, com duração média de 50 segundos, buscando adaptar a forma dos registros às situações registradas.

L'Arrivée d'un train à la Ciotat (Louis Lumière, 1896) é um caso emblemático. Nos segundos que abrem o filme, uma linha de trem corta o espaço da tela numa diagonal em perspectiva. Em cada lado dos trilhos há uma plataforma; na plataforma à direita um grupo de pessoas estão enfileiradas; no limite superior da linha de trem, no fundo da imagem, há uma locomotiva que se aproxima. O avanço do filme coincide com a aproximação do trem: à medida que atravessa a diagonal, o trem preenche gradualmente $o$ espaço à esquerda da tela, cobrindo a visão de uma das plataformas. As pessoas que se encontravam na plataforma à direita se movem em direção aos vagões e outras pessoas atravessam o espaço em profundidade, saindo do trem ou de partes externas àquela região mostrada pela câmera. Assim como a passagem do trem encobriu a visão de uma das plataformas, conforme as pessoas se deslocam na região próxima da câmera o próprio trem é parcialmente encoberto. Nos segundos finais, são as pessoas que ocupam a maior parte da tela, em trajetórias diversas.

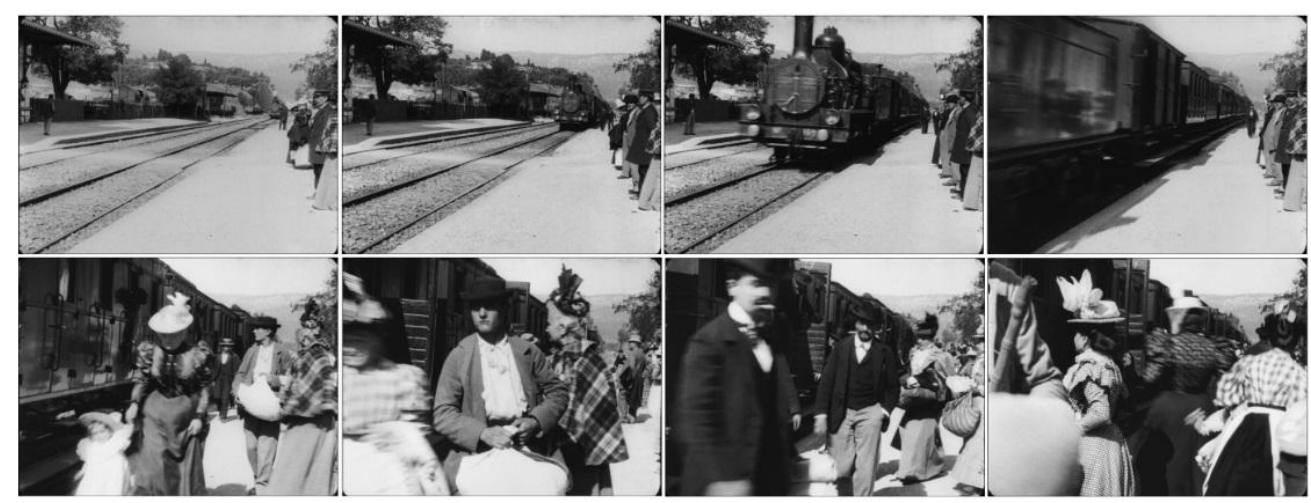

L'Arrivée d'un train à la Ciotat (Louis Lumière, 1896) 
A câmera disposta na plataforma por Louis Lumière registrou, assim, a chegada do trem. A lente da câmera focalizou a luz e a transmitiu à superfície do filme, que foi exposto na frequência de 16 fotogramas por segundo. A distância focal - a distância entre o centro da lente e o ponto onde os raios luminosos convergem - determinou as propriedades dessa imagem, a escala e profundidade dos objetos. ${ }^{159} \mathrm{O}$ evento foi tornado descontínuo por sua fixação em aproximadamente 800 fotogramas, e contínuo pela projeção desses fotogramas na mesma frequência da filmagem. Diferente das animações e colagens analisadas anteriormente, aqui a tecnologia garante que a representação estará de acordo com as leis da óptica e da perspectiva, e que a realidade sensível terá uma contraparte com alto grau de semelhança na imagem fílmica, incluindo a percepção do movimento.

O elogio mais célebre deste processo foi feito por André Bazin, cuja defesa de uma estética realista se funda na própria impessoalidade do dispositivo. Referindo-se à base fotográfica do cinema, Bazin declara:

Pela primeira vez, entre o objeto inicial e sua representação nada se interpõe, a não ser outro objeto. Pela primeira vez, uma imagem do mundo exterior se forma automaticamente, sem a intervenção criadora do homem, segundo um rigoroso determinismo. A personalidade do fotógrafo não entra em jogo senão pela escolha, pela orientação, pela pedagogia do fenômeno; por mais visível que seja na obra acabada, já não figura nela como a do pintor. Todas as artes se fundam sobre a presença do homem; unicamente na fotografia é que fruímos de sua ausência. ${ }^{160}$

A ligação "ontológica" que Bazin identifica entre o cinema e a realidade gera uma diferença fundamental em relação à pintura. Como o cinema, a pintura é uma arte que se constitui num espaço visual delimitado - um quadro emoldurado, na maioria das vezes. Mas, por ser composta de materiais plásticos, ou seja, combinações de tintas sobre um quadro, a pintura deve acrescentar ali todo o seu "conteúdo" visual, já que antes dessa operação não há nada exceto o quadro vazio. O cinema, por sua vez, pode capturar e projetar na tela a própria aparência da realidade, absorvendo um conteúdo visual que de certa forma o precede e o excede. Consequentemente, os limites espaciais do quadro na

\footnotetext{
159 Quanto menor a distância focal, mais se reforça a profundidade e o volume, e mais se distorce as linhas próximas às bordas, que tendem a se curvar na proporção inversa da abertura da lente. Quanto maior a distância focal, mais a imagem parece achatada, e mais são reduzidas as impressões de volume e profundidade, bem como as distorções nas bordas. Em geral, considera-se que as lentes "normais" (por exemplo, a $50 \mathrm{~mm}$ ) equilibram estas propriedades e se aproximam da visão humana. No caso dos Lumière, as lentes variam de $18 \mathrm{~mm}$ a $40 \mathrm{~mm}$, situadas portanto um pouco abaixo da margem das lentes normais.

${ }^{160}$ André Bazin, "Ontologia da imagem fotográfica”, op. cit., p. 31.
} 
pintura definem o perímetro de seu universo, enquanto no cinema as bordas da tela sinalizam não o final de seu universo, mas do alcance da câmera. Se na pintura os conteúdos visuais devem necessariamente remeter à interioridade da imagem, o cinema é capaz de nos remeter à sua própria exterioridade. "A moldura polariza o espaço para dentro", sintetiza Bazin, enquanto "tudo o que a tela de cinema nos mostra, ao contrário, supostamente se prolonga indefinidamente no universo. A moldura é centrípeta, a tela é centrífuga."

O gesto composicional de Louis Lumière envolve o posicionamento da câmera de modo a registrar o evento através de uma distância e um ângulo privilegiados. Por essa distância e por esse ângulo um espaço tridimensional é projetado geometricamente sobre o espaço bidimensional do filme, sendo apresentado ao espectador de modo que os volumes e a disposição dos objetos possam ser reconstituídos mentalmente. O ponto de fuga da imagem, como o vértice de uma pirâmide horizontal, é projetado na tela numa relação complementar à que a câmera opera no espaço que registra. Compor um plano aqui é sinônimo de compor o volume virtual de uma pirâmide cujo vértice encontra-se na câmera e cuja base é formada pelo plano (no sentido geométrico) onde o espaço é recortado pelas bordas. Considerar os planos (fílmicos) possíveis é então análogo ao gesto de "deslizar sobre o mundo uma pirâmide visual imaginária (e às vezes cristalizá-la)". ${ }^{162}$

$\mathrm{O}$ enquadramento determina simultaneamente o conteúdo dessa pirâmide e aquilo que dela será excluído. Um corolário é que as bordas da imagem tornam-se a região de troca entre as duas esferas. Além da relação entre a posição da câmera e os objetos que ela registra, as bordas estabelecem também uma relação - uma "superfície de contato" entre o ponto de onde parte o olhar da câmera e o campo no qual este olhar é projetado. Em L'Arrivée d'un train à la Ciotat, encontramos uma estratégia recorrente nos filmes dos Lumière: a imagem é organizada de modo que os elementos não são fixados no espaço visível, mas incluídos neste espaço, parcialmente e momentaneamente. As pessoas entram e saem do enquadramento, assim como a locomotiva transgride o enquadramento

\footnotetext{
161 Bazin, "Pintura e cinema", op. cit., pp. 206-207.

162 Aumont, $A$ imagem, op. cit., p. 159. Ver também pp. 34-35: "Em nosso âmbito, o espaço físico pode ser descrito com bastante exatidão por meio de um modelo simples e antigo, o da geometria de três eixos de coordenadas, perpendiculares duas a duas (as coordenadas 'cartesianas'). Esse modelo deriva, por aperfeiçoamentos e racionalizações sucessivos, da geometria 'euclidiana', a qual se caracteriza, entre outras coisas, pelo fato de descrever o espaço como formado de três dimensões. Essas três dimensões podem com facilidade ser concebidas de modo intuitivo, em referência a nosso corpo e à sua posição no espaço: a vertical, já mencionada, é a direção da gravidade e da posição em pé; a segunda dimensão, horizontal, é a da linha dos ombros, paralela ao horizonte visual diante de nós; enfim, a terceira dimensão é a da profundidade, correspondente à projeção do corpo no espaço."
} 
no decorrer de sua travessia. "É em boa parte graças a essa atividade nas bordas da imagem", resume Aumont, "que o espaço parece se transformar incessantemente". As bordas tornam-se, assim, "operadores ativos dessa transformação progressiva". ${ }^{163}$

Transformação progressiva, necessariamente. Mas o que caracteriza essa progressão? O tempo da projeção, a cronometria de um número regular de fotogramas por segundo, representa o que podemos chamar de aspecto métrico da composição, a divisão do contínuo temporal em comprimentos absolutos. O caráter absoluto da métrica faz com que o conteúdo interno de um plano seja submetido à mesma divisão em fotogramas que quaisquer outros conteúdos de outros planos. Independente de como ocorram as mudanças no plano, elas devem ocorrer na frequência da projeção. Como imagem em movimento, o plano inclui também os fatores rítmicos, ou seja, um nível temporal sobreposto à métrica da projeção: a configuração particular dos intervalos visuais dentro da unidade daquele movimento, como os exemplos do capítulo anterior. Mas, enraizado na concepção de "ontologia fotográfica", o plano efetua o casamento entre a frequência do registro e a frequência da projeção. Desde que a tomada não seja cortada e que a velocidade da projeção seja a mesma do registro (algo entre 16 e $24 \mathrm{fps}$ ), o tempo do registro será isomórfico ao tempo da projeção - será o que em geral chamamos de "tempo real". ${ }^{164}$ Isso nos leva a outra questão crucial entre a pintura e o cinema, mais claramente representada pela distinção entre o "instante pregnante" e o "instante qualquer".

A noção de instante pregnante deriva das reflexões de Gotthold Ephraim Lessing sobre os critérios da poesia e da pintura. Para Lessing, a poesia, sendo capaz de narrar eventos, atribuindo-lhes relações de sucessão, seria uma arte predominantemente temporal. A mesma capacidade é negada à pintura, que, sendo definida pela simultaneidade de suas partes, deveria selecionar um único evento e representá-lo em seu momento-chave, de máxima expressividade - o instante pregnante. O cinema é uma arte visual, como a pintura; mas seu desvelamento temporal e sobretudo o modo como ele ocorre na projeção fazem com que a noção de instante sofra um deslocamento. Não apenas o cinema tem a possibilidade de representar a evolução temporal de um acontecimento, como o próprio dispositivo que permite essa evolução torna problemática

163 Aumont, O olho interminável, op. cit., p. 39. Ver também Jun Sato, "Les lois de prolongement et leurs effets sur la mise en scène de l'espace cinématographique", Cinémas, vol. 9, n. 1 (outono de 1998), p. 81. As hipóteses psicológicas subjacentes à percepção dessa continuidade entre a periferia da imagem e o espaço virtual imediatamente exterior a ela seriam a "lei de continuidade" (formulada pela psicologia Gestalt) e a "lei de permanência do objeto" (formulada por Jean Piaget).

164 Ver Mary Ann Doane, The Emergence of Cinematic Time Modernity, Contingency, the Archive (Cambridge, Mass./Londres: Harvard University Press, 2002), p. 172. 
a ideia do instante pregnante. Em oposição a esta ideia, Gilles Deleuze propôs um termo inspirado na filosofia de Bergson - o instante qualquer. Segundo seu argumento, é em função dos cortes seccionais equidistantes que o cinema reproduz o movimento contínuo e a imposição dessa grade temporal aos movimentos iguala todas as suas etapas. Não significa com isso que o cinema impossibilita os instantes privilegiados, mas que a isocronia do mecanismo da projeção determina o instante qualquer como a base do processo, de modo que é a partir dele que devem ser destacados momentos particulares, ou seja, que o "singular" é extraído do "qualquer". ${ }^{165}$ Como o tempo do plano se encontra em fluxo, qualquer momento que se destaque é necessariamente visto como uma instância da correnteza que avança o conjunto.

A distinção baziniana entre a pintura e o cinema vale também para a distinção entre as colagens e animações vistas no capítulo anterior e os filmes dos Lumière. Filmes como Rhythmus 21 e Studie $n r .6$ têm sua composição definida por incrementos conscientes: como na pintura, antes que os elementos fossem escolhidos e dispostos na posição e ordem desejadas não poderia haver conteúdo visual algum para ser trabalhado. ${ }^{166}$ Richter e Fischinger puderam testar as combinações que mais lhe pareceram adequadas, mas tudo que vemos sobre a tela necessariamente foi determinado por eles. A escolha de um "vocabulário", a restrição de todo o universo visual a um conjunto de figuras e aos movimentos e combinações entre elas, isso faz com que o nível de arbitrariedade nessas decisões seja considerável, e que toda a organização interna da obra, todo o universo de texturas e ritmos, tudo remeta o espectador a um desígnio consciente. Se os filmes representam movimentos mecanizados ou sugerem a animação de formas geométricas, isso deve ser "construído", como devem ser construídas as referências de orientação gravitacional. É uma situação oposta a que encontramos aqui. O que Bazin chamou de "a pedagogia do fenômeno" é algo como o filtro aplicado à realidade pela organização de um plano - e a marca dos filmes dos Lumière. Uma vez posicionada a câmera e decidido o enquadramento, mesmo que as ações sejam previstas, há todo um conjunto de fatores que podem interferir no registro: a velocidade do trem não é precisamente calculada ao nível do fotograma como nas animações, mas sim um movimento sujeito a variações; a reação das pessoas na plataforma, desde a localização

\footnotetext{
${ }^{165}$ Ver Gilles Deleuze, Cinema 1: A imagem-movimento, trad. Stella Senra (São Paulo: Editora 34, 2018), pp. 16-21.

166 Não havia conteúdo visual exceto, é claro, a própria fita de filme. Consideramos aqui os conteúdos que poderiam ser colocados em movimento, preenchendo o espaço da tela. No caso dos filmes do primeiro capítulo, quando a totalidade da tela é o "molde" para todos os elementos, a questão seria modificada.
} 
delas no quadro até a velocidade de suas caminhadas, tudo isso é também passível de resultados imprevisíveis, como o são os movimentos das árvores e os padrões de fumaça da locomotiva. A soma total dos conteúdos visuais aqui nos remete não ao desígnio do cineasta, mas à rede de causas naturais que subjaz o evento fotografado.

É a partir dessa diferença que podemos compreender a recorrência de ambientes e situações no catálogo Lumière. Dos mais de 1400 filmes inscritos no catálogo, cerca de três quartos foram realizados em ambientes urbanos e, destes, vários têm a movimentação da cidade como tema central. Nesse sentido, a produção dos Lumière é um testemunho da arquitetura urbana (sobretudo a europeia) do final do século XIX. Como as formas abstratas nas animações do capítulo anterior, a organização arquitetônica das cidades serve como uma espécie de vocabulário a estes filmes. E assim como os contornos e as dimensões das formas abstratas sugeriam a cineastas como Richter e Eggeling suas transformações possíveis, algo semelhante parece ter ocorrido aos Lumière: para além das convenções do retrato fotográfico da época, a disposição das ruas e praças, os ângulos e materiais das construções, ou seja, a geometria própria dos locais onde levaram o cinematógrafo, tudo isso parece ter sugerido a eles direcionamentos particulares na composição dos filmes. ${ }^{167}$

Lembremos que, nesse contexto, a tarefa do cineasta era a organização do volume virtual - em transformação constante - a partir da ortogonalidade definida pelas leis ópticas e pela perspectiva. Como se organizam então os conteúdos visuais? Na maioria dos casos, as linhas de força são marcadas por longas diagonais que atravessam o espaço horizontalmente e em profundidade. Seja uma calçada, um trilho ou um corrimão, essas linhas são constituídas frequentemente das partes do tecido urbano voltadas à coordenação da mobilidade. A geometria interna do quadro reflete, assim, a própria geometria à qual se submetem os transeuntes daqueles espaços. E aqui podemos estender a analogia entre a arquitetura das cidades, em sua relação com os movimentos espontâneos que ocorrem à sua volta, e os planos dos Lumière, na forma como também permitem a visualização de uma grade estrutural que nos serve de medida para todas as reações no espaço registrado. Mais do que um instante pregnante, o que os Lumière propõem é um enquadramento pregnante: em vez da busca por um único momento que será o ponto de confluência de todas as ações (a cristalização do fluxo temporal num único espaço), os filmes concentram o olhar numa determinada região onde várias ações

${ }^{167}$ Para mais sobre a importância das cidades na produção dos Lumière, ver André Gardies, "La cité Lumière", CinémAction 75 (1995), pp. 12-16. 
ocorrem (a cristalização do espaço para que tenha passagem o fluxo temporal). A vivacidade dos filmes não é portanto da ordem do controle, e sim da dinamização do transitório e do que parece habitar igualmente todos os centímetros da tela. O movimento é tão onipresente que parece se estender para além das fronteiras do plano. A presença ocasional de elementos naturais, como a fumaça de veículos e chaminés, ou a água de poças e córregos, multiplica a incessante mobilidade, tornando-a ainda mais imprevisível, acrescentando outras texturas que não somente o aspecto sólido do metal e do concreto. As "compensações" na disposição gráfica, que poderiam sugerir alguma estabilidade, nas poucas ocasiões em que estão presentes são atravessadas por movimentos que desequilibram o conjunto. Mesmo o ângulo privilegiado, o recorte exato, mesmo isso não é capaz de esgotar a realidade; as constantes mudanças ocorrendo nas bordas são a prova de que, aqui, a tecnologia pode funcionar como um catalisador daquilo que encerra.

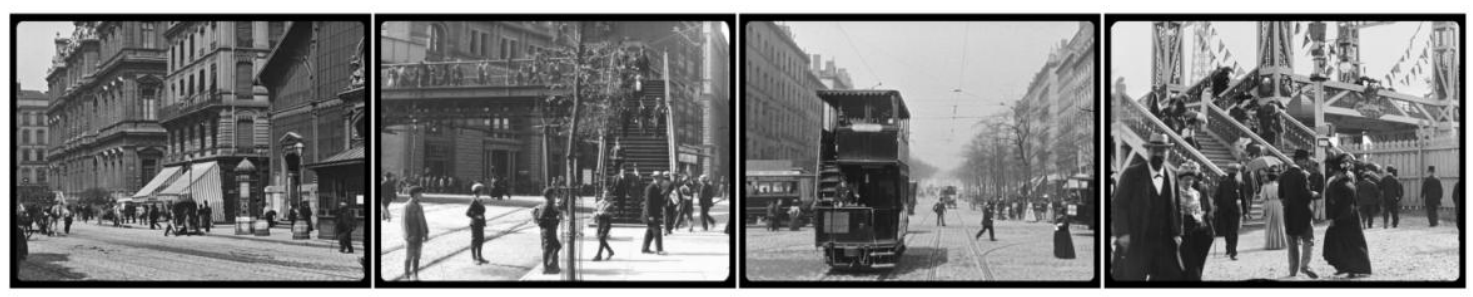

Quatro filmes que exemplificam os registros urbanos dos Lumière, com as linhas de força da arquitetura definindo as "grades" dos enquadramentos, dentro das quais e através das quais pessoas se movem livremente: Place des cordeliers (1895), Descente des voyageurs du pont de Brooklyn (Alexandre Promio, 1896), Place du pont (1897), Les escaliers du pont de l'Alma (1900). ${ }^{168}$

Além da recorrência dos ambientes, podemos notar ainda a recorrências das situações filmadas pelos Lumière, algo resumido por Michaud:

[O que está em jogo] é a revelação da mobilidade do mundo, posta em cena com dificuldade, isto é, simplesmente enquadrada: chegadas e partidas de automóveis, bondes, navios ou trens, operários entrando e saindo de fábricas, circulação de transeuntes, desfiles, procissões, carga e descarga de caminhões, cargueiros e vagões etc. Trata-se de mostrar, nesse batimento de presença e ausência revelado pelo olho estático da câmera, a cadência rítmica do mundo, que exibe com indiferença os gestos do trabalho e os do ócio, e se decompõe no espetáculo infinitamente declinado de aparecimento e desaparecimento dos elementos móveis.

${ }^{168}$ Mesmo quando outros operadores foram responsáveis pela filmagem, consideraremos todas as obras do catálogo Lumière como fazendo parte de um mesmo empreendimento, atribuído aos irmãos por serem eles os responsáveis por suas diretrizes. Nos filmes em que o operador é desconhecido, será dada apenas a data de sua realização. 
No acúmulo dessas situações, nesse "catálogo dos vetores de movimento que atravessam o mundo", os Lumière terminam por desenhar, de modo mais profundo, algo como formas próprias do cinema, identificadas em seus objetos. A linearidade da projeção é, ela mesma, projetada metaforicamente sobre a realidade: "ao dar ao cinema uma aparência, o mundo torna-se sua metáfora". 169

\subsection{A paralaxe do movimento e o fora-de-campo}

O capítulo foi iniciado com um plano que registrava a chegada de um trem. Ali, a câmera estática nos dava a referência da trajetória do veículo através da longa diagonal que cruzava o espaço - espaço que, por sua vez, era gradualmente preenchido pelo trem, num movimento unidirecional, análogo ao desvelamento da projeção. Consideremos então alguns contrafactuais do mesmo evento. Mantendo o enquadramento fixo e a duração de 50 segundos, a câmera poderia ser posicionada numa plataforma de frente à outra, fazendo com que a linha de trem cortasse a tela horizontalmente, num ângulo perpendicular ao direcionamento da câmera. Isso faria com que o trem não fosse visto à distância, surgindo no horizonte, mas apenas quando atravessasse o campo; o mesmo ocorreria com as pessoas presentes, e também a relação entre a visibilidade do trem a partir das pessoas que caminham na plataforma seria distinta. A câmera poderia ainda ser posicionada com a mesma diagonal em profundidade, mas voltada à direção oposta, isto é, na mesma direção na qual o trem avança. Isso criaria algumas relações espaciais semelhantes às do plano original; mas a entrada do trem no campo visível seria não um acréscimo progressivo acompanhado pelo espectador, e sim um evento do qual não teríamos qualquer sinal de proximidade. O que L'Arrivée d'un train à la Ciotat propõe, na recusa desses ângulos, é o preenchimento gradual do volume da pirâmide na qual o espectador tem referências de distância e profundidade em relação ao veículo em movimento, e na qual possui também amplitude suficiente para observar tanto o veículo como as reações das pessoas a ele. Nesse sentido, se há algo como uma linearidade no plano, trata-se de uma "linearidade espacializada", incorporada ao espaço tridimensional, que se manifesta na transformação mesma deste espaço. Não basta que o evento ocorra

169 Michaud, Filme, op. cit., pp. 160-161 (grifos nossos). 
em frente à câmera: ele deve permear toda a duração do plano, assim como todo o volume virtual representado na tela.

Os trilhos, referências constantes na geometria interna dos planos dos Lumière, servem também como fontes de movimentos de outra ordem quando a própria câmera é colocada sobre um veículo, tornada ela mesma um objeto móvel na paisagem. ${ }^{170}$ Observar três filmes dos Lumière voltados a esta configuração nos permite identificar alguns dos caminhos abertos por essa estratégia.

1. Em Passage d'un tunnel en chemin de fer (1898), a câmera é posicionada na parte da frente de um trem que avança rapidamente nos trilhos. Os primeiros segundos do filme são marcados pela travessia de uma ponte metálica e, logo que a ponte chega ao fim, torna-se visível no fundo da imagem um túnel escavado numa montanha. $\mathrm{O}$ trem entra no túnel e a escuridão toma conta da tela. Poucos segundos depois, surge um foco de luz que logo se revela a saída do túnel. Conforme o trem sai do túnel, a luminosidade que havia tomado conta da imagem é ajustada, revelando a paisagem na qual se encontra a estação, onde termina a jornada. Aqui temos um plano que serviria como um contrafactual de L'Arrivée d'un train à la Ciotat, a chegada de um trem à estação do ponto de vista do veículo. Mesmo a frontalidade é semelhante e, como no primeiro filme, temos referências visuais do espaço a ser atravessado pelo trem e pela câmera. Há uma projeção temporal em jogo, e a frequência do movimento do trem, aliada à regularidade da projeção, nos permite inferir onde estará o trem nos próximos segundos, com base nas características do espaço visto em profundidade. O grande diferencial é que a variação interna do plano é tornada dependente da própria variação da paisagem na qual o trem se encontra. Da ponte metálica ao túnel e à estação, diferentes espaços - diferentes contextos para o enquadramento, para a luminosidade, para a textura da imagem - nos são dados como etapas de um único movimento.

\footnotetext{
${ }^{170}$ É frequente a relação entre o cinema e a ferrovia, sobretudo no contexto da modernidade. Para uma visão historiográfica dessa relação, ver Lynne Kirby, Parallel Tracks: The Railroad and Silent Cinema (Durham: Duke University Press, 1997). Sobre a importância dos trens nos filmes dos irmãos Lumière, ver Christa Blümliger, "Lumière, the Train and the Avant-Garde", in The Cinema of Attractions Reloaded, ed. Wanda Strauven (Amsterdam: Amsterdam University Press, 2006), p. 246: "A ferrovia representa a perda da experiência da viagem como um contínuo espacial, na medida em que o trem atravessa um espaço intersticial. Assim, o trem, como o cinema, funciona tanto como uma máquina para organizar o olhar como um gerador de linearidade e movimento" (grifo nosso). Para mais sobre o aspecto metafórico dos trens na representação cinematográfica, ver Annette Michelson, "Track Records, Trains of Events: The Limits of Cinematic Representation", in Junction and Journey: Trains and Film, ed. Larry Kardish (New York: The Museum of Modern Art, 1991).
} 


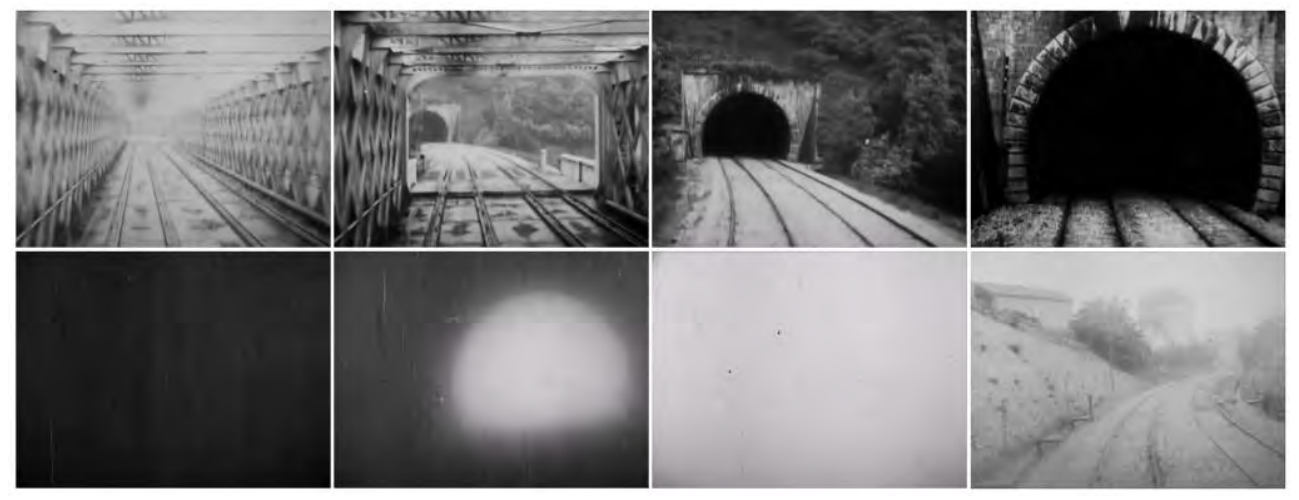

Passage d'un tunnel en chemin de fer (1898)

2. Em Panorama de l'arrivée en gare de Perrache pris du train (1896), a câmera é posicionada na parte lateral de um trem. Os primeiros segundos são marcados pela presença de um prédio próximo à câmera, como um grande bloco de concreto tomando o espaço da tela. $O$ trem avança, e com a fachada do prédio é revelada uma paisagem, onde se destaca uma ponte sobre o mar e uma montanha ao fundo. No decorrer da trajetória, as construções em tons claros contrastam com a massa de tons escuros das árvores, atingindo o ápice ao final do filme quando árvores passam na região mais próxima da câmera, tomando quase toda a imagem. O enquadramento lateral retira justamente a referência presente no exemplo anterior: aqui não é possível saber o que está "à frente" do movimento. O resultado é um panorama, um espaço desvelado como uma linha horizontal, uma condução do olhar semelhante à de um passageiro olhando pela janela do trem. Nessa jornada, toda a modulação do conteúdo visual ocorre nas diferentes proximidades que os objetos têm em relação à câmera, iniciando com o prédio que serve como uma imensa parede, levando à profundidade da paisagem marcada pelas diagonais das ruas e pontes, e finalmente às árvores que cobrem a maior parte da tela. A câmera observa o espaço não mais como um campo a ser atualizado pelos elementos já dados internamente, mas como um campo a ser atravessado e constantemente recriado na tela por essa travessia. O que está em jogo é a mutação das escalas espaciais, o surgimento e a desaparição dos objetos em decorrência do ângulo da câmera. A transformação resultante é a da tela como um volume que alternadamente se expande (quando a imagem é "aberta" pela profundidade de campo) e se contrai (quando a imagem é "fechada" ao ser coberta por massas sem sugestão de volume). 


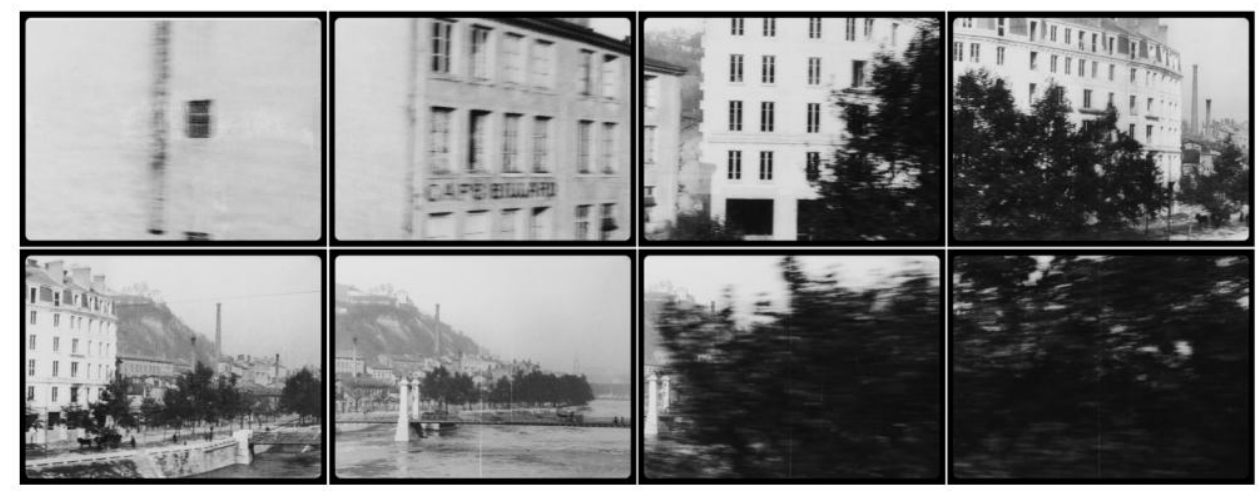

Panorama de l'arrivée en gare de Perrache pris du train (1896)

3. Em Panorama pendant l'ascension de la Tour Eiffel (1897), a câmera é posicionada não sobre um trem, mas no elevador da Torre Eiffel, com vista para o Palais du Trocadéro. Durante todo o plano, o palácio é visível na mesma região da tela, marcando um horizonte levemente inclinado à direita. A ascensão da câmera no elevador, próxima à estrutura metálica da torre, faz com que os cabos e as vigas funcionem como grades em constante movimento, alternadamente encobrindo e emoldurando a visão da paisagem. Como no exemplo anterior, as linhas retas que cruzam a tela funcionam como massas de tons escuros que às vezes se abrem à visão e às vezes a obstruem. A diferença é que, aqui, o fundo permanece o mesmo. O resultado é a movimentação incessante dos objetos entre a câmera e a paisagem de fundo. Como a estrutura da torre é a única referência dada entre a câmera e a paisagem, a impressão é de que, não fossem as breves tremidas na câmera, apenas os cabos e as vigas estariam se movendo perante uma câmera estática.

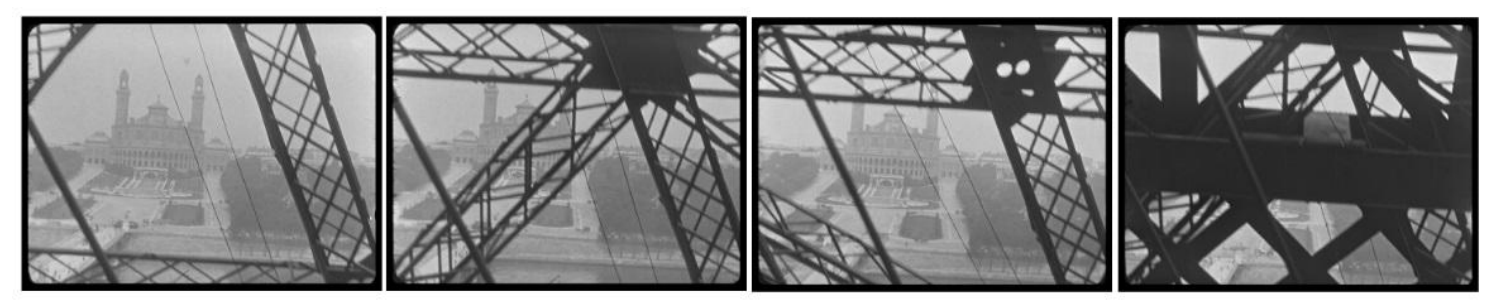

Panorama pendant l'ascension de la Tour Eiffel (1897)

O que estes filmes compartilham é que em todos eles a câmera está posicionada num veículo, com um ângulo fixo em relação à paisagem, e por isso as transformações visuais são inteiramente dependentes do ângulo da câmera, da organização espacial da paisagem e da velocidade da travessia. Seja um movimento frontal sobre trilhos que alterna linhas retas e curvas; seja um movimento lateral, num ambiente que alterna 
objetos próximos e distantes da câmera; seja um movimento vertical, mantendo o fundo constante enquanto a região mais próxima da câmera é modificada por linhas diagonais: em todos esses casos, é o deslocamento da câmera em relação a um espaço fixo que caracteriza a composição. Assim como as animações do capítulo anterior exploravam as coordenadas da tela como um ambiente onde figuras poderiam ser dispostas e transformadas, aqui há uma exploração das coordenadas do espaço tridimensional no qual a câmera pode ser disposta e a busca por formas de realizar esta movimentação de maneira claramente direcionada. ${ }^{171}$

Podemos nos perguntar se há algo na própria impressão de movimento oferecida pelos filmes que sugira o fato de a câmera se mover, e se há resultados em que o movimento pode sugerir um efeito semelhante mas tendo sido realizado em outras condições de produção. O problema envolve o que psicólogos chamam de "paralaxe do movimento". O movimento de câmera é um movimento subjetivo, ou seja, é um movimento do próprio ponto de vista que se projeta no campo visual. A cada instante, cada um dos objetos no campo visual possui uma distância específica em relação a este ponto. A condição básica para que ocorra a paralaxe do movimento, ou o "efeito do movimento de câmera", é que exista uma velocidade angular diferencial entre a linha de visão até um objeto e a linha de visão até qualquer outro objeto no mesmo campo visual. Para que o efeito ocorra, a paralaxe deve ser percebida em todo o campo; se apenas um objeto gera uma velocidade angular diferencial no decorrer do tempo, então o movimento da câmera não será percebido - apenas o movimento daquele objeto. ${ }^{172}$ Isso significa que, na filmagem de um plano, as situações em que o efeito é criado devem envolver necessariamente a movimentação de todos os objetos no campo visual. Pode-se mover de fato a câmera, mas pode-se buscar situações em que a câmera não se move e a mesma configuração é alcançada. Um exemplo seria a câmera dentro de um trem estacionado, enquadrando parte de uma janela, como uma moldura ao enquadramento, e mostrando do lado de fora outro trem, que se encontra em movimento: neste cenário, a ausência de

${ }^{171}$ Para mais sobre o contexto histórico e algumas das principais tendências de movimentação da câmera no primeiro cinema, ver Flávia Cesarino Costa, $O$ primeiro cinema: Espetáculo, narração, domesticação (Rio de Janeiro: Azougue, 2005), pp. 155-167.

172 Ver David Bordwell, "Camera Movement and Cinematic Space", Ciné-Tracts, vol. 1, n. 2 (verão de 1977), pp. 21-22. Para mais sobre a paralaxe do movimento, ver James J. Gibson, The Perception of the Visual World (Cambridge, Mass.: Riverside Press, 1950), pp. 116 ss. 
referências adicionais faria com que o espectador identificasse o movimento do outro trem como um movimento da própria câmera. ${ }^{173}$

A essa propriedade espacial, podemos acrescentar uma propriedade temporal do plano, diretamente ligada à região do espaço excluída pelo enquadramento e que, nestes casos, ganha uma importância ainda maior pela presença do movimento: o fora-decampo. Consideremos, por exemplo, as posições de câmera possíveis num trem em movimento e os resultados prováveis de cada uma delas. Se a câmera está fixa na frente do trem, pode-se ver "o que vem a seguir" como um grande potencial espacial sendo atualizado progressivamente, e tendo como limite apenas o alcance da visão da câmera. Se a câmera está fixa na parte de trás do trem, pode-se ver apenas "o que já passou", como um grande acúmulo, num afastamento gradativo, também mantendo como limite o alcance da visão da câmera. Nesses dois casos, as surpresas são restritas aos limites da imagem - a "atualização" do movimento ocorre, respectivamente, no ponto de fuga e nas bordas. Mas se a câmera está ao lado do trem, como na visão de um passageiro olhando pela janela, a paralaxe faz com que (1) quanto mais distantes da câmera estejam os objetos, menos eles pareçam se mover, e (2) quanto mais próximos estejam da câmera, mais rapidamente eles atravessem o campo. No limite, o espectador é capaz de ver apenas o que está passando naquele exato instante em frente à câmera. Posicionar a câmera na parte de cima do trem (voltada para o céu) ou na parte de baixo (voltada para o chão) radicalizaria esses dois fatores. Nesses casos, a "atualização" do movimento, e consequentemente do fora-de-campo, ganharia outro sentido. ${ }^{174}$

Essa relação entre o fora-de-campo e a "temporalização do plano" é resumida por Jacques Aumont:

O quadro é, antes de tudo, limite de um campo, no sentido pleno que o cinema nascente não tardaria em conferir à palavra. O quadro centraliza a representação, focaliza-a sobre um bloco de espaço-tempo onde se concentra o imaginário, ele é reserva desse imaginário. Acessoriamente [...], ele é o reino da ficção e, aqui, da ficcionalização do real. Corolariamente, o quadro é o que institui um fora-de-campo, outra reserva ficcional onde o filme vai buscar, se for o caso, determinados efeitos necessários a um novo impulso. Se o campo é a dimensão e a medida espaciais do enquadramento, o fora-decampo é sua medida temporal, e não apenas de maneira figurada: é no tempo que se manifestam os efeitos do fora-de-campo. $\mathrm{O}$ fora-de-campo como lugar do potencial, do

\footnotetext{
${ }^{173}$ Para mais sobre o tópico, ver Rudolf Arnheim, Film as Art (Berkeley: University of California Press, 1957), pp. 30-34. Este princípio é utilizado frequentemente em animações (sobretudo cartoons), que não recorrem a movimentos de câmera propriamente ditos. Ao recriar as condições perceptivas, estes filmes sugerem um efeito análogo.

174 Ver André Gardies, L’espace au cinéma (Paris: Méridiens Klincksieck, 1993), pp. 31-33.
} 
virtual, mas também do desaparecimento e do esvaecimento: lugar do futuro e do passado, bem antes de ser o presente. ${ }^{175}$

Os casos mencionados aqui levam essas características a graus elevados por se tratarem de veículos em alta velocidade. Mas o princípio permanece no caso de uma câmera realizando um travelling ou posicionada sobre uma grua. As características identificadas em cada uma das angulações nos servem como referência: pode-se naturalmente realizar a passagem de um ângulo a outro no decorrer de um único plano, como pode-se realizar movimentos que não exibem um direcionamento tão claro. O importante a ser notado é que, ao destacar as propriedades dos casos mais simples, temos referências das principais tendências e das coordenadas básicas da movimentação da câmera.

\subsection{Causalidade e reversibilidade}

Os filmes que mencionamos dos Lumière são normalmente tratados como registros "documentais". Os planos são às vezes referidos como "vistas", no sentido de representarem "um olhar sobre o mundo". Já no primeiro ano em que divulgaram o cinematógrafo, entretanto, o catálogo dos Lumière conta com pelo menos um caso distinto e importante para compreender algumas possibilidades do plano.

Arroseur et arrosé (Louis Lumière, 1895) nos mostra um homem regando um jardim. O enquadramento é o que chamamos hoje de "plano médio". O homem é visto de corpo inteiro na região central da imagem. A mangueira que ele usa para regar o jardim é como uma linha que surge no canto inferior direito e atravessa a tela horizontalmente. A vegetação do jardim é vista numa disposição diagonal e no fundo há um muro, atrás do qual pode-se ver uma série de árvores. A ação é interrompida pelo surgimento de um garoto: entrando no campo pelo lado direito, ele pisa na mangueira, impedindo a saída da água. O regador, confuso, observa a mangueira, finalmente aproximando-a de seu rosto. Neste momento o garoto retira o pé da mangueira, fazendo com que a água volte a correr e atinja o rosto do regador. Percebendo a brincadeira, o homem corre atrás do garoto, que tenta fugir no jardim mas é pego e carregado até a região onde estavam inicialmente.

\footnotetext{
75 Aumont, $O$ olho interminável, op. cit., p. 40 (grifos nossos). Aumont comenta também a importância da concepção psicofísica de Gibson na definição do campo e do fora-de-campo. Ver Aumont, A imagem, op. cit., p. 53: "[essa concepção] supõe que se avaliem as variações das estruturas da imagem retiniana ao referi-las a uma continuidade (a das superfícies) e a uma constância (a dos objetos); em particular, os objetos momentaneamente fora de vista continuam a ser concebidos como existentes."
} 
Após bater no garoto algumas vezes, o homem retoma suas atividades e o plano é encerrado com ele regando as plantas.

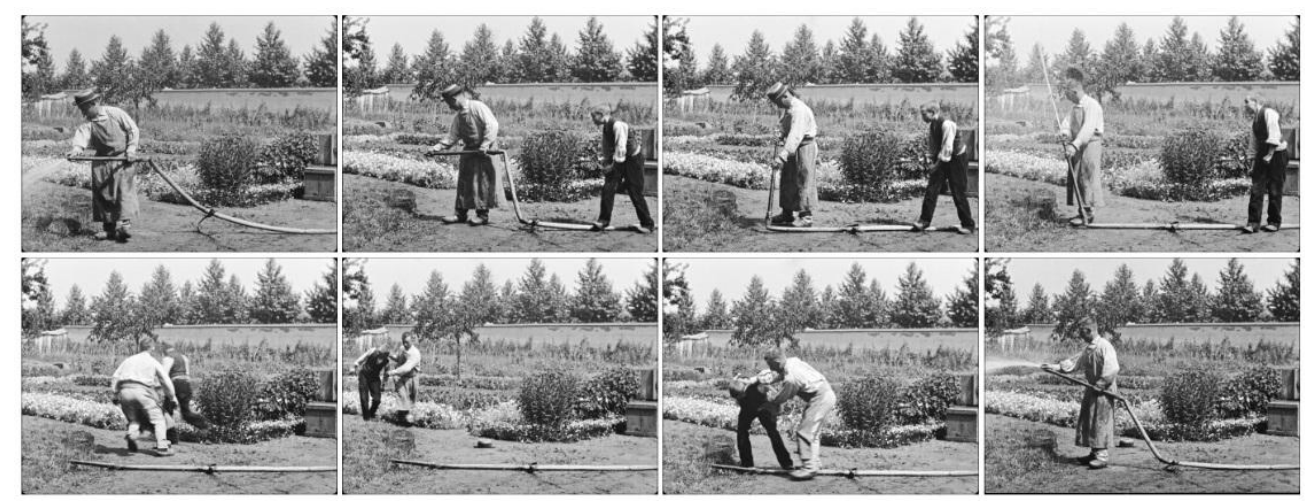

Arroseur et arrosé (Louis Lumière, 1895)

As diferenças em relação aos planos das seções anteriores são evidentes. Sai de cena a arquitetura urbana, entra o ambiente do campo. Saem as multidões das ruas, entram duas pessoas num jardim. Saem o movimento dos veículos e da câmera, entra uma ação isolada perante a câmera estática. Permanecem a ontologia fotográfica, a tela centrífuga, o tempo real, mas surge outro tipo de desenvolvimento, um recorte que cria outro tipo de linearidade. Há aqui algo que nos aproxima da ideia de narrativa.

O que é preciso para que um plano tenha o estatuto de narrativa? André Gaudreault propõe como ponto de partida a definição de Claude Brémond para narrativas verbais: "A mensagem deve representar um sujeito (animado ou inanimado) num tempo $t$, depois num tempo $t+n$, e o que torna-se o sujeito no momento $t+n$ deve resultar dos predicados que o caracterizam no momento $t . " 176$ Um elemento que a cada etapa segue as implicações da etapa anterior sugere uma noção de causalidade. É algo semelhante que percebemos em Arroseur et arrosé. Cada uma das fases de sua descrição serve como uma configuração de sujeitos; mesmo observando apenas fotogramas dessas configurações, somos capazes de reconstruir o sentido das ações, os "predicados que as caracterizam". Assim como Survage desenhou apenas as etapas dos movimentos que desejava representar em seu projeto, aqui as ações são encenadas de modo que as etapas são destacadas como poses marcantes no movimento geral do plano. Diferente de Survage, os Lumière não necessitam deduzir graficamente a passagem de um momento a outro - a

\footnotetext{
176 André Gaudreault, "Film, Narrative, Narration: The Cinema of the Lumière Brothers", in Early Cinema: Space, Frame, Narrative, ed. Thomas Elsaesser (Londres: BFI, 1990), p. 68.
} 
câmera o faz automaticamente, registrando-a com a própria fixação desses momentos na película.

Uma questão se coloca, entretanto. Se o conceito "realista" do plano é baseado na correspondência de seus movimentos com os movimentos da realidade, e se a causalidade é uma propriedade do mundo físico, não seria a causalidade uma decorrência natural de todo e qualquer plano? Se sim, a causalidade não bastaria para caracterizar uma narrativa - todo plano seria igualmente narrativo, e a expressão perderia seu valor. Isso pode ser abordado a partir das diferenças entre Arroseur et arrosé e L'Arrivée d'un train à la Ciotat. A chegada do trem à estação é também um evento cuja causalidade é inegável; observar um fotograma do filme nos levaria à conclusão de que foi causado pelos "predicados que caracterizam" os fotogramas anteriores. O "rigoroso determinismo" que Bazin identifica na tecnologia fotográfica se estende à fixação do movimento nos fotogramas. Aqui, Gaudreault reconhece que é necessário um acréscimo para a distinção entre os dois casos, uma definição da "mínima trama possível" ou a condição necessária para uma narrativa. A definição é proposta por Todorov:

A mínima trama possível pode ser vista como a passagem de um equilíbrio a outro. Este termo, "equilíbrio", que pegamos emprestado da psicologia genética, significa a existência de uma relação estável, mas não estática, entre os membros de uma sociedade; é uma lei social, a regra de um jogo, um sistema particular de trocas. Os dois momentos do equilibrio, semelhantes e diferentes, são separados por um periodo de desequilíbrio, que é composto por um processo de degeneração e um processo de regeneração. ${ }^{177}$

L'Arrivée d'un train à la Ciotat, como os outros filmes da seção anterior, não parece se adequar a essas condições. Há sequencialidade e transformação no filme; há um momento $t$ que nos conduz a um momento $t+n$, que é a causa deste momento seguinte; mas não há “passagem de um equilíbrio a outro". A tendência exibida naqueles filmes é o que Noel Burch chamou de policentrismo, "o enquadramento que geralmente dá um amplo espaço para o desenvolvimento da ação em todas as direções" e que "poderá capturar tanto quanto possível um momento da realidade", filmando "sem qualquer tentativa de controlar ou centralizar a ação". ${ }^{178}$ Nesse sentido, o "sujeito" dos filmes é simplesmente

177 Tzvetan Todorov e Arnold Weinstein, "Structural Analysis of Narrative", NOVEL: A Forum on Fiction, vol. 13, n. 1 (outono de 1969), p. 75 (grifos nossos).

178 Noel Burch, "Charles Baudelaire versus Doctor Frankenstein", in Life to those Shadows (Berkeley e Los Angeles: University of California Press, 1990), pp. 17-19. Esta é uma versão do artigo "Charles Baudelaire versus Doctor Frankenstein", Afterimage 8/9 (primavera de 1981). 
"uma listagem exaustiva de tudo o que pode ser visto na imagem". Se eles "narram" alguma coisa, é a própria passagem do tempo dentro desses recortes.

É diferente o caso de Arroseur et arrosé. Aqui, há uma hierarquização dos elementos. A decisão por um cenário isolado dos grandes movimentos urbanos é crucial; é o que diminui o número de movimentos, que reduz a apenas dois os elementos humanos, que permite também a centralização da ação. Os eventos humanos são colocados em primeiro plano, numa distância menor em relação à câmera, enquanto os eventos naturais tornam-se o fundo. Mesmo a grade geométrica das "vistas" urbanas é reduzida à linha horizontal do muro no fundo da imagem e às diagonais sugeridas pela textura consideravelmente menos nítida do jardim. Dentro desse enquadramento os critérios de uma narrativa, na acepção de Todorov, são mais claramente percebidos. O início e o final do plano são correspondentes no sentido de que ambos mostram um "estado de equilíbrio" - estável, mas não estático. Entre os dois momentos há "um processo de degeneração" e "um processo de regeneração" - o surgimento de um conflito e a resolução deste conflito. A simetria é reforçada pela entrada do garoto no início e a saída dele no final do plano.

Os filmes da seção anterior parecem operar na suposição de que, se o filme é projetado linearmente, se há uma "direção vetorial específica" na projeção da obra, então isso pode organizar, pode mesmo ser a moldura e o sentido do evento representado: o plano, como um todo, torna-se um "evento em linha reta". Arroseur et arrosé, por sua vez, parece supor que, se há essa linearidade, se há uma sucessão de eventos num mesmo recorte, pode-se compor algo sobre a ligação necessária desses eventos, sobre a posição que eles devem constituir na projeção: o plano torna-se, então, o registro de um macroevento em linha reta, mas dentro do qual há outro evento, um "micro-evento", cuja linearidade é de outra ordem e que ocorre inclusive numa divisão temporal (uma divisão em etapas) que não é necessariamente a do registro como um todo. Aqui há uma analogia com a relação entre os filmes do primeiro capítulo - os filmes "sem imagem" - e os filmes do segundo capítulo - as animações abstratas. Se nos primeiros o movimento da película tinha como único índice a frequência de modificação da tela (considerada em bloco), os segundos incluem outro fator, a frequência das transformações e dos deslocamentos das figuras. As vistas urbanas dos Lumière consideram também o plano "em bloco", ao passo que suas encenações incluem dentro dessa mesma realidade um evento destacado, que cria um ritmo distinto. 
Os Lumière retomaram a trama de Arroseur et arrosé em outras ocasiões, variando minimamente o ângulo da câmera e a distância em relação aos dois personagens. Eles filmaram outras situações com o mesmo caráter "encenado", e tanto nas pequenas "ficções" (geralmente cômicas) como nos registros de ações "documentais" são mantidos nestes planos sempre os princípios da ação centralizada e da hierarquia dos movimentos. Demolition d'un mur (Louis Lumière, 1897), por exemplo, possui também um evento claramente destacado pela mesma disposição e hierarquização espacial, com etapas identificáveis e uma relação de causalidade entre elas. No centro da imagem, Auguste Lumière, de costas para a câmera, observa um grupo de homens que se esforçam para derrubar parte de um muro de concreto. Após alguns segundos, o esforço é recompensado: o muro, já quebrado, é gradualmente inclinado para a direita do quadro até que finalmente cede e desaba, elevando do chão, por seu impacto, uma nuvem de poeira. O plano termina com os trabalhadores golpeando com picaretas o muro caído.

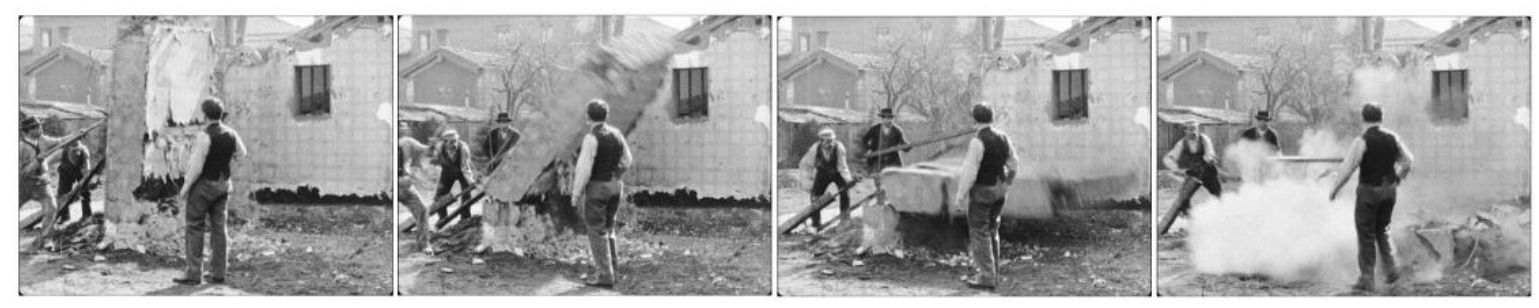

Demolition d'un mur (Louis Lumière, 1897)

Assim como em Arroseur et arrosé, a "trama" aqui é enraizada na realidade do registro, o que nos permite inferir e prever os eventos conforme avançamos em seu desenvolvimento. Identificamos as causas e esperamos os efeitos, assim como esperamos as reações dos homens presentes a eles. A "trama", por mais rudimentar que seja, nos dá referências temporais. Lembremos que a presença da música foi uma das qualidades apontadas por Mitry em algumas das animações abstratas - sem elas, Mitry não via "sentido" no desenvolvimento dessas obras, pois não haviam justamente referências temporais e relações de "necessidade" na organização visual. Se a música era um paradigma de estrutura temporal inteiramente "construída", o plano abre a possibilidade de construir sobre a estrutura temporal "natural". Ao destacar ações com um direcionamento claro, especialmente com início e fim delineados por uma cadeia de causas e efeitos, os Lumière parecem descobrir algo como as melodias naturais da 
realidade, processos que exemplificam o caráter unidirecional do plano cinematográfico mas que possuem também uma curva de expectativa e realização.

Outra característica importante foi explorada pelos Lumière em relação a Demolition d'un mur. Além do plano original, foi impressa também uma versão invertida do mesmo registro, ou seja, com os mesmos exatos fotogramas, mas dispostos na ordem contrária. Esta segunda versão inicia justamente com o que parecem ser os golpes de picareta no muro caído, exceto que agora os golpes parecem acrescentar em vez de retirar fragmentos ao muro. A poeira se acumula gradualmente ao redor dos pedaços de concreto, se concentra cada vez mais até se tornar uma grande massa densa e luminosa no centro da imagem, quando parece entrar no muro, que é repentinamente erguido à posição vertical. O plano termina com os trabalhadores golpeando o muro, sendo observados por Louis Lumière.

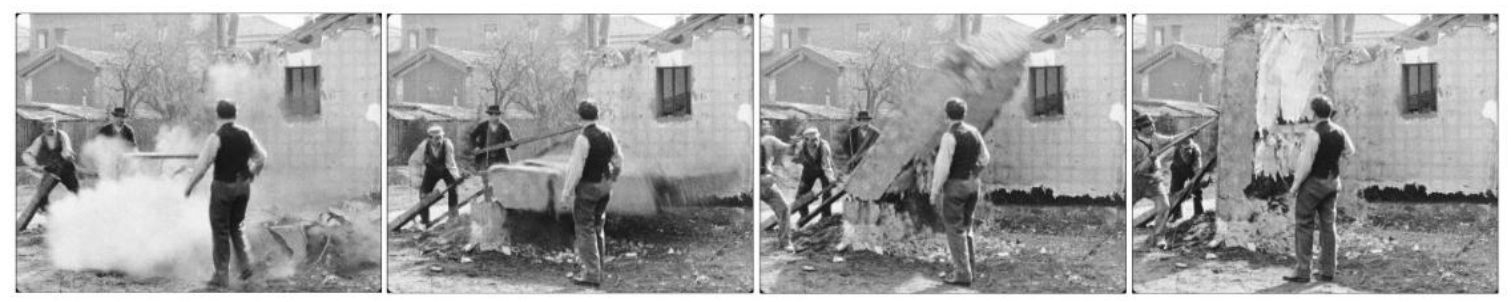

Demolition d'un mur (Louis Lumière, 1897) - a versão invertida

O resultado disso é que, mesmo invertendo a causalidade do plano, permanece seu caráter linear. Na verdade, permanece mesmo algo de sua causalidade, ainda que em outra chave. Considerando a definição de Brémond, há em cada instante $t$ a realização dos predicados do evento $t+n$. Em cada instante nos é possível inferir, com base na configuração das ações, o que deverá ocorrer em seguida. $O$ fato de que as ações não estão acordo com a realidade física não impede essa relação - não são ações caóticas e imprevisíveis que encontramos neste caso, mas ações submetidas à mesma "direção vetorial" do plano original. Na medida em que Demolition d'un mur é um caso típico de um processo registrado de maneira centralizada, o filme nos serve como forma de tocar numa propriedade do plano como um todo. A reversibilidade do movimento registrado nos mostra que, na captura do mundo pela tecnologia fílmica, um evento pode gerar seu contra-evento; e que, se relações de causalidade são perceptíveis em um deles, a inversão de sua linearidade torna perceptível algo como a retrocausalidade, um princípio que, 
mesmo fisicamente impossível no espaço profílmico, é logicamente concebível dadas as condições da representação no cinema. ${ }^{179}$

Essa diferença entre "o mecanismo do intelecto humano" e "o mecanismo de apreensão e expressão cinematográficas" foi um dos pontos de interesse de Jean Epstein, que propôs já nos anos 1920 uma série de reflexões direcionadas à exploração desse problema. O principal argumento de Epstein é que na mente humana as noções de espaço e tempo possuem alguma independência uma em relação à outra, enquanto no cinema elas devem necessariamente ser apresentadas em conjunto. "O homem”, nos diz Epstein, "é capaz de manter a imagem de uma pose ou a memória de um enunciado presente na mente por vários segundos ou ainda mais, desde que sua atenção não se canse, como se sua duração não existisse". O cinema, por sua vez, "não é capaz de dar a mesma imagem ou som sem um ritmo temporal". ${ }^{180}$ Se na compreensão humana há o espaço e há o tempo, no cinema há apenas o espaço-tempo. Longe de considerar um defeito do cinema, Epstein reconhece aqui uma abertura para o uso das técnicas que transfiguram o espaçotempo como normalmente o entendemos. A inversão do movimento é uma dessas técnicas: se na realidade as causas produzem necessariamente os efeitos, e se alguns eventos são determinados necessariamente pelo movimento seguido da estase, o cinema nos possibilita representar expressivamente "os efeitos produzindo as causas" e a estase produzindo o movimento.

Outro nome, diretamente influenciado pelas vanguardas europeias da qual Epstein foi contemporâneo, é o de Maya Deren, que também fez a defesa da reorganização do espaço e do tempo pela técnica cinematográfica. Sobre a inversão do movimento, especificamente, Deren levanta dois pontos. O primeiro é que, na maioria dos casos, o resultado da inversão não é simplesmente "um movimento espacialmente ao contrário", mas um "retorno do movimento". ${ }^{181}$ Em outras palavras, a percepção da causalidade como sendo redirecionada e a disjunção da orientação vetorial da projeção em relação à orientação da ação caracterizam o movimento invertido. O segundo ponto é que, por

\footnotetext{
${ }^{179}$ Para mais sobre a reversibilidade, ver Jean Piaget, Genetic Epistemology (Nova York: Columbia University Press, 1970), pp. 41 ss. Piaget define "operação" como uma "transformação reversível". A adição, por exemplo, é reversível pela subtração; um movimento para a direita é reversível por um movimento para a esquerda; etc. A reversibilidade causa-efeito é fundamental no desenvolvimento da concepção lógica pois é a internalização dessa relação complementar que nos permite inferir o encadeamento dos eventos nas duas direções. Para recorrer a um termo já utilizado aqui, poderíamos descrever a reversibilidade das operações como uma versão temporal da comutatividade.

180 Jean Epstein, "L'intelligence d'une machine" (1946), in Écrits sur le cinéma, vol. I: 1921-1947 (Paris: Éditions Seghers, 1975), pp. 311-312.

${ }^{181}$ Maya Deren, "Cinematography: The Creative Use of Reality", in The Essential Deren, ed. Bruce R. MacPherson (Nova York: McPherson \& Company, 2005), p. 121.
} 
depender de nossa percepção das coordenadas espaciais e temporais da experiência cotidiana, essa técnica só é possível em filmes com alguma base figurativa. Deren menciona em seu argumento as animações abstratas dos anos 1920 e 1930, mas devemos acrescentar que ela parece supor apenas aquelas mais voltadas à pura geometrização das figuras, como Richter e Eggeling. No caso de Fischinger e McLaren, por exemplo, a tendência orgânica cria justamente uma referência figurativa dentro do quadro abstrato, de modo que percebemos ali detalhes como a orientação gravitacional. Em princípio, a construção dessas referências nas animações não impede que também a inversão do movimento seja percebida. A observação de Deren nos leva, portanto, a uma generalização importante: para que o movimento seja percebido como invertido, ele deve primeiramente ser apresentado como um movimento "normal". O caso das animações envolve a criação das condições já mencionadas; mas isso significa também que, num registro realista, apenas movimentos que reconhecemos normalmente são percebidos naturalmente quando invertidos. Movimentos dos quais não temos referências quanto à sua "normalidade" serão vistos necessariamente como "movimentos normais", não como invertidos, ainda que o sejam de fato.

\subsection{Sob o microscópio}

A partir dessas propriedades, consideremos um dos pontos identificados nos capítulos anteriores e suas possíveis aplicações nesta dimensão. Como seria possível aplicar o "princípio da homogeneidade" no plano? A homogeneidade, como definimos no primeiro capítulo, consiste na repetição tão exata quanto possível dos elementos, minimizando suas diferenças. No limite, uma forma homogênea levaria a repetição ao nível dos fotogramas, diminuindo mesmo a sugestão da passagem da fita pelo projetor. Zen for Film exemplifica essa abordagem: nos filmes em que todo o conteúdo visual é igualado à imagem da tela, é a manutenção dessa constante, sem alterações de luz e cor, que caracteriza a homogeneidade. A inclusão de figuras abstratas na tela, como nas animações do segundo capítulo, altera a presença das formas homogêneas. Para que a homogeneidade governasse um filme como Rhythmus 21 ou Mirror Animations, ela deveria incluir cada uma das formas visíveis na tela. Nessas animações, o princípio da homogeneidade ocorre apenas em alguns momentos, quando as figuras permanecem estáticas numa posição. De maneira geral, são instantes tão breves que caracterizam mais 
as etapas de uma trajetória, a marcação de um ritmo, do que a estabilidade daqueles elementos. Em todos esses casos, a articulação composicional permanece na superfície: tanto os flickers como as animações lidam com imagens isoladas da realidade, e cuja existência é reduzida aos aspectos bidimensionais da tela - sem sugestão de volume e profundidade - e aos aspectos métricos da projeção - sem sugestão de isomorfismo com o “tempo real". Isso faz com que a repetição desses elementos possa ocorrer sem nenhum tipo de quebra na percepção espacial e temporal das obras. Pode haver o choque, mas este não é devido à mudança do tipo de realidade representado na obra, e sim aos próprios padrões visuais e rítmicos construídos.

São outros os problemas que se colocam se pensarmos a repetição aplicada ao plano. Considerando a definição proposta no início deste capítulo, o plano exibe uma relação de correspondência com a tomada; exibe, portanto, além da "ontologia fotográfica", uma relação isomórfica com o tempo da filmagem. Isso significa que o plano depende não apenas da continuidade análoga à do "tempo real", mas também da contextualização espacial que seus elementos recebem pela unificação de todo o campo visual em um só registro. Como seria possível, então, compor um plano baseado no princípio da homogeneidade?

Ao menos uma possibilidade se apresenta: reduzir o movimento no interior do plano. Reduzir todas as ações, todas as mudanças de posicionamento e luminosidade na passagem de um fotograma a outro. Se a existência do plano depende da manutenção de sua unidade espaço-temporal, da consistência desse bloco integrado, então a homogeneidade seria talvez passível de manifestação com o nivelamento de todas as etapas, todas as regiões desse bloco, como se não houvesse absolutamente nenhum relevo no tecido temporal. Aqui, como em Zen for Film, a extensão da duração poderia funcionar como um meio de "absorver" o espectador, retirando todas as referências temporais e sugerindo a presença constante e imutável do evento fílmico, mais do que seu desenvolvimento, como se o tempo "passasse" mas tal passagem não afetasse o evento em questão.

Um caso célebre que parece tangenciar a questão é Empire (Andy Warhol, 1964). O filme consiste numa série de planos com o mesmo enquadramento centralizado mostrando o topo do edifício Empire State, em Nova York. Filmados a 16 fps, os planos totalizam mais de oito horas de duração. A estratégia de Warhol leva a definição tradicional do plano ao paroxismo. Se deve haver isomorfismo temporal entre o plano e a tomada - ele parece supor -, então vejamos como se dá essa relação num filme em que 
"nada acontece". ${ }^{182}$ Nada acontece, isto é, nos termos de um evento como aqueles registrados pelos Lumière; nos termos do cinema de vanguarda há uma gama de eventos identificados como fundamentais, especialmente aqueles que tendem a reforçar o caráter material da película. "Nada acontece" com o prédio na maior parte do tempo; isso permite que a granulação do filme e os flares que invadem a tela no início e no final das tomadas ganhem ainda mais destaque. Em vez de permitir que o tempo da projeção seja absorvido pelos eventos da filmagem, Warhol faz o caminho inverso: reduzindo ao máximo as transformações nos planos, a projeção e a própria materialidade da película que é projetada tornam-se os únicos "pontos de acesso tangíveis" ao espectador. ${ }^{183}$ Com a estabilidade do profílmico, ou seja, com a homogeneidade da dimensão "profunda" do plano (espacial e temporal), é sua "superfície" (espacial e temporal) que se revela em movimento. O que se expõe com isso é a inevitabilidade da "entropia" na superfície fílmica e o fato de que as características da superfície permanecem ativas no plano. Ainda que o objeto perante a câmera seja imutável, não o é o filme que o registra.

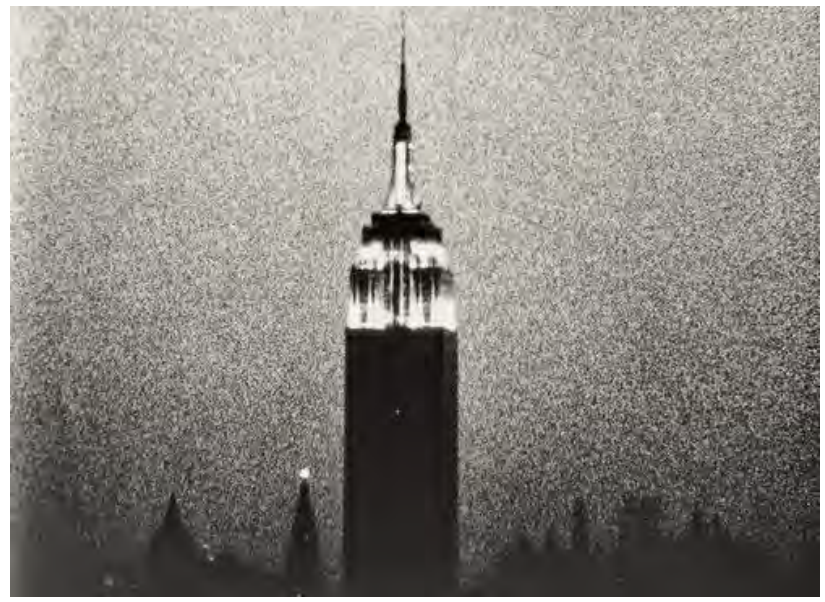

Empire (Andy Warhol, 1964)

Se tomarmos Empire como referência da forma homogênea do plano, podemos imaginar outros experimentos, testando o alcance do modelo. Seria possível que um filme levasse ainda mais longe o caráter homogêneo? Se sim, quais condições deveriam ser

${ }^{182}$ Consideramos aqui sobretudo o "projeto conceitual" representado por Empire, e alguns de seus efeitos recorrentes, mais do que a experiência completa da obra. Há acontecimentos no filme que quebram toda e qualquer noção de homogeneidade, como a revelação do edifício através da neblina, no início (o que sugere um processo), ou a repentina iluminação do edifício, no final (que é uma surpresa). Há inclusive eventos periódicos, como uma luz em outro prédio que é acendida e apagada em intervalos mais ou menos regulares. Para mais sobre os detalhes temporais do filme, ver Pamela M. Lee, Chronophobia: On Time in the Art of the 1960s (Cambridge, Mass.: The MIT Press, 2006), pp. 278-288.

${ }^{183}$ Ver Malcolm Le Grice, "Real Time/Space" (1972), Experimental Cinema in the Digital Age (Londres: BFI, 2001), pp. 156-157. 
modificadas? A câmera de Warhol registra um objeto inanimado, já sendo assim uma redução dos movimentos possíveis; porém, o registro ocorre num espaço aberto, sujeito a variações de movimento e luminosidade que fogem do controle do cineasta. Um reforço da homogeneidade seria, então, um plano num espaço fechado, iluminado artificialmente. Outra condição importante no filme de Warhol é a duração: quanto mais longa a duração, mais o filme "se abre" às variações do ambiente, além das variações da própria película. Uma versão reduzida do filme, portanto, teria provavelmente um acréscimo da homogeneidade.

Há outro projeto de Warhol que nos permite identificar propriedades correlatas do plano: os Screen Tests (1964-66), uma série de planos silenciosos com duração aproximada de três minutos, registrando sempre uma pessoa enquadrada num close-up sobre um fundo neutro, como a parede de um estúdio. Em condições distintas das de Empire, o que Warhol cria aqui é algo como um experimento laboratorial de registro das expressões humanas. Centralizando os rostos contra um fundo achatado, fixando suas posições como num retrato, ele submete cada um dos sujeitos à mesma duração, ao mesmo "teste", equivalente a uma pergunta: o que ocorre quando uma pessoa deve encarar a câmera por esse intervalo de tempo? Os planos então põem à prova cada um dos participantes, exigindo deles concentração e paciência quando talvez estivessem inclinados a reagir de forma distinta. Ampliando suas mínimas reações, o plano dá a cada ensaio de sorriso e piscar de olhos o estatuto de um evento significativo. Da casualidade de Marcel Duchamp sob uma iluminação contrastada até as lágrimas de Ann Buchanan numa imagem tomada por uma tonalidade cinzenta, a imensa variedade de fisionomias e reações capturadas pela câmera de Warhol atesta a produtividade do experimento. Se os Lumière nos fornecem um catálogo arquitetônico da Europa na virada para o século XX, Warhol nos dá um catálogo fisionômico de pessoas que visitaram a Factory em meados do século XX.
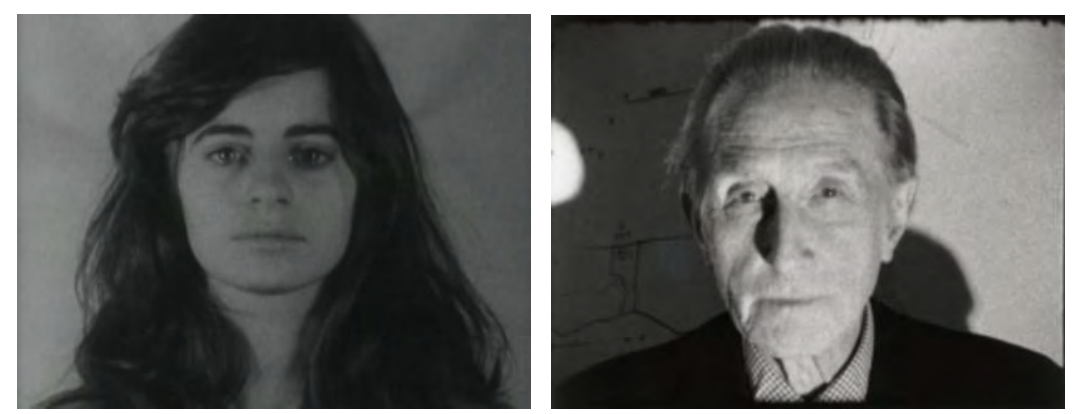

Screen Tests (Andy Warhol, 1965) de Ann Buchanan e Marcel Duchamp. 
Mais do que registrar as expressões faciais, o dispositivo de Warhol parece instigá-las, observando o rosto como sob um microscópio. Se podemos dizer que havia em Empire uma "abertura" aos eventos luminosos do mundo e da película, aqui o "mundo" é praticamente reduzido à paisagem do rosto humano. Em lugar de um objeto inanimado que era tornado uma espécie de "entidade luminosa" dentro do plano, a presença de um corpo humano, especialmente um rosto, torna inevitável a projeção de sentido, de expectativas e intenções subjacentes às expressões visíveis. E se por um lado essa tendência a expor o sujeito filmado à concretude da duração (mantendo visíveis os traços da feitura do próprio registro) rendeu a Warhol o elogio da vanguarda britânica, por outro lado o tornou objeto de ataque por um cineasta como Brakhage. Dedicado a um projeto inteiramente diferente do voyeurismo contemplativo de Warhol, Brakhage teria visto nesses filmes que, "no eixo temporal, o sintagma narrativo poderia ser restaurado, e com ele a espacialidade do corpo como objeto erótico do desejo narrativo". ${ }^{184}$ Isso é representado claramente em testes como os de Nico e Ann Buchanan: no primeiro há o tédio, a impaciência, a mudança constante da postura; no segundo há um rosto imóvel e o acúmulo de lágrimas nos olhos que se recusam a piscar; em ambos há uma interação dinâmica com o recorte, como um aumento e uma diminuição da pressão do tempo no decorrer do plano.

Essa relação entre a concentração do olhar sobre um rosto e o suspense decorrente da espera por uma reação, esse jogo entre o mecanismo da câmera e a máscara da subjetividade presente à sua frente nos leva, invariavelmente, a um termo caro a teóricos e cineastas dos anos 1920: a fotogenia. Autores como Epstein e Dulac propuseram inúmeras descrições do que caracterizaria a fotogenia; faltam, contudo, definições claras e unívocas do termo, fazendo com que permaneça ainda hoje um conceito polivalente. Podemos ao menos tentar delimitar o campo no qual a fotogenia parece manifestar-se. Epstein a define em certa ocasião como "qualquer aspecto das coisas, dos seres ou almas, cujo caráter moral é amplificado pela reprodução fílmica"; mais adiante, ele particulariza dizendo que "apenas os aspectos móveis do mundo, das coisas e das almas, podem ter seu valor moral elevado pela reprodução fílmica"; finalmente, ele afirma que "o aspecto

${ }^{184}$ Annette Michelson, “'Where is Your Rupture?': Mass Culture and the Gesamtkunstwerk” (1991), in October Files 2: Andy Warhol (Cambridge, Mass.: The MIT Press, 2001), p. 106. 
fotogênico de um objeto é uma consequência de suas variações no espaço-tempo". ${ }^{185}$ Ainda que o "caráter moral" não seja elaborado por Epstein, o mesmo argumento é retomado por ele quando as menções à fotogenia ocorrem junto com as menções ao "animismo", ou a capacidade do cinema de "atribuir vida" às coisas. Em comum, encontramos a mobilidade particular que o cinema atribui àquilo que registra, uma mobilidade associada à dinâmica da vida. Não o mero deslocamento espacial, mas um tipo de vibração especial, algo que existiria apenas na interseção entre o objeto filmado e a tecnologia que o filma. É nessa chave que Epstein faz o elogio do close-up, visto por ele como uma técnica privilegiada, uma forma de desvendar o caráter fotogênico das coisas. O que se acreditava inerte e imutável, ao ter suas proporções modificadas no registro e na projeção, ao ser visto de perto, adquire, segundo Epstein, uma vida própria. É algo desse aspecto revelatório, dessa busca pela irradiação das coisas, que encontramos nos Screen Tests de Warhol. Mesmo nos casos em que o sujeito parece "não reagir", a maneira particular como "não reage" se torna significativa na concentração do plano. ${ }^{186}$ Mesmo que a fotogenia seja efêmera, "da ordem do segundo", não ocorrendo em longas durações, o cerco estipulado por Warhol serve como armadilha para capturá-la.

Epstein faz também o elogio da câmera-lenta, que ele considera uma espécie de contraparte temporal do close-up, um microscópio que age na duração dos planos. A definição técnica da câmera-lenta envolve o aumento da frequência do registro para que, durante a projeção na frequência padronizada, o movimento seja apresentado como sendo mais lento do que de fato ocorreu. Em um de seus filmes, Finis Terrae (1929), a câmeralenta é utilizada frequentemente para mostrar as ondas quebrando nas rochas. A variedade de velocidades do registro só é superada pela variedade de tipos de ondas e de efeitos criados pela movimentação da água. O uso de metáforas líquidas é recorrente na produção teórica de Epstein, e aqui percebemos a razão da água ser um elemento marcante para a exploração da fotogenia: alternadamente etérea e furiosa, o impacto da água nas rochas ou suas gotas espalhadas no ar caracterizam uma matéria perfeitamente adequada à representação da mobilidade imprevisível. Essas características são potencializadas pela filmagem em câmera-lenta, a ponto de Epstein defender que "a qualidade resulta da quantidade", isto é, quanto mais se aumenta a velocidade da filmagem, quanto mais lento

\footnotetext{
185 Jean Epstein, “Le cinématographe vu de l'Etna” (1926), in Écrits sur le cinéma, vol. I: 1921-1947 (Paris: Éditions Seghers, 1974), pp. 137 ss. (grifos nossos).

186 Para uma discussão mais detalhada da fotogenia no contexto dos retratos filmados, ver Luiz Carlos Oliveira Junior, "Retratos em movimento", Ars, vol. 15, n. 31 (2017).
} 
é o movimento projetado, mais o evento seria adensado, e com isso mais de suas características microscópicas seriam visíveis.

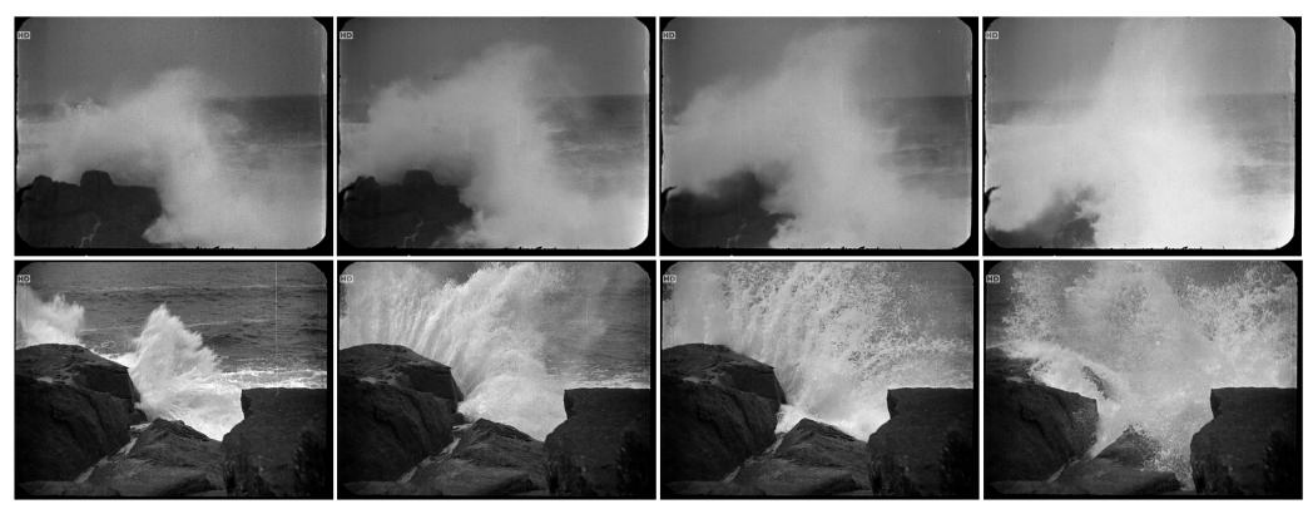

Dois planos de Finis Terrae (Jean Epstein, 1929)

A combinação do close-up e da câmera-lenta, por essa interpretação, seria praticamente uma ferramenta epistemológica. Epstein imagina um rosto sendo filmado num close-up em câmera-lenta durante um julgamento, para que as frações de segundo em que se manifestam as indecisões e os olhares desviados nos permitam acompanhar uma "microdramaturgia", levando ao encontro de uma verdade inacessível à escala humana. O desenvolvimento dessa expressividade é comentado por Béla Balázs também com uma analogia musical, tangenciando a noção que vimos anteriormente de que a música "dá sentido ao tempo":

Uma melodia é composta de notas isoladas que se sucedem umas às outras, em sequência, i.e., no tempo. Entretanto, uma melodia não possui dimensão no tempo na medida em que a primeira nota só se torna um elemento da melodia porque ela se refere à próxima e porque se coloca numa relação definida a todas as outras notas, incluindo a última. É por esta razão que, embora possa não ser tocada durante algum tempo, a última nota já está presente na primeira como um elemento criador da melodia. E a última nota completa a melodia somente porque ouvimos a primeira nota junto com ela. As notas soam uma após a outra, numa sequência temporal e, por isso, possuem uma duração real, mas a linha melódica coerente não possui dimensão no tempo; a relação das notas entre si não é um fenômeno que ocorra no tempo. A melodia não surge gradualmente no fluxo temporal, mas já existe como uma entidade completa assim que a primeira nota é tocada. De que outra forma saberíamos que uma melodia começou? As notas individuais possuem duração temporal, mas suas relações entre si, que dão significado aos sons individuais, estão fora do tempo. Uma dedução lógica também tem sua sequência, mas a premissa e a conclusão não se seguem, temporalmente, uma à outra. $\mathrm{O}$ processo de pensamento enquanto processo psicológico pode ter uma duração, mas as formas lógicas, como as melodias, não pertencem à dimensão temporal.

No momento, a expressão facial, a fisionomia, possui uma relação com o espaço semelhante à relação da melodia com o tempo. Os traços isolados, naturalmente, aparecem no espaço; mas o significado das suas relações entre si não é um fenômeno 
pertencente ao espaço, tal como não o são as emoções, pensamentos e idéias manifestos nas expressões faciais que vemos. Estas são como imagens e, ainda assim, parecem fora do espaço: tal é o efeito psicológico da expressão facial. ${ }^{187}$

Balázs se interessa pelo encadeamento das expressões faciais, do que poderíamos talvez chamar de os instantes pregnantes dos rostos filmados. Encontramos algo desse efeito num filme de Germaine Dulac, Le Souriant Madame Beudet (1923), em que os estados mentais da protagonista são representados por planos subjetivos em câmera-lenta. Num deles ela vê seu marido sentado numa mesa, empurrando um vaso de plantas; em outro, vê o marido gargalhando atrás de sua mesa. Em ambos os casos, a relação da personagem com o objeto dos planos - a insatisfação da Sra. Beudet com o marido - se manifesta em gestos banais, tornados verdadeiros atos performáticos devido à câmeralenta. $^{188}$
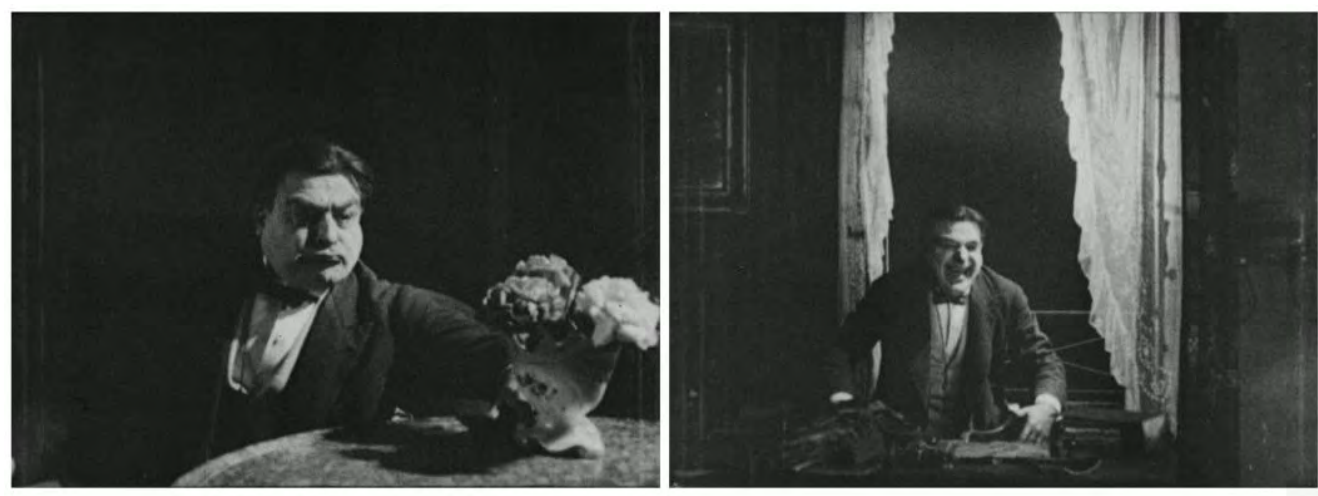

Dois planos de Le Souriant Madame Beudet (Germaine Dulac, 1923): ações simples, vistas em câmera lenta, representando a percepção subjetiva da protagonista.

O close-up e a câmera-lenta são, obviamente, técnicas amplamente utilizadas, em filmes das mais diversas procedências, atentos ou não ao potencial da fotogenia. Mas o que podemos derivar desses exemplos e das reflexões que os atravessam é que há, nos dois casos, este potencial: de que há um caráter de exploração microscópica latente no close-up e na câmera lenta, e que na modificação da escala espacial e/ou temporal certas qualidades dos objetos filmados podem ser vislumbradas ou mesmo analisadas minuciosamente. Os exemplos tratados aqui se voltam para essas qualidades como se

187 Béla Balázs, “A face do homem” (1923), trad. João Luiz Vieira, in A experiência do cinema, ed. Ismail Xavier (Rio de Janeiro: Graal, 1983), pp. 94-95.

188 É significativo que tanto no filme de Epstein como no filme de Dulac a câmera-lenta seja utilizada para mostrar eventos que os personagens observam de maneira reflexiva ou contemplativa. A identificação com esses personagens é fundamental para a trama, mas os planos em câmera-lenta são numerosos e repetitivos para além de qualquer noção de economia narrativa. As situações parecem servir como oportunidades para explorar o caráter puramente expressivo da fotogenia. 
buscassem uma lei natural - daí a concentração espacial, pelo isolamento dos sujeitos; daí o foco em eventos claramente delineados. Mencionamos os "testes" de Warhol, e há algo de experimento científico nessa linhagem. Há também toda uma gama de contrafactuais que poderíamos imaginar a partir de outros filmes, inclusive dos planos registrados pelos Lumière, e que talvez nos revelassem características inteiramente diversas caso fossem filmados por Epstein. Como nos outros casos mencionados, toda uma escala é disponível aos cineastas. Entre o close-up mais extremo e o plano mais distante de seu objeto há uma série de etapas intermediárias, como há entre a câmera-lenta mais radical e sua contraparte, a câmera mais acelerada. Se consideramos um plano e o imaginamos com a mesma duração e velocidade, mas registrado em close-up - quão diferente seria o resultado? Um plano com o mesmo enquadramento e com a mesma duração, mas registrado com o dobro ou o triplo da velocidade da projeção - quão diferente seria? Um plano com a mesma duração mas registrado em close-up e em câmera-lenta - quão diferente seria? Quão diferentes seriam estes planos se invertidos? Quais objetos e situações melhor se prestam a cada uma dessas alternativas? A partir desses questionamentos, a escolha por um plano "normal" pode ser vista não como uma possibilidade natural, mas a preferência por certas categorias espaciais e temporais como mais adequadas ao objetivo desejado.

\subsection{Estados da matéria}

O plano foi visto até aqui como um "conceito". Sabemos que trata-se de um conceito empírico, derivado da utilização recorrente desde a origem do cinema. Sabemos ainda que, em decorrência disso, grande parte dos cineastas tomou como base essa noção, compondo suas obras a partir dela como se fosse sólida e claramente delineada. Vimos algumas de suas propriedades espaciais e temporais, e como elas permitem a criação de efeitos que levam a definição inicial do plano a diferentes direções, mas ainda mantendo sua percepção como um elemento unificado. O que devemos fazer a seguir é um questionamento na direção inversa. Quais os limites desse conceito, e quais modificações podem ser feitas na concepção de plano de modo que a definição inicial seja posta em questão? Em outras palavras: em que condições e através de quais técnicas um plano deixa de ser um plano?

Antes, relembremos os pontos levantados até aqui. 
1. O plano se baseia numa correlação entre a tomada - o registro contínuo feito com a câmera - e o segmento que vemos projetado na tela. Essa correlação é ao mesmo tempo espacial e temporal. Espacial, porque a constituição do dispositivo formado pela câmera, pela lente e pelo próprio filme garantem que a imagem registrada terá uma semelhança com a imagem da realidade vista no momento da filmagem. Temporal, porque a frequência regular da filmagem é a mesma da frequência da projeção, de modo que a ação registrada ocorre como se "em tempo real".

2. O plano pode ser realizado com a câmera estática. A câmera também pode ser movimentada por diferentes meios e em diferentes direções. Cada um desses meios e direções cria efeitos espaciais e temporais específicos. Um movimento para frente e um movimento para trás, por exemplo, são opostos não apenas por seu direcionamento, mas também pelas relações temporais que estabelecem com o espaço fora-de-campo. O ângulo da câmera em relação ao campo e a direção do movimento, em conjunto, determinam quanto desse movimento será feito com referências ao que será visto a seguir e ao que foi visto antes.

3. O plano se apresenta em sucessão e frequentemente descreve um ou vários movimentos, que por sua vez podem ser decompostos em etapas. $\mathrm{O}$ fator temporal faz com que a causalidade seja uma das categorias básicas para compreender essa dimensão sequencial do plano. Um subconjunto desses movimentos pode ser ainda classificado como possuindo uma "mínima trama possível", ou seja, como a passagem de um estado de equilíbrio a um estado de desequilíbrio, e deste a um novo estado de equilíbrio - o que caracterizamos como uma narrativa. Esse encadeamento, causal e/ou narrativo, pode ainda ser invertido, mantendo o aspecto linear mas criando um "vetor retrogradativo".

4. O plano lida necessariamente com escalas e proporções, tanto no espaço como no tempo. Espacialmente, a distância do plano em relação ao objeto que registra permite desde um olhar amplo sobre vários eventos simultâneos, até um olhar concentrado num único evento. Temporalmente, a velocidade do plano pode ser alterada não só pelo registro de eventos com velocidades distintas, mas pela própria velocidade do registro que pode ser elevada ou diminuída, fazendo com que, ao ser projetado, o registro pareça mais lento ou mais rápido que o evento normal, criando efeitos inacessíveis à percepção humana.

No eixo do espaço, o plano se estende pelo enquadramento: seus limites são suas bordas. No eixo do tempo, o plano se estende por sua duração: seus limites são os pontos inicial e final da tomada. Entre esses limites, há o movimento interno do plano, cuja 
velocidade é determinada pela frequência do registro. Consideremos então algumas possibilidades de revisão dos critérios utilizados na definição inicial.

\subsubsection{Questionamento e afirmação das bordas}

A distinção proposta por Bazin entre a pintura e o cinema envolve o que ele chamou de "ontologia fotográfica", uma ligação entre a realidade do espaço profílmico e a realidade da imagem projetada. A ontologia fotográfica é a base do "espaço centrífugo" ao qual Bazin dá preferência: é neste espaço, neste campo aberto, potencialmente infinito, que encontramos a definição tradicional do plano. Se os limites espaciais do plano são as próprias bordas da imagem, questionar esses limites seria equivalente a questionar a presença limitadora dessas bordas. Isso é geralmente sinônimo de atrair a realidade do fora-de-campo, recorrendo a métodos que façam essa realidade invadir e influenciar o conteúdo interno do plano, tornando a "realidade fílmica" uma extensão da "realidade como um todo". Vimos como alguns filmes dos Lumière servem como exemplos dessa tendência, mantendo nas bordas da imagem uma atividade constante. Seja por movimentos de pessoas ou veículos, seja pela movimentação da própria câmera, o que encontramos nesses filmes é algo da ordem do efêmero, do transitório, a impressão de que a configuração particular que identificamos como um enquadramento nada mais é que um instante entre outros, e que este recorte nos permite no máximo vislumbrar a pulsação da realidade através de um olhar direcionado.

Há toda uma linhagem, da qual a exegese foi realizada em grande parte pela crítica francesa, que nos sugere os desenvolvimentos possíveis das premissas consideradas pelos Lumière. O Jean Renoir de Um dia no campo (Une partie de campagne, 1936) é talvez o exemplo quintessencial no início do cinema sonoro: um filme repleto de planos que registram o movimento da natureza ao redor dos personagens, capturando as variações luminosas ao fundo das pequenas tramas de sedução e traição. $\mathrm{O}$ plano célebre é o de Sylvia Bataille no balanço, um plano sem grandes funções narrativas, que se volta inteiramente à expressividade de um rosto no centro da imagem, enquanto a câmera - posicionada no próprio balanço - testemunha a passagem das folhas ao fundo e 
as variações de luz e sombra em formas absolutamente imprevisíveis. ${ }^{189}$ Bazin e outros críticos dos Cahiers du cinéma farão ainda o elogio da profundidade de campo e do plano-sequência como ferramentas necessárias para a construção de um "realismo espacial", supondo que o mundo perante à câmera é palco de toda a complexidade e ambiguidade, e que o papel de um cineasta se restringe a conduzir eventos já existentes, ainda que direcionados pela ficção. A montagem, por consequência, torna-se algo como um pecado original: o corte no fluxo do espaço-tempo que invariavelmente traz a articulação suplementar do registro e com isso a contribuição do artista nesta arte que havia sido destinada a reconstruir o mundo à sua própria imagem. Em sua crítica da montagem, Bazin formula um verdadeiro teorema da vocação realista do plano: "Quando o essencial de um acontecimento depende de uma presença simultânea de dois ou mais fatores da ação, a montagem fica proibida". ${ }^{190}$

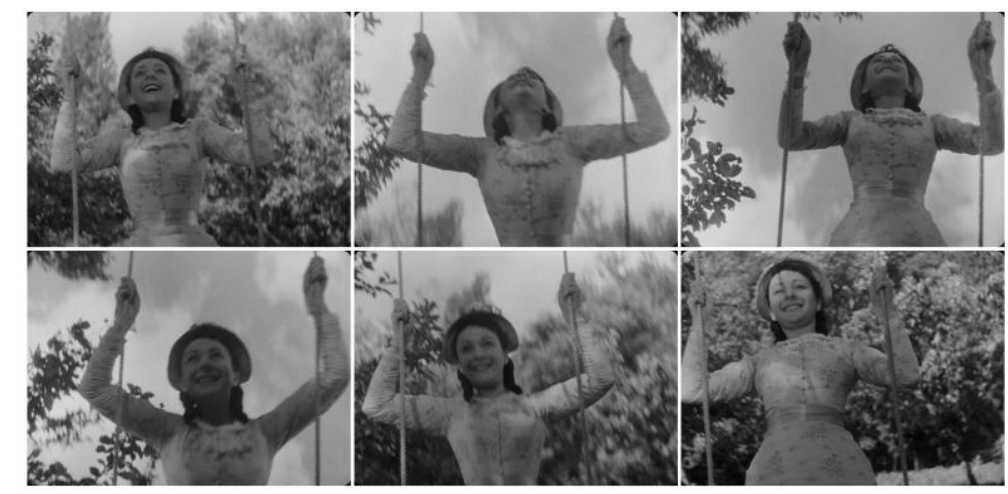

Um dia no campo (Une partie de campagne, Jean Renoir, 1936)

A crítica correspondente fará então o elogio do risco tomado pelo cineasta nesta exploração, da aposta com as inúmeras variáveis da realidade. Neste jogo, a moeda é atirada para o alto e a própria incerteza de seu resultado torna-se a fonte de interesse. Uma das metáforas que expressa diretamente essa preocupação é dada por Jean-Claude Biette ao dizer que, em alguns filmes, a passagem de uma borboleta não interrompe o

\footnotetext{
${ }^{189}$ Noel Burch analisa Nana (Jean Renoir, 1926) com foco nas entradas e saídas de quadro, e usa o filme como exemplo paradigmático do fora-de-campo tornado um princípio composicional ativo. Apesar de Burch se referir ao que consideraremos aqui o "espaço fílmico" (o espaço criado pela articulação de um conjunto de planos), seu comentário é igualmente válido para a análise de planos isolados no filme de Renoir. Ver o segundo capítulo de Noel Burch, The Theory of Film Practice (Princeton: Princeton University Press, 1981), pp. 17-31.

${ }^{190}$ André Bazin, "Montagem proibida", op. cit., p. 92. Outro caso que nos permite observar a elaboração deste raciocínio, ainda que com discordâncias em relação a Bazin, é o de Jacques Rivette. Ver, por exemplo, "L’âge des metteurs en scène", Cahiers du cinéma 31 (janeiro de 1954), pp. 45-48; "Lettre sur Rossellini", Cahiers du cinéma 46 (abril de 1955), pp. 14-24; "Notes sur une révolution", Cahiers du cinéma 54 (Natal de 1955), pp. 17-21.
} 
drama, mas "o ilumina". ${ }^{191}$ Aqui, a rendição do controle do cineasta à dinâmica do mundo é um valor positivo.

É recorrente por isso a menção ao aspecto "documental" da ficção, como se a ontologia fotográfica desse à construção narrativa uma atualidade única, no sentido de que veríamos se desvelar sobre a tela a frequência mesma nas quais as ações foram registradas. Na profusão de gestos espontâneos e que convidam à interação entre a câmera e os atores, um cineasta como John Cassavetes serve também como um dos vetores típicos da concepção "realista". Dedicado à investigação da performance de seus atores, utilizando a câmera como um sismógrafo emocional, Cassavetes é capaz de, num filme como Faces (1968), movimentar o enquadramento pelo cenário em busca dos instantes pregnantes ou fotogênicos, como se não só a realidade física mas o próprio drama excedesse em vários graus de magnitude a capacidade de um enquadramento fixo. Um crítico como Jean-Louis Comolli não deixará de notar como a inscrição desse deslocamento incessante se dá pelo transbordamento das qualidades internas - espaciais e temporais - desses planos:

tal atenção extrema ao instante, aos ângulos diferentes do instante, tem por efeito dilatar e amplificar a duração de todas as coisas, a dimensão de todo ser, enfatizar ou exacerbar as ações, os olhares, os gestos. O efeito de tempo real produz, paradoxalmente, uma tensão, uma histerização da duração. As intensidades são levadas ao extremo. Os corpos, exageradamente aquecidos. A hipersensibilidade dos corpos acelera a confusão dos sentimentos. ${ }^{192}$

191 Ver Jean-Claude Biette, "Le papillon de Griffith" (1986), in Poétique des auteurs (Paris: Cahiers du Cinéma, 1988), p. 146. Será também por isso que a mesma tradição fará a crítica das manipulações do contínuo espaço-temporal. Ver, por exemplo, André Bazin, "Morte todas as tardes" (1949), in $A$ experiência do cinema, op. cit., p. 134, onde um limite ético é mencionado em relação à inversão do registro, e Jean-Claude Biette, "Malédiction du photogramme" (1986), in Poétique des auteurs, op. cit., p. 129, onde o congelamento da imagem é visto negativamente como uma quebra na integridade da realidade.

192 Jean-Louis Comolli, "Mais verdadeiro que o verdadeiro: O cinema de John Cassavetes e a ilusão da vida" (1994), trads. Augustin de Tugny, Oswald Teixeira e Ruben Caixeta, in Ver e poder - A inocência perdida: Cinema, televisão, ficção, documentário, orgs. César Guimarães e Ruben Caixeta (Belo Horizonte: UFMG, 2008), p. 228. 


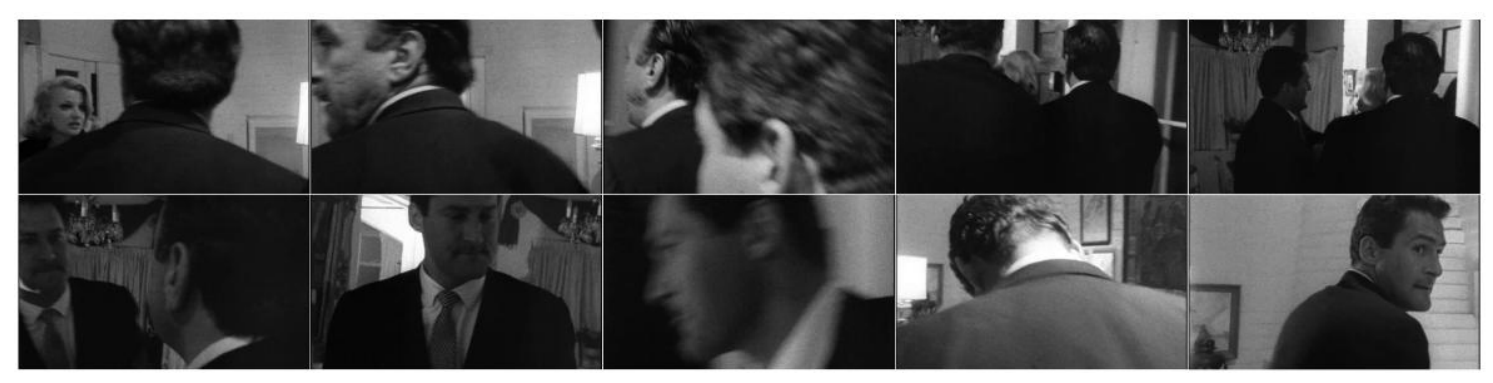

Um plano de Faces (John Cassavetes, 1968), em que a câmera, operada manualmente, segue o deslocamento dos atores, alterando a escala e o ângulo do enquadramento conforme eles reagem às ações uns dos outros.

Se o questionamento dos limites espaciais do plano leva a essa linhagem, a que filmes nos levaria a afirmação desses limites? A contraparte centrípeta do espaço de Bazin seria a negação do fora-de-campo, a afirmação da imagem projetada como um quadro autônomo. ${ }^{193}$ Os modelos para isso são as abstrações vistas no capítulo anterior. Como imagens "construídas", mais do que "registradas", elas exemplificam eventos que não podem ocorrer senão no espaço da tela. Mas, se o plano deve partir em alguma medida do registro contínuo, então esse caminho deverá ser feito necessariamente pela filmagem. A afirmação dos limites espaciais corresponderiam, então, àqueles registros que mais se aproximam da abstração espacial. Não necessariamente uma abstração figurativa - os objetos e eventos não necessitam ser abstratos nesse sentido -, mas sobretudo o contexto espacial no qual ocorrem os eventos.

Já no Anémic cinéma (1926) de Marcel Duchamp, uma das principais técnicas de abstração é aplicada à totalidade do filme: as imagens são isoladas num espaço negro, indistinto, que se funde à escuridão da sala onde o filme é projetado. O resultado é que vemos os discos giratórios centralizados na tela como se flutuassem num espaço sem coordenadas "reais" - reduzidos às coordenadas da própria tela. Mesmo o fato de que os discos giram e que descrevem espirais num andamento constante relaciona-se com essa recusa a sugerir um ambiente fora da tela, na medida em que tudo aponta para o centro da imagem, tudo a ele retorna na mesma frequência, de modo que observamos apenas a sucessão de objetos dispostos nesse espaço, movendo-se num ritmo hipnótico como se fossem suspensos da realidade.

\footnotetext{
193 O próprio Bazin reconhece essa dualidade, identificando "no cinema de 1920 a 1940, duas grandes tendências opostas: os diretores que acreditam na imagem e os que acreditam na realidade". Ver André Bazin, "A evolução da imagem cinematográfica", op. cit., p. 96.
} 

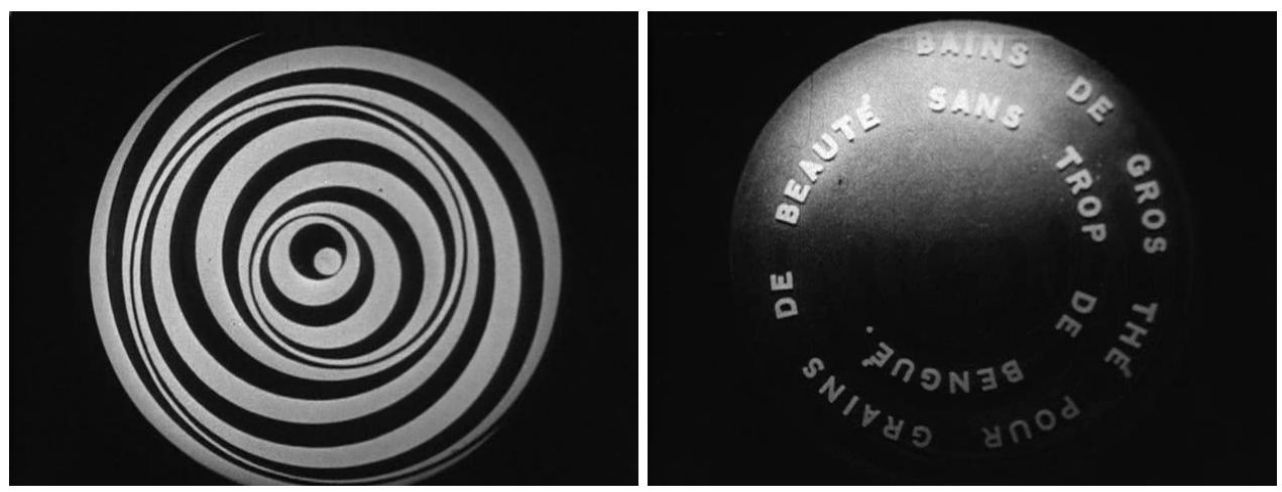

Anémic cinéma (Marcel Duchamp, 1926)

A filmografia de Jordan Belson serve como exemplo dessa mesma técnica num contexto posterior. Outra técnica de abstração é utilizada: Belson não filma objetos reconhecíveis, dando preferência a texturas gasosas e formas coloridas que alternam a clareza das figuras geométricas mais simples (geralmente círculos) com a dissolução dessas mesmas figuras em padrões nebulosos. Mais do que movimentos, seus filmes apresentam vibrações e pulsações no interior dos planos. As imagens mudam de cor, de textura, de luminosidade, parecem se fundir umas com as outras; em todo esse percurso, não temos qualquer acesso a um contexto externo, permanecendo contra o mesmo fundo negro e anônimo do filme de Duchamp. ${ }^{194}$
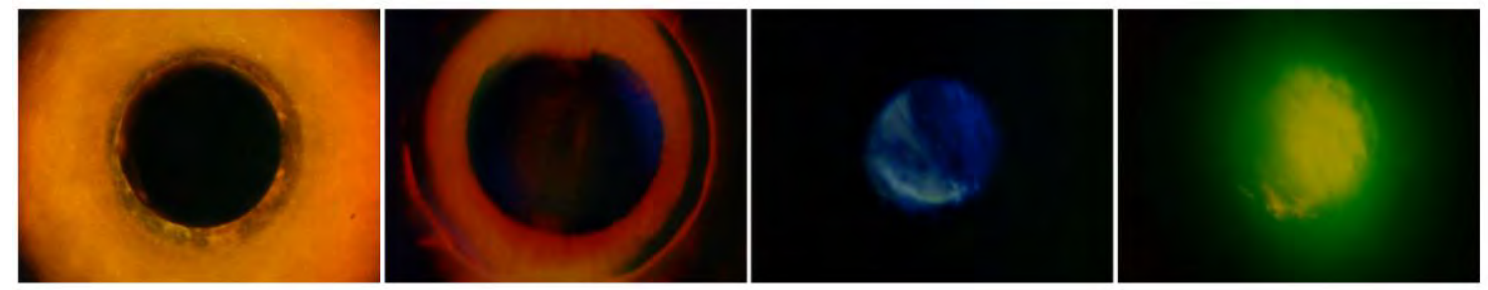

Trechos de Samadhi (Jordan Belson, 1967) - imagens filmadas em continuidade, mas que, pelo isolamento das formas de qualquer contexto exterior, tendem a sugerir a mais completa ausência do fora-de-campo, afirmando a autonomia da imagem fílmica.

A concepção espacial aqui pressuposta é essencialmente distinta daquela apresentada por Bazin. Não um espaço centrífugo, mas um espaço centrípeto é reconhecido no plano. Esse reforço da autonomia da imagem, de seu espaço e de seu

\footnotetext{
${ }^{194}$ Um comentário sobre essa fase da obra de Belson encontra-se em Gene Youngblood, "The Cosmic Cinema of Jordan Belson”, Film Culture 48/49 (primavera de 1970). O lugar de Belson na morfologia histórica da vanguarda americana é comentado por Sitney em Visionary Film, op. cit., pp. 258-267. Sitney traça as origens do cinema de Belson até o filme de Duchamp, passando pelos animadores influenciados por Fischinger, como Harry Smith.
} 
desenvolvimento no tempo, é melhor descrito pela expressão de Hollis Frampton de que a tela representaria, não um recorte da realidade, mas "uma metáfora da consciência".

As coisas encontram suas verdadeiras formas mais prontamente quando olham para si mesmas. O filme, olhando para si mesmo como a máquina total que é o cinema, refotografa e reprojeta sua própria imagem, simplesmente reiterando à infinidade imodificada seu retângulo radiante, afirmando com perfeita redundância seu limite ou perímetro, que se tornou para nós, habitantes da cultura fílmica, um icone da fronteira entre o conhecido e o desconhecido, o visto e o não-visto, o que está presente à consciência e o que está em absolutamente todos os outros lugares e é... inimaginável. ${ }^{195}$

Reencontramos aqui a dualidade da superfície do material fílmico, levando tanto à concretude literal como a uma espécie de representação da imaginação. O importante é notar que existem condições específicas nas quais isso pode ser aplicado ao plano. Se este parecia um debate natural em relação a filmes de capítulos anteriores, aqui devemos nos afastar consideravelmente da definição tradicional do plano para encontrar o mesmo problema.

\subsubsection{Pontos de congelamento e ebulição}

O movimento, como substância temporal do plano, se caracteriza por seus intervalos. Em outras palavras, as diferenças e distâncias entre as configurações visuais que constituem a imagem em cada uma de suas etapas dão o caráter particular ao movimento, o que nos permite classificá-lo por seu direcionamento, sua escala e sua velocidade. Vimos como uma vertente do cinema deu preferência à câmera-lenta como meio de revelar os interstícios dos movimentos, perscrutando o contínuo da realidade em busca daquilo que só poderia ser revelado através do "microscópio temporal". Nos perguntemos, então, se há um limite para esse caminho.

Se o movimento pode ter sua intensidade diminuída, até que ponto isso pode ser feito? Ou ainda, até que ponto isso pode ser feito de modo que ainda tenhamos um plano? Uma resposta é que pode ser feito até onde permitir a velocidade da câmera. Mas, considerando teoricamente uma câmera de velocidade indefinida, podemos imaginar um limite: o ponto no qual a intensidade é reduzida a zero. Isso significaria uma passagem entre fotogramas tão sutil que seria praticamente idêntica à repetição exata do mesmo

${ }^{195}$ Hollis Frampton, "The Withering Away of the State of the Art" (1974), op. cit., p. 264 (grifos nossos). 
fotograma, de modo que a sucessividade da projeção não pareceria mais ter efeito. Em outras palavras, nos levaria ao congelamento da imagem, à redução do plano a uma fotografia estática.

O ramo do cinema que mais diretamente parece ter explorado esse questionamento foi o dos filmes estruturais. Mais especificamente, os nomes que buscaram redefinir o plano em termos que negassem o movimento como um de seus pilares. "Cinema é a projeção de fotografias", afirmou Peter Kubelka, "o que significa imagens que não se movem - em um ritmo muito acelerado." Ainda que a impressão de movimento tenha sido a razão para a criação da tecnologia fílmica, esta permanece apenas um caso especial. Uma análise empírica do dispositivo cinematográfico, Kubelka argumenta, não tem como decorrência o movimento, mas "a rápida projeção de impulsos luminosos". ${ }^{196}$

Um filme que ataca o problema através de seu "limite inferior" - o congelamento do movimento - é One Second in Montreal (1969), de Michael Snow. O filme é constituído por uma série de fotografias filmadas de modo a cobrir todo o espaço da tela. Não vemos, portanto, nada além de fotografias, imagens achatadas, imóveis, tornadas sinônimas do espaço da tela. A duração varia segundo um padrão: as fotografias duram cada vez mais tempo, até que se atinge o centro do filme, a partir do qual as durações são reduzidas progressivamente, numa curva simétrica. As fotografias mostram o que reconhecemos facilmente como sendo paisagens urbanas, cobertas de neve. Mas a equação do campo visual a imagens estáticas e achatadas parece eliminar a vibração particular que caracterizava mesmo os planos mais estáveis dos Lumière. Aqui, o mecanismo da projeção e a substância fotoquímica da película são reduzidos à sua mínima presença dentro de uma abordagem figurativa, chegando ao ponto de o filme tornar difícil a percepção do movimento da própria granulaçao da imagem - sendo ela confundida com a própria granulação das fotografias filmadas. Com isso, a duração métrica toma a frente. ${ }^{197}$

196 Peter Kubelka, "The Theory of Metrical Film”, in The Avant-Garde Film, op. cit., p. 140. Ver também Hollis Frampton, "For a Metahistory of Film: Commonplace Notes and Hypothesis" (1971), op. cit., p. 137: "A ilusão de movimento é certamente um acréscimo comum à imagem fílmica, mas essa ilusão se baseia na suposição de que a frequência de mudanças entre fotogamas sucessivos varia apenas em margens estreitas. Não há nada na lógica estrutural da fita de filme que justifique essa suposição. Logo, nós a rejeitamos."

197 Jean Mitry nos lembra que a imagem fílmica, diferente da fotográfica, não apenas sugere relevo e profundidade, mas cria de fato essas sensações através do movimento que reproduz, ou seja, através das mínimas variações de posição e luminosidade. Ver Mitry, Esthétique et psychologie du cinéma, vol. I: Les structures (Paris: Editions Universitaires, 1965), p. 111-113. Para mais sobre o tema, ver Edward Branigan, "What is a Camera?", in Cinema Histories, Cinema Practices, eds. Patricia Mellencamp e Philip Rosen (University of Michigan, 1984), p. 89. 
A dificuldade em perceber a vibração característica do plano é devida ao fato de que Snow reduz ao máximo os índices que garantiriam essa percepção. Mencionamos que o Empire de Warhol se submetia às vicissitudes de um espaço aberto, e que o extremo de seu projeto seria alcançado num espaço fechado e com iluminação controlada. São precisamente estas as condições instituídas em One Second in Montreal. É, portanto, no cruzamento entre o "plano que filma uma fotografia" e "uma fotografia impressa repetidas vezes" que se coloca o filme de Snow. ${ }^{198}$

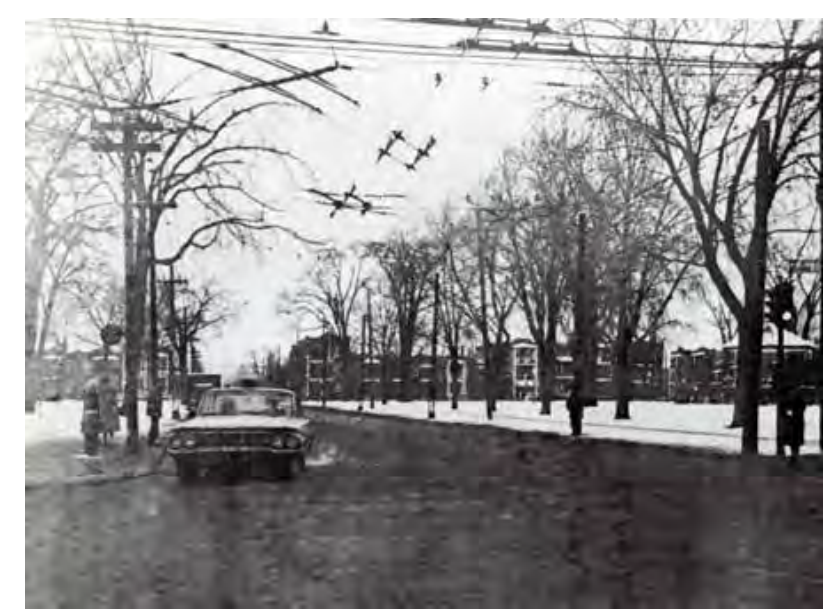

One Second in Montreal (Michael Snow, 1969)

Um filme que ataca o problema através de seu "limite superior" - a ebulição do movimento - é Morning (1968), de Ernie Gehr. O filme se inicia com planos de uma janela, vista por dentro de um quarto. A passagem de um plano a outro é enfatizada tanto pela aceleração da montagem como pelas variações de luz, perceptíveis por seu contraste elevado. Após alguns segundos de escuridão surgem outros planos da mesma janela, agora a uma distância maior, possibilitando a visão do quarto. $O$ enquadramento centraliza a janela; no lado esquerdo vemos uma cama e no lado direito uma estante. Esta é a arena do filme, onde ocorre a principal intervenção de Gehr: fixando a direção do olhar, uma série de alterações é realizada na configuração da câmera, nas proporções do quadro e sobretudo na abertura do diafragma. No que parece ser um único plano, conforme o diafragma se fecha a luz que entra pela janela é esmaecida e percebemos com mais definição os contornos e detalhes dos objetos no quarto; mas em determinado ponto a luz se torna tão fraca que não é suficiente para iluminar o quarto - vemos, assim, apenas

${ }^{198}$ Para uma visão histórica da relação entre a fotografia estática e a projeção fílmica, ligando os primórdios do cinema às vanguardas dos anos 1960, ver Annette Michelson, "The Art of Moving Shadows" (1989), in On the Eve of the Future, op. cit. Para um comentário mais geral sobre o tema, ver também Philippe Dubois, O ato fotográfico e outros ensaios (Campinas: Papirus, 1998), p. 168. 
o contorno da janela e, dentro deste retângulo, o fundo em sua parca luminosidade. Conforme o diafragma se abre, os contornos se evidenciam; mas logo a luz se torna tão intensa que os objetos são envoltos em um halo dourado até finalmente mergulharem na luminosidade que toma conta de todo o espaço, tornando invisível mesmo o contorno da janela. As variações são por vezes graduais, como num avanço em direção à claridade ou escuridão, e por vezes intermitentes, com saltos e intervalos maiores.

A concentração estrutural do filme é evidente. Tendo fixado a direção da câmera e os eventos perante ela, Gehr se dedica à manipulação de poucos parâmetros. Toda a modulação presente em sua duração se deve à variação luminosa, com breves períodos em que o quadro é reduzido ou ampliado. Com isso, investiga-se diretamente algo tomado como pressuposto por uma infinidade de filmes: a luz como aquilo que nos permite reconhecer objetos, espaços e eventos, por ser a própria substância do processo fotográfico. Sendo a luz um dos fatores primordiais, é perfeitamente possível que toda a composição seja organizada em torno dela. Em princípio, não é necessário que nada além da luz seja alterado em um filme. Existe afinal uma escala luminosa; existem pontos onde a luz impede o reconhecimento da realidade espacial, seja este o domínio da clareza ou da escuridão. A liberdade do cineasta nessa escala é análoga à de um músico que improvisa com valores dinâmicos, atingindo ora o silêncio, ora o limite superior da audição. A cada operação, o que resulta é um movimento - mas um movimento possível apenas no cinema, por depender da luz projetada no tempo. O movimento aparenta ser contínuo quando o pulso da luz surge e desaparece do quarto como uma única onda de energia - o que é reforçado pelo único movimento "de fato" no interior do quadro: um gato que atravessa o espaço. Mas quando o movimento é fragmentado, quando ocorrem saltos entre as configurações, percebemos o fator rítmico que ao mesmo tempo isola cada fotograma e os submete ao padrão articulado. A relação entre "fotograma" e "plano" é assim redefinida nos termos próprios de Gehr, para quem um plano nada mais é que uma região do espectro da luz estendida pelo tempo:

Um fotograma tem a ver com uma intensidade particular de luz, uma imagem, uma composição congelada no tempo e no espaço. Um plano tem a ver com a intensidade variável da luz, um balanço interno de tempo dependente do movimento intermitente e um movimento dentro de um determinado espaço dependente da persistência da visão. ${ }^{199}$

${ }^{199}$ Ernie Gehr, "Program Notes by Ernie Gehr”, Film Culture 53/54/55 (1972), pp. 36-37 (grifos nossos). 
O plano é então compreendido através de suas variações luminosas. As variações podem ser contínuas, mas esta é apenas uma possibilidade entre outras. Esse tratamento do plano faz com que sua integridade espaço-temporal - a margem das diferenças entre os fotogramas - seja dinamitada. Nos casos mais extremos, os fotogramas não parecem nos remeter a um mesmo registro em alta velocidade; suas diferenças são tão elevadas que nos sugerem uma série de átomos desconectados uns dos outros, fragmentos dispostos em sucessão.

Na obra de Gehr, outro caso é o de Serene Velocity (1970). Neste filme, o corredor de uma universidade, vazio e à noite, é enquadrado simetricamente, com algumas luzes acesas dando ao espaço uma tonalidade azulada, quebrada apenas pelas sombras, as linhas brancas das lâmpadas fluorescentes e o vermelho das placas de saída. Gehr nos mostra este corredor seguindo um padrão de montagem: alguns fotogramas são apresentados de uma mesma posição; há então um corte para o mesmo enquadramento, o mesmo número de fotogramas, mas com um leve zoom in; em seguida, um corte para o mesmo enquadramento, o mesmo número de fotogramas, mas com um leve zoom out. A combinação dos zooms é como uma sístole e diástole em relação ao enquadramento inicial, o "ponto central" do filme. Não há movimento no interior do espaço. Toda a progressão resulta da variação dos intervalos entre os fotogramas - as distâncias de um enquadramento a outro. O ritmo da variação é constante, mas as distâncias aumentam gradativamente, pois os enquadramentos se afastam cada vez mais do ponto central. Se em Morning a luz era o fator isolado e manipulado, em Serene Velocity isso ocorre com a distância focal da lente: é esta a "escala" escolhida por Gehr para realizar sua composição, desta vez com uma abordagem absolutamente regular.

Serene Velocity se caracteriza também por um movimento propriamente fílmico e pela exploração de um "espectro", efetuada neste caso pela travessia do conjunto de possibilidades. É excluída apenas a região identificada com a continuidade, o que decorre da escolha de um ponto central do qual os trechos posteriores irão se afastar. Não há fluidez, apenas diferentes níveis de contraste. No início do filme, quando a distância entre os enquadramentos é pequena, os fotogramas tremulam como se recém desligados de um movimento contínuo, e sua proximidade permite que o corredor seja percebido com certo volume e profundidade - ou seja, há ainda algo da definição original do plano. A distância aumenta, contudo; o pulso se torna mais percussivo, e a profundidade do corredor dá lugar ao achatamento da tela, transformando os objetos e luzes em formas geométricas que, em sua alternância, sugerem um lento e prolongado efeito de flicker. 

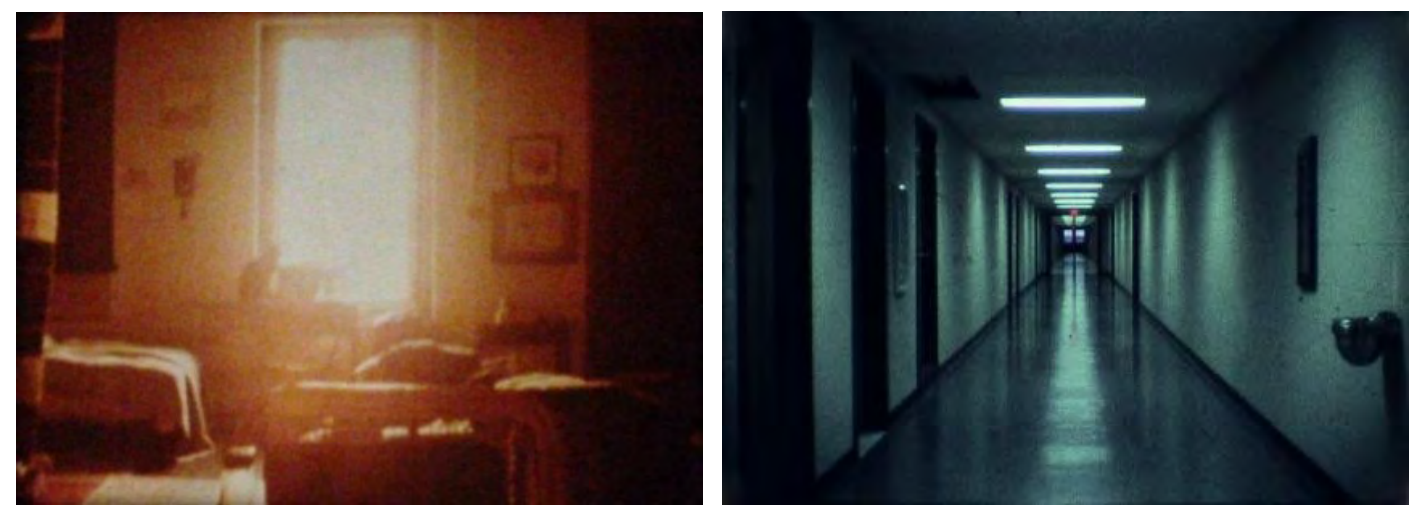

Morning (1968) e Serene Velocity (1970), dois filmes de Ernie Gehr que lidam com a fragmentação do plano, respectivamente através da manipulação do diafragma e da distância focal.

Foi mencionado anteriormente que alguns filmes dos Lumière pareciam identificar, nos próprios ambientes onde faziam os registros, estruturas que lhes serviam como referências composicionais - a arquitetura do mundo servindo como metáfora da arquitetura fílmica. Scott MacDonald propõe um argumento semelhante para os filmes dessa fase da carreira de Gehr. Morning encontraria na janela que permite a entrada da luz no quarto a imagem da camera obscura que é o modelo não só para a câmera mas à própria sala de projeção, ao passo que Serene Velocity teria em seu corredor marcado regularmente uma metáfora da lente que é a fonte da principal técnica utilizada. ${ }^{200}$ Nos dois casos, o reconhecimento de uma arquitetura clara não impede que esta seja transfigurada pela composição. Assim como no tópico anterior, devemos notar que essas técnicas pelas quais o plano é "congelado" ou "fragmentado" são as mesmas que podem ser utilizadas em planos normais - mas que aqui são levadas a seus extremos. Neste processo, como no Empire de Warhol, a investigação dos limites do plano faz com que as características "superficiais" ganhem a frente.

200 Além de Morning e Serene Velocity, é citado ainda Eureka (1974). Ver Scott MacDonald, “Camera Obscura/Lens/Filmstrip", Film Quarterly, vol. 43, n. 4 (verão de 1990), pp. 10-16. Para um comentário mais detido sobre essa fase da obra de Gehr, ver Lucas Bastos Guimarães Baptista, "Fantasmas na máquina: estrutura e movimento nos filmes de Ernie Gehr”, Galáxia 34 (2017). Disponível em: $<$ https://revistas.pucsp.br/galaxia/article/view/26655/22306>. Acesso em dezembro de 2018. 


\subsubsection{Repetição e diferença}

Um dos princípios comentados no primeiro capítulo foi o princípio de repetição. Quando aplicado aos fotogramas, leva ao que chamamos de uma forma homogênea - o que cria a impressão de constância numa única imagem. Quando aplicado com breves alterações, especialmente alterações de um único parâmetro, leva à forma reiterativa. A diferença entre a repetição e a reiteração é marcada pela escala na qual se apresentam as semelhanças e diferenças entre as imagens. A repetição de um único fotograma do plano, como vimos, descaracteriza a própria noção de plano. Mas a repetição de uma sequência de fotogramas leva a uma técnica que permite problematizar essa noção por outro ângulo: o loop.

O caso tido como inaugural do loop consciente de sua repetição material encontrase no Ballet mécanique (1924) de Fernand Léger e Dudley Murphy. Em meio à profusão de planos abstratos e figurativos que permeiam a obra, em certo momento surge um plano sem grandes arroubos expressivos: uma mulher subindo uma escada, vista de cima, carregando um saco sobre o ombro. O plano dura alguns segundos, mas logo é imediatamente retomado, desde o início. O processo se repete inúmeras vezes, e é retomado em outras seções do filme. Aqui, a transgressão dos limites do plano é clara. Apesar de manter o mesmo exato enquadramento, os cortes são explícitos; vemos a mulher subir a escada e, de repente, ela desaparece e retorna ao início da escada, como um Sísifo preso na realidade fílmica. Após algumas repetições, torna-se claro que os gestos que vemos recorrer na imagem são exatamente os mesmos. O espaço fixo do enquadramento não basta para manter a unidade: o corte que marca o final de um movimento e o início de outro é a quebra temporal do plano.

Mas há casos em que essa mesma distinção é tornada ambígua. Em 1966, George Landow criou um filme que se baseia na apropriação de um material fílmico para fins diferentes dos originais. Film in Which There Appear Edge Lettering, Sprocket Holes, Dirt Particles, Etc. tem suas características descritas no próprio título. Trata-se da imagem de uma fita de filme impressa e disposta lado a lado com sua cópia. Vemos o segmento de um teste de projeção ser repetido, algo normalmente encoberto ou recortado das cópias dos filmes, mantido nas pontas iniciais. Neste segmento, vemos imagens da "garota chinesa" sorrindo num enquadramento fixo, e em torno dela, os elementos mencionados no título. Durante seis minutos, acompanhamos o loop do mesmo trecho de 
filme, marcado por alguns índices de temporalidade, dos quais o mais evidente é o momento em que a garota pisca os olhos.
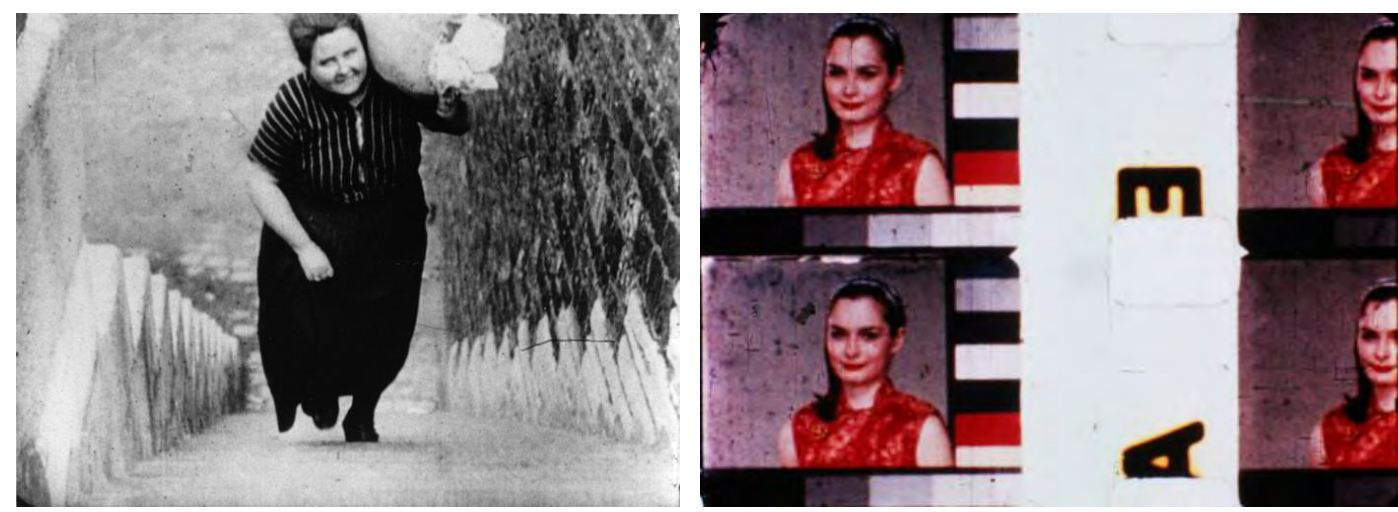

Dois usos da repetição em loop: a repetição de um plano normal em Ballet mécanique (Fernand Léger e Dudley Murphy, 1924) e a repetição de um segmento de fita de filme, em Film in Which There Appear Edge Lettering, Sprocket Holes, Dirt Particles, Etc. (George Landow, 1966).

Pode-se dizer que a presença do corte é evidente no filme de Landow, e que por isso não há dúvida que o plano é terminado; mas a camada adicional da filmagem de uma fita de filme torna mais complexa essa relação. A fita de filme filmada por Landow pode conter emendas e cortes, mas o plano que a filma não exibe a mesma descontinuidade. É essa dúvida quanto à temporalidade sendo proposta que rendeu a Film in Which There Appear... o estatuto de obra paradigmática do cinema estrutural, e que o tornou uma referência para os materialistas britânicos. Le Grice e Gidal mencionam frequentemente as referências à materialidade da película em obras como essa, que "revelam" os componentes da impressão fotográfica. ${ }^{201}$ Nestes casos, características que normalmente seriam escondidas ou neutralizadas tornam-se o próprio foco da composição - grãos, riscos, os furos nas laterais da fita. $\mathrm{O}$ aspecto tátil dos filmes, da própria substância física das imagens, ganha a frente. Além disso, a temporalidade é manipulada através de impressoras que permitem a refilmagem do filme, acrescentando uma camada adicional no registro do plano. Há também uma relação entre a "neutralização" do material visível para que as características do tempo da projeção ganhem a frente. A suposição é que, na articulação desse material, um lado quase escultural do tempo seria acessível ao cineasta, uma vez que ele poderia transformar certas partes da obra e com isso expor a própria função mutável que resulta da interação entre a impressão e a projeção.

201 Para um sumário dos tópicos de interesse da escola materialista britânica, ver as seções "Duration" e "Splice" em Peter Gidal, Materialist Film (Londres: Routledge, 1989), pp. 100-110. Ver também Peter Gidal, "The Anti-Narrative", Screen, vol. 20, n. 2 (julho de 1979), pp. 73-93. 
O que podemos nos perguntar sobre o filme de Landow é se o que vemos na tela consiste em um plano. A película foi filmada com uma câmera no mesmo sentido que um evento registrado pelos Lumière? Ou o segmento de filme foi refotografado em stop motion, isolando os fotogramas do contínuo temporal? A simples observação do filme não oferece dados suficientes para fazer a distinção. Assim como o filme de Snow posiciona-se na interseção perceptiva entre algumas possibilidades, também o filme de Landow parece colocar um problema inerente à definição do plano como a imagem fílmica tradicional.

\subsubsection{Imagem sobre imagem}

Se na repetição temporal, sequencial de um plano é possível colocar em dúvida sua unidade, a repetição espacial de planos no mesmo período de tempo o faz de maneira ainda mais direta. A sobreposição, ou a impressão de dois (ou mais) planos num mesmo segmento da fita de filme, também faz com que a definição original deva ser revista.

Berlin Horse (Malcolm Le Grice, 1970), um filme baseado em loops sobrepostos, serve como exemplo. Todos os planos exibem a mesma ação, um cavalo galopando na parte externa de um estábulo, em padrões circulares, aproximando-se e afastando-se da câmera segundo um padrão rítmico mais ou menos regular. A tensão do filme decorre do fato de que os planos são repetidos não apenas no tempo, mas também no espaço. Vemos um plano normal, e logo vemos, sobre a imagem deste plano, um segundo plano, com a mesma ação, mas impressa com propriedades visuais distintas (o contraste mais elevado, ou as cores invertidas, ou em outra etapa do movimento). $\mathrm{O}$ acúmulo dessa operação no decorrer do filme faz com que ocorram várias combinações, desde um plano sendo impresso sobre si mesmo com uma leve discrepância temporal, até planos completamente diferentes coexistindo no mesmo período. Se um plano é impresso duas vezes sobre a película, o que vemos sobre a tela é um único plano (resultado de dois registros), ou a combinação de dois planos? Se nossa percepção só distingue os dois planos impressos através de suas diferenças, então dois planos que revelam estas diferenças apenas na metade do período tornam-se "dois planos" apenas neste momento? Se sim, o que se tornam? O que Le Grice põe em dúvida ao recorrer a essas estratégias é o caráter 
tautológico da definição original do plano. ${ }^{202} \mathrm{O}$ plano aqui não pode mais ser considerado "um segmento entre duas mudanças de plano".

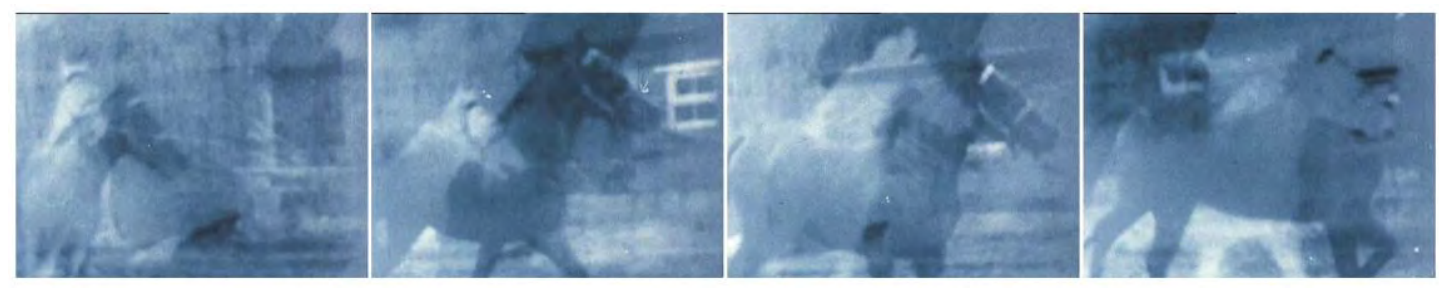

Etapas de um mesmo movimento em Berlin Horse (Malcolm Le Grice, 1970), com dois planos sobrepostos.

Outro caso é o de $A s y l$ (Kurt Kren, 1974). Durante 21 dias não-consecutivos, Kren filmou uma mesma paisagem, sob um mesmo enquadramento, e com os mesmos rolos de filme. Em cada dia, Kren sobrepôs à lente da câmera uma cartela preta com furos que permitiriam à luz entrar apenas em algumas partes da imagem. O resultado é que o espaço da tela é dividido em uma série de blocos, de tamanho semelhante; a progressão do filme é idêntica à mudança dos padrões de blocos que tornam visíveis as regiões da paisagem. Vemos, assim, uma imagem composta por fragmentos de um espaço: alguns desses fragmentos, dispersos no espaço da tela, sugerem uma paisagem sob a luz azulada e difusa do inverno; outros, os tons amarelados do outono. Os fragmentos se combinam, seja em aglomerados próximos, seja em padrões distantes em meio à tela preta. Em determinado momento parece haver a confluência dos fragmentos, que se unem para formar uma única imagem, o que parece ser o único plano de fato do filme.
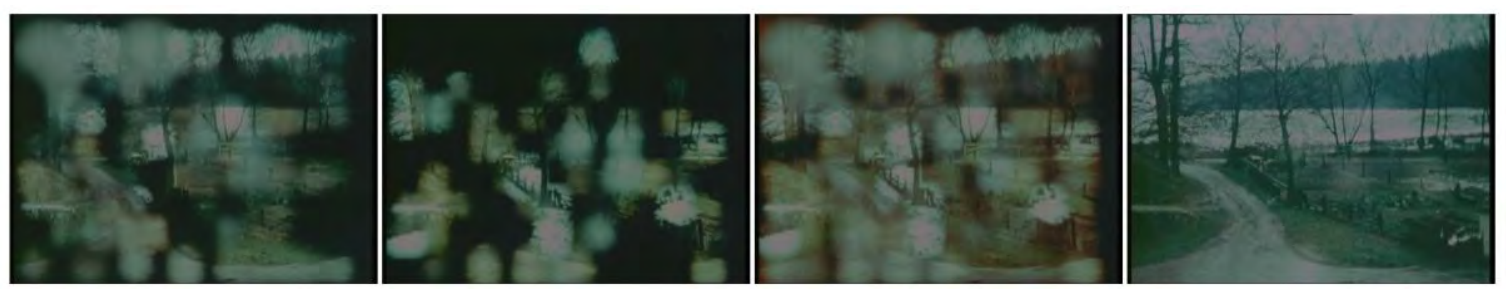

Etapas isoladas de Asyl (Kurt Kren, 1974)

O que devemos nos perguntar nesses dois exemplos é em que ponto deixam de ser planos. Em ambos, há breves momentos em que as imagens, até então dispersas e dissociadas, convergem numa mesma representação. Por alguns instantes, estamos na

\footnotetext{
${ }^{202}$ Para um comentário historiográfico, que apresenta as raízes "não-realistas" da sobreposição, ver Simone Natale, "A Short History of Superimposition: From Photography to Early Cinema", Early Popular Visual Culture, vol. 10, n. 2 (2012), pp. 125-145.
} 
presença do que parece ser um plano. Mas isso ocorre como uma possibilidade num sistema de combinações. Se a configuração do plano é uma instância do sistema combinatório, não seria mais adequado referir-se ao plano como um caso especial, em vez de o paradigma da obra?

\subsubsection{A elasticidade do plano}

Vimos que o plano, no seu sentido tradicional, pode ter sua velocidade reduzida, elevada, sua direção invertida, sem que haja prejuízo na percepção de sua unidade - ao menos até certo ponto. Vimos que o plano pode ser repetido em loop, e que em certas condições isso quebra a unidade espacial e temporal que o caracterizava. Mas vimos isso em casos nos quais as técnicas eram utilizadas separadamente. Consideremos, portanto, exemplos em que as técnicas são utilizadas em conjunto.

Em Pièce touchée (1989), Martin Arnold refotografa uma cena de No domínio do vício (The Human Jungle, Joseph F. Newman, 1954) numa impressora ótica, criando padrões repetitivos de movimentos, avançando e retrocedendo os gestos dos atores em pequenos incrementos. O filme de Arnold inicia com uma mulher sentada na cadeira da sala, enquadrada em plano médio com a porta da casa ao fundo. A imagem tremula de maneira insólita, como se um pequeno conjunto de fotogramas estivesse sendo apresentado num ciclo interminável. $\mathrm{Na}$ banda sonora, ouve-se um ruído maquínico, também repetido incessantemente. Aos poucos, o ciclo parece expandir-se, tomando um número maior de fotogramas, e percebemos os dedos da mulher se movendo. Após dois minutos, a porta se abre. Mas não se abre totalmente: permanece numa gagueira visual, indo e voltando, aumentando e diminuindo seus padrões de movimento, retornando aos mesmos trechos, até que da porta surge um homem. No decorrer do filme, a entrada do homem no apartamento, sua caminhada até a poltrona onde a mulher se encontra e o beijo entre os dois tornam-se matrizes gestuais para a execução de padrões rítmicos. 

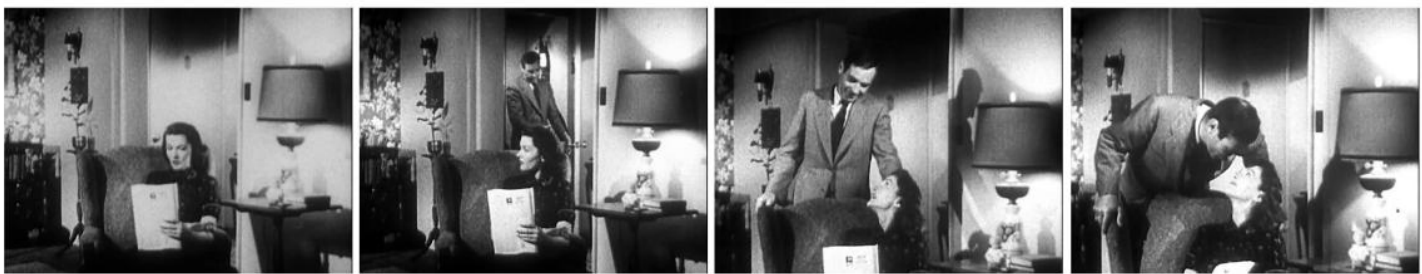

Etapas isoladas de Pièce touchée (Martin Arnold, 1989). Ao redor de cada uma dessas imagens, o filme cria repetições cíclicas, "indo e voltando" nos movimentos.

O plano aqui torna-se uma matéria elástica, cujas transformações ocorrem sobre sua continuidade, mas como se a fita de filme, em vez de transcorrer linearmente pela projeção, fosse passada e retomada diversas vezes, obsessivamente revendo os mesmos detalhes. Várias das possibilidades identificadas nas seções anteriores são utilizadas: o movimento do plano é paralisado, invertido, repetido; combinações entre essas operações são também repetidas em ciclos, e são finalmente invertidas, às vezes seguindo uma operação com seu inverso. Sendo refotografado numa ordem que depende apenas parcialmente da ordem de seu registro, o plano é desligado de sua continuidade temporal. A liberdade com a qual Arnold redireciona a atenção do espectador para o futuro e o passado do plano torna essas categorias praticamente inconcebíveis na lógica do filme: o tempo da ação é completamente submetido ao tempo das manipulações na montagem, o que equivale dizer que o tempo real, em profundidade, do plano, é constantemente submetido ao tempo superficial, cronométrico. ${ }^{203}$ Novamente, nos perguntemos: quando o material original deixa de ser um plano? Se o plano é o ponto de partida do filme, em que momento, em que nível da transfiguração rítmica o plano deixa de manter sua identidade?

As mesmas perguntas devem ser feitas em relação a um filme como Tom, Tom, the Piper's Son (Ken Jacobs, 1969). O título se refere a um curta-metragem homônimo de 1905, realizado por Billy Bitzer e apropriado por Jacobs. O curta é apresentado em sua totalidade, um exemplo típico dos "filmes de perseguição" (chase films). A maior parte

${ }^{203}$ A dimensão temática é obviamente afetada, um ponto enfatizado por Arnold em entrevistas. Sua revelação das possibilidades rítmicas e plásticas do material fílmico revela também as possibilidades de inscrição de significado em certas imagens. Ver, por exemplo, Scott MacDonald, A Critical Cinema 3: Interviews with Independent Filmmakers (Berkeley: University of California Press, 1998), pp. 347-362. É sintomático que Arnold, como Jacobs, dê preferência à apropriação de material alheio, em vez de filmar planos "originais" para neles executar suas variações. O jogo com os conteúdos latentes nos planos filmados para outros fins é parte crucial dessa vertente do filme de apropriação. Para uma reflexão sobre o aspecto criativo envolvido na apropriação, e sua relação com a "metahistória" proposta por Hollis Frampton, ver Michael Zryd, "History and Ambivalence in Hollis Frampton's Magellan", October 109 (verão de 2004), pp. 119-142. Para um diálogo com essas questões, incluindo os problemas relativos ao primeiro cinema, ver Carlos Adriano Jerônimo de Rosa, O mutoscópio explica a invenção do pensamento de Santos Dumont: Cinema experimental de reapropriação de arquivo em forma digital (Tese de doutorado, ECA-USP, 2008), pp. 177-249. 
do que se segue são variações feitas por Jacobs sobre o material do curta. Os mesmos planos são refilmados e reprocessados por um arsenal de técnicas de abstração. Jacobs refilma através de um projetor analítico trechos dos planos em close-up, identificando figuras que antes se perdiam na multidão dos planos abertos; congela os movimentos, inverte suas direções, repete algumas de suas partes, mostra o filme correndo através do projetor.
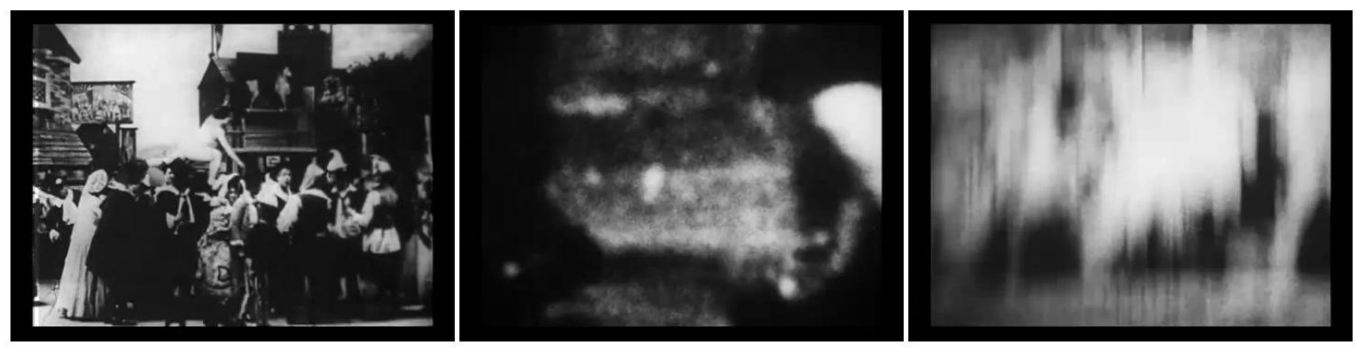

Etapas isoladas de Tom, Tom, the Piper's Son (Ken Jacobs, 1969): o plano inicial do curta homônimo; um close-up de um plano congelado, revelando a constituição granulada da imagem; e um trecho em que a imagem é completamente borrada, em decorrência da fita sendo rebobinada.

Os eventos percebidos no curta original são deslocados de suas coordenadas. A unidade espacial dos planos abertos dá lugar à fragmentação dos close-ups e de movimentos tão rápidos que transformam os gestos em borrões de luz e sombra. A continuidade temporal dos planos dá lugar à flexibilidade cronológica, com ações sendo congeladas, retomadas, repetidas e invertidas livremente. ${ }^{204}$ Como no filme de Arnold, o plano se torna um material a ser esticado, condensado, manipulado por diferentes vias. A maior parte das propriedades que vimos neste capítulo encontra-se no filme, ainda que distorcidas e instáveis, surgindo e desaparecendo a cada nova reformulação.

É, finalmente, uma exploração histórica e contrafactual que Jacobs realiza em Tom, Tom, the Piper's Son. Tomando em mãos um filme finalizado, ele parece se perguntar: o que ocorre se tal parâmetro for modificado? E se outro for modificado? E se forem aplicadas modificações em diferentes partes, e se forem combinadas as modificações, e se forem dispostos os resultados em determinada ordem? Ele refere-se à revelação de características que já estariam presentes nos planos originais como se à

\footnotetext{
${ }^{204}$ Ver Eivind Rossaak, “Acts of Delay: The Play Between Stillness and Motion in Tom, Tom, the Piper's Son", in Optic Antics: The Cinema of Ken Jacobs, eds. Michele Pierson, David E. James e Paul Arthur (Nova York: Oxford University Press, 2011), pp. 96-106.
} 
espera do olhar privilegiado, da manipulação correta, para ver a luz do dia. ${ }^{205}$ Como nos exemplos anteriores, a figuração, o movimento, a continuidade do espaço visível com o fora-de-campo, a fotogenia - tudo se torna uma possibilidade permanente. Mas uma vez realizada a possibilidade, ela necessariamente dá lugar a outras, numa interminável metamorfose. Jacobs refere-se ao "trem de imagens" de seu filme:

Um trem de imagens passa com semelhança o bastante e diferença o bastante para sugerir à mente que seus olhos vêem um braço levantado, ou uma porta fechada; eu queria trazer à superfície aquela multi-rítmica colisão contestadora de forças e áreas de luz e sombra, lutando a cada limite por identidade de formato... ${ }^{206}$

Mais adiante, refere-se à "luta" dos grãos pretos e brancos, como se fosse ao nível dessas unidades que seu filme fosse organizado. Como se, em última instância, tudo fosse redutível às partículas elementares, e como se a jornada de sua obra nos conduzisse pelos diferentes comportamentos, as diferentes substâncias e reações decorrentes de seus experimentos. As partículas às vezes são agrupadas espacial e temporalmente no que só podemos chamar de planos; mas tão logo isso ocorre, a mesma configuração é desfeita, e outros padrões tomam a frente.

Tendo considerado algumas possibilidades de exploração dos limites do plano, podemos tentar propor uma definição que possa generalizar as questões discutidas. Vimos que, espacialmente, o plano pode afirmar sua autonomia como criação abstrata, afastando-se inclusive da relação de correspondência com a tomada, ou então abrir mão de sua autonomia, integrando-se ao mundo exterior, reforçando a correspondência com a tomada e a integridade espaço-temporal dos movimentos. Vimos também que o plano pode intensificar ou diminuir a tensão de seus movimentos, congelando-os ou fragmentandoos.

Se considerarmos essas polaridades, podemos imaginar o ponto onde elas se cruzam - onde todas essas possibilidades se equilibram. Como definição operacional do plano, o que talvez deva ser proposto é menos uma adesão estrita a esse ponto, e mais uma atenção à região mais próxima dele. Pois, se é no afastamento dessas referências que

\footnotetext{
${ }^{205}$ Ver David E. James, Allegories of Cinema: American Film in the Sixties (Nova Jersey: Princeton University Press, 1989), p. 247. James afirma que "assim como, apenas um ano depois, num projeto completamente análogo, o $S / Z$ de Roland Barthes iria abrir a Sarrasine de Balzac com 'um pequeno terremoto' para reescrevê-la como a textualidade modernista, aqui o escrutínio metafílmico de Jacobs descobre não um sentido estável, mas apenas multiplicidade e mudança, um texto centrifugamente disperso, constantemente reformulando-se em novas configurações".

${ }^{206}$ Ken Jacobs, citado em P. Adams Sitney, Visionary Film, op. cit., p. 345.
} 
o plano perde sua unidade espacial ou temporal, é nessa região que encontramos a maior parte das obras, filmes cujos planos tendem a uma direção ou outra, em intensidades distintas, mantendo algo como um equilíbrio dinâmico. Da mesma forma, seria preciso identificar os modos pelos quais o plano é capaz de partir deste centro e se aproximar de um dos limites, ou de partir de um dos limites e atingir este centro. Em resumo, é preciso que as possibilidades estejam dispostas num mesmo campo, para que a transição entre elas seja possível, e que não sejam vistas como categorias em realidades diferentes.

O plano seria, nesse sentido, não um elemento claro e unívoco, mas uma região da composição fílmica, o resultado de uma série de operações formais. Operações que têm uma margem de variação considerável - que permanecem estáveis dentro dessa margem mas que, a partir de certos limites, dão lugar a outros elementos, tornando a noção de plano problemática, e exigindo que se pense em termos de fotogramas, ou combinações de fotogramas, ou combinações de registros. Nesse sentido, não seria possível, dizer com precisão em que ponto exato da escala a configuração de fotogramas deixa de ser um plano; seria possível dizer apenas se ela tem alguma proximidade com o centro imaginário, ou se tende a uma das direções mencionadas. Mais do que a posição exata no campo, o que é posto em evidência são as forças envolvidas nesse posicionamento. Se a definição tradicional do plano caracteriza a "profundidade" espacial e temporal da composição - a unidade tridimensional do espaço e a isocronia do registro com a projeção -, podemos sugerir que os vários questionamentos apontados nesta última parte do capítulo se assemelham no fato de que realizam "efeitos de superfície" sobre essa profundidade. Em outras palavras, as diferentes formas de afastar o plano de sua região central, estável e unificada, são marcadas pela ênfase da superfície da tela, do caráter gráfico da imagem, de seu isolamento da realidade, de sua autonomia plástica, e da superfície da projeção, da frequência da cronometria em sua articulação métrica.

Considerando essas observações, podemos nos referir ao plano não como uma entidade fixa, mas como uma matéria passível de transformações. Uma compreensão mais ampla do plano envolveria, dessa forma, algo como a física da matéria fílmica. Como são possíveis as ligações entre as partes constituintes dessa matéria? O que pode resultar dessas ligações? Quais estados pode esta matéria alcançar, e quais modos de transições entre os estados são possíveis? Vimos algumas dessas possibilidades nos capítulos anteriores, envolvendo agrupamentos de fotogramas sob diversas concepções. Vimos aqui outras possibilidades, ao redor da ideia de plano. Tomando como base esses 
resultados, veremos nos capítulos seguintes outras manifestações dessa matéria, em condições mais específicas. 


\section{CENA}

\section{A CAIXA DE ATRAÇÕES}

\subsection{Entre o palco e a fantasmagoria}

Em 1986, Tom Gunning publicou um artigo no qual buscou retificar algumas noções sobre os filmes produzidos no período inicial do cinema. "A história do cinema dos primórdios, como a história do cinema em geral", argumentou Gunning, "tem sido escrita e teorizada sob a hegemonia dos filmes narrativos". A tradição historiográfica de Lewis Jacobs e Georges Sadoul tendeu a ver em cineastas como Lumière e Méliès etapas no desenvolvimento das funções que mais tarde seriam cristalizadas na obra de Griffith e que nos permitiriam distinguir uma "linguagem do cinema", essencialmente dramática, composta de planos encadeados com base em relações de causalidade e economia narrativa. Características exibidas nos primeiros filmes e que desviaram dessa progressão histórica tenderam a ser vistas como resquícios de outras formas de espetáculo que precisaram ser abandonados para que a "vocação" do cinema fosse encontrada. É a esta concepção que se opõe Gunning, propondo um termo que refere-se aos mesmos filmes, mas que considera suas especificidades fora de uma orientação teleológica:

Sejam quais forem as diferenças que encontremos entre Lumière e Méliès, elas não devem representar a oposição entre cinema narrativo e não-narrativo, ao menos como a compreendemos hoje. Em vez disso, podemos integrá-los numa concepção que veja o cinema menos como forma de contar histórias e mais como meio de apresentar uma série de "vistas" ao público, vistas fascinantes por seu poder ilusionista (seja a ilusão realista do movimento dos Lumière, seja a ilusão mágica de Méliès), e por seu exotismo. Em outras palavras, acredito que a relação proposta ao espectador pelos filmes dos Lumière $\mathrm{e}$ de Méliès (e de muitos outros cineastas antes de 1906) tem uma base comum que difere das principais relações propostas por filmes narrativos após 1906. Eu chamarei esta concepção inicial de "cinema de atrações". ${ }^{207}$

${ }^{207}$ Tom Gunning, "The Cinema of Attractions: Early Film, Its Spectator, and the Avant-Garde" (1986), in Early Cinema: Space, Frame, Narrative, op. cit., p. 57, 66. A proposta de Gunning é desenvolvida em outras publicações do período, em diálogo constante com André Gaudreault, com quem ele colaborou 
O termo "atração" foi inserido no discurso sobre o cinema nos escritos de Eisenstein quando este se dedicava a construir um modelo de análise para o teatro. As atrações, para Eisenstein, se referiam a uma forma de criar "um impacto sensual ou psicológico", mais do que uma representação realista. É nesta chave que Gunning retoma a expressão para sublinhar as relações estabelecidas pelos filmes dos primórdios, relações que seriam influentes em parte das vanguardas nas décadas seguintes - uma “confrontação exibicionista", em vez de uma "absorção diegética".

A obra de Georges Méliès é um caso significativo do cinema de atrações; entre as noções importantes para compreender seus filmes nesse contexto, ao menos três relacionam-se à sua concepção de espaço e tempo. A primeira noção diz respeito à organização teatral conhecida como "palco italiano": uma disposição frontal entre palco e plateia, separados nitidamente pelo fosso e pela cortina de modo que o espaço da representação mantenha sua autonomia, como um outro mundo absorvido em si mesmo, suspenso numa plataforma e visualmente destacado. Méliès, um mágico acostumado aos palcos, transpôs a configuração ao cinema literalizando o enquadramento pela correspondência ao recorte bidimensional da tela, criando na imagem projetada a impressão de uma caixa ou cubo do qual uma das faces - a "quarta parede" - seria retirada para nos permitir a visão.

A segunda noção envolve a descoberta dos efeitos possíveis na imagem cinematográfica uma vez que intervalos ocorram num registro com a câmera fixa. Assim como encontramos no catálogo Lumière uma série de tentativas de explorar os vetores e as ocasiões do movimento no espaço profílmico, encontramos em Méliès as primeiras tentativas de investigar os desdobramentos desses efeitos. O relato de Sadoul dá à descoberta um caráter de revelação:

A ideia da primeira trucagem foi-lhe sugerida acidentalmente. Projetando um filme que ele rodara na Praça da Ópera, teve a surpresa de ver um ônibus da linha MadeleineBastille transformar-se subitamente em carro funerário. Um pouco de reflexão mostroulhe a causa dessa metamorfose: a película ficara obstruída, depois a filmagem recomeçara normalmente. Esse acidente efêmero não havia interrompido o tráfego parisiense. Após

em algumas ocasiões. Ver, por exemplo, "The Non-Continuous Style of Early Film”, in Cinema 1900 1906, ed. Roger Holman (Bruxelas: FIAF, 1982), e "An Unseen Energy Swallows Space: The Space in Early Film and Its Relation to American Avant-Garde Film", in Film Before Griffith, ed. John L. Fell (Berkeley: University of California press, 1983). 
essa pequena interrupção, um carro mortuário encontrava-se no lugar do ônibus. $\mathrm{O}$ acidente foi para Méliès uma verdadeira "maçã de Newton". ${ }^{208}$

Após uma série de filmes que reproduziam a abordagem e mesmo as situações encontradas nos Lumière, Méliès realizou um truque - o desaparecimento de uma mulher - através da técnica de interrupção da filmagem. Em Escamotage d'une dame chez Robert-Houdin (1896), vemos o cineasta e sua assistente entrarem no palco num plano médio frontal, cumprimentarem a câmera (e por consequência o público), e executarem o número esperado. Sentada numa cadeira no centro da imagem, a assistente é coberta com um pano; logo em seguida, Méliès segura o pano numa pose fixa, como se estivesse prestes a retirá-lo. Neste momento ocorre a interrupção da filmagem, durante a qual Méliès permanece em sua pose enquanto a mulher deixa o palco. Retomado o registro, o pano é finalmente retirado por ele, revelando a cadeira vazia.
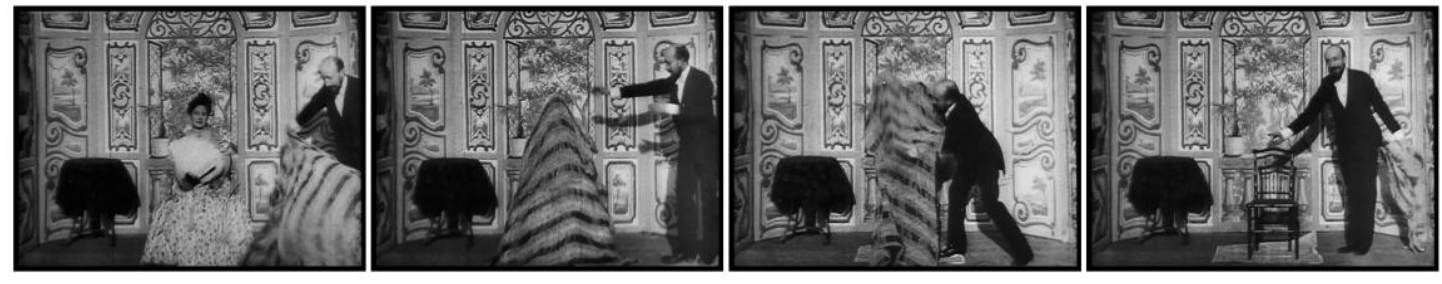

As etapas de Escamotage d'une dame chez Robert-Houdin (Georges Méliès, 1896): (1) a assistente senta na cadeira; (2) o mágico cobre a assistente com o pano; (3) o mágico prepara-se para retirar o pano; (4) o pano é retirado, revelando a cadeira vazia. A interrupção da filmagem ocorre na terceira etapa.

Da concepção do palco italiano, Méliès deriva a unidade espacial, aqui representada pelo enquadramento fixo. Se no teatro a plateia dispõe os espectadores de modo que vejam o espetáculo por ângulos variados, a configuração da sala de cinema faz com que todos vejam a ação pelo mesmo ângulo. A equação do olhar do cineasta, através da câmera, com o olhar do espectador, através da projeção, permite que o filme concentre a atenção diretamente nas suas "atrações". Neste caso, Méliès o faz pela circunscrição desse olhar ao espaço da caixa cênica, tornada o campo onde se desvela todo o evento. A técnica da interrupção adiciona então um novo fator à unidade do plano. Uma vez que o enquadramento permanece fixo durante toda a projeção do filme, a integridade sugerida do espaço serve como base para as transformações executadas. Considerando o último fotograma antes da interrupção e o primeiro fotograma depois dela, o que vemos no

${ }^{208}$ Georges Sadoul, História do cinema mundial, vol. I: Das origens a nossos dias, trad. Sônia Salles Gomes (São Paulo: Martins Editora, 1963), p. 28. 
interior da imagem parece manter alguma estabilidade de posição e direcionamento. Se o plano é definido como um registro contínuo, Méliès propõe que dois planos sejam postos em imediata contiguidade temporal, organizados para sugerir um único movimento. Jacques Malthête nos lembra que, partindo da interrupção da filmagem, Méliès realizou um trabalho adicional: os planos foram cortados, retirando fotogramas que poderiam diminuir a impressão de continuidade, e depois emendados, sintetizando um novo espaçotempo. ${ }^{209}$ Num caso especial da sobreposição de planos mencionada no capítulo anterior, a continuidade aqui foi quebrada apenas para ser reconstruída em outro nível.

A terceira noção importante para o desenvolvimento da composição nos filmes de Méliès é o dispositivo da "fantasmagoria" - uma forma de espetáculo anterior ao cinema que consistia em slides com fundo negro, projetados por uma lanterna mágica por trás de uma tela translúcida numa sala escura. A natureza espectral das projeções e a atmosfera de incerteza visual criavam a impressão de que os espectros apareciam no ar, imaterialmente. De maneira condizente, o repertório das imagens incluía fantasmas, esqueletos e figuras mitológicas. Na produção fílmica de Méliès, a influência da fantasmagoria surge em parte na presença das mesmas figuras, mas sobretudo no uso de fundos pretos contra os quais as figuras são apresentadas, transformadas, decompostas e recompostas. $^{210}$

Un homme de tête (1898) é o primeiro filme de Méliès no qual essas três noções convergem no formato que lhe serviu de modelo para obras subsequentes. Num plano médio frontal, vemos o cineasta de corpo inteiro, num cenário escuro, praticamente neutralizado exceto por duas mesas dispostas cada uma ao lado de uma cadeira ao centro. A lógica exibicionista das atrações é mantida; como no exemplo anterior, Méliès cumprimenta a câmera como faria ao público num espetáculo teatral, gesticulando e chamando atenção para sua própria cabeça. De repente, o gesto faz com que sua cabeça pareça ser descolada do corpo: ele a segura com as mãos e a coloca sobre a mesa à esquerda, enquanto um espaço "vazio", uma escuridão que se mistura ao fundo, permanece no lugar onde estava a cabeça em seu corpo. A cabeça na mesa permanece em movimento, como se reagindo à ação do resto do corpo. Outro gesto faz uma nova cabeça

\footnotetext{
${ }^{209}$ Ver André Gaudreault, "Theatricality, Narrativity, and Trickality", in Fantastic Voyages of the Cinematic Imagination, ed. Matthew Solomon (Nova York: SUNY Press, 2011), p. 42-43.

${ }^{210}$ Para um relato mais detalhado sobre as fantasmagorias, ver Noam M. Elcott, Artificial Darkness: An Obscure History of Modern Art and Media (Chicago: University of Chicago Press, 2016), pp. 77 ss. Ver também Tom Gunning, "Phantasmagoria and the Manufacturing of Illusions and Wonder: Towards a Cultural Optics of the Cinematic Apparatus", in Le Cinématograph, nouvelle technologie du XX siècle, eds. André Gaudreault, Catherine Russell, Pierre Véronneau (Quebec: Payot Lausanne, 2004), p. 34.
} 
surgir no lugar da primeira. O procedimento se repete duas vezes - a cabeça é novamente arrancada, deixando um espaço vazio; é colocada sobre a mesa, e então substituída. Quando três cabeças estão dispostas sobre as mesas, Méliès senta-se na cadeira e começa a tocar um violão enquanto as cabeças se juntam num acompanhamento vocal. Nos últimos segundos, Méliès ataca as cabeças com o violão, fazendo com que elas desapareçam, retornando ao cenário inicial em que as mesas estavam vazias.

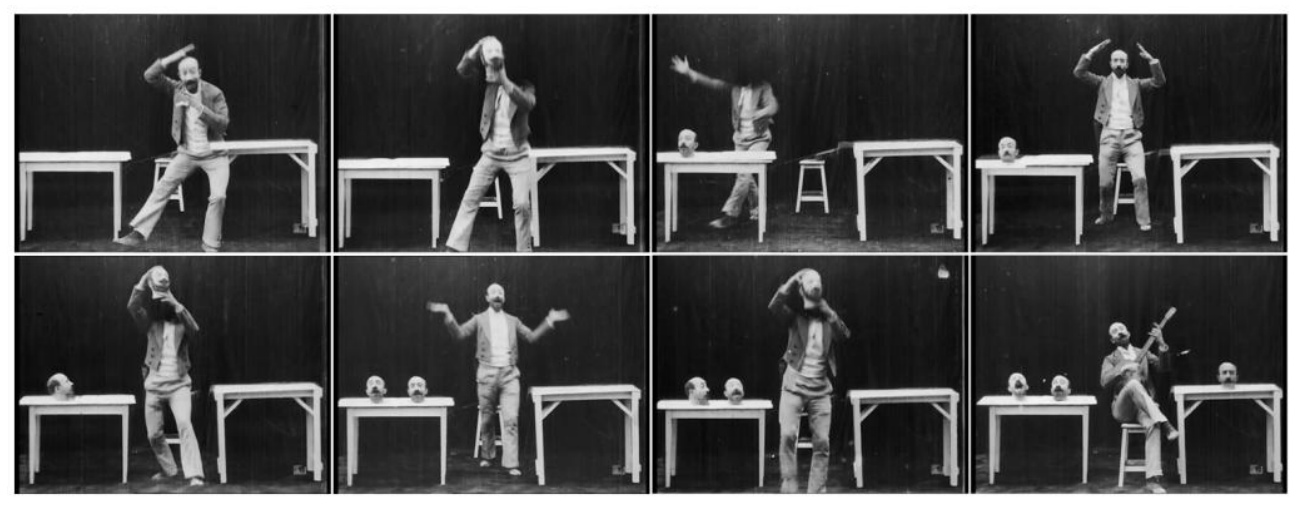

Un homme de tête (Georges Méliès, 1898)

A importância do fundo negro é evidente. A interrupção, que ocorre no momento em que a cabeça é arrancada, exige que a cabeça real seja coberta por um tecido negro que o espectador não deve identificar. $O$ gesto de segurar a cabeça real se transforma com isso no gesto de segurar a cabeça falsa pela continuidade artificial da justaposição dos planos. Da mesma forma, a região abaixo das mesas deve ser revelada como desprovida de truques - o espectador deve identificar que é de fato um espaço vazio, e que as cabeças vistas sobre a mesa não têm seus corpos ali escondidos (como em outros filmes, Méliès passa embaixo de uma das mesas, provando ao público que trata-se de uma mesa normal). O espaço a ser considerado "invisível” é igualado a um fundo preto indistinto. Méliès utiliza a consistência luminosa da imagem cinematográfica em conjunção com a fixidez do ponto de vista para criar a ilusão de um espaço cênico onde ocorrem transformações impossíveis. Uma vez que apenas a luz é impressa na película, o fundo preto serve como o meio privilegiado para as múltiplas exposições no mesmo intervalo de filme; desde que não sejam dispostas sobre a mesma região da tela, as exposições parecem coabitar um mesmo espaço. A escuridão se torna assim análoga ao silêncio da cena, contra o qual percebemos as notas gestuais do mágico.

Se a escuridão pode ser aplicada a todo o palco, como uma cortina negra que absorve a luminosidade no fundo da imagem, pode também ser aplicada a regiões 
isoladas do espaço. Le chevalier mystère (1899) exemplifica essa variante. Méliès, vestido como um cavaleiro, inicia com um desenho a giz no quadro negro: o retrato de uma pessoa usando um chapéu. Através do mesmo gesto do filme anterior, a cabeça "ganha vida", sendo retirada da bidimensionalidade do quadro e tornando-se um objeto tridimensional nas mãos do cavaleiro. Colocada sobre um garrafa em frente ao quadro, a cabeça observa o cavaleiro se mover à sua volta. Em seguida, é novamente carregada por ele até o outro lado da imagem, sendo disposta sobre uma espada, agora perante uma porta aberta, um outro fundo tomado pela escuridão.
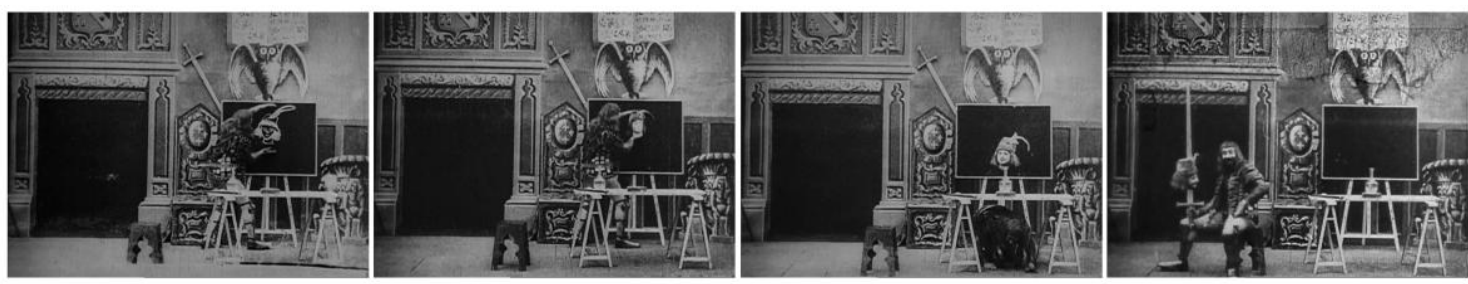

Quatro etapas de Le chevalier mystère (Georges Méliès, 1899): (1) a cabeça sendo desenhada; (2) a cabeça sendo "retirada" do quadro, transformada num objeto tridimensional; (3) o cavaleiro mostrando ao espectador que o corpo não está escondido sob a mesa; e (4) o cavaleiro deslocando a cabeça para outra região da cena, frente a outro fundo preto.

Nestes filmes, sempre que há um fundo preto, Méliès o utiliza como um espaço onde não se aplicam as leis da física, e sim leis próprias do dispositivo cinematográfico. Nas regiões onde não ocorrem os truques, com ou sem o fundo preto, permanecem as condições da representação realista. Mas a estratégia usual de Méliès é fazer a passagem de uma região a outra num movimento contínuo. A profusão gestual, numa sinalização que busca destacar regiões da cena, torna o cineasta de uma só vez o mestre de cerimônias, o feiticeiro, e quase sempre o próprio objeto dos feitiços. Concentrados em sua performance, um eco da frontalidade do enquadramento, somos capazes de reconhecer no composto de planos a integridade de um mesmo número de mágica. Este composto, em sua totalidade, é a atração apresentada.

Uma suposição fundamental aqui é que, no cinema, toda a imagem deve necessariamente ser projetada numa superfície bidimensional. $\mathrm{O}$ enquadramento fixo de Méliès é inteiramente consciente desta noção; considera que, mesmo em sua acepção mais realista, o filme é uma configuração de luzes e sombras nas coordenadas da tela. Isso significa que o fundo preto torna-se uma forma de abstrair as referências contextuais dos objetos. Cercados pela completa escuridão, objetos podem ser apresentados como se a 
única realidade fosse a realidade de sua apresentação no espaço da tela. Dois exemplos servem para que apontemos algumas das consequências desse princípio.

Em L 'homme à la tête de caoutchouc (1901), o cenário da ação é um laboratório. Méliès interpreta um cientista que inicia o plano abrindo um portão, revelando um espaço escuro de onde tira uma mesa, que ele carrega até a região mais próxima da câmera. Como nos filmes anteriores, Méliès coloca sobre a mesa uma cabeça, sinalizando com gestos que algo deve acontecer com ela. Ele passa então a utilizar uma bomba de ar, como se injetasse ar na cabeça, que logo tem seu tamanho aumentado. Atingindo um tamanho máximo, o cientista mexe na abertura de ar, fazendo com que a cabeça retorne ao tamanho normal.

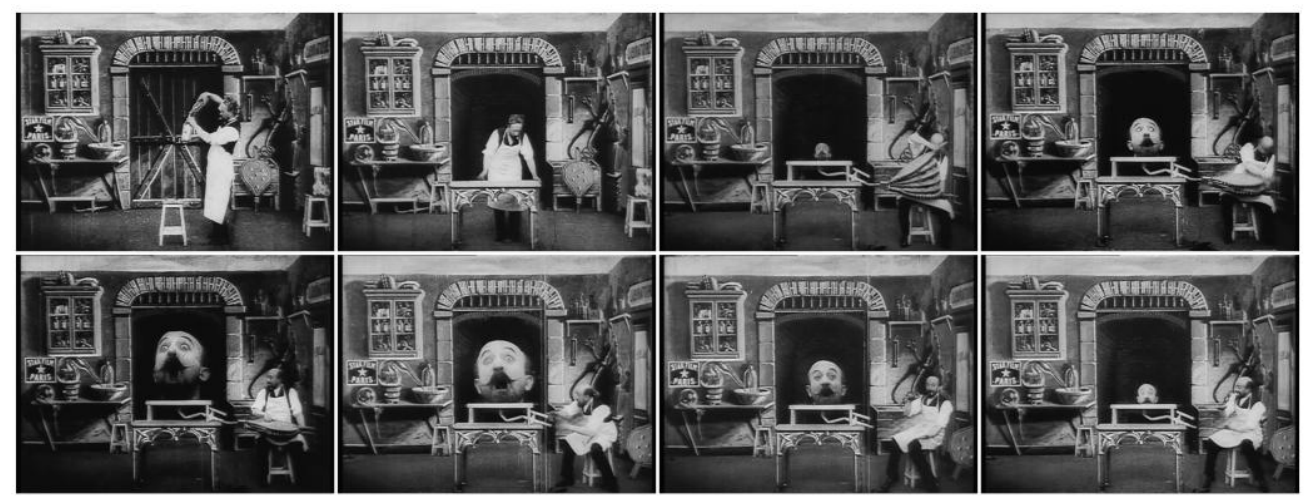

L'homme à la tête de caoutchouc (Georges Méliès, 1901)

Uma técnica recorrente em Méliès é o isolamento dos elementos do cenário pela cobertura com tecidos negros. Se apenas uma cabeça deve ser registrada durante uma exposição do filme, por exemplo, apenas ela é tornada visível, com o resto do cenário sendo coberto; em outra exposição, o inverso ocorre, a cabeça sendo coberta e o resto do cenário filmado normalmente. $\mathrm{O}$ uso de fundos pretos emoldurados é uma das maneiras de facilitar este processo, criando referências para o recorte espacial. ${ }^{211}$ Mas a transformação contínua da cabeça é um efeito diferente da substituição e fragmentação do corpo que encontramos nos outros exemplos. Se num filme como Un homme de tête bastava cobrir o objeto de modo a torná-lo idêntico ao fundo preto, cuidando para que os diferentes registros não cobrissem uns aos outros durante as múltiplas exposições num

\footnotetext{
211 Numa série de artigos no Ciné-Journal em 1926, Méliès listou os truques que criou ou aperfeiçoou, dos quais a grande maioria foi produzida com telas pretas: "máscaras, fusões, sobreposições, duplas exposições, figuras aumentadas ou diminuídas, atores filmados em diferentes planos, atores multiplicados infinitamente, que interpretam vários papéis, desenhos animados, etc.". Ver Elcott, Artificial Darkness, op. cit., p. 143.
} 
único enquadramento, aqui é necessária outra técnica. Disposto sobre um plano inclinado, um carro sobre trilhos foi aproximado e afastado da câmera, de modo que a escala do objeto (a cabeça de Méliès) foi elevada e diminuída continuamente, no decorrer do plano. $\mathrm{Na}$ ausência de contexto espacial, isso corresponde ao aumento e à diminuição do tamanho da cabeça. Através da frontalidade rigorosamente centrada, e principalmente, com a supressão do efeito de perspectiva, Méliès aposta no efeito de achatamento visual, e no fato de que toda a cena representada possui, em última instância, um único plano comum, o plano da própria tela. ${ }^{212}$

Em L'equilibre impossible (1902), Méliès inaugura outro aspecto dessa abordagem. O filme principia com um palco, no qual o fundo é imediatamente transformado em fundo preto com um gesto do cineasta. Sentado no centro, ele multiplica o próprio corpo três vezes, cada uma de suas "cópias" sendo posicionada numa região da tela, uma à esquerda e duas à direita. Neste ponto, as três cópias parecem subir no corpo central, equilibrando-se em suas mãos e em sua cabeça, movendo-se como se libertos da gravidade. Após alguns segundos, Méliès simplesmente faz com que as cópias desapareçam num gesto rápido com as mãos, transformando-os em duas bandeiras, que ele movimenta na conclusão do filme.

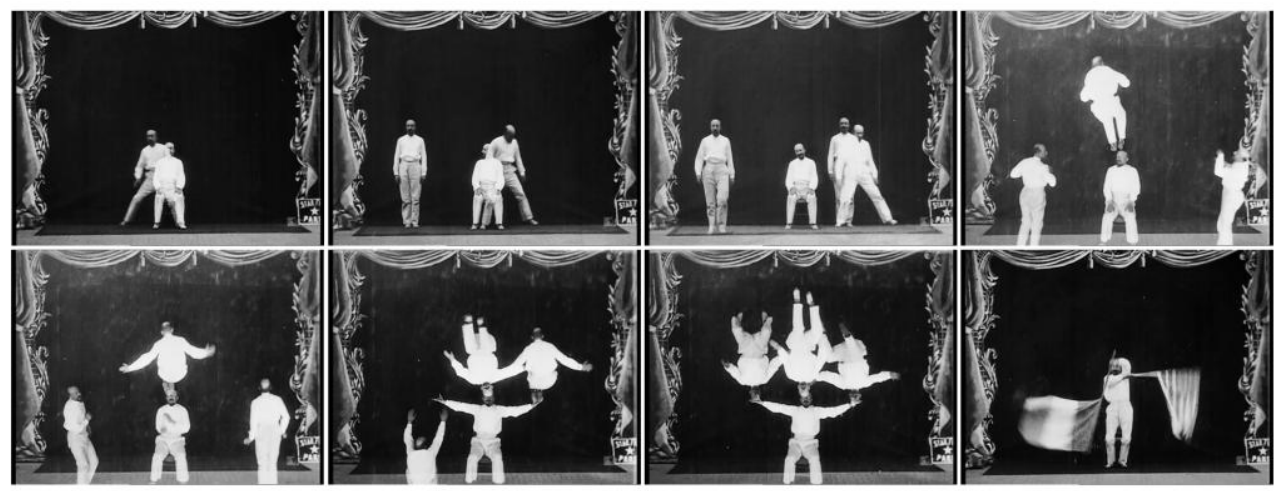

L'equilibre impossible (Georges Méliès, 1902)

O plano principal, no qual Méliès encontra-se na cadeira centralizada, é filmado pelo ângulo frontal, como o são os planos em que as cópias andam sobre o espaço do palco. Mas no momento em que as cópias desafiam a gravidade subindo na figura central, outro ângulo é exigido: a câmera deve ser posicionada no alto, voltada para o chão, onde Méliès executa os movimentos deitado sobre um fundo preto. $\mathrm{O}$ resultado é que,

\footnotetext{
${ }^{212}$ Noel Burch comenta mais extensamente essa tendência de Méliès no contexto de outras produções da época. Ver Noel Burch, "Building a Haptic Space”, in Life to Those Shadows, op. cit., pp. 165-167.
} 
projetados sobre a mesma superfície, os fundos pretos garantem, mais uma vez, que os diferentes planos serão absorvidos pela integridade do enquadramento. Se Fischinger devia atentar para os padrões de movimento de suas formas abstratas para sugerir a orientação gravitacional, Méliès deve atentar para as relações entre o ângulo da câmera e o espaço no qual seu olhar é projetado - nos dois casos, a suposição é que a gravidade deve ser representada como uma atração no eixo vertical da imagem. Considerando o espaço da cena como um cubo, o filme de Méliès parece projetar, através da escuridão, a face superior deste cubo em sua face frontal.

As características que Noel Burch menciona como sendo essenciais para determinar a "autonomia" dos planos em filmes anteriores a 1906 encontram-se nestas obras de Méliès. ${ }^{213}$ Há uma homogeneidade da iluminação, como se fosse buscada uma igualdade volumétrica entre todas as regiões da imagem. Há também a fixidez da câmera, posicionada à frente da ação, como a plateia num palco italiano. Há o uso de fundos que negam a profundidade, seja por sua completa escuridão, seja por sua construção achatada, com detalhes arquitetônicos sendo apenas pintados sobre uma imensa tela. Finalmente, há uma disposição de atores a uma distância da câmera que nos permite ver seus corpos inteiros, quase sempre frontalmente e dispostos lado a lado, sem movimentos no eixo da câmera. Em conjunto, essas características exemplificam a unidade espacial criada por Méliès. O espaço aberto e em profundidade dos Lumière aqui dá lugar a um espaço fechado, caracterizado pela arquitetura do palco, e onde o interesse se volta não a movimentos "naturais", mas a gestos coreografados e cuidadosamente dispostos sobre a tela. As propriedades temporais relacionam-se necessariamente a estes dois fatores: o fechamento do espaço, praticamente negando a existência de um fora-de-campo, e a precisão exigida pela coordenação das múltiplas exposições.

Consideremos então o desenvolvimento temporal destes filmes. Em todos os casos, ao menos um procedimento serve como marcador temporal: os gestos de Méliès, apontando as regiões do cenário, dos objetos ou de seu próprio corpo, as quais devemos atentar pois é onde ocorrerão as transformações. Os gestos estabelecem o que está em jogo, criam a expectativa a ser cumprida. A passagem de uma etapa a outra é portanto uma das medidas internas da duração. Além disso, a organização cênica dos movimentos cria por vezes uma espécie de padrão, trajetórias geometricamente simples, baseadas na disposição dos elementos na superfície da tela. Un homme de tête e L'equilibre 
impossible exemplificam essa tendência: nos dois casos, a figura central é a figura principal, a figura "original”; é ao redor dela, numa distribuição mais ou menos simétrica, que surgem as cópias. Se nas colagens de Harry Smith os objetos pareciam flutuar em torno de uma figura centralizada, em espaços abertos ou apenas vagamente orientados pela gravidade, em Méliès ocorre um processo semelhante, num espaço fechado, análogo ao palco, e apenas brevemente liberto da gravidade. Mesmo o aspecto centrípeto da imagem - o isolamento da realidade fílmica pela quase negação do fora-de-campo - é um ponto de ligação entre os dois cineastas. ${ }^{214}$

Um terceiro exemplo leva adiante essa relação com a "plasticidade combinatória". Em L'homme orchestre (1900), Méliès acrescenta à mesma técnica de multiplicação a construção de padrões de ritmo e posicionamento. Num cenário semelhante a um palco, sete cadeiras são dispostas lado a lado, de frente para a câmera. Méliès, iniciando com os cumprimentos usuais, conta nos dedos os objetos do cenário e logo caminha até a cadeira na extrema direita do quadro. Ao se sentar, uma cópia de si mesmo se levanta, sobreposta à imagem do "primeiro" Méliès, que permanece sentado. $\mathrm{O}$ movimento se repete, desta vez com o "segundo" Méliès sentando-se na cadeira e criando uma terceira versão de si mesmo, que dá seguimento ao processo até que todas as cadeiras são tomadas por cópias do cineasta. Cada uma dessas cópias tem um instrumento musical em mãos. A cópia na cadeira central se levanta e, empunhando uma batuta, passa a reger a apresentação. Podemos visualizar essas etapas, identificando um preenchimento gradativo do espaço horizontal da tela:

${ }^{214} \mathrm{O}$ recurso do fundo preto, o repertório de corpos e objetos, as transformações em padrões de substituição, multiplicação e deslocamento aproximam Méliès a Harry Smith talvez mais do que a qualquer outro cineasta mencionado nos capítulos anteriores. Além disso, a já citada leitura psicanalítica de Annette Michelson para Heaven and Earth Magic destaca a fantasia de onipotência do protagonista diminuto em relação aos processos de desmembramento e reconstrução do corpo feminino, num argumento semelhante ao de Lucy Fisher sobre o cinema dos primórdios, em que são apontados os modos pelos quais Méliès e outros cineastas do período (sobretudo aqueles que popularizaram os filmes de mágica) fizeram das figuras femininas objetos de um controle exibicionista. Ver Lucy Fisher, "The Lady Vanishes: Women, Magic and the Movies", Film Quarterly, vol. 33, n. 1 (outono de 1979), pp. 3040. 


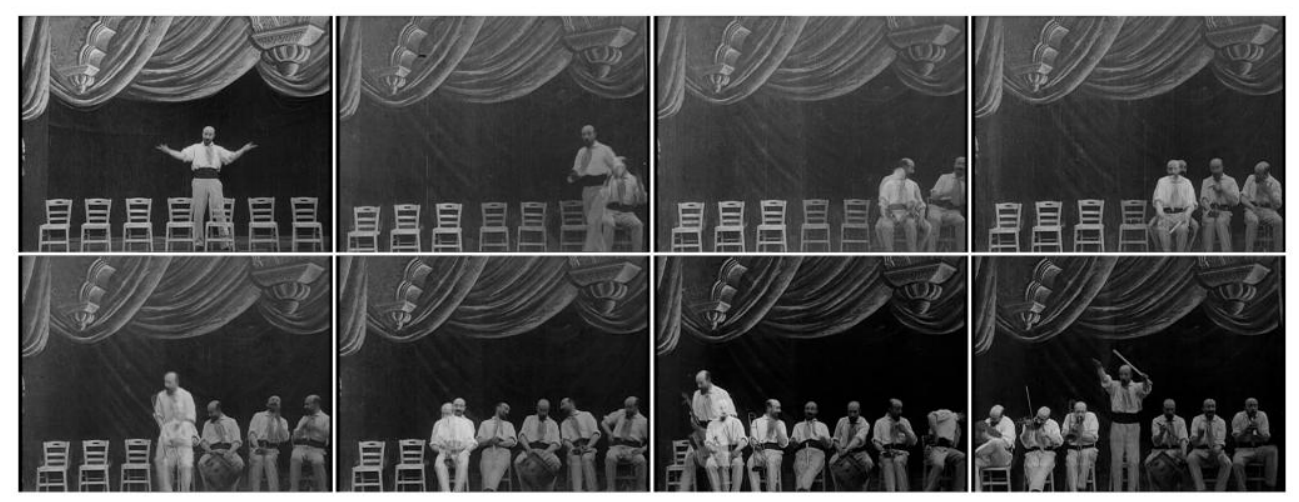

Alguns segundos depois, cessa a apresentação e todos se levantam para cumprimentar o espectador. O regente gesticula como se chamasse as cópias das cadeiras mais externas; elas "entram" nas cópias das cadeiras contíguas, desaparecendo, e o movimento se repete, até que todos "entram" na cadeira do meio, num movimento das bordas em direção ao centro:
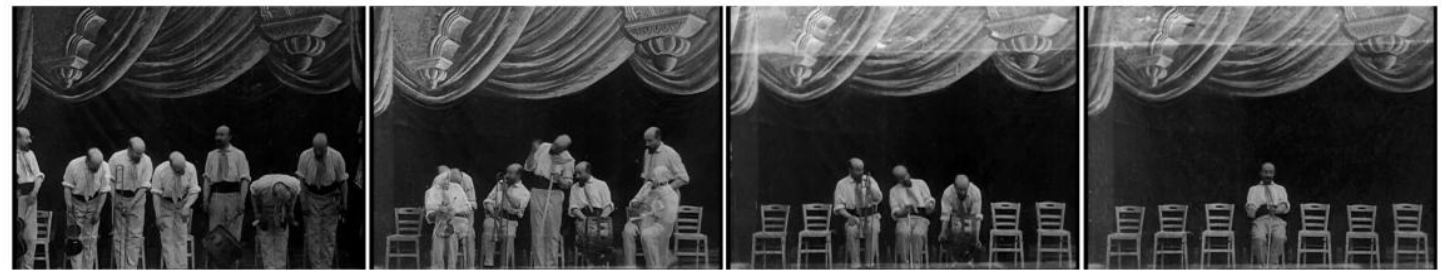

Na maior parte dos filmes em que multiplica sua figura, Méliès encerra a obra a esta altura. O procedimento usual é iniciar com a criação das figuras uma após a outra, como se fossem enumeradas, e encerrar com o desaparecimento dessas figuras. Mas aqui, quando a figura central permanece sozinha no palco, Méliès realiza a desaparição das cadeiras segundo um padrão de compensação espacial: um gesto faz com que três cadeiras desapareçam, da direita até o centro; em seguida, no outro lado do quadro, um gesto semelhante faz com que desapareçam mais três cadeiras, da esquerda até o centro. O padrão aqui é análogo aos processos de ação/reação comentados no segundo capítulo se algo ocorre num lado da imagem, deve ocorrer no outro, de maneira invertida, como um princípio de compensação. 

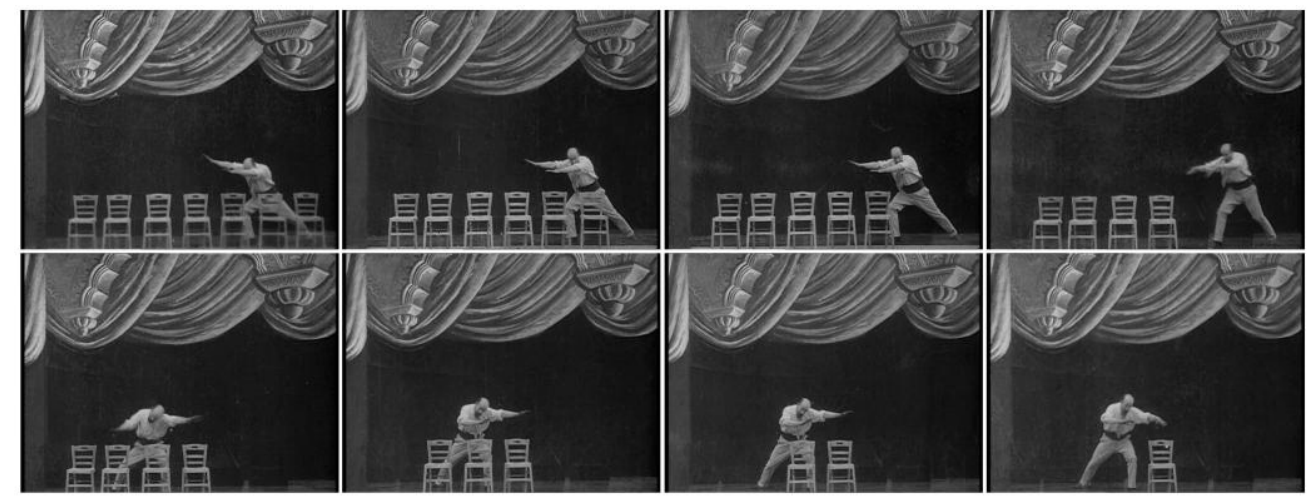

A conclusão de L'homme orchestre (Georges Méliès, 1900), com os gestos que eliminam as cadeiras num padrão complementar.

Podemos, com isso, comparar diferentes estruturas que compõem os filmes de Méliès. As duas operações recorrentes são o deslocamento da cabeça e a multiplicação da cabeça ou do corpo inteiro; a conclusão recorrente é a destruição ou desaparição das cabeças e dos corpos repetidos. ${ }^{215}$ No decorrer dos filmes, o que se produz são essencialmente variações, ou seja, transformações aplicadas a um conjunto de elementos. Quais transformações serão aplicadas, como serão aplicadas e quantas vezes serão aplicadas, tudo isso varia de um filme a outro - como nos outros casos de variações, é uma seleção arbitrária que está em jogo, a escolha de algumas possibilidades reconhecíveis como partes do sistema, mas que não o esgotam, e que não exatamente conduzem o sistema a algo diferente de si mesmo. Um jogo é apresentado, jogado, e encerrado. Os padrões comutativos - movimentos à direita e à esquerda, quase sempre tornam-se critérios de ordenação simples, formas de criar uma moldura temporal.

Um dado estrutural é que os "estados iniciais" e os "estados finais" tendem a ser semelhantes, quando não idênticos: os filmes começam e terminam com Méliès sozinho no centro do plano, cumprimentando a plateia. A passagem de um "estado de equilíbrio" a outro foi apresentada como uma condição para a narrativa; podemos nos perguntar, então, se há um procedimento narrativo em jogo nos filmes de Méliès; e se não há, qual o fator que os diferencia de um desenvolvimento narrativo.

Se consideramos um exemplo do capítulo anterior, como Arroseur et arrosé, percebemos que ali a noção de progressão do filme é inteiramente ligada à causalidade

\footnotetext{
${ }^{215}$ Uma razão para a cabeça ser a parte do corpo mais utilizada por Méliès parece ser a de que a cabeça é uma parte cuja desaparição ou separação não se poderia falsear. Pode-se ter um braço falso, e mesmo mecanizar o movimento de um braço falso para que ele pareça verdadeiro, assim como se pode encontrar um corpo sem um braço; o mesmo não é possível com uma cabeça. Seria, portanto, uma forma de jogar com as expectativas de realismo do espectador. A expressividade dos rostos, sobretudo pela via da caricatura, é também explorada por Méliès nas vezes em que as cabeças são separadas dos corpos.
} 
registrada pelo plano. No filme dos Lumière, cada etapa da ação é causada pela etapa anterior e a causa da etapa seguinte, de modo que apenas as etapas inicial e final permanecem isoladas como "estados de equilíbrio". Encontramos ali uma estrutura simétrica, marcada por uma desestabilização e uma regeneração do equilíbrio. Mantendo a unidade espacial e temporal do plano, Arroseur et arrosé convoca as referências visuais de causalidade para que o espectador possa inferir o sentido das ações e com isso a unidade da obra. Mas o plano não é esgotado por essa relação de causalidade; as ações humanas permanecem ali um subconjunto do evento mais amplo, representado pelo enquadramento. Este é um detalhe fundamental na percepção do cinema dos Lumière: o fato de que os eventos registrados pela câmera, ainda que encenados, fazem parte do movimento do mundo e que têm portanto sua duração submetida ao andamento dos eventos naturais.

Nesse sentido, o isolamento espacial dos planos de Méliès, e principalmente a criação de uma física particular da imagem fílmica, parecem ressignificar a causalidade, e com isso a noção de sentido ou propósito no desenvolvimento temporal dos filmes. Não há nada no caráter dos corpos registrados por Méliès que nos faça inferir as transformações que lhes serão aplicadas; elas procedem numa lógica e mesmo numa ordem arbitrárias. O garoto no filme dos Lumière poderia interromper o fluxo da água em outro ponto da mangueira, ou com as mãos em vez dos pés; mas a interrupção da passagem ocorreria de acordo com as mesmas variantes físicas, e uma modificação na ordem de apenas duas etapas ali seria o bastante para descaracterizar toda a percepção de um encadeamento causal. No caso de Méliès, a arbitrariedade de suas operações é devida à lógica das atrações, o que Gunning chamou de uma polaridade entre aparição e desaparição:

[A estrutura básica das atrações] gira em torno do ato de mostrar, e das antecipações que podem ser intensificadas pelo adiamento ou pelo anúncio do que será mostrado (ou ambos), e sua inevitável desaparição (que pode ser gradual ou repentina). As atrações exibem portanto algo como uma estrutura temporal, mas a estrutura consiste mais no enquadramento de uma aparência momentânea do que no desenvolvimento e na transformação no decorrer do tempo. A atração pode aparecer e desaparecer, e geralmente as duas coisas são feitas. Enquanto está presente na tela, a atração pode de fato mudar, mas quando essas mudanças passam a criar um desenvolvimento, saímos da estrutura das atrações e entramos numa configuração narrativa. ${ }^{216}$

216 Tom Gunning, "Now You See It, Now You Don't: The Temporality of the Cinema of Attractions", in Silent Cinema Reader, eds. Lee Grieveson e Peter Kramer (Londres: Routledge, 2004), p. 47. 
Pode-se dizer que há algum tipo de causalidade operante nesses filmes; mas ela é necessariamente um tipo distinto daquela que identificamos nos Lumière. É uma causalidade reduzida, ou uma "causalidade fraca", encontrada, por exemplo, nos momentos em que o mágico gesticula e chama atenção para uma região do espaço onde deve ocorrer uma transformação - que ocorre logo em seguida. Pode-se dizer que há um reconhecimento da expectativa como fator importante na composição; mas os períodos que lidam com a expectativa tendem a ser breves e indistintos, não exibindo manipulação direta. Mais que o "desenvolvimento" de um gesto a outro, os filmes se caracterizam por irrupções temporais. A ênfase no "ato de mostrar" é tal que o filme praticamente se organiza ao redor destes momentos; o enquadramento fixo isola a atração do resto do mundo como o gesto isola a transformação do que veio antes e do que virá a seguir. $\mathrm{O}$ título do texto de Gunning sintetiza o princípio temporal desses filmes: "agora você vê, agora você não vê". Como nas permutações de Harry Smith, a coordenação temporal dos eventos tende à parataxe, à sucessão desprovida de causalidade.

Não significa com isso que um filme não possa conter simultaneamente elementos narrativos e das atrações. Se a introdução do desenvolvimento temporal - o desenvolvimento necessário de um evento a outro - leva o filme ao terreno da narrativa, podemos então considerar um exemplo do próprio Méliès que parece fazer coexistir os dois impulsos.

Le diable géant ou le Miracle de la Madone (1901) mostra o que parece ser um castelo ou uma catedral, uma construção ampla e visivelmente dedicada à religião, com um abside no centro e uma estátua de Maria no canto direito. No lado esquerdo, um casal conversa num portão aberto. Quando o homem vai embora, a mulher atravessa o espaço da tela até a região da estátua, demonstrando com gestos sua afeição pelo homem. De repente, uma explosão ocorre no centro da imagem, e o abside dá lugar a um espaço negro e à figura de um diabo. Aterrorizada, a mulher corre em direção ao portão, mas um gesto do diabo faz com que apareçam grades, trancando-os no espaço da cena. $\mathrm{O}$ diabo então joga a mulher de volta ao espaço próximo à estátua, e durante alguns segundos passa a aumentar seu tamanho, tornando-se um gigante que dança e gesticula como se para ameaçá-la. A estátua finalmente se move, e ao tocar o diabo, faz com que ele diminua gradualmente o tamanho, retornando à escala humana e logo desaparecendo. Descendo de seu suporte, a madona faz também com que a grade desapareça e o homem possa entrar no espaço da cena. O filme é encerrado com o casal abraçado e agradecendo à mulher de branco no centro da imagem. 


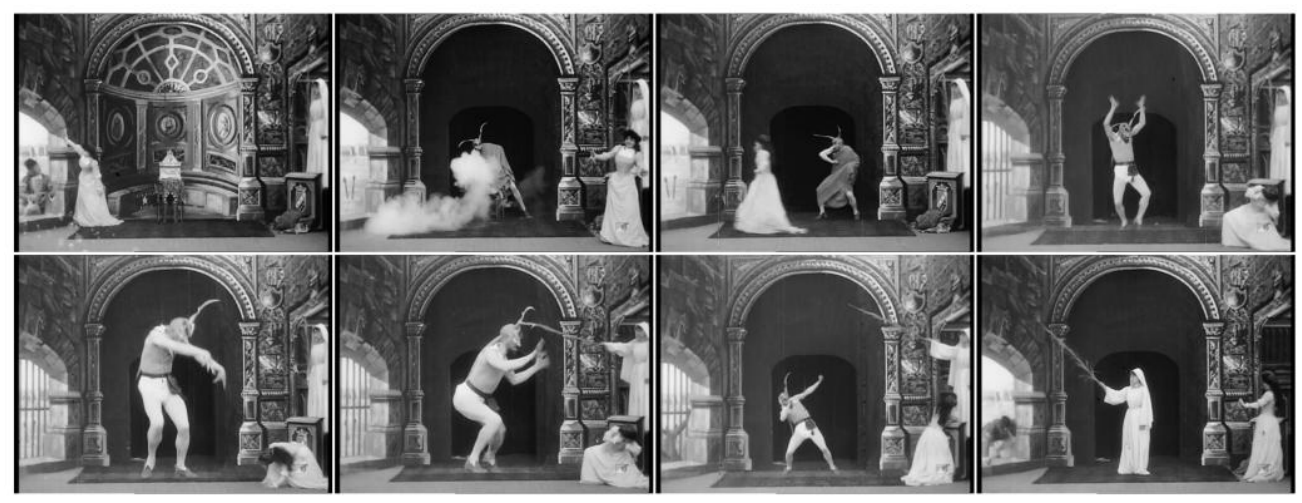

Le diable géant ou le Miracle de la Madone (1901)

Consideremos os estados inicial e final de Le diable géant ou le Miracle de la Madone. O filme abre com um "estado de equilíbrio", a mulher e o homem conversando, e a madona ainda em sua forma inanimada; e encerra com o homem e a mulher abraçados, agradecendo à madona em sua forma animada. No decorrer do plano, Méliès realiza a aparição da figura do diabo, o aumento de sua escala e sua desaparição. O que caracteriza o impulso narrativo no filme é que as transformações são postas em perspectiva umas com as outras, seguindo uma "lógica interativa". Não há aqui um mágico abordando diretamente a câmera, mas uma cena autocontida, em que dois personagens (o diabo e a madona) “justificam” as operações mágicas. Gunning não comenta diretamente a coexistência das duas tendências, mas sua própria definição dos aspectos narrativos e das atrações nos leva às características exibidas pelo filme de Méliès:

Além de dispositivos estilísticos de manipulação temporal, qualquer narrativa implica um desenvolvimento no tempo. Além da base de mudança e progressão temporal simples, isso implica o que Paul Ricoeur chamou de uma configuração de tempo, com o tempo assumindo uma espécie de forma através da lógica interativa dos eventos. Como argumenta Ricoeur, é através desta configuração que os eventos tornam-se uma história e a narrativa se move para além da simples cronologia. O tempo na narrativa, portanto, não é apenas uma progressão linear (uma coisa após a outra), é também o acúmulo de momentos sucessivos num padrão, uma trajetória, um propósito. As atrações, por outro lado, trabalham com o tempo de maneira diferente. Elas basicamente não constroem eventos na configuração com a qual a história integra momentos individuais. Com efeito, as atrações têm uma temporalidade básica, a da alternância de presença e ausência que é incorporada no ato de mostrar. ${ }^{217}$

${ }^{217}$ Gunning, "Now You See It, Now You Don't”, op. cit., p. 44 (grifo nosso). Isso condiz com o argumento de que a maior parte dos filmes até 1906, ainda que apresentassem indícios de que um modo narrativo estava sendo desenvolvido, não o faziam consistentemente, e talvez não conscientemente. Ver também Tom Gunning, "The Non-Continuous Style of Early Film”, op. cit., pp. 219-229. 
Gunning refere-se a um "padrão, uma trajetória, um propósito", e mesmo isso é encontrado no filme. A moldura do cenário religioso onde há o encontro amoroso, seguido do surgimento do diabo e a intervenção da madona que restitui a harmonia pode ser lida como tendo uma "mensagem". Mas a "temporalidade básica", a "alternância de presença e ausência que é incorporada no ato de mostrar", é igualmente presente. A arbitrariedade das transformações, do momento em que surgem à duração que tomam na totalidade do plano, corresponde aqui à dos exemplos anteriores e que não traziam indicações narrativas. ${ }^{218}$

Considerando o conjunto dos filmes de Méliès comentados aqui, podemos traçar algumas de suas características como exemplares das atrações e de algumas concepções de espaço e tempo nos primórdios do cinema.

A concepção espacial é determinada em todos eles pela "autonomia do plano" (que se torna logo a autonomia de um "composto de planos", percebidos como um único elemento), reforçando o isolamento do fora-de-campo e a tendência a centralizar frontalmente a ação, com os deslocamentos sendo predominantes no eixo horizontal. A diagonal em profundidade dos Lumière dá lugar a um espaço achatado e que tende a se aproveitar do caráter bidimensional da tela, onde os efeitos são criados. É por essa chave que pode ser interpretado ainda o repertório visual, em que as vistas urbanas são substituídas por cenas ficcionais e apresentações de mágica voltadas diretamente ao espectador. Em vez da busca pelos movimentos de pessoas, da natureza e da câmera em paisagens naturais ou urbanas, temos movimentos tornados possíveis apenas na tecnologia cinematográfica. Apesar de recorrer ao plano, o vocabulário visual de Méliès, sua resistência à linearidade, os padrões espaciais criados por seus deslocamentos e suas transformações indicam uma proximidade com os animadores do segundo capítulo. A direção "centrípeta" de Méliès, ainda que baseada no registro da câmera, o leva a explorar regiões da composição fílmica em que a "superfície" tem um papel ativo.

${ }^{218}$ Em suas declarações, Méliès dava prioridade às atrações. Ver André Gaudreault, "Theatricality, Narrativity, and Trickality", op. cit., p. 37: "Por vinte anos eu fiz filmes de fantasia de todos os tipos, e minha maior preocupação era, para cada filme, encontrar truques originais, um efeito central sensacional, e um grande final. Depois disso, eu tentava encontrar o período histórico que seria mais adequado para inserir meus personagens (frequentemente o figurino era exigido pelos truques), e uma vez que tudo isso havia sido definido, eu finalmente projetava os cenários de modo a enquadrar a ação de acordo com a época e os figurinos. Quanto ao roteiro, a 'fábula', a 'história' em si, eu trabalhava isso por último; e posso portanto dizer que, trabalhando dessa forma, o roteiro não tinha importância alguma, já que meu único objetivo era utilizá-lo como 'desculpa para a encenação', para truques ou para composições que criassem um efeito agradável." 
Em comparação com os Lumière, a concepção temporal é também determinada por um uso distinto da continuidade. A suposição de isomorfismo entre o registro e a projeção deixa de ser um meio de recriar o tempo real, e torna-se uma ferramenta para criar uma continuidade artificial, onde planos são emendados como se descrevessem um único movimento, ou múltiplas exposições são feitas no mesmo segmento de película de modo que ações deslocadas no tempo da filmagem tornam-se simultâneas no tempo da projeção. Essas ações, por sua vez, não descrevem sempre uma progressão, mas sim a enumeração de truques, uma série de ações contíguas temporalmente, mas que não sugerem necessidade ou propósito. Sob a continuidade artificial, é então algo como o princípio de variação que se manifesta com algumas das transformações mágicas na caixa cênica.

\subsection{A física da caixa}

Um caso importante para entender os desdobramentos do cinema de atrações, e com eles as propriedades do espaço cênico, é o da comédia burlesca nos anos 1920. Influenciada, como os números de mágica, por formas de espetáculo anteriores ao cinema, a comédia burlesca compartilha algumas das características mencionadas por Gunning como definidoras das atrações - a fixidez e frontalidade recorrentes dos enquadramentos, por exemplo, bem como a atenção aos "impactos sensuais e psicológicos". Influenciados também pelas formas de encadeamento narrativo desenvolvidas nos anos 1910, os cineastas do burlesco diferem de alguém como Méliès pela presença de um contexto mais amplo no qual ocorrem esses momentos. Consideremos aqui, no entanto, apenas os pontos de contato entre as duas tradições, mais especificamente a concentração dos eventos no plano e seu desenvolvimento espaço-temporal.

O cineasta que representa mais diretamente a concentração das gags em planos únicos, e que mais enfatiza o caráter físico dessa unicidade, é Buster Keaton. Como Méliès, Keaton foi o responsável pela filmagem, encenação e atuação de seus filmes, ainda que na maioria deles tenha colaborado com outros diretores. Essa relação entre a concepção e a realização das gags é fundamental para que vejamos os filmes de Keaton no conjunto deste capítulo.

Em College (Buster Keaton \& James W. Horne, 1927), Keaton interpreta Ronald, um colegial de aspirações acadêmicas e que despreza o atletismo. Sua paixão por Mary 
(Anne Cornwall) o faz segui-la até uma universidade infestada de atletas, onde ele tenta provar sua capacidade física numa série de esportes. É nesse ambiente que ocorrem a maior parte das gags do filme. Praticamente todas acontecem em planos únicos, enquadramentos fixos num estádio onde Keaton é o único personagem visível. Numa delas, Keaton está posicionado no meio do quadro, de costas para a câmera em plano médio e no centro de um círculo marcado na grama do estádio. Ele prepara-se para lançar um disco com os gestos usuais do esporte, segurando o objeto, dobrando os joelhos, girando os ombros como se o corpo fosse uma mola a ser comprimida. $\mathrm{O}$ contexto cênico é estabelecido e a expectativa é criada pelo direcionamento do olhar; inferimos que o disco será arremessado no espaço à frente da câmera. Após alguns segundos parado, Keaton gira o corpo, aumentando o momento angular a cada revolução, e quando o disco finalmente é lançado, segue na direção oposta à desejada:

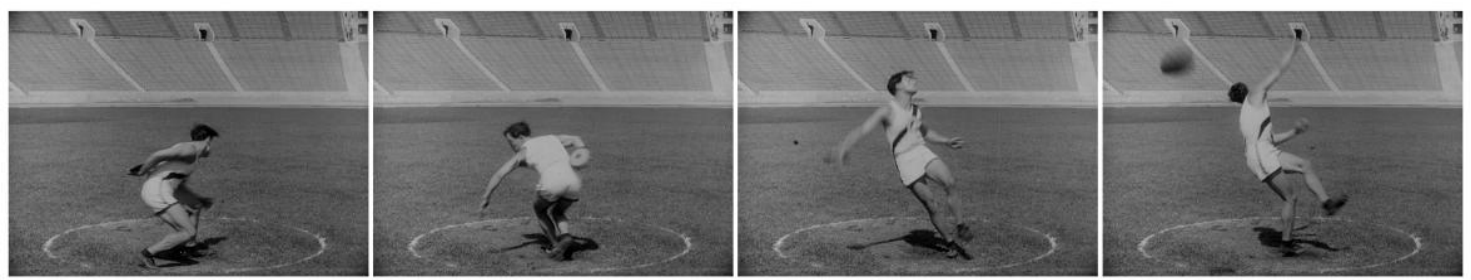

Em outro plano, vemos Keaton no fundo da imagem, face voltada para a câmera, segurando um dardo; à sua frente, na região central do campo, um retângulo marcado no chão. Reconhecemos as condições: ele deve correr até a marcação e dali arremessar o dardo o mais longe possível. Ele corre até o retângulo e faz o arremesso, a velocidade, a força e o ângulo aparentemente corretos. Mas, segundos depois, vemos junto com o personagem o dardo cair e ser fincado na região logo à frente da marcação, dentro do próprio campo, como se toda a força aplicada fosse incapaz de fazer o objeto sair do espaço delimitado pelo enquadramento:

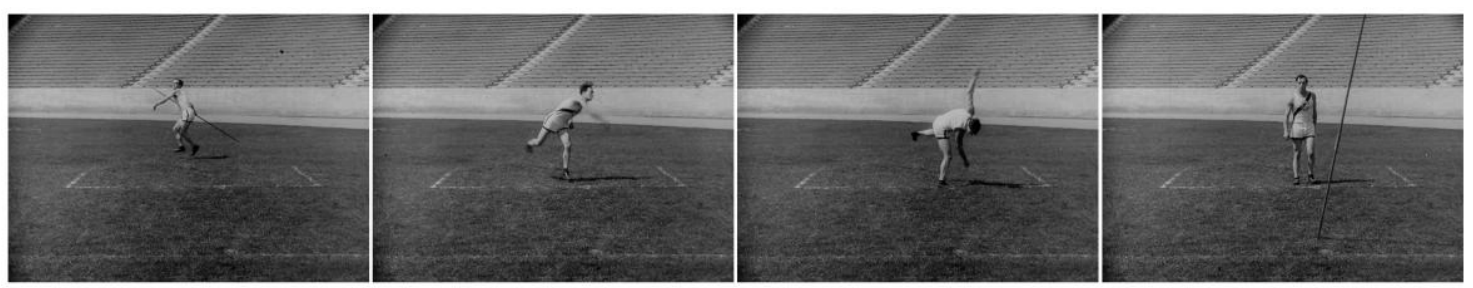


As condições básicas destas gags são simples: uma expectativa é definida, e então é frustrada. Essas expectativas dizem respeito às relações entre a ação e as regiões da cena. No primeiro caso, o objeto deveria ser arremessado em profundidade, mas termina sendo lançado em direção à câmera; no segundo, o objeto deveria ser arremessado em direção à câmera, desaparecendo do campo, e termina retornando ao campo, próximo da câmera. Em outros planos, as expectativas são criadas pelo acúmulo de gags envolvendo as mesmas ações. Quando Keaton tenta saltar sobre uma vara, a situação é mostrada três vezes, e em cada uma delas o resultado é diferente. Em todas, vemos um enquadramento semelhante, um plano geral, frontal, com Keaton ao fundo e as barras na região próxima à câmera; em todas, Keaton deve correr em direção à câmera e realizar o salto sem tocar a vara. Na primeira tentativa, ele realiza o salto - mas não sobre a vara, e sim de encontro a ela. Na segunda, ele corre em direção à vara, agora supostamente consciente de que deve saltar mais alto - mas a vara cai sozinha, antes que ele possa saltar. Na terceira, ele corre, consciente de que deve saltar mais alto e já tendo fixado a vara - mas quando finalmente realiza o salto, em vez de cair em pé ou sentado, mergulha de cabeça na areia, permanecendo enterrado com as pernas ao alto. Distância, velocidade, altura, impulso são mobilizados pela interação do personagem com os objetos e o cenário.

O contexto desses planos é dado inteiramente ao espectador, visto que o objetivo não é a mera surpresa, ou o maravilhamento com eventos impossíveis, mas o reconhecimento de que, dentro de tais possibilidades, um evento pode ser ao mesmo tempo plausível e absurdo. É nessa chave que podemos reconhecer a simplicidade geométrica dos enquadramentos de Keaton, dando acesso aos vetores da ação como se destacassem no espaço da cena as leis que devem regular a situação. Se Méliès restringia a visão para criar o espaço artificial de seus números mágicos, recorrendo ao fundo preto e às múltiplas exposições, Keaton aproxima-se dos Lumière em sua preferência por espaços naturais, quase sempre abertos e claramente determinados em suas linhas de força. 


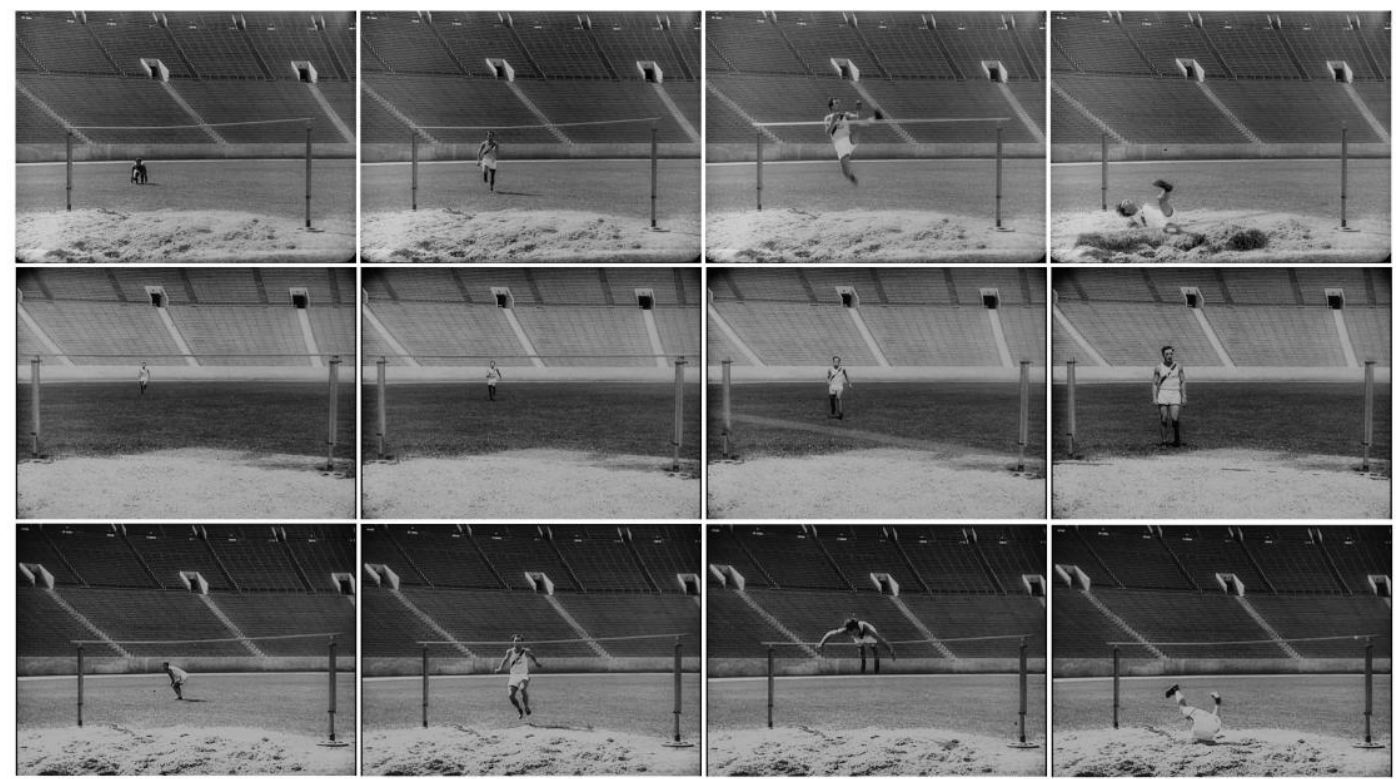

Três planos em College que exemplificam a configuração física na qual as ações de Keaton jogam com as expectativas: no primeiro, o salto derruba a barra; no segundo, a barra cai antes do salto; no terceiro, o salto não derruba a barra, mas Keaton cai de cabeça na areia.

Em outros casos, a própria limitação do enquadramento - o recorte do espaço por um ângulo único - é utilizada para criar o deslocamento entre expectativa e realização. Num plano de The Goat (Buster Keaton \& Malcom St. Clair, 1921), por exemplo, seu personagem procura um meio de fugir de policiais e termina se agarrando ao que parece ser um pneu reserva colocado na parte de trás de um carro. A expectativa é que, segurando o pneu, Keaton será carregado junto com o carro quando este se movimentar. O plano mostra o pneu lateralmente, e vemos com isso as reações de Keaton enquanto a partida é esperada. O motorista chega sem que ele perceba; o carro dá partida, mas tão logo começa a se mover, nos é revelado que o pneu não estava preso ao carro, e sim que era parte de um anúncio colocado próximo à calçada. Keaton permanece segurando o pneu durante alguns segundos, até que finalmente percebe que o carro foi embora:

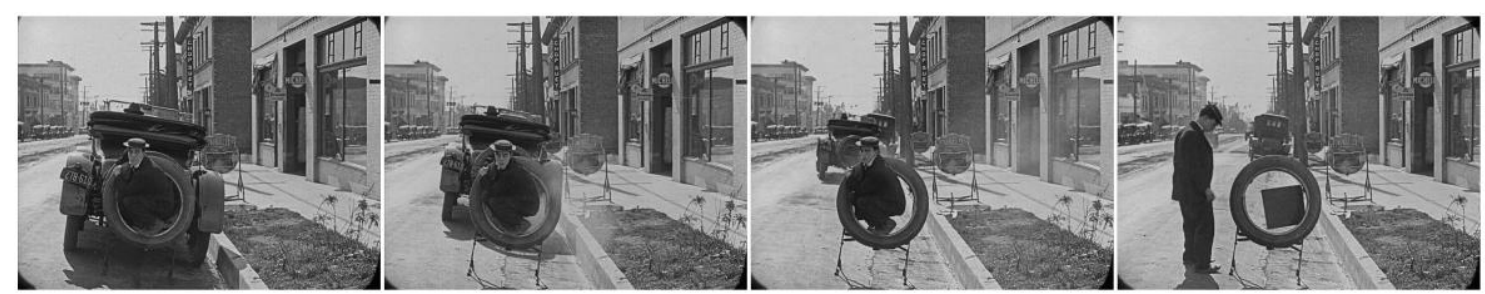

Enquanto o efeito dos filmes de Méliès era devido à possibilidade de substituir as leis da física por "leis da imaginação", as gags de Keaton se caracterizam pela afirmação 
das leis da física na forma como se manifestam no cinema. Em algumas delas ocorre um jogo de interpretações alternativas, projetadas num único enquadramento. O princípio básico, para usar uma terminologia sugerida por Noel Carroll, é o da incongruência mais especificamente, a justaposição de elementos incongruentes de modo a instigar e desviar as expectativas. Uma das gags tornada possível nessa abordagem é a da “interferência ou interpenetração mútua de dois (ou mais) eventos". Neste caso, uma cena, se vista por determinado ângulo, nos revela determinado sentido; mas no momento seguinte, quando vista por outro ângulo ou recebendo o acréscimo de um gesto, revela outro sentido, frequentemente incompatível com o primeiro. As gags de Keaton que mais se aproximam deste tipo são aquelas em que a interpretação do personagem, o modo como ele age e como parece compreender a situação representada, está em conflito direto com o modo como nós - espectadores cujo olhar é associado ao ponto de vista da câmera - vemos e compreendemos a mesma situação. Essa disjunção, percebida no momento em que o personagem começa a agir, nos leva à espera pela quebra de suas premissas, ou seja, a correção, pela realidade física, do que o personagem imaginava ser a forma correta de proceder. $^{219}$

É significativo, portanto, que no discurso crítico sobre os filmes de Keaton haja uma ênfase no papel da gravidade. A frequência das "quedas brutais", dos "impactos com o solo", do "tratamento desengonçado de objetos que caem ou quebram", são indícios de que as relações entre peso e equilíbrio, como entre ação e reação, mais do que acessórios, são muitas vezes o próprio tema dos planos. ${ }^{220}$ A suposição parece ser de que, se o plano é capaz de registrar o encadeamento de causas e efeitos de acordo com as leis naturais, se isso é uma de suas características básicas como registro fotográfico da realidade, então é possível compor planos em que suas características expressivas servirão para tornar mais dinâmico esse encadeamento. O caso é semelhante ao das animações como definidas por

${ }^{219}$ Noel Carroll, "Notes on the Sight Gag", in Theorizing the Moving Image (Nova York: Cambridge University Press, 1996), pp. 146-150. Para uma análise das gags de Cops (Buster Keaton \& Edward F. Cline, 1922) baseada numa visão semelhante, ver Sylvain Du Pasquier, "Les gags de Buster Keaton", Communications 15 (1970), pp. 132-144. Para uma interpretação do fenômeno cômico como um subconjunto de processos perceptivos mais amplos, ver a primeira parte de Arthur Koestler, Insight and Outlook (Nova York: The MacMillan Company, 1949), pp. 3-112. Koestler propõe o termo bissociação para se referir a "qualquer evento simultaneamente ligado a dois contextos habitualmente incompatíveis". Um de seus argumentos é que o fenômeno cômico apresenta uma bissociação específica, onde dois padrões mentais consistentes se vistos isoladamente entrariam numa espécie de curto-circuito quando associados. Por essa ótica, o ponto de maior impacto da gag seria o momento em que percebemos o cruzamento das interpretações incongruentes. Este argumento, que inclui um diálogo com Freud, Bergson e a psicologia cognitiva, é expandido em Arthur Koestler, The Act of Creation (Londres: Penguin, 1964).

${ }^{220}$ Ver Éric Rohmer, "Cinema, the Art of Space" (1948), in The Taste for Beauty (Cambridge: Cambridge University Press, 1989), p. 24. 
Gunning - em ambos, condições prováveis de um elemento fílmico são tornadas princípios composicionais, e o que parecia meramente funcional torna-se a fonte do interesse.

A inteligibilidade das condições espaciais deve se tornar, assim, um dos principais critérios na organização interna dos planos. Para apreciar e mesmo compreender essas relações, as condições físicas que as regulam devem ser tornadas inteligíveis. Se a configuração visual determina a percepção dos eventos, modificar a configuração pode levar à modificação do sentido dos eventos. Ainda que o sentido geral dos planos possa resistir às mudanças de ângulo, distância e iluminação, o caráter cômico e o interesse criado pela expectativa, pelo encobrimento de certas variáveis da cena, algumas dessas características podem ser simplesmente perdidas. E se a gag depende da incongruência entre a ação do personagem e as condições físicas registradas pela câmera, então podemos tomar conhecimento dessa incongruência junto com o personagem (como em College) ou antes dele (como em The Goat). Podemos chamar o primeiro tipo de uma gag subjetiva e o segundo de uma gag objetiva. O tempo dado à revelação dessas incongruências, e às relações entre o momento em que nós, como espectadores, a percebemos, e o momento em que Keaton e outros personagem a percebem, é tornado flexível através do controle das condições físicas.

A gravidade é privilegiada em sua fortuna crítica por ser uma das grandezas físicas fundamentais, por envolver a interação entre as distribuições de massa e energia no espaço cotidiano, e sobretudo por ter efeitos visíveis na escala dos planos médios e gerais. Ainda que a maioria dos planos, na maioria dos filmes, deva se submeter à gravidade, Keaton a torna praticamente uma aliada na construção de seus efeitos cômicos. $\mathrm{Na}$ medida em que o espectador possui um conhecimento - ainda que intuitivo - das relações gravitacionais, Keaton pode estruturar as gags tendo nesse referencial comum uma espécie de medidor interno. Além da inteligibilidade, a cena traz então outro critério: a credibilidade gerada pelo plano único. A clareza da disposição geométrica e da iluminação representa apenas uma parte disso. Se no contexto dos truques mágicos bastava a Méliès passar embaixo de suas mesas para sugerir ao espectador que não se tratava de um corpo escondido sob ela, Keaton deve em suas comédias realizar perante a câmera todas as acrobacias, colocando-se em risco e dando a este risco um papel central no desenvolvimento da ação. Quanto mais se torna claro que toda a ação ocorre em frente à câmera sem qualquer manipulação, e quanto mais o plano sugere a transposição de 
eventos reais ao espaço da tela, mais diretamente as condições subjacentes aos eventos podem ser observadas.

Em One Week (Buster Keaton \& Edward F. Cline, 1920), a maioria das gags envolve as tentativas de montar uma casa segundo instruções que foram embaralhadas. Num dos planos, Keaton parece inteiramente desatento às condições físicas de suas ações: para serrar parte de uma tábua de madeira numa parte elevada da casa, ele senta não na parte que deve permanecer presa, mas na que deve ser retirada, de modo que, serrada a tábua, Keaton cai junto com ela. Num enquadramento lateral, marcado por ângulos retos, o processo é inferido e a expectativa é cumprida:

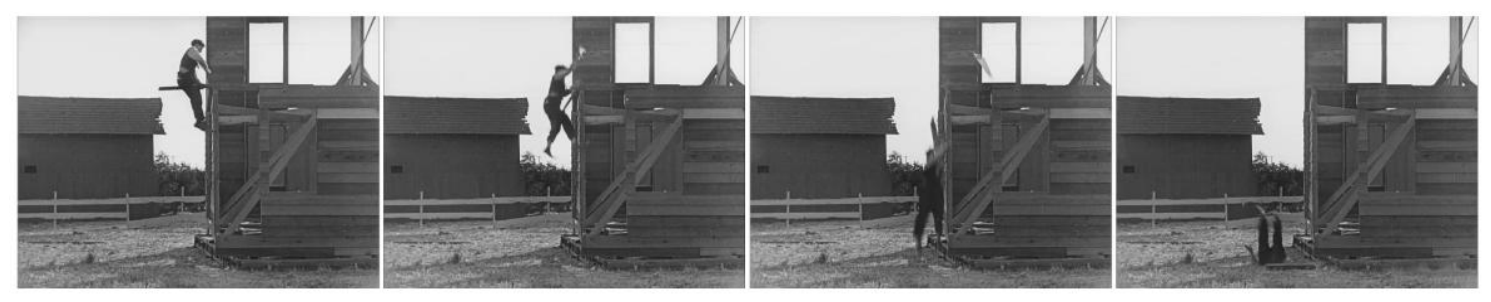

Este ângulo é inclusive semelhante àquele utilizado por McLaren para representar a orientação gravitacional, e sua recorrência nos filmes de Keaton (especialmente em seus curtas) sugere algo como uma convenção ou uma configuração quase arquetípica da representação da gravidade, uma redução do problema a um plano onde a força atua apenas no eixo vertical da imagem. Numa abordagem típica da comédia burlesca do período, Keaton privilegia a disposição sequencial das ações de modo a apreendê-las por sua direcionalidade na superfície da imagem, mais do que por sua profundidade. A perspectiva é mantida em seus mínimos índices, e a percepção é orientada em movimentos laterais e verticais, raramente no eixo da câmera; é deslocada de uma região a outra na tela bidimensional, reconhecendo apenas brevemente os diferentes planos da caixa cênica. $^{221}$

Em outro momento do filme, uma parede é solta do resto da casa, sendo lentamente inclinada, prestes a cair na região onde Keaton se encontra, mais uma vez, sem qualquer noção aparente do que acontece à sua volta. Aqui a expectativa é de outra ordem; percebendo que tanto a parede como Keaton se deslocam, e que há uma região

221 Ver Scott Bukatman, The Poetics of Slumberland: The Animated Spirits and the Animating Spirit (Berkeley: University of California Press, 2012), p. 92. Para um comentário mais detido sobre a "física das animações", numa abordagem que retoma alguns dos pontos mencionados aqui sobre Keaton, ver Scott Bukatman, "Some Observations Pertaining to Cartoon Physics, or The Cartoon Cat in the Machine", in Animating Film Theory, op. cit., pp. 301-316. 
vazia na parede (correspondente à janela), inferimos que há a possibilidade de um encaixe entre as duas trajetórias, ou seja, que Keaton poderá permanecer na exata posição do solo em que será projetada aquela região da parede, o que de fato ocorre:

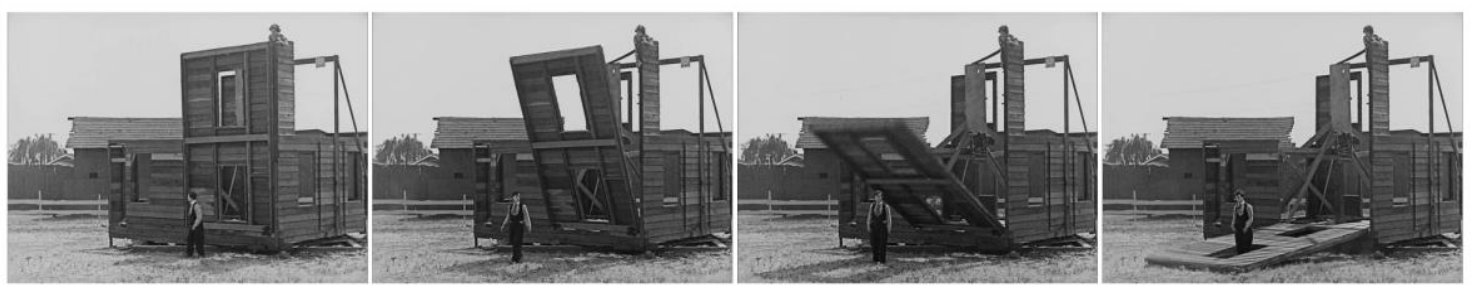

A situação é retomada em Steamboat Bill, Jr. (Buster Keaton \& Charles Reisner, 1928), alterando o ângulo do enquadramento, de uma diagonal que nos permite visualizar a casa e outras construções ao fundo, para um plano frontal em que o espaço cênico é quase totalmente coberto pela casa, e no qual a região segura é consideravelmente menor:
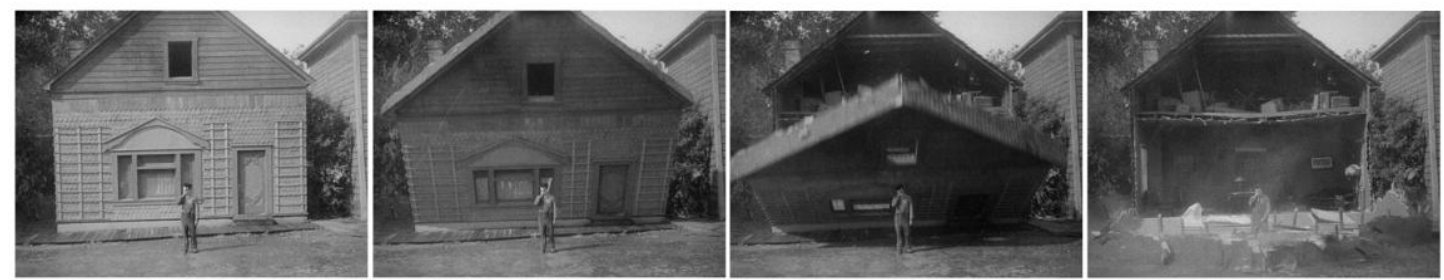

Nos dois planos, permanece o que Gunning chamou de uma "geometria cômica, na qual o próprio Keaton é apenas um ponto na confluência de intricados ângulos e interseções”. O plano se torna o meio para exibir uma habilidade particular, a de "ocupar um ponto matematicamente preciso num processo perigoso". ${ }^{222}$ Novamente, é a clareza na percepção das condições físicas da representação que nos permite compreender as forças que estão em jogo, inferindo seus resultados possíveis. Além da sincronia necessária para a segurança na realização da gag, Keaton menciona a importância desse controle rítmico para a própria criação da comédia:

Efeitos cômicos são evanescentes. Eles devem ser iniciados num momento preciso, dando ao espectador o tempo para se recuperar, e então seguindo as circunstâncias, levando-o ao limite ou recuperando sua progressão. Nesse ritmo, é necessário ter uma precisão matemática, e este ritmo é uma ciência cuja responsabilidade é dependente do diretor. Um

${ }^{222}$ Tom Gunning, "Buster Keaton, or: The Work of Comedy in the Age of Mechanical Reproduction", Cinéaste, vol. 21, n. 3 (1995), p. 15. 
filme de comédia é composto com a mesma precisão do mecanismo interno de um relógio. ${ }^{223}$

Em outro nível da composição, Keaton sugere algo semelhante ao que vimos no primeiro capítulo em relação aos flickers: que o controle perceptivo do espectador deve ser realizado através do encadeamento de seus elementos, que aqui são os gestos e as consequências deles no espaço cênico. Da máquina cognitiva na superfície, passamos à máquina cômica na profundidade. ${ }^{224}$

Em Our Hospitality (1923), as habilidades acrobáticas de Keaton são postas à prova no resgate de seu interesse amoroso (Natalie Talmadge) quando ela cai num rio e, levada pela correnteza, se aproxima de uma queda d'água. A descrição de Gilberto Perez para a situação, filmada num único plano, sintetiza alguns dos temas que apontamos até aqui:

O universo [...] dita seus próprios termos: não há nada a ser feito, neste ponto, contra a atração gravitacional. Mas essa atração pode [...] ser utilizada a seu favor, como Buster Keaton demonstra no clímax de [Our Hospitality], ao construir um pêndulo com essa corda e usar a si mesmo como a massa suspensa: balançando na corda, ele se projeta à frente da rocha e agarra a garota quando ela está sendo jogada no precipício de uma queda d'água, usando a gravidade para vencer a gravidade, já que, graças ao princípio do pêndulo, ele e a garota balançam de volta, em segurança, até a pedra. Costumava-se dizer que Keaton considerava o universo físico como um adversário; alguns comentadores recentes enfatizaram que o tratava como aliado. Com efeito, essas forças geralmente atuam a seu favor, às vezes como resultado de ele se aproveitar delas, às vezes por coincidência. É certamente um exagero dizer [...] que Keaton "confiava" no universo: ele apenas confiava que o universo seria o que é, nem contra e nem a favor dele, mas simples e implacavelmente presente. ${ }^{225}$

${ }^{223}$ Buster Keaton, citado em Georges Sadoul, “A Dinner with Keaton” (1962), in Buster Keaton: Interviews, ed. Kevin W. Sweeney (Jackson: University Press of Mississipi, 2007), p. 153.

${ }^{224}$ Um exemplo de como este problema se coloca de maneira radical em animações é o tratamento de Chuck Jones para um de seus personagens mais próximos de Keaton: Wile E. Coyote. Em seus filmes com o personagem, filmes sem diálogos, inteiramente baseados em ações físicas e mecanismos frustrados, o controle das durações e a sincronia das trajetórias são cruciais. A cena recorrente da queda do coiote do alto de um precipício, por exemplo, teve de passar por inúmeros testes onde diferentes números de fotogramas foram postos à prova. Exatamente dezoito fotogramas foram necessários para mostrar a queda do personagem, e catorze para mostrar o impacto no solo. Jones diz ter feito o teste com um fotograma a mais e um fotograma a menos; nenhum dos dois conseguiu arrancar risos do público. Ver Hugh Kenner, Chuck Jones: A Flurry of Drawings (Los Angeles: University of California Press, 1994), p. 47.

${ }^{225}$ Gilberto Perez, "The Bewildered Equilibrist", in The Material Ghost: Films and Their Medium (Baltimore: The Johns Hopkins University Press, 1998), pp. 102-103. Perez enfatiza a inexorabilidade da mecânica newtoniana, mas aponta que há um desdobramento temático nesses filmes: "Keaton, o acrobata, manobra diligentemente o funcionamento desse sistema, esforçando-se para atingir a configuração desejada, tal como a aproximação dele e da garota que os levará ao altar. Essa abordagem amorosa curiosamente impessoal, que coloca ele e a garota numa interação mais mecânica que emocional, é exigida pelo mundo que habitam, um mundo no qual relações humanas são tão sistematizadas quanto corpos celestes." 


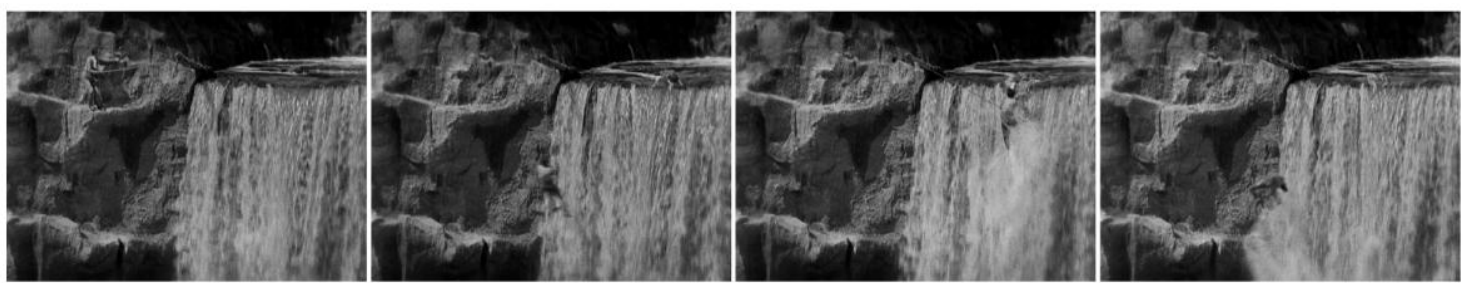

Our Hospitality (Buster Keaton \& John G. Blystone, 1923)

É a partir dessa visão do universo como um sistema de regras implacáveis e invioláveis que podemos interpretar o aproveitamento das leis físicas na composição dos filmes de Keaton. É justamente a regularidade do "universo newtoniano" que garante que ele possa criar tanto as gags onde suas ações são frustradas quanto as gags em que seu domínio acrobático é a fonte do sucesso. Em todos os casos, Keaton deve identificar as condições e delas se aproveitar - deve exibir sua "inteligência corporal". "O corpo possui um entendimento", argumenta Carroll, referindo-se à capacidade de Keaton, dentro da cena, enquadrado da maneira correta, medir qualidades espaciais como distância e orientação nos termos de sua capacidade de ação. A inteligência corporal manifesta-se mais claramente na vitória da adaptabilidade sobre o automatismo. ${ }^{226}$

Nos referimos até aqui a planos em que as condições físicas da cena representada se assemelhavam ou eram idênticas às que um espectador teria se a presenciasse do solo, como um espectador de teatro. A frontalidade centralizada da câmera numa altura média servia como uma espécie de neutralização da angulação, ou a escolha por um ângulo que garantisse a impressão da caixa autocontida - o plano da tela como o plano retirado da caixa cênica. Em alguns filmes, Keaton manipula esses fatores para retomar o princípio das gags de outra maneira.

Em The Boat (Buster Keaton \& Edward C. Cline, 1921), o barco do título é o local de algumas sequências, e a sugestão de uma caixa cênica é feita pelo posicionamento da câmera de frente à porta, mantendo em quadro também as paredes da cabine. A certa altura do filme tem início uma tempestade e o barco é virado pelas ondas de um lado a outro. Neste momento, a fixidez da câmera revela sua importância. Conforme o barco gira, Keaton tenta acompanhar o movimento em meio aos objetos que são jogados sobre ele:

${ }^{226}$ Ver Noel Carroll, Comedy Incarnate: Buster Keaton, Physical Humor, and Bodily Coping (Massachussets: Blackwell, 2007), p. 5. Em sua análise mais extensa, Carroll explora a construção de $A$ General (The General, Buster Keaton \& Clyde Bruckman, 1926), mas seus comentários incluem alguns dos curtas. Ver também Noel Carroll, "Buster Keaton: Film Acting as Action" (1990), in Interpreting the Moving Image (Nova York: Cambridge University Press, 1998), pp. 44-63. 


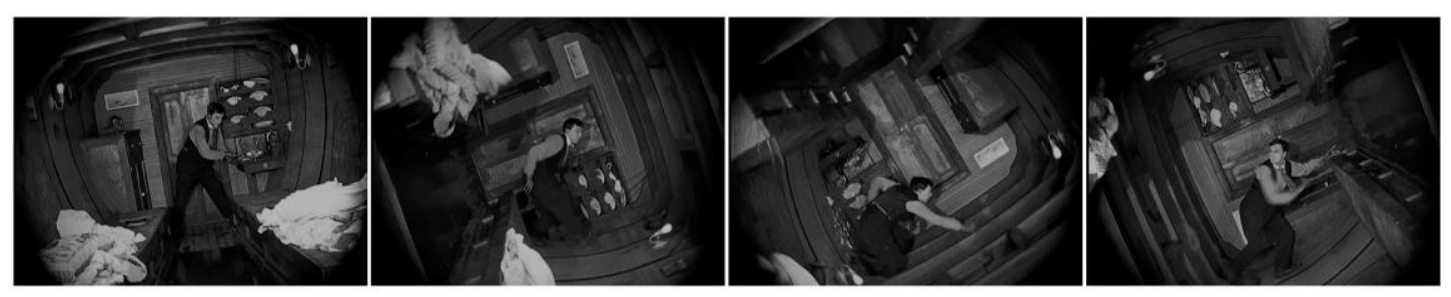

Todo o sentido da cena é baseado no fato de que o próprio palco da ação se movimenta enquanto nós e a câmera permanecemos estáticos. Quando os objetos caem na parte inferior da caixa cênica, isso confirma nosso referencial físico como idêntico ao da câmera, deslocando a igualdade entre a caixa cênica e o retângulo da tela. Da mesma forma, o conflito do personagem se baseia no fato de que ele não é capaz de acompanhar o movimento do barco. Qualquer alteração nessas condições e a cena seria completamente diferente. Este é um dado importante na composição de Keaton: como em outros casos da comédia burlesca, é preciso haver a garantia psicológica de que as ações, ainda que determinadas pelo ângulo da câmera e a organização cênica, poderiam ocorrer sob outros parâmetros. A câmera poderia estar em outro ângulo daquele mesmo espaço porque nos é dada a realidade daquele espaço, como o personagem poderia reagir de outra forma porque sua integração àquele espaço nos é afirmada. Se as formas abstratas de Fischinger interagiam com o ambiente da tela por operações construtivas, que poderiam ser desfeitas a qualquer momento, o realismo que serve de base ao burlesco cria um tipo de interação que é de outra ordem, dando às ações um sentido especial - o valor é atribuído a esta configuração particular justamente por sabermos que poderia ter ocorrido de outra maneira, mas sempre de acordo com a natureza da situação representada. Uma alteração é feita então pelo próprio Keaton quando ele prega os sapatos no chão do barco, fixando seu corpo numa das faces da "caixa" - em outras palavras, adaptando seu corpo ao palco da ação, enquanto os outros objetos permanecem sendo arremessados com a movimentação constante:

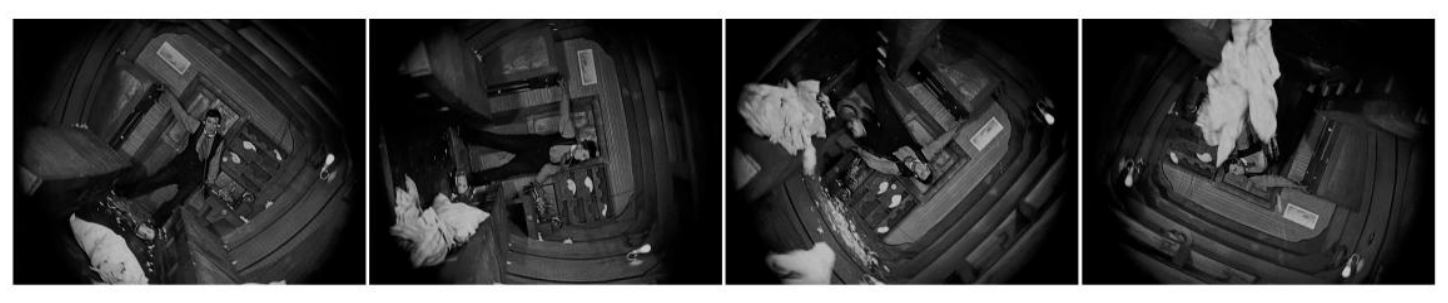


Um outro exemplo, que aproxima Keaton do aspecto mágico de Méliès, é a sequência do sonho em Sherlock $J r$. (1924). O protagonista, um projecionista que almeja ser um detetive e se casar com a filha de um milionário, cai no sono durante a projeção de um filme. No sonho que se segue, ele "entra" na projeção do filme no qual imagina participarem alguns de seus conhecidos - entra na tela como se fosse um palco contíguo ao espaço da sala. Num enquadramento amplo, mostrando frontalmente a tela do cinema e parte da plateia, Keaton passa então a sofrer uma série de impactos causados pelas transições entre os planos do filme-dentro-do-filme. Ele se encontra numa escada, e quando está prestes a descer os degraus, o filme corta para outro ambiente e a escada torna-se o banco de um jardim, do qual ele cai imediatamente. Após se levantar e perceber a mudança, ele decide sentar no banco, mas no meio de seu gesto um corte muda novamente o cenário, e ele cai numa rua movimentada. Caminhando na rua, o cenário muda outra vez, agora para uma montanha, e depois para uma selva onde dois leões descansam sentados.

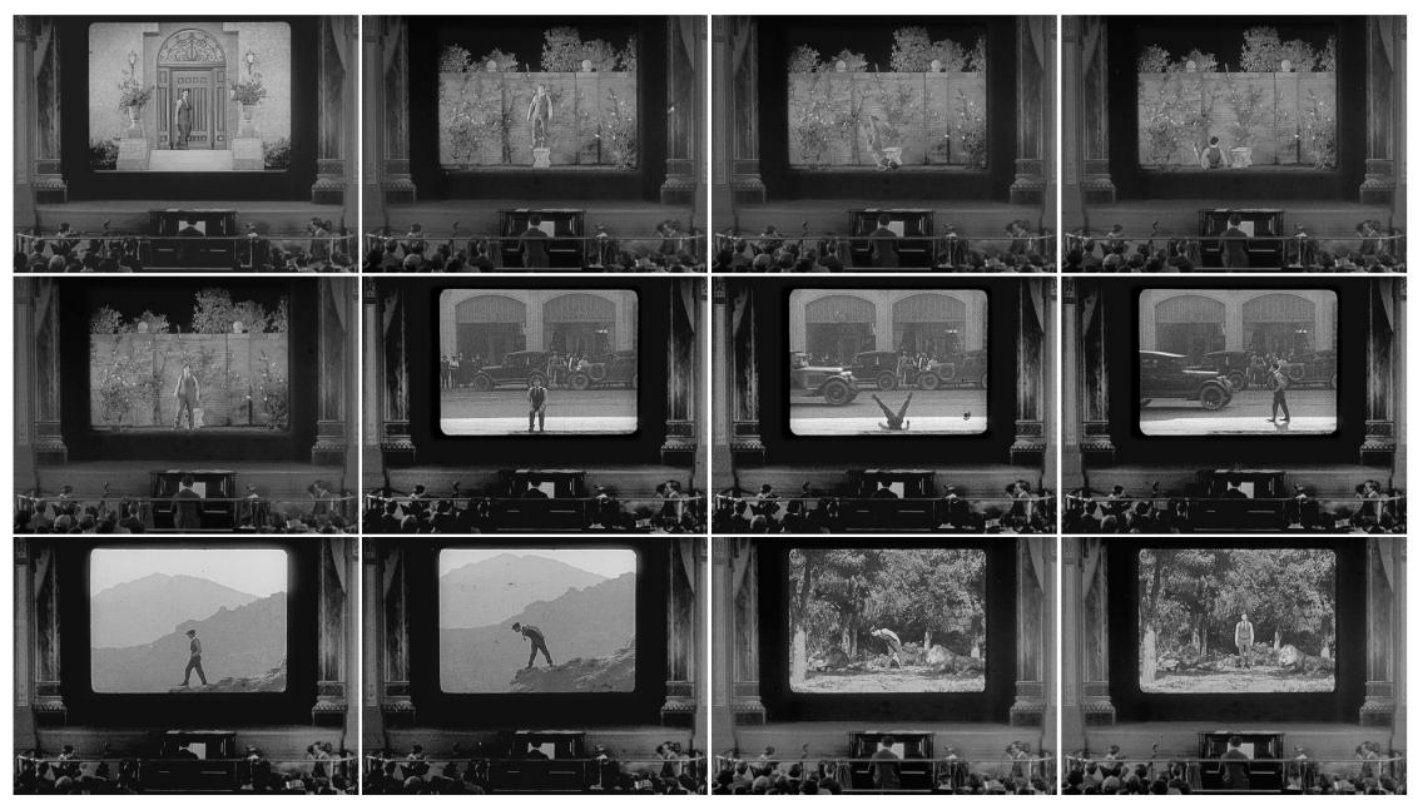

Etapas da sequência do sonho em Sherlock Jr. (Buster Keaton, 1924), onde a impossibilidade da adaptação é o mote da gag, absorvendo a técnica da transformação de Méliès.

Como em Méliès, a sequência exige múltiplas exposições. Um dos planos, registrando o espaço mais amplo da sala de cinema, serve como base para as exposições que fazem parte da montagem central, restrita ao espaço da tela-dentro-da-tela. Nessa montagem, os gestos de Keaton determinam a continuidade que dá sentido à gag: ele é o ponto de ligação entre planos que, sem suas ações, seriam desconexos; ele é mesmo a 
prova de que a sucessão dos planos é arbitrária, na medida em que é o único elemento contínuo entre um e outro. Como em Méliès, a frontalidade da câmera é utilizada para garantir o achatamento da imagem. Com exceção do salto que o coloca "dentro" da tela, como num palco real, todo o espaço tridimensional no qual Keaton se locomove - o espaço do filme-dentro-do-filme - tem suas linhas de força reduzidas ao eixo horizontal e vertical, com Keaton caindo, subindo, caminhando de um lado a outro.

Tanto The Boat como Sherlock $J r$. exemplificam uma camada adicional na concepção cênica de Buster Keaton. O que em outros filmes era uma investigação das possibilidades físicas de um espaço real, ainda que filtrado pelas limitações de ângulo e enquadramento, torna-se nestes casos uma investigação das possibilidades de adaptar a física às condições particulares de registro e projeção da imagem fílmica. O fato de que a tela permanece fixa enquanto a imagem se move, que o próprio espectador tem uma posição estável em relação à tela, que pode conter imagens em diversas orientações gravitacionais - este fato é tornado o apoio dos planos em que o barco gira com a tempestade. Da mesma forma, a estabilidade criada pela manutenção do enquadramento e a angulação constante entre os cortes faz com que em Sherlock $J r$. Keaton possa, com a justificativa diegética de um sonho e de um filme-dentro-do-filme, ser transportado de um ambiente a outro com uma arbitrariedade que logo se revela um perfeito jogo de coincidências desastrosas. ${ }^{227}$ Não por acaso, se em The Boat era possível a ele adaptar-se à realidade da situação, em Sherlock $J r$. a impossibilidade da adaptação decorre da ausência do realismo da situação em primeiro lugar. Aqui, as leis da imaginação de Méliès, ou as leis próprias da física do cinema, da física real adaptada à superfície cinematográfica, tomam o lugar da gravidade como o princípio regulador.

\subsection{Coreografia, ou o valor do movimento}

Um terceiro caso que nos serve para explorar o papel do espaço e do tempo em composições relacionadas à unidade cênica é o de Fred Astaire. Apesar de não assinar a direção dos filmes como Méliès e Keaton, já no início de sua carreira Astaire obteve

\footnotetext{
${ }^{227}$ Outro caso de proximidade entre Keaton e Chuck Jones seria a relação entre a sequência do sonho em Sherlock Jr. e o curta-metragem Duck Amuck (1953), em que Jones executa inúmeras transformações no cenário, interferindo na orientação e na própria consistência do corpo de um protagonista que manifesta sua insatisfação diretamente para a câmera. Neste exemplo, a lógica da caixa autocontida é por um lado desafiada pelo olhar reflexivo, mas por outro reforçada pela completa arbitrariedade das transformações, e sobretudo pela unidade estabelecida em cada imagem.
} 
controle criativo sobre suas cenas de dança, o que significa que, junto com a concepção coreográfica, era responsável também pelo modo como seriam enquadradas, montadas e coordenadas com as músicas. Além do destaque frequentemente dado a essas cenas por seu caráter exibicionista, revelador das habilidades dos protagonistas, os números musicais remetem às atrações por uma série de outros fatores que podemos comentar a partir de alguns exemplos característicos.

Em A roda da fortuna (The Band Wagon, Vincente Minnelli, 1953), Astaire interpreta Tony, um dançarino que é contratado para protagonizar um espetáculo da Broadway. Junto com ele, é contratada também Gaby (Cyd Charisse), uma dançarina de formação clássica. Durante parte do filme, os dois personagens se mantêm emocionalmente distantes, mas a necessidade de alguma proximidade em razão do espetáculo os faz considerar a possibilidade de dançar juntos. Os dois pegam uma carruagem no Central Park, onde caminham até chegar num lugar aberto e completamente vazio. Durante a caminhada, a música Dancing in the Dark (Arthur Schwartz e Howard Dietz), que já estava presente no início da sequência, ganha um contorno mais melódico e intenso, e algo semelhante ocorre com os passos dos personagens - eles realizam, brevemente, movimentos que sugerem uma dança, ainda que retornando logo em seguida à caminhada usual. Num plano médio que os acompanha em andamento constante, vemos a transformação contínua dos movimentos. Podemos visualizar algumas das etapas dessa transformação, da caminhada casual à dança e de volta à caminhada:
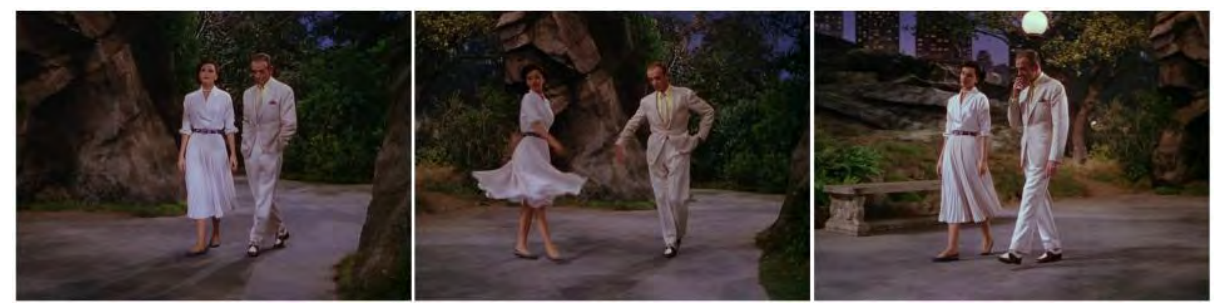

Após mais alguns passos, retorna o impulso coreográfico, desta vez para entrar definitivamente no domínio do número musical. Os dois corpos se movem até a região central do parque e seus gestos os levam a uma pose fixa, na qual permanecem durante alguns segundos, olhando um para o outro - Astaire com as mãos para trás, Charisse com as mãos ao lado de seu corpo, ambos com as pernas esquerdas mantidas como apoio e as direitas na ponta dos pés, como dois compassos prestes a traçar figuras num mesmo plano. Seguindo a melodia sinuosa, eles mantêm as mãos na mesma posição e dançam 
com passos laterais, os dois corpos sendo deslocados paralelamente no espaço da cena, um de frente ao outro, os pés deslizando sobre o chão em padrões de ida e volta, à esquerda e à direita. No mesmo plano de escala média, a câmera os acompanha em breves movimentos no eixo horizontal:
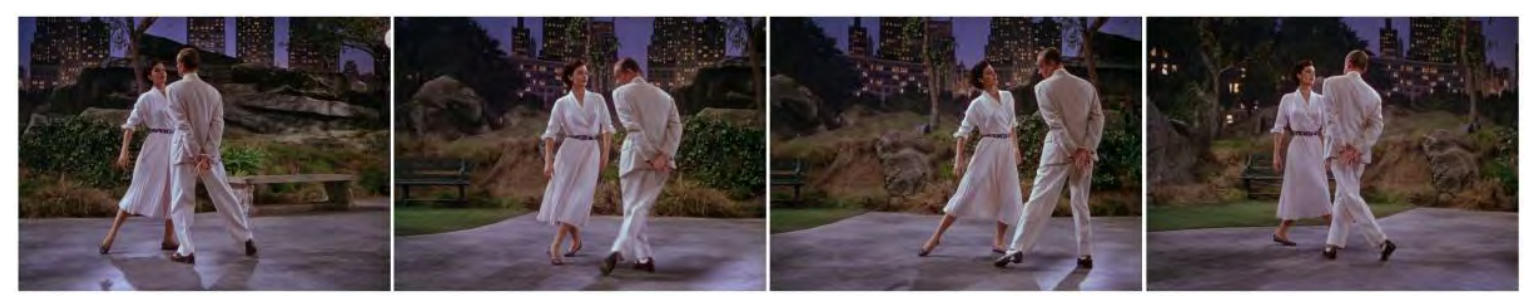

Conforme avança a coreografia, os dois criam elaborados padrões baseados em giros pelo cenário. A crescente proximidade, representada por toques pontuais das mãos no decorrer dos giros, finalmente os leva a um giro em que as mãos são posicionadas na cintura do parceiro e logo afastadas, retomando os toques pontuais entre as mãos:
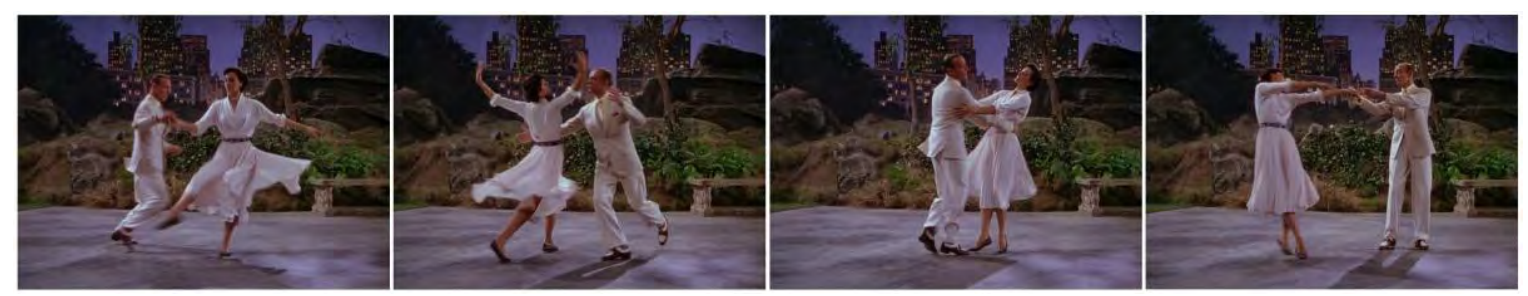

Nos momentos seguintes, ainda que realizem movimentos independentes, a tendência é ao paralelismo e à conjunção desses movimentos num único complexo de gestos que inclui os dois corpos. Nessa sequência de gestos, Astaire conduz Charisse pelo cenário, servindo como seu ponto de ancoragem, permanecendo estático para que ela realize giros e passos que se afastam e voltam a se aproximar, de modo que eles traçam no espaço uma trajetória onde as poses são marcadas pelos braços e pernas dispostos a cada vez numa direção, como se apontassem para regiões diferentes do ambiente: 


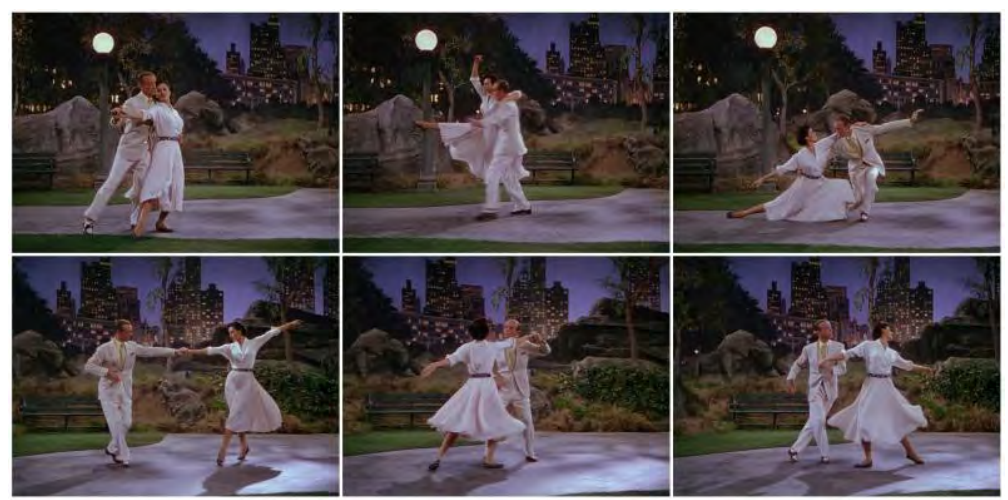

A posição de Astaire como suporte toma outro sentido quando Charisse realiza movimentos mais amplos pelo espaço, sobretudo quando estes movimentos jogam diretamente com a gravidade, como quando ela sobe num dos bancos e cai em seus braços, ou quando, durante uma caminhada, ela deixa seu corpo cair apenas para ser carregada por ele através de um braço ao redor da cintura:

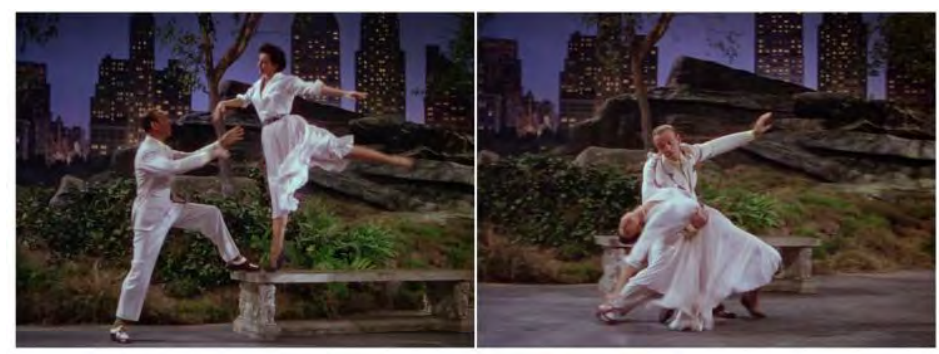

A cena completa, que dura aproximadamente três minutos, possui dois cortes; ambos mantêm a continuidade dos movimentos, ajustando o ângulo, a escala e o posicionamento, sempre cortando para um plano médio frontal e centralizado. Os movimentos da câmera são feitos para acompanhar os movimentos segundo estes critérios, que são presentes até os gestos finais da dança, quando Astaire e Charisse sobem uma escadaria em giros paralelos, e terminam trocando olhares de costas um para o outro enquanto dispõem os braços e pernas em poses fixas, antes de retornarem à carruagem:

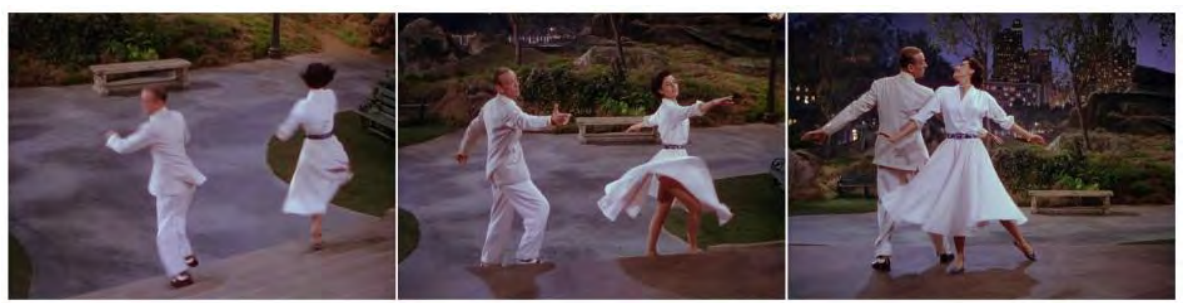


Como em Méliès e Keaton, o número caracteriza uma apresentação ao espectador, a disposição de corpos num espaço para criação de um espetáculo marcado pelo "impacto sensual e psicológico". Como nos exemplos anteriores, a tendência é à manutenção do plano médio, à representação desses corpos em sua totalidade no espaço cênico. Este espaço, por sua vez, é observado de maneira mais ampla que nos filmes anteriores: tanto a mobilidade da câmera como a profundidade de campo são mais pronunciadas, e mesmo a angulação da câmera em relação ao espaço da cena é variada em alguns momentos, apesar da recorrência da frontalidade.

Essas diferenças nos levam aos elementos utilizados em cada um desses filmes. Em Méliès era recorrente a figura do mágico, que transformava a si mesmo e aos outros, dando aos corpos o estatuto de objetos passíveis de manipulação por um desígnio criativo, sujeito às leis próprias do material fílmico. Em Keaton a regra era a figura do homem desatento que devia sobreviver à inexorabilidade de um universo mecânico, tomando conhecimento de suas leis e utilizando os corpos e suas relações em proveito próprio. Em Astaire a figura central é a do dançarino, e a tendência é à transformação de gestos cotidianos em gestos coreográficos, com os dançarinos movendo-se pelos ambientes e interagindo com os objetos, e com a arbitrariedade surgindo não pela manipulação de um feiticeiro, mas pelos próprios agentes presentes, que em vez de alterar a realidade cênica, a utilizam como matéria-prima de um espetáculo com certa autonomia.

Neste espetáculo, Astaire e Charisse realizam padrões gestuais, movimentam os corpos de um lado a outro, com giros e posicionamentos de seus braços e pernas; sugerem ainda padrões de afastamento e proximidade, de contraste e paralelismo. Os movimentos no espaço da cena são marcados por etapas, por algumas poses que se destacam do movimento como intervalos na trajetória. Acompanhados pelo movimento da câmera, que os reenquadra com frequência, os dois dançarinos cobrem então diferentes partes do cenário, e o movimento se torna a passagem de uma configuração a outra. Há, em resumo, uma geometria interna da coreografia, uma evolução ordenada de formas no interior da imagem. Considerando essas observações, ao menos três relações devem ser apontadas.

A primeira é que, como Eggeling em Symphonie Diagonale, há um aspecto puramente construtivo no desenvolvimento dos movimentos - a dança como uma construção que, apesar de inserida num contexto narrativo, expõe suas características como possuindo um valor em si mesmas. Há uma dedicação à criação de movimentos que 
levam os corpos de um ponto a outro, e consequentemente a câmera de uma parte a outra do cenário; e mais especificamente, movimentos que exibem uma geometria perceptível, baseada em círculos, semicírculos, ações à direita seguidas de ações à esquerda. Há também a noção da coreografia como um traçado sobre este cenário, e dos dançarinos como os meios pelos quais o espaço registrado pela câmera pode ser explorado, com os braços e pernas constituindo linhas através das quais o olhar é conduzido e fixado momentaneamente. Uma diferença evidente é que, enquanto Eggeling se voltava ao espaço superficial da tela, a sequência de Astaire e Charisse o faz no espaço em profundidade da cena. Ainda que tudo deva se projetar na superfície, as relações de volume e profundidade caracterizam toda a sequência.

A segunda relação é que, como em Fischinger, a coreografia é uma série de movimentos visuais que remete à banda sonora. Astaire e Charisse não se movem com absoluta independência, mas a todo momento respondendo à estrutura da peça musical, reagindo às mudanças de tom, andamento e melodia. Como nos estudos de Fischinger, não há uma correspondência exata entre os gestos visuais e sonoros. A música é a linha contínua no decorrer de todo o número; dentro desse fluxo, os dançarinos, como a câmera, executam seus movimentos em complemento à movimentação sonora. As próprias condições técnicas que predominam na realização dos números musicais sugerem essa relação: as gravações são normalmente feitas antes da filmagem, de modo que a realidade acústica da peça tem pouca relação com a acústica do espaço fíccional ou com o espaço no qual se encontram os atores no momento do registro. A existência da música precede a existência da coreografia, e o fato de ser uma composição predeterminada sugere o imediatismo dos gestos filmados em continuidade. Ainda que não sejamos testemunhas do registro fílmico em si, o registro nos é apresentado como isomórfico ao tempo real, de modo que acompanhamos a evolução dos gestos e todas as reações no espaço à medida em que ocorrem perante a câmera.

A terceira relação envolve a importância da gravidade na coreografia. Fischinger, lidando com formas abstratas sobre um fundo preto, sem nenhum contexto prévio aos seus movimentos, precisava construir a orientação gravitacional. Keaton, tomando como unidade básica o plano, necessitava apenas voltar a câmera para a região do espaço onde ocorreria a ação e executá-la pelo ângulo escolhido, fazendo com que própria realidade das leis físicas se manifestasse em seus movimentos. Fischinger tendia, portanto, a oscilar entre a presença e a ausência da gravidade, pois era para ele um estado momentâneo, uma das configurações que suas formas poderiam tomar no espaço pictórico em movimento, 
ao passo que Keaton mantinha a gravidade como um absoluto, o único contexto qual poderiam ocorrer suas gags, e onde ele poderia oscilar entre ser a vítima e o herói, aquele que sofre pela desatenção e aquele que é bem-sucedido pela adaptabilidade. Num filme como $A$ roda da fortuna, Astaire exemplifica uma terceira via para a questão. Como Keaton, ele tem no plano sua unidade espaço-temporal, e com isso mantém a gravidade da cena como uma referência constante. Mas toda a elaboração da coreografia é definida por um jogo com a gravidade, ou mesmo um desafio à gravidade. Cada um dos gestos de Astaire e Charisse possui um nível de tensão com a linha horizontal do solo, o plano onde se deslocam continuamente. A diferença fundamental em relação a Keaton é que, aqui, a gravidade é tratada não com o pragmatismo de quem deve solucionar um problema mecânico, mas com uma espécie de graça e leveza: em vez de buscar a menor distância entre dois pontos, os dançarinos mostram a possibilidade de uma distância ser atravessada com movimentos sem propósito especial, como se o próprio deleite com a mobilidade fosse o bastante para manter o equilíbrio do corpo que realiza a travessia. A inteligência desse corpo, capaz de girar e saltar na mais perfeita sincronia, de responder aos gestos de outro corpo na cadência de uma música, de sugerir com isso a modulação do próprio tempo, tornando-o lânguido ou urgente conforme se interage com o espaço - essa demonstração de uma habilidade sem propósito é algo que se encontra no cerne do gênero musical, e que Astaire exemplifica de maneira emblemática.

Outro exemplo nos serve de complemento a este tópico. Em Núpcias reais (Royal Wedding, Stanley Donen, 1951), Astaire interpreta Tom, dançarino de um espetáculo da Broadway que viaja para fazer apresentações em Londres. Durante as preparações na cidade, Tom se apaixona por Anne (Sarah Churchill). Numa cena na segunda metade do filme, Tom rouba uma foto de Anne de um cartaz e a leva para seu quarto. Chegando no quarto, senta numa poltrona e observa a foto, enquanto a música toma a banda sonora, com a letra dando expressão verbal a seus pensamentos. Astaire segura a foto e anda com ela pelo apartamento, sendo acompanhado num plano americano até que, seguindo uma mudança de seção na música, passa ele mesmo a cantar enquanto dança e se movimenta pelo cômodo - sua dança composta basicamente por gestos cotidianos, como sentar numa cadeira ou apoiar o pé num sofá, mas ritmados e delineados aqui para fazer parte de uma coreografia.

Quando cessa a parte cantada da música, Astaire passa a dançar no meio do quarto. Num plano médio, ele sobe na cadeira, salta e gira de um lado a outro, até que finalmente ocorre uma mudança na configuração espacial: com os dois pés sobre a 
poltrona, ele coloca as mãos próximas à parede, e conforme seu corpo é inclinado, percebemos que desafia a gravidade. Daqui em diante, a cena é marcada por este princípio. Astaire dança como se tivesse completa liberdade em relação à gravidade, sobre a parede, sobre o teto, fazendo de sua trajetória uma verdadeira descrição de todo o perímetro do quarto. No decorrer da dança - que tem aproximadamente cinco minutos ele interage com os objetos do cenário geralmente como apoio, mas como se também eles fossem deslocados em relação à gravidade, como quando ele segura a cadeira e, de cabeça para baixo, deixa os pés se moverem livremente próximos ao teto. Durante todo o número ele segura a foto de Anne, e a cena termina onde começou, na poltrona, com Astaire observando a foto.

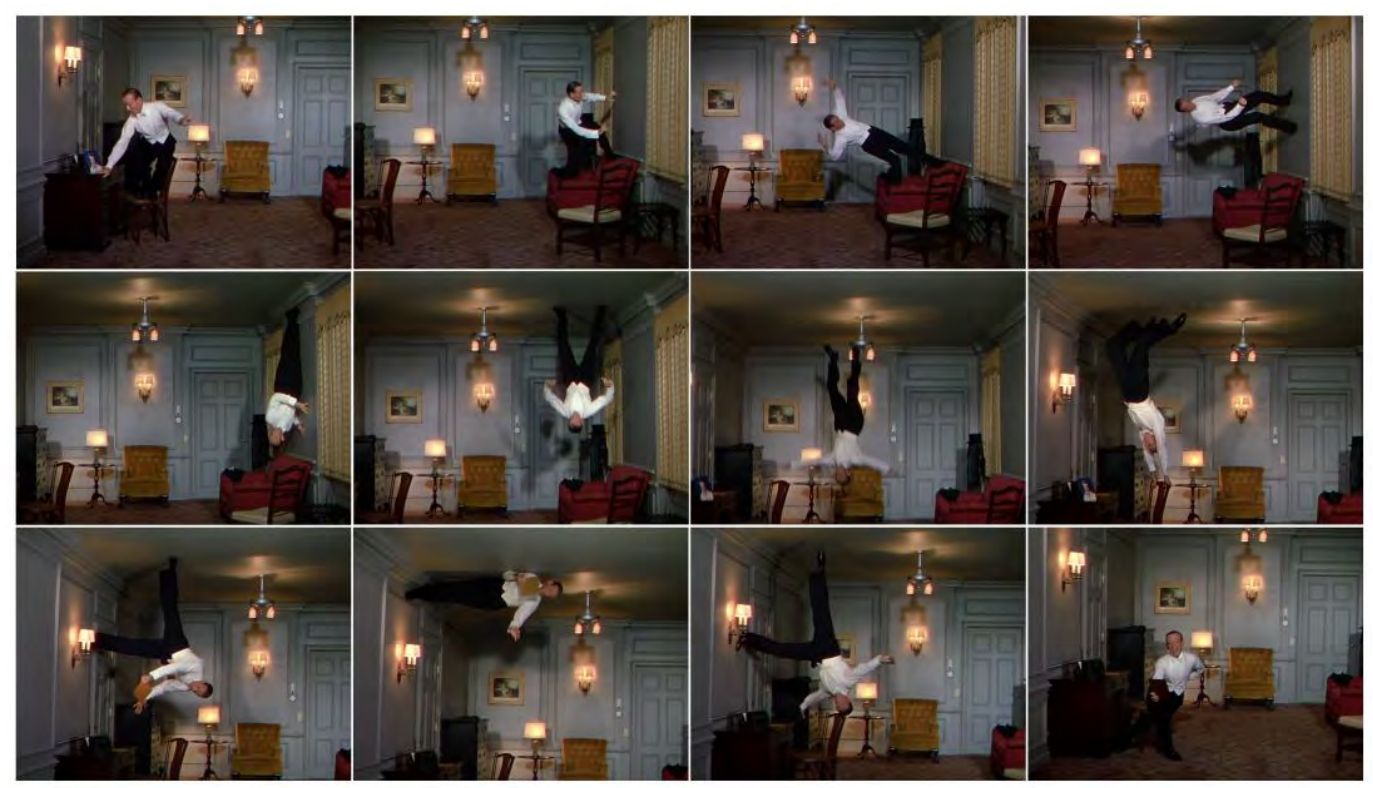

Etapas do número "You're All the World to Me" (música de Burton Lane e Alan Jay Lerner), em Núpcias reais (Stanley Donen, 1951), quando Astaire dança em quatro faces do cubo cênico.

Aqui encontramos um procedimento semelhante ao de Keaton em The Boat: o deslocamento da relação entre a câmera, o cubo cênico e o personagem. Mas se Keaton mantinha a câmera fixa enquanto girava o cenário, em Núpcias reais a câmera é deslocada junto com o cenário, de modo que as faces do cubo cênico permanecem nas mesmas posições durante toda a sequência. E se o personagem de Keaton devia se adaptar com dificuldade à movimentação do cenário que nos era visível, o personagem de Astaire dança graciosamente no espaço que nos é dado como estável, de modo que é o próprio corpo do dançarino que nos parece ser deslocado da realidade. A gravidade, a força impassível que nos filmes de Keaton pode ser apenas aceita, mas nunca desafiada, torna- 
se nos planos de Astaire, e neste de maneira radical, uma força submetida ao talento e à inspiração do dançarino, que pode ser, ainda que momentaneamente, abolida para revelar outra realidade do cubo cênico que não a da física newtoniana, mas a de uma física imaginativa onde a euforia basta para que um homem caminhe nas paredes.

Nos dois filmes comentados, a coreografia se relaciona estreitamente com os gestos cotidianos. Em A roda da fortuna, a caminhada dá lugar à dança, que ao final retorna a uma caminhada, como se esta tivesse sido interrompida ou colocada em suspensão momentânea. Em Núpcias reais, a entrada da canção e a passagem desta para a dança envolvem desde o início gestos simples que poderiam constar em filmes totalmente distantes dos números musicais, de modo que estes gestos são absorvidos na dança, passam a fazer parte de seu vocabulário. Se por um lado se pode dizer que há uma diferença clara entre os gestos cotidianos e o repertório de gestos típicos da dança, por outro lado é evidente nos números de Astaire que há um "caráter coreográfico" dado a todo e qualquer gesto realizado em cena. Pode-se argumentar em defesa de uma separação estrita do "gesto direcionado" e do "gesto puro", como o faz Paul Valéry num argumento semelhante à sua distinção entre prosa e poesia; mas o esforço de Astaire, como de outros nomes do musical americano, é justamente em direção à eliminação dessa fronteira. ${ }^{228}$ É condizente com isso a influência do jazz, desde a presença do estilo musical na banda sonora até a concepção de movimentos que parecem improvisados, e que enfatizam ritmos sincopados e imprevisíveis. Nos números de Astaire isso toma a forma não apenas de gestos que ecoam ou respondem à síncope das composições musicais, mas também a algo como a equivalência espacial desse princípio: “em vez de retornar constantemente a um centro verticalizado", como descreve Beth Genné, num vocabulário que nos remete às representações de Kandinsky, "sua linha preferida era uma diagonal, com seu corpo formando um vetor dinâmico no espaço, de modo que mesmo

\footnotetext{
228 Ver Paul Valéry, “Acerca de O cemitério marinho" (1936), in Variedades, trad. Maíza Martins De Siqueira (São Paulo: Iluminuras, 2011), p. 177: "A essência da prosa é perecer, ou seja, ser 'compreendida' - ou seja, ser dissolvida, irremediavelmente destruída, inteiramente substituída pela imagem ou pelo impulso que ela significa de acordo com a convenção da linguagem. Pois a prosa sempre subentende o universo da experiência e dos atos, universo no qual - ou graças ao qual - nossas percepções e nossas ações ou emoções devem finalmente corresponder-se ou responder-se de uma única maneira, uniformemente. O universo prático se reduz a um conjunto de objetivos. Atingido tal objetivo, a palavra expira. [...] Mas a poesia sugere um 'Universo' bem diferente: universo de relações recíprocas, análogo ao universo dos sons, no qual nasce e movimenta-se o pensamento musical. Nesse universo poético, a ressonância prevalece sobre a causalidade, e a 'forma', longe de desvanecer-se em seu efeito, é como que novamente exigida por ele." Ver também Paul Valéry, Degas Dança Desenho (São Paulo: Cosac Naify, 2003), pp. 27-32.
} 
em pé ele parecia se mover com um elemento de risco". ${ }^{229}$ Conforme entramos no território de seus números, no espaço da caixa cênica onde ocorrem suas coreografias, praticamente todos os movimentos tornam-se parte das atrações. Não significa que em cenas anteriores e posteriores não houvesse o caráter coreográfico; significa que apenas não estava posto em evidência, no centro das atenções, ou mesmo tornado o princípio condutor de toda a ação. ${ }^{230}$

Um terceiro exemplo nos permite ligar alguns dos temas já comentados, especialmente a interação com o cenário e a utilização da gravidade. Em Romance inacabado (Blue Skies, Stuart Heisler, 1946), Astaire novamente interpreta um dançarino, e desta vez a cena é uma apresentação musical no próprio contexto da narrativa: um número de sapateado ao som de Puttin' on the Ritz (Irving Berlin). Como de costume no gênero, Astaire realiza uma série de passos em que o contato das pontas dos sapatos com o chão serve de complemento rítmico aos movimentos de suas pernas e de seus braços - é na conjunção entre esses gestos, e o ritmo da música com o acréscimo do sapateado que reside a estrutura da cena. Filmado num plano médio, Astaire segura ainda uma bengala, que utiliza como um instrumento durante todo o número.

No início, a bengala é disposta horizontalmente sobre uma das mãos, ao que a outra a ataca com um golpe, fazendo-a girar. Acompanhando o giro da bengala, que permanece em sua mão e depois é colocada sob um dos braços, Astaire ajusta os pés de modo que um deles permanece como uma base enquanto o outro joelho é lentamente dobrado, projetando o corpo à frente:

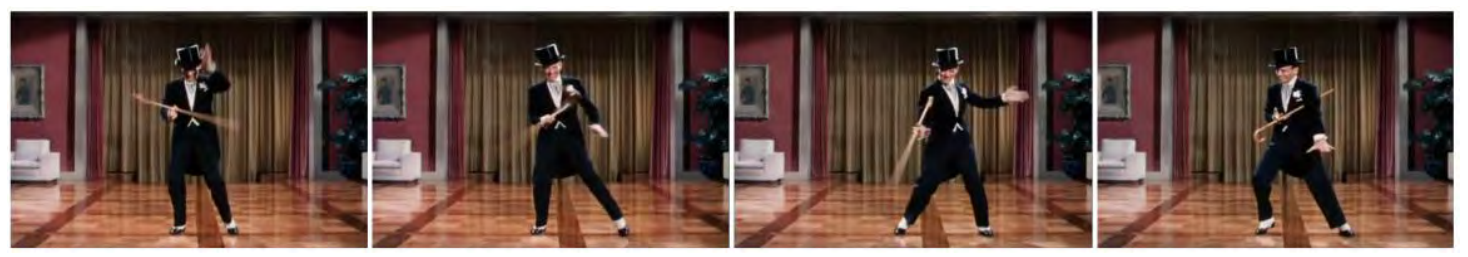

Em seguida, a bengala é apoiada no chão, e com uma das mãos Astaire a segura levemente como se deixasse a mão sofrer o efeito do peso do objeto; a isso ele segue com

229 Beth Genné, Dance Me a Song: Astaire, Balanchine, Kelly, and the American Film Musical (Nova York: Oxford University Press, 2018), p. 56.

${ }^{230}$ Essa definição ampla do "caráter coreográfico" do movimento é abordada por Noel Carroll, ainda que sob outra terminologia. Ver Noel Carroll, "Toward a Definition of Moving-Picture Dance" (2001), in Engaging the Moving Image (New Haven: Yale University Press, 2003), pp. 234-254. Para um comentário sobre as questões relativas ao movimento como princípio fundador nas atrações e nos números musicais, ver também Cristian Borges, "Mais perto do coração selvagem (do cinema)", in Narrativas sensoriais, ed. Osmar Gonçalves (Rio de Janeiro: Editora Circuito, 2014), pp. 41-59. 
um breve gesto que joga a bengala para o lado oposto ao que se inclinava, segurando-a com a outra mão. A repentina lentidão dos gestos contrasta com a música, que permanece no mesmo andamento. A bengala é então jogada para o alto com um chute, capturada, e com ela de volta na mão, Astaire desfere um golpe contra o chão. Podemos visualizar algumas dessas etapas, todas sob o mesmo plano médio em que Astaire se encontra no centro do quadro:

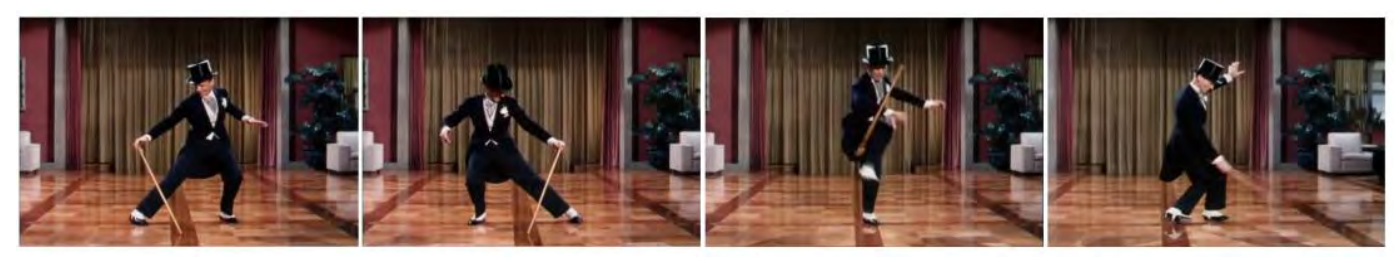

A coreografia envolve gestos que, como nas cenas mencionadas anteriormente, parecem iniciar casualmente, mas que são logo absorvidos na coreografia. Astaire caminha, e seus passos logo se revelam a transição de uma pose a outra, de um gesto a outro:

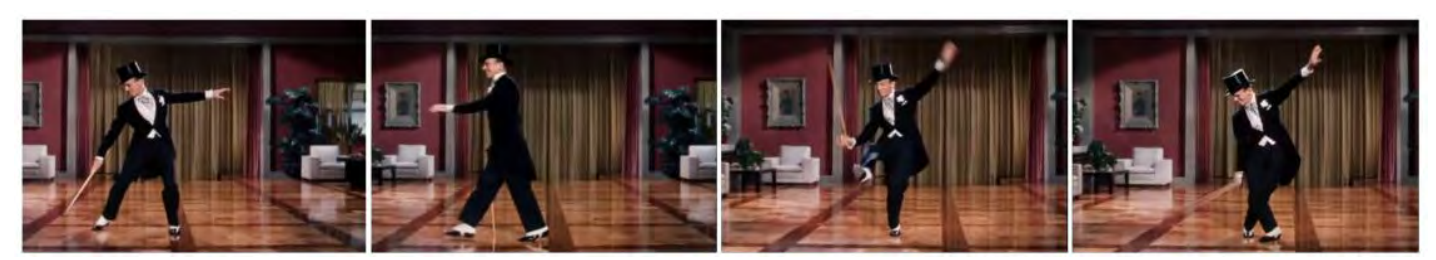

A bengala, o objeto privilegiado na cena, é utilizada para golpear o chão em diversos momentos, criando padrões rítmicos que se acrescentam aos padrões do sapateado. Em certos trechos a bengala é largada no chão e Astaire parece ignorá-la, dançando em outras partes do cenário, sendo acompanhado pela câmera; mas logo retorna ao ponto onde a bengala se encontra, e com isso faz um gesto com as mãos que parece atrair magneticamente a bengala:
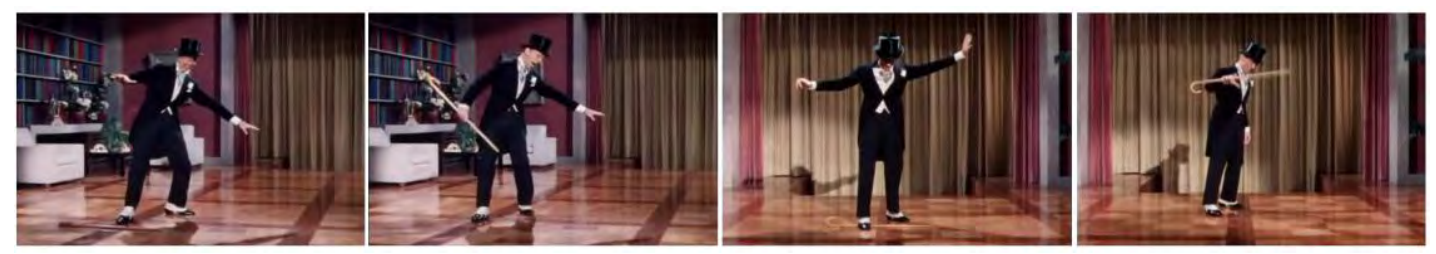
No trecho final, ele atravessa uma porta e chega a um local onde vemos, no fundo, várias cópias de seu personagem, com a mesma roupa e executando os mesmos gestos em perfeita sincronia. Como Keaton, também ele recorre ao procedimento das múltiplas exposições para criar sua versão das atrações. Astaire passa então a dançar como se as cópias formassem um acompanhamento para sua coreografia, por vezes repetindo seus movimentos, por vezes servindo de contraponto a eles, até que todos convergem num gesto final de cumprimento ao público:

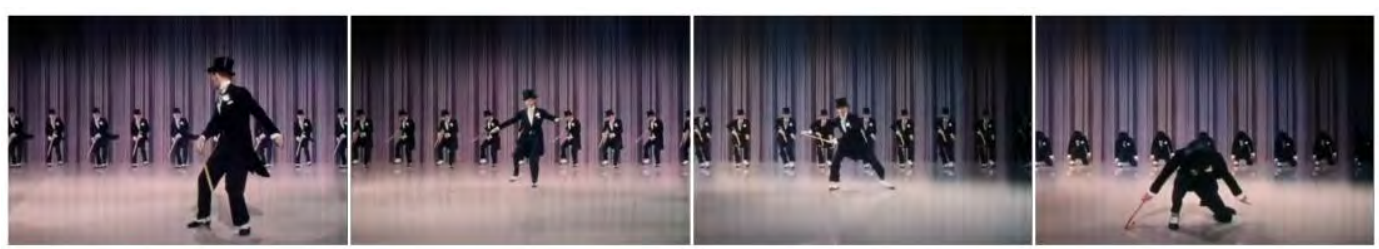

Nesta dança-solo, o aspecto virtuosístico de Astaire é o foco, sobretudo em sua utilização da bengala e dos pés como instrumentos rítmicos. A concentração durante a maior parte da cena num plano frontal e com poucos ajustes de movimento faz com que o cenário torne-se ainda mais próximo da ideia de um palco visto por uma plateia. Neste palco, Astaire parece ter completa liberdade: aqui sua performance não sugere um cortejo ou uma demonstração de euforia, e sim uma apresentação conscientemente coreográfica. Como Méliès em seus números de mágica, o dançarino aborda a câmera como abordaria o público de um teatro. Mencionamos no segundo capítulo os traçados de Kandinsky para reproduzir a dinâmica de movimentos sobre a tela da pintura, e é algo desse interesse que encontramos nos gestos de Astaire: a mesma tendência a organizar seus elementos (que aqui são as partes de seu próprio corpo) em vetores pelo espaço, procurando as configurações que poderão representar a tensão entre os pontos, as linhas e o plano onde se inscrevem. Consciente de sua restrição no espaço do enquadramento tanto quanto da pressão temporal exercida pela música, ele pode jogar com essas margens, aproximar-se de seus limites, apontar às diferentes regiões da tela, aumentar ou diminuir a velocidade de suas ações. A bengala, como o objeto de destaque, torna-se alternadamente um objeto a ser afastado e uma extensão direta do corpo do dançarino, sendo ela mesma utilizada para desafiar a gravidade (num efeito realizado dentro do próprio plano: a bengala era posicionada em locais com jatos de ar que a jogavam para o alto nos momentos necessários). Na conclusão do número, a multiplicação típica de Méliès surge como um meio de reforçar o caráter exibicionista e autocontido da cena - aberta uma cortina no 
fundo do cenário, é revelado outro espaço, onde o dançarino é tornado o modelo para todo o espetáculo. Como num cruzamento entre a musicalização das imagens das animações abstratas e da interação com as leis da física da comédia burlesca, o musical se revela uma forma de construir variações no espaço cênico através de sua exploração lúdica.

\subsection{Possibilidades de uma caixa}

Os filmes de mágica, a comédia burlesca e o musical compartilham algo que, senão é idêntico, é pelo menos relacionado ao conceito de atração. Méliès exemplifica mais diretamente essa proximidade, e com isso podemos identificar características espaçotemporais que servem como referências para os outros casos.

Em primeiro lugar, há um espaço influenciado pelo palco italiano, marcado pela frontalidade de um plano médio que mostra pessoas de corpo inteiro num ambiente geralmente fechado, análogo a um cubo. Nesse espaço se realiza um conjunto de ações que, por serem unificadas no mesmo plano, ou num conjunto de planos, adquirem um caráter de exploração desse espaço e da duração desses planos; e que, por serem realizadas em sequência, podem sugerir relações de causalidade, e com isso uma narrativa. Keaton exemplifica uma variante dessas premissas. Saem os números de mágica, entram as gags, situações cômicas baseadas na criação e frustração (ou confirmação surpreendente) de expectativas, relacionadas aqui às condições físicas da representação, as leis que regulam os movimentos no espaço profílmico e que são registradas pela câmera, ou refratadas por esse registro.

Keaton já marca portanto uma diferença em relação a Méliès. Neste, temos a submissão das ações e de seu ritmo à lógica do número mágico, algo que parece existir apenas para ser filmado, e que torna o espaço em profundidade da cena um aspecto do espaço superficial da tela. A própria alternância dos atos de mostrar e não mostrar, de muitas vezes apenas suceder os atos sem qualquer relação de necessidade interna, dependendo da "invasão" do plano principal por outras exposições, na medida em que estabelece um critério à parte do tempo "natural" do plano, sugere uma interação mais direta com o aspecto cronométrico da composição. No caso de Keaton, tudo se volta à credibilidade e à inteligibilidade da cena como um espaço real, um sistema que revela o caráter inexorável da mecânica newtoniana, onde as relações de causa e efeito, de 
velocidade e gravidade, nos permitem inferir as consequências das ações e suas durações, como se nos fossem dadas as coordenadas gerais da situação - o que se reflete nas gags, situações simples onde vemos um problema ser apresentado e "atualizado". Mesmo quando Keaton recorre aos efeitos de sobreposição, como na cena do sonho em Sherlock $J r$, ele o faz para recriar a predominância da gravitação. O espaço e o tempo em profundidade são o alvo de Keaton: é neste ambiente que ocorrem os momentos-chave de suas gags. A gravidade torna-se, ali, como a reguladora da dinâmica interna da cena, análoga à dinâmica que Arnheim identificou no quadro pictórico.

O musical acrescenta outra camada ao problema. O cubo cênico ganha aqui uma flexibilidade espacial e temporal. Espacial, porque a câmera se abre à profundidade de campo, às diagonais que eram raras em Méliès e Keaton, além de exibir uma constante mobilidade no acompanhamento dos dançarinos, ainda que se retorne com frequência à configuração frontal do palco. Temporal, porque tanto a dança como a música exploram a duração incessantemente, aumentando e diminuindo a intensidade e o andamento dos sons e gestos, contrapondo ritmos e direções. Além disso, novas relações são criadas entre a arbitrariedade do espetáculo proposto ao espectador e as condições físicas do espaço profílmico. Os dançarinos também exploram este espaço, mas o fazem de maneira livre, dando às leis da física um aspecto contingencial que não quebra a unidade do registro, mas que se manifesta dentro dela.

Temos com isso uma espécie de escala de configurações espaciais. Num extremo, um espaço que busca respeitar a realidade da cena, enfatizando em alguma medida suas condições físicas, análogas às do espaço real, e nos dando com isso referências com as quais podemos inferir e projetar outros aspectos das ações. No outro extremo, um espaço que é criado pela submissão da cena tridimensional à superfície bidimensional da tela, de modo que os efeitos de profundidade são transpostos para outro contexto, onde as referências de realismo dão lugar a uma arbitrariedade quase total. Entre os dois extremos, encontraríamos uma série de graus intermediários, como diferentes combinações dos dois modelos, das quais uma seria o musical.

Temos, paralelamente, uma escala de configurações temporais. Num extremo, o tempo real da ação, o tempo do plano, que pode ou não ser dinamizado pelo jogo entre os gestos e a criação de expectativas, por repetições gestuais e por relações de causalidade. No outro extremo, o tempo criado pela manipulação de elementos que vão além da unidade do plano, como nas múltiplas exposições sobre um mesmo espaço, operações que 
acrescentam um caráter métrico e rítmico à duração interna do registro. Entre os dois extremos, novamente, graus intermediários, como combinações dos outros princípios.

Nas diferentes configurações da caixa cênica, encontramos uma recorrência de alguns personagens: mágicos, mímicos, acrobatas, dançarinos. O que os caracteriza? Em primeiro lugar, lidam diretamente com o movimento - mais especificamente, com o movimento como algo a ser apreciado por sua expressividade, por sua originalidade, por sua dificuldade, por sua precisão. Em segundo lugar, lidam com objetos e com o cenário de maneiras pouco convencionais - partem de algo que é familiar e que tornam diferente, seja pela maneira como utilizam, seja pela situação em que se encontram.

Os mágicos de Méliès, por exemplo, realizam gestos extremamente convencionalizados. A profusão de sinais e ornamentos manuais às ações é parte do espetáculo mágico. A relação com os objetos, por sua vez, é reduzida aos objetos que fazem parte dos números, mantendo o cenário como um fundo esquemático, quando não a escuridão que neutraliza a própria ideia de um cenário. Neste ponto, Méliès dá continuidade ao projeto de Étienne-Jules Marey, que utilizou panos escuros pra construir caixas à prova de luz, o modelo da escuridão impermeável que sugeria uma tela bidimensional onde seriam visíveis as marcas fotográficas dos movimentos de seus sujeitos. Não apenas o realismo fotográfico, mas a possibilidade de capturar os feixes luminosos na superfície da imagem constituiu um dos interesses de Marey. É um interesse comum pelo aspecto dinâmico das ações em conjunção com sua realidade luminosa quando vistas por uma tecnologia fotográfica. ${ }^{231}$

Já em Keaton, tanto os objetos como os cenários são cruciais, e muitas vezes constituem o próprio tema das ações. Em contraste com Méliès, Keaton apresenta gestos que sugerem um pragmatismo mais elevado. Suas ações têm propósitos, e seu ritmo é o ritmo de quem interage com o trânsito das cidades e com as perseguições de policiais e criminosos, não o de quem se isola num estúdio para realizar truques de mágica. Se o projeto visual de Méliès nos remete a Marey, a clareza dos planos de Keaton e seu interesse pelo movimento em estado natural, desprovido de efeitos, o aproxima talvez de Eadweard Muybridge, em cujas placas homens e animais foram registrados

\footnotetext{
${ }^{231}$ Para uma contextualização histórica da obra de Marey e algumas de suas relações com o cinema, ver os capítulos 4 e 6 de Marta Braun, Picturing Time: The Work of Étienne-Jules Marey (Chicago: University of Chicago Press, 1994). Para o relato do próprio Marey sobre o desenvolvimento de sua metodologia, com exemplos fotográficos de seus experimentos, ver Étienne-Jules Marey, Movement (Nova York: D. Appleton and Company, 1895).
} 
sistematicamente contra uma grade geométrica que permitia a visualização das distâncias e dos ângulos entre as partes. ${ }^{232}$

Nos trechos comentados de Fred Astaire, objetos e cenários parecem estar à disposição da dança, podendo ser mobilizados e modificados no decorrer da coreografia, sempre com o agenciamento dos dançarinos. Isso faz com que os objetos e o cenário ganhem ou revelem propriedades que não possuíam ou demonstravam anteriormente, uma tendência que podemos chamar de "metafórica". Essa tendência não é incomum na comédia burlesca e no musical, e parece alinhada à tendência das atrações de criar um impacto que se resolve em si mesmo - neste caso, o impacto da substituição imaginativa, da condensação de significados no espaço da cena. Encontramos, por exemplo, num trecho de Em busca do ouro (The Gold Rush, 1925), quando Chaplin usa os garfos para transformar os pães em sapatos e realizar uma dança sobre a mesa. ${ }^{233}$ Ou então na sequência de Casa, comida e carinho (Summer Stock, Charles Walters, 1950), em que Gene Kelly descobre o rangido de uma tábua solta no assoalho e a transforma num verdadeiro instrumento musical em seu improviso de sapateado, logo fazendo o mesmo com um jornal caído no chão.

${ }^{232}$ Para a relação entre Muybridge e o cinema, ver Gordon Hendricks, Eadweard Muybridge: The Father of the Motion Picture (Mineola: Dover, 2001). Para o relato do próprio Muybridge sobre o desenvolvimento de seu método, com foco na figura humana, ver Eadweard Muybridge, The Human Figure in Motion (Nova York: Dover, 1955). Marey também recorreu ao fundo preto para treinar soldados com o apoio do exército francês, e seus métodos foram aperfeiçoados nas décadas seguintes por Frank B. Gilbreth, que registrou planos de seus trabalhadores aplicando um esquema métrico para otimizar sua produtividade. Os dois casos sugerem o potencial analítico das técnicas de Méliès e Keaton. Ver Elcott, Artificial Darkness, op. cit., p. 20.

233 Arnheim faz repetidas vezes o elogio à capacidade de Chaplin utilizar criativamente as limitações de uma imagem tridimensional projetada num plano bidimensional. Seus exemplos preferidos são as gags de incongruência, como no início de $O$ imigrante (The Immigrant, 1917), quando o protagonista é visto de costas num navio em alto mar, curvado sobre o muro do convés, sugerindo que vomita de enjôo, mas revelando depois que na verdade estava sorridente pescando um peixe. Ver Rudolf Arnheim, Film as Art, op. cit., pp. 36-37, 51, 143 ss. 

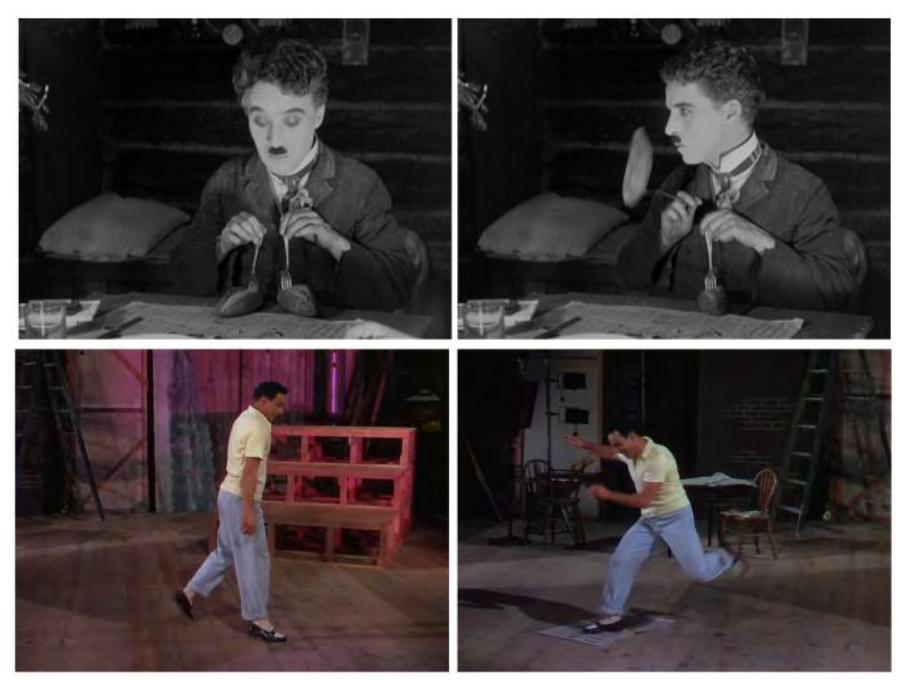

Charlie Chaplin fazendo a dança dos pães, numa cena de Em busca do ouro (The Gold Rush, 1925), e Gene Kelly utilizando o rangido da tábua e o jornal caído como instrumentos numa dança de Casa, comida e carinho (Summer Stock, Charles Walters, 1950).

Podemos considerar, ainda, outras explorações das propriedades da cena, partindo de exemplos do musical e da comédia mas buscando dialogar também com outros casos, baseados nos mesmos critérios espaciais e temporais.

Um tipo de número musical que difere daqueles protagonizados por Astaire é o que encontramos nas sequências coreografadas por Busby Berkeley. Em vez da câmera centrada num dançarino ou num casal de dançarinos, aqui temos a câmera voltada para uma configuração mais ampla que substitui o plano médio frontal por planos gerais, muitas vezes em ângulos altos que abstraem as referências humanas em formas simples, e os espaços em planos achatados. Essa tendência à geometrização faz com que pessoas, objetos e cenários sejam unificados numa grande atração. A recorrência do formato circular e dos movimentos espirais centralizados sugerem inclusive uma proximidade com as imagens de Jordan Belson apresentadas no capítulo anterior. A diferença é que o cinema de Berkeley não tem como objetivo a demonstração plástica em si, mas os caminhos pelos quais se atinge essa plasticidade - o que Comolli descreveu como "o nascimento fantasmagórico, passo a passo". ${ }^{234}$ Há algo dos "efeitos de superfície" de Belson, mas o delírio da plasticidade ganha força aqui pelas metamorfoses, pelas rupturas e pelos retornos ao equilíbrio figurativo.

\footnotetext{
${ }^{234}$ Ver Jean-Louis Comolli, "La danse des images: kaleidoscope de Busby Berkeley", Cahiers du cinéma 174 (janeiro de 1966), p. 24. Ver também Martin Rubin, "Busby Berkeley and the Backstage Musical", in Hollywood Musicals: The Film Reader, ed. Steven Cohan (Londres: Routledge, 2002), pp. 53-58.
} 

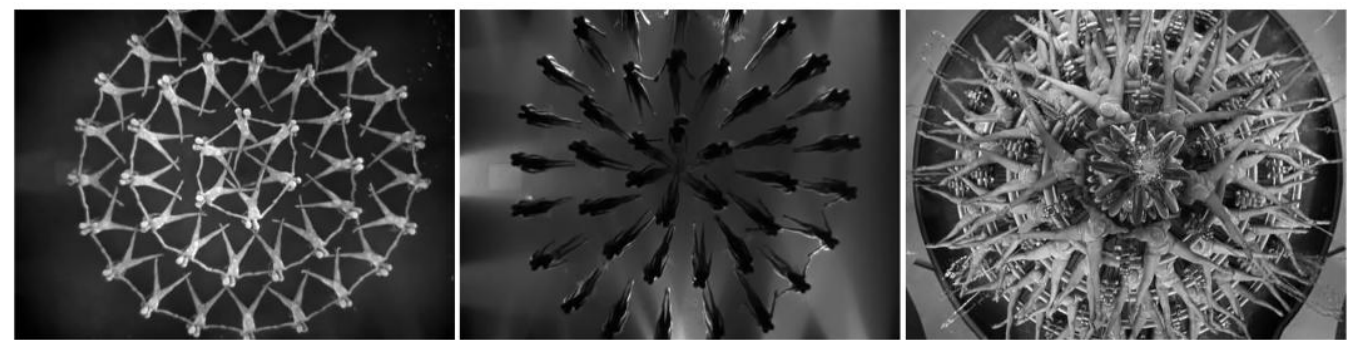

Planos de Belezas em Revista (Footlight Parade, Lloyd Bacon, 1933), exemplos da tendência geométrica de Busby Berkeley, abstraindo o conjunto de dançarinas nas formas dispostas em planos com pouca ou nenhuma sugestão de volume e profundidade.

Jacques Tati, como Keaton, se interessa pela física da representação; mas diferente dele, não se concentra no propósito mecânico das ações, e sim por uma exploração curiosa do espaço. O personagem típico de Tati, Sr. Hulot, é o perfeito curioso silencioso, humilde, paciente. Jogando com os gestos, os olhares, os sons, com o ritmo e a textura dos objetos, Tati faz com que tudo à sua volta se torne parte de uma coreografia de acidentes. Playtime (1967) é a culminação dessas técnicas em sua obra, e seu filme no qual a narrativa é descentralizada de maneira mais clara. Já em filmes anteriores, seu personagem era representado pela imagem descrita por Bazin como "o grão de sal que é jogado para que algo se cristalize à sua volta": Hulot surge num ambiente e sua presença serve como um catalisador, revelando desequilíbrios e conflitos, e mesmo a sugestão de um desenvolvimento temporal no que antes parecia um exemplo de placidez. Em Playtime, Hulot é cada vez menos presente, mas sua ausência multiplica o problema: vários personagens agem como Hulot, alguns chegam inclusive a se vestir como ele. Conforme avança o filme, todas as ações tornam-se atrações em potencial. ${ }^{235}$

Neste filme, as gags de incongruência são inúmeras, como quando o Sr. Hulot confunde um reflexo no vidro com a presença concreta do homem que procura, fazendo sinais em direção ao espaço no qual o homem não se encontra. O tratamento lúdico dos objetos também é recorrente na forma como o personagem toca em cadeiras e desliza os sapatos nos pisos escorregadios, como se testasse a elasticidade e o atrito do ambiente.

\footnotetext{
${ }^{235}$ Ver André Bazin, "Monsieur Hulot e o tempo" (1953), op. cit., p. 77: "Ele pode estar pessoalmente ausente das gags mais engraçadas, pois M. Hulot é apenas a encarnação metafísica de uma desordem que se perpetua muito tempo depois de sua passagem." Bazin escreveu sobre As férias do Sr. Hulot (1953), mas sua observação é ainda mais adequada a Playtime. É importante nesse contexto também o argumento de Kristin Thompson, para quem o filme de Tati opera em três vias: a negação das gags, a realização das gags, e o excesso de gags. Ver Kristin Thompson, "Playtime: Comedy at the Edge of Perception", in Breaking the Glass Armor (Princeton: Princeton University Press, 1988), pp. 255 ss. Para uma comparação entre Tati e Chaplin, que aproxima Tati e Keaton, ver John K. Simon, "Hulot, or The Common Man as Observer and Critic", Yale French Studies 23 (1959), p. 19. O principal argumento de Simon é que Chaplin tende a propor novos ângulos de interpretação para os eventos, enquanto Tati (como Keaton) tende a observar e descobrir o funcionamento usual das coisas.
} 
Mesmo a transposição da física real à uma física cinematográfica é utilizada no filme, como quando vemos uma janela sendo limpada e refletindo um ônibus de turistas - a movimentação da janela movimenta o reflexo do ônibus, e logo ouvimos o suspiro maravilhado dos turistas, como se eles mesmos fossem carregados junto com a imagem refletida.

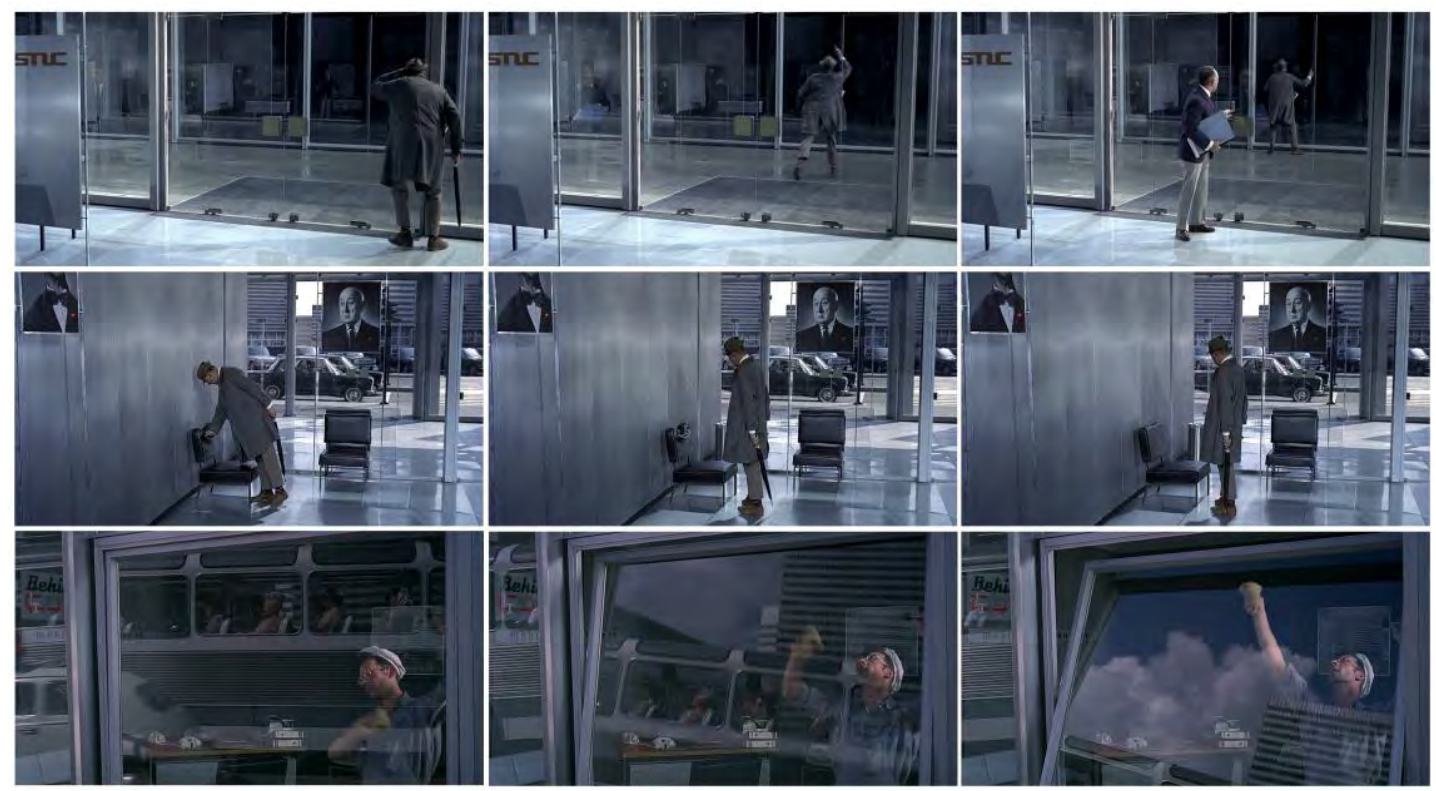

Três planos de Playtime (Jacques Tati, 1967) que exemplificam a variedade das técnicas de exploração lúdica do espaço cênico: (1) a gag de incongruência; (2) a interação livre com os objetos do cenário; (3) o jogo com a transposição da física real à física cinematográfica.

Fora dos gêneros dos filmes de truques, da comédia burlesca e do musical, algumas encarnações da caixa cênica nos permitem complementar suas características. Este espaço, normalmente associado ao palco, tem como referência principal a linha do horizonte, o solo onde se dispõe a câmera e que é idêntico, ou pelo menos análogo, ao solo onde ocorre a ação. Um desvio recorrente se torna então a construção de caixas nas quais a concepção do horizonte e do solo é abolida. O desvio se bifurca em ao menos dois ambientes: a água e o espaço sideral.

$\mathrm{Na}$ água, a característica marcante é a redução do efeito da gravidade. Ainda presente, a gravidade age como se reduzida aos seus índices mínimos; os corpos se movem com lentidão, e tudo parece flutuar com uma languidez inversamente proporcional aos esforços para se mover. $\mathrm{O}$ ambiente sub-aquático, com sua densidade usual, altera não só a distribuição da luz pelo espaço (e com isso a percepção de profundidade), mas também a impressão de que o espaço em volta dos corpos possui uma substância, o que se torna aqui equivalente a um éter, algo que só vemos em certos 
momentos e indiretamente, mas que permanece presente, potencialmente, durante todo o plano. O Taris, roi de l'eau (1931) de Jean Vigo explora diretamente alguns dos efeitos que resultam dessa caixa sub-aquática, como o faz Jean Painlevé em grande parte de sua filmografia. Em Taris, inúmeros planos do nadador são apresentados, vários deles com a câmera dentro da piscina, criando a imagem de uma caixa que permanece sem orientações direcionais até que o personagem mergulha e, cercado de bolhas e gesticulando incessantemente, multiplica as formas visuais em seu interior.

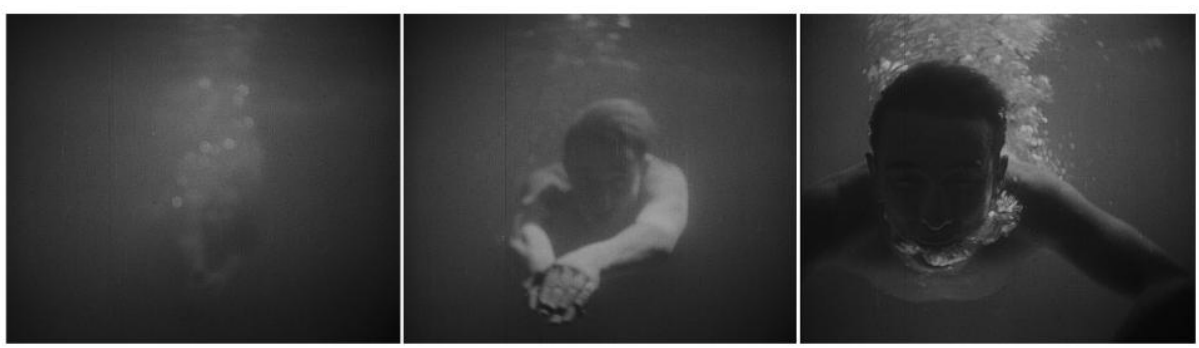

Taris, roi de l'eau (Jean Vigo, 1931)

No espaço sideral, destaca-se também a ausência de gravidade, o que é sinônimo quase sempre da ausência de orientação no eixo horizontal. A lentidão encontrada na água é aqui tornada ainda mais presente, mas é removido o efeito de que o espaço em si é substancial; o espaço torna-se algo abstrato, como um campo de movimentos potenciais, sem orientações que os possam dar sentidos prévios ou que nos permitam inferir as consequências das interações com os objetos. O espaço puramente relacional que encontramos nos fundos pretos das animações abstratas é talvez a referência mais próxima. O exemplo paradigmático é 2001: Uma odisseia no espaço (2001: A Space Odyssey, Stanley Kubrick, 1968), um filme que explora as manifestações da ausência de gravidade tanto em locais fechados como em locais abertos, tanto em movimentos ativos como em deslocamentos passivos. Como no trecho comentado de Núpcias reais, a abolição da gravidade é criada por um deslocamento na relação entre a câmera, o cenário e o personagem. ${ }^{236}$

\footnotetext{
${ }^{236}$ Ver Annette Michelson, "Bodies in Space: Film as Carnal Knowledge", Artforum, vol. 7, n. 6 (1969), pp. 54-63. A leitura epistemológica de Michelson - que inclusive faz uma breve comparação entre Kubrick e Keaton - enfatiza o caráter maiêutico do filme, e o modo como explora "as potencialidades estruturais da desorientação háptica como agentes da cognição".
} 

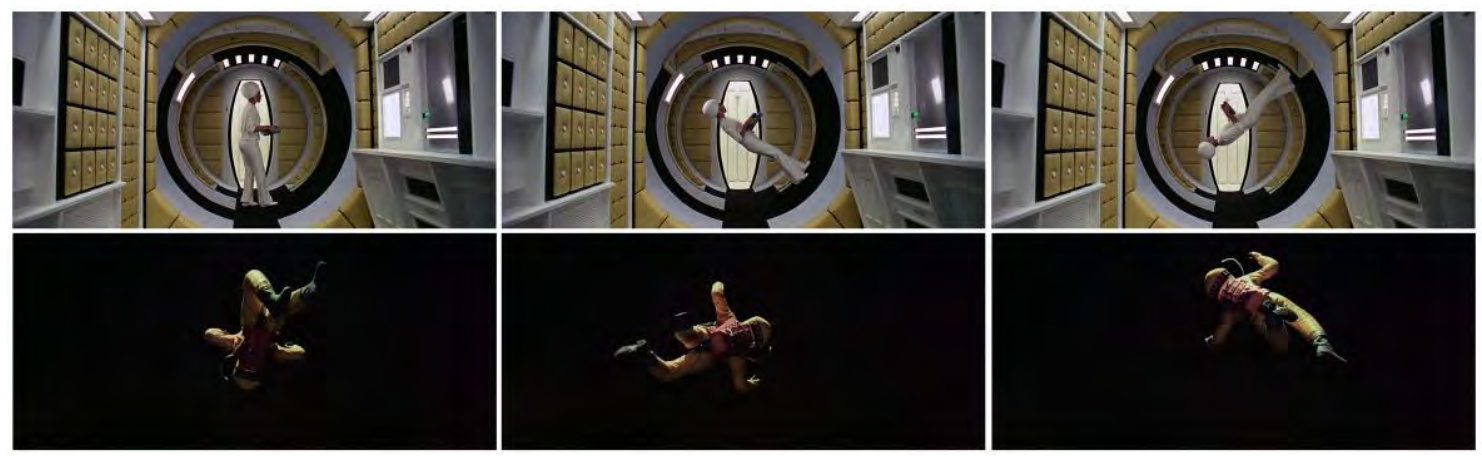

Dois planos de 2001: Uma odisseia no espaço (2001: A Space Odyssey, Stanley Kubrick, 1968) que exemplificam os usos da caixa fechada e aberta, nos dois casos lidando com a orientação gravitacional.

Essa distinção entre uma caixa "fechada" e uma caixa "aberta" é retomada ainda em outra discussão sobre o cinema moderno, especialmente quando, nos anos 1970, se reconhece em algumas obras a retomada de princípios cênicos típicos das atrações como o plano que busca uma "autonomia" e a concentração do olhar em ações que parecem interpelar o espectador num esforço distinto do encadeamento narrativo. Um caso significativo é Jeanne Dielman, 23, quai du commerce, 1080 Bruxelles (1975), em que Chantal Akerman propõe uma série de planos rigorosamente dispostos como caixas fixas, observando o cotidiano de uma mulher (Delphyne Seyrig), que vemos, por exemplo, cortar batatas sentada numa mesa, enquadrada num plano médio, durante longos minutos, uma ação contemplativa sob as mesmas coordenadas de um gesto burlesco, mas com um efeito praticamente oposto. Em vez da profusão de gestos que buscam criar um "impacto sensual e psicológico", a ênfase é dada na banalidade e na minúcia de um gesto. $^{237}$

${ }^{237}$ Manny Farber e Patricia Patterson analisam Jeanne Dielman no contexto dos anos 1970, identificando no período dois tipos de estrutura: "o espaço disperso e o espaço da caixa rasa". No primeiro tipo estariam os filmes que "acreditam implicitamente na ideia de não-solidez, de que tudo é uma massa de partículas de energia, e que o objetivo, estruturalmente, é alcançar um espaço de fluxo para igualar o conteúdo atomizado e a ideia de manter o frescor e a energia de um mundo real dentro do espaço do enquadramento" - exemplos seriam Rameau's Nephew (Michael Snow, 1974) e Céline e Julie vão de barco (Céline et Julie vont en bateau, Jacques Rivette, 1974). No segundo tipo, mais próximos de Jeanne Dielman, estariam aqueles que "apresentam um palco raso com imagens ritualizadas e pouco povoadas, marcando os limites do quadro. Frente a uma câmera um tanto próxima, o conteúdo formalabstrato-intelectual se desenvolve a ângulos retos em relação à câmera, o que geralmente significa que o cineasta cercou intelectualmente seu material" - exemplos seriam Nostalgia (Hollis Frampton, 1971) e No império dos sentidos (Ai no corida, Nagisa Oshima, 1976). Ver Manny Farber \& Patricia Patterson, "Beyond the New Wave, I: Kitchen Without Kitsch", Film Comment, vol. 13, n. 6 (novembro/dezembro de 1977), pp. 47-50. 


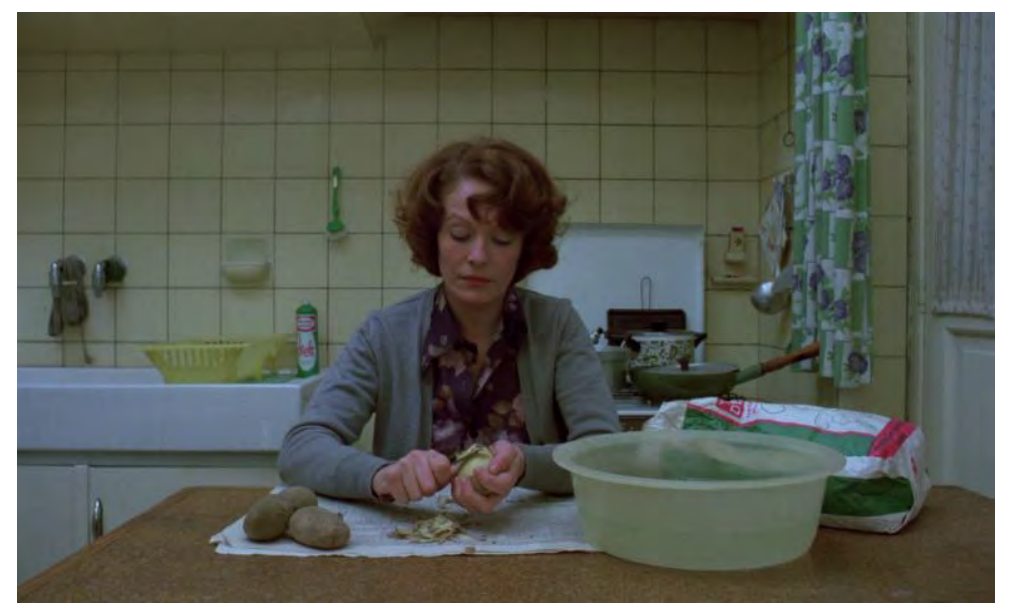

Jeanne Dielman, 23, quai du commerce, 1080 Bruxelles (Chantal Akerman, 1975), um exemplo da caixa como cenário para ações banais e repetitivas, estendidas pela longa duração de planos fixos.

\subsubsection{O problema da integração}

Em comum, todos os filmes tratados neste capítulo possuem o fato de que, sejam quais forem os efeitos criados, eles derivam sua força e, na maioria das vezes, mesmo seu sentido, da própria configuração cênica imediata, e não de um contexto que os antecede e os precede. É um esforço de criação e esgotamento do potencial da cena que vemos ser delineado neste conjunto de filmes e trechos de filmes.

O caso de Méliès, sendo diretamente ligado às atrações, é talvez o mais simples. Seus filmes que consideramos aqui, ao manter como base um único enquadramento e realizar todas as ações dentro dele, fazem com que a unidade do plano seja o limite tanto para a atração como para a narrativa. O mesmo não ocorre com as gags de Keaton e os números de Astaire. Nesses casos, os trechos que analisamos constituem momentos destacados numa composição mais ampla - que supõe tanto um espaço como um tempo além daqueles mostrados nos planos que selecionamos. Que há algum grau de autonomia tanto nas gags como nos números é algo tacitamente aceito pela maioria dos autores, que reconhecem a lógica própria destes trechos, o que os caracteriza como objetos especiais. Mas há outro problema a ser abordado e que atravessa constantemente estes objetos: o problema da "integração" desses momentos à narrativa. O problema é mais frequentemente tratado em relação aos musicais, mas consideremos aqui seu aspecto geral, o mesmo problema envolvendo as atrações, as gags, os números musicais, e toda 
composição que se caracteriza por princípios semelhantes. ${ }^{238}$ Para isso, é necessário mencionar a relação entre o número "integrado" à narrativa e o número "diegético".

O termo "diegese", que em Platão designava "narrativa" (em oposição a "mímese", "imitação"), foi retomado por Étienne Souriau para se referir ao "mundo ficcional". ${ }^{239}$ Seria diegético qualquer evento que ocorressem no espaço contido pela narrativa. Os números musicais diegéticos são tipicamente definidos como os números que ocorrem em situações realistas, justificadas narrativamente. Essa definição se baseia na suposição de que o mundo ficcional possui as mesmas leis físicas e as convenções sociais às quais nos acostumamos. Mas além de não proceder em gêneros cuja presença da fantasia é recorrente, também não é uma consequência da definição proposta por Souriau - não há nada que impeça um filme de representar um mundo irreal, com distorções nas leis da física, ou com diferentes convenções gestuais. Referir-se apenas a números realistas como diegéticos implica que outros números, não-realistas, não representam eventos no mundo ficcional, e sim uma quebra em relação a este mundo. Uma decorrência é que estes números tornam-se uma categoria oposta à narrativa.

Uma versão moderada do mesmo argumento é feita por Martin Sutton, ao defender que

O musical é um gênero que se volta essencialmente à imaginação rebelde e à sua batalha diária com uma ordem social restritiva e "realista". Esta batalha nasce de uma tensão entre a trama realista e o número espetacular/fantástico. Todo o realismo narrativo herdado do romance do século XIX (trama linear, desenvolvimento cronológico, um gráfico regular de emoções) está por trás desta tensão. $\mathrm{O}$ número funciona como interrupção narrativa, uma tangente fantástica que de uma só vez frustra e libera o espectador. A trama em si, entretanto, circunda, regula e mantém em cheque os excessos voluptuosos e não-realistas do número musical. A trama, assim, toma a parte de "superego" em relação ao "id" do número. ${ }^{240}$

Sutton mantém a distinção, mas propõe uma relação constante entre a esfera do realismo e a da fantasia, afirmando o número como o evento privilegiado na exploração da

\footnotetext{
${ }^{238}$ Para um argumento mais extenso do que será apresentado aqui, uma defesa da gag como pertencendo ao "domínio vertical", em contraste ao "domínio horizontal" da narrativa, ver Lisa Trahair, The Comedy of Philosophy: Sense and Nonsense in Early Cinematic Slapstick (Albany: SUNY Press, 2007), pp. 35-57.

${ }^{239}$ Ver Etienne Souriau, "La structure de l'univers filmique et le vocabulaire de la filmologie", Revue internationale de filmologie 7/8 (1951), pp. 231-240.

${ }^{240}$ Martin Sutton, "Patterns of Meaning in the Musical", in Genre: The Musical, ed. Rick Altman (Londres: Routledge, 1981), p. 191. A interpretação de Sutton, com sua base psicanalítica, é semelhante à de Sylvain Du Pasquier sobre as gags de Keaton: "A gag, como um parasita, corrompe a trama, e um corolário é que as múltiplas mensagens escondidas no discurso normal ou realista são expostas, desmascaradas, desnudadas. A gag explora os múltiplos sentidos escondidos no discurso realista." Ver Du Pasquier, "Les gags de Buster Keaton", op. cit., p. 132.
} 
contradição entre elas. Ainda que possua valor em relação aos musicais, essa distinção parece limitada como modelo para uma generalização que incluiria os números de mágica, as gags e outros casos inspirados nas atrações. É o caráter explicativo e mesmo interpretativo de Sutton que parece responsável por esta limitação.

Numa tentativa de abordar o problema por outra via, John Mueller propõe diferentes modos pelos quais um número poderia ser integrado à narrativa. ${ }^{241}$ Os modos formariam, segundo seu argumento, algo como uma escala, da maior à menor integração. No extremo da máxima integração estariam os números em que todas as características e sua própria existência como evento perante a câmera seriam justificadas na trama. Neste caso, o teste para a integração seria retirar o número; se isso fizer com que a narrativa perca algo de seu encadeamento lógico, então o ponto de maior integração foi atingido. No extremo da mínima integração estariam os números em que todas as características seriam arbitrárias, "gratuitas" do ponto de vista narrativo - nenhuma informação apresentada seria necessária para o desenvolvimento da trama. Na região intermediária estariam os números que ocorrem no mundo narrativo, em perfeita conformidade com as leis físicas e sociais que regem a trama em seus outros momentos, mas que não contribuem com novas informações exceto o fato de que um espetáculo ocorre perante a câmera; e os números que ocorrem numa espécie de suspensão narrativa, numa alteração das leis físicas e/ou sociais, mas que parecem ainda assim acrescentar informações à trama, mesmo que em outra esfera, como se houvesse uma mudança de linguagem, do cotidiano à coreografia. ${ }^{242}$ Esta escala de Mueller, ao menos por seu esforço mais descritivo que interpretativo, parece ter uma utilidade maior para pensar as relações entre os musicais e os outros gêneros que mencionamos.

Rick Altman propõe ainda uma concepção de "narrativas de foco duplo", que seria exemplificada nos musicais. Uma narrativa de foco duplo seria composta de um eixo cronológico e progressivo ("sintagmático", na terminologia semiótica), mas também de um eixo marcado por oposições binárias entre elementos estáticos (o eixo "paradigmático"). ${ }^{243} \mathrm{O}$ argumento de Altman é importante por defender a coexistência de

241 Ver John Mueller, "Fred Astaire and the Integrated Musical", Cinema Journal, vol. 24, n. 1 (outono de 1984), pp. 31-35. Para uma escala baseada na "formalização e funcionalização" das performances, ver também Nina Penner, "Rethinking the Diegetic/Nondiegetic Distinction in the Film Musical", Music and the Moving Image, vol. 10, n. 3 (outono de 2017), pp. 6-8.

${ }^{242}$ Para uma interpretação do problema da "suspensão narrativa" no musical, dialogando com as proposições de Carroll e com a noção de fotogenia de Epstein, ver João Vitor Leal, "A imagem interessante: cinema e suspensão narrativa”, Significação, vol. 43, n. 45 (2016).

243 Ver Rick Altman, The American Film Musical (Bloomington: Indiana University Press, 1987), pp. 1627. 
duas ordens numa mesma composição. Em sua proposta, os estados de narrativa e nãonarrativa, bem como os diferentes graus na escala de integração, poderiam talvez ser considerados como ativos durante todo, ou quase todo um filme. O detalhe crucial aqui é a ideia de elementos relacionados de maneira não-causal, ou seja, a ideia de que a unidade de uma obra não se caracteriza apenas por sua linearidade, mas também por aspectos estruturais mais amplos, por uma visão de conjunto. Algo parece acumular-se entre as seções de uma obra, e a presença de certos elementos numa etapa anterior pode com isso servir para ressignificar a presença de elementos numa etapa posterior, ainda que não haja um encadeamento propriamente narrativo entre eles. ${ }^{244}$

Nessas discussões, permanece a tensão entre a finalidade das operações fílmicas em especial dos gestos feitos pelos personagens - e a plasticidade dessas mesmas operações - o efeito puramente visual e rítmico gerado por elas. Se considerarmos que há um "caráter coreográfico" em movimentos representados no cinema, que os padrões de movimentos podem constituir um valor e um interesse em si mesmos, uma decorrência seria que essa plasticidade ocorre independentemente da finalidade, isto é, que a plasticidade é algo como uma dimensão "superficial" da composição, e que a finalidade, ou o propósito inserido no contexto de uma trama, é um caso especial, uma aplicação "em profundidade" das mesmas características. Por consequência, a plasticidade é um componente inevitável dos movimentos, ao passo que a finalidade é um componente possível, mas não necessário. Uma análise das tensões espaciais e temporais de um número musical poderia ser realizada então sem o contexto da narrativa, independente de o número ser ou não integrado à ela. $\mathrm{O}$ caráter puramente coreográfico seria, por essa ótica, algo que o número musical compartilha com toda e qualquer cena que tenha no movimento um de seus princípios. Não significa que uma análise das reverberações narrativas do número não seja importante; significa que esta análise seria necessariamente um acréscimo à dimensão básica do movimento, da pura evolução temporal e espacial da cena.

É sobre a metamorfose desse caráter coreográfico, portanto, que a concepção das atrações na caixa cênica pode ser vista em conjunto. O espaço-tempo da caixa pode ter sua realidade afirmada ou questionada: se afirmada, permanece a correspondência com o

\footnotetext{
${ }^{244}$ Há uma semelhança deste argumento com a proposta de "não-linearidade" por Jonathan Kramer em relação à música. Kramer define a não-linearidade como "a determinação de características da peça de acordo com implicações que emergem de princípios ou tendências que governam uma seção da peça", em contraste com a linearidade, na qual as implicações seriam emergentes de eventos imediatamente anteriores. Ver Jonathan D. Kramer, The Time of Music: New Meanings, New Temporalities, New Listening Strategies (Nova York: Schirmer Books, 1988), pp. 40-42.
} 
espaço-tempo real, enfatizando a previsibilidade das condições físicas; se questionada, os mesmos critérios são postos em cheque, e crescem os "efeitos de superfície" na composição, fazendo com que o espaço bidimensional da tela e o tempo cronométrico da projeção ganhem a frente. Em meio aos dois extremos, pode-se combinar algumas das técnicas mencionadas: pode-se aceitar o realismo das condições físicas, mas não torná-las o tema das ações; pode-se aceitar este realismo e efetuar uma investigação completamente lúdica do espaço da cena; pode-se fazer isso e, no decorrer da investigação, distorcer as leis da física e progressivamente dar lugar às leis da fantasia; pode-se fazer o caminho inverso; e assim por diante. Dentro deste quadro, mais importante que esgotar as possibilidades é perceber que surgem coordenadas para localizar a composição das cenas. 
PARTE III

VIRTUALIDADE 


\title{
SEQUÊNCIA
}

\author{
ENCADEAMENTO E FIGURAÇÃO
}

\subsection{A linearização da montagem}

Em 1983, Noel Burch publicou um texto no qual buscou esquematizar algumas observações sobre a morfologia do primeiro cinema. O problema que chamou sua atenção, e ao redor do qual organizou o artigo, foi o problema do encadeamento de planos. Mais especificamente, a ligação de planos que não levaria aos resultados encontrados nas atrações, mas ao que ele chamou de "formas narrativas em larga-escala". Se as atrações baseavam-se numa frontalidade que se oferecia ao espectador como uma série de efeitos organizados mais por seus impactos que por critérios narrativos, esta "concatenação biunívoca" deveria pressupor registros descontínuos que, dispostos numa certa ordem, produziriam um sentido. Ao processo pelo qual os encadeamentos de planos tornariam-se mais distantes das atrações e mais próximos da narrativa, Burch deu o nome de "linearização". 245

$\mathrm{Na}$ busca pelas primeiras tentativas de linearização, Burch e outros pesquisadores depararam-se com alguns casos significativos. As lutas de boxe filmadas para o Quinetoscópio de Thomas Edison, por exemplo: planos de um minuto, cada um mostrando um round de uma mesma luta, agrupados como partes de um mesmo programa. Apesar do caráter "documental”, a premissa era que o espectador já possuía o conhecimento do evento representado, e que seria por isso capaz de atribuir um sentido à sequência de planos. Isso significa que o sentido não residia nas características internas dos planos ou na maneira como eram dispostos, mas em informações externas a eles. No

\footnotetext{
${ }^{245}$ Ver Noel Burch, "Passions and Chases - A Certain Linearisation", in Life to Those Shadows, op. cit., pp. 143-161. Esta versão é uma elaboração do artigo original, "Passion, poursuite: la linéarisation", Communications 38 (1983), pp. 30-50.
} 
limite, um espectador que não tivesse o conhecimento prévio não poderia diferenciar os planos de uma luta dos planos de outra luta.

A pergunta que Burch se coloca é: como pode uma sequência de planos criar um sentido narrativo sem recurso ao comentário externo? Podemos especificar o questionamento, deslocando-o para os critérios do espaço e tempo, nos perguntando quais os modos de composição espacial e temporal que caracterizam a linearização. Considerando ainda o encadeamento dos planos, podemos colocar a pergunta sob a terminologia das três dimensões e associar este processo à "virtualidade" da composição: como poderiam os planos ser dispostos em sequência de modo a sugerir um espaço-tempo que não aquele de seus registros isolados, mas um espaço-tempo construído através deles, inferido a partir deles, e que de certa forma os engloba? No estudo da linearização, dois gêneros recebem destaque por seu caráter ambivalente; uma comparação de suas tendências composicionais nos serve como uma via de acesso a esta pergunta.

O primeiro desses gêneros, a Paixão, é definido com as primeiras adaptações da história cristã para o cinema. ${ }^{246}$ Apesar do nome, lidam com vários episódios da vida de Cristo, da Anunciação até a Ressurreição. Espacialmente, os planos das Paixões são idênticos aos de algumas atrações. São planos abertos, fixos, que dispõem as pessoas sobretudo no eixo horizontal e numa escala pouco variável. Temporalmente, são marcados por ações que, vistas à distância e sem um esforço de hierarquização, misturamse à duração geral do registro. Por essas características, as Paixões enquadram-se no Modo de Representação Primitivo (MRP) definido por Burch, que inclui as atrações e que é constituído por quatro tendências: (1) a autonomia do quadro, (2) o aspecto nãocentrado da imagem, (3) a distância da câmera em relação à ação, e (4) o não-fechamento do evento. Mas há uma outra característica que torna o gênero representativo de uma "vontade de linearização". Trata-se do uso de cartelas de texto entre os planos, descrevendo o conteúdo dos acontecimentos a serem vistos a seguir. Os episódios da história são nomeados e ordenados segundo a tradição do Cristianismo. Vemos, portanto, Maria em sua casa, sendo visitada pelo anjo Gabriel, num plano intitulado "A anunciação". No plano seguinte, "A chegada de José e Maria em Belém”, vemos o casal atravessar um espaço urbano. A cada término de plano, vemos a cartela que nos apresenta o título, o conteúdo e mesmo o sentido do plano a ser visto em seguida. Neste processo, o

\footnotetext{
246 "Paixão" e "Perseguição" serão utilizados com as iniciais em maiúsculas para designar os gêneros do primeiro cinema. Menções a "perseguições”, por exemplo, se referem ao sentido usual do termo.
} 
espectador é conduzido pela narrativa - uma narrativa cuja matéria é dada pelas imagens e a forma pelo texto.
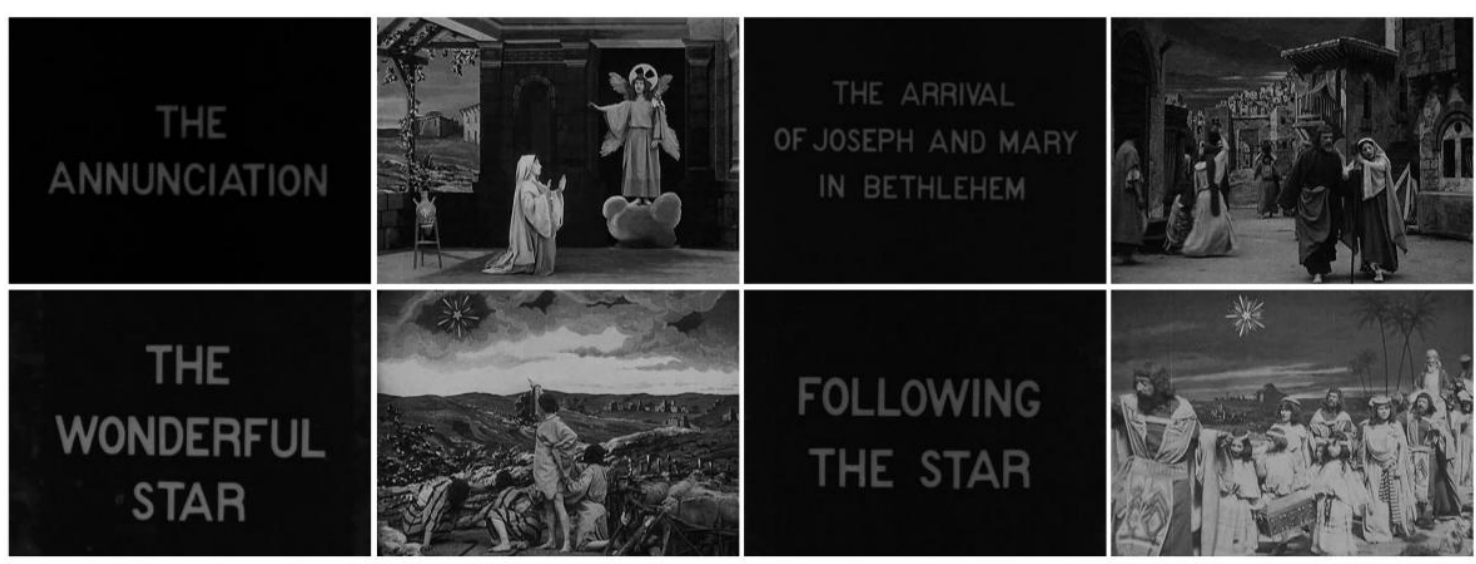

As quatro primeiras cartelas e os respectivos planos de Life and Passion of Jesus Christ (Ferdinand Zecca, 1905), um exemplo típico das Paixões filmadas nos primeiros anos do cinema.

Um segundo gênero importante para compreender a linearização é o gênero da Perseguição. Como a Paixão, a Perseguição está enraizada no MRP; seus planos tendem à fixidez, a uma organização não-centrada, a uma distância da ação, ao registro de eventos que não sugerem uma conclusão. A Perseguição, entretanto, cria um referencial interno que estava ausente na Paixão. $O$ gênero se caracteriza por um personagem que corre de outro personagem, ou de um grupo de personagens - ou seja, um perseguido e um perseguidor. Uma estratégia definidora é que os inícios e finais de cada plano são marcados por entradas e saídas de quadro segundo um mesmo padrão. A cada plano, o perseguido atravessa o espaço da tela, corre de um lado a outro (ou em profundidade) e termina saindo da tela por uma de suas extremidades laterais; em seguida, no mesmo plano, o perseguidor faz o mesmo percurso, entrando na tela pela mesma região, atravessando a mesma parte que o perseguido e saindo do quadro pelo mesmo lado que ele. Os planos são, portanto, esvaziados, preenchidos e esvaziados novamente da presença dos personagens. Temporalmente, isso cria um formato que, apesar de rudimentar, joga com os elementos visíveis nos planos, e principalmente, com seus elementos comuns, o que significa que, tendo visto um plano, o espectador possui referências mais ou menos estáveis para o plano seguinte, numa expectativa que é realizada na medida em que retornam os mesmos personagens e o mesmo padrão.

Em Tom, Tom, the Piper's Son (Billy Bitzer, 1905), o plano inicial radicaliza o MRP em sua profusão de ações que dificultam ou mesmo impossibilitam a hierarquia dos 
conteúdos visuais. Vemos o plano geral de uma feira, organizada perante a câmera como um espetáculo teatral, uma multidão que inclui uma acrobata e um palhaço, entre várias outras pessoas. $\mathrm{O}$ espectador informado sabe que o título deriva de uma canção popular cujos primeiros versos dizem: “Tom, Tom, the piper's son, stole a pig and away he run". O roubo do porco é o evento que serve como ponto de partida à perseguição. Nos planos seguintes, vemos um garoto fugir da multidão segundo o padrão de entradas e saídas de quadro, passando de um cenário a outro, até que no plano final o garoto é capturado e a perseguição chega ao fim. A clareza da narrativa parece não ser o critério central; a explicação permanece numa referência externa e verbal. Mas há um avanço em direção à lógica interna das ações no sentido de que os elementos que atravessam a cena são retomados em outros planos, são aproximados, e finalmente se juntam na conclusão. Na redução dos eventos filmados a "corpos em movimento", e sobretudo à passagem desses corpos no espaço, na transição de um cubo cênico a outro, a Perseguição esboça uma unidade diegética.

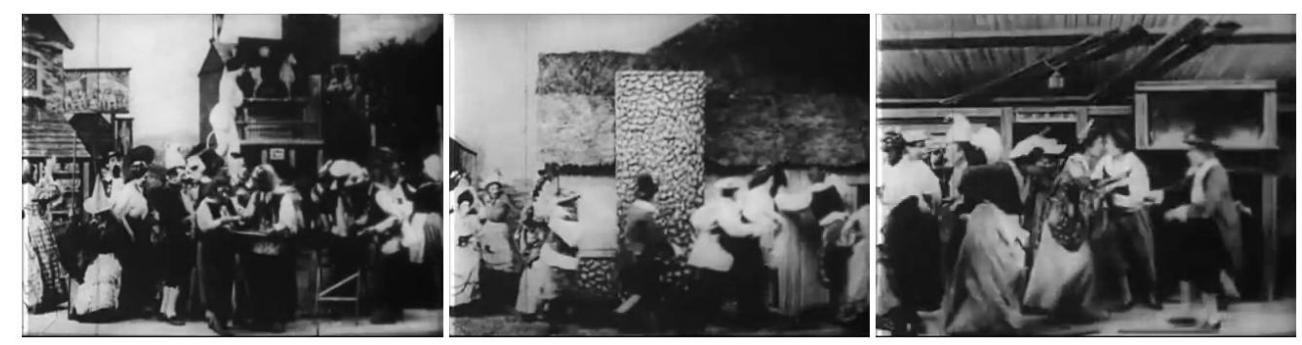

Os planos iniciais de Tom, Tom, the Piper's Son (Billy Bitzer, 1905), um exemplo das Perseguições.

O aspecto transicional desses gêneros é devido ao fato de que partem das características definidoras do MRP, mas que sugerem um desvio deste modo, incluindo o início daquilo que caracterizaria um modo posterior - a linearidade. Um terceiro caso, o mais emblemático neste contexto, é o de Life of an American Fireman (Edwin S. Porter, 1903). No filme de Porter, temos um complexo de escolhas que nos permite observar os problemas já mencionados e as alternativas que eles implicam.

O primeiro plano do filme mostra um bombeiro dormindo no canto esquerdo do quadro; no lado direito, como um recorte de outro plano sobreposto ao fundo preto, vemos uma mulher e uma criança. $\mathrm{O}$ composto de planos forma uma única imagem, sugerindo um motivo convencional - o homem sonha com sua família. A passagem do primeiro ao segundo plano é feita por uma técnica típica de pontuação. Um fade distancia 
temporal e espacialmente os eventos, faz com que um movimento óptico se interponha entre as ações; lineariza temporalmente o período, enfatiza mesmo que se trata da passagem de um plano a outro. O segundo plano é o close-up de um alarme de bombeiros, que vemos ser ativado por alguém. Os planos seguintes decorrem desta ação. Os bombeiros acordam, descem até a garagem, saem em seus carros e chegam até o local do incêndio. A lógica das perseguições é mantida neste trecho, ainda que não haja um personagem sendo perseguido; os planos começam vazios, ou com a movimentação dos carros, e só terminam quando estes saem de quadro. A presença do mesmo contexto temático de um plano a outro e o contexto imediato das ações sugerem, com sua simples sucessão, algumas relações de causalidade - há um bombeiro; há um alarme que é ativado; há bombeiros que são acordados por um alarme; os bombeiros seguem para apagar o fogo.

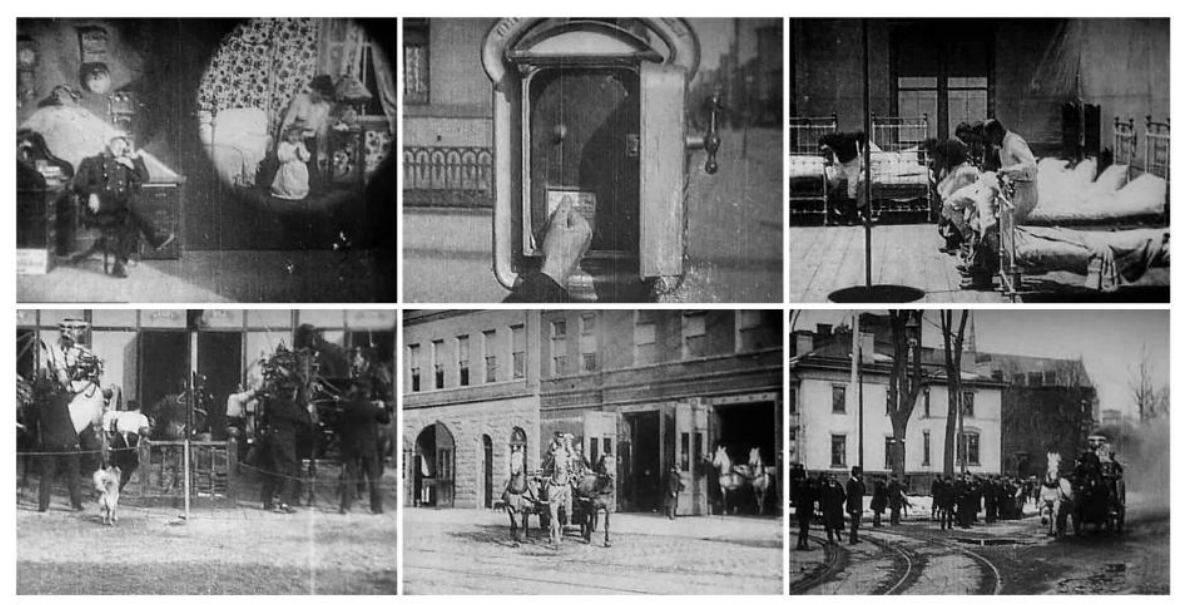

Os seis primeiros planos de Life of an American Fireman (Edwin S. Porter, 1903)

Os planos do filme são quase todos fixos. A exceção é o sétimo, que inicia mostrando uma rua em profundidade, na qual se aproxima o carro, e que, acompanhando o movimento do veículo, realiza uma panorâmica à esquerda, enquadrando finalmente, num ângulo frontal, a casa onde ocorre o incêndio:
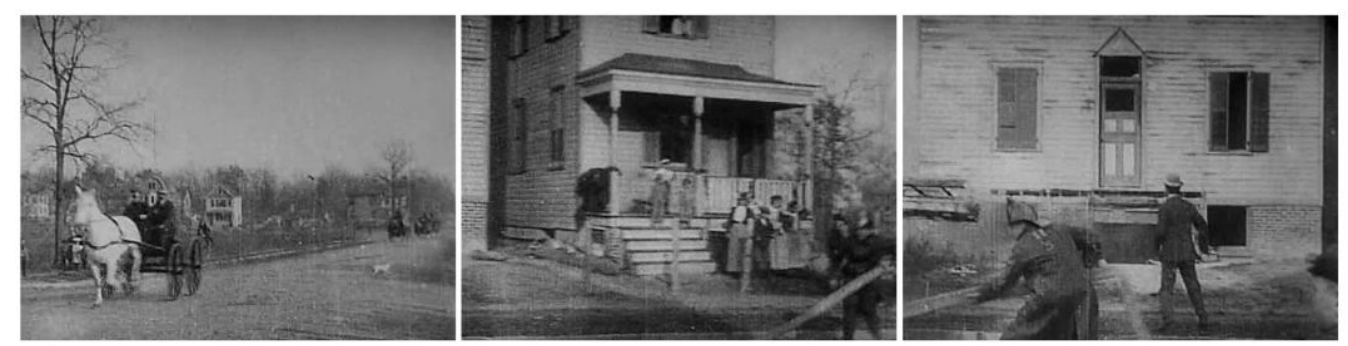
É a partir deste momento que encontramos a operação mais sintomática do filme. Do plano exterior e geral da casa vista de frente, o filme corta para um plano médio de uma mulher vista dentro da casa. O plano inicial do filme (o bombeiro dormindo) e o plano imediatamente anterior a este (a fachada da casa) nos prepararam para identificar a mulher como a esposa do bombeiro e a casa como o local onde ocorre o incêndio. Vemos então, na confirmação desse contexto, o bombeiro entrar pela janela e salvar a mulher e a criança. Mas, imediatamente depois, sem o fade ou qualquer outro tipo de pontuação, após um corte seco, vemos o bombeiro subir a escada, abrir a janela, salvar a mulher e a criança - num plano geral e frontal da casa, vista de fora. Podemos observar o mesmo evento, com suas mesmas etapas, representadas em sequência, pelos dois ângulos:
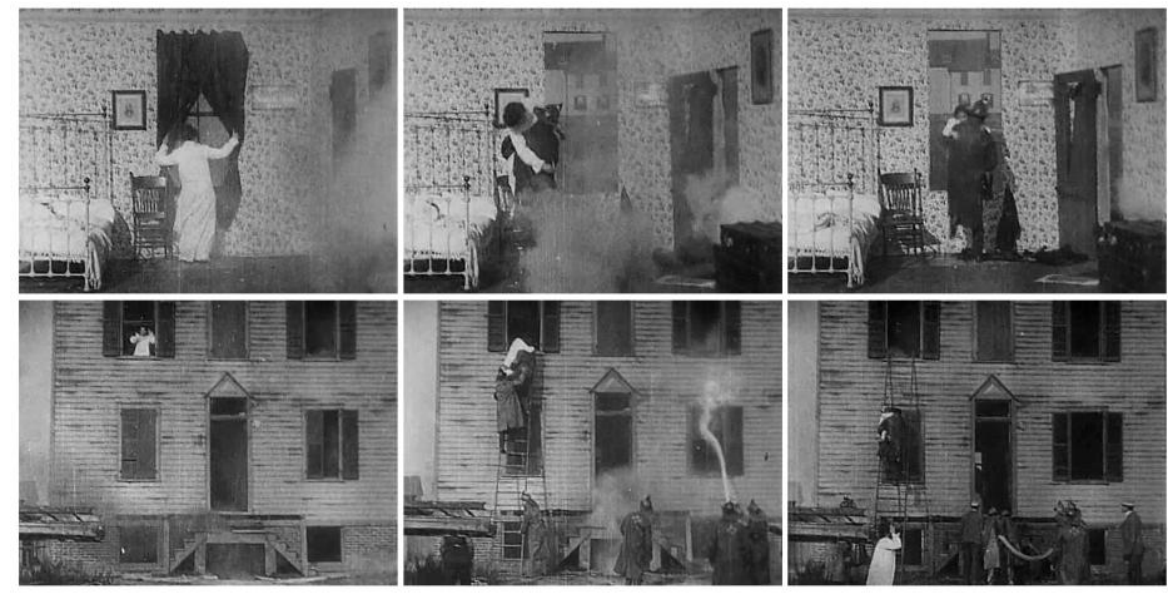

Se considerarmos a totalidade do filme de Porter, veremos que diferentes estratégias temporais são utilizadas, e que elas não são exatamente condizentes umas com as outras. Nos primeiros planos, a sequencialidade rudimentar das Perseguições é a regra. Cada plano tem início pouco depois que a ação do plano anterior se encerra, como se mostrasse um evento posterior àquele, cuja distância cronológica não podemos aferir com precisão, mas que sugere ainda assim um único fluxo de ações encadeadas - as brechas espaciais entre os eventos não impedem a criação de uma unidade virtual que os contenha. O final recorre a outra abordagem. Quando o plano do carro chegando à casa é seguido pelo plano de dentro da casa, com o bombeiro salvando a mulher, a relação entre sequencialidade e cronologia é estabelecida: o homem subiu as escadas e salvou a mulher pouco depois de chegar à casa. O que ocorre depois, entretanto, é uma quebra nessa relação. A mesma ação é vista por outro ângulo, como se a sequencialidade fosse 
mantida, mas não a cronologia - como se fosse efetuado um "retorno ao passado", a um momento anterior do fluxo de eventos, para que a ação fosse retomada por outro ponto de vista.

Num estudo da obra de Porter, Charles Musser descreve as contradições internas do filme:

A organização frontal dos elementos profílmicos que ocorre na maioria das cenas é quebrada pelo movimento da câmera no plano 7, que revela momentaneamente um espaço fora-de-campo contíguo ao espaço que existe no retângulo estático do enquadramento. $\mathrm{O}$ "presentacionalismo" insistente, influência de práticas tradicionais do teatro, é novamente contradito pela câmera "onisciente", que vê as mesmas ações por duas (e, se por duas, por quê não por três, quatro, ou cinco?) perspectivas diferentes. Planos são compostos como discretos, como unidades independentes, ainda que sejam partes de uma narrativa mais ampla. Tendo desenvolvido estratégias que superam o papel do exibidor como editor, Porter continua a se basear em sua experiência como exibidor ao combinar cenas de quatro brigadas de bombeiros (como um exibidor poderia projetar uma Paixão utilizando filmes de quatro produtores diferentes). Este filme sincrético se posiciona em algum lugar entre a apresentação de uma realidade simulada e uma história ficcional. Essa história, que existe na medida em que o chefe dos bombeiros e sua visão da esposa e da criança ressoa sobre as cenas posteriores, é sacrificada periodicamente em nome do espetáculo. ${ }^{247}$

Musser refere-se ao "papel do exibidor como editor". Como nas Paixões, os planos do filme de Porter em que os carros seguem pelas ruas seriam intercambiáveis: seu caráter autônomo, desprovido de ligações imediatas com planos contíguos, faria com que registros de outros produtores fossem substitutos possíveis, de modo que a estrutura geral não seria radicalmente afetada. Essa importância dada ao espetáculo visual leva Musser a comparar também a abordagem de Porter à poesia medieval francesa tratada por Erich Auerbach. No comentário a obras como Chanson de Roland e Chanson d'Alexis, Auerbach nota que ambas têm os mesmos retornos a ações já descritas, as mesmas "progressões por espasmos", a mesma ênfase em acontecimentos individuais em detrimento da continuidade narrativa. ${ }^{248} \mathrm{O}$ filme de Porter faria também a aposta na

247 Charles Musser, Before the Nickelodeon: Edwin S. Porter and the Edison Manufacturing Company (Berkeley: University of California Press, 1991), p. 226.

248 Ver Erich Auerbach, Mimesis: A representação da realidade na literatura ocidental, trad. Suzi Frankl Sperber (São Paulo: Perspectiva, 1971), p. 89: "Evidentemente, tanto as séries de acontecimentos semelhantes como as retomadas são fenômenos cujo caráter se aproxima do da parataxe nas formas das orações. Quer, em lugar de uma representação de massas, apareça a enumeração, sempre recomeçada, de cenas isoladas, de conformação e desenvolvimento semelhantes; quer, em lugar de uma ação intensiva, apareça a múltipla repetição da mesma ação, começando sempre no ponto de partida; quer, enfim, em lugar de um acontecimento que se desenvolva em vários membros, apareçam repetidas voltas ao ponto de partida, com, em cada caso, a adição do desenvolvimento de diferentes membros ou motivos: sempre se trata de evitar a recopilação racionalmente articulada e de preferir um processo 
habilidade dos espectadores de julgar a eficácia e a qualidade da realização em comparação a outras representações do mesmo evento. Mesmo desprovido das cartelas de texto das Paixões, Life of an American Fireman possui ainda como base um conjunto de imagens, gestos e episódios convencionalizados - um gênero estabelecido, portanto. ${ }^{249}$

A ambivalência representada pela obra de Porter teria sua apoteose na dúvida quanto à prioridade de uma entre duas cópias do filme. Uma das cópias, depositada na Library of Congress e confirmada nas últimas décadas como a verdadeira, fiel à montagem original, tem a estrutura que aqui descrevemos. Mas outra cópia, depositada no Museum of Modern Art (MoMA), traz uma montagem diferente: no final, em vez de mostrar as ações completas em seus dois ângulos, consecutivamente, mostra as ações entrecortadas de modo a sugerir a simultaneidade. Se na versão original os planos 8 e 9 (os planos do resgate) são dispostos em sequência, um após o outro, cada um mostrando a mesma ação em sua totalidade, na versão do MoMA os planos são fragmentados e apresentados em partes, alternando uma parte do plano 8 com uma parte do plano 9, fazendo a ação comum entre os dois servir como referência de continuidade: no momento em que a ação de um plano atinge determinada etapa, corta-se para o outro plano na mesma etapa, sugerindo com isso apenas a mudança de ângulo da câmera, sem uma quebra no fluxo temporal. Musser comenta extensamente os argumentos de historiadores e críticos que, na defesa de uma "evolução da linguagem cinematográfica", viram nesta segunda cópia de Life of an American Fireman o surgimento de outro modo de representação, uma quebra definitiva com o modo primitivo. ${ }^{250}$ Como um estudo contrafactual do filme, a versão do MoMA revela o potencial de linearização contido no material original; mas revela também, com isso, o contraste entre essa linearização e a montagem original.

Quais seriam então os modos de articulação temporal que encontramos nesses exemplos? Já no filme de Porter encontramos três tipos: (1) na passagem do primeiro ao segundo plano, quando parece haver uma distância temporal entre os eventos, há uma elipse, reforçada pelo fade; (2) na passagem do terceiro ao quarto, quando um movimento

estacante, justapositor, que avança e retrocede aos empurrões, com o que se dissipam as relações causais, modais e até temporais."

249 No caso das Paixões, a questão seria ainda mais presente: em teoria, todos os planos seriam substituíveis, já que lidam com ações convencionalizadas ao extremo, e isoladas verbalmente pelas cartelas. Desde que seguindo a iconografia cristã e as tendências do MRP, as diferenças internas dos planos poderiam, em princípio, ser ignoradas em nome da unidade criada pelo texto.

250 Ibid., pp. 231-233. Um defesa da versão do MoMA encontra-se no segundo capítulo de Lewis Jacobs, The Rise of the American Film: A Critical History (Nova York: Teachers College Press, 1975), "Edwin S. Porter and the Editing Principle", pp. 35-31. 
que vimos acontecer num plano (os bombeiros acordando e descendo pela barra) é parcialmente retomado no plano seguinte (os bombeiros descendo pela barra até a garagem), há o que podemos chamar, com um termo sugerido por Tom Gunning, de overlap; (3) na passagem do plano de dentro da casa ao plano de fora da casa, quando toda a ação do plano é retomada por outro ângulo, teríamos uma simultaneidade. ${ }^{251}$ Podemos visualizar os três modos, considerando as possibilidades cronológicas entre dois planos, A e B, onde A é sempre apresentado antes de B:

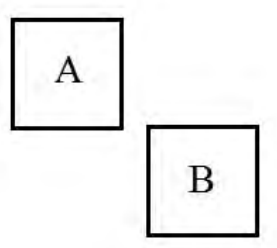

ELIPSE

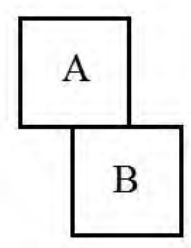

OVERLAP

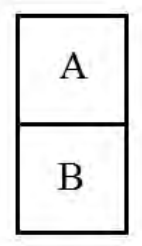

SIMULTANEIDADE

O problema encontrado pelos defensores da versão do MoMA do filme de Porter é o problema da linearização da simultaneidade, isto é, da representação de dois eventos em sucessão mas que devem sugerir algo que não é a sucessividade. O "anacronismo" da versão original do filme é um indício de que, para Porter, como para outros cineastas de sua época, a estabilidade da ancoragem espacial predominava sobre a questão da linearidade: a totalidade da ação num espaço homogêneo era um critério mais importante que a apresentação do segmento temporal de uma ação. O modo temporal que está ausente da versão original de Life of an American Fireman mas presente na versão do MoMA, e que caracteriza a passagem definitiva à linearidade, é o que podemos chamar de ligação por continuidade, quando a duração de um plano parece levar imediatamente à duração de outro plano, como se o tempo da ação permanecesse um só, num fluxo subjacente, sendo apenas confirmado pela heterogeneidade espacial:

\footnotetext{
${ }^{251}$ Para uma elaboração destes modos e uma referência de sua representação gráfica, ver André Gaudreault, "Temporality and Narrativity in Early Cinema (1895-1908)", in Cinema 1900-1906: An Analytic Study by the National Film Archive (London) and the International Federation of Film Archives, ed. Roger Holman (Bruxelas: FIAF, 1982), pp. 203-210. Outra referência considerada foi a classificação de Noel Burch em The Theory of Film Practice, op. cit., pp. 4-12.
} 


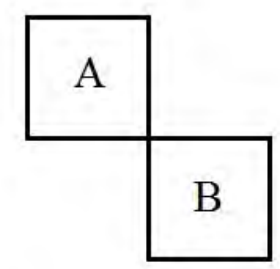

CONTINUIDADE

Na continuidade criada pela montagem alternada, os eventos registrados em A e B são divididos em partes, e as partes são apresentadas de modo que apenas uma de suas versões apareça na sequência, como se encobrisse a outra. Assim, se a parte 1 da ação é apresentada pelo plano $\mathrm{A}$, a parte 1 do plano B não é tornada visível; o plano B se apresenta como a continuação, a parte 2; e assim por diante. Podemos visualizar o princípio através de uma ação dividida em quatro partes:

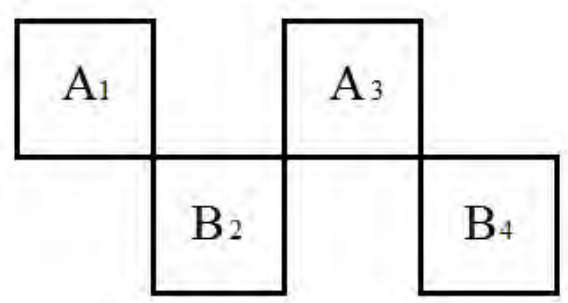

André Gaudreault propõe uma distinção que é útil para pensar este problema. Ele considera que todo plano, na lógica de um registro contínuo, pode organizar algum tipo de narrativa. Na medida em que o plano captura a passagem de tempo em determinado recorte espacial, ele pode nos apresentar relações de causalidade e sequencialidade sob os critérios que vimos no terceiro capítulo, e que teriam Arroseur et arrosé como exemplo. Chamemos esta de uma "narrativa em profundidade", por ocorrer inteiramente na dimensão do plano. Mas há outro nível de narrativa, que ocorre ao serem dispostos dois ou mais planos em sequência: um nível que não considera apenas a realidade deste ou daquele registro, mas o conjunto formado por eles. Chamemos esta de uma "narrativa virtual". Como no princípio das dimensões, este nível, para existir, deve necessariamente absorver o primeiro; deve fazer com que os eventos registrados em cada plano não tenham sua autonomia posta em evidência, e que não pareçam isolados uns dos outros, mas que sejam, ao contrário, integrados uns com os outros, tornados interdependentes. Para que o espectador não perceba uma série de pequenas narrativas isoladas, as 
características internas delas precisam ser organizadas de modo a sugerir a unidade mais ampla. As micro-narrativas de cada plano devem ser organizadas de modo a constituir a macro-narrativa formada pela série de planos. ${ }^{252}$

\subsection{Paralelismo e convergência}

A referência à linearidade nos permite retomar o uso do termo que fizemos nos capítulos anteriores. Na superfície composicional, ou seja, na dimensão em que as obras são definidas pela articulação do espaço da tela e do tempo cronométrico, a linearidade é uma analogia com o direcionamento da projeção. Os fotogramas agrupados, criando a impressão de movimento ou de alterações progressivas no campo visual, tornam-se os índices da frequência com a qual a projeção desvela a fita de filme. Na profundidade, em obras definidas por articulações do espaço cênico e do tempo real, a linearidade torna-se uma analogia com o plano, estabelecendo uma correspondência entre a frequência da exposição do filme no momento de seu registro e a frequência da projeção. Na virtualidade, se as obras são definidas pela articulação de planos, de um espaço-tempo construído entre os planos, a linearidade deve fazer referência a algum tipo de continuidade; se não a continuidade estrita, que busca reconstruir o tempo real, ao menos uma continuidade que justifique internamente mudanças que possam ocorrer na vetorização temporal (como elipses e flashbacks). Isso significa que, nesta dimensão, o trabalho de linearização é sinônimo de criar e elaborar os referenciais "internos", os dados em cada um dos planos que, apresentados em série, tornarão possível a criação de uma unidade na imaginação do espectador. A linearidade aqui é portanto uma analogia à "continuidade psicológica" da relação entre o espectador e a obra.

O cineasta que representa de maneira mais contundente a linearização da montagem, sobretudo em sua utilização da montagem paralela como forma privilegiada da continuidade, é D.W. Griffith. Contemporâneo de Porter, Griffith apresenta já em seus primeiros curtas-metragens produzidos para a Biograph os pilares do que será chamado por Burch de um Modo de Representação Institucional (MRI), o formato linear tradicional.

\footnotetext{
${ }^{252}$ Ver André Gaudreault, "Film, Narrative, Narration: The Cinema of the Lumière Brothers", in Early Cinema: Space, Frame, Narrative, op. cit., pp. 71-73.
} 
O primeiro filme de Griffith, The Adventures of Dollie (1908) não possui cartelas de texto, mas apresenta alguns traços do MRP e uma estrutura próxima das Perseguições. No plano inicial, vemos um tableau da família no campo: o pai, a mãe, e a filha, Dollie. No segundo plano, a mãe é vista à distância com Dollie na beira de um rio, quando um cigano se aproxima e tenta vender algo à mãe; ela recusa, ao que o cigano se sente ofendido e tenta arrumar uma confusão, mas é interrompido por outras pessoas e afastado por elas. No terceiro plano, o cigano é visto numa carroça, conversando com uma mulher que parece ser sua esposa, demonstrando raiva pela humilhação sofrida. No quarto plano, Dollie é vista em outro tableau com a família, mas desta vez ela é deixada sozinha por alguns segundos e logo surge ao fundo o cigano, que rapidamente pega a criança e foge.

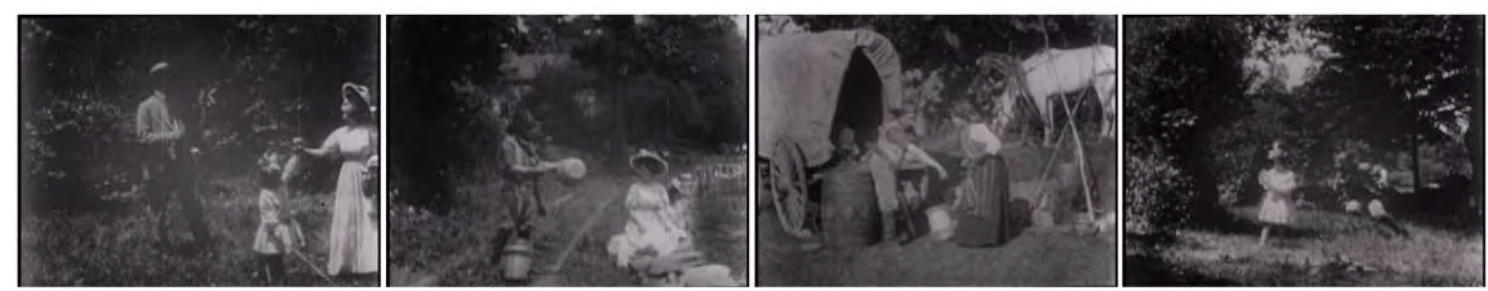

Os primeiros quatro planos de The Adventures of Dollie (D.W. Griffith, 1908)

No sexto plano, após ser mostrado correndo com a criança, o cigano é visto novamente em sua carroça - na primeira repetição espacial do filme, sendo inclusive uma repetição do mesmo enquadramento. O cigano esconde Dollie num barril, e logo chegam pessoas procurando a criança, acusando-o do sequestro. Deste ponto em diante, o filme segue a lógica da Perseguição, ainda que não haja exatamente perseguidores e perseguidos. O cigano vai embora com sua carroça, a cada plano sendo visto num ambiente diferente, até que, entrando num rio, o barril cai na água e é levado pela correnteza, sendo também visto a cada plano num local diferente, os planos iniciando e terminando com as entradas e saídas de quadro do barril. $\mathrm{O}$ encadeamento é modificado quando, dos planos do barril na água, o filme corta para o mesmo plano à beira do rio que vimos no início, onde vemos agora um pescador retirar o barril da água, finalmente reunindo Dollie com sua família. 


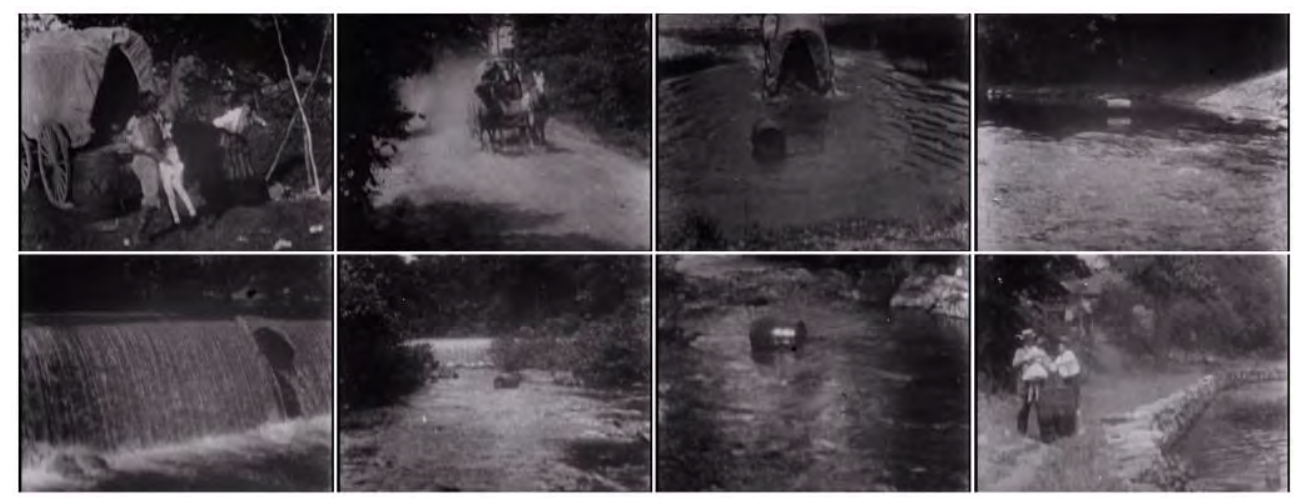

Os planos finais de The Adventures of Dollie, seguindo a lógica da Perseguição: (1) a criança sequestrada é colocada num barril; (2) o barril é carregado numa carroça; (3) a carroça passa num rio e o barril cai na água; (4-7) o barril é levado pela correnteza; (8) o barril é retirado da água e a criança é resgatada.

Como nas Perseguições, os enquadramentos são distantes, no máximo planos médios. Praticamente não há movimento de câmera, com exceção de uma breve panorâmica no plano final. Cada locação tem um único plano, ou ainda, um único ângulo, o que é enfatizado pelas duas repetições de enquadramento. As passagens entre os planos mantêm as distâncias espaciais e temporais indefinidas; não há overlap ou simultaneidade, e o barril serve inclusive como ponto de ligação entre os diferentes espaços; mas também não há uma continuidade estrita, e sim uma vaga sequencialidade. Como nas Perseguições, há uma recorrência de personagens. Isso é tornado ainda mais importante pela diminuição do número de personagens: o número reduzido de pessoas e espaços envolvidos na ação, além da repetição desses elementos, faz com que uma hierarquia seja estabelecida no filme, algo que não encontramos tipicamente nas Perseguições. Se o MRP é caracterizado por um "policentrismo", ou seja, por uma abertura excessiva do enquadramento aos eventos perante a câmera, de modo que a imagem parece colocar-se de uma só vez ao espectador, é porque o caráter fotográfico do plano dá a essa composição visual a garantia de que toda complexidade presente no mundo será representada no registro. A performatividade frontal das atrações deriva dessa força, que é ao mesmo tempo sua limitação quanto ao desenvolvimento narrativo. $\mathrm{O}$ esforço da linearização, nesse sentido, é o esforço de superar a resistência "natural" do plano, dando forma e propósito à massa de detalhes contingentes.

Em The Sealed Room (1909), Griffith propõe uma abordagem mais concentrada do problema. Neste filme são apresentados dois espaços consideravelmente mais restritos, e uma noção de contiguidade entre eles. O filme inicia com cartelas de texto que servem para dar uma hierarquia aos eventos, indicando para onde e para quem devemos olhar, 
qual será o foco da ação. No primeiro plano, o rei constrói um quarto para sua amante favorita. Vemos que o quarto não possui janelas, apenas uma porta. Em seguida, através de uma ligação por continuidade, o rei se desloca para um espaço contíguo ao primeiro, ou seja, do lado de fora do quarto anterior. O rei é então cercado de pessoas - súditos, mulheres, soldados e um músico que troca olhares com a amante do rei. Podemos visualizar as duas primeiras cartelas e seus respectivos planos, que servem como a apresentação dos espaços e das premissas dramáticas:
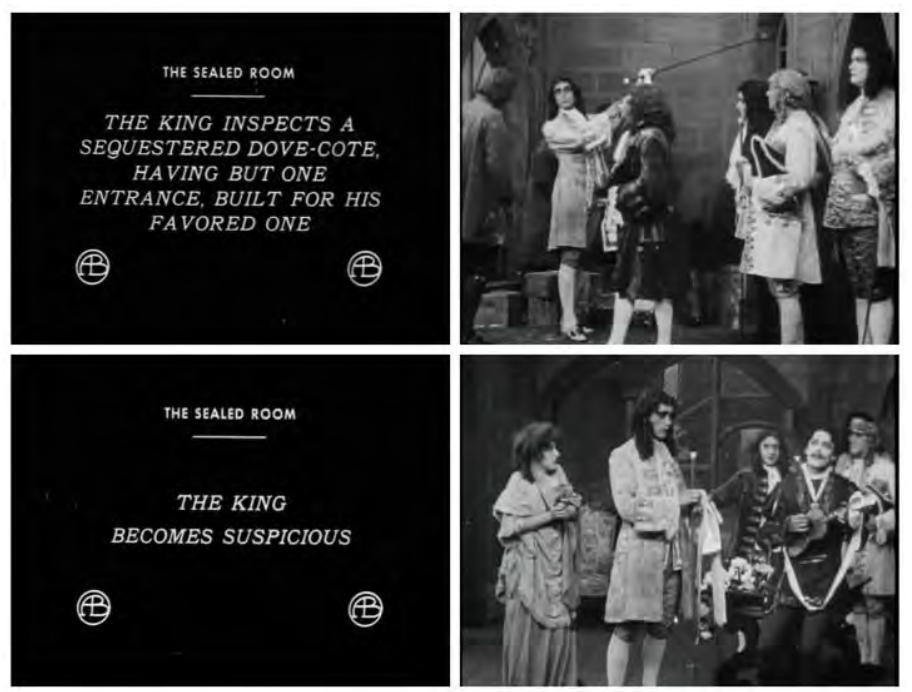

O conflito é estabelecido quando o rei passa a desconfiar da relação entre o músico e sua amante. No que se segue, não há cartelas, apenas a alternância das ações nos dois espaços. O rei é chamado por alguém; todos saem do quadro como se saíssem de um palco, exceto o músico e a mulher, que logo revelam ser verdadeira a suspeita - eles se escondem no quarto, e pouco depois o rei volta e os vê juntos através da porta. A solução do rei é fechar o quarto, trancando lá dentro os amantes. Para interromper a ligação entre os dois espaços, o rei manda que seus operários cubram a porta com tijolos enquanto os amantes permanecem distraídos. A câmera alterna de um ambiente a outro, nos mostrando as etapas da construção numa organização paralela: de um lado, os planos mostram o casal sorrindo, o músico cantando, a mulher retirando uma a uma as pétalas de uma flor; do outro, o rei, eufórico com sua vingança, observando os tijolos cobrindo gradualmente a porta. Em cada um dos espaços, um enquadramento fixo é mantido sob o mesmo ângulo frontal, evocando o cubo cênico, e a cada vez que o enquadramento é retomado, temos as mesmas referências temporais, índices da passagem de tempo. $\mathrm{O}$ paralelismo que encerra o filme nos mostra então a descoberta da situação pelo casal e a 
euforia do rei por ter sua vingança realizada. Os dois espaços tornam-se absolutamente incomunicáveis espacialmente. Apenas a câmera nos dá a ver seus conteúdos, como um ponto de vista livre da ação.

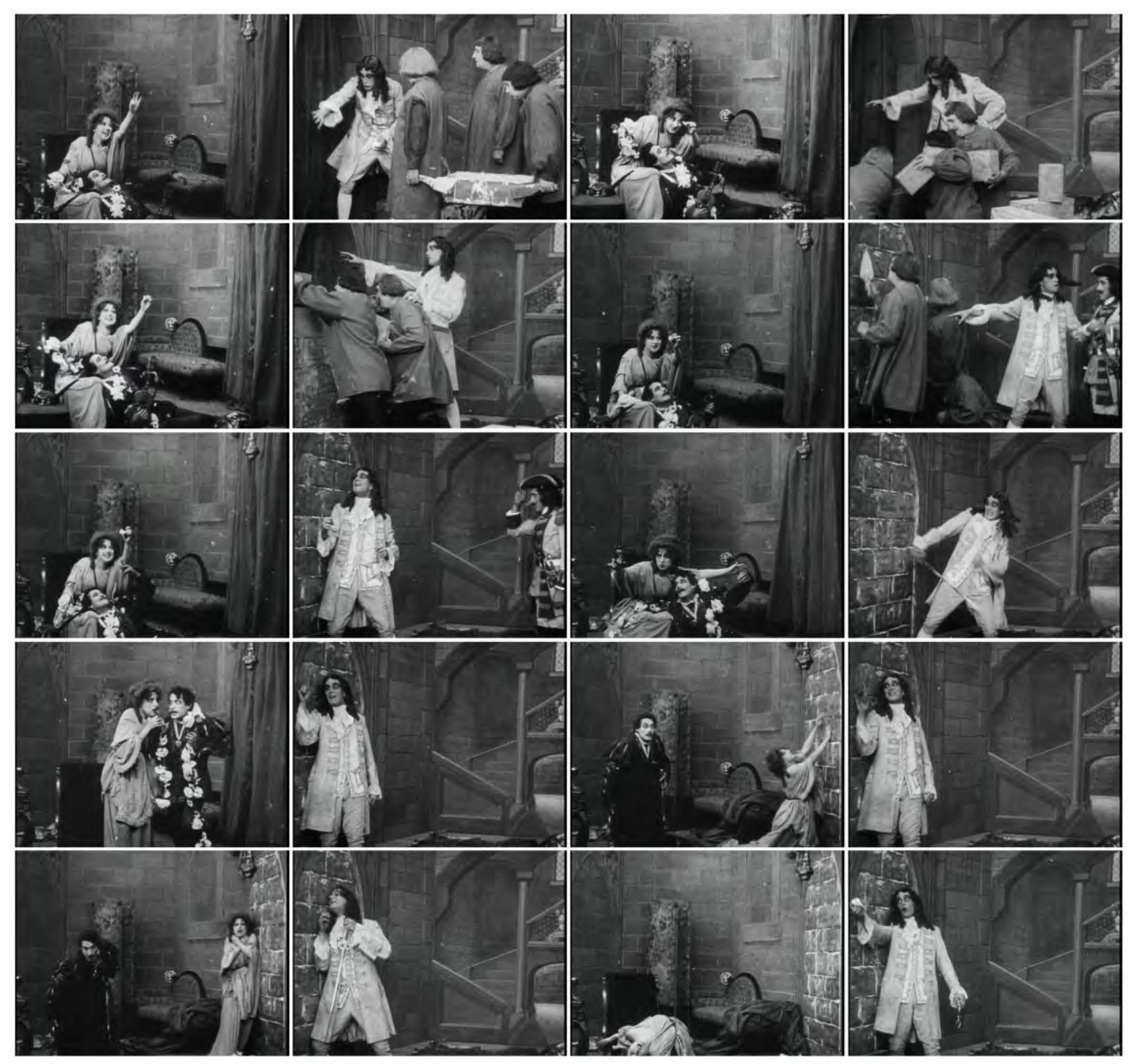

The Sealed Room (D.W. Griffith, 1909) - os últimos vinte planos, alternando os dois espaços em enquadramentos fixos, com medidas internas (as pétalas e os tijolos) marcando o progresso temporal.

Neste filme, a organização espacial torna-se praticamente o tema da narração. Os dois espaços impedem a lógica da Perseguição; o interesse é na dualidade entre espaços fechados em si mesmos e espaços que podem ser atravessados nas duas direções. Se a fixidez dos enquadramentos mantidos idênticos a cada repetição afirma a autonomia desses espaços, a continuidade criada pelo movimento dos personagens afirma a possibilidade de travessia entre eles. Temporalmente, esse isolamento supõe o paralelismo. Quando se passa de um plano a outro, o tempo da ação "continua" no espaço 
anterior, mesmo que ele não seja visível. Isso reforça que está em jogo um tempo virtual, que inclui o tempo dos registros mas é diferente deles. Este tempo deve necessariamente supor o tempo cronométrico, o tempo absoluto da projeção, como se pudesse construir sobre ele uma nova continuidade a partir da junção de elementos descontínuos. A evolução de cada plano é então marcada por ações que ilustram as etapas de processos retomados periodicamente: a retirada das pétalas e a construção do muro, vistos um em relação ao outro, sugerem um terceiro processo, o processo de alternância que os inclui sob uma mesma duração.

Mas além disso, a passagem de um plano a outro sugere também uma virtualidade espacial. A predominância das elipses nas Perseguições era acompanhada da ausência de orientações espaciais constantes; o espaço de um plano não era definido claramente em relação ao espaço dos outros planos, de modo que as entradas e saídas de quadro tornavam-se muitas vezes arbitrárias, podendo ocorrer às vezes da direita para a esquerda, e às vezes ao contrário. Nesse sentido, as Perseguições supõem algo do fator "relacional" que encontramos nas animações de Richter e Eggeling, a simetria dos eixos espaciais, onde os movimentos podem ocorrer em todas as direções sem que haja prejuízo da lógica composicional. A proposta de Griffith é uma mudança análoga à introdução da orientação gravitacional nas animações. Se a presença da orientação gravitacional institui uma assimetria no eixo vertical da imagem gráfica, a construção de um sistema de coordenadas espaciais na cena, sobretudo no eixo horizontal, faz com que as entradas e saídas de quadro, bem como os olhares direcionados entre os espaços, não sejam mais arbitrários, mas que devam seguir certas leis para manter sua unidade.

Como forma de ilustrar a questão, podemos comparar a passagem do primeiro ao segundo plano em Tom, Tom, the Piper's Son com a passagem entre dois planos em The Sealed Room. No filme de Bitzer, os personagens podem encerrar o primeiro plano saindo pelo lado esquerdo da tela e iniciar o segundo plano entrando pelo lado esquerdo porque a frontalidade do enquadramento, a manutenção da distância média da câmera e a lógica de uma ação identificável como a perseguição bastam como pilares da obra: 

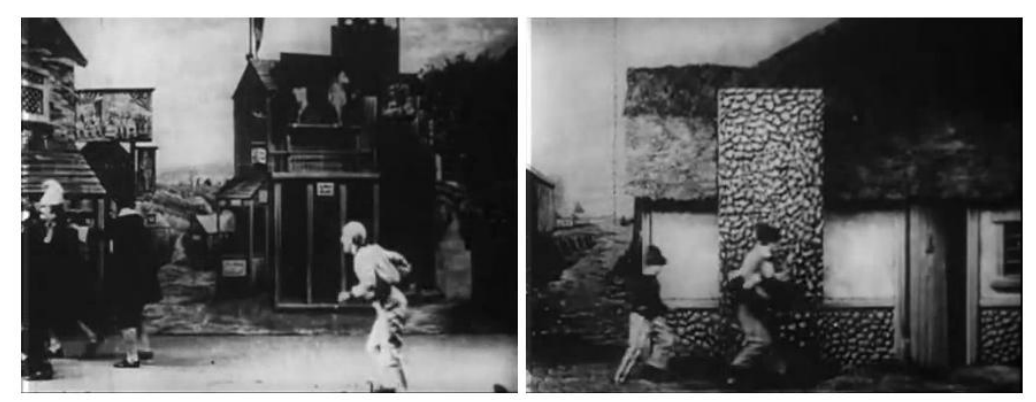

O sistema de orientação utilizado por Griffith é uma adaptação da unidade cênica do teatro ao espaço da tela cinematográfica. Se no teatro o espaço do palco é absoluto, se é nele que ocorrem todos os movimentos, então no teatro as entradas e saídas pelos lados direito e esquerdo devem apenas seguir a imutabilidade deste espaço, a referência fixa. Mas no cinema, a referência fixa é a tela; é dentro do espaço da tela que os diferentes planos são projetados, podendo inclusive ser apresentados cada vez num ângulo diferente, modificando a posição de seus referenciais internos. A estratégia de Griffith é basicamente dar prioridade às referências direcionais da tela sobre as dos planos individuais, mantendo-as constantes e fazendo com que as orientações dos planos as respeitem. Assim, se um personagem olha para o lado esquerdo da tela num plano, o plano do outro espaço é filmado num ângulo tal que seu olhar possa vir do lado direito da tela, pois é onde o personagem deveria estar para olhar à esquerda:
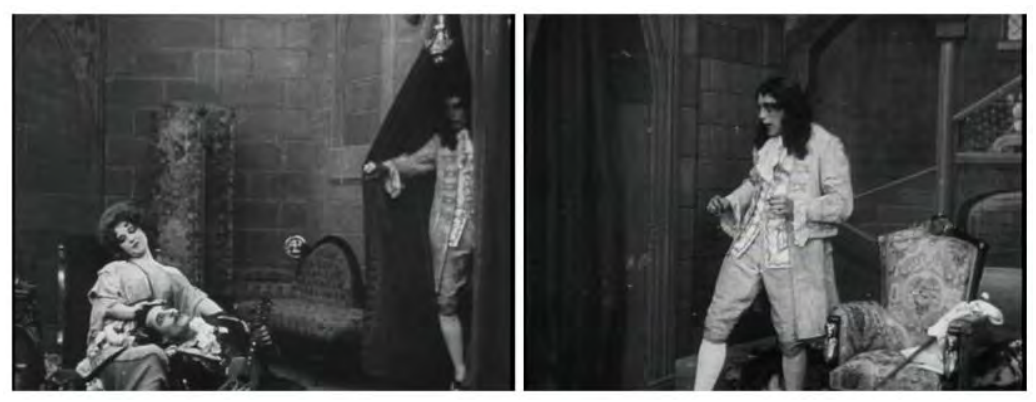

Nos anos seguintes, Griffith aperfeiçoou a estratégia com o acréscimo de duas técnicas de hierarquização espacial e temporal. Em The Lonedale Operator (1911) e An Unseen Enemy (1912), por exemplo, o número de espaços é multiplicado. Como em The Adventures of Dollie, há diferentes ambientes pelos quais os personagens transitam; mas como em The Sealed Room, os espaços são retomados e organizados por coordenadas fixas, de modo que uma unidade virtual é inferida a partir deles. 
The Lonedale Operator narra a história de uma garota que trabalha numa estação de telégrafo substituindo o pai doente. Quando um pagamento é entregue no local, dois andarilhos tentam roubar o dinheiro. O filme alterna planos da estação, onde a garota mantém os assaltantes do lado de fora, com planos da cidade, onde está seu pretendente, que recebe mensagens pelo telégrafo. A alternância é cada vez mais rápida, ecoando a proximidade crescente do pretendente como um evento paralelo às tentativas dos assaltantes de invadir o local. As ações convergem quando os assaltantes derrubam a porta, sendo rendidos pela garota logo que chega seu pretendente.

An Unseen Enemy, por sua vez, narra a história de duas jovens irmãs que perderam o pai recentemente e que vivem numa casa no campo. O irmão mais velho delas vai até a cidade, deixando-as com empregados que sabem de um valor em dinheiro recém-adquirido, e que tentam roubar. A estrutura é semelhante à do filme anterior: as garotas mantém os vilões do lado de fora do quarto e comunicam-se com o irmão pelo telefone, ao que se segue uma montagem alternada cada vez mais acelerada das tentativas dos empregados de entrar no quarto e a viagem do irmão até a casa, convergindo no momento de maior tensão, ao que tudo é prontamente resolvido e as jovens protagonistas são salvas.

Nos dois casos, o close-up é utilizado como ferramenta de hierarquização espacial e temporal. O close-up faz com que o espaço seja recortado e que a escala da imagem seja modificada apenas para retornar à escala média em seguida, sugerindo assim uma relação comutativa entre o todo e uma de suas partes, o que significa que há uma inferência constante quanto ao que está presente na tela e o que está presente à sua volta. Quando a jovem operadora envia uma mensagem ao pretendente, vemos primeiro ela num plano aberto, enquadrando todo o cenário; mas em seguida, vemos um enquadramento mais próximo, concentrado na parte superior de seu corpo e permitindo a visão mais detalhada de seu gesto; e logo depois, vemos num close-up a mensagem recebida e transcrita por seu pretendente, ao que se segue um plano aberto, mostrando-o em sua sala. Da mesma forma, quando os empregados tentam invadir o quarto das irmãs, eles descobrem um buraco na parede, pelo qual colocam uma arma, que é vista em close-up antes de ser vista pelas irmãs num plano médio, nos dando primeiro acesso ao meio da ameaça para que logo em seguida vejamos as reações a ela. O close-up, nestes casos, ao ser utilizado em continuidade, reforça a estabilidade temporal e espacial: inserido entre planos mais 
abertos, é a prova de que as mesmas condições cênicas permanecem idênticas antes e depois da mudança de escala visual. ${ }^{253}$

Nesses dois filmes, também a concepção do paralelismo é modificada, com o acréscimo da convergência. Se nas Perseguições a distância indefinida entre os espaços sugere apenas a diferença entre eles, e se o isolamento de espaços contíguos em um filme como The Sealed Room estabelece o paralelismo, a montagem de Griffith aqui faz com que seja criada uma escala de distâncias. Podemos utilizar uma terminologia sugerida por André Gaudreault e Philippe Gautier, caracterizando os espaços utilizados num eixo formado por identidade e alteridade. Quando se corta de um plano a outro plano do mesmo espaço, a relação estabelecida é de identidade. Seria o caso dos close-ups que aproximam a visão no mesmo ângulo, e que reforçam, portanto, que se trata de um mesmo espaço nos dois planos. Quando se corta de um plano a outro plano de um espaço diferente, a relação é de alteridade. A alteridade se divide em dois tipos: um espaço pode ter com o outro uma relação de contiguidade ou disjunção. As passagens entre os dois cômodos em The Sealed Room exemplificariam a relação de contiguidade, estabelecida pela ligação contínua entre os planos. A disjunção, por sua vez, se bifurca em outros dois tipos, podendo ser próxima e distante. Podemos definir a disjunção próxima como "a menor distância que não é contígua", ou ainda, como uma propriedade transitiva dos espaços - se o espaço $a$ é contíguo ao espaço $b$ e o espaço $b$ é contíguo ao espaço $c$, então o espaço $a$ possui uma relação de disjunção próxima com o espaço $c$. A disjunção distante pode ser definida como "a relação disjuntiva entre um espaço e qualquer outro espaço com o qual não possui uma ligação transitiva". O resultado é uma escala de proximidade que vai da identidade à disjunção distante: identidade - contiguidade - disjunção próxima - disjunção distante. ${ }^{254}$ Podemos representá-la também em forma de diagrama:

${ }^{253}$ É importante ter em mente o caráter tentativo dessas técnicas, e o modo como tiveram um lento desenvolvimento histórico. Ver, por exemplo, Ismail Xavier, D.W. Griffith: O nascimento de um cinema (São Paulo: Brasiliense, 1984), p. 36: “A pesquisa mais recente não cansa de mostrar o quanto é comum uma 'conquista' de linguagem estar presente num filme sem que sejam claras para os responsáveis suas implicações dessa presença. Porter, por exemplo, usa o primeiro plano em 1903, sem quebrar a continuidade da cena - isso não o impede de passar anos sem retornar a ele. Em Griffith, encontramos o primeiro plano em Betrayed by a Handprint (1908); isso não significa que o recurso se torna usual a seguir. Ele só volta ao primeiro plano em 1909, dezenas de filmes depois, quando uma necessidade explicativa o requer - o critério de funcionalidade, o engenho a serviço da mensagem são traços do cineasta que, neste caso, favorecem a lenta integração do novo. Em Betrayed, o motivo é a impressão digital desmascaradora; em The Golden Louis (1909), é necessário mostrar a moeda; em The Medicine Bottle (1909), o drama exige o destaque do frasco perigoso junto a uma criança deixada numa casa."

${ }^{254}$ Ver André Gaudreault e Philippe Gauthier, "D.W. Griffith et l'émergence du montage alterné", Revue Canadienne d'Études cinématographiques, vol. 26, n. 2 (outono de 2017), pp. 1-30. 


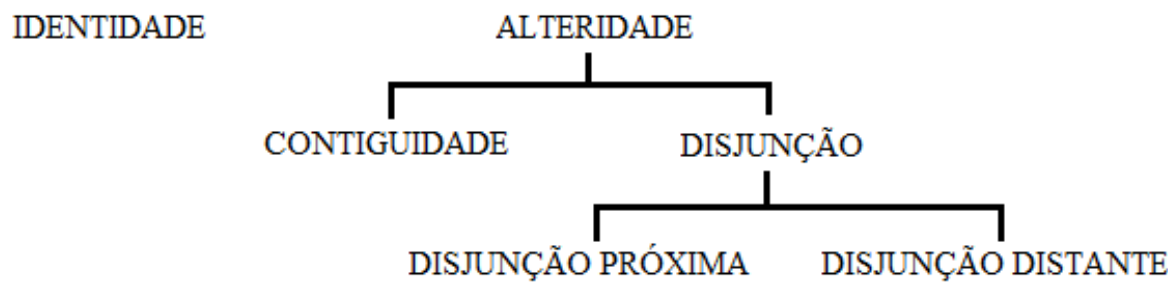

Isso tem consequências diretas nos objetos utilizados na narrativa. A porta em The Sealed Room serve como um paradigma de limiar espacial, ao mesmo tempo limite e local de passagem. Em The Lonedale Operator e An Unseen Enemy, portas e janelas servem como aberturas a outros espaços, a serem fechadas mas não indefinidamente, podendo ser abertas ou perfuradas, numa constante mobilidade do olhar e dos gestos. Além disso, a presença do telégrafo e do telefone, instrumentos que permitem a comunicação à distância, serve como um símbolo do controle espacial exercido pelo narrador - seu ponto de vista onisciente, capaz de nos levar de um espaço a outro, de atravessar espaços distantes em frações de segundos. Assim como os Lumière parecem ter encontrado na arquitetura urbana e nas ferrovias alguns elementos significativos para a construção de obras fílmicas, ou mesmo metáforas para as formas dos filmes que desenvolviam, o mesmo parece ter ocorrido na utilização de alguns elementos recorrentes por Griffith. ${ }^{255}$

Essa liberação do olhar narrativo, da câmera associada à montagem mais do que à ação, é o que Gunning afirma ser a principal contribuição de Griffith. “A montagem paralela", ele argumenta, "representa um salto dialético na representação do espaço e do tempo no primeiro cinema". O filme com isso torna-se capaz de seguir o curso de uma ação mas também de abandoná-la parcialmente, de voltar o olhar para outras ações, jogando com a expectativa, adiando sua realização, nos lembrando que, enquanto ocorre $a$, também ocorre $b$ :
Ainda que o formato da perseguição alongasse a narrativa por um certo número de planos, mantinha uma homologia estrita entre a continuidade da ação representada e a linearidade de sua representação. Com a montagem paralela, o sistema do narrador se afirma através de uma divergência entre a ação e sua representação, entre história e discurso. Ao quebrar a linha contínua da ação encontrada no formato da perseguição, a montagem

\footnotetext{
${ }^{255}$ Daí também a afirmação de Gaudreault de que o gênero do "resgate de última hora" é inovador por dar ao tempo uma prioridade na lógica narrativa. As versões de Griffith para o gênero são inteiramente dependentes das possibilidades narrativas abertas pelas então recentes tecnologias da ferrovia, do telégrafo e do telefone. Ver André Gaudreault, "Temporality and Narrativity in Early Cinema (18951908)", op. cit., p. 212.
} 
paralela afirma um controle sobre a organização dos significantes do filme, criando novas relações com o espectador, sob as categorias de tempo e voz verbais. ${ }^{256}$

O que Gunning chama de "sistema do narrador" torna-se um caso representativo da virtualidade espacial e temporal. Com a multiplicação das técnicas de controle narrativo, o que se alcança é uma maior unidade entre planos dispersos, unidade baseada inteiramente nas relações de espaço e tempo, determinadas pela hierarquia na escala dos enquadramentos e pela orientação e continuidade dos movimentos.

Este "controle sobre a organização dos significantes" pode envolver a mobilização de diferentes níveis da composição. Em The Lonedale Operator, por exemplo, Griffith cria associações entre os espaços que serão mais tarde alternados, dispondo-os sempre no mesmo enquadramento mas orientados para lados opostos. Na primeira estação, vemos o trem se afastando da câmera, e a mesa da operadora no canto esquerdo do quadro; na segunda estação, vemos o trem se aproximando da câmera, e a mesa do operador no canto direito do quadro. Mantendo ângulos semelhantes em relação ao espaço cênico, os enquadramentos são perfeitamente simétricos, na disposição gráfica e no direcionamento das ações. Essa complementaridade dos espaços na economia narrativa é um dos motivos que Raymond Bellour argumenta estar presente no "volume textual" de alguns filmes de Griffith no período. A atenção ao caráter "intervalar" dos planos, na passagem de uma organização visual à outra, mantendo uma unidade entre elas, seria uma forma de inscrever as simetrias, inversões e repetições na própria disposição cênica, como se já nesta dimensão fossem criadas as condições de percepção do sentido narrativo da obra. ${ }^{257}$

256 Tom Gunning, D.W. Griffith \& The Origins of American Narrative Film: The Early Years at Biograph (Urbana, Chicago: University of Illinois Press, 1994), p. 77 (grifos nossos).

257 Ver Raymond Bellour, "To Alternate/To Narrate", in The Analysis of Film (Bloomington: Indiana University Press, 2000), pp. 262-277. Bellour refere-se a The Lonedale Operator, mas a mesma estratégia já se encontra em The Sealed Room e talvez em outros filmes entre 1908 e 1909. 


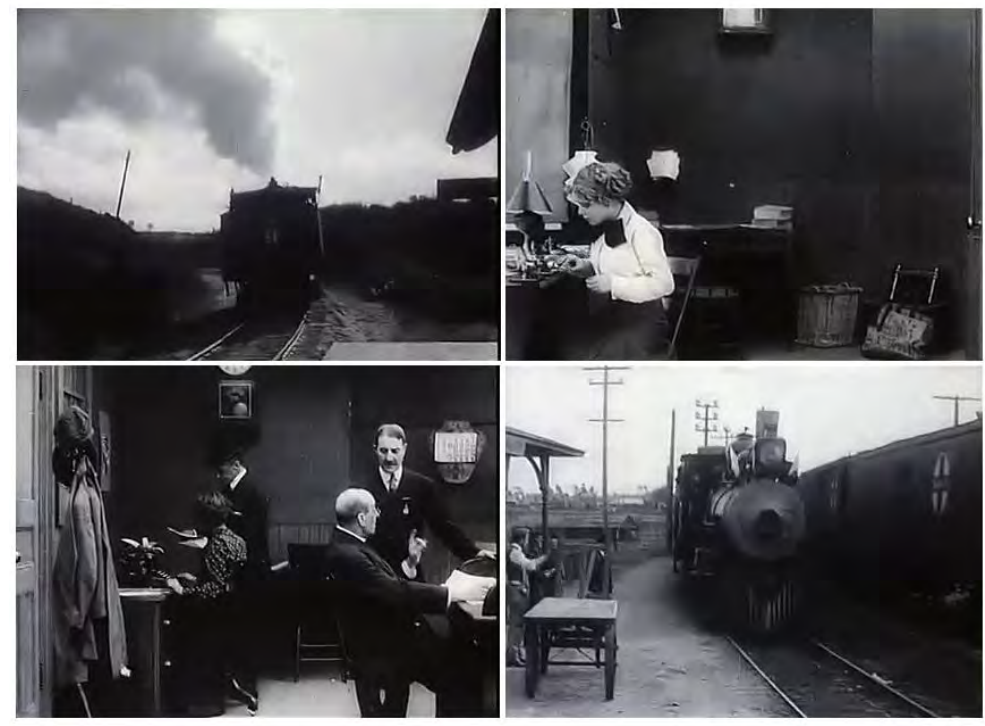

Alguns dos planos no início de The Lonedale Operator (D.W. Griffith, 1911), exemplificando o uso de inversões e simetrias na disposição cênica para criar relações de complementaridade entre os planos, e consequentemente entre os espaços que serão alternados mais adiante pela montagem.

Se os casos mencionados exemplificam o uso da montagem como forma de estabelecer o paralelismo entre espaços contíguos ou distantes, mas que em algum momento se relacionam pela disposição e movimentação dos personagens, deve-se mencionar ainda os filmes em que a montagem estabelece paralelismos entre espaços que em momento algum são relacionados diretamente. Em outras palavras, as formas pelas quais a virtualidade pode ser construída sem a base estritamente física da ação. Como ilustrações do princípio de divergência ação-narrador descrito por Gunning, estes filmes tratam os espaços como eixos de acontecimentos desenvolvidos sob o mesmo processo narrativo, mas cuja alternância descreve algo que é conduzido tematicamente, mais do que por etapas na trajetória dos personagens. O paralelismo é usado então para direcionar a atenção de um aspecto a outro da diegese.

Com um grau elevado de independência narrativa, Griffith coordena, num filme como A Corner in Wheat (1909), ações desligadas espacialmente, mas que por uma ressonância temática, especificada pelas cartelas, revelam um mesmo processo em curso. São três as linhas narrativas: (1) fazendeiros infelizes com os resultados da colheita de trigo; (2) um empresário, o "rei do trigo", dedicado à especulação financeira; (3) pessoas na cidade que não têm dinheiro para comprar pão. Os personagens em cada uma dessas linhas permanecem dentro delas; não há encontro entre eles, como não há passagem de uma linha a outra. Alternando o desenvolvimento em cada espaço, Griffith cria com isso algumas comparações, como quando o banquete da família do empresário é sucedido pela 
fila de pessoas famintas na padaria. O resultado é a construção de uma cadeia diegética que não se caracteriza pela interação de suas partes através do deslocamento dos personagens, mas por uma espécie de comentário apresentado em parte nas cartelas, e em parte na própria estrutura sequencial. $^{258}$

O projeto mais ambicioso de Griffith nesse sentido, e que unifica todas essas características apontadas, é Intolerância (Intolerance: Love's Struggle Throughout the Ages, 1916). Tendo desenvolvido as técnicas de close-up e paralelismo em seus longasmetragens anteriores, Griffith compõe em Intolerância um espécie de polifonia narrativa, coordenando diferentes linhas históricas ao redor de um mesmo eixo temático: (1) uma narrativa contemporânea, envolvendo operários americanos; (2) uma narrativa passada na França, na véspera do Massacre de São Bartolomeu; (3) a narrativa da vida de Jesus; e (4) a narrativa da queda da Babilônia. As cartelas iniciais declaram o tema comum, já apresentado no título. Entre as quatro histórias, Griffith recorre ainda a planos que mostram uma mulher (interpretada por Lilian Gish) embalando uma criança ao lado de um berço. Como um refrão, este plano é retomado periodicamente, servindo de referência cíclica e poética ao progresso das narrativas.

Em termos locais, considerando isoladamente cada uma das narrativas dentro do filme, Griffith mantém a mesma concepção espacial e temporal de um filme como $O$ nascimento de uma nação (The Birth of a Nation, 1915). Há uma escala de planos, criando uma hierarquia de detalhes e contextos, direcionando o olhar para as regiões da tela nos momentos cruciais. Há uma alternância de espaços, estabelecendo relações de contiguidade e proximidade entre os locais na diegese. Como em seus filmes de resgate, temos aqui ações inteiramente ligadas pela movimentação dos personagens. Mas a alternância das várias linhas narrativas acrescenta uma nova camada à composição. As narrativas não são apresentadas continuamente, e sim entrecortadas; as ações são interrompidas, tornadas paralelas a ações de outras histórias, em contextos inteiramente diversos. Se Griffith propunha com A Corner in Wheat a alternância de espaços no que parecia ser a mesma diegese, em Intolerância ele alterna o que parecem ser diegeses

\footnotetext{
${ }^{258}$ Gunning menciona outros filmes em que Griffith contrasta classes sociais, condenando moralmente a ganância dos personagens. Além de A Corner in Wheat, fazem parte deste grupo filmes como The Usurer (1910) e For His Son (1911). Entre estes, o filme de 1909 é o único que faz a abolição completa da ligação dos espaços pela movimentação dos personagens. Ver Gunning, D.W. Griffith and the Origins of American Narrative Film, op. cit., p. 134, 244.
} 
completas. Em decorrência disso, o teor comparativo não reside apenas na passagem de um plano a outro, mas em todo o conjunto de planos que define a obra. ${ }^{259}$

As premissas de Intolerância nos permitem, então, identificar duas questões relativas ao encadeamento de planos em larga escala. A primeira delas é que, como a diegese de uma narrativa não se comunica com as outras, a alternância de alguns planos não cria simplesmente uma operação equivalente ao "enquanto isso" literário: cria uma suspensão daquele fluxo temporal. Em vez de deslocar a atenção do espectador para outra região do espaço diegético, supondo que o tempo da projeção continuará análogo ao tempo diegético, Griffith parece sugerir que o espectador deixe de lado essa analogia, e que considere o tempo da narração como primordial, pois é através dele, mais do que de um tempo interno da diegese, que se dá a construção de sentido pelos encadeamentos. A mesma operação ocorre com os espaços. O agrupamento de planos em cada narrativa faz com que seja construído um espaço virtual naquele contexto; mas esses contextos são alternados uns com os outros, e a própria concepção deles como representando períodos históricos diferentes faz com que a ideia de um mesmo fluxo temporal em espaços distantes seja deslocada. A relação entre os espaços das diferentes linhas históricas não pode ser classificada pelos termos de Gaudreault e Gauthier: é uma nova espécie de alteridade que parece ser colocada, algo como a "disjunção diegética".

A segunda questão envolve o tratamento dado aos aspectos métrico e rítmico da montagem. A tendência ao paralelismo e a recorrência de narrativas envolvendo "resgates de última hora" fizeram com que Griffith criasse em algumas ocasiões um padrão de montagem que lhe parece ter servido como modelo para uma estrutura dramaticamente bem-sucedida:

O ritmo deve ser acelerado do início ao fim. Isso não deve levar, entretanto, a uma ascensão contínua. A ação deve ser acelerada até chegar a um clímax menor, e então tornada mais lenta, e construída novamente até o próximo clímax, que deve ser mais rápido, e dali construir para o terceiro, quando o ritmo deve ser ainda mais rápido. Nos grandes momentos da narrativa o ritmo deve ser como a batida de um pulso intensificado. ${ }^{260}$

\footnotetext{
${ }^{259}$ Para uma contextualização mais detalhada do lugar da estrutura alternada de Intolerância no conjunto da obra de Griffith e no momento de seu lançamento, ver Stanley J. Solomon, "The Narrative Structure of the Film Idea: Intolerance", in The Film Idea (Nova York: Harcourt Brace Jovanovich, 1972), pp. 122-134.

${ }^{260}$ D.W. Griffith, "Pace in the Movies", Liberty (1926), p. 31.
} 
Lembremos que a montagem métrica se caracteriza pelo comprimento absoluto da fita de filme, ou seja, a duração puramente cronométrica de um segmento, ao passo que a montagem rítmica considera os intervalos desse segmento, isto é, os movimentos presentes nas imagens e as frequências de suas mudanças de configuração. Nos filmes de Griffith em que a técnica da montagem alternada está plenamente desenvolvida, a construção das sequências é o resultado de uma relação entre o tempo métrico e o tempo rítmico, entre a duração absoluta dos planos e a duração dos movimentos que ocorrem dentro desses planos. Planos com a mesma duração métrica podem mostrar eventos ritmicamente diferentes, que por sua vez podem ser alternados e dispostos em contextos que dão sentidos distintos aos seus ritmos internos. Novamente, são os padrões criados pela narração que estabelecem o sentido geral das sequências. $O$ tempo da narração acrescenta a dimensão "virtual" à temporalidade "superficial" do tempo métrico e à "profundidade" do tempo rítmico.

Griffith fala da construção de seus filmes nos termos de uma curva, com uma "ascensão" e um "clímax". Estudos recentes abordam sua obra de maneira semelhante, do ponto de vista da análise estatística. Autores como Yuri Tsivian propuseram um olhar sobre os dados quantitativos dos filmes, identificando o número de planos, a duração dos planos, a distribuição da escala de planos. O estudo de Tsivian sobre Intolerância é fundamental para compreender o papel da estrutura rítmica na montagem em larga escala empreendida por Griffith. Observando a "dinâmica interna" do filme, Tsivian separa as quatro narrativas e identifica a curva temporal de cada uma delas, marcando seus planos e suas respectivas durações. O resultado é significativo. Enquanto a narrativa moderna e a babilônica revelam uma estrutura semelhante - um clímax inicial seguido pela redução da velocidade que leva a outro clímax e deste a um terceiro -, a narrativa de Cristo é claramente dividida em dois momentos de clímax, e a narrativa francesa se caracteriza por um único clímax, ao que se segue uma ascensão mais ou menos contínua. ${ }^{261}$ Podemos observar a disposição das curvas, lado a lado:

${ }^{261}$ Para a referência dos gráficos, ver Yuri Tsivian, "Beyond Comparing: The Internal Dynamics of Intolerance", in Cinemetrics. Disponível em: < $<\mathrm{http}: / /$ www.cinemetrics.lv/tsivian.php $>$. Para um estudo semelhante, voltado para os curtas de Griffith para a Biograph, ver Mike Baxter, "Cutting Patterns in D.W. Griffith's Biographs: An Experimental Statistical Study", in Cinemetrics. Disponível em: $<$ http://www.cinemetrics.lv/dev/baxter_q3_b_opt.pdf $>$. Ambos acessados em dezembro de 2018. 

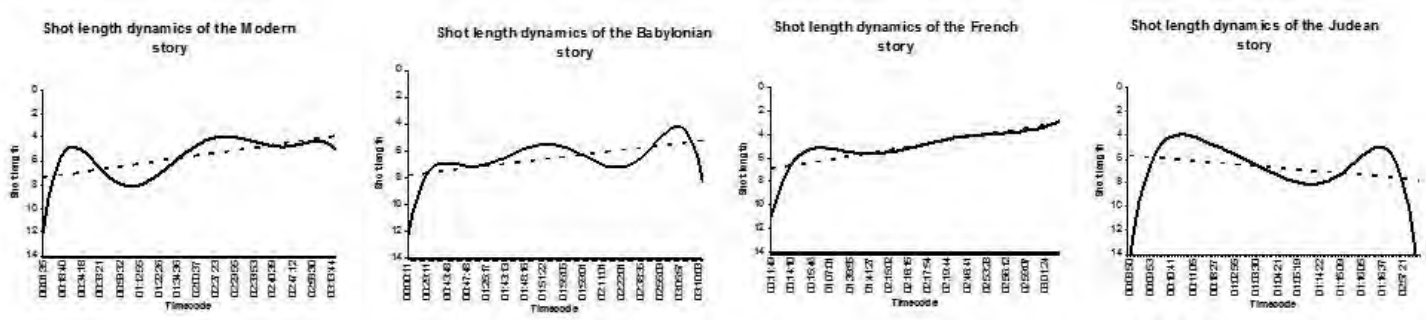

As dinâmicas de duração de planos nas quatro narrativas de Intolerância: (1) a narrativa moderna, (2) a narrativa babilônica, (3) a narrativa francesa, (4) a narrativa de Cristo. As linhas pontilhadas marcam as "linhas de tendência" em cada narrativa .

Considerando as diferenças entre as curvas dinâmicas, Tsivian especula se haveria uma razão específica para os desvios da regra mencionada por Griffith. A narrativa de Cristo, por exemplo - a única com uma linha de tendência decrescente, ou seja, a única que tem uma redução na tendência rítmica -, teria alguma semelhança com a dinâmica das Paixões? Seria uma tendência presente em outros filmes que contam a vida de Cristo, ou seria uma organização específica do material por Griffith? Da mesma forma, haveria uma razão particular para a narrativa francesa ser a única a ser abandonada in media res, sem uma resolução? Não sendo um procedimento usual na obra de Griffith, seria uma inclusão necessária para a manutenção do desenho geral da montagem alternada? Tsivian apresenta outros dados que indicam mais claramente a fonte de alguns efeitos. Partindo da dinâmica de planos do filme em sua totalidade, ele chega a uma versão suavizada da curva da narrativa francesa; e partindo da alternância entre as narrativas, chega a uma curva que se assemelha a uma onda senoidal:
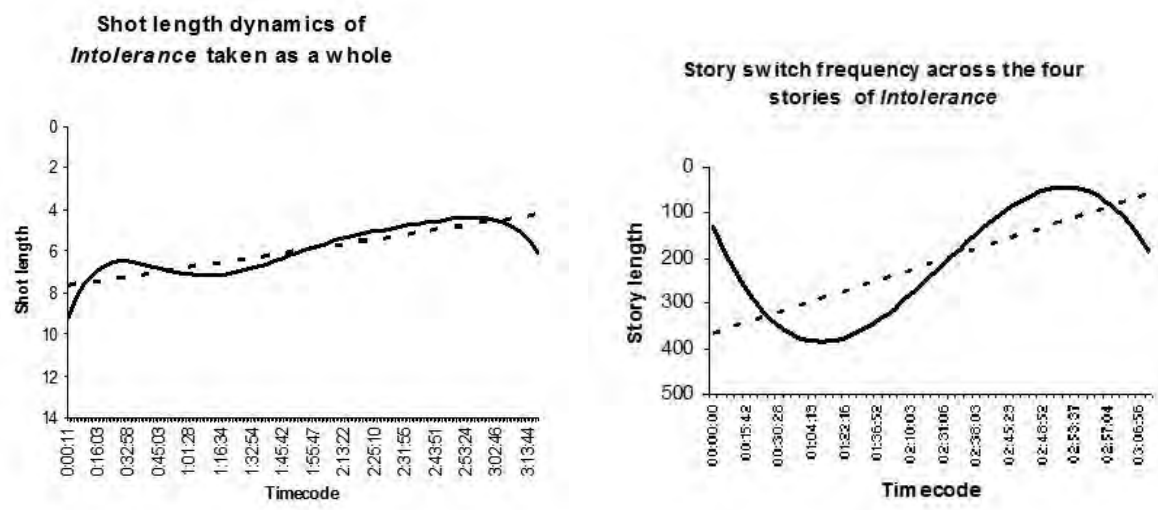

Estes gráficos servem como referências objetivas de aspectos da composição de Intolerância. Através deles, podemos observar como a métrica da montagem opera em Griffith quase sempre em gradações, com aumentos e diminuições nas durações dos 
planos, mais do que por saltos e grandes contrastes. E podemos ver que há uma noção geral de "curva dramática" que não envolve esta ou aquela narrativa, mas todo o conjunto das narrativas, ou seja, a narração que as engloba.

A partir desses exemplos, podemos ver como as características do MRP são modificadas no cinema de Griffith: em vez da autonomia do plano, planos que tornam-se parte de uma cadeia de significados; em vez do não-centramento da imagem, a imagem composta hierarquicamente; em vez da distância média da câmera, a variação das distâncias; em vez do não-fechamento das ações, as ações com um objetivo claro. O paralelismo e a convergência se mostram formas recorrentes de linearização, e a figura do narrador toma a frente como uma instância composicional, o resultado dos procedimentos de montagem e significação. Essas modificações caracterizam o que Burch chamou de "Modo de Representação Institucional", uma tendência que se tornaria nas décadas seguintes a principal referência para o cinema narrativo.

\subsection{O ponto de vista e as coordenadas do suspense}

Se em Griffith já encontramos close-ups que estabelecem uma hierarquia no espaço diegético e uma atenção à curva de tensão narrativa, na obra de um cineasta que teve início a partir dos anos 1920 encontramos os mesmos aspectos do MRI num estágio avançado. Nos filmes de Alfred Hitchcock, a câmera ganha em mobilidade e em liberdade para variar também as angulações: não apenas a liberdade de um narrador que pode cortar de um espaço a outro, mantendo quase sempre os mesmos ângulos nos enquadramentos, mas de um narrador que pode cortar de um lado a outro no mesmo espaço, alterando os ângulos e inclusive mostrando a visão dos personagens que participam de uma situação. Essa liberdade é potencializada pelo acréscimo do som, que retira parcialmente da imagem o fardo da representação e torna possível o uso da voz como ferramenta narrativa. $O$ crescente investimento psicológico na cena e o reconhecimento de que há diferentes vetores agenciando suas relações internas são marcas do MRI, que nesse sentido tem em Hitchcock um de seus grandes representantes. Para compreender seu papel nesse contexto, devemos compreender as bases de algumas de suas técnicas recorrentes.

Burch descreve, de maneira resumida, a passagem do MRP ao MRI, apontando as principais tendências formais que caracterizariam o segundo: 
os períodos de tempo representados eram ligados por relações de sucessão imediata, de simultaneidade, ou por anterioridade e posterioridade mais distantes; os espaços se comunicavam diretamente ou a certas distâncias; e, acima de tudo, o todo constituía um ambiente no qual o espectador poderia entrar como um observador invisível e imaterial [...]. A ubiquidade da câmera e as estratégias que levaram à identificação do espectador com o ponto de vista da câmera (junto com o sistema de orientação pelo qual as relações entre direita e esquerda do corpo do próprio espectador organizavam sua apreensão de todas as relações espaciais de um plano a outro) reforçaram essa impressão de integridade espacial. Essas duas aquisições finalmente convergiram na figura conhecida como plano/contraplano, destinada a se tornar a pedra fundadora de todo um edifício de significação visual. ${ }^{262}$

É importante a menção à "figura do plano/contraplano" como "a pedra fundadora de todo um edifício de significação visual". É uma figura no sentido retórico, ou seja, um procedimento a ser aplicado ou adaptado a certas condições, levando a determinados efeitos ou conjuntos de efeitos. Neste caso, é um procedimento que envolve, justamente, o encadeamento entre planos, e o modo como este encadeamento dá à dimensão virtual da cena um papel central.

A configuração típica do plano/contraplano posiciona a câmera a ângulos oblíquos dos atores, mostrando um após o outro, fazendo com que os planos representem uma seção do espaço comum entre eles. Mais especificamente, quando um plano é apresentado, implica uma determinada área fora de seu enquadramento, uma área que é apresentada por outro ângulo, no outro plano. Isso cria uma linha de ancoragem que preserva a orientação direita-esquerda, nos permitindo calcular ângulos e distâncias, mapeando o espaço virtual. Essa linha - convencionalmente chamada de "linha dos 180 graus" - serve então como um eixo imaginário para a diegese. Podemos observar uma representação gráfica desse modelo, considerando dois atores, um de frente ao outro, filmados por duas câmeras:

${ }^{262}$ Noel Burch, "Film's Institutional Mode of Representation and the Soviet Response" (1979), in In and Out of Synch, op. cit., pp. 118-119. 


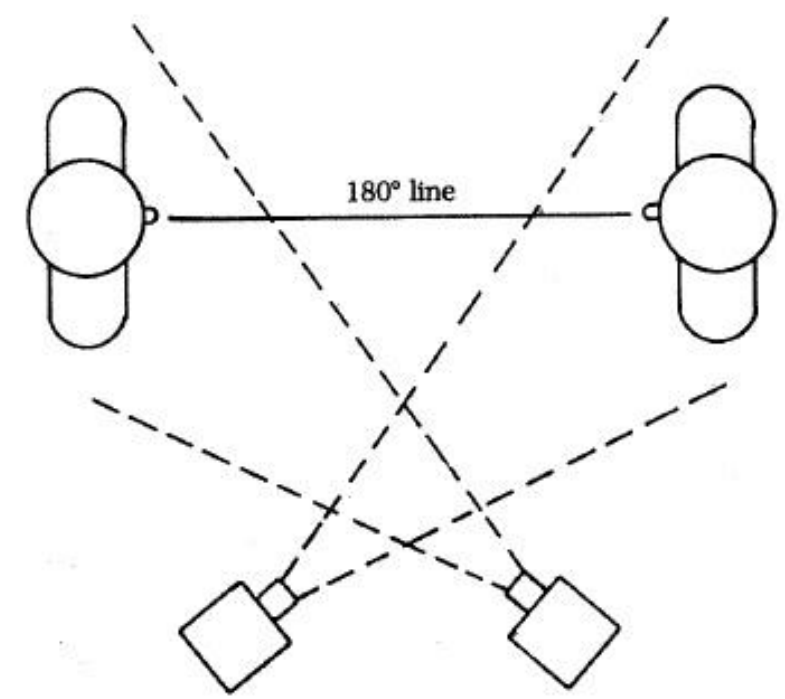

Se uma das câmeras cruza a linha, a orientação espacial é invertida, o que significa que a localização mental dos elementos na diegese é invertida, fazendo com que se deva realizar novas inferências. ${ }^{263}$ A tendência em Hitchcock, como é usual no MRI, é à manutenção desta unidade. Características redundantes, como o mesmo fundo e a mesma iluminação, tornam-se referências espaciais, como a continuidade sonora torna-se uma referência para a temporalidade que abarca o conjunto dos planos.

Em teoria, o plano/contraplano não necessita de atores ou mesmo da disposição oblíqua. Como figura de organização diegética, poderia ser generalizado para qualquer disposição de planos em que partes do espaço são apresentadas em dois segmentos de modo a sugerir o espaço mais amplo que os inclui. ${ }^{264}$ Por essa lógica, a figura do plano/contraplano representa a ideia de que a integridade espaço-temporal de uma cena pode ser seccionada, desde que mantenha algumas coordenadas. Os ângulos, as escalas, os movimentos podem ser variados porque relações de interdependência são criadas entre os planos. Uma vez que se tenha estabelecido as regiões comuns, as direções, e em alguns casos as distâncias, planos que não possuem ligação contígua podem ser alternados, fazendo com que o espectador, ciente da referência geral, seja capaz de localizá-los no espaço total. Assim como a interdependência das formas visuais, quando orientadas pela

${ }^{263}$ Esta representação gráfica encontra-se em David Bordwell, Narration in the Fiction Film, op. cit., p. 110.

${ }^{264}$ Para uma interpretação do plano/contraplano que considera seus efeitos numa base psicanalítica, ver Jean-Pierre Oudart, "La suture", Cahiers du cinéma 211 (abril de 1969). Para duas visões contrastantes do conceito de Oudart, respectivamente negativa e positiva, ver William Rothman, "Against the System of the Suture", Film Quarterly, vol. 28, n. 1 (outono de 1974), e Stephen Heath, "Notes on Suture", Screen, vol. 18, n. 4 (dezembro de 1977). 
gravidade, sugeria um ambiente comum nas animações vistas no segundo capítulo, também os planos criam uma espécie de ambiente comum para os registros através de suas relações espaciais e temporais. Nos dois casos, o ambiente não é preconcebido, mas criado pelas relações entre os elementos. A recriação das coordenadas reais do espaço cênico é possível, mas não necessária.

Nesse sentido, um complemento fundamental à figura do plano/contraplano é o plano de ponto de vista. É um papel de orientação espacial e temporal que o plano de ponto de vista representa no "edifício de significação" mencionado por Burch. A questão é resumida por Edward Branigan da seguinte maneira:

Um olhar atravessa o espaço: seu direcionamento nos orienta a algo próximo, nos permitindo assim construir relações espaciais dentro de uma cena. Um olhar implica ainda relações temporais: um objeto visto é interpretado como existindo num tempo contínuo, ou simultâneo, ao tempo do ato de ver. Além disso, um olhar pode ser ligado diretamente às intenções de um personagem, ou a um ato futuro do personagem, ou a uma reação (quando agem sobre o personagem). ${ }^{265}$

Assim como o movimento dos corpos serve como forma de realizar ligações entre os planos através do sistema de orientações, o olhar serve como uma espécie de ligação abstrata, o traçado de uma linha mental entre os espaços. Se esta característica já se encontra no plano/contraplano usual, o plano de ponto de vista serve como uma depuração do princípio, eliminando muitas vezes a necessidade da referência espacial comum.

Com base nisso, ao menos duas propriedades espaciais e temporais do plano de ponto de vista devem ser mencionadas. Em primeiro lugar, sempre há um ponto de vista físico no plano. Isso cria uma polaridade entre o reforço da físicalidade do ponto de origem do olhar e sua abstração. Quanto mais busca traduzir visualmente o que uma pessoa veria em tal situação (através da altura, do ângulo, do movimento do plano), podese dizer que mais "físico" é o ponto de vista. O caso-limite aqui seria o cinéma vérité, onde a presença do operador de câmera é afirmada inclusive diegeticamente. ${ }^{266}$ Por outro

\footnotetext{
265 Edward Branigan, Narrative Comprehension in Film (Londres: Routledge, 1992), p. 53.

266 Ver Jean-Louis Comolli, "Do realismo como utopia" (1997), Ver e poder, op. cit., p. 218: "Sabemos que o primeiro nível (o grau zero) do realismo cinematográfico não é senão a relação - real, sincrônica, cênica - do corpo filmado com a máquina filmadora: chamo de 'inscrição verdadeira' e 'cena cinematográfica' a especificidade do cinema de colocar junto, em um mesmo espaço-tempo (a cena) um ou vários corpos (atores ou não) e um dispositivo maquínico, câmera, som, luzes, técnicos. A experiência compartilhada entre os corpos filmados e a máquina filmadora é gravada em uma fita de filme. Esse registro testemunha o que se passou aqui e agora, em determinado lugar, em determinado tempo."
} 
lado, quanto mais busca se igualar a um olhar neutralizado, como o olhar médio da própria câmera, desprovido de qualquer articulação, mais "abstrato" seria o ponto de vista. Como no caso das tendências orgânicas e mecânicas das animações, a dualidade envolve por um lado o reforço da "individualidade" das articulações, e por outro a identificação dessas mesmas articulações com a regularidade do dispositivo fílmico. $\mathrm{O}$ importante aqui é que a distinção não pode ser feita a priori. O ponto de vista é físico ou abstrato no contexto de sua articulação, de sua composição, sua ligação com outros planos, ou com um texto, ou com uma banda sonora. ${ }^{267}$

A segunda propriedade diz respeito aos aspectos temporais. Considerando dois planos, sendo o primeiro o plano do sujeito que observa (S) e o segundo o plano do objeto que é observado (O), ambos marcam uma posição no espaço virtual da cena, e a passagem de um plano a outro implica, em geral, uma continuidade ou simultaneidade. $\mathrm{O}$ que destaca muitas vezes as sequências em que esses planos são apresentados é sua simetria, com o plano do sujeito retornando após o plano do objeto - numa estrutura que podemos representar como S-O-S. Assim como a alternância de planos abertos e closeups, a simetria dos planos de ponto de vista gera um efeito característico; sugere um "fechamento" na medida em que retorna ao início do processo, como se ali fosse encerrada uma cadeia de significado. No estabelecimento de um olhar, do alvo deste olhar, e com o retorno ao ponto de origem, as condições espaciais e temporais que os integram são reveladas como estáveis.

Quando recorre ao plano de ponto de vista, Hitchcock o faz muitas vezes para colocar o problema do suspense. O ponto de vista se torna uma grande questão no suspense pois decorre do fato de que não podemos ver tudo de uma só vez e não podemos ver tudo por todos os ângulos. Hitchcock parece supor que, se no cinema devemos receber as informações por determinados ângulos, numa determinada ordem e frequência, então o ângulo, a ordem e a frequência pelos quais as informações são fornecidas e processadas podem se tornar a própria substância da composição.

Uma de suas sequências mais célebres serve como exemplo. Em Intriga internacional (North by Northwest, 1959), Roger Thornhill (Cary Grant) é confundido com um agente secreto e se envolve numa trama com policiais e criminosos. Após marcar um encontro com o que ele acredita ser o homem com quem foi confundido, Thornhill

\footnotetext{
${ }^{267}$ A extensa análise de Branigan do conceito de plano de ponto de vista serve como base para essas conclusões. Ver o quinto capítulo de Edward Branigan, Point of View in the Cinema (Nova York: Mouton, 1984), pp. 103-121.
} 
espera no local combinado, um ponto de ônibus numa estrada deserta. O suspense da sequência é devido à desconfiança de que algo deve ter sido tramado para que ele seja capturado ou assassinado. Numa série de planos, Hitchcock alterna Thornhill e seus pontos de vista. A cada vez ele olha para um lado, numa tentativa de se localizar, reconhecendo o ambiente. Posicionado próximo ao centro de um cruzamento, o protagonista cria uma espécie de bússola pessoal, associando a cada ponto cardeal uma seção do espaço, filmada sempre no mesmo enquadramento:

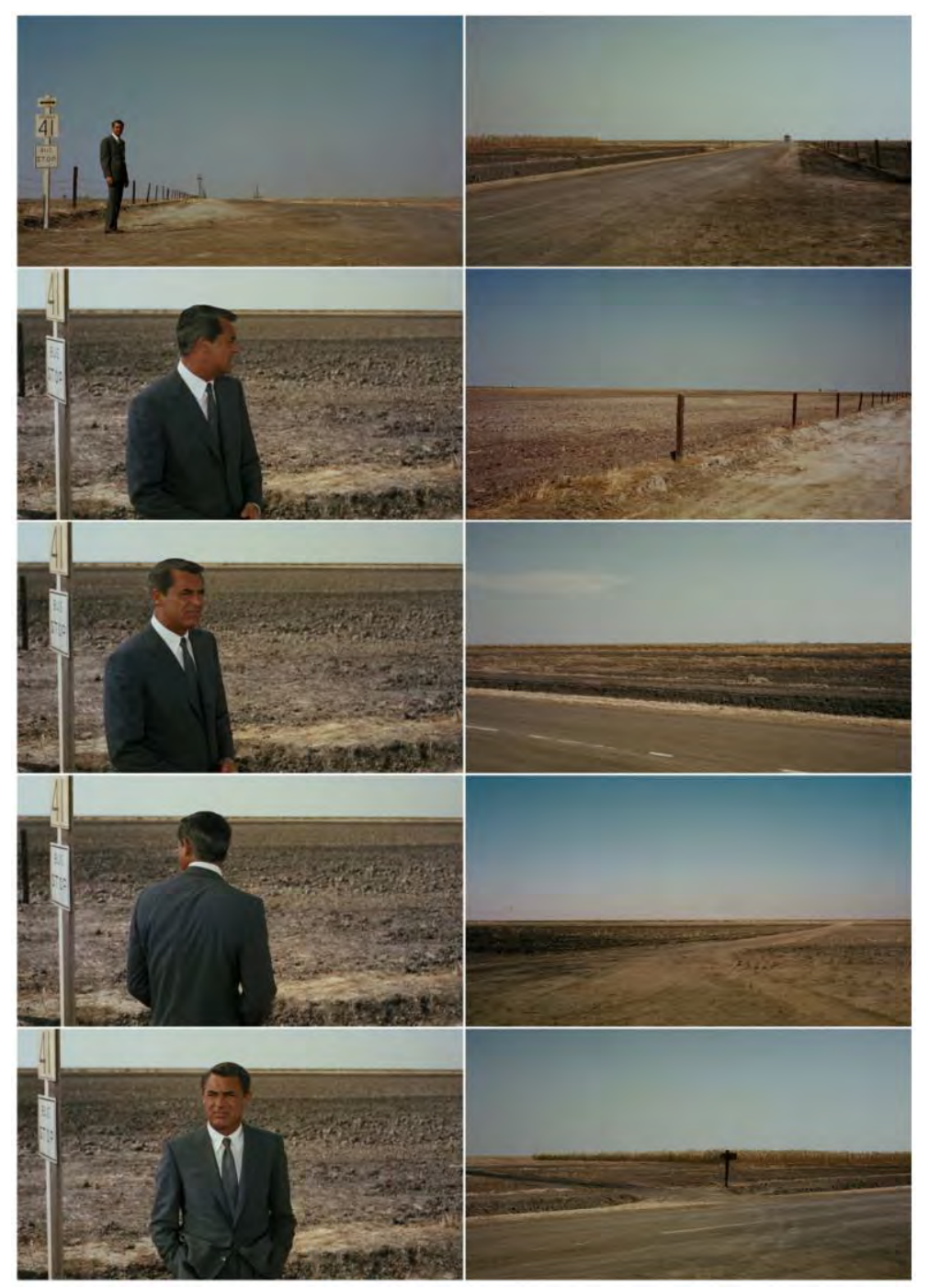

Em todas as direções, Thornhill encontra um horizonte aberto, com a presença humana sugerida apenas pelo ônibus que o deixou ali e que agora desaparece na estrada, e por um avião agrícola visto também à distância. Após cerca de um minuto de silêncio e imobilidade, um carro branco se aproxima na estrada principal - mas logo passa por Thornhill. Segundos depois, surge outro carro, vindo do outro lado, agora uma limusine 
preta; conforme se aproxima, Thornhill tira as mãos do bolso, como se preparado para fugir - mas logo o carro também passa por ele.

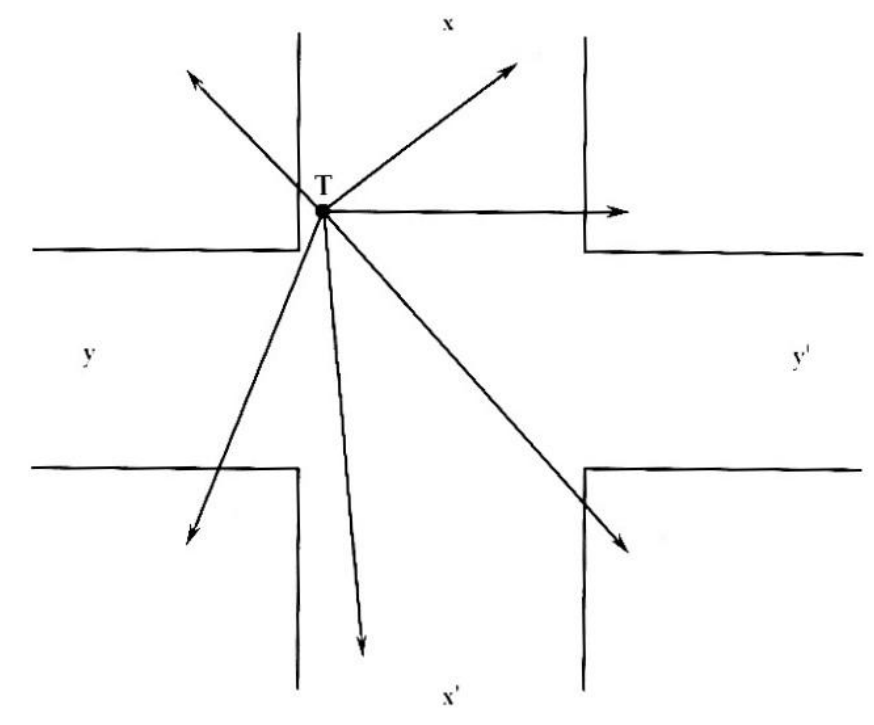

O mapa da sequência de Intriga internacional por Raymond Bellour, onde $\mathrm{T}$ é o protagonista, Thornhill, os eixos $x-x^{\prime}$ e $y-y$ ' são as estradas, e as setas representam as direções dos planos de ponto de vista. As referências espaciais são dadas em etapas discretas, através do ponto de vista do personagem. ${ }^{268}$

Com isso, são estabelecidas as coordenadas da cena. Sabemos que o espaço é aberto em todas as direções; que a aparição de um objeto no ponto central onde Thornhill se encontra só pode ocorrer gradualmente; e que não há qualquer objeto próximo que lhe sugira uma ameaça. Sabemos isso através do protagonista, tendo visto por seus olhos e medido as durações através de suas expectativas. Como Thornhill, nos acostumamos com essas condições durante mais de quatro minutos, nos quais todas as sugestões de conflito se revelaram incorretas. Em outras palavras, as expectativas foram todas, sem exceção, frustradas. É sobre esta base que Hitchcock constrói o restante da sequência. O ataque, temido pelo personagem, acontece, afinal, fora do plano horizontal: Thornhill percebe que a aproximação do avião agrícola não é casual, e logo deve correr para fugir de seus tiros e investidas verticais. As coordenadas recebem com isso outro valor. O completo isolamento, o tempo que as distâncias levam para serem atravessadas, tudo é agora motivo de tensão, pois o protagonista deve correr e não possui qualquer lugar para se esconder.

${ }^{268}$ Raymond Bellour, "Symbolic Blockage", The Analysis of Film, op. cit., p. 108. Foram retirados do mapa os números que Bellour utiliza para indicar a ordem em que as direções são apresentadas nos planos. Os fotogramas da sequência incluídos no corpo do texto envolvem apenas cinco das seis direções marcadas no mapa; a sexta ocorre num trecho posterior. 
A insistência de Hitchcock em tornar claras as referências espaciais e temporais na primeira metade da sequência revela-se uma ferramenta crucial no desenvolvimento do suspense. Identificados com o olhar do personagem, temos acesso ao que parece ser uma descrição clara e adequada do cenário. Essa clareza é atravessada pelo conhecimento de que algo deve acontecer, e pela espera desse acontecimento por longos minutos. A projeção do acontecimento durante esses minutos decorre justamente das inferências de como ele, por esses ângulos e durações, poderia ocorrer. Conforme a nova referência é acrescentada e a tensão é liberada - conforme a tensão da espera torna-se a tensão da perseguição -, o suspense dá lugar à ação.

Essa característica é mencionada na definição de suspense por Hitchcock, em oposição à surpresa:

\begin{abstract}
Estamos agora tendo uma conversa inocente. Mas vamos considerar que há uma bomba sob a mesa. Nada acontece, e então, de repente, BUM! Há uma explosão. O público está surpreso, mas antes dessa surpresa viu uma cena absolutamente banal, sem nenhum significado especial. Agora, vamos considerar uma situação de suspense. A bomba está sob a mesa e o público sabe disso, provavelmente porque viram o anarquista colocá-la ali. $\mathrm{O}$ público sabe que a bomba vai explodir à uma da tarde, e há um relógio no cenário. $\mathrm{O}$ público vê que faltam quinze minutos para uma hora. Nessas condições, a mesma conversa inócua se torna fascinante porque o público está participando na cena. O público se contorce, querendo avisar os personagens: "Vocês não deveriam falar de coisas tão banais. Há uma bomba sob a mesa e ela vai explodir!"

No primeiro caso, damos ao público 15 segundos de surpresa no momento da explosão. No segundo, damos 15 minutos de suspense. A conclusão é que, sempre que possível, o público deve ter as informações. ${ }^{269}$
\end{abstract}

O comentário de Hitchcock põe a ênfase na absorção psicológica do espectador pela ordem da cena. Uma vez apresentados os elementos, pode ter início o lento desgaste de suas relações; mas é apenas com essa apresentação que o período de tempo passa a ter valor como suspense. A comparação entre o mesmo evento dentro do contexto de suspense e fora dele é fundamental por revelar o quanto, para Hitchcock, o suspense é "uma anamorfose do tempo". ${ }^{270}$ A linearização dos encadeamentos aqui leva a uma espécie de atração magnética que distorce a percepção duracional dos eventos.

Uma comparação com as preferências narrativas de Griffith nos permite identificar com mais precisão os traços do cinema de Hitchcock, e com isso as possibilidades abertas por suas escolhas. Griffith tende a dar a cada espaço um mesmo enquadramento, na maioria das vezes evocando a ideia do cubo cênico, de um ângulo

\footnotetext{
269 Alfred Hitchcock, em François Truffaut, Hitchcock (Nova York: Touchstone, 1985), p. 73.

${ }^{270}$ Pascal Bonitzer, "Le suspense hitchcockien", in Le champ aveugle, op. cit., p. 41.
} 
frontal semelhante à vista do palco italiano, como se houvesse um olhar padronizado ao qual pudesse recorrer para filmar qualquer ambiente. A postura é reforçada quando se retorna aos mesmos espaços sob os mesmos enquadramentos. Hitchcock, por sua vez, filma os espaços por diferentes ângulos, torna inclusive a multiplicidade de ângulos um dos temas de suas sequências. Da mesma forma, Griffith volta a câmera para ações específicas; seus espaços estão sempre marcados pela presença humana, e mais do que isso, pelos agentes das ações, que ele conduz tendo em vista o desenvolvimento narrativo em seu sentido mais físico e "exteriorizado". Em Hitchcock, encontramos os mesmos fatores, mas também uma profusão de espaços vazios, de objetos e ações que, se vistos isoladamente, parecem banais; o que torna esses elementos significativos é, justamente, o fato de serem o alvo de um olhar. A narrativa hitchcockiana ocorre muitas vezes "internamente".

Um complemento pode ser feito com outra sequência, que mantém igualmente a centralidade de um personagem e constrói a orientação espacial através de seu ponto de vista. Em Psicose (Psycho, 1960), o detetive Arbogast (Martim Balsam) chega ao Bates Motel em busca de Marion Crane (Janet Leigh), assassinada no primeiro terço do filme. O suspense é devido ao fato de que, quando Arbogast vai até a casa atrás do motel, o espectador sabe que lá mora a mãe de Norman Bates, a provável assassina de Marion. Hitchcock mostra, como em Intriga internacional, o personagem observando o local à sua volta, associando cada região do espaço a um plano de ponto de vista. Durante cerca de trinta segundos, Arbogast permanece na entrada da casa, voltando seu olhar de um lado a outro. Com ele, o espectador tem referências de estabilidade: nenhuma presença humana, nenhum movimento, nenhum ruído. Como Thornhill no exemplo anterior, as inferências quanto ao perigo da situação coexistem com a desconfiança de que algo deve acontecer. Podemos observar os primeiros planos, atentando para seu caráter esquemático, numa marcação nítida dos ângulos da casa alternados com o mesmo plano do personagem, que serve como centro psicológico da cena: 


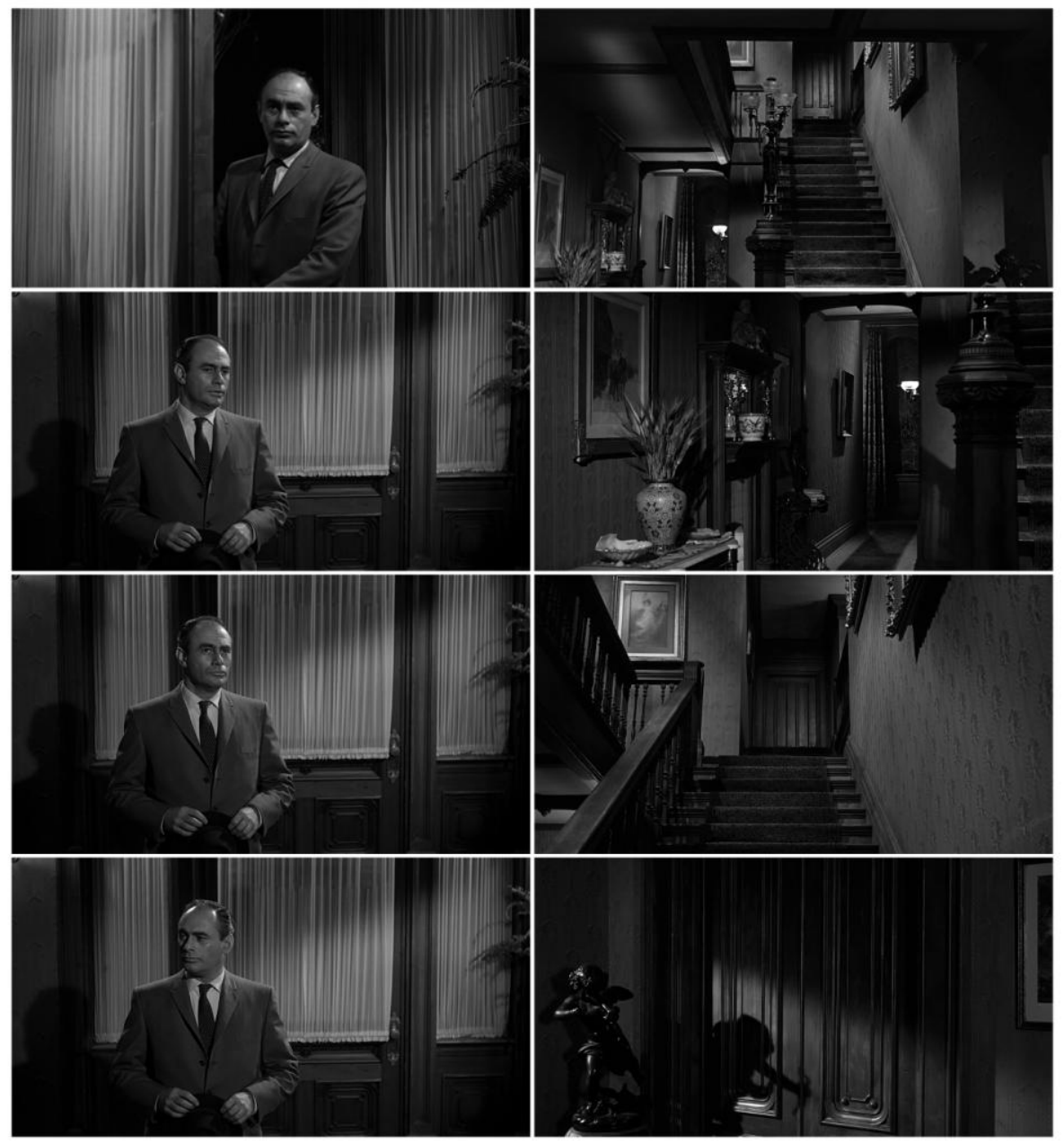

À medida que Arbogast sobe as escadas, a desconfiança é reforçada. Hitchcock corta para um plano próximo do chão, com a lenta abertura de uma porta projetando um feixe de luz numa diagonal. Quando retornamos ao plano de Arbogast, o sentido de sua subida é modificado: o aumento da tensão na música reflete agora o suspense criado pelo fato de que ele se aproxima da porta que se abre. O próximo corte, em sincronia com a radical mudança na música - das notas longas em tensão crescente para os golpes breves, agressivos e dissonantes -, representa o ataque num ângulo zenital. Aqui, a relação entre os planos do sujeito e os planos que o sucedem é subvertida. Se no início da sequência alternava-se entre o personagem que observava e os espaços que ele observava, no trecho final o personagem é alternado justamente com aquilo que ele não era capaz de observar, e que nos levará a ver seu assassinato: 


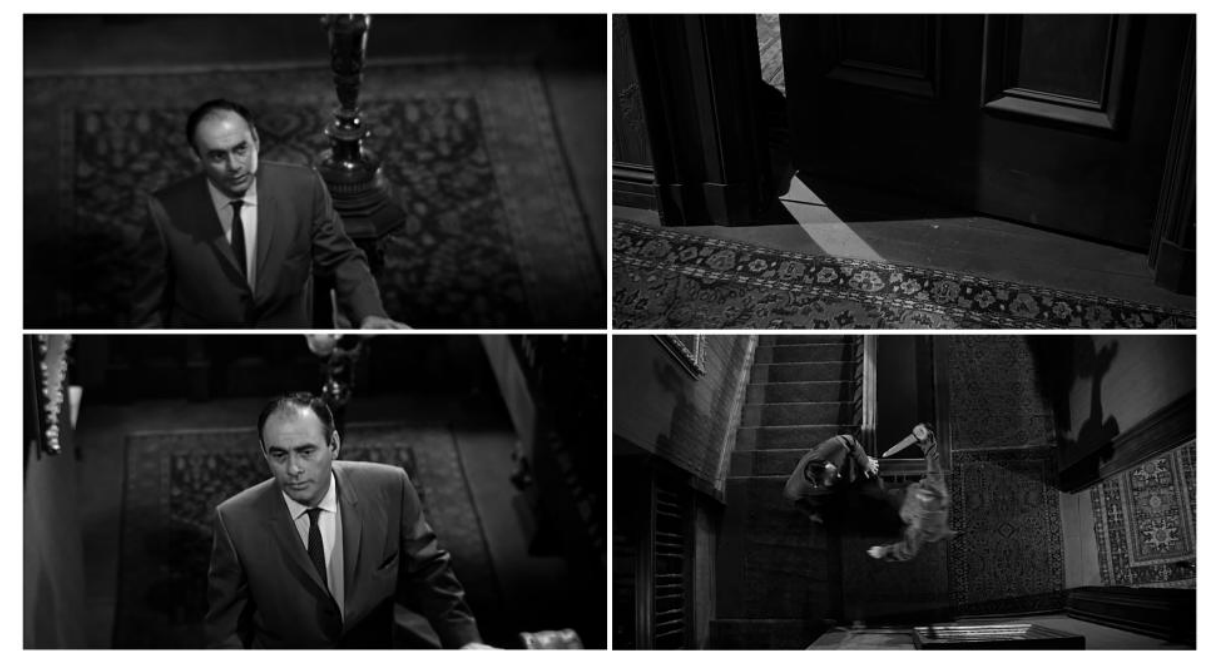

Considerando a arquitetura da casa, principalmente os espaços que nos são dados a ver na sequência, percebemos como o ponto crítico se encontra justamente no limite da visão do personagem. Podemos observar a planta baixa da casa, em que as regiões claras são aquelas diretamente visíveis ao detetive, reveladas por seu ponto de vista, e as regiões cinzas são aquelas que o personagem é capaz de inferir através da arquitetura externa e interna da casa, mas que não é capaz de observar diretamente. ${ }^{271} \mathrm{O}$ círculo representa o local de onde parte o assassino, como o final de toda a trajetória visual da sequência:

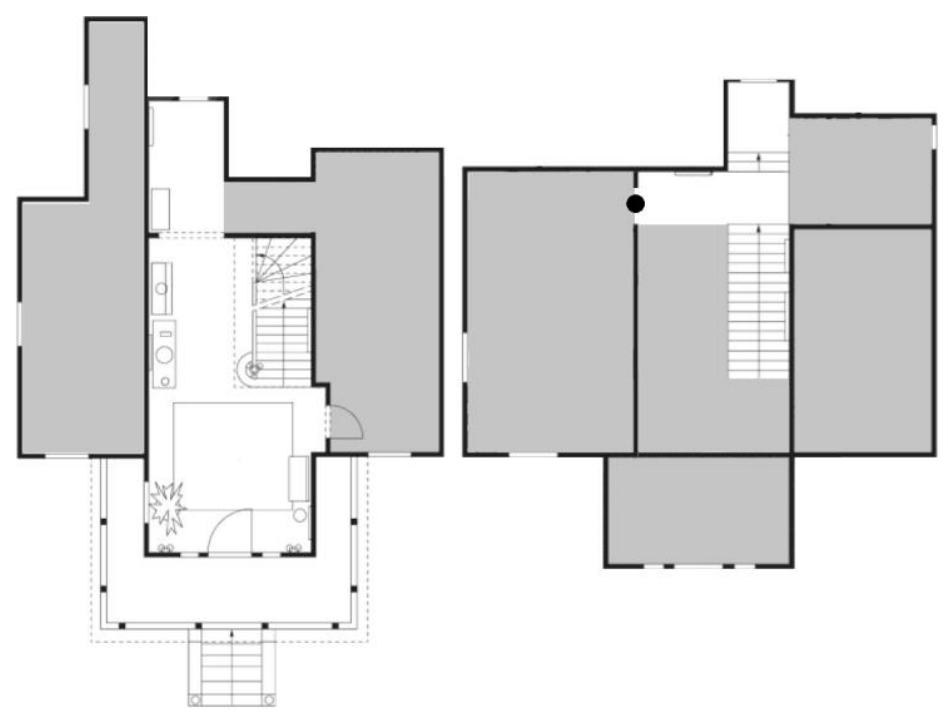

${ }^{271}$ As imagens são baseadas nos desenhos de David Claus em Steven Jacobs, The Wrong House: The Architecture of Alfred Hitchcock (Rotterdam: 010 Publishers, 2017), p. 120. O desenho foi adaptado para se adequar à sequência da morte do detetive. Não considera, portanto, informações dadas por sequências posteriores, e que permitem uma visualização mais completa da casa. 
A diferença de duração nos dois exemplos é significativa. Em contraste com os mais de nove minutos da sequência de Intriga internacional, o trecho de Psicose tem pouco mais de um minuto. Isso decorre em parte do tipo de espaço envolvido na construção - aberto ou fechado -, algo que se desdobra nos tipos de ações e nas inferências que podemos fazer através delas. A abertura do espaço faz com que Thornhill possa ver o avião se aproximando, ainda que não possa fazer nada para impedir o ataque. A restrição espacial, por sua vez, faz com que Arbogast seja incapaz de ver alguns ângulos da casa, e é justamente de um desses lugares que vem o ataque. A manipulação das inferências espaciais e temporais aqui leva a uma estrutura compacta, à breve apresentação seguida da nova informação e da virada conclusiva. Mas nos dois casos, Hitchcock deve utilizar as características específicas do espaço e delas derivar a estrutura da sequência, pois é a partir delas que tanto o personagem como o espectador fazem as inferências quanto às possibilidades da situação. Esse jogo com as expectativas remete à descrição feita sobre as gags de Keaton, e o caráter físico da composição, sobretudo o controle das forças envolvidas e do momento exato em que serão reveladas, é o modelo do "método hitchcockiano" como descrito por Bazin:

\begin{abstract}
Não se trata de um "clima" do qual todos os perigos podem sair como a tempestade, mas um desequilíbrio como o seria o de uma pesada massa de aço que começa a deslizar sobre um declive excessivamente liso e cuja aceleração futura se poderia facilmente calcular. A encenação seria então a arte de não mostrar a realidade senão desses momentos em que a perpendicular baixada do centro de gravidade dramática vai sair do polígono de sustentação, desdenhando tanto o abalo inicial quanto o fragor final da queda. ${ }^{272}$
\end{abstract}

Como nas gags de Keaton, a inteligibilidade do espaço é um critério tanto para a orientação no mapa virtual da cena quanto para a construção do efeito de suspense. Tanto a sequência de Intriga internacional como a de Psicose baseiam-se inteiramente na construção de um espaço, e na exploração desse espaço no contexto do suspense. A criação de mapas mentais é necessária não apenas aos personagens, dadas suas motivações no interior da narrativa, mas também ao espectador que, alinhado aos personagens, toma conhecimento da realidade cênica através de seus olhares. Esse alinhamento, que não encontramos da mesma forma em Griffith, é parte constituinte do suspense hitchcockiano. Acreditamos ter as informações necessárias para compreender os

272 André Bazin, "Hitchcock contra Hitchcock" (1954), in O cinema da crueldade, trad. Antônio de Pádua Danesi (São Paulo: Martins Fontes, 1989), pp. 145-146. Bazin escreveu anos antes do lançamento de Intriga internacional e Psicose, mas seus comentários permanecem válidos para a maior parte da filmografia de Hitchcock. 
eventos que podem ocorrer naqueles espaços. ${ }^{273}$ Nossas expectativas são informadas por essa crença. Elas são, finalmente, derrubadas com a revelação de que estávamos limitados pelo conhecimento dos personagens.

Vimos como, nas gags de Keaton, essa revelação das condições físicas poderia ocorrer antes para o espectador e depois para o protagonista, ou simultaneamente para os dois. Isso nos leva a uma distinção semelhante, também comentada por Hitchcock, entre o suspense objetivo e o suspense subjetivo. ${ }^{274}$

O suspense objetivo seria aquele no qual o espectador é colocado numa posição de conhecimento (em relação às informações pertinentes ao desenrolar da sequência) superior à do personagem. Os elementos são então orquestrados num "cálculo de probabilidades", o confronto da probabilidade das ações indesejáveis e das ações desejáveis, ou de ações negativas e positivas. É este o modelo dominante na obra de Griffith, que atribui ao "sistema do narrador", formado pela conjunção entre câmera e montagem, um papel de onisciência diegética.

Na obra de Hitchcock, essa tendência é representada mais claramente por Festim diabólico (Rope, 1948). O desafio auto-imposto por Hitchcock neste filme é o de construir uma narrativa com o menor número possível de planos. O filme conta a história de dois jovens que matam um colega para demonstrar a própria superioridade intelectual - a capacidade de cometer um crime e não ser capturado. O cadáver é escondido num baú, e os protagonistas recebem no apartamento um grupo de conhecidos numa festa, na qual o colega "ausente" é frequentemente o tema das conversas. A câmera se move de um lado a outro do cenário, acompanha os personagens, observa a ação por distâncias

${ }^{273}$ Nas duas sequências comentadas, a ameaça vem de uma região superior do espaço. Dennis Zirnite mostra como nos filmes de Hitchcock os momentos emblemáticos muitas vezes envolvem "uma tensão dialética no espaço vertical". Seja pela altura dos locais, seja pela angulação da câmera, a força está nas associações espaciais determinadas pelo eixo vertical no contexto da sequência. Filmes como Um corpo que cai e Os pássaros estão repletos de planos que exemplificam essa leitura, tendo no eixo vertical um de seus temas centrais - num deles, pela acrofobia do protagonista; no outro, pelos ataques de pássaros. Ver Dennis Zirnite, "Hitchcock on the Level: The Heights of Spatial Tension", Film Criticism, vol. 10, n. 3 (primavera de 1986), pp. 3-4. Para uma descrição mais extensa desses motivos na filmografia de Hitchcock, ver Michael Walker, Hitchcock's Motifs (Amsterdam: Amsterdam University Press, 2005), principalmente as seções "Heights and Falling" (pp. 238-247) e "Staircases" (pp. 350-372). Um comentário breve destes e de outros motivos já se encontra em Philippe Demonsablon, "Lexique mythologique pour l'oeuvre de Hitchcock", Cahiers du cinéma 62 (agosto/setembro de 1956), pp. 1829.

${ }^{274}$ Ver Richard Allen, "Hitchcock and Narrative Suspense: Theory and Practice", in Camera Obscura, Camera Lucida: Essays in Honor of Annette Michelson, eds. Richard Allen e Malcolm Turvey (Amsterdam: Amsterdam University Press, 2003), pp. 174-175. Ver também Noel Carroll, "Toward a Theory of Film Suspense", in Theorizing the Moving Image, op. cit., pp. 94-117. A definição de Carroll é considerada por Allen, que busca corrigir algumas de suas insuficiências. Em termos gerais, o argumento de Carroll é válido apenas para o "suspense objetivo", que ele considera ser o tipo mais frequente. 
variadas, enquadra e reenquadra os gestos e olhares. $\mathrm{O}$ filme é composto por dez planos além do plano dos créditos iniciais; entre os dez cortes, cinco são "camuflados" pela configuração cênica, e cinco são tornados explícitos, mas dispostos em momentos fundamentais da trama. ${ }^{275}$

Em Festim diabólico, sabemos que o crime foi cometido; sabemos quando, onde, como e por quem foi cometido. Tudo nos é revelado já no primeiro corte do filme, de um plano aberto mostrando a janela fechada, vista de fora, para um plano dentro do apartamento onde ocorre a ação - um plano cuja ligação é feita pelo grito da vítima. $\mathrm{O}$ que se segue é o acréscimo de outros personagens, que não possuem as mesmas informações, mas que estão em condições de as descobrir. As condições nos foram dadas; sabemos que um dos assassinos teme ser pego, que ele talvez prefira se entregar, e que o outro se gaba de ter cometido o crime, e que talvez fale demais. Além disso, há um objeto privilegiado, o baú no qual o cadáver foi escondido. A câmera se aproxima e se afasta do baú, se movimenta à sua volta; num momento-chave, permanece estática, com o baú na borda do enquadramento, como se à espera dos personagens que foram a outro cômodo quando retornam, o enquadramento revela sua importância: a empregada, prestes a abrir o baú, é interrompida por um dos protagonistas. O suspense decorre então do fato de que temos referências no interior da diegese para medir o valor e a probabilidade do que deve ocorrer. Não sabemos exatamente o quê e como vai acontecer, mas conforme acontecem os eventos, temos uma orientação que nos permite relacionar cada um deles ao contexto mais amplo. O tipo objetivo do suspense depende portanto dessas coordenadas que nos permitem fazer as inferências necessárias, e sua dinâmica é uma consequência do adiamento, da aproximação e mesmo da sedução presentes na articulação dessas referências. ${ }^{276} \mathrm{O}$ desejo constante pela realização dos eventos, sejam eles positivos ou não aos protagonistas, é instigado frequentemente pela encenação.

De maneira característica, a câmera em Festim diabólico não recorre estritamente ao plano de ponto de vista. $\mathrm{O}$ fato de que o filme procura esconder seus cortes e igualar a câmera a uma espécie de observador invisível do espaço cênico faz com que o padrão S-

275 Para uma contextualização do experimento de Hitchcock na "teatralização da duração", um motivo recorrente no cinema americano dos anos 1940, ver David Bordwell, Reinventing Hollywood: How 1940s Filmmakers Changed Movie Storytelling (Chicago: University of Chicago Press, 2017), pp. 170171.

${ }^{276}$ Bonitzer, "Le suspense hitchcockien", op. cit., pp. 50-51: "Esse alongamento subjetivo, essa viscosidade do tempo, possui uma relação com o erotismo. É o tempo erotizado na indecidibilidade prolongada, fundamentalmente angustiante, de um evento. O suspense é o prolongamento erótico do trajeto da moeda lançada no ar, antes que ela caia de um lado (cara: sim) ou de outro (coroa: não)." 
O-S não seja possível. Por essa mesma razão, é sintomático que Hitchcock recorra, ainda assim, à estrutura básica do ponto de vista. Como apenas cinco cortes no filme são tornados visíveis, quando estes ocorrem, criam um efeito significativo na encenação, quebrando a integridade do registro. A quebra é enfatizada por Hitchcock. Em pelo menos dois cortes ele recorre ao olhar de um personagem para realizar a ligação entre os dois momentos. No segundo corte do filme, por exemplo, a conversa dos protagonistas com Kenneth (Douglas Dick) sobre a chegada de sua ex-namorada na festa é interrompida pela campainha que sugere a introdução da personagem. De um close-up lateral de Kenneth, passa-se a um plano aberto que parece perpendicular ao enquadramento precedente, com os movimentos dos protagonistas servindo como verdadeiras cortinas se abrindo para revelar a personagem; e no último corte do filme, um close-up da mão de Brandon (John Dall) em seu bolso, segurando um revólver, leva ao close-up do rosto de Rupert (James Stewart), olhando para baixo, na direção em que estaria o objeto do plano anterior:

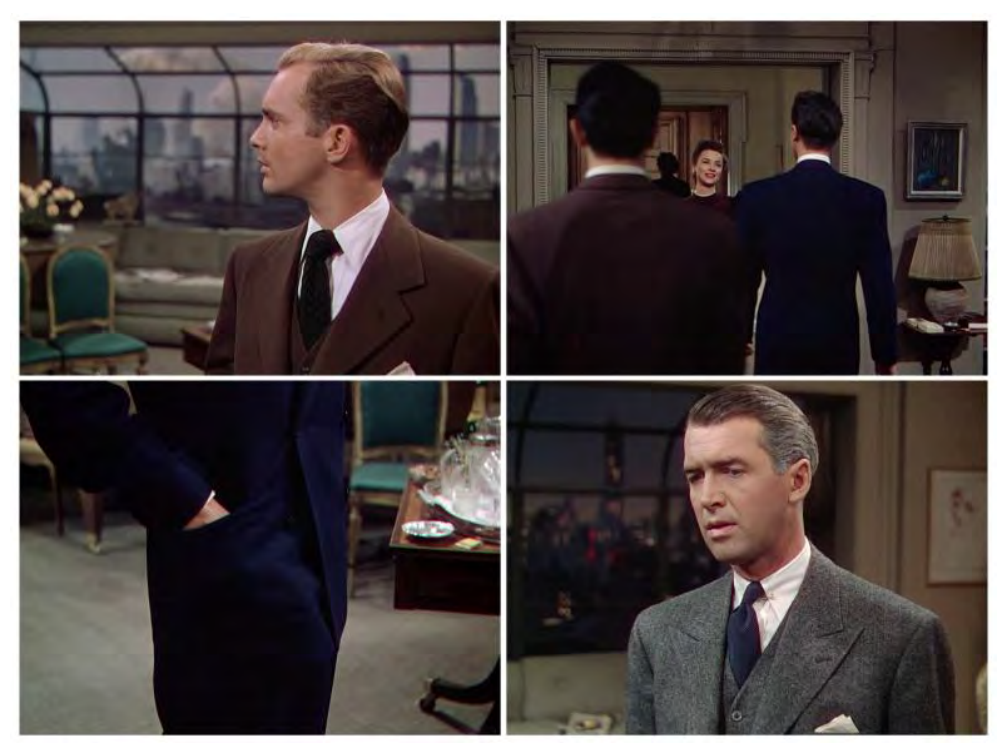

Nos dois casos, não é o suspense propriamente dito que se articula no encadeamento entre os planos, mas uma tensão reveladora da passagem entre imagens que é feita pela visão de um personagem - tanto com a estrutura S-O do primeiro como com a estrutura O-S do segundo. Mesmo neste, que é o caso extremo de "suspense objetivo" na obra de Hitchcock, há um componente "subjetivo", representado pelo jogo com os olhares dos personagens e o olhar da própria câmera. 
Se no suspense objetivo o espectador é informado das condições num grau mais elevado que os personagens, no suspense subjetivo essa relação é nivelada. A situação está parcialmente encoberta, por assim dizer, tanto para os personagens como para o espectador. A progressão é idêntica ao descobrimento dessas condições; ela procede num acúmulo gradual de informações. Normalmente, sabemos o mesmo que um dos personagens; normalmente, Hitchcock associa o ponto de vista narrativo ao protagonista.

O caso representativo é o de Janela indiscreta (Rear Window, 1954). Jeff (James Stewart) está imobilizado com uma perna engessada, e permanecemos com ele num espaço restrito: seu apartamento, com vista a uma espécie de pátio comum a outros prédios. Observando os vizinhos pela janela, seu olhar é projetado no cenário, permitindo a visão parcial de vários apartamentos. Entre as múltiplas janelas abertas ao seu olhar, Jeff logo se concentra num apartamento onde uma mulher parece ter desaparecido após brigar com o marido. ${ }^{277}$

Nos filmes de Keaton, vimos como as inferências quanto às condições físicas dos planos - sobretudo relações de distância, peso, velocidade, equilíbrio - eram partes constituintes das gags. Nos filmes de Griffith, vimos como as inferências quanto às relações espaciais e temporais entre os planos - suas posições na escala de identidade e alteridade - também faziam parte de uma organização física da diegese. Em Janela indiscreta, temos um exemplo de como a relação entre os pontos de vista e a unidade da diegese pode tomar um caminho mais abstrato, onde a apreensão visual e sua organização mental em uma sequência lógica torna-se o próprio tema da narrativa. Hitchcock refere-se em várias de suas entrevistas ao experimento de Kuleshov sobre o "plano de reação", e menciona Janela indiscreta como sua exploração mais aprofundada desse efeito. A redução da mobilidade do personagem, refletida na redução dos ângulos possíveis pelos quais a câmera pode filmar as ações, gera um cenário repleto de incompletudes. Neste

277 John Belton lembra que o cenário do filme é inteiramente construído para satisfazer as demandas narrativas. Ver John Belton, "The Space of Rear Window", MLN, vol. 13, n. 5 (dezembro de 1988), p. 1126: "Miss Torso, por exemplo, recebe um espaço amplo porque ela é uma dançarina e seus movimentos exigem um espaço como esse; e o formato de suas janelas nos permite ver suas danças. O espaço de seu apartamento é contínuo, diferente do apartamento dos Thorwalds. No caso dos Thorwalds, ainda que o apartamento seja idêntico ao do casal com o cachorro (que mora em cima) e da Miss Lonelyhearts (que mora embaixo), a ênfase é na distância entre o casal; eles ficam em quartos separados - ele na sala, ela no quarto; mesmo a cor das paredes nesses lugares é diferente, o que não ocorre com as paredes de nenhum outro apartamento no filme. O casal com o cachorro é frequentemente visto junto na saída de incêndio, por exemplo, enquanto a Miss Lonelyhearts, ainda que sozinha, movese várias vezes de um cômodo a outro, unificando em alguma medida seu espaço pelo deslocamento contínuo através dele. O cenário e a encenação de Hitchcock fazem com que as janelas dos Thorwalds tornem-se quadros fixos que dramatizam seu isolamento um do outro e sua discordância como casal." 
cenário, a curiosidade do protagonista o transforma numa verdadeira máquina de inferências: ele é acometido pela "síndrome de Kuleshov".

Jeff torna-se, já no primeiro terço do filme, uma espécie de detetive. Observando as janelas com binóculos e câmeras fotográficas, ele busca os eventos no plano onde seu olhar é projetado como se tentasse identificar uma figura através de algumas tangentes. É a um trabalho dedutivo que se dedica o personagem. Em alguns casos, a dedução é verbalizada a outro personagem, mas na maioria das vezes é inscrita na própria estrutura da montagem. Alternando incessantemente os eventos do prédio em frente com os eventos no rosto de Jeff, o que o filme desenvolve é o paralelismo entre a narrativa que se desvela nas janelas e a narrativa que se constrói na mente do protagonista. $\mathrm{O}$ terceiro vértice do triângulo é a narrativa construída na mente do espectador a partir dos dois lados: em ambos, temos apenas indícios, e é através deles que o filme nos conduz pela investigação, pelos recortes das janelas e pelas expressões faciais de James Stewart.

$O$ avanço da narrativa aqui torna-se uma erosão temática, a submissão da sequência de imagens à interdependência dos olhares, como se, mais cedo ou mais tarde, algum significado devesse emergir dessas combinações. É esse o sentido do comentário de Bonitzer, de que o suspense reside "na insistência da encenação sobre a contaminação progressiva, a perversão progressiva ou súbita da paisagem inicial". ${ }^{278}$ Visto isoladamente, o plano de um homem de meia-idade dormindo na sala de seu apartamento não é particularmente sugestivo de uma trama violenta; visto no contexto do filme, com a janela do quarto fechada após uma noite de repetidas viagens durante a chuva, e principalmente, após um serrote e uma faca serem embrulhados em jornais, o mesmo plano ganha outro sentido:

\footnotetext{
${ }^{278}$ Bonitzer, "Le suspense hitchcockien", op. cit., pp. 41-42. Ver também p. 51: “A operação do suspense resulta de fato da montagem, mas aqui a montagem utilizada é o inverso da aceleração griffithiana de ações paralelas, é uma montagem de ações convergentes num espaço homogêneo, que pressupõe a dilatação temporal e que é sustentada pelo olhar, ele mesmo evocado por um terceiro elemento, o objeto perverso ou a mancha." Bonitzer usa o termo "mancha" para se referir aos elementos perturbadores da normalidade no cinema de Hitchcock, nos lembrando que é em torno deles que ocorrem a maior parte dos "efeitos de suspense".
} 


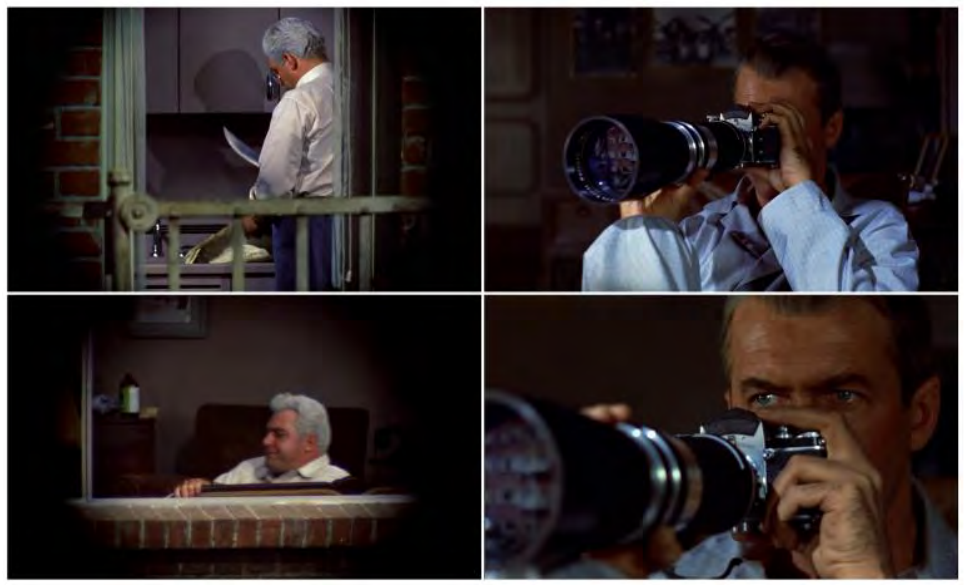

Mantendo essa abordagem, o filme apresenta todo um repertório de permutações entre os planos do sujeito que observa e os planos dos objetos observados. A estrutura SO-S permanece a mais frequente, como quando vemos Jeff, depois o alvo de seu olhar, e então retornamos a Jeff, identificando em sua expressão o valor atribuído ao olhar. Vemos também Jeff observar um objeto e depois a câmera seguir num movimento contínuo, levando seu olhar até outro objeto, numa estrutura S-O-O. Este retorno ao plano do sujeito é inclusive adiado por uma elipse em pelo menos uma ocasião, quando, na noite chuvosa em que Thorwald sai com a mala, Jeff observa o relógio, e um fade separa este plano do seguinte, indicando a passagem de tempo:

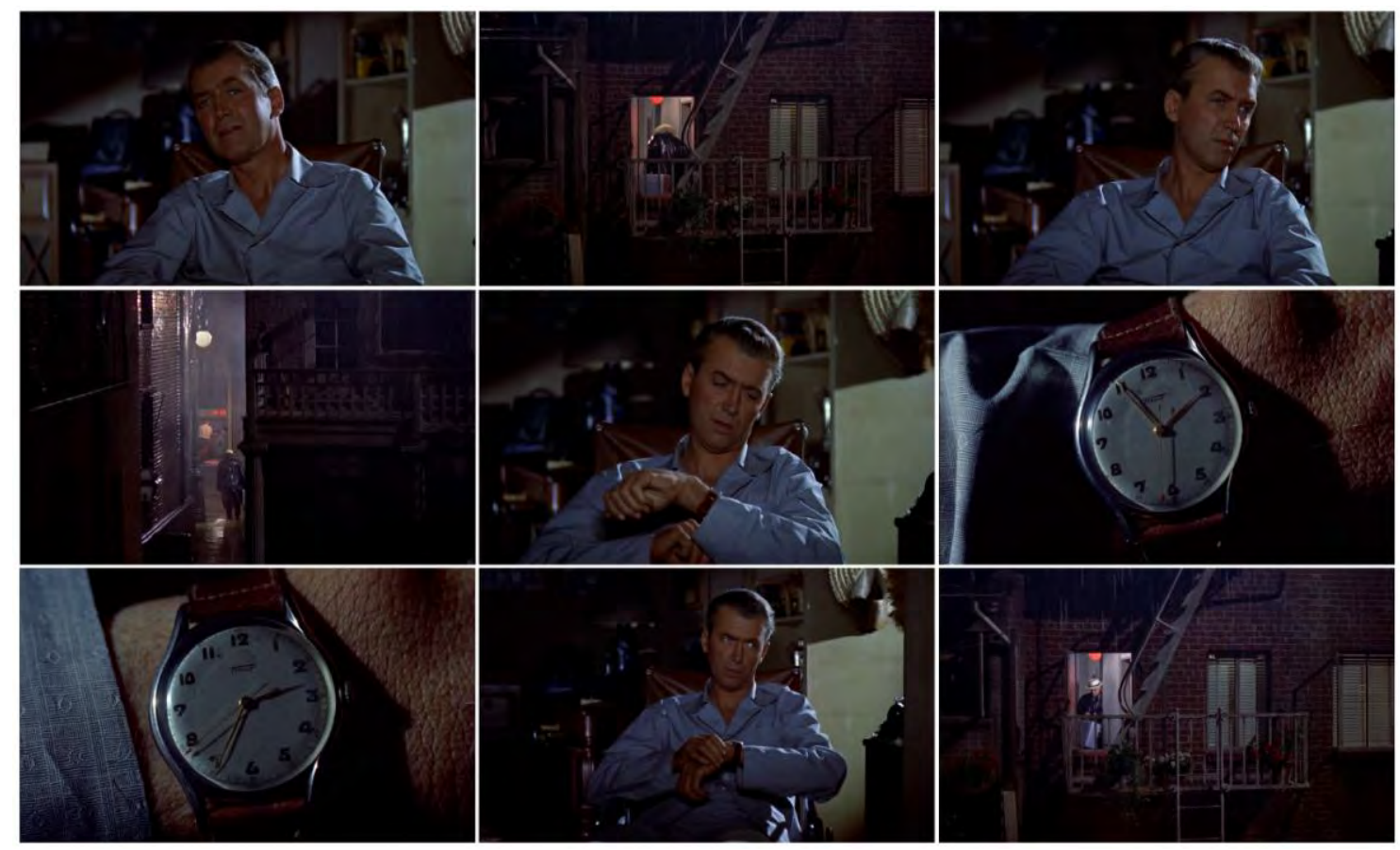


A variação mais radical na estrutura do ponto de vista ocorre no final desta sequência. O início dela ocorre com um plano de Jeff dormindo; em poucos segundos, ele acorda, percebe que começou a chover, e seu olhar vaga pela vizinhança. Logo após os planos apresentados acima, há um fade indicando passagem de tempo, e quando a imagem retorna, é novamente um plano de Jeff dormindo. Mais uma vez ele acorda, mais uma vez seu olhar se dispersa pela vizinhança, e mais uma vez ele observa a chegada de Thorwald. Depois, um novo fade, e um novo plano de Jeff dormindo. Até aqui, os planos da vizinhança, especialmente os planos que mostram Thorwald, nos foram dados através de Jeff, ou seja, pela via subjetiva. Mas desta vez há um deslocamento para o olhar objetivo. De um close-up de Jeff dormindo, a câmera faz uma panorâmica à direita, mostrando a vizinhança à noite, parando o movimento quando enquadra em plano geral o apartamento de Thorwald, que é visto chegando em casa acompanhado de uma mulher. Segundos depois, a câmera retorna com uma panorâmica para o close-up de Jeff, ainda dormindo:

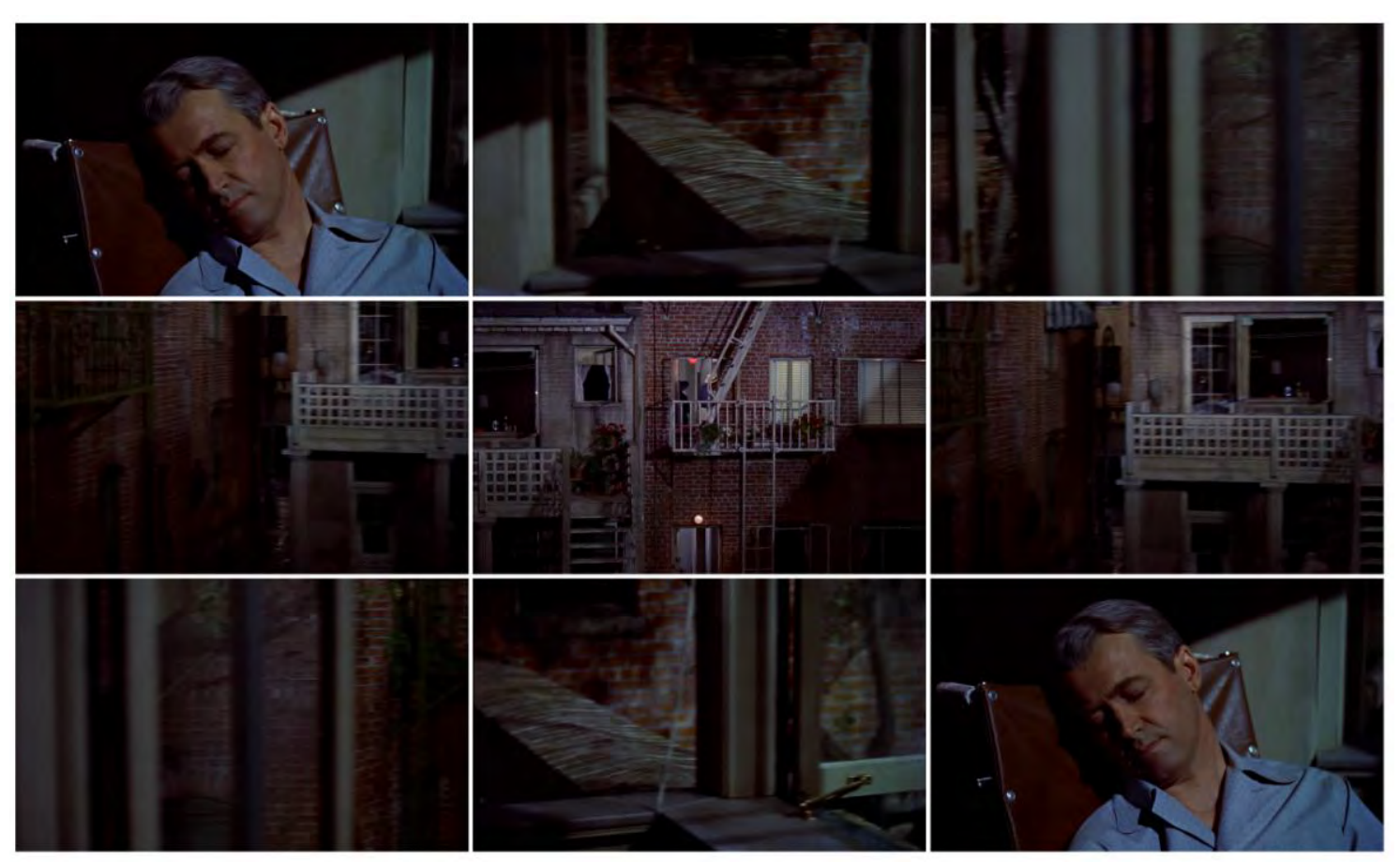

A linearidade simétrica do movimento, o fato de que posiciona Jeff no início e no final da panorâmica, faz com que a duração do plano se torne o intervalo no qual a câmera não está focada em seu rosto. Vimos em outra ocasião Jeff acordar na hora exata em que Thorwald chegava em casa, a tempo de processar uma informação crucial na trama. Mas aqui a informação é dada numa panorâmica, e a continuidade do plano faz com que não 
saibamos, no decorrer do movimento, se Jeff acordou ou não - por consequência, não sabemos se o que vemos é ou não alinhado com o conhecimento do personagem. A estrutura subjacente é a mesma da tríade simétrica do ponto de vista, da qual é uma espécie de perversão: iniciando com o que seria o sujeito do olhar, a câmera volta a atenção ao seu objeto, e finalmente retorna ao sujeito, mantendo até o último momento a possibilidade de nos ter representado um olhar subjetivo ou objetivo.

Assim como em Festim diabólico um programa de encenação que privilegiava a objetividade se revelava contaminado pela lógica subjetiva através dos cortes em pontos de vista, também em Janela indiscreta a eleição do suspense subjetivo como regra abre espaço para momentos em que a câmera se desliga do personagem e nos revela algo de maneira objetiva. Nos dois casos, o fator crucial é a identificação dos planos de ponto de vista com a "neutralidade" da câmera. Com exceção dos planos em Janela indiscreta vistos através da câmera ou do binóculo, os pontos de vista são representados sem qualquer "índice corporal", sem qualquer sinal de que estamos vendo através dos olhos de uma pessoa e não de uma câmera. $\mathrm{O}$ único dado que nos indica ser um ponto de vista é o contexto da montagem. É esta característica que permite a Hitchcock transitar com liberdade entre os diferentes aspectos do ponto de vista, e consequentemente, do suspense. Podemos então observar casos em que a passagem de um tipo a outro influencia na compreensão temporal e no significado interno da sequência.

Em Interlúdio (Notorious, 1946), por exemplo, Alicia (Ingrid Bergman) é uma espiã do governo americano que se casa com Sebastian (Claude Rains) para se infiltrar numa organização. Em determinado trecho do filme, ela deve obter a chave para uma porta trancada, e para isso pede ao marido que pegue a chave com a mãe - que suspeita dela. Acompanhamos o casal num plano médio, subindo as escadas, até que os dois se separam e seguimos com Alicia para seu quarto enquanto Sebastian vai ao quarto da mãe. Em vez de entrar no quarto, Alicia permanece na porta, e a partir disso é construída uma alternância de planos. (1) Um plano americano de Alicia na porta, olhando em direção ao corredor, enquanto soam ao fundo as vozes abafadas de Sebastian e de sua mãe. (2) O que parece ser o ponto de vista de Alicia, um plano médio do corredor, onde seguem as vozes abafadas da conversa. (3) Alicia, em close-up, tentando ouvir a conversa. (4) O mesmo plano do corredor, que parece ser o ponto de vista de Alicia, com o som da conversa ainda mais abafado, quase inaudível. (5) Alicia, em close-up, na porta. (6) O mesmo plano do corredor. Desta vez, Sebastian abre a porta e anda pelo corredor em direção ao quarto, sendo acompanhado pela câmera. Ele vai até a porta, que está fechada, e a abre. 
(7) Num plano médio dentro do quarto, vemos, ao fundo, Sebastian abrir a porta, e em primeiro plano, Alicia arrumar suas roupas. Sebastian entra para entregar a chave para ela, e se despede com um beijo. Podemos visualizar a sequência, considerando os quadros 6-8 como estágios do penúltimo plano:

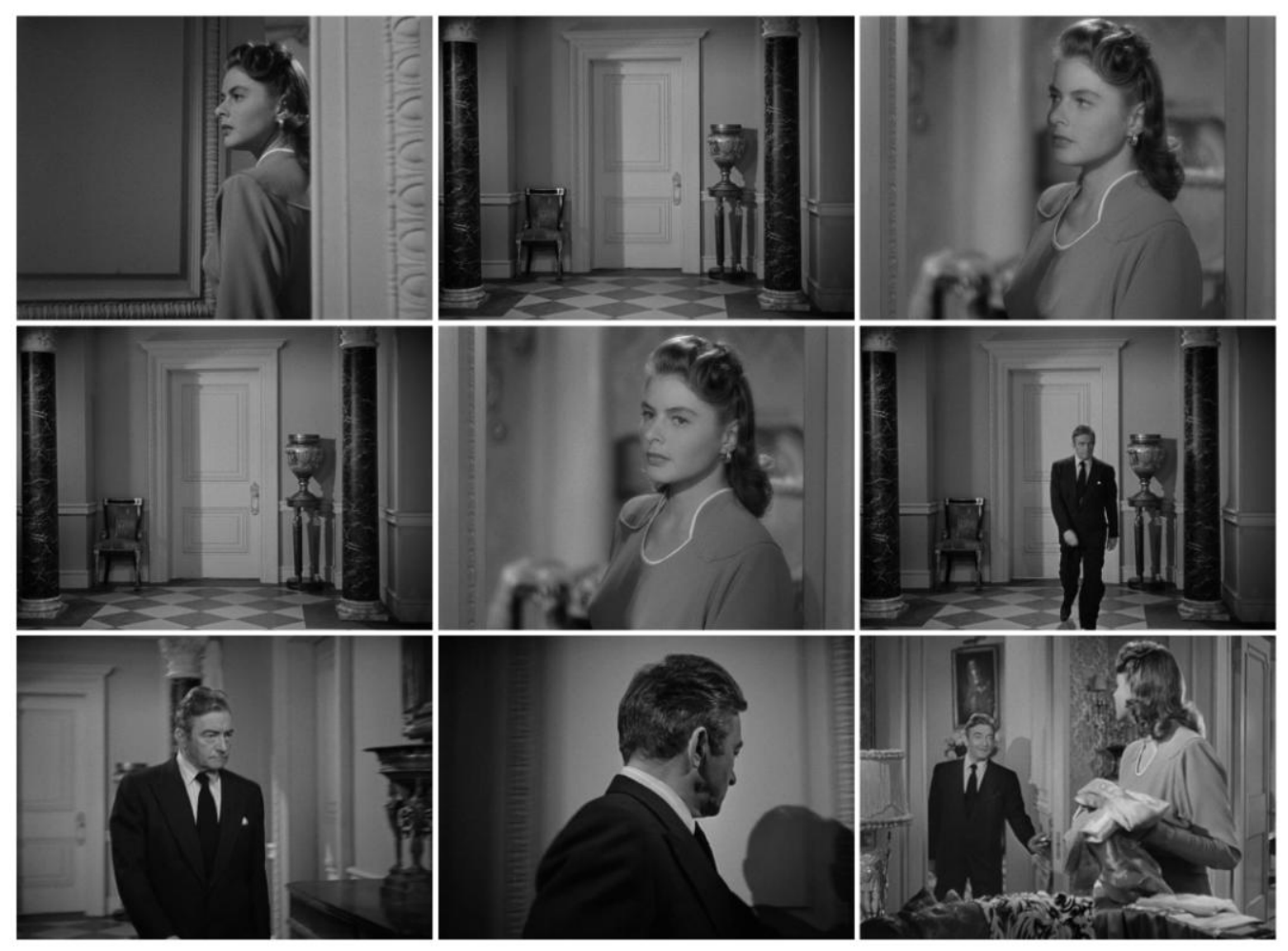

Considerando a equivalência da duração da sequência com o tempo real, em algum momento entre os planos 5 e 6, entre Alicia observando a porta e Sebastian saindo por ela, Alicia entrou em seu quarto e começou a mexer em suas roupas. O objetivo, como percebemos no contexto do filme, era fingir despreocupação e convencer o marido de que a chave não é um objeto importante, não é algo que a preocupa. Sebastian é de fato enganado. No decorrer dos planos, entretanto, o próprio espectador é vítima do engano na medida em que recebe os dados para construir determinada expectativa - o plano da porta é sinônimo do ponto de vista de Alicia - apenas para, na conclusão da sequência, ver essa expectativa ser derrubada. O processo de avaliação retrospectiva da orientação espacial nos leva igualmente à reavaliação da motivação da personagem: através de nossa incompreensão espacial, compreendemos as intenções mais profundas, e não declaradas, da personagem.

A cena cria, assim, alguma orientação espacial, apenas para subverter nossas expectativas. É um exemplo de compreensão retroativa: pensamos estar no domínio da 
subjetividade, e talvez estejamos na maior parte do tempo, mas no final somos levados ao domínio da objetividade sem qualquer índice para esta transição. Quando a revelação ocorre, pode-se inclusive considerar que houve uma elipse. Mas não é necessário que haja uma elipse para que a cena seja consistente; o que há, certamente, é uma mudança no espaço fora do plano. Essa mudança espacial sugere uma mudança temporal.

Algumas gags de Buster Keaton, como vimos, envolvem a justaposição de elementos incongruentes de modo a instigar e desviar as expectativas. Lembremos a descrição: uma cena, vista por determinado ângulo, nos revela determinado sentido; no momento seguinte, quando vista por outro ângulo, ou recebendo o acréscimo de um gesto, revela outro sentido, incompatível com o primeiro. O que encontramos aqui é um procedimento semelhante, como uma adaptação do princípio da incongruência ao domínio do suspense. Pela montagem, somos levados a fazer inferências sobre os dados visuais e sonoros, e tentados a buscar constâncias nessas relações. Imaginamos que, se um condição espacial/temporal é constante, deve permanecer constante; e que, se uma relação nos levou a determinada conclusão, uma relação semelhante nos levará a uma conclusão semelhante. ${ }^{279}$ Se a alternância entre o plano de Alicia e o plano da porta se mostrou duas vezes consistente, o retorno ao plano da porta uma terceira vez deve manter a consistência. $\mathrm{O}$ desenvolvimento da sequência revela que não é o caso. $\mathrm{O}$ suspense está nessa criação de orientações e expectativas, no conforto mesmo de apreender situações de maneira controlada, apenas para descobrir um elemento desestabilizador. Por essa razão, se há algo como um automatismo no tratamento do suspense por Hitchcock, ele ocorre nas situações em que nos são dadas informações, a partir das quais fazemos inferências, e em seguida as inferências são corrigidas pela realidade da situação, numa compreensão retroativa. Se em Keaton o alvo da gag do automatismo é o personagem, em Hitchcock o alvo do automatismo é muitas vezes o próprio espectador.

${ }^{279}$ O que parece ser instigado na composição da sequência é o que David Hume chamou de "o problema da indução". Se na dedução parte-se de premissas e, aplicando a lógica, deriva-se as conclusões, na indução parte-se de dados, e a partir deles se faz generalizações. Para Hume, o problema é que, se na dedução temos o silogismo pra garantir que as premissas foram analisadas corretamente, na indução não temos uma referência igualmente precisa. Não haveria então como saber se um número suficiente de dados foi considerado, ou se a constância dos dados é um fator influente na conclusão - não haveria como saber se eventos dos quais não temos experiência assemelham-se aos eventos dos quais temos experiência. $\mathrm{O}$ exemplo do cisne negro é frequentemente citado: durante séculos, apenas cisnes brancos foram vistos por europeus, portanto (por indução) concluíram que todos cisnes são brancos; até que cisnes negros foram encontrados na Austrália, e a conclusão teve que ser corrigida. O problema da indução, quando revelado, força uma compreensão retroativa. Para a formulação do problema, ver Hume, A Treatise on Human Nature, op. cit., pp. 86-94. 
Outro exemplo semelhante, e que realiza a passagem do suspense objetivo ao subjetivo, é a sequência em que Melanie (Tippi Hedren) visita a escola, em Os pássaros (The Birds, 1963). A sequência tem 12 planos, e por toda a sua duração ouve-se o canto repetitivo das crianças na escola. (1) Melanie caminha até um banco próximo ao parque infantil, onde se senta para esperar a professora. Ao fundo do quadro, atrás de Melanie, um corvo pousa sobre um brinquedo no parque. (2) Num plano mais próximo de Melanie, excluindo do campo de visão o brinquedo, vemos a protagonista tirar um cigarro da bolsa e começar a fumar. (3) Em seguida, há um plano médio da seção espacial que foi excluída no plano anterior, mostrando justamente o brinquedo, onde mais pássaros estão pousados. (4) Um close-up de Melanie fumando. (5) Novamente, um plano médio do brinquedo, onde pousa mais um pássaro. (6) Um novo close-up de Melanie fumando, inquieta, olhando algumas vezes para a escola. (7) Plano médio do brinquedo no parque, com ainda mais pássaros. (8) Close-up de Melanie fumando. No final deste plano, Melanie vê algo na região superior do espaço. (9) Do ponto de vista de Melanie, vemos um corvo atravessar o céu. (10) Melanie, em close-up, acompanha o vôo do pássaro com seu olhar. (11) Plano do pássaro, sendo acompanhado pela câmera até pousar no brinquedo do parque, que está agora coberto de pássaros. (12) Melanie se levanta num close-up, aterrorizada.

Nesta sequência, a câmera nos mostra já no início algo que a protagonista não vê: os pássaros que pousam no brinquedo do parque. Durante quatro planos, vemos o brinquedo ter um número cada vez maior de pássaros; temos uma determinada referência, portanto, quanto à frequência desse aumento, reforçada pela manutenção da frequência do canto das crianças. Após essas alternâncias, nosso ponto de vista é alinhado com o de Melanie. Num close-up da personagem, sabemos que ela está prestes a se surpreender, pois não viu o que vimos nos planos anteriores. Mas quando, nos planos seguintes, a revelação é feita a Melanie, também nós somos surpreendidos. Em algum momento, a frequência de pássaros aumentou consideravelmente, e como não nos foi dado qualquer índice desse momento, nossas inferências são derrubadas pelo resultado. 


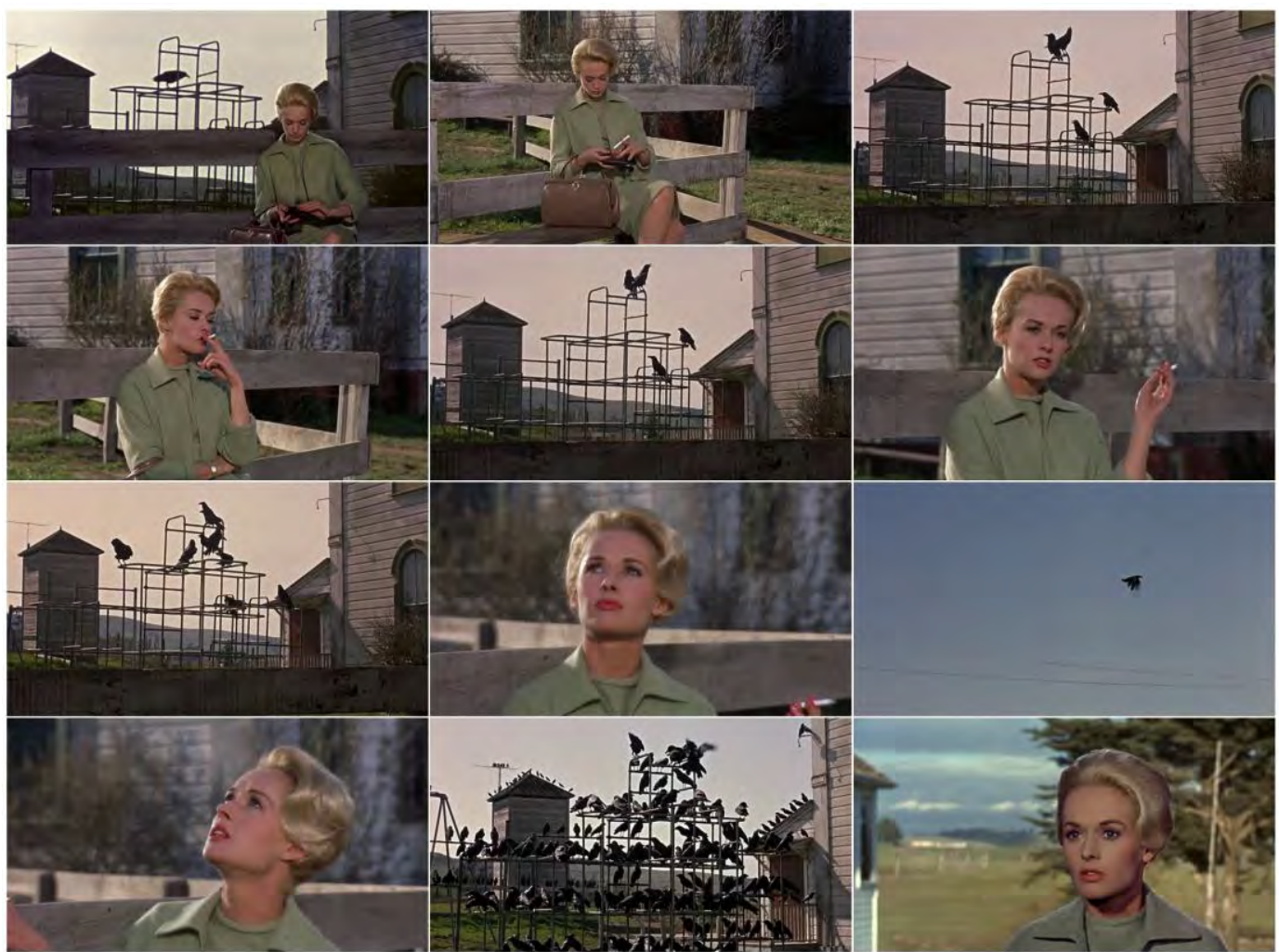

Os pássaros (Alfred Hitchcock, 1963): até o sétimo plano, a frequência com que os pássaros chegam no parque é dada ao espectador como uma informação deslocada do ponto de vista da protagonista; do sétimo plano em diante, o olhar da câmera é alinhado ao ponto de vista dela, e neste período a frequência é modificada, fazendo que tanto o espectador como a personagem sejam surpreendidos.

É através da constante manipulação das figuras do plano/contraplano e do plano de ponto de vista que podemos compreender o lugar de Hitchcock no "sistema do narrador" iniciado por Griffith. O uso de figuras pressupõe algum tipo de retórica, e é nesse sentido - na construção de uma relação entre um orador/narrador e um ouvinte/espectador - que se torna clara a postura representada por Hitchcock. O reconhecimento de que a atenção, a expectativa e as inferências exigidas no decorrer de uma narrativa podem ser inscritas em operações fílmicas é o que permite a Hitchcock realizar o que ele chamou de "direção de espectadores": a condução de determinados fatores no interior dos filmes como forma de conduzir o espectador. Da máquina cognitiva dos filmes de flicker na dimensão superficial, e da máquina cômica das gags na dimensão da profundidade, passa-se à máquina do suspense na dimensão virtual. 


\subsection{Da figuração à montagem intelectual}

Foi mencionado que, na hierarquização espacial proposta por Griffith, a alternância de planos abertos, médios e close-ups baseava-se numa constante inferência sobre as relações entre o espaço representado na tela e o espaço criado pela narração. Esta relação entre parte e todo, tratada como uma figura de linguagem, recebe na retórica o nome de sinédoque. A compreensão retroativa, como vimos em algumas cenas de Hitchcock, é uma espécie de hipérbato - a reordenação de termos ou sentidos numa sequência. $\mathrm{O}$ estudo da figuração no cinema, partindo de Griffith, nos leva necessariamente a confrontar a obra de um cineasta que foi diretamente influenciado por ele, mas que levou suas descobertas a outras direções que não aquelas exploradas por Hitchcock.

Num conhecido estudo sobre a afasia, um distúrbio caracterizado pelas limitações de formulação e compreensão da linguagem, Roman Jakobson identificou duas operações fundamentais na construção de um discurso. Nessa construção, o encadeamento de um tópico a outro pode ocorrer segundo a contiguidade ou segundo a semelhança. "O caminho metafórico seria o termo mais apropriado no primeiro caso e o caminho metonímico no segundo", argumenta Jakobson, “já que encontram sua expressão mais condensada, respectivamente, na metáfora e na metonímia”. Na metáfora, uma identidade é criada entre dois elementos: considerando $x$ e $y$, afirma-se que " $x$ é $y$ ", ou seja, que $x$ e $y$ possuem determinadas características em comum. Na metonímia, uma proximidade é criada entre dois elementos: considerando $x$ e $y$, afirma-se que " $x$ é parte de $y$ ", ou que " $x$ está ligado a $y$ ", ou seja, que $x$ e $y$ possuem um contexto comum. Jakobson traz a questão para o cinema: Griffith é apontado por ele como um representante da metonímia, em sua "capacidade altamente desenvolvida de mudar o ângulo, a perspectiva e o foco dos planos"; como representante da "montagem metafórica", ele menciona Eisenstein. ${ }^{280}$

\footnotetext{
${ }^{280}$ Roman Jakobson, "Two Aspects of Language and Two Types of Aphasic Disturbances" (1954), in Selected Writings, vol. II: Word and Language (Paris: Mouton \& Co., 1971), pp. 254-256. Esta é a formulação mais difundida entre críticos e teóricos de cinema. Para um comentário anterior sobre a mesma questão, ver Roman Jakobson, "Decadência do cinema?" (1933), in Linguística. Poética. Cinema (São Paulo: Perspectiva, 2007), pp. 155-159. Como outros autores, Jakobson considera a sinédoque uma espécie de metonímia. Uma crítica importante à classificação de Jakobson é feita por Christian Metz em Psychoanalysis and Cinema: The Imaginary Signifier (Londres: MacMillan Press, 1983), pp. 174 ss. A divisão de Jakobson serviu de base para equacionar semelhança/contiguidade aos eixos paradigmático/sintagmático na construção de um discurso, e Metz argumenta que essa operação é inadequada para o tratamento da metáfora e da metonímia como figuras de linguagem. Apesar de não considerarmos aqui outros aspectos do livro de Metz (sua fundamentação na semiologia e psicanálise),
} 
Eisenstein recorre inúmeras vezes à metonímia. O exemplo recorrente em análises de sua obra é o do pince-nez do médico em Encouraçado Potemkin (Bronenosets Potyomkin, 1925). ${ }^{281} \mathrm{O}$ personagem é visto já em sua primeira aparição com os óculos sendo ajustados; mais adiante, quando ocorre a rebelião no navio, Eisenstein o filma num plano próximo, com os óculos pendurados no rosto; minutos depois, quando a rebelião é bem-sucedida, é visto apenas o pince-nez pendurado numa corda:
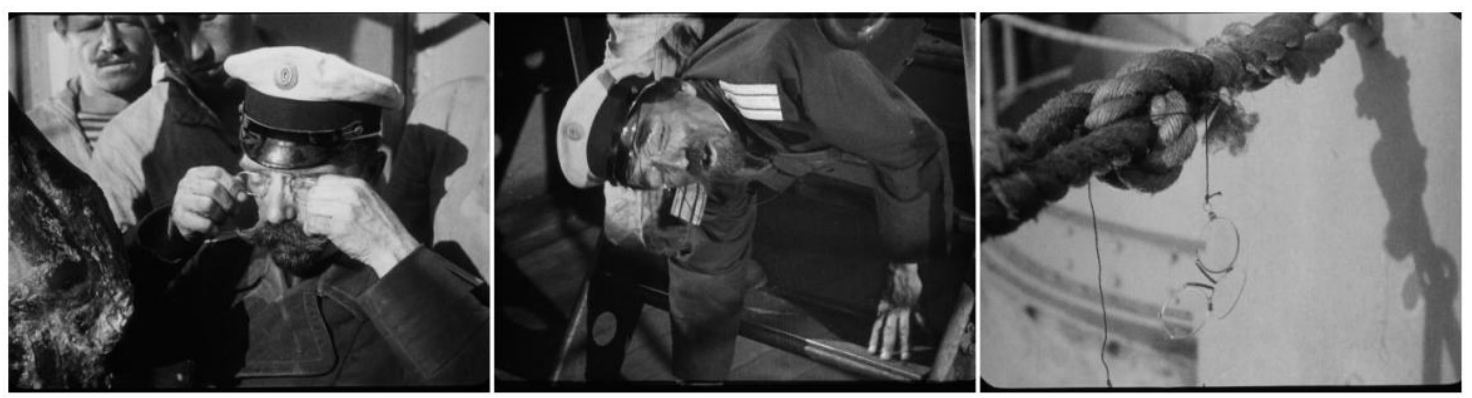

Se o seu uso da "parte pelo todo" em alguns momentos é semelhante àquele preferido por Griffith e Hitchcock, em outras situações é consideravelmente diverso. Na identificação dessas diferenças, podemos observar a variedade dos encadeamentos possibilitada pela figuração, inclusive retomando, em outra chave, modos de encadeamento que vimos anteriormente.

A elevação da ponte em Outubro (Oktyabr, 1928) é um caso importante na compreensão do uso radical da metonímia por Eisenstein. A sequência tem início quando, após uma manifestação bolchevique ser reprimida pelo exército, o governo ordena a elevação da ponte com o objetivo de cortar as ligações com a cidade. A ponte é erguida, com objetos e cadáveres dispostos em sua extensão. Numa série de planos, vemos no centro do quadro o corpo de uma garota morta próximo à interseção das duas partes da ponte, o movimento de ascensão fazendo com que sua mão e seu cabelo sejam lentamente deslocados. Vemos o início do movimento da ponte em seis planos com duração média de um segundo, todos centrados na garota, mas cada um deles enquadrado por um ângulo diferente, reorganizando a disposição cênica com intervalos cada vez mais contrastantes, e repetindo o mesmo trecho do evento por overlap:

tomamos como referência o mesmo argumento para tratar a metáfora e a metonímia como analogias para operações formais específicas, e não como princípios gerais de composição.

281 No primeiro volume de Esthétique et psychologie du cinéma, por exemplo, Jean Mitry comenta inúmeras vezes o close-up do pince-nez, tratando o plano como um caso ilustrativo da metonímia. 


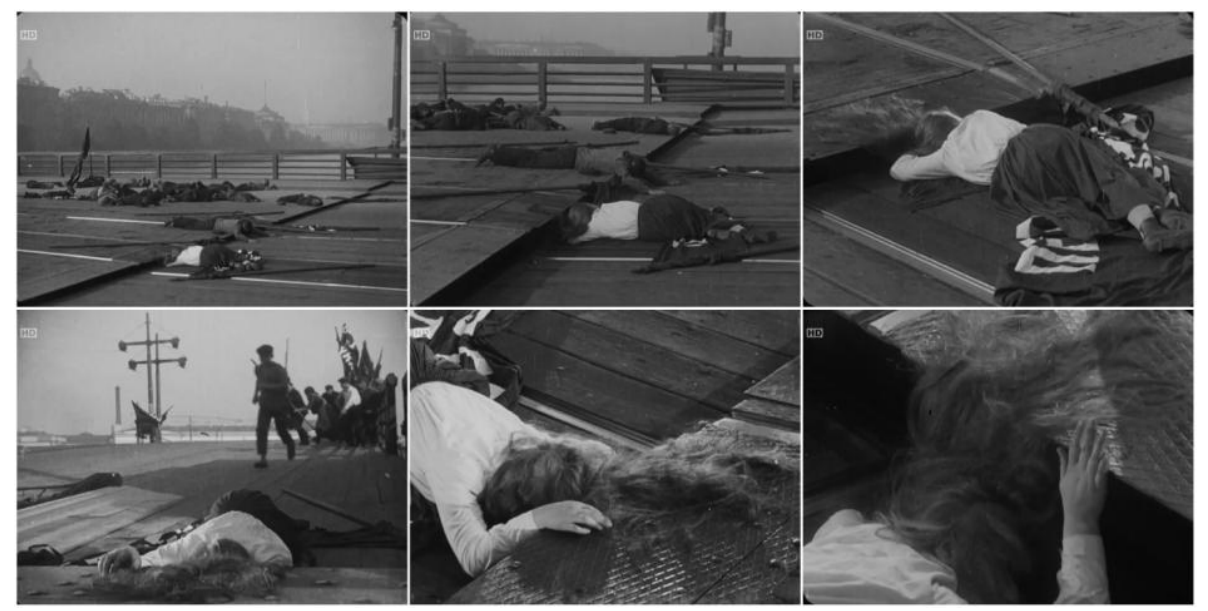

A sequência prossegue, alternando conjuntos de planos em overlap com breves avanços na ação, como se etapas do evento nos fossem apresentadas de maneira reiterativa. Os avanços são marcados pelas referências cênicas; conforme o cabelo da garota se desprende da ponte, o foco é dado a outra região, onde um cavalo morto está pendurado numa carroça, prestes a cair. A própria carroça, tendo sua posição na ponte fixada através do contrapeso do cavalo, é mostrada, também em overlap, em relação ao poste que marca a trajetória, e depois em relação ao horizonte, filmado como uma linha reta que gira à medida que a câmera, presa na ponte, gira em torno do próprio eixo em decorrência da elevação da ponte:

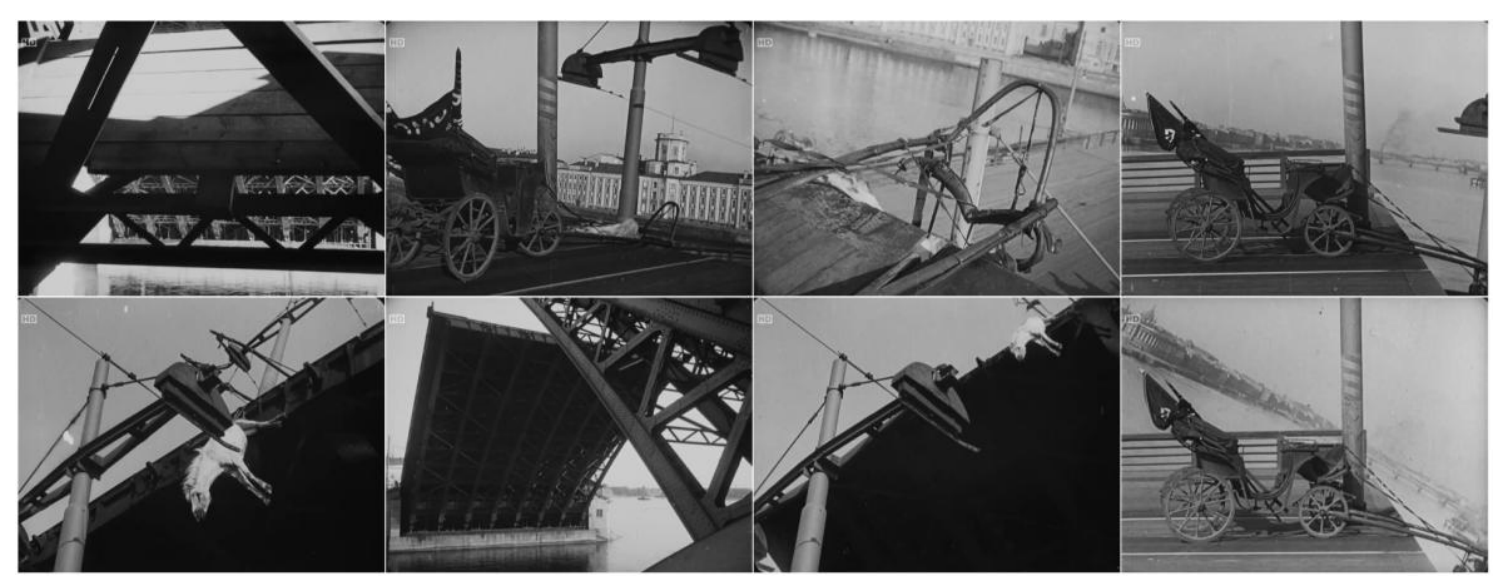

Nesta orquestração de movimentos que enfatiza os objetos por sua quase palpabilidade, a organização interna dos enquadramentos por seu esquematismo, e os padrões rítmicos por sua distorção da continuidade temporal, encontramos uma alternativa à montagem paralela. Em lugar da sucessão de planos que busca instigar o espectador pela alternância dos espaços, pelo jogo entre presença e ausência, mantendo na duração subjacente do 
conjunto uma temporalidade fluida, Eisenstein constrói uma sequência cuja força reside nas colisões realizadas de um momento a outro, e que prioriza, no encadeamento de saltos e transições, uma espécie de suspensão, onde o fluxo dos eventos é percebido indiretamente, através de uma síntese de fragmentos que prioriza o choque, o impacto dos intervalos visuais entre os planos. O direcionamento da ação é uma fonte de tensão, mas uma tensão que, em vez de bifurcada em vetores paralelos, é mantida pela inclusão de múltiplas referências, de objetos cujas relações físicas nos são dadas e medidas, retomadas e intensificadas pelo acúmulo da montagem.

A leitura da cena por Annette Michelson baseia-se no argumento de Erich Auerbach no capítulo inicial de seu estudo sobre as representações da realidade na literatura ocidental. Auerbach, comparando o estilo homérico ao estilo bíblico, defende que um excurso como aquele sobre a cicatriz de Odisseu em sua volta para Ítaca se caracteriza pela "externalização" da realidade. Não uma hierarquização de partes e informações, o que Homero apresenta é um conjunto de fenômenos no qual tudo parece ser dado ao leitor, sem atenção especial para a tensão resultante do tempo do discurso ou da psicologia dos participantes de seus pontos de vista. Neste modo, a digressão, em vez de interromper a narrativa, toma o espaço mental do leitor para "tornar presente" aquilo que descreve, no momento em que descreve. ${ }^{282}$ É uma estratégia semelhante que Michelson identifica no cinema de Eisenstein:

Conforme a ação é submetida a uma reorganização extensivamente analítica, quando uma multiplicidade de ângulos e posições de movimentos alteram o fluxo temporal do evento e da estrutura narrativa ao seu redor, as relações disjuntivas das partes constituintes são proclamadas, exigindo um tipo especial de atenção, e inferências quanto à organização espacial e temporal, e aos ajustes de percepção. E as inferências, os ajustes solicitados, reforçam a visibilidade das coisas, levam a um tipo particular de clareza. A visibilidade gerada por esse excurso é criada pelo refinamento e pela complexidade da montagem que o criou. Eisenstein nos dá, com essa inserção, outro complexo de inserções que intensificam nossa impressão do fluxo temporal, conferindo à sequência (e ao filme, que faz amplo uso de técnicas de adiamento temporal) algo que podemos chamar de a momentaneidade do estilo épico. ${ }^{283}$

${ }^{282}$ Auerbach refere-se ao estilo homérico como agindo sempre "em primeiro plano", porque "apesar dos muitos saltos para trás ou para diante, deixa agir o que é narrado, em cada instante, como presente único e puro, sem perspectiva". Ver Auerbach, Mimesis, op. cit., p. 9.

283 Annette Michelson, "Camera Lucida/Camera Obscura" (1973), in Stan Brakhage: Filmmaker, op. cit., pp. 48-49. A relação entre o argumento de Auerbach e a montagem soviética é levada adiante em Gilberto Perez, "All in the Foreground: A Study of Dovzhenko's Earth", The Hudson Review, vol. 28, n. 1 (primavera de 1975). As diferenças entre Dovzhenko e Eisenstein não serão tratadas aqui, mas um caminho possível de comparação seria o uso que ambos fazem das mesmas figuras de linguagem. Para leituras retóricas da obra de Dovzhenko, ver dois artigos de P. Adams Sitney, "Dovzhenko's Intellectual Montage", in The Essential Cinema: Essays on Films in the Collection of Anthology Film Archives, ed. 
Como uma reorganização cubista da diegese, a metonímia aqui se torna uma ferramenta para outros fins que não a construção de uma linearidade contínua. É uma sequencialidade fraturada que resulta dessa manipulação do espaço e do tempo; uma representação que utiliza a continuidade como um centro ao redor do qual variações são apresentadas. Encontramos mesmo os contornos do suspense no evento representado; mas este evento, em sua gravidade e amplitude, é inferido por suas reiterações, experimentado apenas através de sua própria decomposição. As referências internas, em vez de serem apresentadas de maneira clara e ordenada, como em Hitchcock, são multiplicadas e estendidas para além de sua duração real. O "tempo do narrador" ganha um sentido distinto.

A sequência da ascensão de Kerensky, também em Outubro, é representativa da conjunção entre metonímia e metáfora por Eisenstein. Nela encontramos uma estratégia semelhante à sequência da ponte, mas o acréscimo da metáfora se revela um detalhe importante. Kerensky sobe uma escadaria, e a subida é distorcida em sua continuidade: recorrendo novamente ao overlap como a um tropo retórico, Eisenstein repete parcialmente trechos da ação em diferentes planos, entrecortando-os com cartelas de texto que se referem ao personagem. Vemos, então, Kerensky subindo uma série de degraus, ao que a imagem é interrompida pela cartela "Ditador". Vemos depois Kerensky subindo o mesmo trecho, mas seguido da cartela "Ministro do exército". O processo é repetido em outros trechos da escadaria, com as cartelas "Ministro da marinha", "Primeiro ministro", e logo a cartela "Etc". A distorção da continuidade transpõe o evento para uma esfera onde a extensão repetitiva do gesto adquire outro significado - não a mera repetição da ação por seu agente, mas a reiteração metonímica da ação pelo cineasta, associada à reiteração dos títulos políticos.

Mais adiante, Kerensky espera no lado de fora da sala do Czar, com as mãos para trás segurando as luvas, hesitante em meio aos lacaios e oficiais que o observam. Eisenstein corta então para planos de um pavão mecânico, visto contra um fundo preto; numa montagem alternada, o pavão é entrecortado com Kerensky e os lacaios, com expressões e insígnias vistas em fragmentos isolados. Em certo momento, a dispersão dos close-ups cristaliza-se num padrão: planos de Kerensky visto de costas, o close-up de sua 
mão e o close-up de seus pés são seguidos de close-ups do pavão e de sua cauda sendo aberta como um leque:

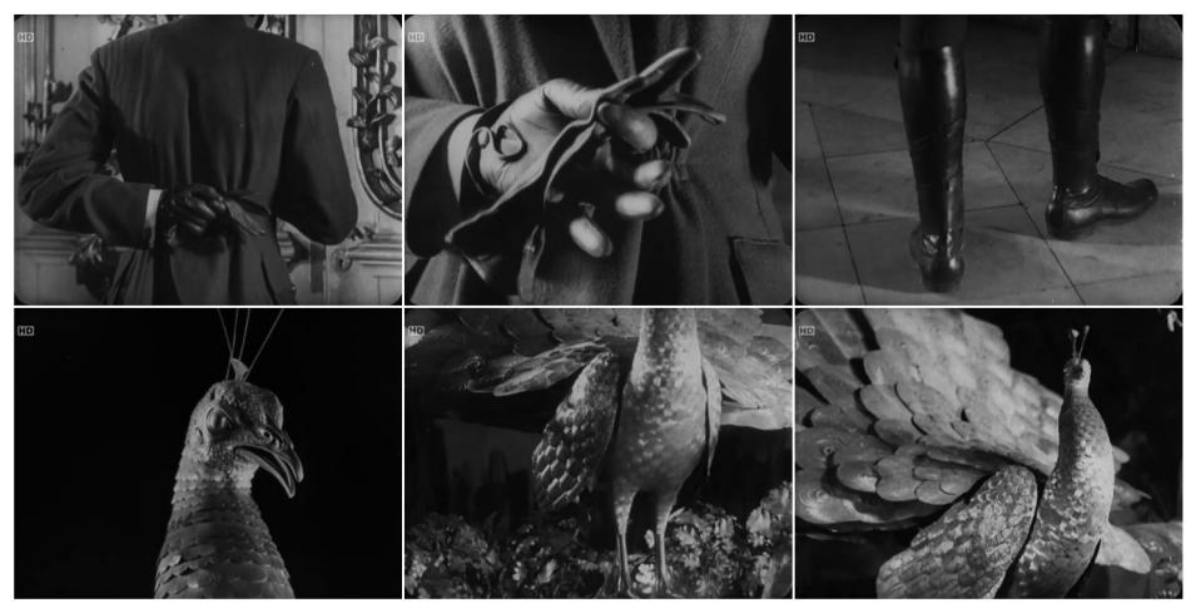

As duas tríades metonímicas, comparadas em proximidade e ritmo, dão finalmente lugar a uma associação por movimentos quando, em poucos segundos, Eisenstein nos mostra o pavão girando para revelar sua cauda e Kerensky em frente à porta que se abre - nos dois movimentos, o mesmo padrão metonímico dos três close-up, e o mesmo overlap temporal:

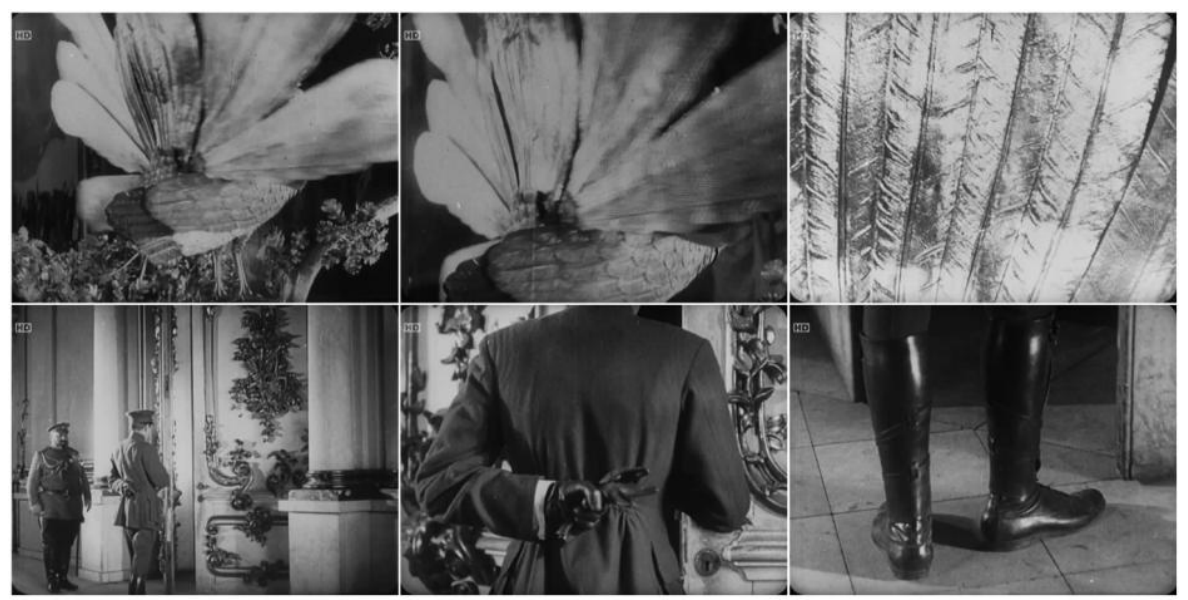

Assim como na elevação da ponte, Eisenstein parece aqui supor a continuidade espacial e temporal, e sobre essa unidade realizar mudanças abruptas de escala e posição. Essas mudanças, ocorrendo às vezes sobre o movimento e às vezes sobre objetos estáticos, refletem uma dualidade na representação espacial, algo apontado por Rosalind Krauss em sua análise do filme. A dualidade se revela de maneira mais direta no final da 
sequência, quando os planos de Kerensky são alternados com os planos do pavão. Se os planos até então envolviam o overlap, é porque envolviam algo como uma realidade diegética, um espaço virtual construído através dos fragmentos dispostos em sequência. Mas os planos do pavão não possuem qualquer referência diegética, permanecendo isolados dos outros objetos, inclusive em sua iluminação - um fundo preto indistinto. Krauss chama estes tipos diferentes de espaço "documental" e "formal":

No modo documental, são o espaço e o tempo dos eventos objetivos e sua factualidade aparentemente absoluta. No caso do modo formal ou estético, é a referência do espaço e do tempo presentes durante os quais percebemos o objeto artístico e sua aparente resistência a mudanças. ${ }^{284}$

Essa dialética entre os dois tipos de espaço, mais que uma característica incidental, tornase um fator constituinte da operação metafórica. Kerensky e o pavão são entrecortados várias vezes, o que significa que o espectador é retirado periodicamente do espaço documental e levado a um espaço formal. Eisenstein recorre à "aceleração" que Griffith aplicava ao clímax de um filme - a redução progressiva das durações métricas dos planos -, mas aqui o efeito criado é como uma reverberação crescente no decorrer da sequência. A uma frequência cada vez maior, a realidade cênica é invadida pela imagem do pavão. A predominância do espaço documental é logo suplantada pela alternância deste com o espaço formal, atingindo o ápice quando os dois parecem coincidir no movimento da cauda e da abertura da porta. ${ }^{285}$

O importante nestes exemplos é que a metonímia, ainda que possa ser utilizada para fins relativamente não-narrativos - como na elevação da ponte -, permite a narrativa, ou coexiste com a narrativa na medida em que lida com a fragmentação do espaço diegético. Em outras palavras, o espaço diegético é mantido como referência. Os encadeamentos metafóricos, por sua vez, tendem, em Eisenstein, a ocorrer justamente na quebra deste espaço, num reforço do "espaço formal" mencionado por Krauss. É necessário, por isso, observar os momentos em que Eisenstein se volta à metáfora de maneira mais concentrada, reduzindo ao máximo o uso da metonímia.

\footnotetext{
${ }^{284}$ Rosalind Krauss, "Montage October: Dialectic of the Shot", Artforum, vol. 11, n. 5 (janeiro de 1973), p. 62.

${ }^{285}$ Ver Marie-Claire Ropars, "Fonction de la métaphore dans Octobre d'Eisenstein", Littérature 11 (outubro de 1973), p. 112. Ropars argumenta que essa não-dependência do espaço realista, ainda que momentânea, é um dos pontos no qual Eisenstein diverge de Dovzhenko, outro cineasta soviético que recorreu frequentemente à montagem metafórica. Ver também a menção aos textos de Sitney, duas notas acima.
} 
O uso da metáfora por Eisenstein ocorre já em seu primeiro longa, A greve (Stachka, 1925). Ele utiliza, por exemplo, na apresentação de alguns personagens, associando-os a animais, filmando planos próximos e frontais de seus rostos, sobrepondo a eles planos de animais. A iluminação dos planos ocorre de tal maneira que somos capazes de ver, numa única imagem, tanto o rosto do personagem como o animal, e o personagem parece reproduzir, em sua expressão, as mesmas características do animal como a boca semiaberta de uma raposa, ou as rápidas piscadas de olho de uma coruja:

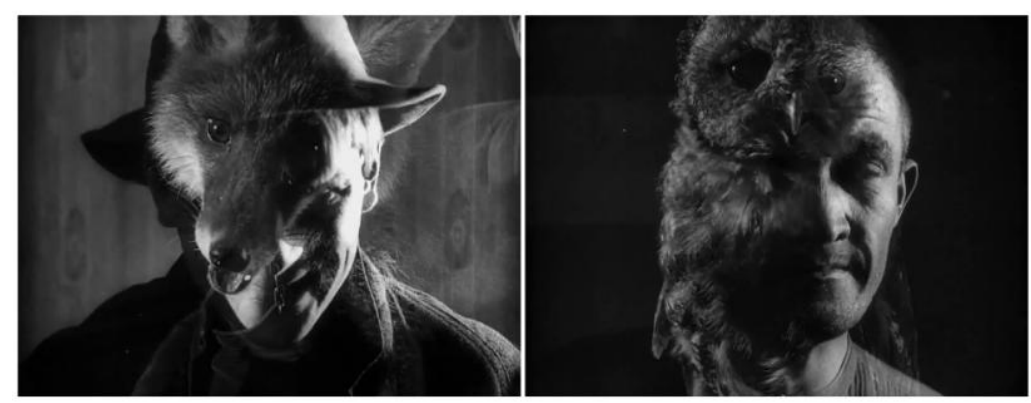

São planos isolados do encadeamento narrativo; funcionam como apresentações dos personagens, sendo inclusive precedidos por cartelas indicando seus apelidos, que coincidem com os animais utilizados nas metáforas. Da mesma forma, por sua brevidade, não interrompem o movimento da narrativa.

A necessidade encontrada por Eisenstein de "dar o passo seguinte" e utilizar a construção metafórica em sequências sem o referencial narrativo envolve suas críticas a Griffith. Uma delas é que o cineasta americano permaneceria ao nível da "representação do objeto", sendo incapaz de fazer a transição da narrativa à metáfora. Eisenstein considera Intolerância apenas uma combinação de quatro histórias, quando para ele deveria ser "a fusão de quatro fenômenos numa única síntese plástica". ${ }^{286}$ A questão a ser colocada é que, se um filme pode ser composto de modo a contar histórias pela alternância de espaços, e se essa alternância pode criar comparações unicamente no nível temático, então teoricamente um filme poderia ser composto de comparações temáticas sem o recurso à narrativa. Essa questão nos leva diretamente à formulação da "montagem intelectual" ${ }^{287}$

${ }^{286}$ Sergei Eisenstein, "Dickens, Griffith e nós" (1944), in A forma do filme, op. cit., p. 211.

${ }^{287}$ A montagem intelectual é um conceito de difícil tratamento, sendo definida por Eisenstein de maneira dispersa. Para uma análise mais aprofundada da montagem intelectual como conceito, ver Jacques Aumont, Montage Eisenstein (Bloomington: Indiana University Press, 1987), pp. 156-170, 176-180. Aumont oferece uma leitura comparativa de vários textos de Eisenstein, informada por interpretações 
A montagem intelectual parece representar, para Eisenstein, uma etapa natural em seu desenvolvimento, a sucessão lógica dos outros tipos de montagem que havia proposto. A cada tipo de montagem corresponderia um nível de percepção, ou do potencial expressivo do material fílmico; o desenvolvimento da montagem ocorreria na absorção dialética de um nível pelo nível seguinte. No primeiro nível da percepção, teríamos o fenômeno simples da reprodução do movimento, um efeito puramente óptico, causado pela mudança de um fotograma a outro - o equivalente deste nível seria a montagem métrica. No segundo nível, absorvendo o efeito do movimento "natural", teríamos a representação de um movimento "artificial", criado pelos intervalos, as passagens de um plano a outro - o equivalente da montagem rítmica. No terceiro nível, combinações de planos gerariam associações emocionais, organizando o que Eisenstein chamou de as "dominantes" de cada plano, absorvendo o conjunto de características gráficas, rítmicas, e suas relações com o objeto representado - o equivalente seria a montagem "tonal". ${ }^{288}$ No quarto nível, teríamos finalmente a "liberação dos determinantes do espaço e do tempo", e a recusa da linearidade narrativa para criar um efeito conceitual - cujo equivalente seria a montagem intelectual. Considerando o trabalho de figuração da montagem como central nesse desenvolvimento, Eisenstein afirma:

Passo a passo, por um processo de comparar cada nova imagem com a denotação comum, o poder é acumulado atrás de um processo que pode ser formalmente identificado com o da dedução lógica. A decisão de liberar estas ideias, assim como o método usado, já é concebido intelectualmente.

A convencional forma descritiva do cinema leva à possibilidade formal de uma espécie de raciocínio cinematográfico. Enquanto dirige as emoções, o filme convencional propicia uma oportunidade de estimular e dirigir todo o processo de pensamento. ${ }^{289}$

O trecho de Eisenstein que melhor representa seu esforço para realizar a montagem intelectual é a sequência em Outubro intitulada "Por Deus e pela pátria". Declarada pelo próprio Eisenstein como uma tentativa de criar um verdadeiro argumento fílmico, a sequência é interpretada extensivamente por Noel Carroll, talvez quem melhor

críticas citadas nas notas correspondentes a estas páginas. A definição considerada aqui é essencialmente a mesma apresentada por ele.

288 Ver Sergei Eisenstein, "Métodos de montagem", op. cit., p. 82: "Na montagem tonal, o movimento é percebido num sentido mais amplo [do que na montagem rítmica]. O conceito de movimentação engloba todas as sensações do fragmento de montagem. Aqui a montagem se baseia no característico som emocional do fragmento - de sua dominante. O tom geral do fragmento."

289 Sergei Eisenstein, "Dramaturgia da forma do filme" (1929), in A forma do filme, op. cit., p. 69. 
tenha analisado seu caráter retórico. ${ }^{290}$ Carroll inicia com a suposição (compartilhada por Eisenstein) de que um espectador deve, ainda que inconscientemente, fazer inferências na passagem de um plano a outro. Ele acrescenta a isso uma observação histórica que nos é de certa forma confirmada pelo desenvolvimento do MRI, de Griffith a Hitchcock: que tradicionalmente, as inferências envolvem os aspectos espaciais, temporais, causais e psicológicos dos planos. É no contexto de uma continuidade subjacente que se baseiam a maior parte dos encadeamentos entre os planos, e consequentemente as inferências consideradas pelos filmes. ${ }^{291}$ Pode-se, entretanto, realizar a combinação entre os planos tendo como base outros critérios, como o uso de um "conceito", como o próprio Griffith o faz, ainda que parcialmente, em Intolerância. É nesta brecha que se insere a defesa da montagem intelectual: é buscando superar o exemplo de Griffith que Eisenstein considera a possibilidade de um filme ser composto a partir de ligações intelectuais sem o recurso à narrativa.

$\mathrm{O}$ argumento da sequência envolveria um procedimento típico: a redução ao absurdo. Neste procedimento, uma premissa é considerada verdadeira, e dessa premissa é derivada uma contradição; o objetivo é demonstrar a falsidade da premissa para sugerir, por consequência, a veracidade de seu inverso. Eisenstein inicia com as cartelas "Por Deus e pela Pátria", "Por Deus", "Deus". A primeira imagem além das cartelas é a de uma igreja; em seguida, uma estátua de Cristo. As premissas seriam, portanto, que há um Deus; que este Deus é representado por uma instituição; e que essa representação se estende a um objeto. Partindo dessas premissas, Eisenstein acrescenta imagens de deuses de outras religiões e imagens de outros edifícios religiosos, seguindo padrões rítmicos semelhantes, às vezes invertendo horizontalmente a organização gráfica das imagens. Essa operação comparativa, nos termos de um argumento, seria equivalente a declarar que, "à crença no deus $a_{1}$, na instituição $b_{1}$ e na representação $c_{1}$, podemos opor a crença no deus $a_{2}$, na instituição $b_{2}$ e na representação $c_{2}$ ". Além disso, a ordem na qual as representações são dispostas leva a outro motivo: a crescente abstração do realismo nas estátuas. Partindo de uma estátua do Cristo representado em proporções realistas, Eisenstein conduz a sequência por uma variedade de distorções do realismo, atingindo o grau máximo nos ídolos que encerram a sequência, onde a ideia da representação de uma entidade é abstraída na materialidade de um bloco de madeira. Pela multiplicação das

\footnotetext{
290 Noel Carroll, "For God and Country" (1973), in Interpreting the Moving Image, op. cit., pp. 81-90.

291 Carroll elabora a concepção da montagem com base em diferentes tipos de inferência em "Toward a Theory of Film Editing", in Theorizing the Moving Image, op. cit., pp. 403-420.
} 
perspectivas religiosas, e pela correspondência estabelecida entre suas manifestações, Eisenstein colocaria em dúvida a posição inicial: se há uma, duas, três ou mais alternativas à crença, à instituição e à forma de representação, e se todas convergem na materialidade de objetos construídos pelo homem, qual a validade destes termos? ${ }^{292}$

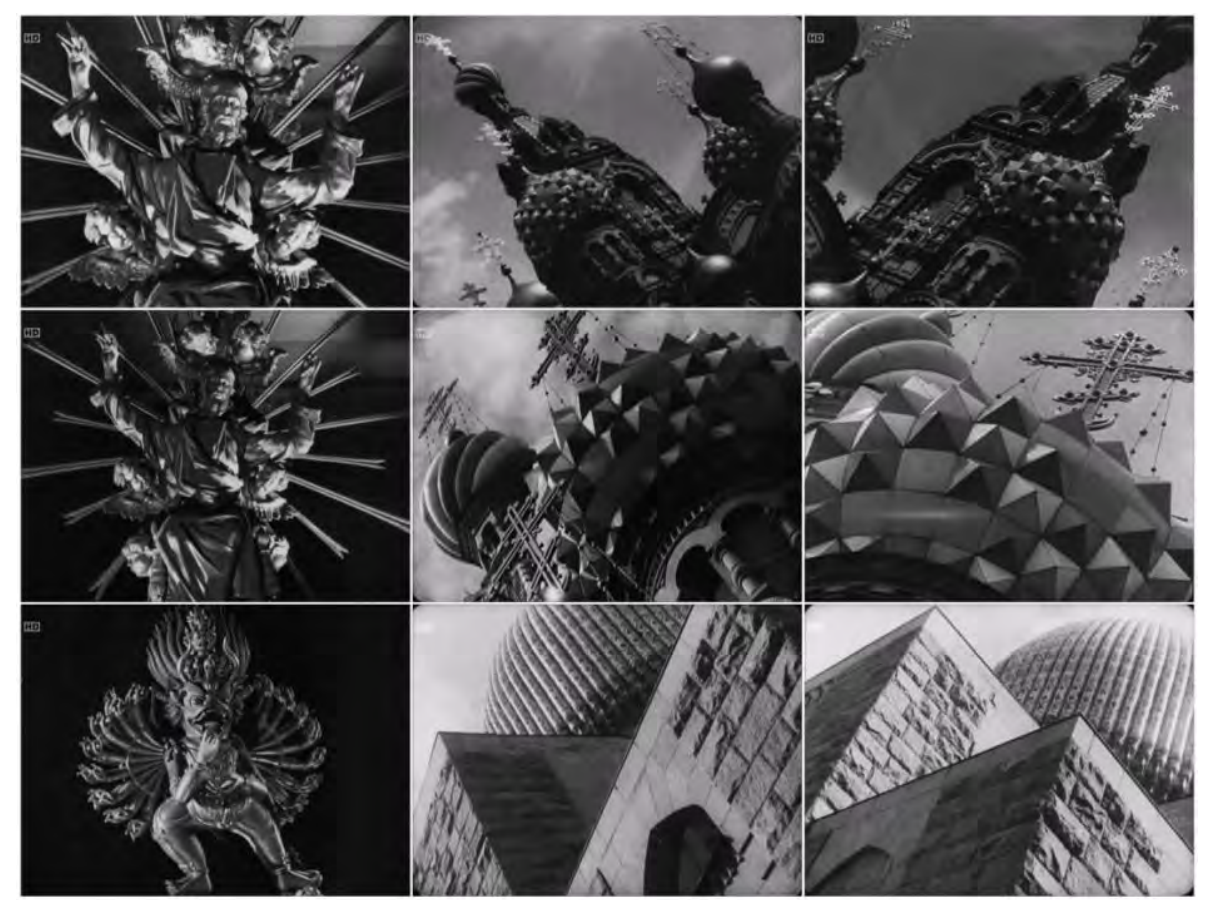

Planos sucessivos da primeira parte da sequência "Por Deus e pela pátria", de Outubro, onde encontramos o padrão rítmico e a alternância das direções e dos espaços "documental" e "formal" como estratégias comparativas.

A segunda parte da sequência é um complemento à primeira. Kerensky e Kornilov, rivais políticos, são ambos entrecortados com planos de igrejas, de cerimônias religiosas, e de estátuas de Napoleão. Há uma caracterização da esfera política como possuindo sua própria iconografia, suas medalhas, seus representantes, suas estátuas; o padrão de apresentação dos elementos e mesmo o espaço negro onde são dispostos estabelecem uma correspondência com a esfera religiosa. Como na primeira parte, as figuras são enquadradadas de forma esquemática, voltadas a diferentes lados da tela, suas oposições ideológicas marcadas por oposições visuais. Isso atinge outro nível quando as figuras são dispostas uma frente à outra no mesmo enquadramento, com a sobreposição de dois planos: a inversão das direções em espaços isolados torna-se uma oposição no mesmo espaço da tela. $\mathrm{O}$ questionamento da validade das premissas religiosas, baseado

\footnotetext{
${ }^{292}$ Como na análise de Carroll, não queremos aqui pressupor que o argumento de Eisenstein é correto, apenas que é logicamente válido. A mesma estrutura da sequência, se retirada do contexto do filme, poderia talvez - sob a ótica da mitologia comparada, por exemplo - nos levar a conclusões distintas.
} 
na correspondência das diversas perspectivas, é aqui estendido ao questionamento de Kerensky e Kornilov, equacionados tanto entre si como em relação às figuras religosas:

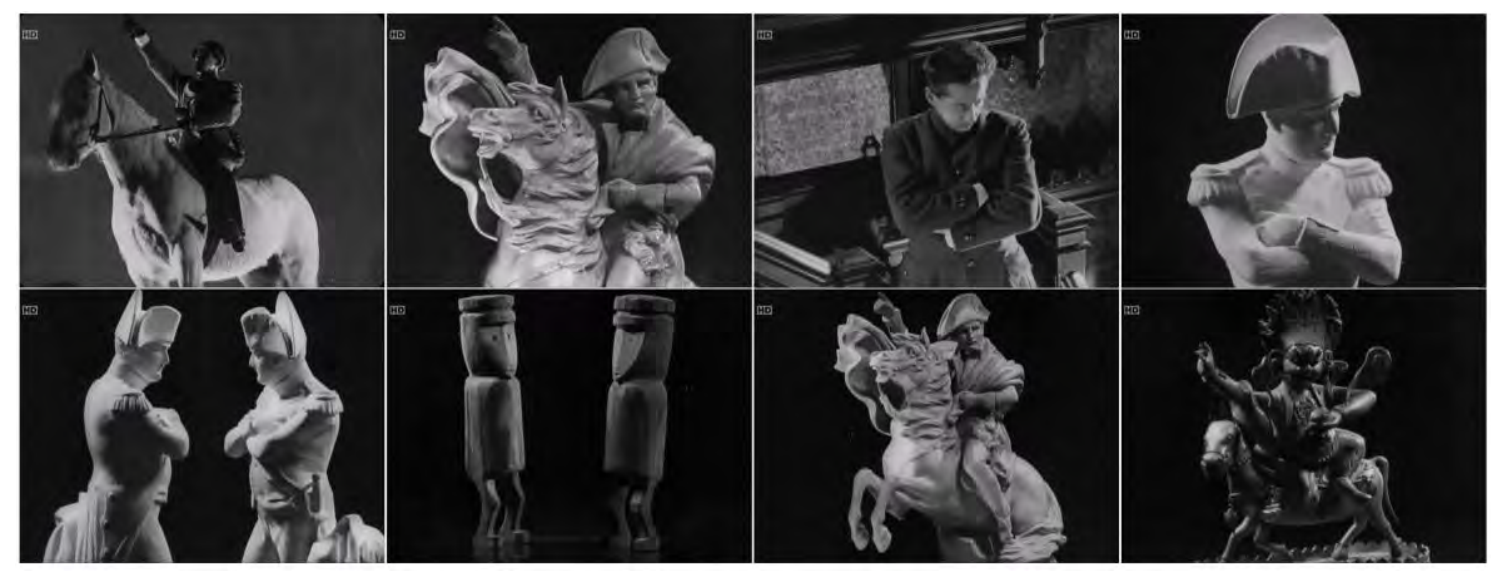

A predominância da metáfora faz com que o recurso à diegese torne-se consideravelmente menor. Os planos de Kerensky e Kornilov são quase tão abstratos em seu isolamento quanto os planos das estátuas sobre o fundo negro, e os planos das igrejas não possuem qualquer antecedente diegético, sendo enquadrados em padrões altamente formalizados, de maneira diagramática. Não se constrói, na passagem de um plano a outro, um espaço unificado; o fundo preto, comum às estátuas religiosas e militares, torna-se uma espécie de negação do espaço diegético, caracterizado pela escuridão que destaca as imagens enquanto as mantém suspensas, tendo a tela como seu único contexto; torna-se, de certa forma, um modelo para o espaço mental, onde a realidade dos objetos é submetida à sua posição no espaço da tela e na cadeia dedutiva da sequência. ${ }^{293}$ Temporalmente, uma abstração semelhante é alcançada. A sequência é constituída em grande parte por objetos estáticos, o que significa que não há movimento nos planos que possa servir de referência para a duração. Padrões temporais são criados, mas como medidas arbitrárias, impostas às imagens, equacionando umas às outras pelas relações entre a distribuição dos conteúdos visuais e a duração estabelecida para cada plano. Vistas em conjunto, essas propriedades sugerem algo como uma musicalização de conceitos: a montagem intelectual como a tentativa de transpor um raciocínio a uma dimensão puramente formal, encontrando para cada etapa mental um corpo, uma textura, uma

${ }^{293}$ Ver Annette Michelson, "Reading Eisenstein Reading Capital (Part 2)", op. cit., p. 88 (grifo nosso): "Qual seria a estratégia cinematográfica que poderia implementar este projeto que, como em Malevich, priorizava a interioridade e o ataque ao espaço da representação? Como este ataque seria realizado? Não pela destruição dos objetos e das ações representados na narrativa, mas antes pela transformação das coordenadas espaço-temporais que os condicionam, as coordenadas que os localizam e os definem." 
proporção plástica e um lugar na dinâmica dos intervalos. Nesse esforço para isolar e compor ao máximo os elos da cadeia, o close-up, que em Griffith servia para desenvolver a hierarquia diegética, torna-se um reforço na direção contrária. Da mesma forma, o que em Hitchcock se tornava um processo dedutivo através da diegese, através do ponto de vista dos personagens e de suas relações com a cena, torna-se aqui uma construção que suspende a unidade diegética para apresentar diretamente ao espectador - sem a mediação de um personagem - as referências de um processo mental. ${ }^{294}$

Se considerarmos os tipos de encadeamento mencionados anteriormente, veremos que nas primeiras sequências Eisenstein recorre especialmente ao overlap e à elipse, raramente à continuidade. Mas, na medida em que a tendência metafórica toma conta e as coordenadas da cena são abolidas, surge outro tipo de operação. Quando não parece haver referências de contiguidade espacial, de posição temporal, o realismo fotográfico é reduzido aos seus mínimos denominadores, à presença de objetos sobre a tela e à duração cronométrica de seus registros. Uma oposição conceitual é assim inscrita na oposição visual dos elementos sobre a superfície da tela, e a repetição de um padrão rítmico equivale à comparação de seus termos. O que permanece entre os encadeamentos, o que se acumula como uma energia, é, talvez, o processo intelectual vislumbrado por Eisenstein, projetado na unidade psicológica do espectador. O horizonte da montagem intelectual, nesse sentido, parece envolver a redução do contexto do encadeamento à apreensão dialética de suas partes.

\subsection{O contexto de implicação}

Todos os filmes deste capítulo têm em comum o fato de que trabalham com o encadeamento de planos. Todos criam, pela combinação de planos, um novo espaço e/ou tempo que não é aquele representado num dos planos individuais, mas que é necessariamente sugerido através deles - lidam, portanto, com o que chamamos de a dimensão virtual da composição.

\footnotetext{
${ }^{294}$ Para um argumento mais extenso sobre a importância do close-up na montagem de Eisenstein, ver Pascal Bonitzer, "Le Gros orteil", Cahiers du cinéma 232 (outubro de 1971), pp. 14 ss. Um dos pontos levantados por Bonitzer é que o close-up limita o realismo do plano na medida em que diminui sua profundidade bem como sua amplitude, tradicionalmente as garantias da "veracidade" do registro, de sua ligação com a realidade mais ampla.
} 
Num recorte das primeiras décadas do cinema, vimos como algumas questões relativas ao encadeamento foram colocadas pelos filmes e interpretadas por críticos. Vimos como as tendências dominantes em certos períodos foram identificadas por Noel Burch como "modos de representação", e que as diferenças entre esses modos são essencialmente diferenças na organização espacial e temporal. Mais especificamente, vimos como o Modo de Representação Primitivo (MRP) se caracteriza por uma aproximação do tempo do registro e do espaço do enquadramento com a totalidade da ação representada, fazendo com que os planos pareçam se oferecer como eventos "autônomos" e "policêntricos", ou ainda, pouco hierarquizados, dificultando o estabelecimento de ligações com outros planos. No Modo de Representação Institucional (MRI), por sua vez, a crescente hierarquização espacial (pela redução na quantidade de eventos na cena e pela variação na escala dos enquadramentos) e temporal (pela adaptação da duração do registro à duração da ação, e por ligações de continuidade) permite a linearização dos encadeamentos, tornando os planos menos autônomos, mais interdependentes, e delineando o que Gunning chamou de "sistema do narrador". Vimos ainda como esse sistema foi absorvido e adaptado por cineastas num período posterior, levando à exploração de diferentes caminhos abertos por essas descobertas.

Nos anos 1920, um grupo de jovens soviéticos reuniu-se no que foi então chamado de um "laboratório", com o objetivo de analisar e compreender as "leis" da construção fílmica. $\mathrm{O}$ coordenador deste projeto, além de ser citado frequentemente por Hitchcock como o formulador das diretrizes do "cinema puro", teve como principal objeto de estudo o cinema americano da época - que tinha em Griffith seu maior representante -, e teve Eisenstein como um de seus alunos. Assim, Lev Kuleshov nos serve como uma espécie de nexo de relações entre os cineastas aqui tratados, e através deles, entre os problemas do encadeamento de planos. Sob a coordenação de Kuleshov, testes foram realizados, identificando as operações mais comuns em filmes bemsucedidos, reconstruindo-as num contexto experimental. A suposição era de que, uma vez reconhecidos os fatores mais relevantes, estes poderiam ser investigados e mesmo tornados vetores para a criação. Podemos então observar os dois experimentos mais célebres, e com eles tentar organizar mais claramente o campo de possibilidades da dimensão virtual.

Num dos experimentos, Kuleshov filmou dois atores caminhando nas ruas, montando os planos de modo que os dois pareciam se cumprimentar à distância, caminhar um em direção ao outro, e finalmente se encontrar em frente a um prédio. O detalhe 
crucial é que os planos foram filmados em diferentes cidades; foram os olhares e gestos, portanto, que criaram a impressão de um único local. O que Kuleshov chamou de "geografia criativa" é uma versão do sistema de orientações desenvolvido por Griffith, no qual planos descontínuos são organizados para sugerir uma continuidade. A propriedade isolada e investigada é a tendência integrativa da dimensão virtual, em que o espaçotempo de cada plano é adaptado ao referencial fixo da tela e da projeção, tendo como objetivo a criação de um novo espaço-tempo, resultado do acúmulo de elementos apresentados em sequência. É importante notar que essa unidade possui alguma independência nos eixos temporal e espacial. Em princípio, pode-se recorrer a diferentes ligações temporais sob as mesmas coordenadas espaciais, isto é, tanto a elipse como o overlap e a continuidade podem ser utilizados, e podem manter a unidade no espaço desde que respeitem o sistema de orientações. Além disso, como a unidade dos espaços reais não é idêntica à do espaço virtual, a geografia criada não necessita ser plausível em relação aos espaços reais; a reconstituição das referências reais é uma possibilidade, mas não uma necessidade. A geografia virtual é a proposta de um novo contexto ao qual os planos devem se adequar.

Em outro experimento, Kuleshov combinou três planos: (1) num close-up, o rosto inexpressivo de um homem com o olhar voltado para uma região fora da tela; (2) em outro close-up, um prato de sopa, centralizado, sob o mesmo olhar impassível da câmera, e a mesma iluminação genérica; (3) um retorno do close-up do homem. Tendo como base esta sequência, Kuleshov generalizou o procedimento, substituindo o segmento central, o plano do prato de sopa, por outros planos, como uma criança deitada num caixão e uma mulher sorrindo. O experimento é análogo a uma pergunta: o que ocorre quando o plano de um rosto humano é intercalado com o plano de um objeto? A variedade de objetos acrescenta outra questão: mantendo o rosto e mudando o objeto, o resultado da sequência é modificado? Os resultados são conhecidos. Acreditou-se que a presença do objeto entre os planos do rosto sugeria que este objeto era o alvo do olhar, e que, no retorno do rosto, o espectador seria capaz de reconhecer, numa espécie de projeção, uma expressão neste rosto que correspondia à relação dele com o objeto. Esta expressão seria a fome, o luto, o desejo: variáveis numa equação visual. Nenhum dos planos, se visto isoladamente, sugeriria mais que o registro de um objeto; vistos em sequência, sugeriam um sentido particular. A posição dos elementos na cadeia daria a eles um novo contexto. Aqui, a propriedade destacada é a possibilidade, ou mesmo a necessidade de se realizar inferências durante uma sequência. Balázs argumenta que 
a confiança de que estamos vendo uma obra de intenção criativa e com um propósito, e não uma série de imagens jogadas e coladas ao acaso, é uma pré-condição psicológica para o espectador de cinema, e sempre esperamos, pressupomos e procuramos algum sentido nos filmes que vemos. ${ }^{295}$

E quando Eisenstein afirma que a montagem possui um aspecto dialético - que algo sempre surge na colisão de diferentes planos -, há a defesa por um método criativo, mas também o reconhecimento de uma tendência a reconhecer sentidos em justaposições de imagens, no que Jean Mitry chamou de "lógica da implicação". 296

Uma pergunta que deve ser feita é se a validade dos efeitos depende apenas do tipo de objeto/evento filmado, ou se não depende também da maneira como é filmado. Em suas descrições dos experimentos, Kuleshov parece considerar objetos/eventos que não interagem necessariamente com a dinâmica do espaço pictórico; no caso do segundo experimento, são objetos que não se movem, e que parecem iluminados e filmados por um ângulo tal que somos capazes de os identificar sem dificuldade. Essas escolhas condizem com as necessidades de um experimento: para revelar mais claramente uma propriedade, os parâmetros devem ser tornados tão fixos, tão estáveis, tão "neutros" quanto for possível. Mas, se por um lado isso dá à sequência um aspecto silogístico, por outro lado não toca na questão das variáveis "expressivas", limitando o alcance da demonstração. No caso, se algo é demonstrado, não o é necessariamente em casos distantes da configuração estilística proposta. O que seria formulado, nesse sentido, não é apenas um princípio de ordenação de elementos de modo a criar sentido; o que se formularia, ainda que indiretamente, seriam as condições nas quais esta "projeção de sentido" ocorreria de forma menos resistente, com menos interferência dos parâmetros expressivos. Conforme a configuração da sequência afasta-se deste modelo, pode-se considerar que mais as características expressivas de cada plano contribuiriam à criação ou mesmo ao condicionamento deste sentido.

Por mais arbitrários que pareçam os experimentos de Kuleshov, eles ainda assim recorrem a convenções. No primeiro experimento, o sistema de orientações é uma convenção, ainda que seja uma convenção "natural", ou a mais próxima de uma adaptação do espaço real ao espaço virtual. No segundo experimento, a convenção é o plano de ponto de vista, ou ainda, o "plano de reação". Nos dois casos, há uma escolha

\footnotetext{
295 Béla Balázs, Theory of the Film (London: Dobson, 1952), p. 119.

296 Jean Mitry, Esthétique et psychologie du cinéma, vol. I, op. cit., pp. 283-285.
} 
dos tipos de planos que limita as inferências: entre todas as associações possíveis, o espectador é direcionado a apenas uma, ou a um conjunto reduzido que possibilita a compreensão dentro de uma margem estreita. Um plano então passa a "reagir" ao plano anterior, ou aos planos anteriores, de forma específica, menos arbitrária. Pode-se dizer que uma propriedade integrativa da sequência permite a leitura, que sempre haverá algum sentido a ser derivado da justaposição; mas o sentido "emerge" também por ser convencional, e é tão mais claro quanto mais os planos se encaixam nas convenções. Em Janela indiscreta, por exemplo, os planos de Jeff nos sugerem o que pensar e sentir. Os mesmos planos dos eventos observados por ele, sem estas reações, teriam outro contexto, isto é, seriam implicados na sequência de outra forma; na ausência de um contexto bem definido, os mesmos planos seriam provavelmente ambíguos. Podemos mesmo definir neste caso a ambiguidade como o enfraquecimento do contexto entre os planos. Como a existência de um sentido unívoco é implicada no contexto, e como o contexto se organiza por inferências mais ou menos direcionadas, a ambiguidade resultante de sua ausência seria como uma energia potencial, em busca de resolução.

O que Burch chamou de Modo de Representação Institucional, e que às vezes é tratado como a "linguagem do cinema clássico", preza por uma economia nessas relações. Aumont se refere ao "aristotelismo perfeito" desse cinema, uma abordagem que busca eliminar as faltas e os excessos nesta apreensão, que busca reduzir a ambiguidade e dar a cada evento uma causa compreensível - o que, no nível imediato dos planos, levaria à eleição da continuidade como princípio de encadeamento central. Isso se basearia, da mesma forma, numa convenção, ou ao menos no reconhecimento tácito, pelo espectador, de que certos critérios estão envolvidos na apresentação da obra:

Toda a montagem clássica, resultante do que se chama às vezes estética da transparência, supõe que o espectador seja capaz de 'recolar os pedaços' do filme, isto é, de restabelecer mentalmente as relações diegéticas, logo, temporais, entre blocos sucessivos. Isso só pode ser feito por meio de um saber, ainda que mínimo, sobre a montagem, ou melhor, sobre a mudança de um plano em um filme. É indispensável, entre outras coisas, para compreender bem um filme (para compreendê-lo como seu dispositivo quer que seja compreendido), saber que uma mudança de plano representa uma descontinuidade temporal na filmagem - que a câmera que registrou a cena não se deslocou bruscamente para outro ponto do espaço, mas que houve, entre as tomadas de cena e a projeção, esta outra operação que é a montagem. ${ }^{297}$

${ }^{297}$ Aumont, A imagem, op. cit., p. 175. Ver também Aumont, O cinema e a encenação, op. cit., pp. 37-38. 
Tomando como base essas observações, consideremos a seguir alguns desvios possíveis dessas mesmas propriedades, como formas de explorar as mesmas categorias as mesmas referências do espaço e tempo virtuais - com outros fins.

\subsubsection{Variantes da figuração}

Em meados dos anos 1920, no período em que Eisenstein produzia seus primeiros longasmetragens, um cineasta estoniano radicado na França realizou filmes com uma proposta significativa no recorte aqui considerado. Dimitri Kirsanov fez parte de uma tendência, que também incluiu outros cineastas na Alemanha, dedicada a explorar o potencial puramente visual do cinema. Recusando os intertítulos, esse cinema buscou construir narrativas em que tudo seria dado pelos gestos e olhares dos atores, e pelos procedimentos técnicos da câmera e da montagem. ${ }^{298} \mathrm{~A}$ insistente recusa à palavra fez com que uma série de manobras tivessem de ser encontradas para representar o desenvolvimento das histórias, o que torna a obra de Kirsanov, e sobretudo seu filme mais conhecido, Ménilmontant (1926), um exemplo de construção figurativa. ${ }^{299}$

A primeira sequência do filme é um assassinato representado de forma extremamente fragmentada. Sem qualquer contexto ou apresentação, um casal é retirado à força da própria casa por um homem que, após uma briga, mata ambos com um machado. A fragmentação ocorre no espaço e no tempo: no espaço, pelo recorte da cena em uma

${ }^{298}$ No cinema alemão do período, foi no kammerspiel que a recusa aos intertítulos teve mais força. Exemplos seriam Hintertreppe (Paul Leni, 1921), Sylvester (Lupu Pick, 1924) e A última gargalhada (Der Letzte Mann, F.W. Murnau, 1924). Para uma contextualização dessa produção e de suas influências, ver o capítulo 11 de Lotte Eisner, A tela demoníaca (São Paulo: Paz e Terra, 2003). A partir dos anos 1930, as obras que seguem nessa direção parecem se enquadrar no que Michel Chion denominou "cinema ritualizado", filmes em que a redução do diálogo, bem como da música, "liberta o ouvido e nos permite ouvir como os sons e o movimento visual organizam o tempo". Ver Michel Chion, Film: A Sound Art (Nova York: Columbia University Press, 2009), pp. 111-113. Nos EUA, os exemplos estão às vezes em produções de gênero: thrillers como O ladrão silencioso (The Thief, Russell Rouse, 1952) e Demência (Dementia, John Parker, 1955), ou musicais como Convite à dança (Invitation to the Dance, Gene Kelly, 1956). Na Europa, pode-se encontrar o mesmo impulso em diversos contextos: Trafic (Jacques Tati, 1971), O baile (Le bal, Ettore Scola, 1983), Tren de sombras (José Luis Guerín, 1997) e Essential Killing (Jerzy Skolimowski, 2010) seriam casos representativos. Dois cineastas que se dedicaram constantemente a essa questão foram Sharunas Bartas e Franco Piavoli. Consideramos aqui os filmes que parecem ter ambições narrativas; no terreno do cinema experimental e no documentário os exemplos se multiplicariam indefinidamente.

${ }^{299}$ Kirsanov é talvez o único nome citado nesta tese que se refere ao cineasta como um "compositor de filmes". Músico de formação, ele defendeu que o compositor no cinema deveria "reger" todas as etapas e disciplinas de sua arte, fazendo referência ao conhecimento de ritmo, harmonia, melodia e arranjo por um compositor musical. Ver Dimitri Kirsanov, "De la synthèse cinématographique", Revue musicale (dezembro de 1934), pp. 30-31. 
série de close-ups que nos mostram apenas partes da ação; no tempo, pelo isolamento desses close-ups de qualquer contexto, qualquer referência do que ocorre antes ou depois, incluindo apenas gestos rápidos e marcantes. Em termos de figuração, Kirsanov recorre portanto à sinédoque e à elipse.

A sinédoque é melhor exemplificada nos primeiros planos, todos mostrando uma porta fechada, mas alterando rapidamente a escala dos enquadramentos, mostrando num plano médio os personagens através do vidro, e depois, em close-up, a maçaneta sendo girada, para logo em seguida retornar ao vidro e depois à maçaneta:
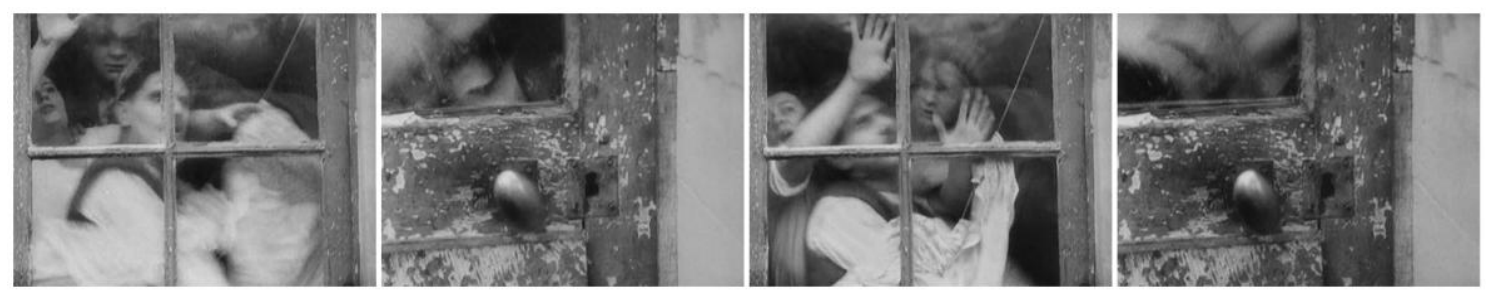

Essa estratégia permanece no decorrer da sequência. As ações são recortadas e vistas por diferentes enquadramentos, como se todas as partes e etapas pudessem ser observadas alternadamente, mas nunca a totalidade da ação. Se o recorte espacial é inevitável, o uso de figuras torna-se uma maneira de potencializar este recorte, de dar a ele uma força expressiva. Em Ménilmontant, o potencial expressivo é quase sempre utilizado pela via de maior sugestividade: a postura de Kirsanov parece ser que, se há uma possibilidade de representar o evento indiretamente, esta é a possibilidade a ser escolhida. Os close-ups, então, fazem alusão ao espaço virtual; não apenas ao espaço do fora-de-campo, do espaço imediatamente externo àquele enquadramento, mas ao espaço total que é criado pelo acúmulo de close-ups. Ao recorrer quase exclusivamente aos close-ups, Kirsanov faz com que a "construtividade" do espaço seja permanente.

Da mesma forma, a restrição visual a uma parte isolada desse espaço faz com que o espectador não tenha qualquer referência quanto ao seu contexto temporal. Não são dadas marcações de duração ou frequência; o espectador não é capaz de medir uma ação em relação a outra, ou duas ações em relação a uma referência comum a ambas. $O$ domínio temporal do filme é o de um presente constantemente atravessado por ações, sendo que algumas delas criam fraturas na continuidade, parecem retornar ou avançar brevemente no fluxo do evento. Um momento significativo desse efeito é quando, durante a briga fora da casa, Kirsanov corta repetidas vezes para um machado. O primeiro close- 
up do machado surge como uma inserção misteriosa, a revelação de uma parte do espaço que não nos havia sido apresentada; mas, dado o contexto da cena, e conforme outros planos são apresentados, torna-se claro que os personagens vão em breve interagir com o objeto. Durante oito planos extremamente breves, alterna-se planos médios e close-ups, o machado presente na maior parte deles como uma entidade investida de força magnética, até que no último desses planos o invasor finalmente consegue pegar o machado, e o plano seguinte mostra a mulher já ferida, caindo no chão:
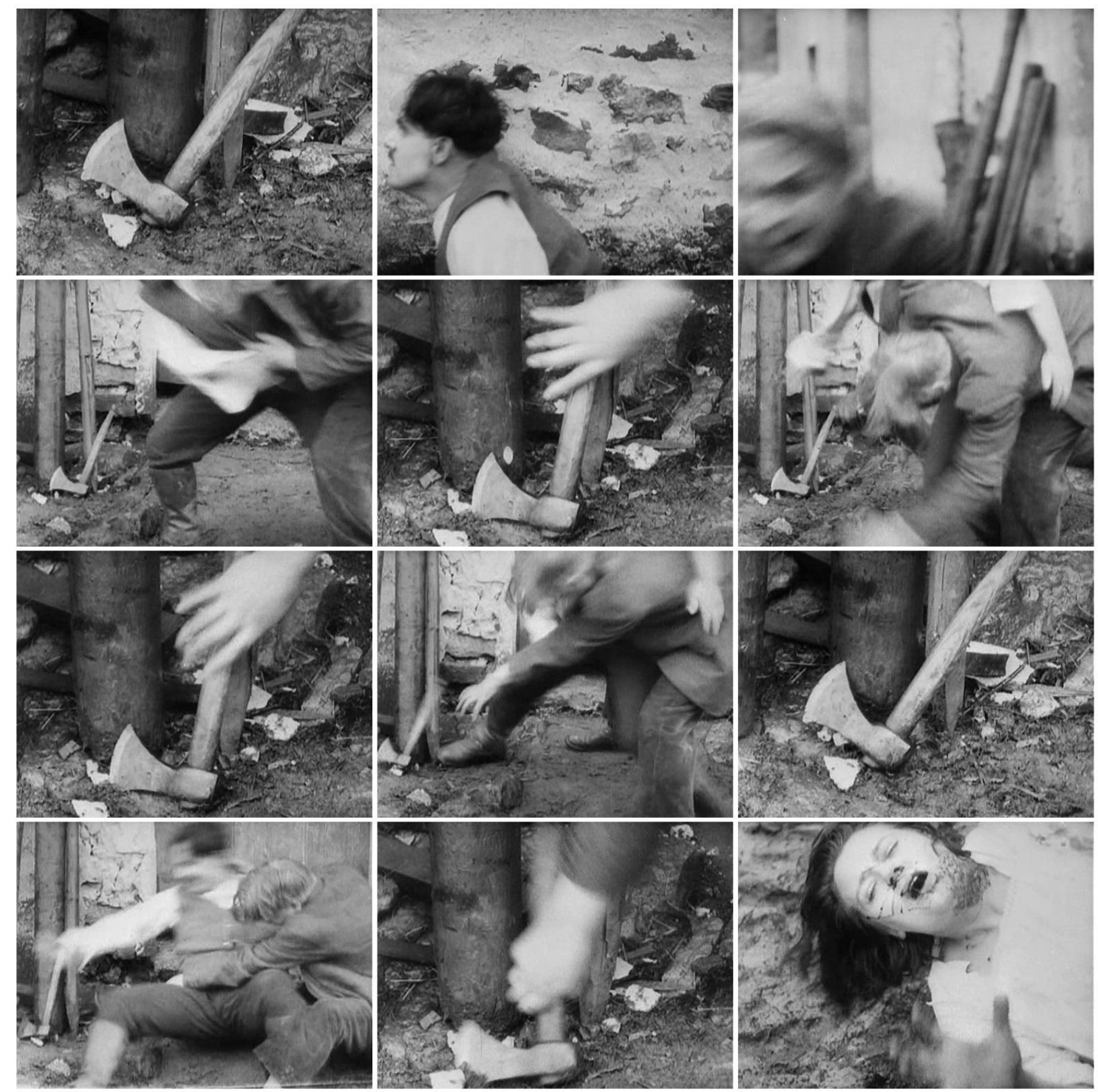

Na sequência seguinte, as filhas do casal descobrem a morte dos pais, e há uma elipse para as duas no cemitério, perante os túmulos. Vemos o túmulo do pai e o túmulo da mãe, cada um num close-up separado; um close-up do caminho por onde elas chegaram; e novamente as duas garotas no cemitério, agora num plano mais aberto. 
Kirsanov apresenta então outros planos dos túmulos, desta vez cobertos por vegetação e com a cruz e as flores caídas, representando claramente uma passagem de tempo, reforçada pelas transições lentas entre as imagens. Mas, imediatamente após as duas elipses, isto é, logo após indicar um avanço na cronologia em relação aos planos das garotas no cemitério, o filme segue com um plano das duas caminhando numa estrada com as mesmas exatas roupas vistas anteriormente - as roupas do luto -, com os mesmos gestos e o mesmo andamento, como se houvéssemos retornado ao momento anterior. $\mathrm{O}$ que havia sido apresentado como uma elipse torna-se agora, por compreensão retroativa, uma prolepse, o vislumbre de um tempo futuro. O importante é notar que a figura da prolepse só é caracterizada após o "retorno"; sem isso, permaneceria uma elipse convencional. $^{300}$
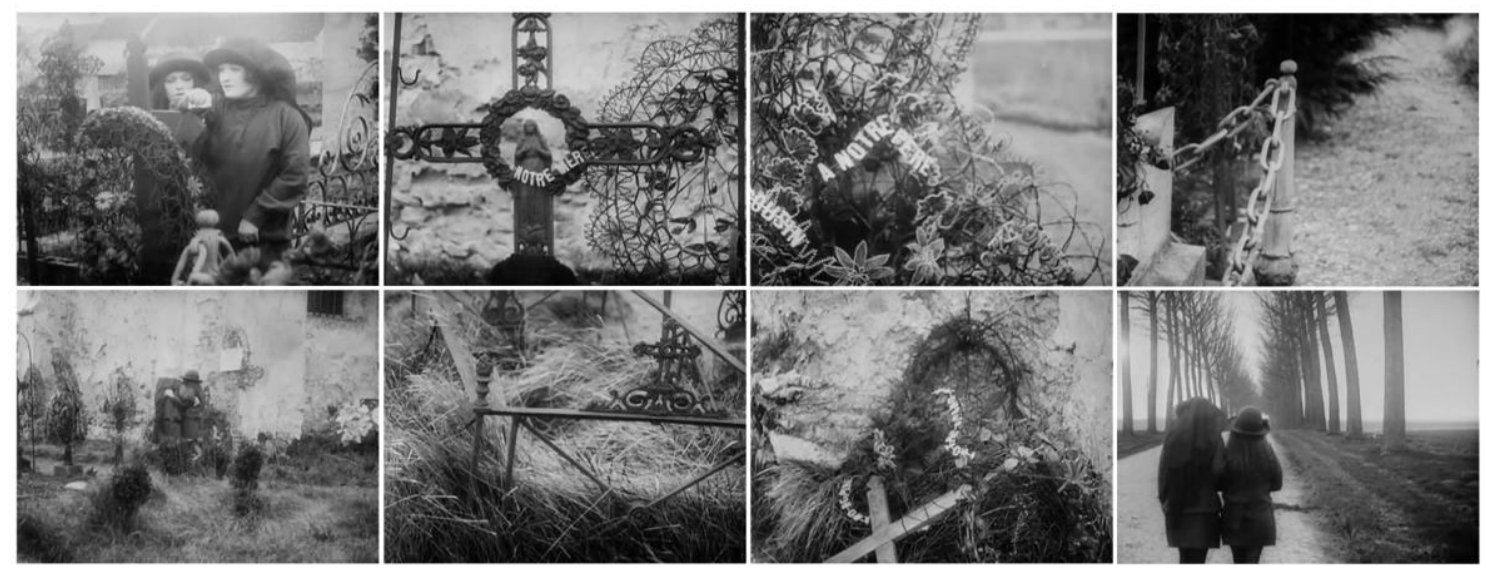

Ménilmontant (Dimitri Kirsanov, 1926): os quadros 6 e 7 representam elipses em relação aos anteriores; mas no quadro seguinte, o retorno cronológico torna os planos anteriores um exemplo de prolepse.

O que estes trechos de Ménilmontant nos permitem observar é como, na ausência de uma referência inicial, a propriedade construtiva da montagem faz com que o "contexto de implicação" pareça constantemente ativo, reformulando e instigando inferências a cada nova imagem. Um plano é assim capaz de apresentar uma região do espaço que ainda não foi tornada parte da ação sem quebrar a cronologia, numa sugestão que ocorre dentro da continuidade, assim como é capaz de fazê-lo quebrando a

\footnotetext{
${ }^{300}$ Para um comentário mais detido sobre a primeira metade do filme, inclusive fazendo referência constante às figuras retóricas, ver P. Adams Sitney, "The Idea of Abstraction", Film Culture 63/64 (1976). Sitney complementa essas observações na seção sobre Kirsanov em Cinema: A Critical Dictionary, vol. II, ed. Richard Roud (Nova York: Viking Press, 1980), pp. 551-553. Ver também o segundo capítulo de P. Adams Sitney, The Cinema of Poetry (Nova York: Oxford University Press, 2014), onde Kirsanov é analisado no contexto das discussões sobre o "cinema de poesia", a partir do artigo de Pasolini.
} 
cronologia, com uma prolepse ou um flash-forward. Podemos então rever o diagrama apresentado com os possíveis encadeamentos entre os planos, incluindo as inversões cronológicas:

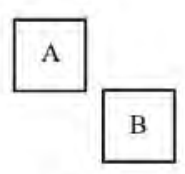

ELIPSE

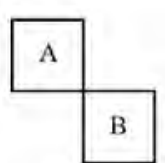

CONTINUIDADE

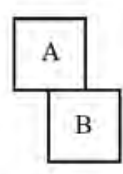

OVERLAP

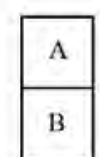

SIMULTANEIDADE

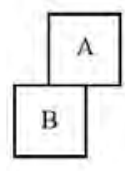

OVERLAP INVERSĀO

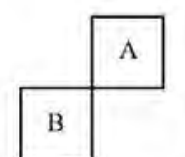

INVERSÃO

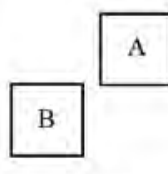

ELIPSE INVERSÃO

Outro caso nas vanguardas dos anos 1920 que nos permite um acréscimo à reflexão sobre as figuras é o dos surrealistas, mais especificamente um filme como $U m$ cão andaluz (Un chien andalou, Luis Buñuel, 1928). O surrealismo foi apontado por Jakobson como uma reação metafórica à tendência metonímica do cubismo: no lugar da transformação de um espaço por sua decomposição, propuseram substituições de objetos em contextos inteiramente discrepantes. A orientação metafórica é presente no filme de Buñuel, mas já na sequência de abertura é revelada também a importância do aspecto metonímico da montagem.

Num close-up, vemos um homem (o próprio Buñuel) fumando um cigarro, olhando para cima. Corta para seu ponto de vista: um plano do céu, à noite, com a lua na região esquerda do quadro, e uma nuvem surgindo do lado direito. Retornamos ao closeup do homem e ele se prepara para usar uma navalha. Há então um close-up do rosto de uma mulher, com as mãos do homem preparadas para cortar seu olho. A navalha é posicionada na horizontal e tem início o movimento da mão. No momento em que veríamos a navalha cortar o olho, retorna o plano do céu: a nuvem que surgia no canto da imagem passa sobre a lua. De repente, corta para um close-up ainda mais fechado que o anterior, mostrando o olho de um animal sendo cortado por uma navalha e expelindo um líquido viscoso: 


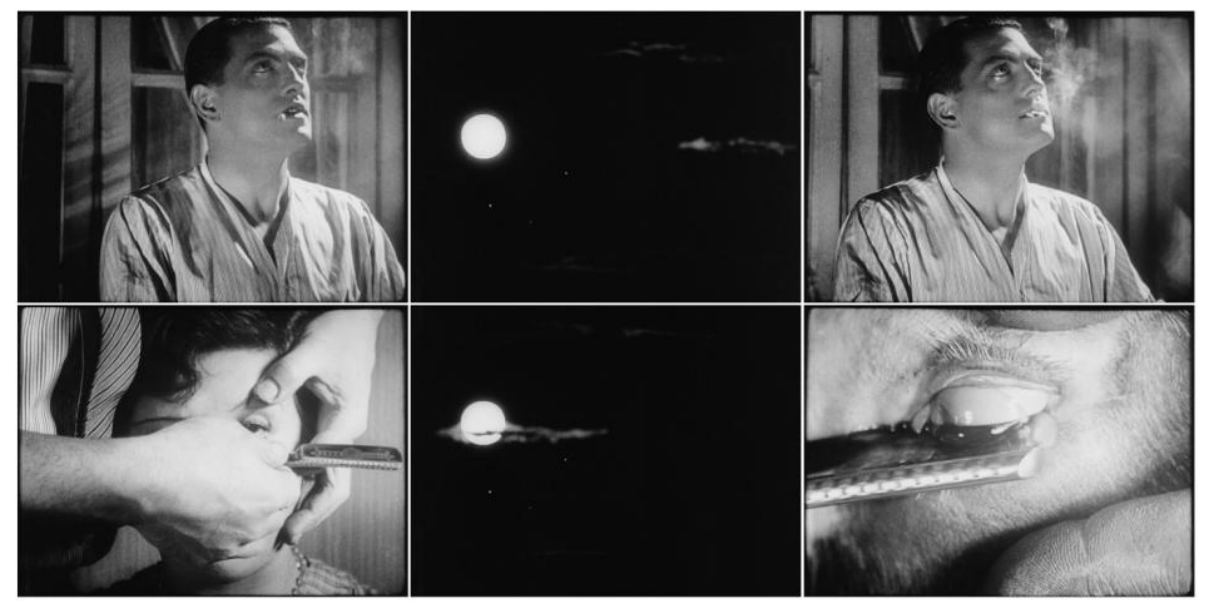

Em termos de figuração, o encadeamento desses planos é uma combinação de metáfora e metonímia. As relações entre os planos iniciais são metonímias tradicionais a construção de uma mesma cena através de suas partes, relacionadas por olhares e segmentações de corpos. O plano da lua, em sua primeira aparição, sugere apenas uma parte do espaço cênico, o objeto do olhar do personagem. Ao retornar no exato momento em que a navalha cortaria o olho da mulher, entretanto, sugere uma metáfora daquele gesto, ou seja, a substituição de uma ação por semelhança visual. A posição dos objetos na mesma região da tela, a orientação e a velocidade dos movimentos, tudo contribui para que os dois planos sejam associados como paralelos, como se uma ação fosse a calma evocação da violência da outra. Mas imediatamente depois, surge um novo plano, ainda mais violento do que sugeria o gesto anterior: num enquadramento ainda mais próximo, o olho é mantido no centro da imagem, na concretização do gesto que pensávamos ter sido substituído.

A preferência surrealista por justaposições irracionais é recorrente no filme, quase sempre através da montagem metafórica. Numa das cenas, um personagem observa sua mão, e o filme corta para um close-up que parece seu ponto de vista: ele vê a própria mão, com um furo no meio, de onde saem formigas. A mão é posicionada como uma diagonal que atravessa a tela do canto superior esquerdo ao canto inferior direito; plasticamente, é uma massa sólida em tons de cinza, com a região pouco abaixo do centro marcada pelas formigas, pontos escuros que se destacam. Há então uma fusão, e seguimos a outro closeup, desta vez da axila de uma mulher deitada na areia da praia: seu braço está posicionado na mesma diagonal que a mão no plano anterior, e os pelos pretos sob seu braço estão na mesma região da tela que as formigas. Segundos depois, uma nova fusão, agora para o close-up de um ouriço, também na areia da praia, uma forma circular escura posicionada 
na mesma região que as formigas e os pelos. Finalmente, há uma fusão para o plano de uma mulher observando uma mão decepada na rua - um plano visto de cima, e com o enquadramento marcado por uma íris, ecoando a forma circular do ouriço mas invertendo as relações de escuridão e clareza sobre a tela:

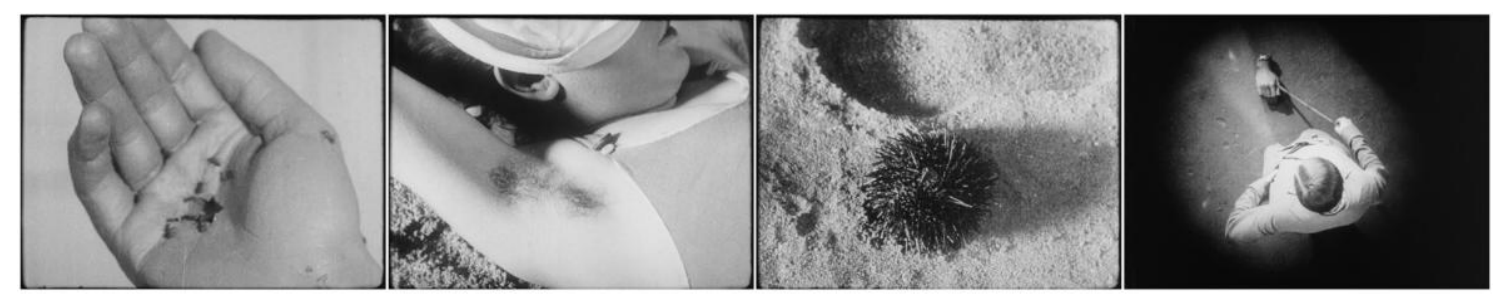

O caráter arbitrário das substituições é o gatilho da sequência, enfatizando a semelhança puramente visual entre os objetos. Não há movimento ou contexto espacial comum entre os planos; a passagem de um a outro é justificada pelas fusões e a organização dos elementos na tela. $\mathrm{O}$ encadeamento retorna ao ambiente do quarto onde o personagem observou a própria mão, mas após imagens com as quais não possui qualquer ligação. A sequência, como um todo, poderia ser estendida indefinidamente, pela inclusão de outros objetos entre os planos das mãos; desde que sob a lógica da semelhança visual, a mesma impressão de uma sucessão ao acaso, que dispersa as possibilidades de construir um único espaço e um único direcionamento temporal, seria mantida.

O filme de Buñuel, como o de Kirsanov, exemplifica as interferências que a figuração pode exercer no caráter espacial e temporal das sequências. Uma vez que a cronologia e a plausibilidade das ações não são os critérios centrais, e uma vez que a continuidade espaço-temporal é vista como flexível, como podendo ser articulada neste ou naquela direção, tendo esta ou aquela parte destacada ou deslocada - nessas ocasiões, o pensamento figurativo torna-se uma forma de encontrar novas formas de organizar o material.

\subsubsection{O gesto e a ligação vertical}

No terceiro capítulo, foi mencionado que, para Maya Deren, o cinema deveria ser uma ferramenta para reconstruir o espaço e o tempo. Deren fez a defesa de um cinema com base estritamente fotográfica, ou seja, desconsiderando a alternativa das animações e 
colagens. A partir disso, podemos ver em alguns de seus filmes um exemplo da reorganização do material fílmico de modo a explorar as possibilidades construtivas da dimensão virtual.

Na abertura de At Land (1944), uma mulher, interpretada pela própria cineasta, é deixada pelas ondas na areia de uma praia. Em planos invertidos, vemos as ondas retornarem ao mar como se todo o movimento anterior fosse apenas uma forma de carregar a personagem. Quando a mulher acorda, ela se arrasta pelo lugar e se aproxima de um imenso tronco caído. Em câmera-lenta, ela se agarra ao tronco e inicia o que parece ser uma escalada, filmada em uma série de close-ups mostrando as mãos e os pés apoiados em partes do tronco. De repente, é inserido o close-up de um espaço incongruente: vemos as mãos da mulher sobre uma mesa de jantar, como se fosse o ponto alto de sua escalada. Em seguida, um close-up de seus pés, apoiados no tronco. Um novo espaço, impossível em cada um dos planos isolados, é criado por sua justaposição:

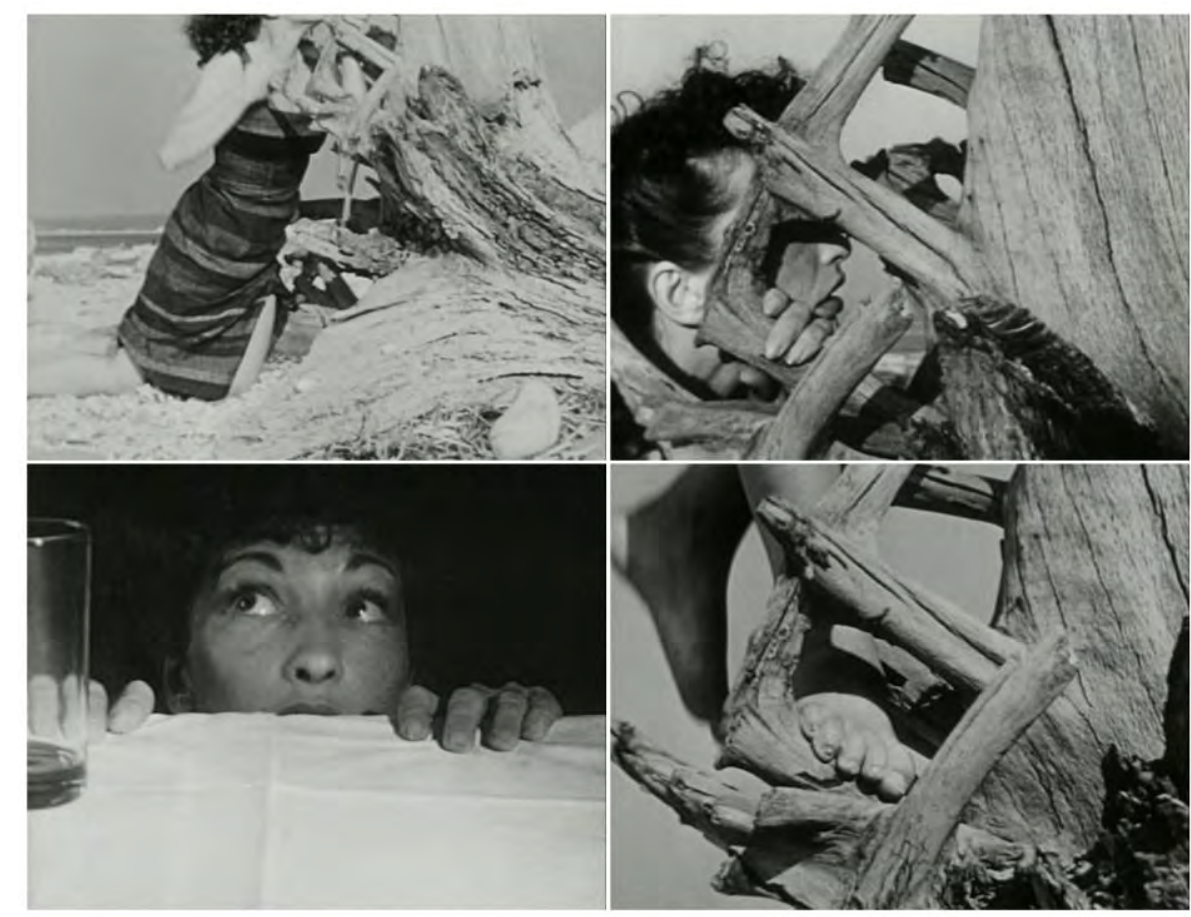

Deren reforça o quanto o procedimento depende da presença de um corpo, e mais especificamente de um movimento, para realizar a ligação entre os espaços:

Eu utilizei a integridade do movimento - sua continuidade de ritmo e andamento - para ligar ambientes originalmente distantes. Isso é obviamente um uso do potencial temporal 
do filme, no sentido de que reside no ritmo e no movimento, e no fato de que dois locais separados podem ser conectados pela força desse ritmo. ${ }^{301}$

Se a continuidade "real" é negada, por outro lado é instituída uma "continuidade artificial". O importante a notar é que os critérios da percepção desta nova continuidade são os mesmos do sistema de orientação tradicional. Lembremos que Deren fez também a defesa do referencial fotográfico para que os planos invertidos e em câmera-lenta tivessem sua força evidenciada: é por essa ótica que podemos compreender sua preferência pela manutenção das condições físicas, e mesmo por movimentos simples e reconhecíveis. As distorções do registro servem aqui não para impedir a construção de uma unidade espaço-temporal, mas para permitir a construção de uma nova unidade espaço-temporal que depende da submissão de cada plano ao contexto estabelecido pela sequência. Se numa das coreografias de Fred Astaire poderíamos dizer que encontramos uma investigação do caráter unificado da cena, tornando os movimentos um perpétuo jogo com a gravitação, no caso de Deren essa mesma investigação é realizada no encadeamento entre os planos. Não mais o virtuosismo de um dançarino no espaço cênico da performance, o que se apresenta é o virtuosismo da própria concepção geral do filme, da coordenação entre a filmagem e a montagem.

A Study in Choreography for Camera (1945) aborda o problema de maneira ainda mais direta. A câmera faz uma panorâmica numa floresta, mostrando, durante sua passagem, o dançarino Talley Beatty realizando uma coreografia. A panorâmica prossegue numa atualização do campo cênico, e quando a região onde Beatty foi visto é inteiramente deixada fora do quadro, vemos Beatty em outra parte do espaço, como se já estivesse lá desde o início do movimento. A panorâmica continua, e o mesmo processo ocorre mais duas vezes, sendo que na segunda, Beatty está numa região próxima da câmera - a câmera então estaciona o movimento, mostrando seu rosto lateralmente, num close-up:

${ }^{301}$ Maya Deren, “Creating Movies with a New Dimension: Time”, op. cit., pp. 135-136. 

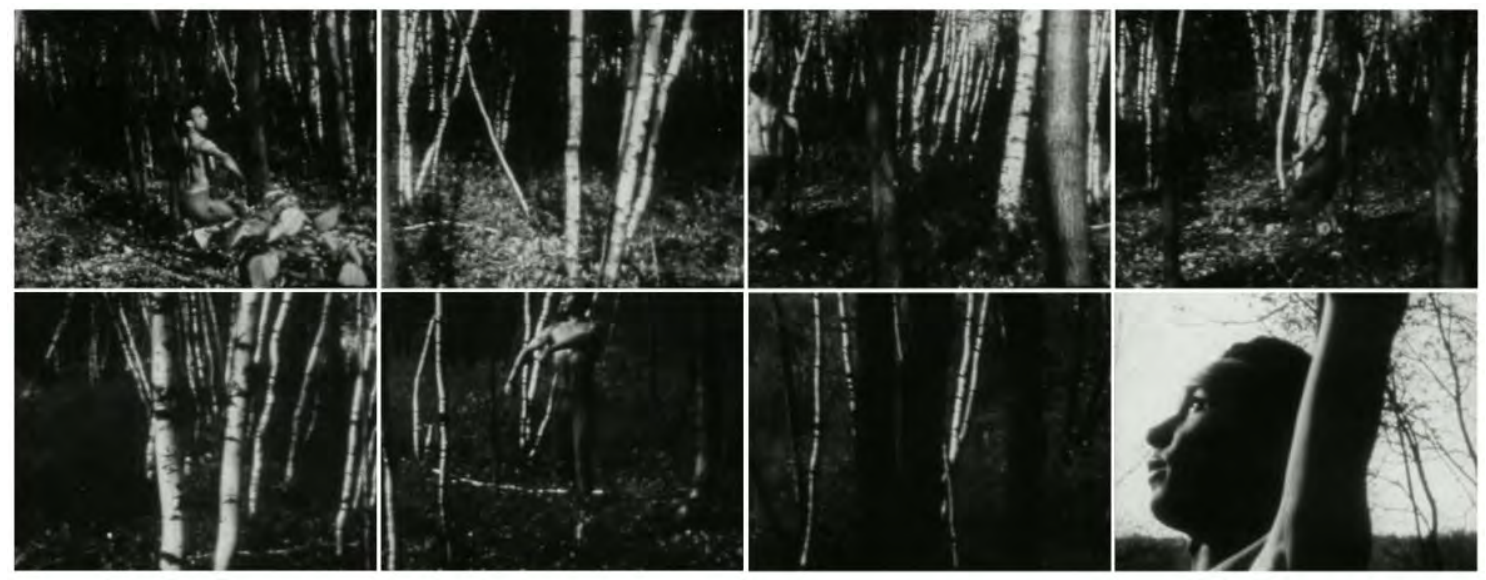

Em seguida, o close-up dá lugar a um plano de Beatty visto de corpo inteiro no espaço da floresta. Sua perna é erguida lentamente, e quando tem início o movimento descrescente, o filme corta para outro espaço, o que parece ser um quarto, onde vemos, no lado esquerdo da tela, a perna de Beatty num movimento que dá continuidade ao que vimos anteriormente. Segue-se a isso um plano de Beatty dançando no quarto, e durante um giro, corta-se para um novo espaço, o que parece ser um pátio, onde vemos, em close-up, os pés de Beatty fazendo o mesmo giro que teve início no quarto.

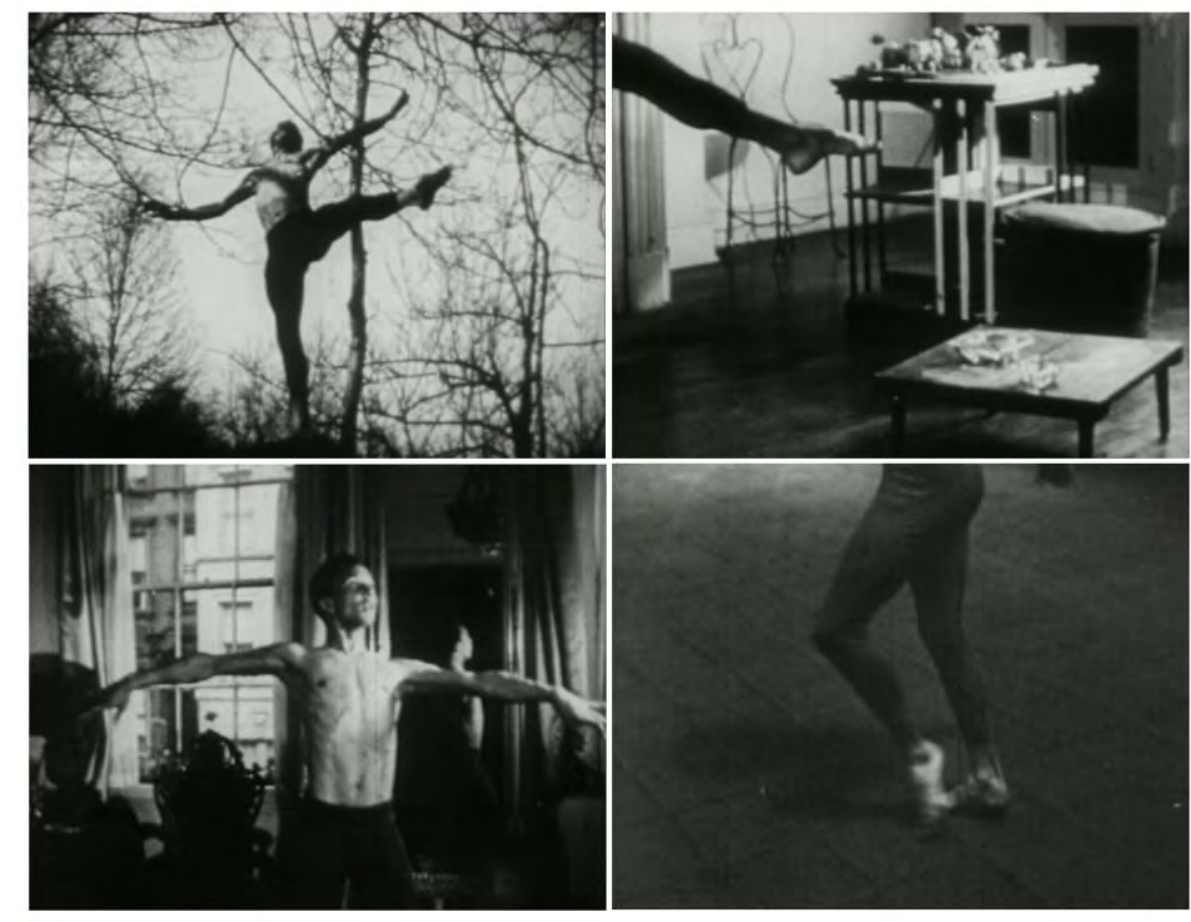

As mudanças de espaço através da continuidade coreográfica em A Study in Choreography for Camera (Maya Deren, 1945) 
Como em At Land, Deren organiza A Study in Choreography for Camera inteiramente ao redor dos gestos de atores-dançarinos. A lógica nesses filmes é que, se por um lado a câmera possui a liberdade para cortar de um espaço a outro, de ampliar o alcance diegético para locais que não eram pressupostos anteriormente, por outro lado essa operação é sempre realizada pela ancoragem do movimento humano. A razão para isso é simples: o corpo humano se torna aqui o objeto privilegiado para criar as orientações espaciais e temporais, ou seja, as referências direcionais e duracionais pelas quais os planos justificam seus encadeamentos.

Essa justificativa depende, igualmente, do que Noel Carroll apontou como sendo uma versão do efeito da "ampliação" descrito por Michotte. O efeito de ampliação é caracterizado pela "passagem" do movimento de um objeto a outro, como se o movimento do segundo fosse causado pelo movimento do primeiro. Carroll argumenta como essa adaptação do efeito pelo cinema, "não para reforçar a impressão de causalidade entre eventos concebíveis como relacionados, mas para criar a impressão de conexão entre eventos claramente discrepantes", é um procedimento típico, é mesmo um tropo do filme de vanguarda. ${ }^{302}$ Além dos filmes de Deren, encontramos também num filme como Dance in the Sun (1953), de Shirley Clarke, onde um dançarino é filmado em dois locais diferentes, de modo que a montagem alterna entre os dois espaços através da unidade coreográfica. Novamente, são os critérios da orientação realista, da continuidade de um movimento entre os planos, que embasa a percepção de um único evento atravessando dois locais distintos. O ângulo em relação ao qual o corpo é visto, a direção do movimento, a região da tela mobilizada pelo movimento são as propriedades internas de cada plano consideradas na organização das sequências no filme de Clarke. O resultado é um paralelismo dos espaços "reais" - os espaços em profundidade de cada plano - criado pela unidade do movimento sobre a tela, como se fosse possível articular de maneira independente a figura e o espaço no qual ela se encontra.

${ }^{302}$ Ver Noel Carroll, "Causation, the Ampliation of Movement and Avant-Garde Film", in Theorizing the Moving Image, op. cit., p. 171. 


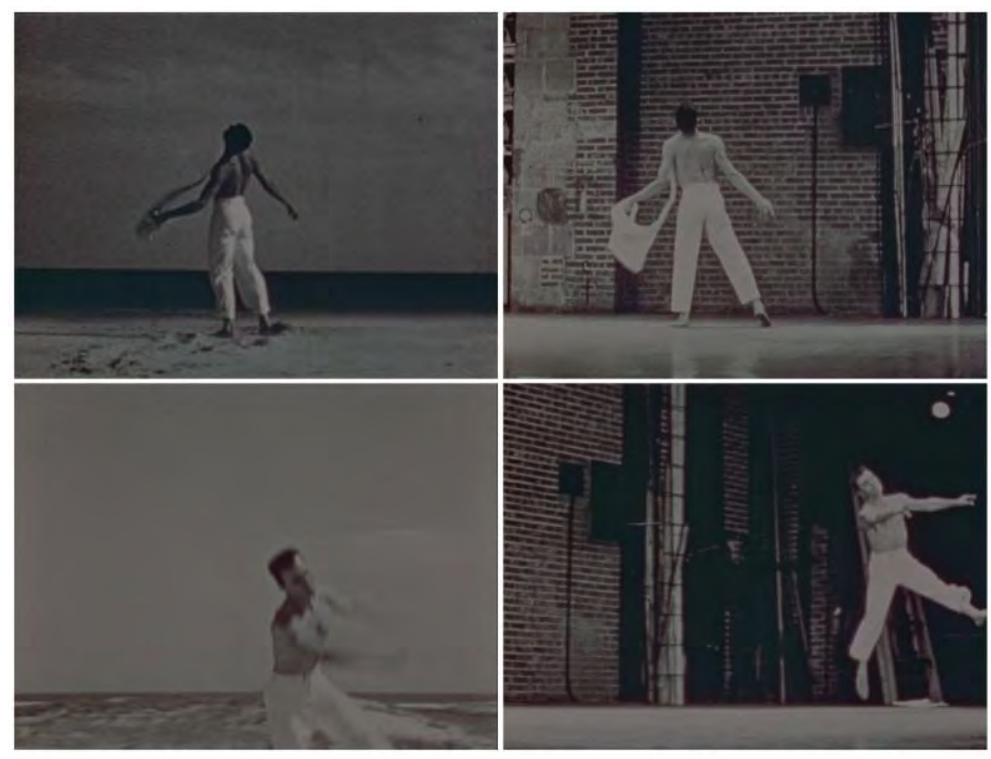

Dois trechos de Dance in the Sun (Shirley Clarke, 1953) nos quais a passagem de um espaço a outro é realizada continuamente, através dos gestos coreográficos.

A esse tipo de montagem, que opera a transição contínua entre os planos mas que não se baseia numa concepção narrativa, Deren propôs o nome "montagem vertical". Assim como na distinção entre o gesto prático e o gesto coreográfico, Deren faz a distinção entre o desenvolvimento horizontal, "lógico", das ações, baseado na causalidade estrita, e o desenvolvimento "vertical", onde as ações seriam conectadas por "uma ideia ou uma emoção que atrai para si mesma as imagens dispersas”. Ela se refere à investigação de uma situação, da "ramificação do momento", como se as ações registradas pela câmera, mais do que os eventos em si, fossem matrizes composicionais. Se a continuidade espaço-temporal pode ser respeitada em sua reconstrução pela montagem, pode também ser variada em diversos aspectos, estabelecendo relações entre os espaços que se assemelham a ligações metafóricas. Um espaço $x$, sem perder sua identidade, é confrontado com um espaço $y$ que, mesmo afirmando sua própria identidade, possui em comum o fato de servir de palco ao que a montagem torna um único movimento, inscrito na mesma região do espaço da tela. Nos termos do encadeamento, $x$ e $y$ são equacionados. ${ }^{303}$

${ }^{303}$ Maya Deren, "Poetry and the Film: A Symposium", in Film Culture Reader, op. cit., p. 178. Para mais sobre o alcance das reflexões de Maya Deren sobre a montagem vertical, inclusive em sua relação com outros teóricos da época (sobretudo Eisenstein, o primeiro a sugerir o termo), ver Annette Michelson, "Poetics and Savage Thought: About Anagram" (2001), in On the Eve of the Future, op. cit., pp. 79108. 


\subsubsection{Permutações virtuais}

No terceiro capítulo, vimos como algumas propriedades do plano poderiam ser encontradas de forma concentrada em alguns filmes; como alguns deles poderiam levar essas propriedades aos seus limites; e como alguns poderiam combinar várias dessas técnicas, servindo como verdadeiros modelos para a exploração das capacidades do plano. Devemos mencionar aqui, de maneira semelhante, ao menos um exemplo que parece representar o mesmo papel quanto aos encadeamentos de planos.

O ano passado em Marienbad (L'année dernière à Marienbad, Alain Resnais, 1961) é um caso representativo dessa questão. O filme, baseado num roteiro de Alain Robbe-Grillet, tem como ambiente para sua narrativa um imenso hotel no qual vemos inúmeras pessoas vestidas como numa festa de gala. Entre essas pessoas, duas logo se destacam: um homem (interpretado por Giorgio Albertazzi) e uma mulher (Delphine Seyrig), personagens sem nome. ${ }^{304}$ Conforme o filme avança, é delineada uma trama em que ele tenta convencê-la de que tiveram um relacionamento no ano passado, em Marienbad, e que haviam combinado de se reencontrar para fugir juntos. Durante aproximadamente 90 minutos, o filme mostra as tentativas do homem de persuadir a mulher, as resistências da mulher às tentativas de persuasão do homem, os encontros e reencontros de ambos no espaço do hotel, e a intervenção de um terceiro personagem, um homem (Sacha Pitoëff) que parece dedicado a impedir que o outro consiga seu objetivo. A incerteza quanto à veracidade do discurso do homem (que é também o narrador, num texto que surge e desaparece na banda sonora em contraponto com a música) e às respostas da mulher é mantida durante todo o filme. Essa incerteza logo se revela parte da estrutura geral, definida por uma incerteza na orientação espacial e temporal em inúmeras sequências.

Já nos primeiros minutos, encontramos um corte semelhante aos de Dance in the Sun. Uma mulher, vista no espaço amplo do hotel, gira seu corpo como se para olhar para trás, e durante o movimento, há o corte para outro plano no qual ela permanece na mesma região da tela, com a mesma roupa, sob o mesmo ângulo e com a mesma distância em relação à câmera, mas com o espaço à sua volta sendo alterado, fazendo com que

\footnotetext{
${ }^{304}$ No roteiro, Robbe-Grillet se refere ao homem como "X" e à mulher como "A". Por conveniência, utilizaremos aqui apenas "homem" e "mulher", ou então "ele" e "ela", deixando claro que não consideremos o terceiro personagem, chamado de "M" por Robbe-Grillet.
} 
tenhamos um deslocamento em diferentes níveis. Espacialmente, somos ancorados na mulher e em seu gesto; é através dele que nos é dada a mudança de local. O breve efeito sugere que apenas o fundo sofre a transformação, não a figura em destaque. Temporalmente, a continuidade do gesto sugere uma continuidade entre os dois planos: ainda que o espaço seja modificado, é como se fosse modificado pelo próprio gesto, como se nesse contexto fosse possível deslocar não apenas o corpo de um ponto a outro do espaço, mas também os espaços ocupados por um corpo. Essa inversão da relação usual é instituída já no início do filme, servindo como uma espécie de regra para o que se desenvolve nas sequências posteriores.

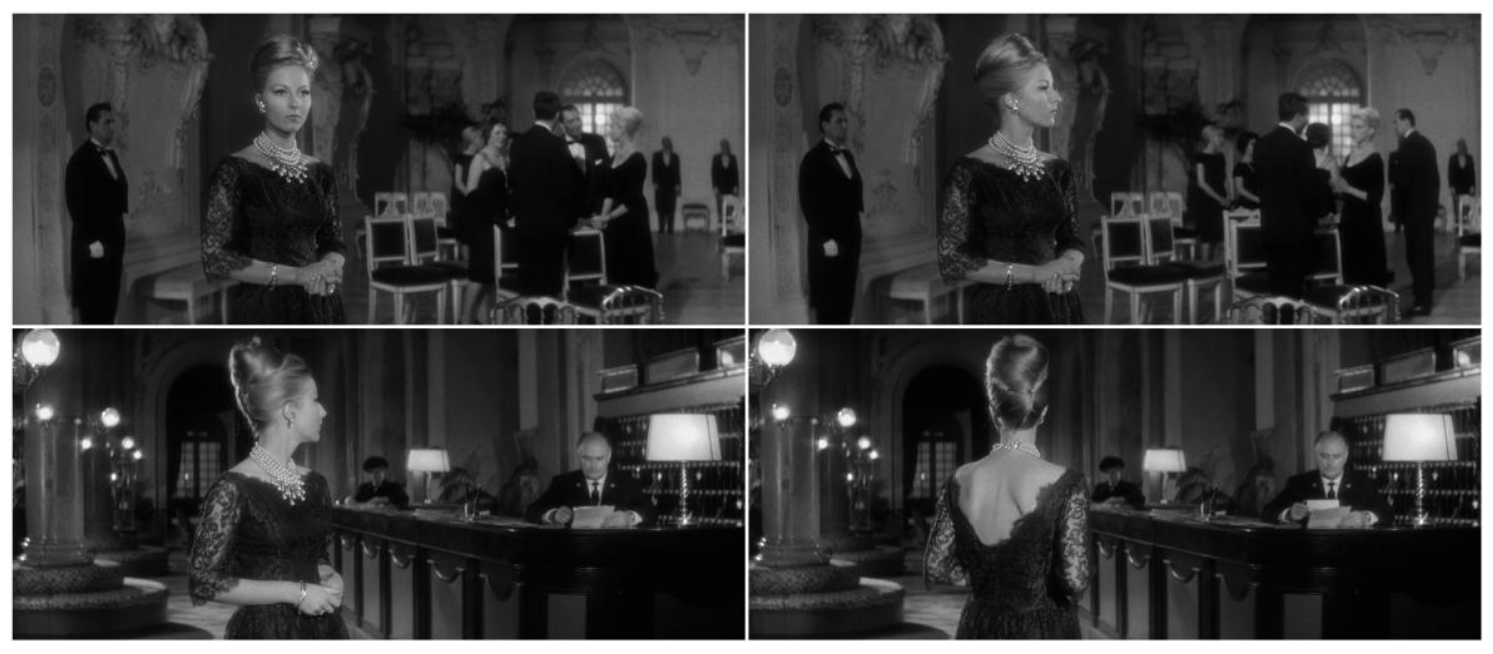

Algumas interações entre o casal de protagonistas são também marcadas por essa técnica, ainda que sua aplicação seja distinta. Em determinado trecho, os dois são enquadrados numa parte bem iluminada do hotel, com outros homens ao fundo. Ele estende a mão a ela, como se a convidasse para sair dali. No exato momento em que ele ergue o braço, há um corte para o salão de danças, onde os dois iniciam uma dança em meio a outros casais, num espaço completamente diferente, da iluminação à cenografia. $O$ momento do corte é justamente o momento de um gesto - a suspensão de um braço - que torna a ação de um plano o eco da outra. Em outro trecho, ele estende a mão como se a convidasse para segui-lo, e novamente há um corte para outro local, onde o mesmo gesto é realizado. Aqui a transição é mais significativa pois as roupas dos personagens não permanecem as mesmas, fazendo com que a proximidade temporal seja diminuída ou mesmo negada. 
A ressonância temática desse efeito no decorrer do filme é evidente. Se a narrativa diz respeito à tentativa de persuasão de um personagem pelo outro, e se parte do argumento nessa tentativa envolve a possibilidade de que ambos tenham se encontrado naquele mesmo lugar em outra época, as constantes idas e vindas espaciais, mantendo o espaço do hotel e o contexto de uma festa de gala, fazem com que, potencialmente, todas as transições caracterizem elipses para o passado ou para o futuro. A ambiguidade ao nível temático - o fato de que não é possível aferir se ele ou ela estão mentindo, ou se esqueceram o que aconteceu - se liga à ambiguidade com a qual o espectador necessariamente deve localizar as ações no contexto imediato dos cortes e no contexto mais amplo da narrativa.

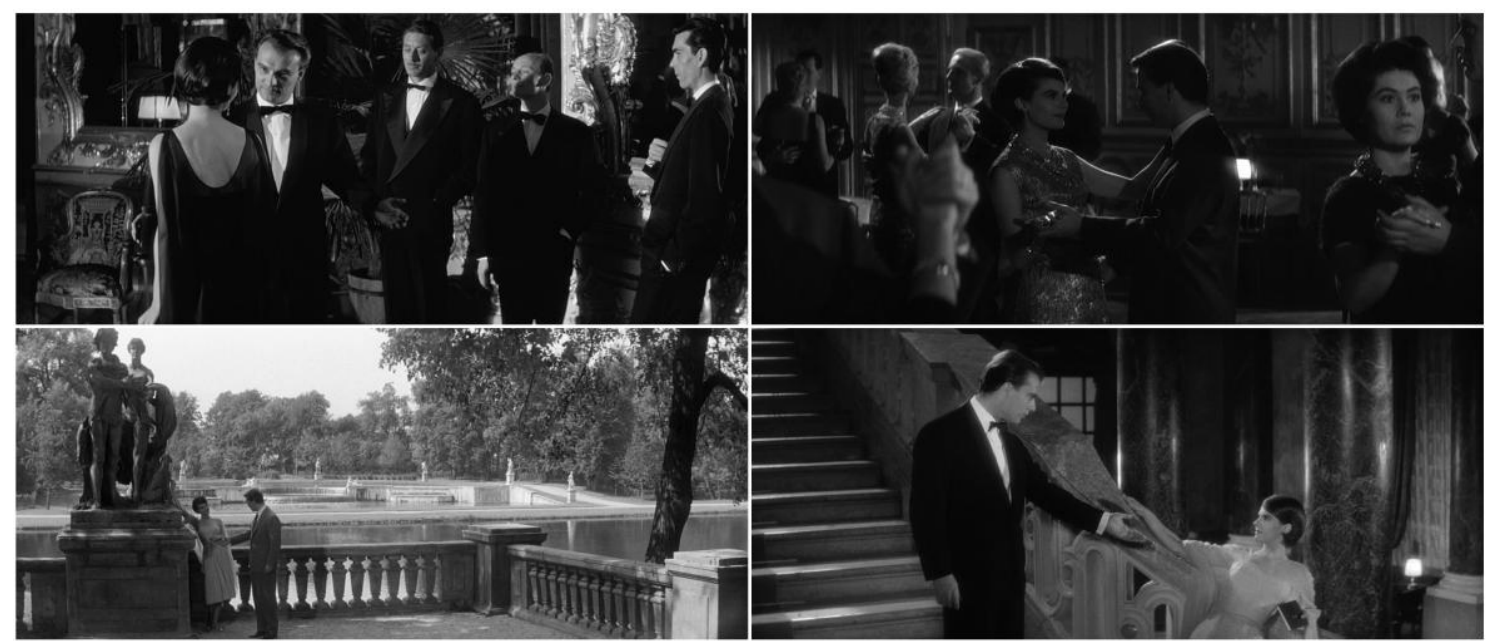

Dois trechos de $O$ ano passado em Marienbad (Alain Resnais, 1961) em que o corte, no momento de um gesto do personagem, leva a outra situação, espacial e temporalmente distante, mas ligada através do movimento, como se a continuação do gesto sugerisse a continuação do evento anterior.

Uma citação de Robbe-Grillet é útil para compreender essa lógica temporal do filme:

O universo no qual se desenrola o filme é, de maneira característica, o de um presente eterno que torna impossível qualquer recurso a memória. É um mundo sem passado que se basta a si mesmo a cada instante e que se apaga gradativamente. Esse homem e essa mulher apenas começam a existir quando aparecem na tela pela primeira vez; antes, não eram nada; e, uma vez terminada a projeção, não são mais nada novamente. A existência deles dura apenas o que dura o filme. Não pode haver realidade fora das imagens que são vistas, das palavras que se ouvem. ${ }^{305}$

${ }^{305}$ Alain Robbe-Grillet, "Tempo e descrição no romance atual”, in Por um novo romance (São Paulo: Nova Crítica, 1969), p. 102. 
Mais adiante, ele descreve o mesmo princípio em termos que ressoam com o que consideramos aqui a dimensão virtual da composição, especialmente no caráter central dado à consciência do espectador, como uma tela onde são projetadas as imagens da obra:

\begin{abstract}
Mas, poderão dizer, que representa, nessas condições, as cenas às quais assistimos? Em particular, que significam essas sucessões de planos diurnos e noturnos, ou essas bem numerosas trocas de roupas, incompatíveis com uma duração tão curta? Evidentemente, é aí que as coisas se complicam. Só pode se tratar aqui de um desenrolar subjetivo, intelectual, pessoal. Essas coisas devem estar acontecendo na cabeça de alguém. Mas de quem? Do herói narrador? Ou da heroína hipnotizada? Ou então, por uma constante troca de imagens entre eles, na cabeça dos dois juntos? Seria melhor admitir uma solução de uma outra espécie: assim como o único tempo que importa é o do filme, o único 'personagem' importante é o espectador; é em sua cabeça que se desenvolve toda a história, que é exatamente imaginada por ele. ${ }^{306}$
\end{abstract}

Vimos como, para Eisenstein, a montagem intelectual deveria "se livrar do espaço e do tempo", e como, para ele, isso significou se livrar do espaço-tempo de uma diegese claramente ordenada - baseado no espaço cênico e no tempo real. A montagem intelectual deveria, em vez disso, se voltar às coordenadas superficiais da composição; não para construir algo fundado diretamente na superfície, mas para tornar mais presentes os fatores superficiais, abstraindo a profundidade dos planos. No filme de Resnais, a diegese não é abstraída da mesma forma. Os planos mantêm a realidade das ações, tanto no eixo espacial como no eixo temporal. Vemos em cada plano um recorte bem definido da diegese. Mas esses recortes, ao serem combinados, geram um conjunto que não parece internamente consistente, e sim repleto de contradições. Contradições espaciais, como quando um gesto tem início num local e é transposto a outro local; ou quando, durante o que parece ser um único plano, alguém surge numa região do espaço e depois em outra, sem que nos seja dado seu deslocamento, como se fosse possível um transporte pelo espaço virtual que não atravesse o campo visível, e como se em algumas ocasiões fosse possível a uma pessoa estar de uma só vez em dois lugares. Contradições temporais, como quando a fluidez da câmera nos leva ao congelamento dos atores, como se o tempo do registro permanecesse transcorrendo mas não o tempo da ação; ou quando uma ação que vimos ser descrita ou representada é retomada em outro contexto, como se um evento pudesse ser variado sem ligações diretas com eventos anteriores e posteriores - como se um evento fosse, em suma, uma configuração puramente visual e sonora, algo independente de seu "lugar no tempo". Essas variações ocorrem, como aponta Robbe-

${ }^{306}$ Ibid., pp. 102-103 (grifo nosso). 
Grillet, num nível de compreensão "subjetivo", pois é na projeção das sequências na unidade psicológica representada pelo espectador que os eventos são relacionados. As tendências permutativas que vimos em capítulos anteriores fizeram a recusa da linearidade e da causalidade, e o mesmo parece ocorrer num filme como Marienbad, onde a contradição se torna uma decorrência das variações. O filme torna-se uma sucessão de seus próprios contrafactuais.

Uma sequência no meio do filme representa de forma quase esquemática a liberdade de articulação permitida pela recusa da consistência diegética. A sequência tem início com a mulher no quarto. Em outros momentos do filme, vimos o quarto como o ambiente no qual ela permanece sozinha, quase sempre à espera de algo ou de alguém. É nesse contexto, nesse campo de inferências, que nos são apresentados os planos. No total, a sequência tem 24 planos, e pode ser dividida em três partes, cada uma com oito planos. $\mathrm{Na}$ primeira parte, são apresentados oito planos seguindo o padrão sujeito-objeto. Ela volta o olhar para determinada direção, e logo em seguida corta-se para o plano de um objeto, do que parece ser o alvo de seu olhar. Nas três primeiras vezes em que aparece, ela parece estar na mesma região do espaço; mas na quarta, há uma mudança aparente, quando ela aparece próxima à janela em vez de no meio do quarto. A orientação espacial é brevemente posta em questão:

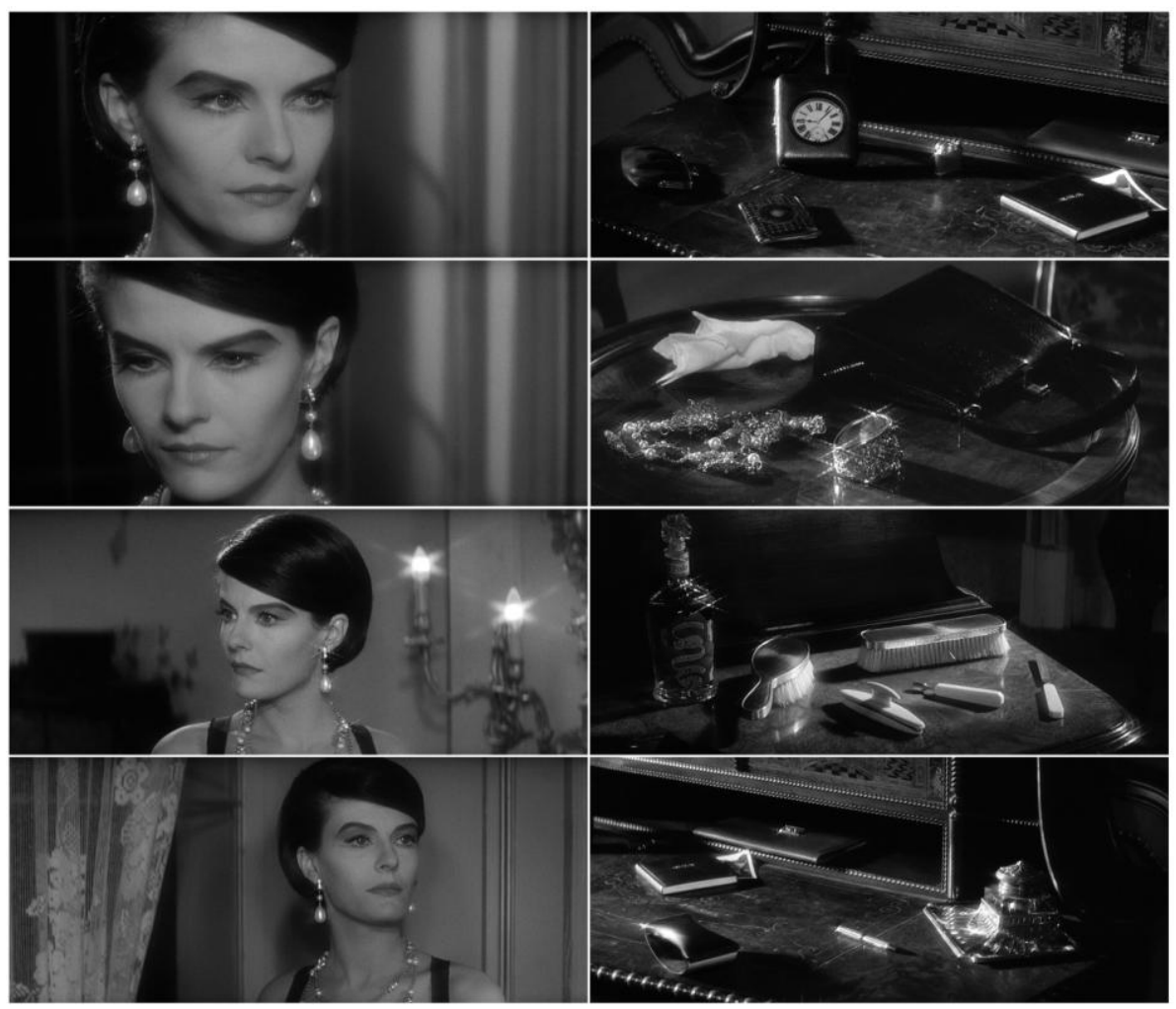


Na segunda parte, os oito planos reformulam esse padrão, retirando mais ainda de sua carga realista. Vemos um plano dela observando uma região do espaço, como na primeira parte; mas, quando ela gira a cabeça, voltando seu olhar da direita para a esquerda, um corte nos leva para outro plano, agora dela na janela, no que parece ser justamente a parte do espaço para a qual ela olhava no plano anterior. A sugestão de que ela observa a si mesma é complicada pelo fato de que a posição de Seyrig no enquadramento é semelhante, e que o final de um plano (o movimento da cabeça, da direita para a esquerda) é ligado ao início do outro (o movimento da cabeça da esquerda para a direita). A continuidade do movimento sobre a tela coexiste com as referências discrepantes no espaço virtual. O processo é repetido mais duas vezes; a cada vez ela surge numa parte diferente do quarto; a cada vez as direções de seus gestos e olhares descrevem uma trajetória diferente sobre a tela. Os outros quatro planos mostram objetos, como na primeira parte; mas agora os planos são apresentados imediatamente após os planos de olhares terem sido tornados completamente paradoxais, de modo que não há inferências a serem feitas quanto às suas localizações ou quanto ao fato de estarem sendo observados pela personagem. Se na primeira parte a montagem seguia o padrão S-O-S-OS-O-S-O, na segunda parte o padrão construído é S-S-S-S-O-O-O-O:

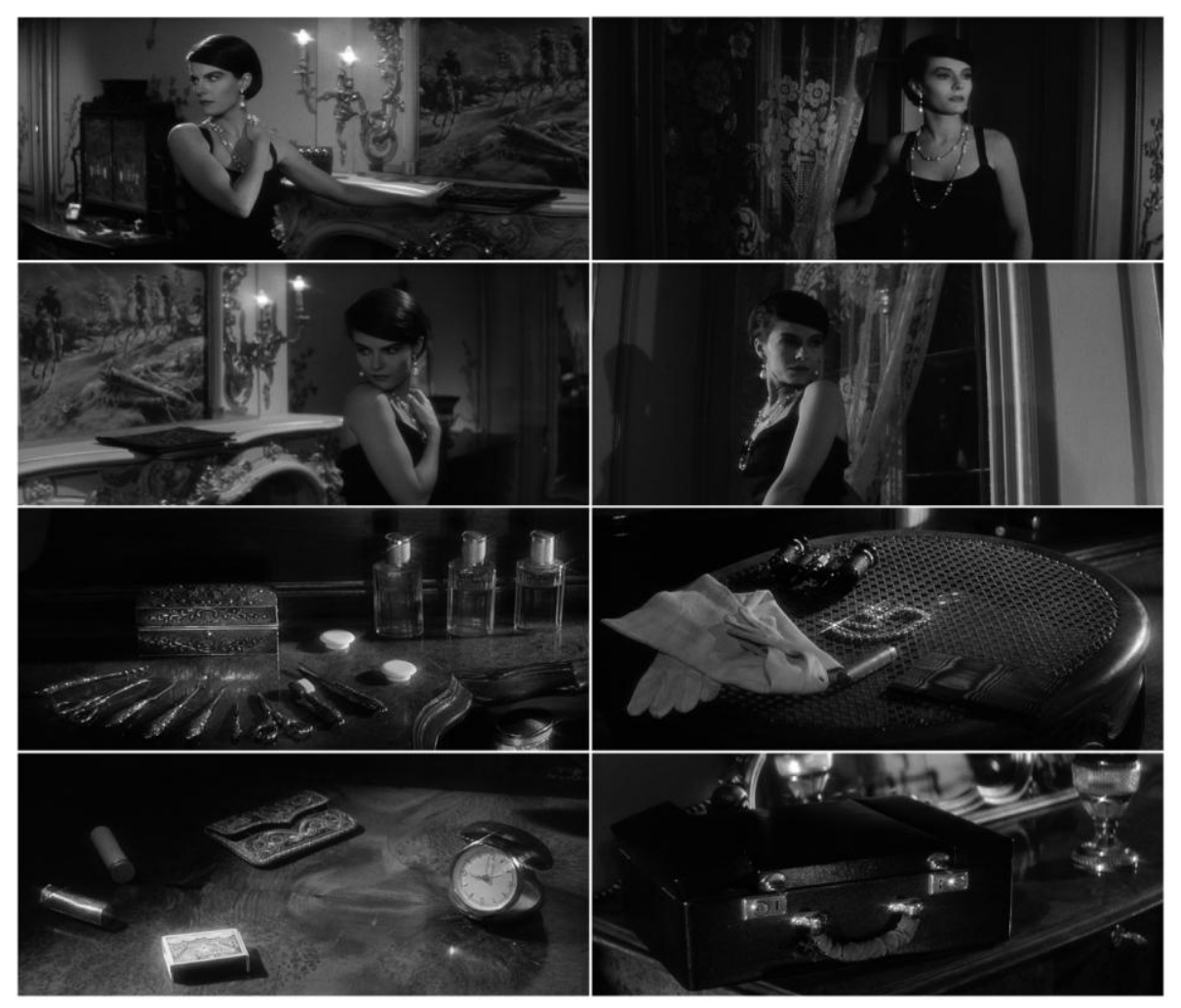


$\mathrm{Na}$ terceira parte da sequência, a mulher caminha pelo quarto, sendo acompanhada pela câmera num travelling. Durante seu movimento, visto por seu lado direito, há um corte que nos leva a outro plano em que ela é vista caminhando, ao que parece, em direção à mesma região do quarto, mas agora vista pelo lado esquerdo, e mesmo no outro lado do quarto. Mais do que quebrar a linha dos 180 graus, invertendo a direção dos movimentos sobre a tela, aqui Resnais nos apresenta dois eventos paralelos, como duas linhas que parecem convergentes.

O processo é repetido mais duas vezes; como no início da segunda parte, cada reiteração modifica a direção do gesto, e neste caso também o ângulo da câmera, fazendo com que diferentes partes da tela sejam mobilizadas. Nos quatro últimos planos, a mulher, segurando um álbum, deixa seu corpo cair lateralmente na cama. Vemos a mesma ação quatro vezes, cada vez por um ângulo, cada vez o movimento direcionado a uma parte da cena e da tela - da esquerda para a direita, da direita para a esquerda, da esquerda para a direita, da direita para a esquerda:

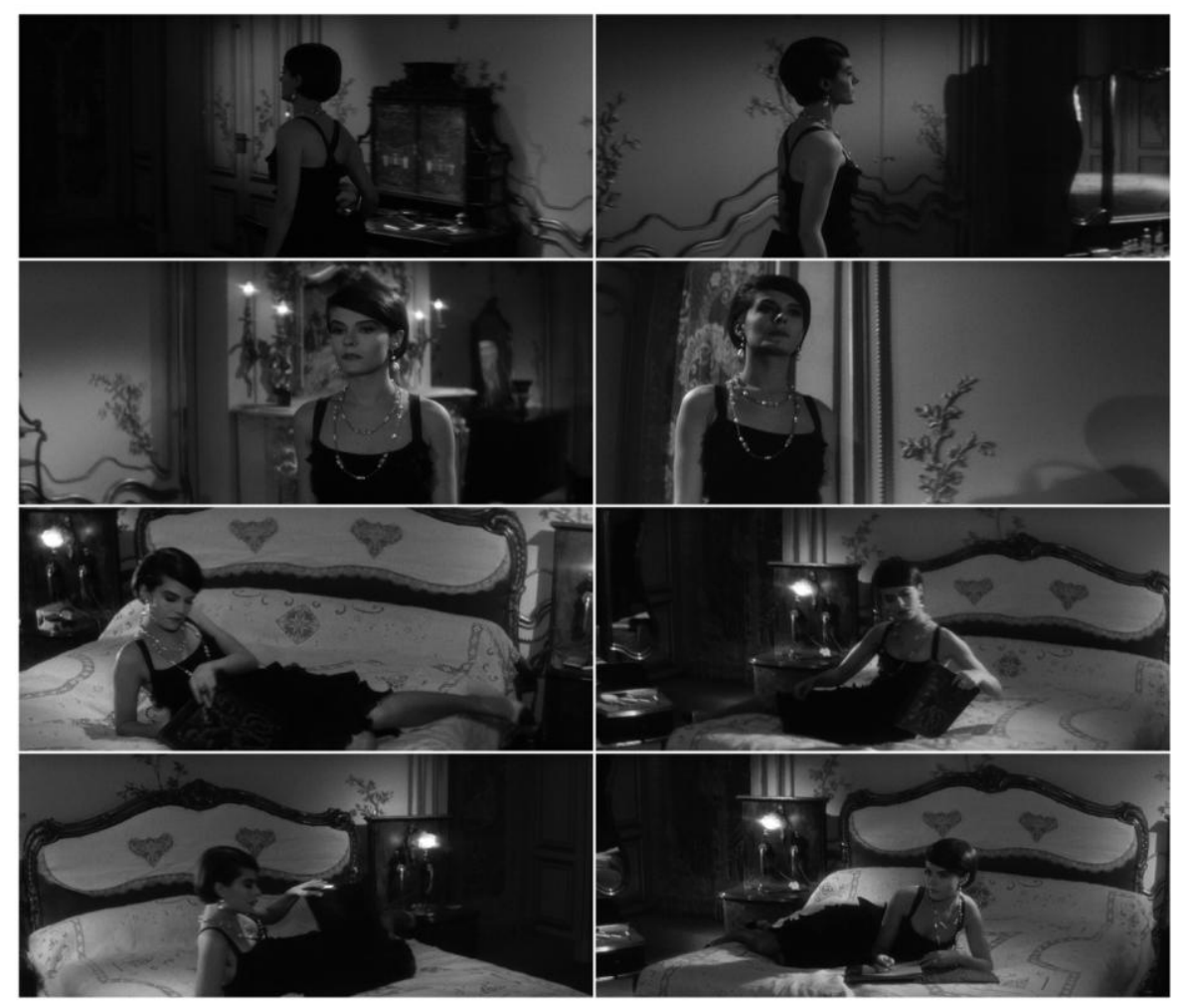

As estratégias que vimos na sequência dos deuses em Outubro - a "musicalização" dos planos, jogando com sua plasticidade e seu ritmo - são aqui 
retomadas fora das exigências de um argumento. Os gestos são comparados e sucedidos de maneira ainda mais arbitrária. Da mesma forma, os parâmetros que encontramos numa sequência de Hitchcock são aqui absorvidos com outros fins. A localização do sujeito que observa e do objeto observado, em vez de servir à expressão de um sentido delimitado, para a redução das inferências possíveis no contexto da narrativa, serve aqui para ampliar ainda mais as inferências, e para impossibilitar a fixação de um único contexto para os diferentes planos. Os elementos presentes nas relações internas de uma cena são reconhecidos e isolados apenas para serem recombinados em outros contextos, levando a resultados que põem em questão a unidade que havia sido sugerida por outras situações.

Considerando essa propriedade, André Labarthe traça uma linhagem curiosa: ele identifica no filme de Resnais a continuação de um desenvolvimento que teria sido iniciado por Orson Welles e pelo neo-realismo italiano. Entre as características comuns, ele menciona as lacunas no roteiro, a ambiguidade nos eventos, e um certo esforço exigido do espectador na compreensão da narrativa. Seria uma via particular do cinema moderno, um afrouxamento de certos parâmetros que haviam sido cristalizados nas décadas anteriores. Labarthe argumenta que

O cinema tradicional conseguiu se livrar de qualquer possível ambiguidade, construindo cada cena e cada plano de modo a direcionar o que o espectador deveria pensar, isto é, seu sentido. Levado ao extremo, esse tipo de cinema não necessita do espectador, pois o inclui no próprio filme. A novidade dos filmes de Welles e dos grandes neo-realistas foi exigir claramente a participação do espectador. ${ }^{307}$

A originalidade do filme de Resnais, por sua vez, seria a sistematização dessa descoberta. Se em Rossellini e Welles as lacunas seriam toleradas, porque vistas como inevitáveis, em um filme como Marienbad elas tornariam-se o próprio tema da obra.

A leitura de Labarthe se apoia no comentário de Bazin sobre Rossellini, em si uma contraposição da abordagem neo-realista em relação à “decupagem clássica”. Bazin refere-se à descrição dos soviéticos, do plano como um tijolo na construção arquitetônica do filme. É, em suma, a concepção griffithiana que serviu de modelo aos experimentos de Kuleshov, e que teve em Pudovkin seu maior defensor no campo teórico. Ao caráter préconcebido dos tijolos, Bazin opõe as pedras dispersas num rio:

O tijolo é um elemento da casa. Isso está inscrito em sua própria aparência. Podemos ter o mesmo raciocínio, por exemplo, com as pedras que compõem uma ponte. Elas se

307 André S. Labarthe, “Marienbad année zéro”, Cahiers du cinéma 123 (setembro de 1961), pp. 29-30. 
encaixam perfeitamente para formar o arco. Mas blocos de rocha dispersos num vau são e continuam sendo rochas, sua realidade de pedras não é afetada, porque, saltando de pedra em pedra, sirvo-me delas para atravessar o rio. Se pude usá-las provisoriamente, foi porque soube dar ao acaso de sua disposição meu complemento de invenção, acrescentar ali o movimento que, sem modificar a natureza e aparência delas, deu-lhes provisoriamente um sentido e uma utilidade. ${ }^{308}$

A ideia de que a realidade dos planos pode ser mantida, e que, mesmo com a ausência de ligações claras e diretas entre os planos o contexto da montagem pode fazer emergir um sentido particular, mas que mantém o que ele acreditou ser a complexidade e a ambiguidade da natureza - essa ideia está no cerne da concepção de realismo de Bazin. Ela nos leva, por sua vez, a uma distinção feita mais claramente pelos formalistas russos, a distinção entre fábula e trama.

A fábula seria a cadeia de eventos que ocorrem na diegese, em analogia com a cadeia de eventos que ocorrem no mundo físico, fora da diegese. A trama seria a forma dada à fábula numa determinada obra: a seleção, ordenação e a transformação dos eventos num padrão ou numa estrutura. Uma consequência dessa distinção é que, ao travar contato com uma obra, não temos acesso direto à fábula, mas apenas à trama; é através dela que podemos inferir as características da fábula. Nesse sentido, uma narração é idêntica ao processo de fornecer ao espectador os dados que lhe permitem construir mentalmente a fábula. ${ }^{309}$

O que nos é dado como a trama de Festim diabólico, por exemplo, é uma série de enquadramentos e movimentos, alterações no foco visual, de um personagem a outro, de uma ação a outra. Os elementos tornados visíveis sugerem, em alguns momentos, elementos mantidos fora do enquadramento, ou anteriores ao tempo da narrativa. As relações a serem feitas entre esses domínios, portanto - as inferências quanto à transformação da fábula em trama -, são feitas através de seleções espaciais e temporais. A decisão por um ponto de vista que prolonga ao máximo sua continuidade faz com que a duração e a ordem dos eventos na fábula e na trama não sejam parâmetros articulados diretamente. O que Hitchcock parece fazer é mantê-los homeomórficos, isto é, mantê-los semelhantes ou mesmo idênticos na fábula e na trama, do que decorre o efeito de "tempo

\footnotetext{
308 André Bazin, “Defesa de Rossellini” (1955), Op. cit., pp. 369-370 (grifos nossos).

309 Estas definições se baseiam numa leitura semelhante àquela proposta por David Bordwell sobre os formalistas russos, em que a fábula não é vista como um material bruto a ser elaborado pela trama, mas sim como uma "propriedade emergente" da trama, ou seja, como a unidade sugerida pelas relações internas da trama. Ver David Bordwell, Narration in the Fiction Film, op. cit., pp. 44 ss., 344-345 (nota 7). Para uma contextualização e uma análise mais aprofundada de outros aspectos da distinção fãbula/trama, ver Tzvetan Todorov, "A herança metodológica do formalismo", in As estruturas narrativas (São Paulo: Perspectiva, 1969), pp. 27-50.
} 
real" no filme. No caso de Janela indiscreta, a decupagem baseada nas alternâncias entre pontos de vista coexiste com a manipulação da duração dos eventos. Hitchcock poderia manter aqui o mesmo exato princípio de homeomorfismo temporal que utilizou em Festim diabólico; em vez disso, recorre a várias elipses, ou seja, compressões temporais, modificações do tempo da fábula em sua transposição ao tempo da trama.

É também por essa ótica que podemos reconsiderar a ideia dos contrafactuais. Em filmes que lidam com a transformação da fábula na trama, um contrafactual é sinônimo de uma trama possível da mesma fábula. Tanto Festim diabólico como Janela indiscreta lidam com assassinatos e tentativas de resolver o crime, ou seja, possuem elementos comuns em suas fábulas. Mas um posiciona o crime no início da trama, e outro no meio; um nos revela os criminosos no início da trama, e outro no final; um nos coloca num ponto de vista objetivo, e outro no ponto de vista do investigador. Um exercício de permutação desses critérios faria com que o suspense que caracteriza esses filmes desse lugar a um resultado completamente diverso. O processo de transposição da fábula em trama depende, nesses filmes, como em vários outros de Hitchcock e de outros cineastas, de um ponto ótimo no aproveitamento das possibilidades da fábula e da trama, através do desvio da atenção e do adiamento das respostas, típicos do suspense.

O contraste entre Marienbad e o filme anterior de Resnais é útil para compreender algumas dessas relações. Em Hiroshima Mon Amour (1959), a montagem nos leva frequentemente a outros contextos que não o do presente narrativo representado pelas cenas do casal no hotel. Quando a mulher (Emmanuelle Riva) observa o homem (Eiji Okada) dormindo, o close-up da mão dele, em vez de retornar como objeto do ponto de vista, é substituído momentaneamente pelo close-up de outra mão, de outra pessoa, em outro lugar - o que mais tarde descobrimos ser o ex-amante alemão da protagonista, durante a guerra: 


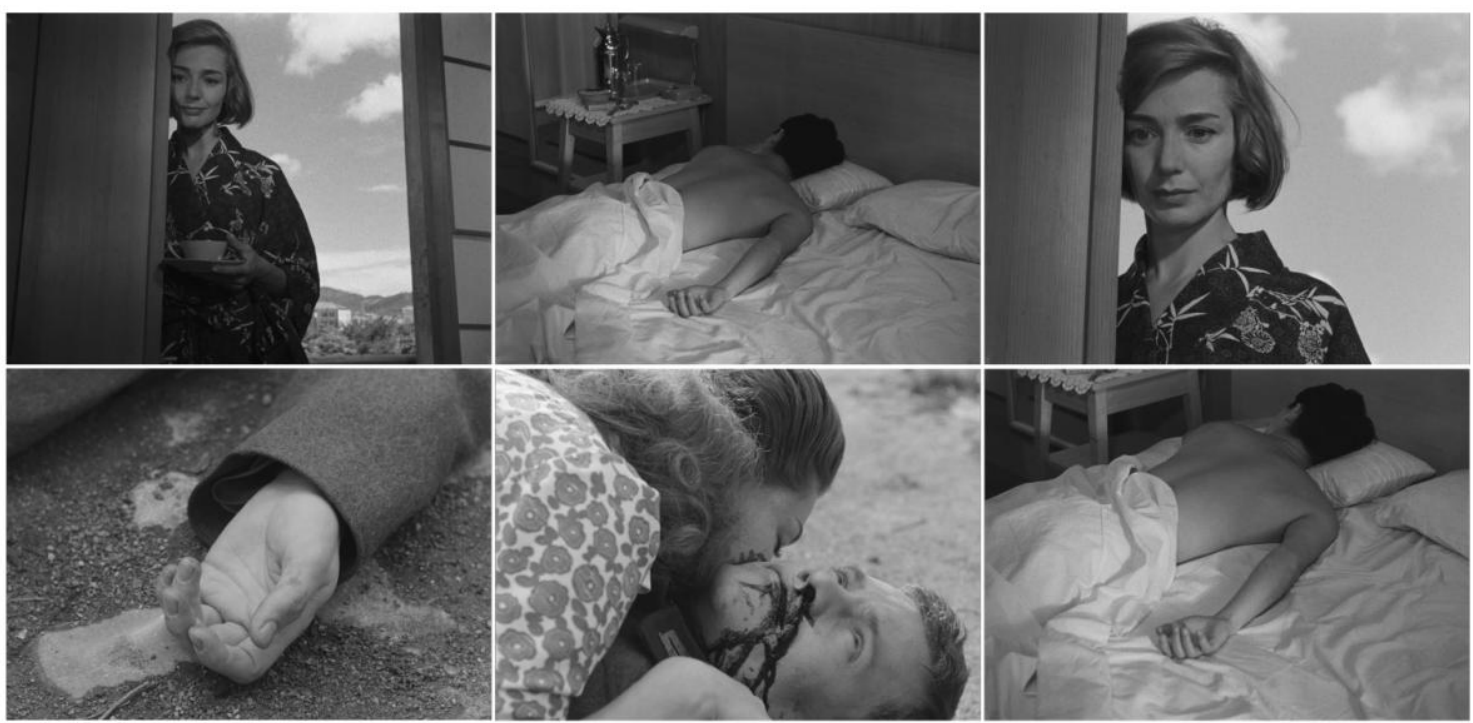

O filme estabelece comparações entre diferentes épocas através da semelhança visual imediata entre as imagens, mas a razão para as comparações não são dadas imediatamente, e sim nos momentos posteriores da narrativa. Isso significa que, no decorrer da trama de Hiroshima, a fábula é constantemente vislumbrada, ainda que as peças só possam ser encaixadas mais adiante. ${ }^{310}$

A abordagem de Marienbad é distinta. Não há no filme qualquer informação que permita ao espectador se conduzir em meio às possibilidades representadas. Se as diferentes camadas temporais de Hiroshima podem ser relacionadas metaforicamente, é porque a base diegética é constante - as metáforas funcionam como mapeamentos de uma região da fábula sobre a outra. A recusa dessa base constante, por sua vez, é o que impede Marienbad de realizar operações semelhantes. Se em qualquer narrativa a fábula deve ser convertida numa trama, através de um processo de seleção, ordenação e adaptação dos eventos, Marienbad demonstra que um filme pode ser composto tendo como princípio estrutural, e mesmo como núcleo temático, o processo de seleção, ordenação e adaptação dos eventos, isto é, a construção de uma história naquele universo. É também este o caso de Cidadão Kane (Citizen Kane, Orson Welles, 1941), e mesmo de Rashomon (Akira Kurosawa, 1950). Mas o filme de Resnais leva este princípio a um grau mais extremo. Como a realidade do filme é igualada à presentificação das ações, sem a perspectiva temporal que seria instituída por uma diegese consistente, e que poderia estabelecer uma hierarquia entre as ações, todas as ações tornam-se, potencialmente, metafóricas. Como

\footnotetext{
${ }^{310}$ Meir Sternberg usa o termo "exposição adiada e distribuída" para se referir a estratégias como esta, que necessariamente coexistem com o que ele chamou de "controle retórico" - as técnicas utilizadas para estabelecer a hierarquia de informações. Ver os capítulos 3 e 4 de Meir Sternberg, Expositional Modes and Temporal Ordering in Fiction (Baltimore: The Johns Hopkins University Press, 1978).
} 
não há uma realidade à qual as metáforas fazem referência, todas as ações tornam-se versões do mesmo presente; tornam-se variações sem um tema, tramas sem uma fábula. ${ }^{311}$

Assim como Tom, Tom, the Piper's Son toma o plano como uma matéria flexível, a ser manipulada, congelada, fragmentada, invertida e reorganizada, $O$ ano passado em Marienbad aborda a concepção de diegese com o mesmo objetivo. A própria noção de unidade diegética, de uma integridade espaço-temporal no decorrer da obra, é alvo de transformações incessantes. Como no caso de Maya Deren, o respeito de Resnais pelo caráter fotográfico dos planos, e mesmo pela solidez dos planos, pela clareza de sua geometria interna, parece um fator crucial no filme. Aqui, Resnais parece em consonância com o que Noel Burch disse ser para ele a grande questão do cinema: "a abstração do puramente concreto, a integração dos elementos da realidade cotidiana em padrões elaborados, artificiais e abstratos, de tal forma que esses elementos perdem seu significado sem perder sua identidade". 312

311 Jorge Luis Borges refere-se a Cidadão Kane como "um labirinto sem centro", e a expressão parece ainda mais adequada ao filme de Resnais. Ver Jorge Luis Borges, "Um filme esmagador", em Edgardo Cozarinsky, Borges do/no cinema (Lisboa: Horizonte, 1983), pp. 58-59.

312 Noel Burch, “Qu'est-ce que la nouvelle vague?", Film Quarterly, vol. 13, n. 2 (inverno de 1959), p. 26. 


\section{CONSIDERAÇÕES FINAIS}

Esta tese apresentou uma variedade de filmes, e através deles, uma variedade de abordagens críticas e teóricas sobre o espaço e o tempo no cinema. Tentamos mostrar onde essas obras e metodologias teriam lugar numa visão abrangente sobre a composição fílmica. O trabalho foi constituído em grande parte por conexões traçadas entre imagens e ideias, sob a crença de que algumas experiências fundamentais possíveis no cinema estão disponíveis em obras já existentes, e de que algumas formulações cruciais no pensamento sobre o cinema também se encontram disponíveis em textos já publicados. Se a visão que apresentamos é ou não a mais adequada, ainda assim foram apresentados indícios de que essas abordagens dialogam umas com as outras através dos parâmetros espaciais e temporais, e que portanto uma visão de conjunto adequada deve incluir, se não as ligações que aqui foram propostas, outros tipos de ligações que possam dar conta dessas mesmas questões. Como foi dito na introdução, a tese não propõe um sistema fechado e definido, mas uma perspectiva sobre sistemas já existentes e válidos por si mesmos.

A tentativa de estabelecer diálogos entre os diferentes métodos de reflexão sobre a composição teve como referência as próprias obras fílmicas pois são elas os pontos de convergência, os objetos comuns aos quais devemos nos ater. Por essa mesma razão os esquemas de Rohmer e Gidal, propostos de início como um quadro de referências, não foram afirmados no decorrer das análises: uma vez fixada a grade dos tipos de espaço e tempo, buscou-se encarar os filmes e identificar os problemas composicionais presentes desde seu nível mais imediato até em suas relações com outras obras. O acúmulo dessas relações descreve algo como um campo de possibilidades, e dentro deste campo as coordenadas que fomos capazes de traçar sugerem limites e tendências do material fílmico. As escalas, os diagramas e as polarizações no decorrer das análises mostram 
como, numa visão que se pretende abrangente do cinema, surgem linhas de força que dão forma ao campo.

Algumas das questões com as quais nos deparamos dizem respeito a filmes específicos; outras, a conjuntos de filmes que lidam com os mesmos elementos ou procedimentos técnicos. Mas há outras questões que devem ser mencionadas numa visão retrospectiva da tese: são as que parecem atravessar os problemas composicionais deste ou daquele filme, ou mesmo desta ou daquela dimensão, revelando afinidades ou analogias entre objetos e conceitos distantes. Se por um lado isso é recorrente em todos os capítulos, por outro lado é consideravelmente disperso, e devemos apontar ao menos alguns casos como forma de tornar mais clara a visão de conjunto.

\section{II}

Consideremos o problema da "entropia", mencionado já no primeiro capítulo em relação ao mergulho na homogeneidade caracterizado por Zen for Film. O mesmo problema é de certa forma retomado em outro nível num filme como Empire. Trata-se de obras que, em suas respectivas dimensões, expõem as condições mais imediatas da composição: o fato de que nos é dada uma tela na qual passa uma fita de filme em determinada frequência, e o fato de que mesmo num plano ocorre essa passagem, podendo interferir diretamente na percepção do objeto filmado. Se o exemplo paradigmático do plano se encontra nos Lumière, o filme de Warhol é uma espécie de Lumière multiplicado pelo Fluxus, ou a revelação do substrato material presente mesmo na definição tradicional do plano.

O mesmo ocorre em relação à linearidade, que vimos primeiramente através de Entrance to Exit, mas que logo se desdobra em outros filmes que recorrem a algum tipo de progressão gradual, desde Mothlight até L'arrivée d'un train à la Ciotat. O aspecto "processual" da projeção, a "base cognitiva" mencionada por Sharits, é expressa de maneiras completamente diversas nessas obras. Se numa delas a tela é desprovida de imagens, expondo sua temporalidade na frequência do fade, em outra essa mesma frequência é inscrita no movimento dos objetos colados sobre a película, e na terceira é sinônimo da movimentação natural registrada pela câmera. Nos três exemplos, um aspecto fundamental do dispositivo é tornado um princípio composicional. Que os três direcionamentos levem a resultados completamente diferentes não muda o fato de que se voltam à possibilidade de uma construção linear. A "linearização da montagem" no quinto capítulo acrescenta ainda outra camada ao princípio. Se há um caráter processual 
na projeção e no plano, como se daria o mesmo caráter no encadeamento de planos? É este o problema atacado por inúmeros cineastas do primeiro cinema, desde aqueles que parecem ter abordado a linearidade de maneira pontual até os que fizeram dela o horizonte de toda a composição. Se a organização técnica e narrativa empreendida por Griffith fez as vezes de uma revolução, é provavelmente devido ao papel central que a linearidade representou na imaginação de seus espectadores e críticos, como se um dos parâmetros essencias da arte fosse enfim conquistado num plano complexo, além da pura duração dos registros. As estratégias de paralelismo e convergência atestam a produtividade do princípio linear no âmbito narrativo.

Um terceiro princípio mencionado já no primeiro capítulo é também recorrente em outros contextos: o princípio de variação. Se em Kubelka a variação é sinônimo de alternar as durações métricas de fotogramas monocromáticos, em Richter encontramos a variação que busca combinar formas visuais deduzidas do próprio formato da tela. $\mathrm{O}$ interesse na comutatividade dos procedimentos - luz e sombra, direita e esquerda, "ação e reação" - leva ambos a recusar os formatos simples e previsíveis, dando preferência à enumeração de combinações. É um princípio semelhante que encontramos em alguns números de mágica de Méliès. Há o mesmo temperamento combinatório, ainda que enraizado nas convenções teatrais; a mesma disposição que sucede cada gesto por seu contragesto, cada aparição por uma desaparição, cada movimento à direita por outro à esquerda. Enquanto ocorrem as permutações, enquanto o material parece ser remontado periodicamente à nossa frente, a linearidade é diminuída e o filme parece afirmar, mais do que sua processualidade, a variedade multidirecional de seus elementos. Daí o alto nível de permutações num filme como $O$ ano passado em Marienbad, que logo se torna um verdadeiro estudo sobre como uma narrativa pode sugerir diversos caminhos e não eleger nenhum deles como o definitivo.

Homogeneidade, linearidade e variação são, nesse sentido, princípios que encontramos em diferentes ocasiões. É importante notar que os cineastas mencionados nem sempre discutiram suas composições nesses termos: eles parecem ter encontrado, cada um à sua maneira, soluções para a criação de obras que tocavam no problema dessas formas básicas, concentrados na dimensão que mais lhes interessava como se aquele domínio fosse o único do problema a ser tratado. 


\section{III}

$\mathrm{O}$ espaço da tela, como mostrou Arnheim, opera à maneira de um campo de forças. $\mathrm{O}$ surgimento e o deslocamento de imagens dinamiza as regiões desse espaço: marca as distâncias entre os objetos e o centro, entre os objetos e as bordas, entre um objeto e outro. De Richter a Brakhage, o que vimos foram tentativas de potencializar esse espaço, de dar às suas transformações o sentido abstrato encontrado normalmente na música. A geometrização torna-se uma estratégia frequente por utilizar formas simples e reconhecíveis, como se todo o universo visual fosse reduzido a um vocabulário e dele se tentasse extrair uma série de declarações. A estratégia complementar se revela uma resistência desse mesmo processo, a dispersão e multiplicação de formas e cores de modo a evitar que uma forma se destaque e possa sugerir um padrão visual ou rítmico. Entre as posições intermediárias destacam-se nomes como Fischinger e McLaren, nos quais a metamorfose abstrata da tela às vezes dá lugar a uma configuração análoga à da orientação gravitacional. Nesse espaço que se institui pela mais absoluta superficialidade, e pela simetria em seu campo de forças, torna-se possível criar uma orientação específica, uma modificação de todo o ambiente, fazendo com que as figuras se comportem segundo determinadas leis que não as da pura variação.

O espaço da "caixa cênica" revela operações distintas em seu campo de forças. Se nas animações o princípio da orientação gravitacional deve ser rigorosamente construído, em filmes que têm no plano sua unidade básica a gravitação é simplesmente um dado natural. Mas o que encontramos nas gags de Keaton ou nos números musicais de Astaire é o mesmo interesse na interação das figuras (aqui, atores) com as forças presentes no espaço (aqui, o espaço em profundidade). A dinâmica presente entre as bordas e o centro, como entre os centros perceptivos e o centro geométrico, permanece nestes filmes como em quaisquer outros que utilizem planos; acrescenta-se, contudo, as distâncias em relação à câmera, ou entre objetos vistos em perspectiva. Principalmente, acrescenta-se a inexorabilidade das leis físicas: em vez de flexíveis e momentâneas como nas animações, tornam-se invioláveis, devendo ser utilizadas em conjunção com todo o aparato de filmagem e o cenário para sugerir variações significativas. Em decorrência disso, Keaton e Astaire, como avatares das formas mecânicas e orgânicas, realizam as interações possíveis com objetos, cenários e outros personagens, nos permitindo observar como gestos podem ser práticos ou lúdicos, e como há uma habilidade especial para se adequar 
às leis da física segundo um padrão simples e previsível ou segundo um padrão complexo e imprevisível.

$\mathrm{Na}$ terceira dimensão, é o sistema de orientações estabelecido por Griffith que representa um papel semelhante. Tomando como dados o campo de forças da tela e a orientação gravitacional no plano, a tradição que cristalizou o Modo de Representação Institucional propõe uma redução da "arbitrariedade diegética". Assim como as animações deveriam criar as condições que permitiriam a percepção da gravidade, também os filmes narrativos deve compor seus planos de modos específicos para que o espectador possa acompanhar os encadeamentos como sendo contínuos. E da mesma forma que as animações poderiam desfazer a sugestão de gravidade, retornando à predominância "relacional" da tela, também os cineastas que lidam com o encadeamento de planos são capazes de, conscientemente ou não, desfazer as condições em que essa orientação é percebida. De Porter a Resnais, há provavelmente toda uma linhagem que explora as possibilidades à margem do sistema de orientações.

O que devemos apontar nesses exemplos é que a unidade espaço-temporal em cada dimensão possui características que parecem "naturais", ou pelo menos que surgem mais facilmente em suas articulações. Essas propriedades coexistem, entretanto, com outras, que surgem através de técnicas específicas. O espaço da tela, da cena, da narrativa, pode ser organizado, e em todos esses casos a organização adapta a percepção do espaço que temos "fora do cinema".

\section{IV}

A paralaxe do movimento e as diferentes relações estabelecidas entre o campo e o forade-campo são exemplos de efeitos espaciais e temporais que resultam da relação da câmera com o espaço que ela registra. Mais especificamente, os efeitos decorrem do fato de que a câmera deve recortar o espaço por um só ângulo, e que muitas vezes temos poucos ou nenhum indício quanto ao que ocorre fora desses limites. Os filmes dos Lumière em que a câmera é posicionada em trens e outros veículos são casos representativos: na constante atualização das bordas e da perspectiva, a relação do olhar com o ambiente é de pura exploração, de uma descoberta em conjunto com o registro, como se estivéssemos recebendo as vistas em sincronia com o operador da câmera. No contexto de uma gag, as explorações de Buster Keaton tomam um desvio importante: concentrado em um ou em poucos espaços, Keaton organiza situações em que o ponto de 
vista da câmera sugere à primeira vista uma determinada interpretação, mas que logo em seguida, por um acréscimo de ação ou por uma mudança nas condições espaciais, essa interpretação é revelada como incorreta. O que Noel Carroll denominou "gag de incongruência" é uma das marcas no cinema de Keaton, e uma tática frequente na comédia burlesca. Ao controlar seus gestos perante a câmera fixa, Keaton indiretamente controla as inferências feitas pelo espectador, podendo confirmá-las ou negá-las à medida em que isso for conveniente para a estrutura da comédia. Em outro contexto, é essa também a abordagem de Hitchcock. Recorrendo ao ponto de vista como uma verdadeira armadilha para o espectador, Hitchcock controla as inferências espaciais e temporais através dos olhos dos personagens e de olhos que acreditamos ser dos personagens mas que logo se revelam o próprio olhar da câmera.

Nessa cadeia de exemplos, o que se manifesta é a capacidade do filme de jogar com as expectativas em diferentes níveis, desde a percepção imediata do contexto espaçotemporal do plano até a interação entre personagens e objetos num universo narrativo. A ideia de que um filme pode, através de suas operações formais, conduzir a atenção e a expectativa, como pode instigar o medo e o riso do espectador, é algo que encontramos de forma ainda mais depurada no primeiro capítulo quando mencionamos os filmes que operam como "máquinas cognitivas". Os efeitos decorrentes dos acelerados padrões de flicker, medidos com precisão por alguns cineastas, são como o primeiro nível desta tendência. Sobre ele, encontramos os efeitos decorrentes do plano, às vezes como experimentos isolados, como em certas gags e sequências de suspense. Finalmente, há os efeitos que decorrem do encadeamento dos planos. O "sistema do narrador" griffithiano é, entre outras coisas, um controle de informações ao nível virtual: apresentando, encobrindo, alternando e intensificando os modos como percebemos os eventos na diegese, Griffith conduz o olhar e a imaginação para efeitos de revelação e catarse. É também por essa ótica que podemos compreender o papel importante das figuras, sejam elas utilizadas para fins narrativos ou para deslocar o avanço da narrativa; e é onde podemos enquadrar a "montagem intelectual" de Eisenstein, o nível virtual do edifício de modos de montagem por ele proposto.

\section{$\mathbf{V}$}

Algumas insuficiências da abordagem proposta na tese devem também ser mencionadas. 
Em primeiro lugar, como já foi mencionado na introdução, há a preferência pelo direcionamento centrípeto em detrimento do centrífugo. Autores que dão preferência à investigação centrífuga tendem aos problemas citados por Noel Carroll e Malcolm Turvey; mas não significa que não haja observações sugestivas ou mesmo importantes em obras marcadamente centrífugas. A escolha da tese foi por uma rejeição de muitas dessas obras, por uma razão simples: em muitos casos, a rede formada pela terminologia ou a base filosófica que precede as análises fílmicas deveria ser desfeita antes que as ideias pudessem ser absorvidas na argumentação. Em outras palavras, para evitar o acréscimo de tópicos que pudessem desviar o foco, foi preferido limitar o diálogo, mantendo fora dele esse aspecto das "grandes teorias". ${ }^{313}$ Por isso mesmo, um desdobramento desta pesquisa poderia, e talvez deveria ocorrer justamente no diálogo com alguns desses campos. Os dois livros de Gilles Deleuze sobre cinema são exemplos a serem citados aqui, por seu tratamento particular do espaço e do tempo, de inspiração bergsoniana. Outro caso seria o trabalho de Christian Metz na semiologia, desde suas primeiras teorizações até sua inclusão da psicanálise nas reflexões sobre a significação no cinema.

Em segundo lugar, a tese deu preferência à imagem em detrimento do som. Já no período inicial da pesquisa foi compreendido que o acréscimo do som à estrutura geral ou mesmo a inclusão de um único capítulo dedicado exclusivamente ao som - levaria a desdobramentos teóricos que impossibilitariam a manutenção de alguma consistência e mesmo de um volume textual equilibrado. Uma escolha prática, portanto, mas não sem consequências: filmes que poderiam estabelecer diálogos importantes em diversos capítulos não foram tratados, deixando em aberto toda uma região da composição fílmica a ser investigada nos termos do espaço e do tempo. Entre os casos emblemáticos, podemos citar Wochenende (1930) de Walter Ruttmann, um filme composto por uma montagem sonora inspirada na música concreta, e que mantém constante uma tela preta; o Hurlements en faveur de Sade (1952) de Guy Debord, que alterna a tela preta com uma tela branca, e paralelamente alterna silêncios e leituras gravadas por um grupo de pessoas; e Blue (1993) de Derek Jarman, uma tela azul que serve de base para uma meditação verbal e musical sobre a morte e a memória. Estes são apenas alguns dos filmes que poderiam complementar os filmes do primeiro capítulo. Há também filmes como

\footnotetext{
${ }^{313}$ Não significa que as incursões centrífugas da tese estejam isentas de pressupostos, mas sim que seu aspecto descritivo nos parece poder ser trazido à discussão com alguma independência deles. Aqui, importa menos a consistência geral das grandes teorias e mais a aplicabilidade de suas observações, sobretudo no diálogo com descrições geradas por outros pressupostos. É o confronto permanente com as obras, através das descrições comparadas, que nos serve de princípio regulador.
} 
Pickpocket (1959) de Robert Bresson e Unsere Afrikareise (1966) de Peter Kubelka, exemplos do que poderíamos chamar, respectivamente, de um uso metonímico e um uso metafórico do som.

As insuficiências históricas são talvez as mais numerosas, o que é provavelmente uma decorrência natural de propor um recorte sobre um tema desta amplitude. Ainda que esta não seja uma tese historiográfica, ela faz uso de observações históricas e trata mesmo alguns momentos históricos como partes dos argumentos sobre a composição fílmica. Não se pretende, evidentemente, traçar um quadro que descreva a história deste ou daquele problema composicional; mas foi considerado durante todo o percurso que, se um redirecionamento histórico do tema pode ser feito, ele deve poder dialogar com esta abordagem.

Num projeto que desvia da historiografia para explorar algo como seu eixo perpendicular, o "eixo das formas", o anacronismo torna-se um problema constante. Alguns dos filmes analisados tiveram uma função social em sua época bastante diferente da que o cinema veio a ter nos anos seguintes; uma função que pode não ter sido considerada propriamente estética. A concepção de uma "obra de arte", ou de um objeto composto para fins exclusivamente artísticos, é recente, e acima de tudo, é uma convenção. Isso significa que tratar esses filmes como "obras de arte compostas para a apreciação estética" faz com que se perca algo de sua função original. Mas uma das premissas desta tese é que o papel que uma visão de conjunto do cinema, e sobretudo o que uma visão da composição fílmica pode representar é uma constante atualização dessas funções, uma recriação delas em cada novo contexto. Se os Lumière não eram vistos em sua época como os vemos hoje, é uma perda por um lado, mas por outro é uma oportunidade: que vejamos os Lumière em perspectiva com todas as épocas que deles nos separam, e que acrescentam camadas às suas obras que seus contemporâneos não podiam imaginar. É esta a função teórica de uma concepção de "campo de possibilidades". Na medida em que a tecnologia fílmica permanece minimamente estável desde sua criação, pode-se aprender com o desenvolvimento de suas formas em cada contexto mas também à parte de qualquer contexto. Além de uma "história das formas", deve-se poder imaginar algo como a "tabela periódica das formas". 


\section{BIBLIOGRAFIA}

Abel, Richard (ed.). French Film Theory and Criticism: A History/Anthology, 19071939, vol. I: 1907-1929. Princeton: Princeton University Press, 1988. . French Film Theory and Criticism: A History/Anthology, 1907-1939, vol. II: 1929-1939. Princeton: Princeton University Press, 1988.

AdRIANO, Carlos. O mutoscópio explica a invenção do pensamento de Santos Dumont: Cinema experimental de reapropriação de arquivo em forma digital. Tese de doutorado, ECA-USP, 2008.

Adriano, Carlos; Vorobow, Bernardo. Peter Kubelka: A essência do cinema. São Paulo: Babushka, 2002.

Agel, Henri. L'Espace cinématographique. Paris: Éditions universitaires, 1978.

Allen, Richard; Turvey, Malcolm (ed.). Camera Obscura, Camera Lucida: Essays in Honor of Annette Michelson. Amsterdam: Amsterdam University Press, 2003.

Altman, Rick (ed.). Genre: The Musical. Boston: Routledge, 1981. . The American Film Musical. Bloomington: Indiana University Press, 1987.

ANDREw, Dudley. As principais teorias de cinema. Rio de Janeiro: Zahar, 2002.

Andrew, Dudley; Joubert-Laurencin, Hervé (ed.). Opening Bazin. Nova York: Oxford University Press, 2011.

ARNHEIM, Rudolf. Art and Visual Perception. Londres: Faber and Faber, 1972. . Film as Art. Berkeley: University of California Press, 1957. . "The Center Surviving Mondrian". The Journal of Aesthetics and Art Criticism, vol. 44, n. 3, primavera de 1986.

. The Dynamics of Architectural Form. Los Angeles: University of California Press, 1977.

ArthUR, Paul. A Line of Sight: American Avant-Garde Film Since 1965. Minneapolis: University of Minnesota Press, 2005.

Arthur, Paul; James, David; PIERson, Michele (ed.). Optic Antics: The Cinema of Ken Jacobs. Nova York: Oxford University Press, 2011. 
AUERBACH, Erich. Mimesis: A representação da realidade na literatura ocidental. São Paulo: Perspectiva, 1971.

Aumont, Jacques. A imagem. Campinas: Papirus, 1990. . Montage Eisenstein. Bloomington: Indiana University Press, 1987. . O cinema e a encenação. Lisboa: Texto \& Grafía, 2006. . O olho interminável. São Paulo: Cosac Naify, 2004.

Aumont, Jacques; Bergala, Alain; Marie, Michel; Vernet, Marc (org.). A estética do filme. São Paulo: Papirus, 2006.

Aumont, Jacques; MARIE, Michel. Dicionário teórico e crítico de cinema. Campinas: Papirus, 2001.

Baer, Nicolas; Cowan, Michael; KaEs, Anton (ed.). The Promise of Cinema: German Film Theory, 1903-1933. Oakland: University of California Press, 2016.

BAILEY, Kathryn. The Twelve-Tone Music of Anton Webern. Nova York: Cambridge University Press, 1991.

. "Symmetry as Nemesis: Webern and the First Movement of the Concerto, Opus 24". Journal of Music Theory, vol. 40, n. 2, outono de 1996.

BALÁzs, Béla. Theory of the Film. London: Dobson, 1952.

BAPTISTA, Lucas Bastos Guimarães. "Fantasmas na máquina: estrutura e movimento nos filmes de Ernie Gehr”. Galáxia 34, 2017.

BArker, Adam; Elsaesser, Thomas (ed.). Early Cinema: Space, Frame, Narrative. Londres: BFI, 1990.

BARTHES, Roland. "Introduction à l'analyse structurale des récits”. Communications 8, 1966.

BAtTCOCK, Gregory (ed.). The New American Cinema: A Critical Anthology. Nova York: E.P. Dutton, 1967.

BAZIN, André. O cinema da crueldade. São Paulo: Martins Fontes, 1989. . O que é o cinema? São Paulo: Cosac Naify, 2014.

BeAuvais, Yann. Poussière d'image. Paris: Paris Expérimental, 1998.

Beckman, Karen (ed.). Animating Film Theory. Durham e Londres: Duke University Press, 2014.

Bellour, Raymond. "Cine-Repetitions”. Screen, vol. 20, n. 2, julho de 1979. . The Analysis of Film. Bloomington: Indiana University Press, 2000.

BeLton, John. "The Space of Rear Window". MLN, vol. 13, n. 5, dezembro de 1988. 
Benson, Timothy O.; Shatskikh, Aleksandra. "Malevich and Richter: An Indeterminate Encounter". October 143, inverno de 2013.

BiETte, Jean-Claude. Poétique des auteurs. Paris: Cahiers du Cinéma, 1988.

Bonitzer, Pascal. Décadrages. Paris: Editions de l'Etoile, 1995.

. Le champ aveugle: essays sur le réalisme au cinéma. Paris: Cahiers du cinéma, 1982.

. "Le Gros orteil". Cahiers du cinéma 232, outubro de 1971.

. "Voici (La notion de plan et le sujet du cinéma)". Cahiers du cinéma 273, janeiro-fevereiro de 1977.

Bordwell, David. "Camera Movement and Cinematic Space”. Ciné-Tracts, vol. 1, n. 2, verão de 1977.

. "Eisenstein's Epistemological Shift". Screen, vol. 15, n. 4, inverno de $1974 / 75$

. Figuras traçadas na luz. Campinas: Papirus, 2008.

. Narration in the Fiction Film. Madison: University of Wisconsin Press, 1985.

- Reinventing Hollywood: How 1940s Filmmakers Changed Movie

Storytelling. Chicago: University of Chicago Press, 2017.

. The Cinema of Eisenstein. Londres: Routledge, 2005.

. "The Musical Analogy”. Yale French Studies 60, 1980.

Bordwell, David; Carroll, Noel (org.). Post-Theory: Reconstructing Film Studies. Madison: University of Wisconsin Press, 1996.

BORGES, Cristian. "Mais perto do coração selvagem (do cinema)", In GoNÇALVES, Osmar (ed.). Narrativas sensoriais. Rio de Janeiro: Editora Circuito, 2014.

BRANIGAN, Edward. Narrative Comprehension and Film. Londres: Routledge, 1992. . Point of View in the Cinema. Nova York: Mouton, 1984.

Braun, Marta. Picturing Time: The Work of Étienne-Jules Marey. Chicago: University of Chicago Press, 1994.

Brunetta, Gian Piero (ed.). Storia del cinema mondiale, vol. I, t. I: Gli Stati Uniti. Torino: Giulio Einaudi, 2001.

(ed.). Storia del cinema mondiale, vol. V: Teorie, strumenti, memorie.

Torino: Giulio Einaudi, 2001. 
Bukatman, Scott. The Poetics of Slumberland: Animated Spirits and the Animating Spirit. Berkeley: University of California Press, 2012.

Bulgakowa, Oksana (ed.). Kazimir Malevich, The White Rectangle: Writings on Film. Berlim e São Francisco: Potemkin Press, 2002.

Burch, Noel. In and Out of Synch: The Awakening of a Cine-Dreamer. Aldershot: Scolar Press, 1991. . Life to Those Shadows. Berkeley: University of California Press, 1990. . “Qu'est-ce que la nouvelle vague?”. Film Quarterly, vol. 13, n. 2, inverno de 1959. . The Theory of Film Practice. Princeton: Princeton University Press, 1981.

CAGE, John. Silence. Hanover: University Press of New England, 1973.

Caixeta, Ruben; Guimarães, César (ed.). Jean-Louis Comolli, Ver e poder - A inocência perdida: Cinema, televisão, ficção, documentário. Belo Horizonte: UFMG, 2008.

CArroll, Noel. Comedy Incarnate: Buster Keaton, Physical Humor, and Bodily Coping. Massachussets: Blackwell, 2007. . Interpreting the Moving Image. Nova York: Cambridge University Press, 1998. . Philosophical Problems of Classical Film Theory. Princeton: Princeton University Press, 1988. . Theorizing the Moving Image. Nova York: Cambridge University Press, 1996.

CASSIRER, Ernst. A filosofia das formas simbólicas, vol. II: O pensamento mítico. São Paulo: Martins Fontes, 2004.

ChÂTEAU, Dominique. "Le rôle de la musique dans la définition du cinéma comme art". Cinémas: Revue d'études cinématographiques, vol. 3, n. 1, 1992.

Chion, Michel. Film: A Sound Art. Nova York: Columbia University Press, 2009.

CoHan, Steven (ed.). Hollywood Musicals: The Film Reader. Londres: Routledge, 2002.

ColladO, Esperanza. "Takahiko Iimura in Interview”. Experimental Conversations 5, inverno de 2009/2010. Em: $<$ www.experimentalconversations.com/articles/484/takahiko-iimura-in-interview $>$. Acesso em março de 2018. 
Comolli, Jean-Louis. "La danse des images: kaleidoscope de Busby Berkeley”. Cahiers du cinéma 174, janeiro de 1966.

CONRAD, Tony. “On The Flicker”. Film Culture 41, verão de 1966.

CORNWELl, Regina. "Paul Sharits: Illusion and Object". Artforum, vol. 10, n. 1, setembro de 1971.

. Snow Seen: The Films and Photographs of Michael Snow. Toronto: PMA Books, 1980.

Costa, Flávia Cesarino. O primeiro cinema: espetáculo, narração, domesticação. Rio de Janeiro: Azougue, 2005.

Cotт, Jonathan. Stockhausen: Conversations with the Composer. Londres: Picador, 1974.

COZARINSKY, Edgardo. Borges do/no cinema. Lisboa: Horizonte, 1983.

CURTIS, David. Experimental Film. Londres: Studio Vista, 1971.

DAMISCH, Hubert. The Origin of Perspective. Cambridge, Mass.: The MIT Press, 1994.

De BAECQue, Antoine. Les Cahiers du Cinéma: Histoire d'une revue, t. I: À l'assault du cinéma (1951-1959). Paris : Editions Cahiers du Cinéma, 1991.

De Lauretis, Teresa; Heath, Stephen (ed.). The Cinematic Apparatus. Londres: Macmillan, 1988.

DeleuZe, Gilles. Cinema 1: A imagem-movimento. São Paulo: Editora 34, 2018. . Cinema 2: A imagem-tempo. São Paulo: Editora 34, 2018.

Demonsablon, Philippe. "Lexique mythologique pour l'oeuvre de Hitchcock". Cahiers du cinéma 62, agosto/setembro de 1956.

DoAne, Mary Ann. The Emergence of Cinematic Time Modernity, Contingency, the Archive. Cambridge, Mass./Londres: Harvard University Press, 2002.

Drummond, Phillip (ed.). Film as Film: Formal Experiment in Film, 1910-1975. Londres: Arts Council of Great Britain, 1979.

Du PASQUIER, Sylvain. “Les gags de Buster Keaton”. Communications 15, 1970.

DuBOIS, Philippe. O ato fotográfico e outros ensaios. Campinas: Papirus, 1998.

Dworkin, Craig. No Medium. Cambridge, Mass.: The MIT Press, 2013.

EISENSteIn, Sergei. A forma do filme. Rio de Janeiro: Jorge Zahar, 2002. . Nonindifferent Nature. Nova York: Cambridge University Press, 1987. . O sentido do filme. Rio de Janeiro: Jorge Zahar, 2002.

Elcott, Noah M. Artificial Darkness: An Obscure History of Modern Art and Media. Chicago: University of Chicago Press, 2016. 
Elder, R. Bruce. Harmony and Dissent: Film and Avant-Garde Art Movements in the Early Twentieth Century. Ontario: Wilfrid Laurier University Press, 2008.

EPSTEIN, Jean. Écrits sur le cinéma, vol. I: 1921-1947. Paris: Éditions Seghers, 1974 . Écrits sur le cinéma, vol. II: 1946-1953. Paris: Éditions Seghers, 1975.

Farber, Manny; Patterson, Patricia. "Beyond the New Wave, I: Kitchen Without Kitsch”. Film Comment, vol. 13, n. 6, novembro/dezembro de 1977.

FELL, John L. (ed.). Film Before Griffith. Berkeley: University of California Press, 1983.

FiSHER, Lucy. "The Lady Vanishes: Women, Magic and the Movies". Film Quarterly, vol. 33, n. 1. outono de 1979.

Flaubert, Gustave. Correspondance, III. Paris: Louis Conard, 1927.

FLUDD, Robert. Utriusque cosmi maioris scilicet et minoris metaphysica, physica atqve technica historia, Oppenheim, 1617-21.

Foster, Stephen C. (ed.). Hans Richter: Activism, Modernism, and the Avant-Garde. Cambridge, Mass.: The MIT Press, 1998.

FrAISSE, Paul. Les structures rythmiques. Paris: Éditions Érasme, 1956.

Friedman, Ken (ed.). The Fluxus Reader. Nova York: Academy Editions, 1998.

FRYE, Northrop. Anatomia da crítica. São Paulo: É Realizações, 2014.

GANGuly, Suranjan (ed.). Stan Brakhage: Interviews. Jackson: University Press of Mississipi, 2017.

GARDIES, Andrés. "La Cité Lumière”. CinémAction 75, 1995. . L'Espace au cinéma. Paris: Méridiens Klincksieck, 1993.

Gaudreault, André; Gauthier, Philippe. "D.W. Griffith et l'émergence du montage alterné". Revue Canadienne d'Études cinématographiques, vol. 26, n. 2, outono de 2017.

Gaudreault, André; Russell, Catherine; Véronneau, Pierre (ed.). Le Cinématographe, nouvelle technologie du XXe siècle. Quebec: Payot Lausanne, 2004.

GEHR, Ernie. "Program Notes by Ernie Gehr”. Film Culture 53/54/55, 1972.

GEnNÉ, Beth. Dance Me a Song: Astaire, Balanchine, Kelly, and the American Film Musical. Nova York: Oxford University Press, 2018.

Gibson, James J. The Perception of the Visual World. Cambridge, Mass.: Riverside Press, 1950.

GIDAL, Peter. Materialist Film. Londres: Routledge, 1989. (ed.). Structural Film Anthology. Londres: BFI, 1978. 
. "The Anti-Narrative". Screen, vol. 20, n. 2, julho de 1979.

Grieveson, Lee; Kramer, Peter (ed.). Silent Cinema Reader. Londres: Routledge, 2004.

GrifFITH, D.W. "Pace in the Movies". Liberty, 1926.

Gombrich, E.H. Art and Illusion: A Study in the Psychology of Pictorial Representation. Oxford: Phaidon, 1990.

Goodman, Nelson. Languages of Art. Indianapolis: Hackett, 1976.

GraF, Alexandre; Scheunemann, Dietrich (ed.). Avant-Garde Film. Nova York: Rodopi, 2007.

GunNING, Tom. "Buster Keaton, or: The Work of Comedy in the Age of Mechanical Reproduction". Cinéaste, vol. 21, n. 3, 1995.

. D.W. Griffith \& The Origins of American Narrative Film: The Early Years at Biograph. Urbana, Chicago: University of Illinois Press, 1994.

HEATH, Stephen. Questions of Cinema. Londres: Macmillan, 1981.

. "Notes on Suture". Screen, vol. 18, n. 4, dezembro de 1977.

Higgins, Hannah. Fluxus Experience. Berkeley: University of California Press, 2002.

HiLl, Donald L. (ed.). Walter Pater, The Renaissance: Studies in Art and Poetry. Berkeley: University of California Press, 1980.

HendRICKS, Gordon. Eadweard Muybridge: The Father of the Motion Picture. Mineola: Dover, 2001.

Herbener, Gerald F.; Van Tubergen, Norman; Whitlon, Scott. "Dynamics of the Frame in Visual Composition". Educational Communication and Technology, vol. 27, n. 2, verão de 1979 .

Holman, Roger. Cinema 1900/1906: An Analytical Study by the National Film Archive (London) and the International Federation of Film Archives. Bruxelas: FIAF, 1982.

Horrocks, Roger. Art That Moves: The Work of Len Lye. Auckland: Auckland University Press, 2009.

Hume, David. A Treatise of Human Nature. Oxford: Oxford University Press, 1992.

JACOBS, Lewis. The Rise of the American Film: A Critical History. Nova York: Teachers College Press, 1975.

JACOBS, Steven. The Wrong House: The Architecture of Alfred Hitchcock. Rotterdam: 010 Publishers, 2017.

Jakobson, Roman. Linguística. Poética. Cinema. São Paulo: Perspectiva, 2007. . Selected Writings, vol. II: Word and Language. Paris: Mouton \& Co., 1971. 
JAMES, David E. Allegories of Cinema: American Film in the Sixties. Nova Jersey: Princeton University Press, 1989. (ed.). Stan Brakhage: Filmmaker. Filadélfia: Temple University Press, 2005.

Jenkins, Bruce (ed.). On the Camera Arts and Consecutive Matters: The Writings of Hollis Frampton. Cambridge, Mass.: The MIT Press, 2009.

Kandinsky, Wassily. Point and Line to Plane. Nova York: Dover, 1979.

Keller, Sarah; Paul, Jason N. (ed.). Jean Epstein: Critical Essays and Translations. Amsterdam University Press, 2012.

KIRBY, Lynne. Parallel Tracks: The Railroad and Silent Cinema. Durham: Duke University Press, 1997.

KIRSANOV, Dimitri "De la synthèse cinématographique". Revue musicale, dezembro de 1934.

KocH, Gertrud. "Rudolf Arnheim: The Materialist of Aesthetic Illusion: Gestalt Theory and Reviewer's Practice”. New German Critique 51, outono de 1990.

KoffKa, Kurt. Principles of Gestalt Psychology. Londres: Kegan Paul, Trench, Trubner \& Co., 1936.

Kotvun, Evgueny. Russian Avant-Garde. Nova York: Parkstone, 2007.

KRAMER, Jonathan. The Time of Music. Nova York: Schirmer, 1988.

KRAUSS, Rosalind. "Grids”. October 9, verão de 1979. . "Montage October: Dialectic of the Shot". Artforum, vol. 11, n. 5, janeiro de 1973

Kuntzel, Thierry. “The Défilement: A View in Close-Up”. Camera Obscura 2, outono de 1977.

LABARTHe, André S. "Marienbad année zéro”. Cahiers du cinéma 123, setembro de 1961.

LAwDER, Standish. The Cubist Cinema. Nova York: Anthology Film Archives, 1975.

Le Grice, Malcolm. Abstract Film and Beyond. Cambridge, Mass.: The MIT Press, 1977. . Experimental Cinema in the Digital Age. Londres: BFI, 2001.

LEAL, João Vitor. “A imagem interessante: cinema e suspensão narrativa”. Significação, vol. 43, n. 45, 2016.

LeE, Pamela M. Chronophobia: On Time in the Art of the 1960s. Cambridge, Mass.: The MIT Press, 2006.

LEWIS, David. Counterfactuals. Oxford: Blackwell, 1973.

LHERMINIER, Pierre (ed.). L'Art du cinéma. Paris: Editions Seghers, 1960. 
MacDonald, Scott. A Critical Cinema: Interviews with Independent Filmmakers. Berkeley: University of California Press, 1988.

. A Critical Cinema 3: Interviews with Independent Filmmakers. Berkeley: University of California Press, 1998.

. "An Interview with Taka Iimura". Journal of the University of Film Association, vol. 33, n. 4, outono de 1981.

(ed.). Art in Cinema: Documents Towards a History of the Film Society.

Filadélfia: Temple University Press, 2006.

. “Camera Obscura/Lens/Filmstrip". Film Quarterly, vol. 43, n. 4, verão de 1990.

Malthête, Jacques; Mannoni, Laurent (ed.). Méliès: Magie et cinéma. Paris: Musées, 2002.

MAREY, Étienne-Jules. Movement. Nova York: D. Appleton and Company, 1895.

MCLAREn, Norman. Cameraless Animation. Montreal: National Film Board of Canada, 1958.

McPherson, Bruce R. (ed.). The Essential Brakhage. Nova York: McPherson and Company, 2001.

(ed.). The Essential Deren. Nova York: McPherson \& Company, 2005.

MEYER, Leonard B. Emotion and Meaning in Music. Chicago e Londres: University of Chicago Press, 1956.

Michaud, Philippe-Alain. Filme: por uma teoria expandida do cinema. São Paulo: Contraponto, 2014.

Michelson, Annette. "Bodies in Space: Film as Carnal Knowledge". Artforum, vol. 7, n. 6, 1969.

(ed.). Kino-Eye: The Writings of Dziga Vertov, Berkeley: University of California Press, 1984.

. On the Eve of the Future: Selected Writings on Film. Cambridge, Mass.: The MIT Press, 2017.

. "The Wings of Hypothesis: On Montage and the Theory of Interval", in Teitelbaum, Matthew (ed.). Montage and Modern Life, 1919-1942. Cambridge, Mass: MIT Press, 1992. 
. "Track Records, Trains of Events: The Limits of Cinematic Representation”. In: KARDISH, Larry (ed.). Junction and Journey: Trains and Film. Nova York: The Museum of Modern Art, 1991.

Michotтe, Albert. The Perception of Causality. Londres: Methuen, 1963.

Mitry, Jean. Esthétique et psychologie du cinéma, vol. I: Les structures. Paris: Editions Universitaires, 1963. . Esthétique et psychologie du cinéma, vol. II: Les formes. Paris: Editions Universitaires, 1965.

Moore, Rachel. Hollis Frampton: (nostalgia). Londres: Afterall Books, 2006.

Moritz, William. "Beyond 'Abstract' Criticism”. Film Quarterly, vol. 31, n. 3, primavera de 1978.

. "The Films of Oskar Fischinger”. Film Culture 58/59/60, 1974.

Mueller, John. "Fred Astaire and the Integrated Musical". Cinema Journal, vol. 24, n. 1 , outono de 1984 .

Munsterberg, Hugo. The Photoplay: A Psychological Study. Nova York: D. Appleton and Company, 1916.

Musser, Charles. Before the Nickelodeon: Edwin S. Porter and the Edison Manufacturing Company. Berkeley: University of California Press, 1991.

Mussman, Tony. “An Interview with Tony Conrad”. Film Culture 41, verão de 1966.

MuYBRIDGE, Eadweard. The Human Figure in Motion. Nova York: Dover, 1955.

NAtAlE, Simone. "A Short History of Superimposition: From Photography to Early Cinema". Early Popular Visual Culture, vol. 10, n. 2, 2012.

Nesthus, Marie. "The Influence of Olivier Messiaen on the Visual Art of Stan Brakhage in Scenes from Under Childhood, Part One". Film Culture 63/64, 1976.

Noguez, Dominique. Éloge du cinéma expérimental. Paris: Paris Expérimental, 2010.

O'BRIEN, John (ed.). Clement Greenberg, The Collected Essays and Criticism, vol. I: Perceptions and Judgements, 1939-1944. Chicago: University of Chicago Press, 1988. (ed.). Clement Greenberg, The Collected Essays and Criticism, vol. IV: Modernism with a Vengeance, 1957-1969. Chicago: University of Chicago Press, 1988.

OliveIRA JR., Luiz Carlos. "Retratos em movimento". Ars, vol. 15, n. 31, 2017.

ONG, Walter J. Rhetoric, Romance, and Technology: Studies in the Interaction of Expression and Culture. Ithaca: Cornell University Press, 1971. 
OudART, Jean-Pierre. "La suture”. Cahiers du cinéma, n. 45, abril de 1969.

PANOFSKY, Erwin. Perspective as Symbolic Form. Nova York: Zone Books, 1991.

PENNER, Nina. "Rethinking the Diegetic/Nondiegetic Distinction in the Film Musical". Music and the Moving Image, vol. 10, n. 3, outono de 2017.

Perez, Gilberto. The Material Ghost: Films and Their Medium. Baltimore: The Johns Hopkins University Press, 1998.

PETRIC, Vladimir. Constructivism in Film: The Man with the Movie Camera, A Cinematic Analysis. Nova York: Cambridge University Press, 1997.

PIAGET, Jean. Genetic Epistemology. Nova York: Columbia University Press, 1970.

REICH, Willi (ed.). Anton Webern, The Path to the New Music. Bryn Mawr: Theodore Presser, 1963.

Reichenbach, Maria (ed.), Hans Reichenbach, The Direction of Time. Berkeley: University of California Press, 1971.

Richmond, Scott C. Cinema's Bodily Illusions. Minneapolis: University of Minnesota Press, 2016.

RobBe-Grillet, Alain. Por um novo romance. São Paulo: Nova Crítica, 1969.

Rogers, Holly; BARHAM, Jeremy (ed.). The Music and Sound of Experimental Film. Nova York: Oxford University Press, 2017.

ROHMER, Éric. L'organisation de l'espace dans le Faust de Murnau. Paris: UGE, 1977. . The Taste for Beauty. Cambridge University Press, 1989.

ROPARS, Marie-Claire. “Fonction de la métaphore dans Octobre d'Eisenstein”. Littérature 11, outubro de 1973.

Rothman, William, "Against the System of the Suture". Film Quarterly, vol. 28, n. 1, outono de 1974.

SAdoul, Georges. História do cinema mundial, vol. I: Das origens a nossos dias. São Paulo: Martins Editora, 1963.

SALNIKER, Stephen. "Visual Responses in Perceptual Cinema". Journal of the University of Film Association, vol. 32, n. 1/2, inverno/primavera de 1980.

SATO, Juno. "Les lois de prolongement et leurs effets sur la mise en scéne de l'espace cinématographique”. Cinémas, vol. 9, n. 1, outuno de 1998.

SCHAEFFER, Pierre. "Le contrepoint du son et de l'image". Cahiers du cinéma 108, junho de 1960.

."L’élement non visuel au cinéma”. Revue du cinéma 1/2, 1946. 
SHARITs, Paul. "Words Per Page”. Film Culture 65/66, 1978.

Silva, Mateus Araújo. "Adorno e o cinema: um início de conversa". Novos Estudos CEBRAP 54, julho de 1999.

Simon, John K. "Hulot, or The Common Man as Observer and Critic". Yale French Studies 23, 1959.

Sitney, P. Adams (ed.) Film Culture Reader. Nova York: Cooper Square, 2000. . "Kubelka Concrete”, Film Culture 34, 1964. (ed.). The Avant-Garde Film: A Reader of Theory and Criticism. Nova York: Anthology Film Archives, 1987. . The Cinema of Poetry. Nova York: Oxford University Press, 2014. (ed.). The Essential Cinema: Essays on Films in the Collection of Anthology

Film Archives. Nova York: Anthology Film Archives, 1989. . "The Idea of Abstraction”. Film Culture 63/64, 1976. . "The Idea of Morphology”. Film Culture 53/54/55, 1972. . Visionary Film: The American Avant-Garde, 1974-2000. Nova York: Oxford University Press, 2002.

SMulewiCZ-Zucker, Gregory (ed.). Jonas Mekas, Movie Journal: The Rise of the New American Cinema, 1959-1971. Nova York: Columbia University Press, 2016.

Solomon, Stanley J. The Film Idea. Nova York: Harcourt Brace Jovanovich, 1972.

SOURIAU, Etienne. "La structure de l'univers filmique et le vocabulaire de la filmologie". Revue internationale de filmologie 7/8, 1951.

SoUTER, Gerry. Malevich: Journey to Infinity. Nova York: Parkstone Press, 2008.

SPILlmanN, Lothar (ed.). Max Wertheimer, On Perceived Motion and Figural Organization. Cambridge, Mass.: The MIT Press, 2012.

Steinhoff, Erik (ed.). Stan Brakhage: Correspondences. Chicago: Chicago Review, 2001.

SternBerg, Meir. Expositional Modes and Temporal Ordering in Fiction. Baltimore: The Johns Hopkins University Press, 1978.

Strauven, Wanda (ed.). The Cinema of Attractions Reloaded. Amsterdam: Amsterdam University Press, 2006.

SWEENEY, Kevin (ed.). Buster Keaton: Interviews. Jackson: University Press of Mississipi, 2007. 
SwITZER, Judith A. "The Animated Abstractions of Harry Smith". Millennium Film Journal 6, primavera de 1980. . "The Spatial Strategies of Harry Smith's Heaven and Earth Magic". Film Reader, vol. 3, 1978.

TARKOVSKI, Andrei. Esculpir o tempo. São Paulo: Martins Fontes, 2002.

TAYLOR, Richard (ed.). Sergei Eisenstein, Selected Works, vol. I: Writings, 1922-1934. Londres: I.B. Tauris, 2010. (ed.). Sergei Eisenstein, Selected Works, vol. III: Writings, 1934-1947. Londres: I.B. Tauris, 2010.

TAYLOR, Richard; GlenNY, Michael. Sergei Eisenstein, Selected Works, vol. II: Towards a Theory of Montage. Londres: I.B. Tauris, 2010.

TolEDO, Dionísio de Oliveira (org.). Teoria da literatura: formalistas russos. Porto Alegre: Globo, 1973.

TODOROv, Tzvetan. As estruturas narrativas. São Paulo: Perspectiva, 1969.

TODOROv, Tzvetan; WeInSteIn, Arnold. "Structural Analysis of Narrative". NOVEL: A Forum on Fiction, vol. 13, n. 1, outono de 1969.

Trahair, Lisa. The Comedy of Philosophy: Sense and Nonsense in Early Cinematic Slapstick. Albany: SUNY Press, 2007.

TRUFFAUT, François. Hitchcock. Nova York: Touchstone, 1985.

TsiviAN, Yuri. "Beyond Comparing: The Internal Dynamics of Intolerance". In: Cinemetrics. Disponível em: $<\mathrm{http}: / / \mathrm{www}$. cinemetrics.lv/tsivian.php $>$. Acesso em dezembro de 2018.

TUPISTSYN, Margarita. Malevich and Film. New Haven: Yale University Press, 2002.

TuRveY, Malcolm. "Dada Between Heaven and Hell: Abstraction and Universal Language in the Rhythm Films of Hans Richter”. October 105, verão de 2003. . Doubting Vision: Film and the Revelationist Tradition. Nova York: Oxford University Press, 2008. . The Filming of Modern Life: European Avant-Garde Film of the 1920s. Cambridge, Mass.: The MIT Press, 2011.

Uroskie, Andrew V. Between the Black Box and the White Cube. Chicago: University of Chicago Press, 2014.

WALKER, Michael. Hitchcock's Motifs. Amsterdam: Amsterdam University Press, 2005. 
WeES, William. Light Moving in Time: Studies in the Visual Aesthetics of Avant-Garde Film. Berkeley: University of California Press, 1992.

WeIBEL, Peter (ed.). Beyond Art: A Third Culture. Nova York: Springer Wien, 1997.

WEVER, Ernest Glen. "Figure and Ground in the Visual Perception of Form". The American Journal of Psychology, vol. 38, n. 2, abril de 1927.

WEYL, Hermann. Symmetry. Nova Jersey: Princeton University Press, 1952.

WHITNEY, John. Digital Harmony. Peterborough: McGraw-Hill, 1980.

WiLliamS, Linda. "Hiroshima and Marienbad: Metaphor and Metonymy". Screen, vol. 17, n. 1, primavera de 1976.

WitTGenstein, Ludwig. Observações filosóficas. São Paulo: Edições Loyola, 2005.

Wollen, Peter. Readings and Writings: Semiotic Counter-Strategies. Londres: Velso/NLB, 1982.

XAVIER, Ismail (org.). A experiência do cinema. São Paulo: Graal, 2003. . D.W. Griffith: O nascimento de um cinema. São Paulo: Brasiliense, 1984. . "Eisenstein: A construção do pensamento por imagens". In: MENDES, Adilson (org.). Eisenstein/Brasil/2014. Rio de Janeiro: Azougue, 2014. . O discurso cinematográfico: a opacidade e a transparência. Rio de Janeiro:

Paz e Terra, 1977. . O olhar e a cena. São Paulo: Cosac Naify, 2003. . Sétima arte: um culto moderno. São Paulo: Perspectiva, 1978.

YoungBlood, Gene. "The Cosmic Cinema of Jordan Belson". Film Culture 48/49, primavera de 1970.

ZIRNITE, Dennis. "Hitchcock on the Level: The Heights of Spatial Tension". Film Criticism, vol. 10, n. 3, primavera de 1986.

ZRYD, Michael. "History and Ambivalence in Hollis Frampton's Magellan", October 109, verão de 2004 . 


\section{FILMOGRAFIA}

Arroseur et arrosé (Louis Lumière, 1895)

Place de Cordelier (1895)

L'Arrivée d'un train à la Ciotat (Louis Lumière, 1896)

Demolition d'un mur (Louis Lumière, 1896)

Escamotage d'une dame chez Robert-Houdin (Georges Méliés, 1896)

New York, descente des voyageurs du pont de Brooklyn (Alexandre Promio, 1896)

Panorama de l'arrivée en gare de Perrache pris du train (1896)

Place du pont (1897)

Le chevalier mystère (Georges Méliès, 1898)

Panorama pendant l'ascension de la Tour Eiffel (1898)

Passage d'un tunnel en chemin de fer (1898)

Les Escaliers du Pont de l'Alma (1900)

L’homme orchestre (Georges Méliés, 1900)

Le diable géant ou le miracle de la madonne (Georges Méliès, 1901)

L'homme d'un tête caoutcouch (Georges Méliés, 1901)

The Life and Passion of Jesus Christ (Ferdinand Zecca, 1903)

Life of an American Fireman (Edwin S. Porter, 1903)

Tom, Tom, the Piper's Son (Billy Bitzer, 1905)

The Adventures of Dollie (D.W. Griffith, 1908)

A Corner in Wheat (D.W. Griffith, 1909)

The Sealed Room (D.W. Griffith, 1909)

O nascimento de uma nação (The Birth of a Nation, D.W. Griffith, 1915)

Intolerância (Intolerance: Love's Struggle Throughout the Ages, D.W. Griffith, 1916)

O imigrante (The Immigrant, Charles Chaplin, 1917)

One Week (Buster Keaton \& Edward F. Cline, 1920)

The Boat (Buster Keaton \& Edward F. Cline, 1921)

The Goat (Buster Keaton \& Malcolm St. Clair, 1921)

Lichtspiel: Opus I (Walter Ruttmann, 1921)

Licthspiel: Opus II (Walter Ruttmann, 1921) 
Rhythmus 21 (Hans Richter, 1921)

La souriante Madame Beudet (Germaine Dulac, 1923)

Our Hospitality (Buster Keaton \& John G. Blystone, 1923)

Ballet mécanique (Fernand Léger \& Dudley Murphy, 1924)

Lichtspiel: Opus III (Walter Ruttmann, 1924)

Sherlock, Jr. (Buster Keaton, 1924)

Symphonie Diagonale (Viking Eggeling, 1924)

A greve (Stachka, Sergei Eisenstein, 1925)

Encouraçado Potemkin (Bronenosets Potyomkin, Sergei Eisenstein, 1925)

Em busca do ouro (The Gold Rush, 1925)

Anémic cinéma (Marcel Duchamp, 1926)

A General (The General, Buster Keaton \& Clyde Bruckman, 1926)

Nana (Jean Renoir, 1926)

College (Buster Keato \& James W. Horne, 1927)

Outubro (Oktyabr, Sergei Eisenstein, 1928)

Steamboat Bill, Jr. (Buster Keaton \& Charles Reisner, 1928)

Finis Terrae (Jean Epstein, 1930)

Studie nr. 6 (Oskar Fischinger, 1930)

Studie nr. 7 (Oskar Fischinger, 1931)

Taris, le roi de l'eau (Jean Vigo, 1931)

Belezas em revista (Footlight Parade, Lloyd Bacon, 1933)

Um dia no campo (Une partie de campagne, Jean Renoir, 1936)

Boogie-Doodle (Norman McLaren, 1940)

Color Sequence (Dwinell Grant, 1943)

Interlúdio (Notorious, Alfred Hitchcock, 1946)

Romance inacabado (Blue Skies, Stuart Heisler, 1946)

Festim diabólico (Rope, Alfred Hitchcock, 1948)

Casa, comida e carinho (Summer Stock, Charles Walters, 1950)

Núpcias reais (Royal Wedding, Stanley Donen, 1951)

A roda da fortuna (The Band Wagon, Vincente Minnelli, 1953)

Duck Amuck (Chuck Jones, 1953)

As férias do Sr. Hulot (Les vacances de Monsieur Hulot, Jacques Tati, 1953)

Janela indiscreta (Rear Window, Alfred Hitchcock, 1954)

Mirror Animations (Harry Smith, 1956) 
Um corpo que cai (Vertigo, Alfred Hitchcock, 1958)

Intriga internacional (North by Northwest, Alfred Hitchcock, 1959)

Arnulf Rainer (Peter Kubelka, 1960)

Psicose (Psycho, Alfred Hitchcock, 1960)

Heaven and Earth Magic (Harry Smith, 1962)

Mothlight (Stan Brakhage, 1963)

Os pássaros (The Birds, Alfred Hitchcock, 1963)

Empire (Andy Warhol, 1964)

Zen for Film (Nam June Paik, 1964)

Screen Tests (Andy Warhol, 1964-65)

Entrance to Exit (George Brecht, 1965)

The Flicker (Tony Conrad, 1965)

Film in Which There Appear Edge Lettering, Sprocket Holes, Dirt Particles, Etc. (George Landow, 1966)

Ray Gun Virus (Paul Sharits, 1966)

Playtime (Jacques Tati, 1967)

Samadhi (Jordan Belson, 1967)

Faces (John Cassavetes, 1968)

Morning (Ernie Gehr, 1968)

2001: Uma odisseia no espaço (2001: A Space Odyssey, Stanley Kubrick, 1968)

One Second in Montreal (Michael Snow, 1969)

Tom, Tom, the Piper's Son (Ken Jacobs, 1969)

Berlin Horse (Malcolm Le Grice, 1970)

Serene Velocity (Ernie Gehr, 1970)

Céline e Julie vão de barco (Céline et Julie vont en bateau, Jacques Rivette, 1974)

Eureka (Ernie Gehr, 1974)

Asyl (Kurt Kren, 1975)

Jeanne Dielman, 23 Quai du Commerce 1080 Bruxelles (Chantal Akerman, 1975)

24 Frames per Second (Takahiko Iimura, 1975)

No império dos sentidos (Ai no corida, Nagisa Oshima, 1976)

Animated Motion (Norman McLaren \& Grant Munro, 1976-78)

The Dante Quartet (Stan Brakhage, 1987)

Pièce touchée (Martin Arnold, 1989)

Antiphon (Peter Kubelka, 2012) 